SEISMIC VULNERABILITIES AND RISKS FOR URBAN MITIGATION PLANNING IN TURKEY

A THESIS SUBMITTED TO

THE GRADUATE SCHOOL OF NATURAL AND APPLIED SCIENCES OF MIDDLE EAST TECHNICAL UNIVERSITY

BY

TUĞÇE SÖNMEZ SANER

IN PARTIAL FULFILLMENT OF THE REQUIREMENTS

FOR

THE DEGREE OF DOCTOR OF PHILOSOPHY

IN

CITY AND REGIONAL PLANNING

FEBRUARY 2013 



\section{SEISMIC VULNERABILITIES AND RISKS FOR URBAN MITIGATION PLANNING IN TURKEY}

submitted by TUĞÇE SÖNMEZ SANER in partial fulfillment of the requirements for the degree of Doctor of Philosophy in City and Regional Planning Department, Middle East Technical University by,

Prof. Dr. Canan Özgen

Dean, Graduate School of Natural and Applied Sciences

Prof. Dr. Melih Ersoy

Head of Department, City and Regional Planning

Prof. Dr. Melih Ersoy

Supervisor, City and Regional Planning Dept., METU

Prof. Dr. Murat Balamir

Co-Supervisor, City and Regional Planning Dept., METU

\section{Examining Committee Members:}

Assoc. Prof. Dr. Çağatay Keskinok

City and Regional Planning Dept., METU

Prof. Dr. Melih Ersoy

City and Regional Planning Dept., METU

Assoc. Prof. Dr. Tarık Şengül

Political Science and Public Administration Dept., METU

Assoc. Prof. Dr. Serap Kayasu

City and Regional Planning Dept.., METU

Assoc. Prof. Dr. Kübra Cihangir Çamur

City and Regional Planning Dept., Gazi University 
I hereby declare that all information in this document has been obtained and presented in accordance with academic rules and ethical conduct. I also declare that, as required by these rules and conduct, I have fully cited and referenced all material and results that are not original to this work.

Name, Last name: Tuğçe SÖNMEZ SANER

Signature 


\title{
ABSTRACT \\ SEISMIC VULNERABILITIES AND RISKS FOR URBAN MITIGATION PLANNING IN TURKEY
}

\author{
Sönmez Saner, Tuğçe \\ Ph.D., Department of City and Regional Planning \\ Supervisor : Prof. Dr. Melih Ersoy \\ Co-Supervisor : Prof. Dr. Murat Balamir
}

February 2013, 237 pages

\begin{abstract}
Chronic seismic hazards and resulting secondary impacts as natural conditions of the country, and loss of robust building and prudent settlement practices as aggravated by rapid population growth make cities the most vulnerable geographical and social entities in Turkey. In contrast, Turkish disaster policy is solely focused on post-disaster issues and no incentives or provision exist to encourage risk analysis or risk mitigation approaches, despite current international efforts.
\end{abstract}

For the development of risk reduction policies an essential step is to prioritize settlements according to their vulnerability levels. This could be determined by hazard probabilities and attributes of the building stock of each settlement. Measurement of vulnerability levels allows the ordering of settlements into risk categories.

Vulnerability levels of settlements are then assumed to depend on a number of attributes of cities to explore if vulnerability could be related to a set of urban properties. Results of statistical analyses indicate that total building loss is related to the ratio of population over the total number of buildings in mid-range settlements, and directly related to population in metropolitan cities. Relative loss on the other hand is related with rate of agglomeration and development index in almost every size category of settlements.

Observations provide guiding principles for effective mitigation practices in Turkey by ordering settlements and offer means of differential implementation. These could contribute to improved safety measures in urban standards, building codes, building supervision procedures, insurance systems, investment priorities, and Law (6306) on Redevelopment of Areas under Disaster Risk.

Keywords: Urban Seismic Risk, Seismic Vulnerabilities, Mitigation Planning, Risk Assessment, Mitigation Policies 
öz

\title{
TÜRKİYE'DE SAKINIM PLANLAMASI İÇİN KENTSEL YERLEŞMELERİN SİSMİK ZARAR GÖREBİLİRLİKLERİNİN VE RİSKLERİNİN BELİRLENMESİ
}

\author{
Sönmez Saner, Tuğçe \\ Doktora, Şehir ve Bölge Planlama Bölümü \\ Tez Yöneticisi : Prof. Dr. Melih Ersoy \\ Ortak Tez Yöneticisi : Prof. Dr. Murat Balamir
}

Şubat 2013, 237 sayfa

\begin{abstract}
Türkiye, jeolojik konumu ve yetersiz yasal düzenlemeleri nedeniyle kronik sismik tehlikeler ve ağır sonuçları olan afetlerle karşı karşıyadır. Yerleşimlerin yer seçiminde yapılan yanlışlıklar, altyapının plansız olması, yapı stokunun yapım aşamasında ve sonrasında denetlenmemesi ile yaratılan kalitesiz yapılaşma gibi nedenler de afetler sonucunda yaşanan can ve mal kayıplarını artırmıştır. Tüm bu bileşenler Türkiye'de şehirleri coğrafi ve sosyal açıdan zarar görebilir duruma getirmiştir. Yüksek risklere sahip Türkiye'de uluslar arası politika değişikliklerine büyük ölçüde yabancı kalınmış, sakınım alanında yetersiz ve yanlış uygulamalara girilmiş ve afet politikaları afet-sonrası çalışmaları odaklanmıştır.
\end{abstract}

Çalışma kapsamında yerleşimlerin zarar görebilirlik önceliklerine göre sıralanması sakınım politikalarının geliştirilebilmesi açısından en temel adım olarak belirlenmiştir. Yerleşimlerin zarar görebilirliklerin belirlenmesi amacıyla bir yandan tehlike olasılıkları ve bundan doğan kayıplar düzeyi incelenirken, diğer yandan yerleşimlerin temel özellikleri ve bina stoku değişkenleri ile bunların kayıplar düzeyine olan etkileri incelenmiştir. Elde edilen zarar görebilirlik değerleri yerleşimlerin önceliklerine göre sıralanmasında kullanılmıştır.

Zarar görebilirlik seviyelerinin yerleşimlerin hangi özellikleri ile ilişkili olduğu belirlemek amacıyla istatistiksel analizler yapılmıştır. İstatistiksel analizlerin sonuçları incelendiğinde; toplam bina kaybının orta büyüklükteki yerleşimlerde nüfusun toplam bina sayısına oranı ile büyükşehirlerde ise nüfus ile doğrudan ilişkili olduğu, bina kaybının bina stokuna oranının ise tüm yerleşim gruplarında kentleşme oranı ve gelişme indeksi ile ilişkili olduğu görülmektedir.

Çalışmanın sonuçları daha etkili sakınım politikaları geliştirmek için yerleşimlerin zarar görebilirliklerine göre sıralanması ve bu sıralamaya göre farklı uygulamalar yapılması konularında yol gösterici nitelik taşımaktadır. Kentsel standartların geliştirilmesi, yapı yönetmelikleri ve denetim süreçleri, sigorta sistemleri, yatırım öncelikleri ve Afet Riski Altındaki Alanların Dönüştürülmesi (6306) Kanunu konularında ise sakınım politikalarına katkı sağlamaktadır.

Anahtar Kelimeler: Kentsel Sismik Risk, Sismik Zarar Görebilirlik, Sakınım Planlaması, Risk Değerlendirme, Sakınım Politikaları 
To My Parents 


\section{ACKNOWLEDGMENTS}

I wish to express my deepest gratitude to my supervisors Prof. Dr. Murat Balamir and Prof. Dr. Melih Ersoy for their guidance, advice, criticism, encouragements and insight throughout the research.

I would like to thank my jury members; Assoc. Prof. Dr. Çağatay Keskinok, Assoc. Prof. Dr. Tarık Şengül, Assoc. Prof. Dr. Serap Kayasu and Assoc. Prof. Dr. Kübra Cihangir Çamur for their advice and criticism.

I would like to thank my parents, İlgin and Kaya Sönmez, for their endless patience and faith in every stage of my life. I am grateful to them for the feeling of safety they offer. I would also like to thank my mother-in-law Suna Afacan for her support and motivation throughout this research.

I am also very thankful to Dr. Ezgi Orhan for her friendship and support at every stage of this study.

Above all, I am specifically grateful to my dear husband Serhan Saner for his greatest support, motivation and encouragement in all parts of this study and my life.

Also I offer sincere thanks to Prota Engineering for their support. The method used by Prota Engineering in the "Consultancy Services for Prioritization of High Seismic Risk Provinces and Public Buildings" Project, which is supported by World Bank, is adopted partially in this study and used for developing an algorithm for prioritization. 


\section{TABLE OF CONTENTS}

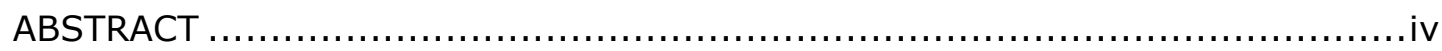

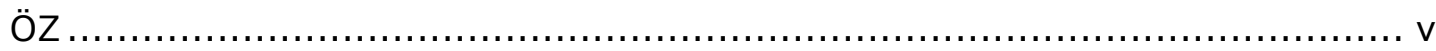

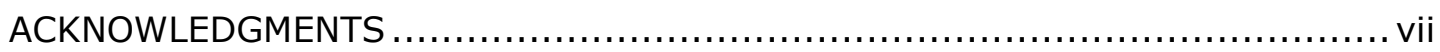

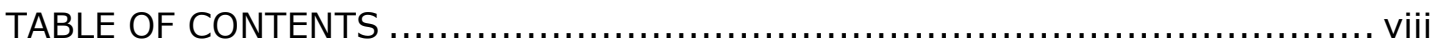

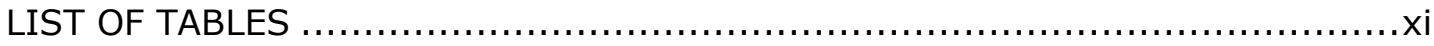

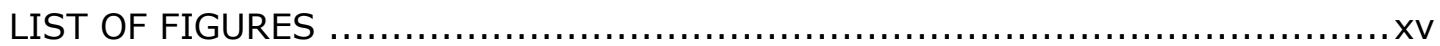

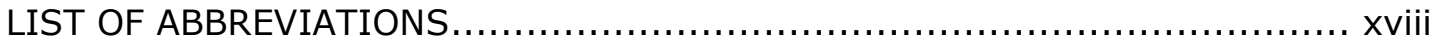

CHAPTERS

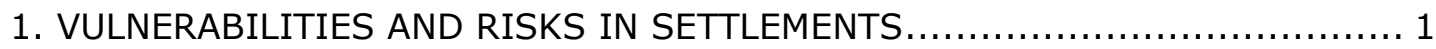

1.1. Hazards, Vulnerabilities and Risks in World Cities and in Turkey............ 4

1.2. The Need for Assessing Vulnerabilities for Policy Development and

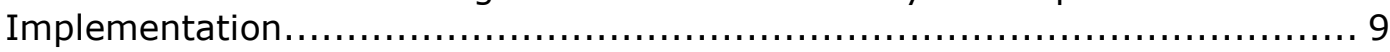

1.3. Description of the Problem and Its Context ............................. 14

1.4. Scope, Approach and Method of the Study .............................. 15

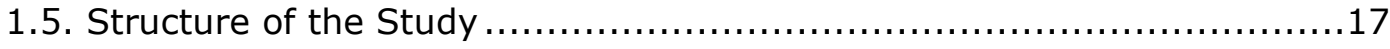

2. SETTLEMENT LEVEL MANAGEMENT OF SEISMIC VULNERABILITIES AND RISKS

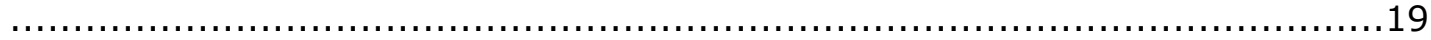

2.1. Risk Assessment Research and Studies.................................. 19

2.2. Settlement Level Vulnerability and Risk Mitigation Policies .................23

2.3. Settlement Level Vulnerability and Risk Assessment Studies in Turkey and

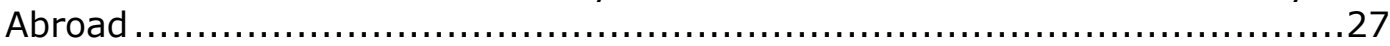

3. SEISMIC LOSS ESTIMATIONS IN SETTLEMENTS OF TURKEY $\ldots \ldots \ldots \ldots \ldots \ldots \ldots . \ldots \ldots$

3.1. Seismic Hazard Probabilities of Settlements ................................. 35

3.1.1. Different Measures of Seismic Hazard.................................. 39

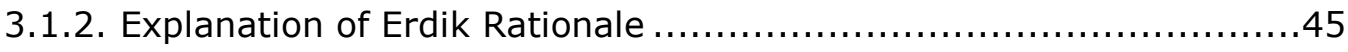

3.2. Loss Levels in Building Stock ............................................ 47

3.2.1. Loss Levels as a Function of Settlement Attributes ....................49

3.2.2. Building Loss Estimates as a Function of Likely Seismicity and Building Categories .65 
4.1. Settlement Population ................................................. 78

4.2. Population Growth Rate.............................................. 79

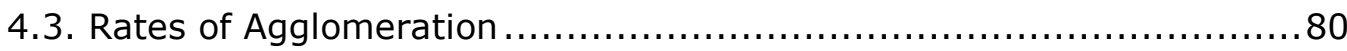

4.4. Population/Total Number of Buildings................................... 81

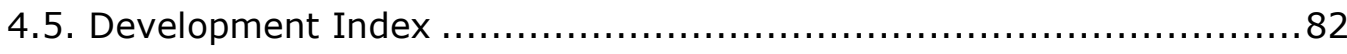

5. ANALYSIS OF MACRO INDICATORS OF SETTLEMENT VULNERABILITY ........87

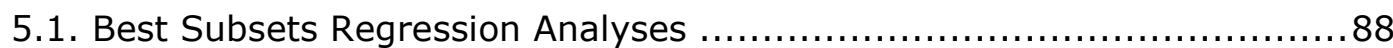

5.1.1. Best Subsets Regression Analyses for Category I (0-50.000

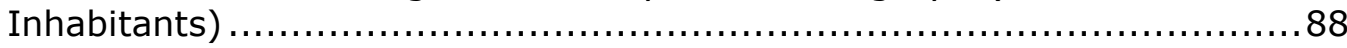

5.1.2. Best Subsets Regression Analyses for Category II (50.000-490.000

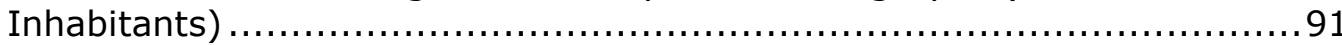

5.1.3. Best Subsets Regression Analyses for Category III (Metropolitan

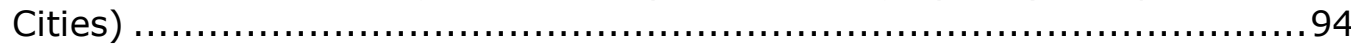

5.1.4. Evaluation of Best Subsets Regression Analyses ...................... 96

5.2. Analyses by Means of Regression Methods ............................... 98

5.2.1. Analyses by Means of Regression Methods for Category I (0-50.000)

5.2.2. Analyses by Means of Regression Methods for Category II (50.000490.000)

5.2.3. Analyses by Means of Regression Methods for Category III (Metropolitan Cities) ........................................................ 113

5.3. Evaluation of Regression Analyses ................................... 120

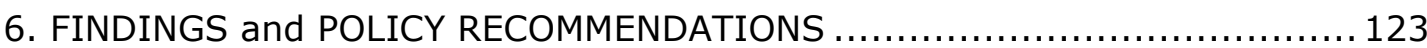

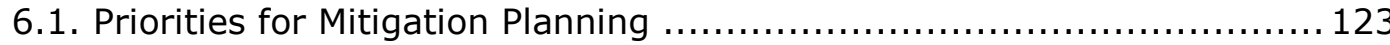

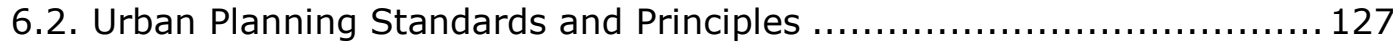

6.3. Law on Redevelopment of Areas under Disaster Risk (6306) ............. 129

6.4. Building Codes and Development Regulations........................... 132

6.5. Building Supervision Practices ........................................... 139

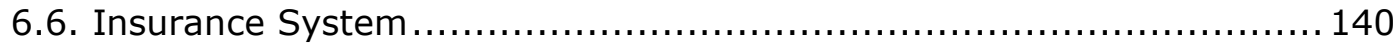

6.7. National Investment Priorities and Regional Planning .................... 144

7. CONCLUSION AND FURTHER LINES OF INVESTIGATION $\ldots \ldots \ldots \ldots \ldots \ldots \ldots \ldots \ldots$

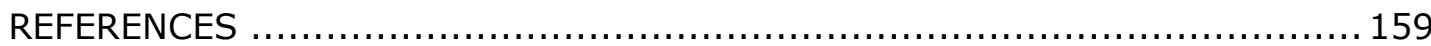

APPENDICES

A. BUILDING STOCK ATTRIBUTES ACCORDING TO CONSTRUCTION TYPE AND

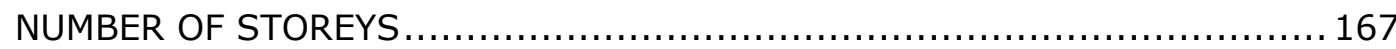


B. TOTAL LOSS IN BUILDING STOCK ACCORDING TO BUILDING TYPES WITH REFERENCE TO VULNERABILITY CURVES.

C. TOTAL LISTS OF CATEGORIES OF SETTLEMENTS PRIORITIZED ACCORDING TO ABSOLUTE LOSS 184

D. TOTAL LISTS OF CATEGORIES OF SETTLEMENTS PRIORITIZED ACCORDING TO RELATIVE LOSS

E. DEPENDENT AND INDEPENDENT VARIABLES OF THE RESEARCH ..........200

F. SOCIO-ECONOMIC DEVELOPMENT INDEX (SEDI) VARIABLES.

G. COMPARISON OF THE SETTLEMENTS PRIORITIZED ACCORDING TO THE ABSOLUTE LOSS WITH THE HAZARD ZONES DETERMINED BY THE OFFICIAL EARTHQUAKE HAZARD MAP

H. COMPARISON OF THE SETTLEMENTS PRIORITIZED ACCORDING TO THE RELATIVE LOSS WITH THE HAZARD ZONES DETERMINED BY THE OFFICIAL EARTHQUAKE HAZARD MAP

I. COMPARISON OF THE PROVINCES PRIORITIZED ACCORDING TO THE ABSOLUTE LOSS WITH THE LOCATION OF SETTLEMENTS ACCORDING TO THE INVESTMENT PRIORITY REGIONS

J. COMPARISON OF THE SETTLEMENTS PRIORITIZED ACCORDING TO THE RELATIVE LOSS WITH THE LOCATION OF SETTLEMENTS ACCORDING TO THE INVESTMENT PRIORITY REGIONS 


\section{LIST OF TABLES}

\section{TABLES}

Table 1.1 Summarized Table of Natural Disasters in Turkey from 1900 to 2011

Table 3.1 Evaluation of Settlements Subject To 6.5+ Seismic Intensities According to the Seismic Intensity Map With Respect to the Official Earthquake Hazard Map ................................................... 37

Table 3.2 Richter Magnitude Scale ........................................... 40

Table 3.3 European Macro Seismic Scale (EMS-98) ............................ 42

Table 3.4 Modified Mercalli Intensity Scale (MM) ............................... 43

Table 3.5 Relationship between the Richter Magnitude Scale and Modified Mercalli Intensity Scale ................................................. 44

Table 3.6 Expected Hazard Intensity Level Distribution of Province and SubProvince Centers....

Table 3.7 Distribution of Settlements According to Number of Settlements and Total Population with Seismic Hazard Intensity Levels of 6.5 and Above

Table 3.8 The Distribution of Province and Sub-Province Centers with Reference to all Seismic Intensity Levels According to Total Population.

Table 3.9 The Distribution of Province and Sub-Province Centers with Reference to all Seismic Intensity Levels According to Number of Settlements....57

Table 3.10 Building Stock Categories of Settlements According to Construction Type and Number of Storeys $(6.5+$ Seismic Intensity) ...................59

Table 3.11 Building Stock Averages of Settlements According to Construction

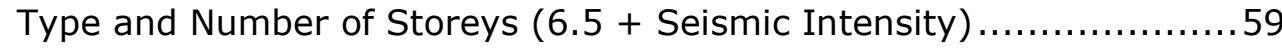

Table 3.12 Building Stock Categories of Settlements According to Construction Type and Number and Storeys by Percentages (6.5 + Seismic Intensity)

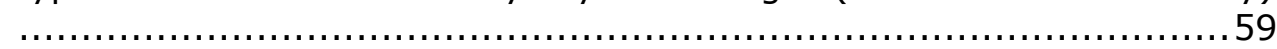

Table 3.13 Building Stock Categories of Settlements According to Construction Type and Number and Storeys by Percentages (6.5 + Seismic Intensity) .......................................................................... 59

Table 3.14 Description of Damage Grades in MSK-81 Intensity Scale .............63 63

Table 3.15 Coefficients of Likely Forms of Loss in the Building Stock of Settlements Subject to Varying Levels of Seismic Intensity 64

Table 3.16 Top-20 Settlements for 0-50.000 Population Prioritized According to

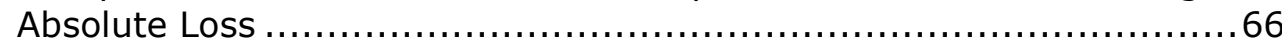

Table 3.17 Top-20 Settlements for 50.000-490.000 Population Prioritized According to Absolute Loss. 
Table 3.18 Metropolitan Provinces Prioritized According to Absolute Loss Levels.

Table 3.19 Average Absolute Loss According to the Settlement Categories......68

Table 3.20 Top-20 Settlements for 0-50.000 Population Prioritized According to

Relative Loss .......................................................... 70

Table 3.21 Top-20 Settlements for 50.000-490.000 Population Prioritized According to Relative Loss....

Table 3.22 Metropolitan Provinces Prioritized According to Relative Loss Levels 72

Table 3.23 Average Relative Loss According to the Settlement Categories .......72

Table 3.24 Dependent Variables of the top-20 Settlements for 0-50.000 Population

Table 3.25 Dependent Variables of the top-20 Settlements for $50.000-490.000$

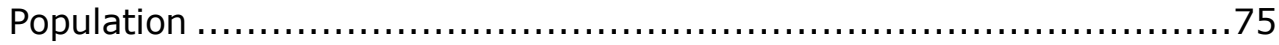

Table 3.26 Dependent Variables of the Research for Metropolitan Cities ...........75

Table 4.1 Average Values of Population in Settlement Categories..................78

Table 4.2 Average Values of Population Growth Rates in Settlement Categories 79

Table 4.3 Average Values of Agglomeration Rates in Settlement Categories .....80

Table 4.4 Population Density in Settlement Categories ............................ 81

Table 4.5 Average Values of Development Index in Settlement Categories.......82

Table 4.6 Independent Variables of the Top-20 Settlements for 0-50.000 Population

Table 4.7 Independent Variables of the Top-20 Settlements for $50.000-490.000$

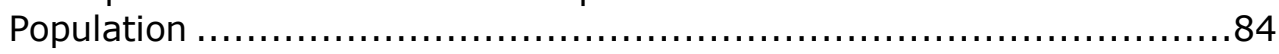

Table 4.8 Independent Variables for Metropolitan Cities ...........................85

Table 5.1 Dependent and Independent Variables of the Top-20 Settlements for

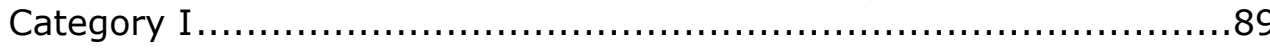

Table 5.2 Best Subsets Regression 1: Y1 versus $x 1 ; x 2 ; x 3 ; x 4 ; x 5 \ldots \ldots \ldots \ldots . . .90$

Table 5.3 Best Subsets Regression 2: Y2 versus $\times 1 ; \times 2 ; \times 3 ; \times 4 ; \times 5 \ldots \ldots \ldots \ldots . . .90$

Table 5.4 Dependent and Independent Variables of the Top-20 Settlements for

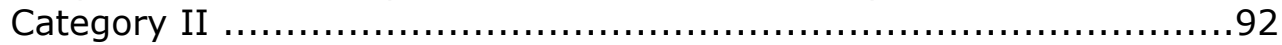

Table 5.5 Best Subsets Regression 3: Y1 versus x1; x2; x3; x4; x5 ............93

Table 5.6 Best Subsets Regression 4: Y2 versus $x 1 ; x 2 ; \times 3 ; x 4 ; x 5 \ldots \ldots \ldots \ldots . . .93$

Table 5.7 Dependent and Independent Variables of the Top-20 Settlements for

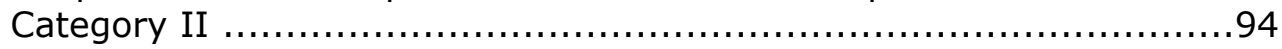

Table 5.8 Best Subsets Regression 5: Y1 versus x1; x2; x3; x4; x5 .............95

Table 5.9 Best Subsets Regression 6: Y2 versus x1; x2; x3; x4; x5 ............96

Table 5.10 Evaluation of Best Subsets Regression Analyses .....................97

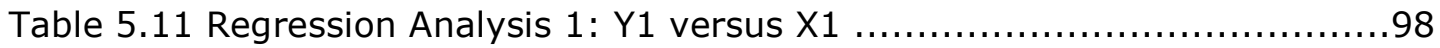

Table 5.12 Regression Analysis 2: Y1 versus X5 ................................. 100 
Table 5.13 Regression Analysis 3: Y2 versus X1 ............................. 101

Table 5.14 Regression Analysis 4: Y2 versus X3 ............................... 103

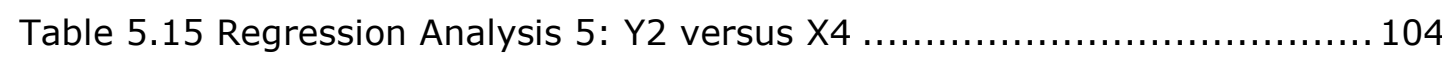

Table 5.16 Regression Analysis 6: Y2 versus X5 ............................. 106

Table 5.17 Regression Analysis 7: Y1 versus X2 ............................. 108

Table 5.18 Regression Analysis 8: Y1 versus X4 ............................... 109

Table 5.19 Regression Analysis 9: $Y 2$ versus X1 ............................ 111

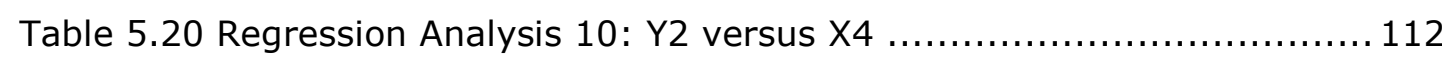

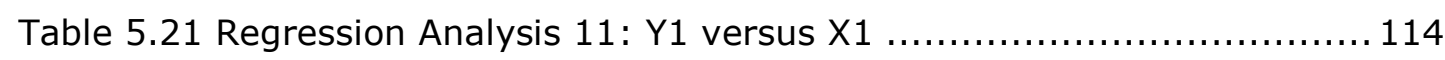

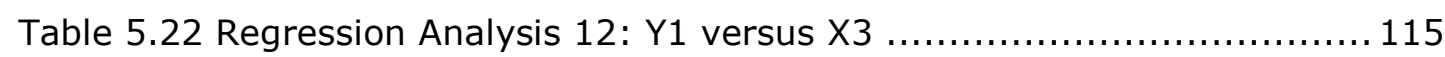

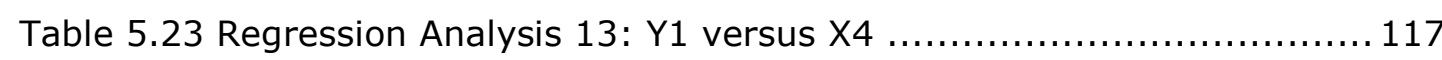

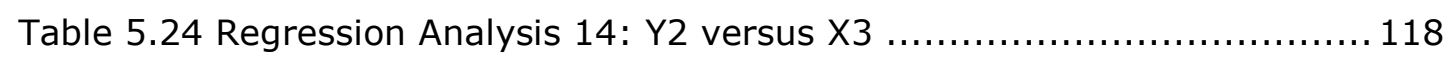

Table 5.25 Regression Analysis 15: Y2 versus X4 ............................. 119

Table 5.26 Evaluation of Regression Analyses .................................. 121

Table 6.1 Top-20 Settlements Prioritized According to Absolute Loss that Mitigation Plans Should be Compulsory .............................. 125

Table 6.2 Metropolitan Provinces Prioritized According to Absolute Loss that Mitigation Plans Should be Compulsory ................................ 125

Table 6.3 Top-20 Settlements Prioritized According to Relative Loss that Mitigation Plans Should be Compulsory ............................. 126

Table 6.4 Metropolitan Provinces Prioritized According to Relative Loss that Mitigation Plans Should be Compulsory ............................... 126

Table 6.5 Key events in the evolution of seismic design codes in Turkey ........ 132

Table 6.6 The Effective Ground Acceleration Coefficient.......................... 133

Table 6.7 Evaluation of the Top-20 Settlements Prioritized According to the Absolute Loss with respect to the Hazard Zones Determined by the Official Earthquake Hazard Map

Table 6.8 Comparison of the Top-20 Settlements Prioritized According to the Relative Loss with the Hazard Zones Determined by the Official Earthquake Hazard Map ............................................. 137

Table 6.9 Rates of Compulsory Earthquake Insurance Scheme .................. 140

Table 6.10 Comparison of the Top-20 Settlements Prioritized According to the Absolute Loss with the Hazard Zones Determined by the Official Earthquake Hazard Map....

Table 6.11 Comparison of the Top-20 Settlements Prioritized According to the Relative Loss with the Hazard Zones Determined by the Official Earthquake Hazard Map

Table 6.12 Comparisons of the Top-20 Settlements Prioritized According to the Absolute Loss with the Location of Settlements According to the Investment Priority Regions 146 
Table 6.13 High Risk Settlements Located in the Region Six Prioritized According to the Absolute Loss .................................................. 149

Table 6.14 Comparison of the Top-20 Settlements Prioritized According to the Relative Loss with the Location of Settlements According to the Investment Priority Regions..............................................150 


\section{LIST OF FIGURES}

\section{FIGURES}

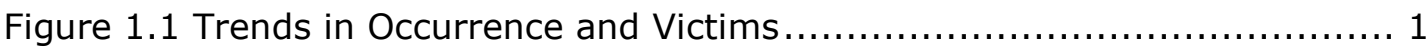

Figure 1.2 Relative Vulnerability for Earthquakes $1980-2000 \ldots \ldots \ldots \ldots \ldots \ldots \ldots . \ldots \ldots$

Figure 1.3 Absolute and Relative Mortality Risk for Earthquakes ................. 4

Figure 1.4 Vulnerabilities in Plan Making and Building Construction Functions.... 8

Figure 1.5 Chronology of International Disaster Management Policy Development

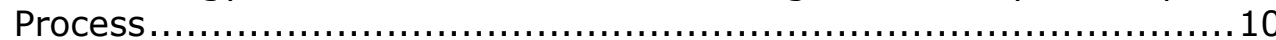

Figure 1.6 Expected Outcome, Strategic Goals and Priorities for Action 2005-

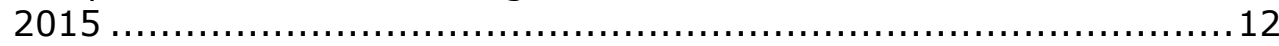

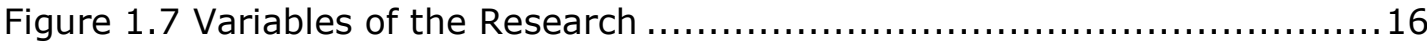

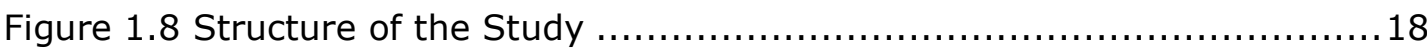

Figure 2.1 Basic Stages in a Risk Assessment Process ............................. 20

Figure 2.2 Questions to Ask In a Risk Assessment Process ........................ 21

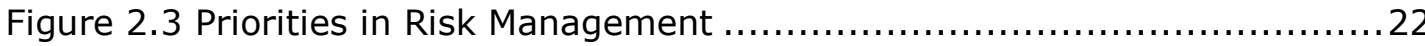

Figure 3.1 Dependent and Independent Variables of the Research .................34

Figure 3.2 Earthquake Hazard Zoning Map of Turkey ............................ 35

Figure 3.3 Intensity Distributions for 72 Years and $\% 50$ Probability ................36

Figure 3.4 Evaluation of Settlements Subject To 6.5+ Seismic Intensities According To the Seismic Intensity Map with Respect to the Official Earthquake Hazard Map .................................................. 38

Figure 3.5 The Richter, Modified Mercalli and the Moment Magnitude Scales ....44

Figure 3.6 Flow Chart of Settlement Level Loss Determination ................... 48

Figure 3.7 Intensity Distributions for 72 Years and \%50 Probability ...............49

Figure 3.8 Spatial distributions of 72 -year return period intensity and $50 \%$ probability and distribution of settlements ............................ 50

Figure 3.9 Expected Hazard Intensity Level Distributions of Province and Sub-

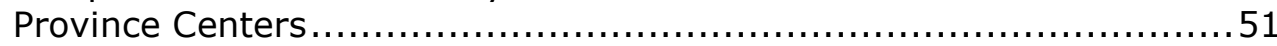

Figure 3.10 The Frequency Distribution of Province and Sub-Province Centers According to Population ................................................. 53

Figure 3.11 The Frequency Distribution of Province and Sub-Province Centers According to Number of Settlements ................................... 53

Figure 3.12 The Distribution of Province and Sub-Province Centers According to Number of Settlements ................................................. 54

Figure 3.13 The Distribution of Province and Sub-Province Centers According to Total Population ........................................................... 54

Figure 3.14 Spatial Distributions of Settlement Categories ........................55 
Figure 3.15 The Distribution of Province and Sub-Province Centers with Reference to all Seismic Intensity Levels According to Total Population

Figure 3.16 The Distribution of Province and Sub-Province Centers with Reference to all Seismic Intensity Levels According to Number of Settlements.

Figure 3.17 Intensity Based Vulnerability Curves for Load-Bearing and Low-Rise

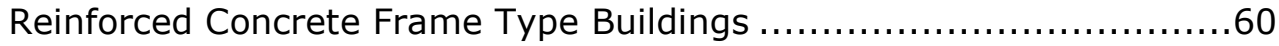

Figure 3.18 Intensity Based Vulnerability Curves for Mid-Rise Reinforced

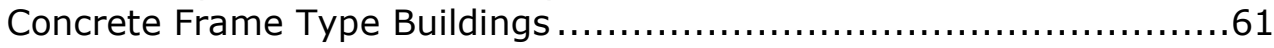

Figure 3.19 Intensity Based Vulnerability Curves for High-Rise Reinforced Concrete Frame Type Buildings ....

Figure 3.20 Classification of Damage to Reinforced Concrete Buildings ..........62

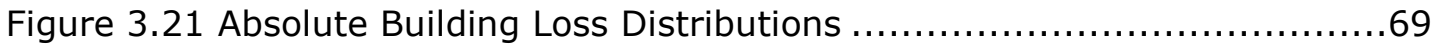

Figure 3.22 Relative Building Loss/ Loss Rate Distributions ......................73

Figure 4.1 Urban Population Distributions ..................................... 78

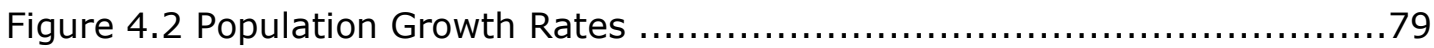

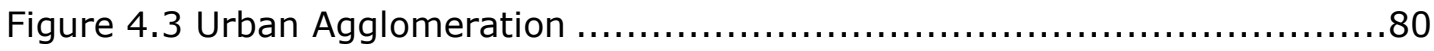

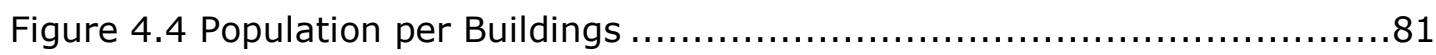

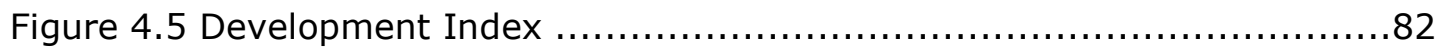

Figure 5.1 Vulnerability Measures and Assumed Contributing Attributes Overview .87

Figure 5.2 An Example For The Best Subset Regression Analyses.................88

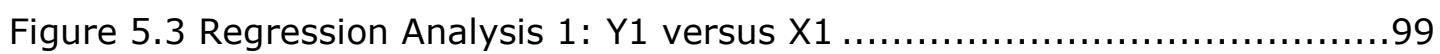

Figure 5.4 Regression Analysis 2: Y1 versus X5 ............................... 100

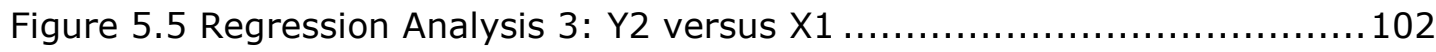

Figure 5.6 Regression Analysis 4: Y2 versus X3 .............................. 103

Figure 5.7 Regression Analysis 5: Y2 versus X4 ................................ 105

Figure 5.8 Regression Analysis 6: Y2 versus X5 .............................. 106

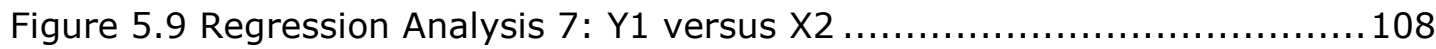

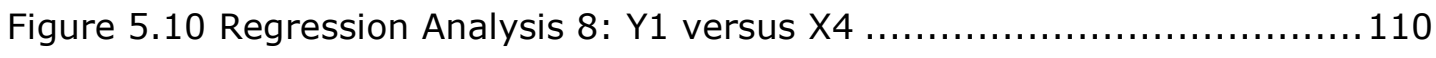

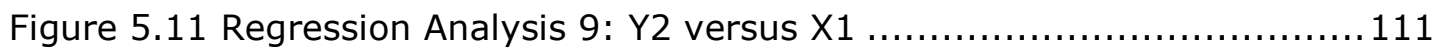

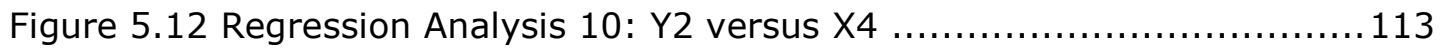

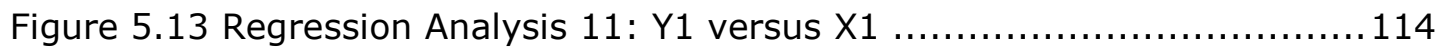

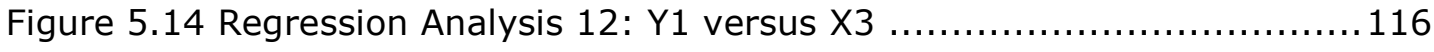

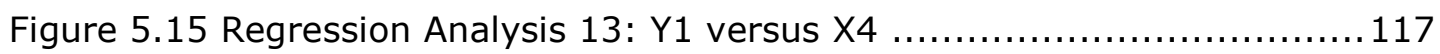

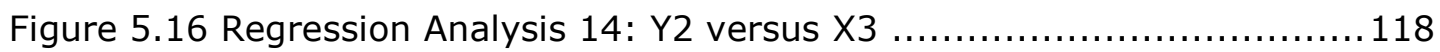

Figure 5.17 Regression Analysis 15: Y2 versus X4 .............................. 120 
Figure 6.1 Evaluation of the Top-20 Settlements Prioritized According to the Absolute Loss with Respect to the Hazard Zones Determined by the Official Earthquake Hazard Map

Figure 6.2 Evaluation of the Top-20 Settlements Prioritized According to the Relative Loss with Respect to the Hazard Zones Determined by the Official Earthquake Hazard Map .......................................... 138

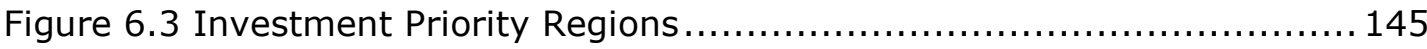

Figure 6.4 Evaluation of the Top-20 Settlements Prioritized According to the Absolute Loss with Respect to Investment Priority Region .............. 148

Figure 6.5 Evaluation of the Top-20 Settlements Prioritized According to the Relative Loss with Respect to Investment Priority Regions............. 151

Figure 6.6 Evaluation of Development Index Rates with Respect to the

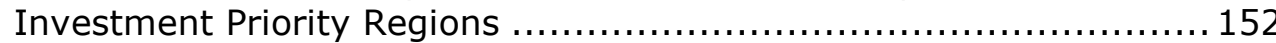




\section{LIST OF ABBREVIATIONS}

\begin{tabular}{|c|c|}
\hline ADPC & Asian Disaster Preparedness Centre \\
\hline AEL & Annualized Earthquake Loss \\
\hline AELR & Annualized Earthquake Loss Ratio \\
\hline AFDB & African Development Bank \\
\hline CGS & California Geological Survey \\
\hline CRED & Centre for Research on the Epidemiology of Disasters \\
\hline DMA-2000 & Disaster Mitigation Act of America \\
\hline DRM & World Institute for Disaster Risk Management \\
\hline DRR & Disaster Risk Reduction \\
\hline EM-DAT & Emergency Events Database \\
\hline EMPI & $\begin{array}{l}\text { Earthquake Master Plan of Istanbul } \\
\text { (Istanbul Deprem Master Planı - IDMP) }\end{array}$ \\
\hline EMS & European Macro Seismic Scale \\
\hline FEMA & Federal Emergency Management Agency \\
\hline GAR & Global Assessment Report on Disaster Risk Reduction \\
\hline GDCD & $\begin{array}{l}\text { General Directorate of Civil Defense } \\
\text { (Sivil Savunma Genel Müdürlüğü - SSGM) }\end{array}$ \\
\hline GDDA & $\begin{array}{l}\text { General Directorate of Disaster Affairs } \\
\text { (Afet İşleri Genel Müdürlüğü - AIGM) }\end{array}$ \\
\hline HAZUS & Hazards United States \\
\hline IATF/DR & Inter-Agency Task Force on Disaster Reduction \\
\hline ICPD & International Conference on Population and Development \\
\hline IDNDR & International Decade for Natural Disaster Reduction \\
\hline IFRC & International Federation of Red Cross and Red Crescent Societies \\
\hline ISDR & International Strategy for Disaster Reduction \\
\hline
\end{tabular}


ISMEP Istanbul Seismic Risk Mitigation and Emergency Preparedness Project

JICA Japan International Cooperation Agency

KOERI Kandilli Observatory and Earthquake Research Institute (Kandilli Rasathanesi ve Deprem Araştırma Enstitüsü)

LESSLOSS Risk Mitigation for Earthquakes and Landslides Project

MDG Millennium Development Goals

MEU Ministry of Environment and Urbanism

MSK Medvedev - Sponheuer - Karnik Scale

NAF North Anatolian Fault Line

(Kuzey Anadolu Fay Hattı - KAF)

NGO Non-governmental Organization

(Sivil Toplum Örgütleri - STK)

PGA Peak Ground Acceleration

R-Sq (adj.) Adjusted R-Square

SEDI Socio-Economic Development Index

SPO State Planning Organization

TCIP Turkish Catastrophe Insurance Pool

(Doğal Afet Sigortalar Kurumu - DASK)

TEFER Turkey Emergency Flood and Earthquake Recovery

TEMAD Turkish Emergency Management General Directorate (Türkiye Acil Durum Yönetimi Genel Müdürlüğü - TAY)

TURKSTAT Turkish Statistical Institute

(Türkiye İstatistik Kurumu - TÜİK)

UCTEA Union of Chambers of Turkish Engineers and Architects (Türk Mühendis ve Mimar Odaları Birliği - TMMOB)

UN United Nations

UN/ISDR United Nations Inter-Agency Secretariat for the ISDR

UNDP United Nations Development Program

USGS United States Geological Survey 
WCDR Word Conference on Disaster Reduction

WSSD World Summit for Social Development

WSSD World Summit on Sustainable Development 


\section{CHAPTER 1}

\section{VULNERABILITIES AND RISKS IN SETTLEMENTS}

Over the past decade, countries across the world have witnessed thousands of major natural disasters that threaten the sustainability of cities, disrupting their resources and affecting millions of people through losses of life, serious injury and loss of assets and livelihoods. The number of reported natural disasters and their impact on human and economic development worldwide has been increasing yearly and shows a relentless upward movement. The well-known statistical analysis of the Munich-Re Geo Risk Research Group shows a threefold increase in the occurrence of extreme natural hazard events and an approximately sixfold increase in associated economic damages over the last three decades.

As shown in the Figure 1.1; the number of reported disasters in 2010 (385) approximated the annual average disaster occurrence during 2000 to 2009 (387). Besides, the number of victims increased from 198.7 million in 2009 to 217.3 million in 2010.

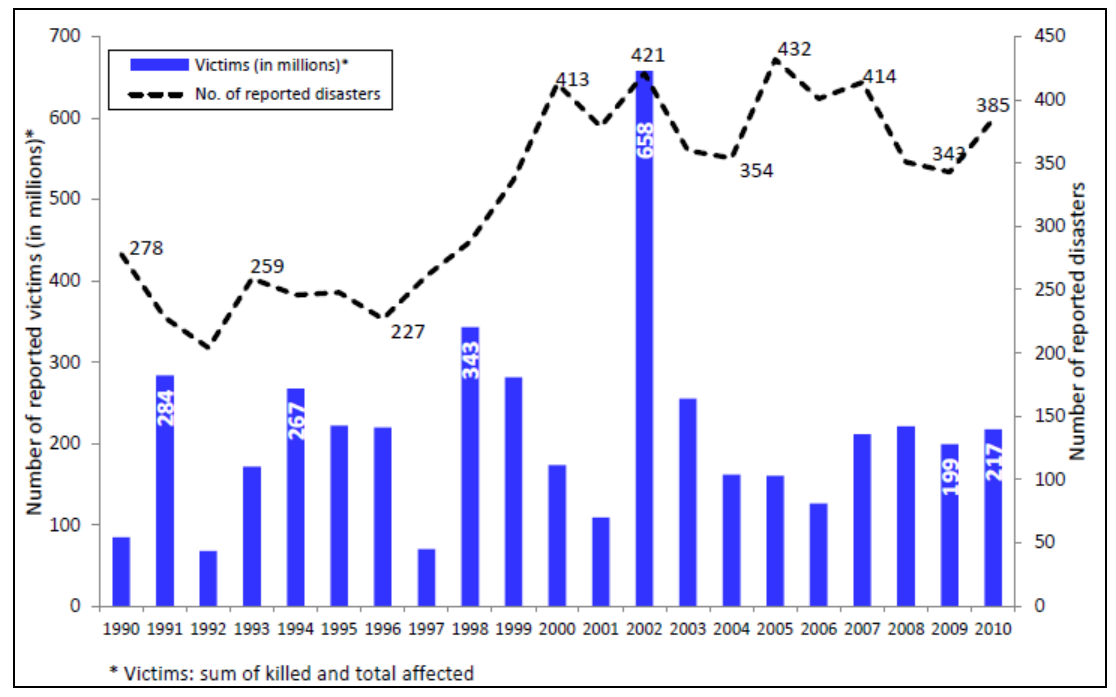

Figure 1.1 Trends in Occurrence and Victims (Source: CRED, 2010)

These trends especially in urban areas underline the need for still more efforts and more focused disaster risk management and reveal the necessity to recognize risk, make people aware of and prepared to live with risk (Bogardi, 2006). 
"The ongoing impacts of disasters have contributed to an increasing perception of human vulnerability to multiple hazards that can negatively impact assets and livelihoods among many people in many places around the world. As a result, there is increasing interest in how to build resilience to multiple hazards/risks at individual, household, community, local, national and international levels" (Siegel, 2011).

According to McEntire (2001) our attitude toward disasters has evolved from a fatalistic fear of 'Acts of God' to a broader understanding of the role human decisions play in determining our vulnerability and capacity to cope with the consequences of extreme events. In fact, we can say that there has been a major paradigm shift in the development community to increasingly focus attention on causes of human vulnerability and on building resilience. In other words the paradigm shifts from relief and response to mitigation, risk assessment and disaster risk management.

Today, there is increasing recognition that risk and vulnerability are crucial elements in reducing the negative impacts of hazards and thus essential to the achievement of sustainable development. This makes natural disaster risk reduction and mitigation ranks among the top 10 most important and urgent global issues of the twenty-first century.

As the number of events and the losses from disasters are increasing worldwide, natural disaster events occurred in Turkey are increasing as well. When we examine the natural disaster profile of Turkey we can easily say that "Turkey is a disaster-prone country and has always been vulnerable to various kinds of natural hazards, because of its geology, topography and meteorological conditions. These hazards, coupled with high physical and social vulnerability, have caused excessive losses of life, injury and damage to property" (Jica, 2004).

According to the Summarized Table of Natural Disasters in Turkey; 151 natural disaster events occurred in Turkey since 1900 and these disasters can be classified in seven groups as earthquakes, epidemic, extreme temperature, flood, slides, storms and wild fires. As a result of these disaster events; 91.431 people lost their lives, 8.902 .008 people affected and the total damage is 25 billion USD.

The statistics of number of events, death ratios and all the other values exposed that earthquakes are far and away in the first place and the biggest portion of the losses is related to the earthquakes. This portion is $48.3 \%$ of events, $96.9 \%$ of deaths, $77.3 \%$ of affected people and $91.2 \%$ of total damage. 
Table 1.1 Summarized Table of Natural Disasters in Turkey from 1900 to 2011 (Source: EM-DAT, 2011)

\begin{tabular}{|l|r|r|r|r|}
\hline & $\begin{array}{c}\text { Number } \\
\text { of Events }\end{array}$ & \multicolumn{1}{c|}{ Killed } & \multicolumn{1}{c|}{$\begin{array}{c}\text { Total } \\
\text { Affected }\end{array}$} & $\begin{array}{c}\text { Damage US\$ } \\
\text { (000's) }\end{array}$ \\
\hline Earthquake & 73 & 88.589 & 6880841 & 22941400 \\
\hline Epidemic & 8 & 613 & 204855 & 0 \\
\hline Extreme Temp. & 7 & 100 & 8450 & 1000 \\
\hline Flood & 37 & 1.321 & 1778517 & 2195500 \\
\hline Slides & 12 & 693 & 14556 & 26000 \\
\hline Storm & 9 & 100 & 13639 & \\
\hline Wild Fires & 5 & 15 & 1150 & 2200 \\
\hline
\end{tabular}

As seen above, the disaster history of Turkey is dominated by earthquakes and earthquake is a synonym with the concept of disaster in Turkey.

Therefore, the United Nations Development Program (2004) announced Turkey as the third country according to the number of deaths as a result of earthquakes (See Figure 1.2) and Global Assessment Report on Disaster Risk Reduction (2009) identified Turkey in high risk class according to mortality risk for earthquakes (See Figure 1.3).

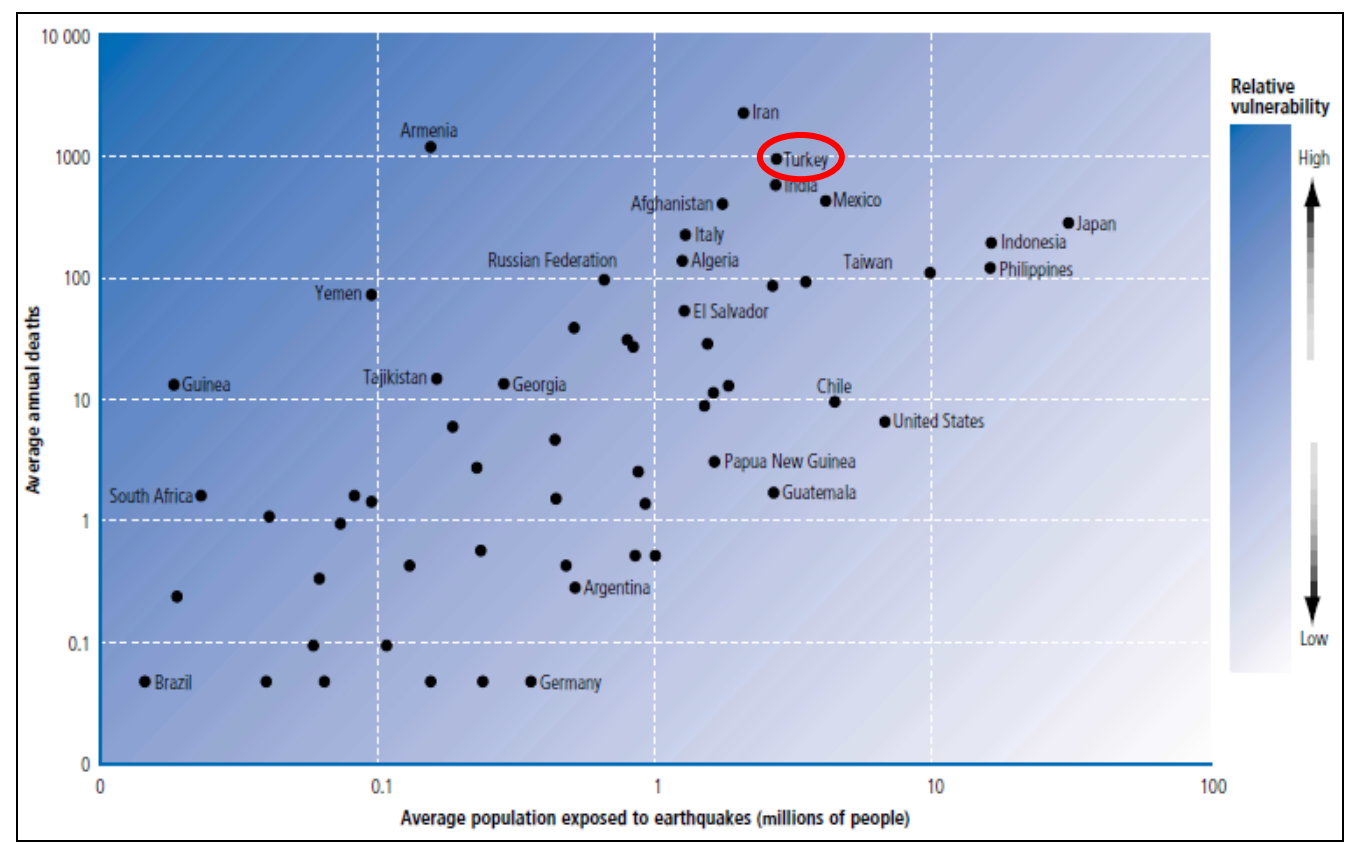

Figure 1.2 Relative Vulnerability for Earthquakes 1980-2000 (Source: UNDP, 2004) 


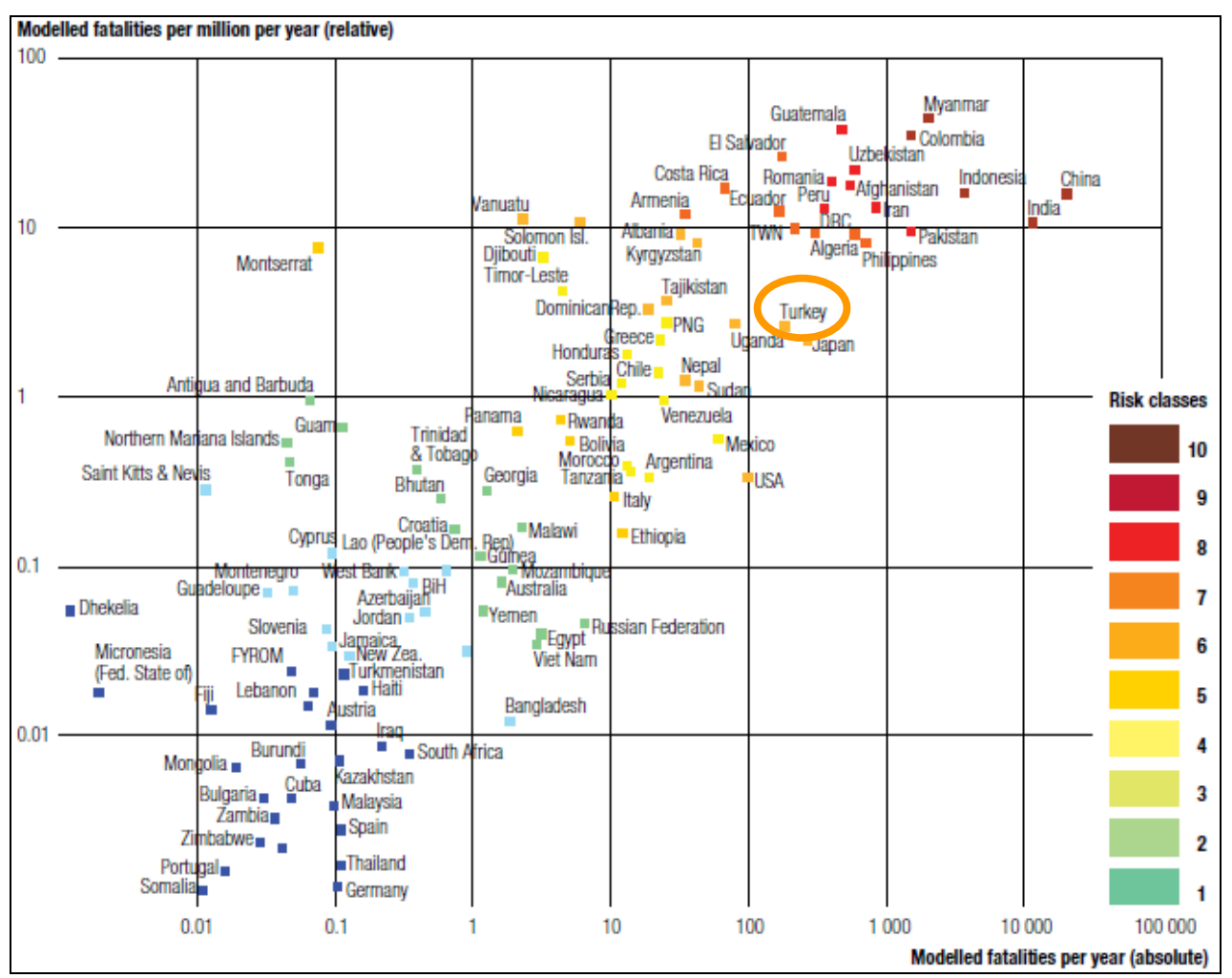

Figure 1.3 Absolute and Relative Mortality Risk for Earthquakes

(Source: GAR, 2009)

\subsection{Hazards, Vulnerabilities and Risks in World Cities and in Turkey}

As the social and economic effects of natural disasters have been rising in its multiples, an increasing number of hazards and risk researches from several different disciplines in earth, engineering and social sciences have contributed to our current knowledge of disasters and their management.

"However, this multiple exploration is based on different theoretical approaches and definitions. Scholars and practitioners of the hazards and disaster research use the terms hazard, vulnerability, risk and disaster, in multiple ways" (Gencer, 2007). Therefore, these concepts can be defined in a number of ways according to the relevant field, specific application on situational contexts. Although all of these definitions are acceptable, the most comprehensive and relevant definitions about these concepts for our field of thesis is made by United Nations International Strategy for Risk Reduction (UNISDR).

UNISDR Terminology on Disaster Risk Reduction (2009) defines;

Hazard as "A dangerous phenomenon, substance, human activity or condition that may cause loss of life, injury or other health impacts, property damage, loss of livelihoods and services, social and economic disruption, or environmental damage". 
Hazards can be divided into two categories as natural hazards and human-made hazards. Natural hazards are natural processes or phenomena that may constitute a damaging event like earthquakes, cyclones, floods, landslides and storms. Human-made hazards include dangers originating from technological or industrial accidents, dangerous procedures or infrastructure failures (industrial pollution, nuclear activities and industrial or technological accidents...). It is important to understand that the hazard itself does not result in a disaster.

Vulnerability as "The characteristics and circumstances of a community, system or asset that make it susceptible to the damaging effects of a hazard"

Different aspects of vulnerability can be grouped into four categories as physical, social, economic and environmental vulnerabilities, which all categories interact with each other and increase the susceptibility of a community to the impact of hazards.

"Societies need to measure their vulnerabilities in advance and make adequate provisions. In order to do this they have to understand the complex relationships between natural hazards and the related social, economic and environmental vulnerabilities. Recognizing and measuring vulnerabilities is the first and perhaps most important step towards disaster resilient societies" (Bogardi, 2006).

Risk as "The probability of harmful consequences, or expected losses (deaths, injuries, property, livelihoods, economic activity disrupted or environment damaged) resulting from interactions between natural or humaninduced hazards and vulnerable conditions".

"The risk of disaster is a compound function of the natural hazard and the number of people, characterized by their varying degrees of vulnerability to that specific hazard, who occupy the space and time of exposure to the hazard event. There are three elements here: hazard, vulnerability and risk" (Wisner et al., 2003).

Conventionally the relation between these elements is expressed by the notation;

\section{Risk = Hazard $x \quad$ Vulnerability (a probability) (value of likely losses)}

As is seen above, risk is the probability that a hazard will turn into a disaster and we can easily say that vulnerability and hazards are not dangerous, taken separately. But if they come together, they become a risk or, in other words, the probability that a disaster will happen (Greene, 2000). Accordingly, two communities located in hazard-prone areas with similar physical settings cannot be described as equal in risk if they differ in their vulnerabilities to the hazard.

The United Nation report (2004) on world urbanization prospects projects that more than 50 percent of the world's population will be dwelling in cities and almost all the growth of the world's population between 2000 and 2030 is expected to be absorbed by the urban areas of less developed regions. This is a clear indication of "the world is steadily becoming urban" (Boulle et al., 1991). 
"Urbanization process increases vulnerability to natural disasters through the concentration of people and assets" (Quarantelli 2003). The increasing urban risk results in vicious circle of disasters affecting urbanization and urbanization affecting disasters (Pelling 2003).

By their nature, cities are particularly vulnerable to natural hazards. Many of the elements that define cities also contribute to their vulnerability. One of the key elements to reduce disaster risk is to better understand how urban areas are at risk and how these patterns of risk differ from rural areas. "Under conventional understanding of disasters, public authorities and some of the professional approaches tend to assume that cities are only agglomerations of individual buildings and methods to achieve robust buildings would therefore suffice for seismic safety in a city. This is a misconception. Cities as distinct physical systems have their own complex functional integrity and are subject to failure should any of the sub-components receive a natural or human-made hazard impact. Cities are vulnerable in very many different ways, and manifest a multitude of risks" (Balamir, 2007).

Factors contributing to the increasing vulnerability of urban areas are a complex set of interrelated processes, including: the concentration of people and assets, the location of urban centers, the rapid growth of urban areas and unplanned urbanization, the modification of the built and natural environment through human actions, poverty and other social vulnerabilities and weak urban governance (ADPC, 2010).

"Urban stock texture, networks, distribution of land-uses, public facilities, their interaction with hazard prone locations, size of population served and many other factors have interdependent impacts on the vulnerabilities or resilience of settlements" (Prota, 2011). The risk in urban centers is compounded due to unplanned urbanization, development within high risk zones, lack of adherence to building codes, deficient urban management practices and inappropriate construction practices (Lewis and Mioch, 2005).

According to Pelling (2007), "Cities are better described as hotspots of disaster risk. Risk comes from increasing poverty and inequality and failures in governance, high population density, crowded living conditions and the residential areas close to hazardous industry or in places exposed to natural hazard".

The way in which cities are planned and built also contributes to urban vulnerability. Because resistance to natural hazards is rarely built into new construction and redundancy schemes are rarely incorporated into infrastructure, failure of a particular building or system in the event of a disaster can mean tremendous losses. "Nearsighted land-use planning puts people in harm's way, while a lack of commitment to mitigation leaves inhabitants to bear the full impact of disaster losses" (McBean and Henstra, 2003).

"Sectors of risk are distinctly manageable clusters of vulnerabilities at the citylevel for which a coordinated action is necessary. Different levels of spatial units (national, regional, city, local) could have entirely different sets of vulnerability and risk definitions, definitely different from risks at the building level" (Balamir, 2007). As cities have their own complex functional integrity, they are vulnerable in very different ways and very different risk sectors. Risk sectors are areas of causal relations on specific risks according to Earthquake Master Plan of Istanbul (EMPI). 
More than a dozen of city-level risk-sectors have been identified in Istanbul. Risk-Sectors of EMPI are given below;

- Risks in Macro-Form and Growth Tendencies (settlement configuration alternatives)

- Urban Fabric Risks (building height/proximity, plots, density, roads, carparks, etc.)

- Incompatible Land-Use Risks (buildings and districts)

- Risks of Productivity Loss (industrial plants)

- Risks in the Building Stock, Infrastructure and Lifelines

- Risks in Emergency Facilities and Lifelines (hospitals, schools, etc.)

- Special Risk Areas/ Special Buildings (landslide, flooding/historic buildings)

- Risks in Hazardous Uses (LPG and petrol stations, etc.)

- Open Space Deficiency Risks

Besides these risk sectors Balamir (2009) defines some of the city level risks in Turkey as:

"Hazardous locations of cities are historically inherited but it is the manner of our urbanization and deceptively convenient reinforced concrete structures produced at unprecedented rates without supervision that make them deep risk pools. Deficient open spaces, haphazard infrastructure, dangerous neighboring, illogical locationing of emergency facilities, uncontrolled industrial units are some of the city level risks directly related to physical planning. Administrative incapabilities and inert public attitudes are almost genetically programmed."

The deficiences in urban planning and building construction systems and the factors that make these processes more vulnerable is defined by Balamir (2004) as follows. It "indicates how over the decades, the urban planning system in Turkey has been left vacuously devoid of any concern in its provisions and procedures of tools and means for maintaining seismic safety" (Balamir, 2004). 


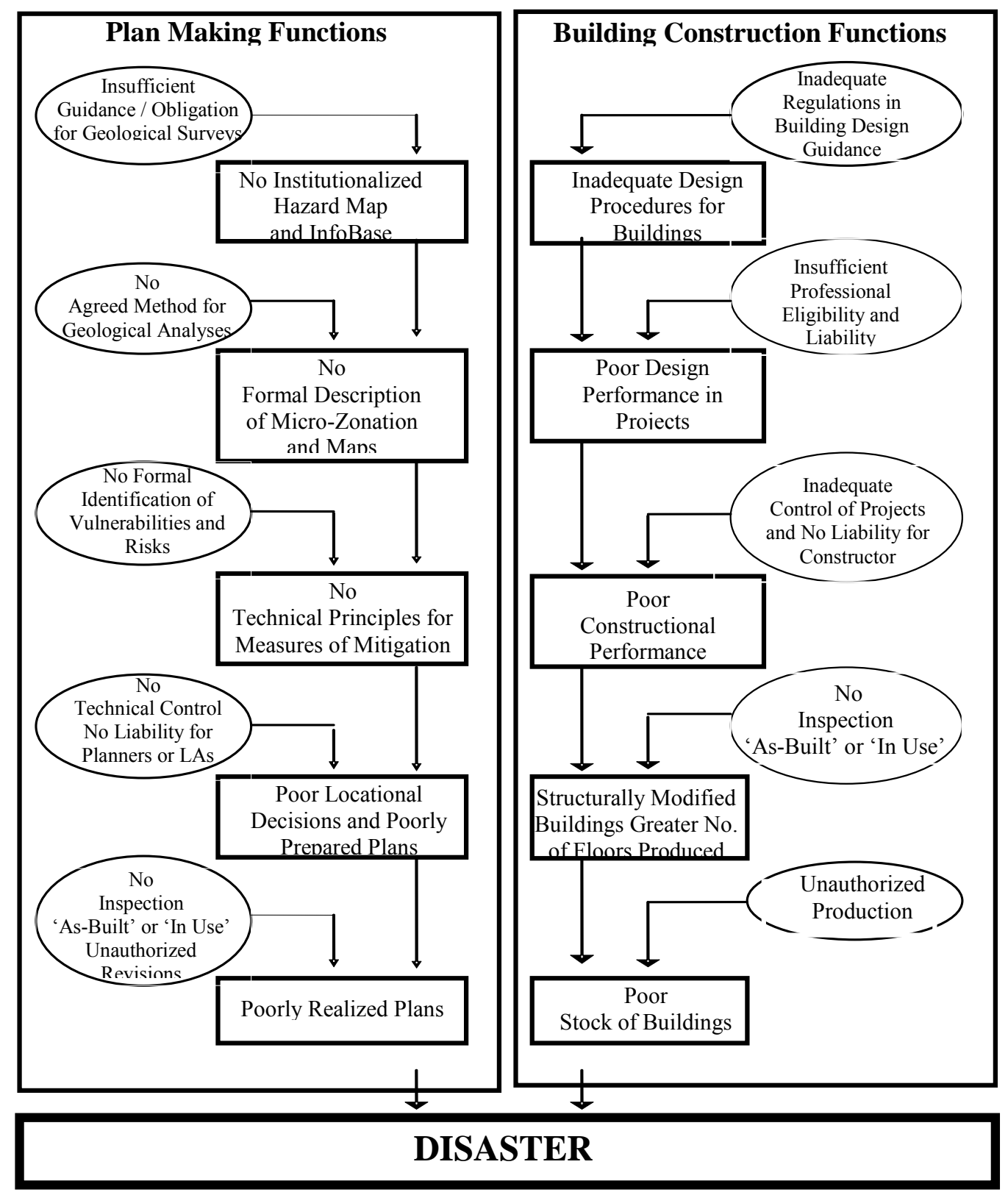

Figure 1.4 Vulnerabilities in Plan Making and Building Construction Functions (Source: Balamir, 2004) 


\subsection{The Need for Assessing Vulnerabilities for Policy Development and Implementation}

Over the past 30 years, disaster reduction has become an increasingly important issue on the international agenda and there has been a continuous evolution in the practice of crisis or disaster management.

These bodies of practice have been known, variously, as civil defense, emergency assistance, disaster response and relief, humanitarian assistance, emergency management, civil protection, disaster mitigation and prevention and total disaster risk management.

An increase in human casualties and property damage in the 1980's motivated the United Nations General Assembly in 1989 to declare the 1990's the International Decade for Natural Disaster Reduction (IDNDR).

With the effect of this declaration, the risk concept became popular in the academic literature after 1990's and the rise of risk reduction concept begs our understanding which accompanied a phenomenal quantitative growth in references to risk.

During the 1990 's, stimulated by the IDNDR, many researches dealing with risks and disasters were developed around the world. The topic gained importance and it is being increasingly recognized that the terms hazard, vulnerability and risk have had different meanings and implications from both the methodological and practical angles (Cardona, 2004).

The idea for conducting a global review of disaster reduction initiatives was born in the millennium, following the United Nations International Decade for Natural Disaster Reduction 1990-1999.

In 1999, UN decided to continue the activities on disaster prevention and vulnerability reduction carried out during the IDNDR.

It thus established the International Strategy for Disaster Reduction (ISDR), which is supported by the scientific and technical expertise and knowledge accumulated during the IDNDR.

Following this idea, a series of declarations of interest and determination to reduce risks have taken place at the international context (Balamir, 2005).

These are; World Conferences on "Risk Reduction" in Yokohama, Japan-1994, Toronto, Canada-2004 and Kobe, Japan-2005 have extended and sharpened this awareness about natural hazard risks and efforts of risk reduction on global agenda. 


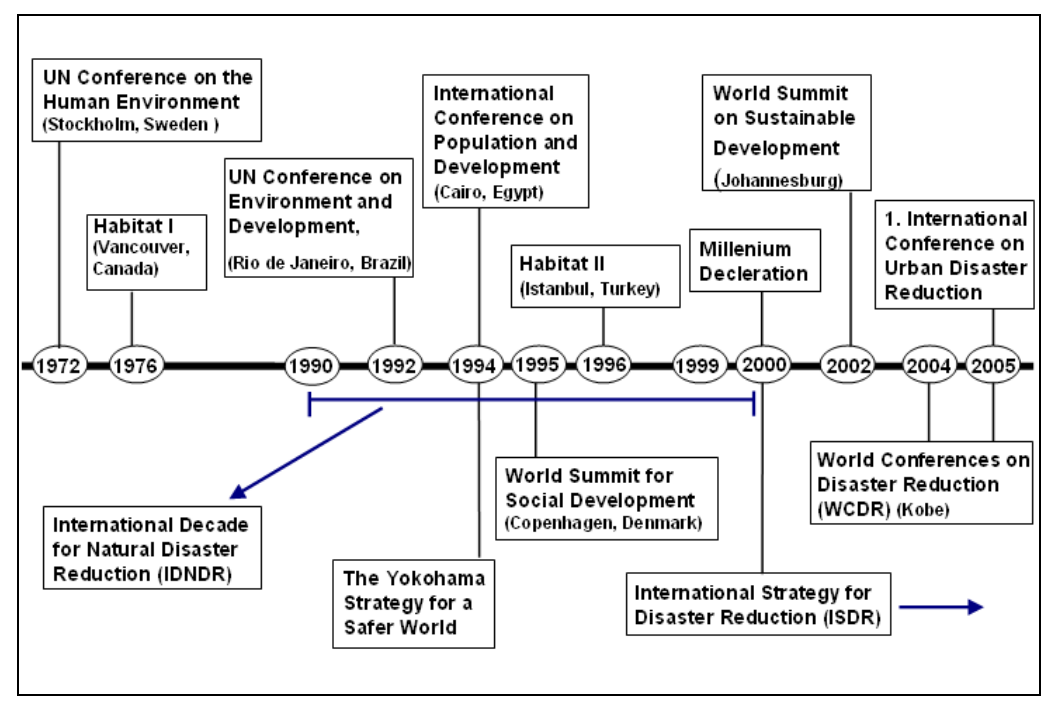

Figure 1.5 Chronology of International Disaster Management Policy Development Process

The Yokohama Strategy for a Safer World and its Plan of Action was a cornerstone point of reference for disaster reduction, comprising a range of commitments and identifying specific activities that have since served as an international blueprint in the field (Briceno, 2004). The Yokohama Strategy sets guidelines for action on prevention, preparedness and mitigation of disaster risk.

The Yokohama Strategy for a Safer World and its Plan of Action stressed that; "... each country has the sovereign responsibility to protect its citizens from the impact of natural disasters" and adopts the following ten principles;

1. "Risk assessment is a required step for the adoption of adequate and successful disaster reduction policies and measures.

2. Disaster prevention and preparedness are of primary importance in reducing the need for disaster relief.

3. Disaster prevention and preparedness should be considered integral aspects of development policy and planning at national, regional, bilateral, multilateral and international levels.

4. The development and strengthening of capacities to prevent, reduce and mitigate disasters is a top priority area to be addressed so as to provide a strong basis for follow-up activities to the Decade.

5. Early warnings of impending disasters and their effective dissemination are key factors to successful disaster prevention and preparedness.

6. Preventive measures are most effective when they involve participation at all levels from the local community through the national government to the regional and international level. 
7. Vulnerability can be reduced by the application of proper design and patterns of development focused on target groups by appropriate education and training of the whole community.

8. The international community accepts the need to share the necessary technology to prevent, reduce and mitigate disaster.

9. Environmental protection as a component of sustainable development consistent with poverty alleviation is imperative in the prevention and mitigation of natural disasters.

10. Each country bears the primary responsibility for protecting its people, infrastructure, and other national assets from the impact of natural disasters" (UNISDR, 1994).

After the Yokohama Strategy for a Safer World and its Plan of Action, the World Conference on Disaster Reduction (WCDR) in Kobe presents a milestone opportunity to bring together local, national and international decision-makers active in social and economic development and environmental management; disaster risk managers and practitioners; civil society; and community groups, setting a new international agenda to build disaster-resilient communities.

The WCDR in 2005 has the following five specific objectives;

1- " To conclude and report on the review of the Yokohama Strategy and its Plan of Action, with a view to updating the guiding framework on disaster reduction for the twenty-first century;

2- To identify specific activities aimed at ensuring the implementation of relevant provisions of the Johannesburg Plan of Implementation of the World Summit on Sustainable Development (WSSD) on vulnerability, risk assessment and disaster management;

3- To share good practices and lessons learned to further disaster reduction within the context of attaining sustainable development, and to identify gaps and challenges;

4- To increase awareness of the importance of disaster reduction policies, thereby facilitating and promoting the implementation of those policies;

5- To increase the reliability and availability of appropriate disasterrelated information to the public and disaster management agencies in all regions, as set out in relevant provisions of the Johannesburg Plan of Implementation" (UNISDR, 2005). 


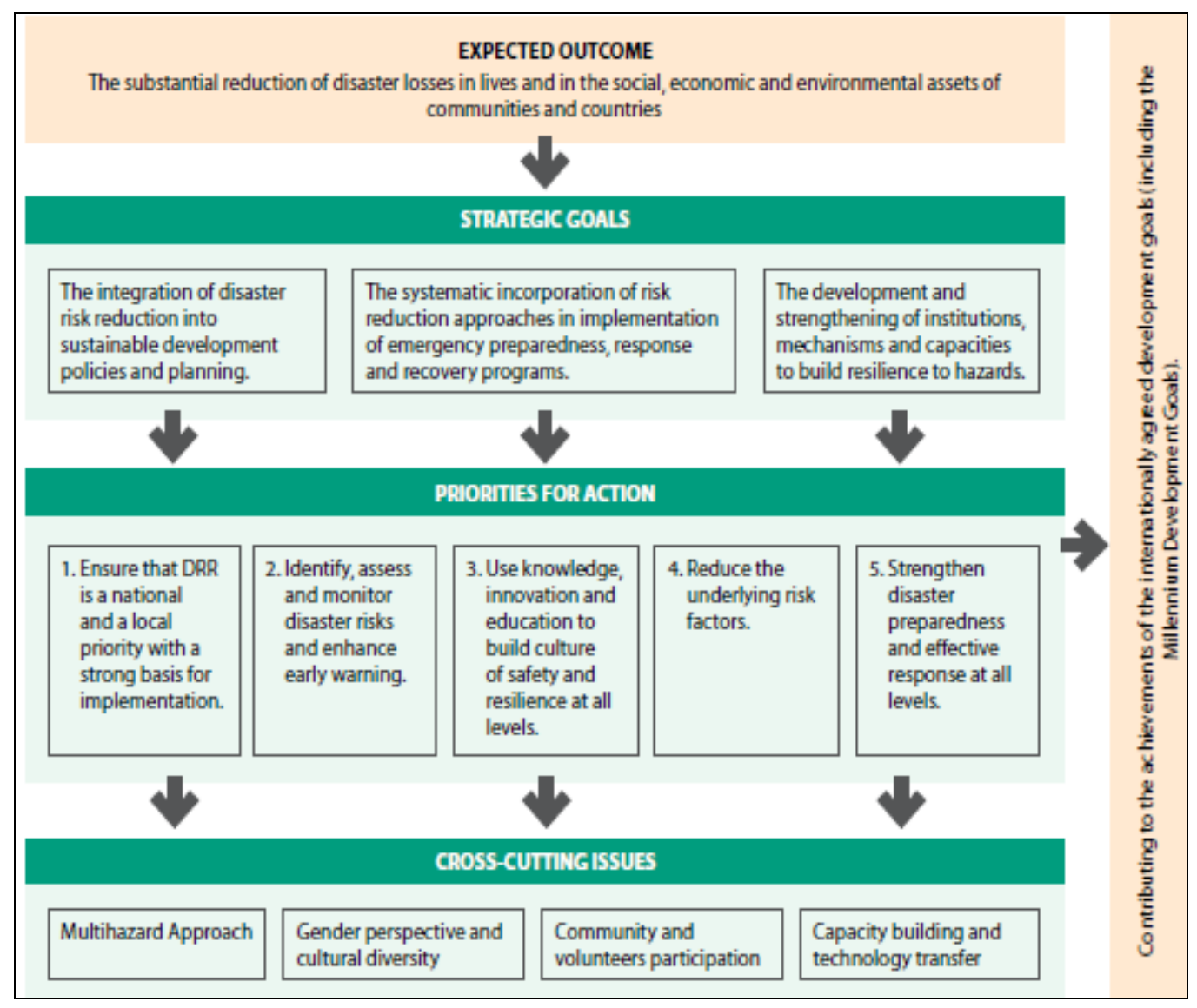

Figure 1.6 Expected Outcome, Strategic Goals and Priorities for Action 20052015

Source: (UNISDR, 2005)

Despite the fact that numerous countries revised their disaster policies for risk mitigation, Turkey as one of the current extreme risk cases in the world remains totally alien to the new policy. "Not only the Yokohama and Kobe Conference performances and the national report produced for Kobe fell far from describing the realities, but the administrations have refrained from communicating disaster affairs in the public sphere, abolishing the National EQ Council (2007), avoiding all suggestions made by the Council (2002), ignoring the need for new organizational and legal provisions. Neither has the participation of Turkey in the Global Platform (2007) produced tenable results" (Balamir 2007).

Report on Disaster Reduction prepared by the Republic of Turkey for the World Conference on Disaster Reduction in Kobe (2005) clearly reveals that the approach in Turkey to risk assessment, risk reduction and risk mapping are deficient and remains limited due to development of regulations that can not be fully implemented. This is a clear indication of Turkish disaster policy has mainly focused on the post-disaster period, no incentives or legislation existed to encourage risk analysis, risk mitigation or risk spreading approaches.

The conventional legal provisions and organizational habits in Turkey decisively target the post-disaster period. 
"The 'Disasters Law' is a regulatory device primarily for 'healing the wounds' and the Development Law ignores the reality and risks of earthquakes and contains no mechanism or procedure in itself to secure environmental, building and implementation standards for mitigation control. Therefore, a double bias for post-disasters has been the dominant nature of policy in Turkey" (Balamir, 2001).

However, "the earthquakes of 1999 generated a strong national determination in Turkey to devise new and effective methods of tackling disasters". Since then, much effort and debate has been taking place in political, official and academic circles to refresh the attitudes, management and structures of responsibilities, as well as to revise the related legal framework (Balamir, 2002).

After the 1999 earthquakes, three important steps were taken by the government and conventional approach in disaster policy has been restructured. With the newly introduced 'Obligatory Building Insurance', 'Building Control', and 'Professional Proficiency' systems, greater emphasis is given to mitigation efforts and the focus of attention have shifted towards risk management and the pre-disaster period.

Despite its deficiencies, these will hopefully change the conventional policy in building practice. "These decisions may be interpreted as attempts to convert the existing system that is over-occupied with crisis management and the aftermath of disasters into some form of an overall strategy for disaster mitigation" (Balamir, 2002).

On the other hand, risk reduction or mitigation policies demand new approaches, new methods and expertise. "The new policy requires a capacity for identifying various types of risks at different levels, making projections for likely consequences, and also a capacity for devising methods to 'avoid, reduce, and share' risks" (Balamir 2007).

"The disaster information system in Turkey need to concentrate on settlements, and this system be managed by some central authority to maintain the high standards and rigour in upkeep. Settlements under high risks have to revise their development plans according to the micro-zonation information provided, and update them as new information becomes accessible and as new assessments of risks are made based on this set of data. 'Integrated Disasters Maps' need be institutionalized and incorporated in the Development Law, making such maps a prerequisite for all plan preparations and revision activities which in turn need be restructured to allow greater local community participation" (Balamir, 2001).

"World experiences indicate that pre-disaster risk mitigation efforts always prove to represent a more efficient use of resources, compared to costs born at the aftermath of disasters. Investments in the mitigation of seismic risks are particularly relevant in this context. There are numerous reasons why predisaster use of resources may be more efficient than resources disposed of in the post-disaster relief activities. Whereas former resources are employed in a carefully planned, transparent and competitive environment, the latter use of resources is often carried out in a panic environment and with the least of accountability" (Balamir, 2011). 
"Whereas the acquisition of former resources may be spread in time and between various local donors and may have lower 'opportunity costs', the need for immediate use of resources in the emergency environment will often represent random allocations, mistakes, unjustified expenditures, unavoidable high costs for unknown causes. Whereas, the former is likely to generate greater added values, the opportunity costs of immediately needed resources acquired, borrowed or allocated in the emergency environment will have greater and uncontrollable waste rates. The productive use of resources allocated for mitigation would necessitate the determination of risk priorities on the one hand, and different efficiency measures than used in market assessments on the other" (Balamir, 2011).

\subsection{Description of the Problem and Its Context}

Chronic seismic hazards and resulting secondary impacts are due to the geological conditions of Turkey and the nature of current response mechanisms. Local know-how of building and settlement that evolved over centuries eroded with the growth in population, and the introduction of reinforced concrete building economics. This makes cities the most vulnerable geographical and social entities in Turkey.

On the contrary, Turkish disaster policy has mainly focused on the post-disaster period and remains limited due to development of regulations that can not be fully implemented. No incentives or legislations existed to encourage risk analysis or risk mitigation approaches. This makes Turkey totally alien to the new risk mitigation policies and risk mapping approaches.

Accordingly, the Earthquake Hazard Map of Turkey, prepared by the General Directorate of Disaster Affairs (GDDA) in 1996, that is the basic premise of the disaster management system in Turkey remains deficient to the new risk mitigation policies.

Official Earthquake Hazard Zoning Map of Turkey segments the country into five macro-level regions, as determined by the statistical occurrence of seismic events and only indicates hazard exposure levels of provinces and settlements. Although both of these two notions represent distinct concepts, such distinction is not made in most policy orientations and hazard is often confused with the notion of risk.

Yet, two communities located in hazard-prone areas with similar physical settings cannot be described as of equal in risk if they differ in their vulnerabilities to the hazard.

Consequently, the official hazard map does not consider primary factors of risk, neither social vulnerabilities nor attributes of the building stock. It only indicates hazard exposure levels without providing any information about risk levels and does not specify any quantitative earthquake hazard parameters for any zone. Besides it doesn't indicates any information about ordering and prioritization of settlements in the same hazard zones, all settlements located in the same hazard zones are accepted as of equal in risk apart from their physical settings and vulnerabilities. 
These deficiencies of the official earthquake hazard map and the necessity of differentiations of locations should be made on risk-basis maps constitutes both the most crucial problem in disaster management system of Turkey and the main problematic of the study.

\subsection{Scope, Approach and Method of the Study}

The World Conferences on 'Risk Reduction' in Yokohama and Kobe provided a unique opportunity to promote a strategic and systematic approach to determination and reducing seismic vulnerabilities and risks of settlements. The principles and priorities determined by these conferences are a guiding framework on disaster reduction for the twenty-first century.

The Hyogo Framework for Action 2005-2015: Building the Resilience of Nations and Communities to Disasters determined five priorities for action:

1. Ensure that disaster risk reduction is a national and a local priority,

2. Identify, assess and monitor disaster risks and enhance early warning,

3. Reduce the underlying risk factors,

4. Use knowledge, innovation and education to build a culture of safety and resilience,

5. Strengthen disaster preparedness for effective response at all levels.

These priorities constitute the starting point of the research and the overall objective of this research is to evaluate how these priorities are served in the settlements of Turkey especially; in the identification, assessment and monitoring of disaster risks, the reduction of the risk factors and the use of knowledge to build a culture of safety and resilience. The major purpose of this research is to develop a method for the identification of vulnerabilities and prioritization of most vulnerable settlements in anticipation of earthquake related hazards.

With this purpose, the aim of this research is to examine the factors that determine seismic vulnerabilities and risks of settlements and establish analysis of seismic risks in cities and living environments could be determined on the basis of a set of attributes of the building stock. The scope is to exhibit and analytically compare such factors in settlements of Turkey.

Quantitative information about a set of attributes of settlements is investigated statistically to determine which of the factors contribute most to risk levels described locally. The seismic hazard maps of the Kandilli Observatory and Earthquake Research Institute (KOERI), Erdik estimations of seismicity and statistics published by the Turkish Statistical Institute (TurkStat), like census and housing data have a leading contribution to make. These secondary sources of information help to compose the database for a series of comparisons in the seismic vulnerabilities and risk levels of cities.

In order to determine the seismic vulnerabilities and risks of settlements, disaster component that reveals the settlement level loss in building stock is examined on one side and the basic attributes of settlements and their effects on loss levels on the other side. 
In the determination of seismic vulnerabilities and risks of settlements, risk in settlement units is defined as a function of material loss in the building stock with respect to the expected seismic event. It is assumed that loss in the building stock in each settlement can be used as a proxy to express the comparative loss of human life, economic loss, damages in infrastructural systems, as well as secondary and indirect levels of losses in the settlement. Therefore, settlement level loss in the building stock is the basic indicator of assumed risk and provides the dependent variables of the research.

The basic attributes of settlements are composed of building inventory data and related attributes of building stock on each settlement obtained from TurkStat. 'Building Construction Statistics', 'Building Census' and 'Population Census' prepared by TurkStat and 'Development Index' prepared by State Planning Organization is used within this research. Attributes of settlements that are assumed to contribute to vulnerabilities and estimated loss are measurable indicators as independent variables. Independent variables of the research are; Settlement Population, Population Growth Rate, Rates of Agglomeration, Population/Total Number of Buildings and Development Index.

This study is expected to provide information about the most effective attributes that could describe vulnerabilities best in cities and be related to an expression of risk in cities.

The basic question of the research is: "How do loss levels in building stock correlate to independent variables?" and regression analyses are used to examine this question.

Findings of such analysis could provide guiding criteria for the prioritization of mitigation measures in Turkey and the levels of absolute and relative loss could be used in the ordering of settlements for more effective disaster policy.

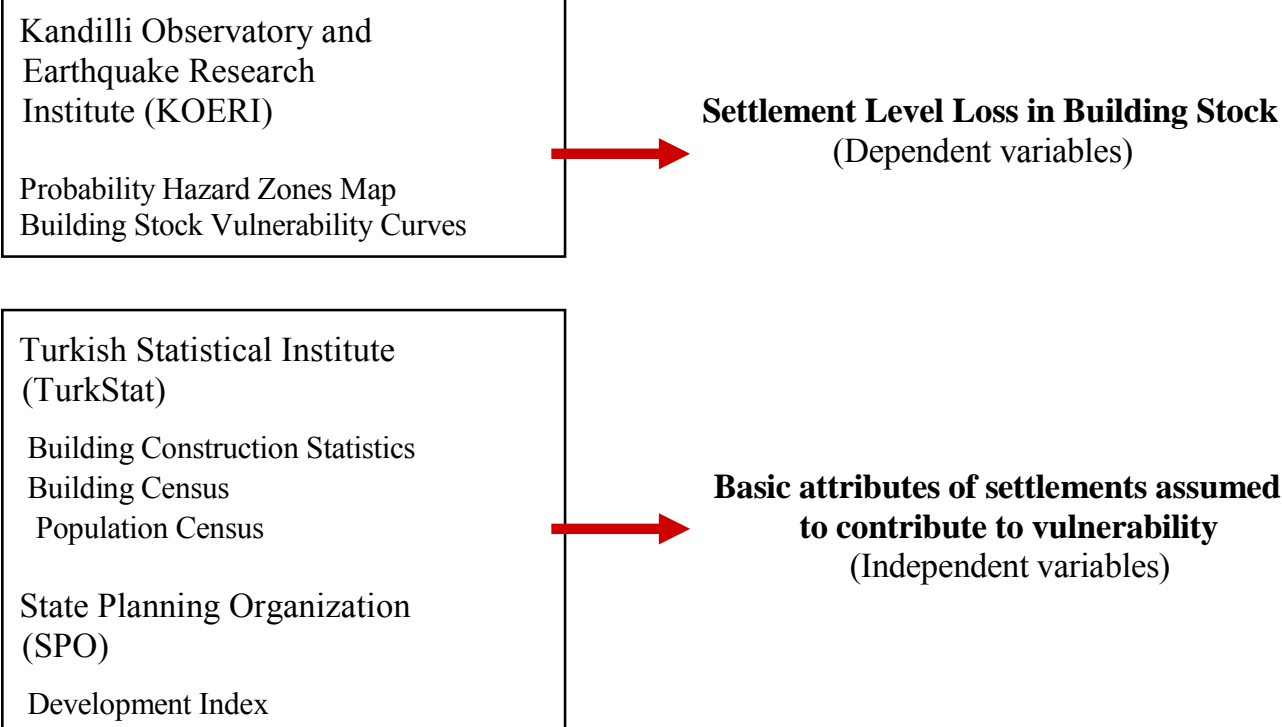

Settlement Level Loss in Building Stock

(Dependent variables)

Basic attributes of settlements assumed to contribute to vulnerability (Independent variables)

Figure 1.7 Variables of the Research 


\subsection{Structure of the Study}

This study composed of seven chapters. The first chapter describes the basic concepts and background of the study briefly, underlines the importance of assessing settlement level vulnerabilities for mitigation policies and defines the problem, scope, approach, method and the policy relevance of the study.

Second chapter identifies risk assessment researches and their relevance for planning and development of mitigation strategies describes stages and essential steps of risk assessment processes, settlement level vulnerabilities and risk mitigation policies and gives examples about settlement level vulnerability and risk assessment studies in Turkey and abroad.

Third chapter of the study determines seismic vulnerabilities and risks of settlements by evaluating seismic hazard intensity via seismic hazard maps and building stock vulnerability curves. Within the third chapter loss levels in building stock is defined as a function of likely seismicity and expected building loss estimations in the settlements of Turkey is identified.

Chapter four examines the attributes assumed to have contributed to vulnerabilities of settlements.

Chapter five investigates relations between estimates of loss and assumed contributing attributes by best subsets regression analyses and analyses by means of regression methods.

Chapter six evaluates the findings of the research according to mitigation policies and urban planning in several lines like Priorities for Mitigation Planning, Urban Standards, Law on Redevelopment of Areas under Disaster Risk, Building Codes, Building Supervision Practices, Insurance System and Investment Priorities.

The last chapter of the study, Chapter seven, briefly evaluates the key findings of the research and concludes the study by identifying further lines of investigations. 


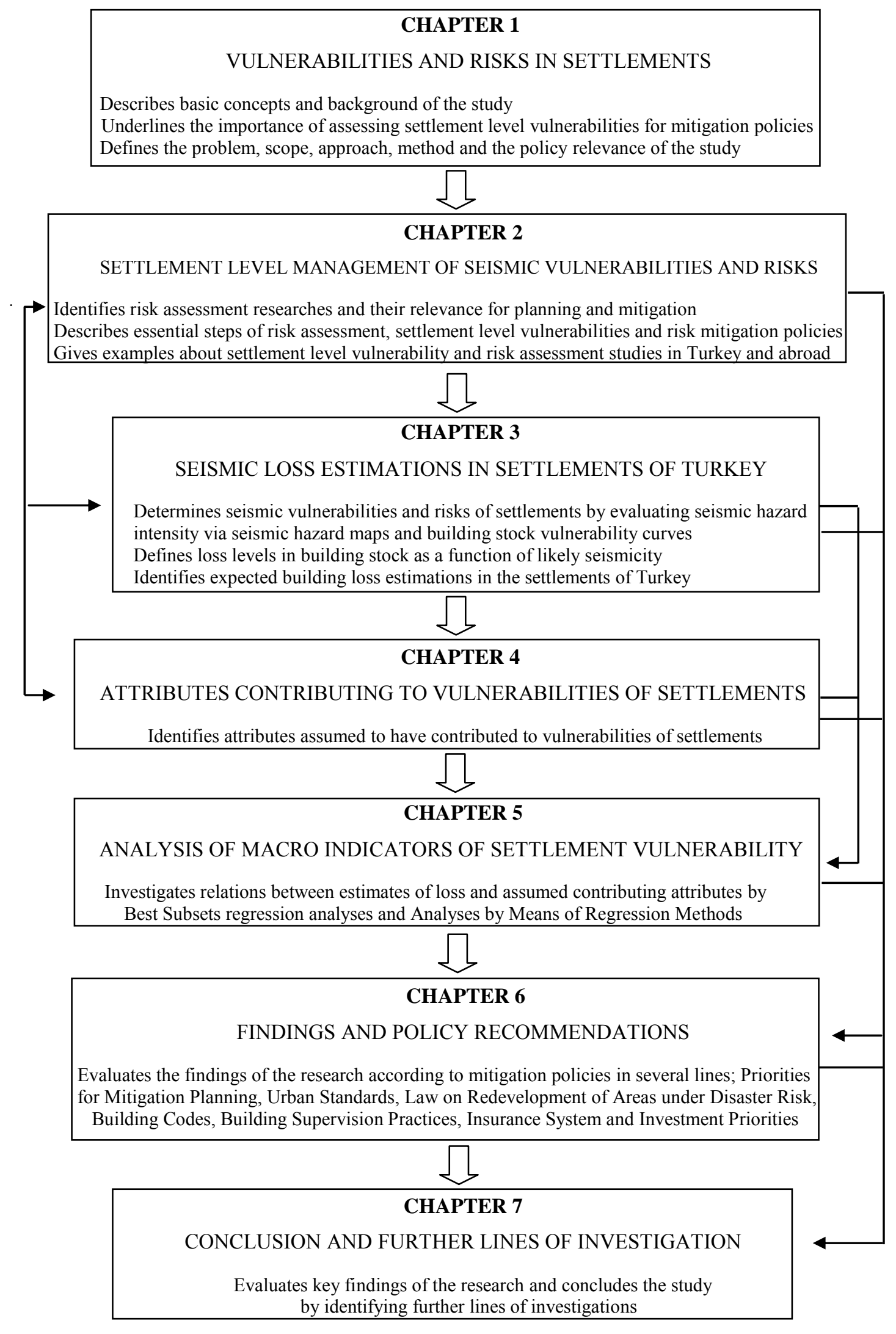

Figure 1.8 Structure of the Study 


\section{CHAPTER 2}

\section{SETTLEMENT LEVEL MANAGEMENT OF SEISMIC VULNERABILITIES AND RISKS}

\subsection{Risk Assessment Research and Studies}

Risk assessment is the process of measuring the potential loss of life, injury and property damage resulting from natural hazards by assessing the vulnerability of people, buildings and infrastructure to natural hazards. It helps basically to point out the fields has to be prioritized and to make better decisions in management issues and provides to estimate probable losses in human life, economy and infrastructure.

UNISDR Terminology on Disaster Risk Reduction (2009) defines Risk Assessment as "a methodology to determine the nature and extent of risk by analyzing potential hazards and evaluating existing conditions of vulnerability that together could potentially harm exposed people, property, services, livelihoods and the environment on which they depend".

Risk assessments include detailed quantitative and qualitative understanding of risk, its physical, social, economic and environmental factors and consequences. It is a necessary first step for any serious consideration of disaster reduction strategies.

Its relevance for planning and development of disaster risk reduction strategies was explicitly addressed during the IDNDR. "In the year 2000, all countries, as part of their plans to achieve sustainable development should have in place comprehensive national assessments of risks from natural hazards, with these assessments taken into account in development plans." This was also outlined in Principle 1 of the 1994 Yokohama Strategy and Plan of Action for a Safer World. "Risk assessment is a required step for the adoption of adequate and successful disaster reduction policies and measures" (UNISDR, 2004).

Risk assessment researches are conducted at different levels from global to local levels and for different purposes. But essentially, it provides a systematic process to answer questions about the risks faced by the community or city.

The risk assessment process focuses attention on areas most in need by evaluating which populations and facilities are most vulnerable to natural hazards and to what extent injuries and damages may occur. It gives us the answers about what these hazards can do to physical, social, and economic assets; which areas are most vulnerable to damage from these hazards; and the resulting cost of damages or costs avoided through future mitigation projects.

Risk assessment researches should not be undertaken as one-off analyses but as an integral and regular element of the planning process and are essential for disaster mitigation and preparedness (ADPC, 2010). 
According to UNISDR, risk assessments include; "a review of the technical characteristics of hazards such as their location, intensity, frequency and probability; the analysis of exposure and vulnerability including the physical social, health, economic and environmental dimensions; and the evaluation of the effectiveness of prevailing and alternative coping capacities in respect to likely risk scenarios". This series of activities is sometimes known as a risk analysis process.

The stages/essential steps of a risk assessment as suggested by UNISDR are given below;

1. Hazard Identification - includes identifying the nature and location of a threat.

2. Hazard Assessment - includes estimating the likelihood of experiencing the hazards and the characteristics, intensity, probability/frequency and potential severity of the hazards.

3. Vulnerability and Capacity Assessment - includes determining the existence and degree of vulnerabilities and exposure to a threat, identify the capacities, resources, and knowledge available to reduce the level of risk or the impact of hazards and cope with them.

4. Risk Estimation - includes combining all of the above steps to analyze the identified risks and the extent of their impact to determine levels of risk.

5. Risk Evaluation - includes examining how important the risks are to different groups of people and make decisions about which risks need countermeasures and priorities. The purpose of risk evaluation is to help identify and prioritize risk reduction measures.

Each step in a risk assessment process requires different types of data and there are a range of approaches and techniques that can be used to obtain and process the data. They range from quantitative analysis built around scenario modeling and mapping, to qualitative, non-technical approaches. The choice depends upon the kinds of output that need to be generated. The selection of methodology is dependent on the purpose of the assessment, its coverage (citywide or selected communities), the availability of reliable data and the availability of resources.

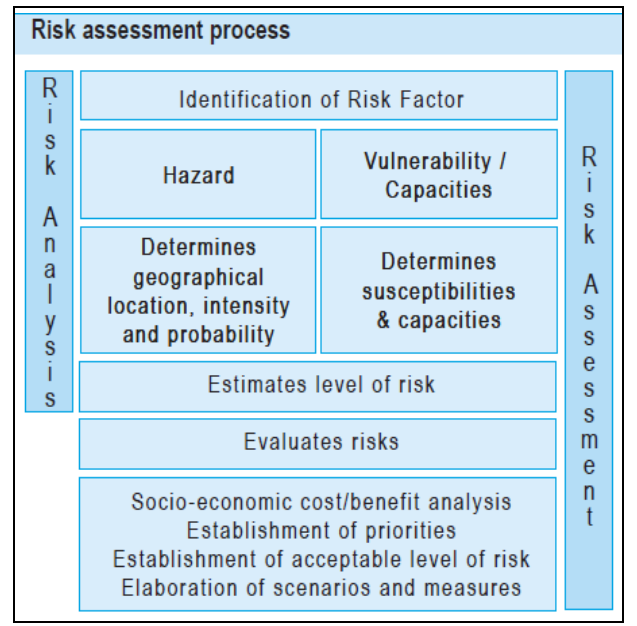

Figure 2.1 Basic Stages in a Risk Assessment Process (Source: UNISDR, 2004) 
The basic stages undertaken in a risk assessment process is shown in Figure 2.1 and the questions that could be asked in the basic stages of a risk assessment process can be seen in the Figure 2.2.

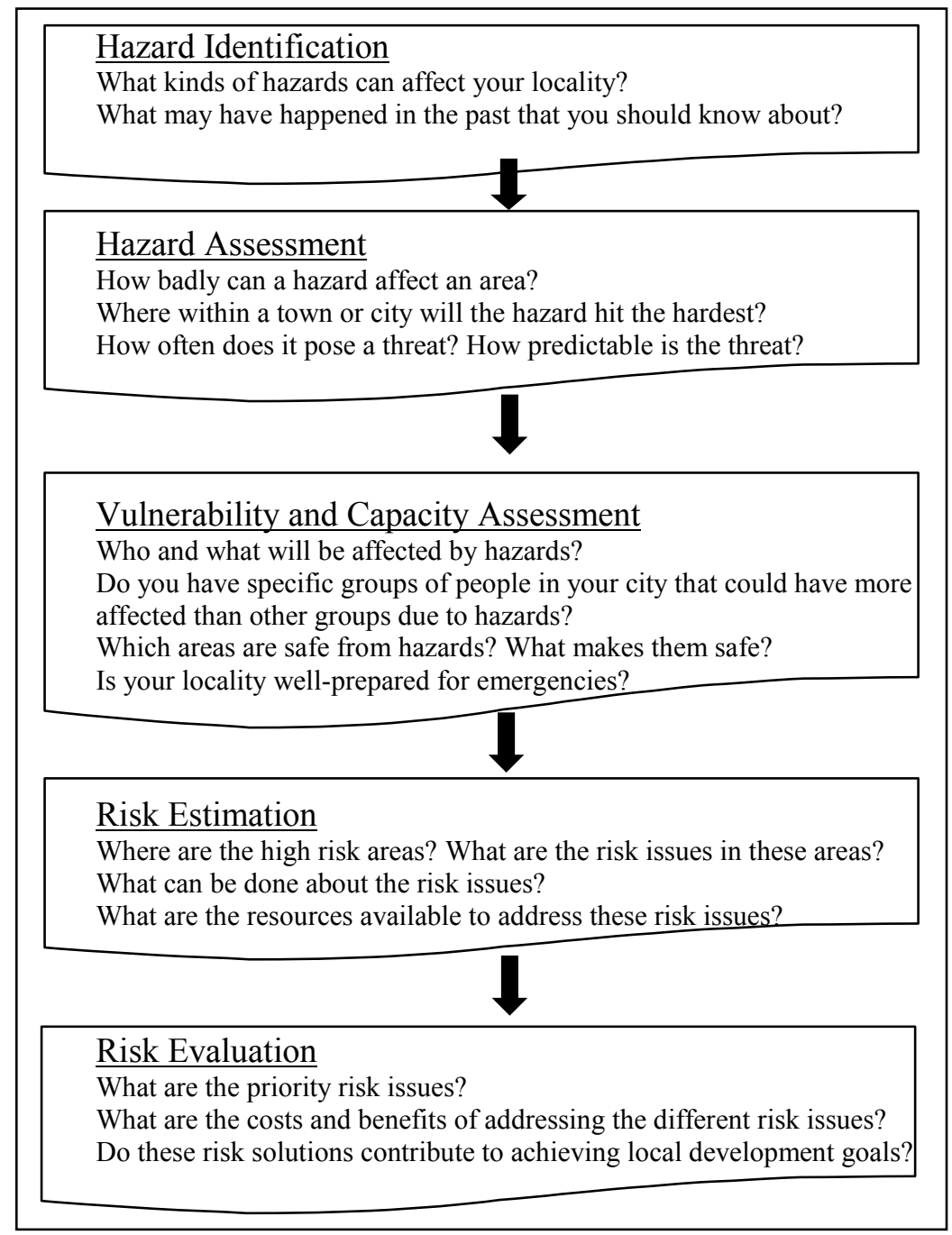

Figure 2.2 Questions to Ask In a Risk Assessment Process (Source: Adapted from ADPC, 2010)

Risk assessment results allow local government to decide where and what disaster risk reduction interventions can be most effective, establish early response priorities by identifying potential hazards, vulnerable people and assets and the capacities. Findings from risk assessments can be used in training and educational programs and as awareness campaigns in the pre-disaster phases. Risk assessments are also critical for guiding the future growth and land use patterns of cities and contribute to improved development decisions. Risk assessment provides the foundation for the rest of the mitigation planning process. 
Institutionalizing disaster risk assessment has many advantages and benefits because the efforts involved are important development management tools on its own. Disaster risk assessment is useful for several purposes, including: making risk-responsive physical and economic policy, regulatory framework for development, promoting participatory development through public education and awareness, private sector and business decision-making and risk sharing and transfer interventions (AFDB, 2004).

For a more effective bundle of mitigation measures, it is essential that the various forms of risk management should be performed in a logical sequence. This sequence is usually identified as the 'priorities of risk management' in any problem context, and is currently adopted by the World Bank (Kreimer, et. al., 1999) and other authors (Burby, 1999).

"'Avoidance of risks' has the foremost priority and largely to be maintained (in the case of earthquakes) by means of renewed land-use planning practices and regulations. 'Minimization of risks' is a second set of tasks to be undertaken in infrastructural networks and the design and production of buildings. Having accomplished both of the former steps of risk management, the remainder unavoidable risks are to be 'shared' between the members of the society by some explicitly preferred method and criteria. This set represents then the most general family of rules to follow at every scale of physical design for safe buildings and environments" (Balamir, 2001).

RISK AVOIDANCE
Avoidance (avoiding areas of natural hazard for settlement)
Distancing (specifying minimum distances from nodes of hazard)
PLANNING SERVICES
Refusal (prohibiting existing uses with high risks and source of chain-disasters)
risk zoning; plan preparation, implementation, control and up-dating services
$\mathbf{2}$
RISK MINIMIZATION
Discarding Risks At Source (eg. flood reservoirs, induced avalanches or land-slides)
Upgrading Resistance At Location of Effect (eg. levees, building codes, retrofitting)
ARCHITECTURAL AND ENGINEERING SERVICES
higher standards in disaster-resistant design and construction;
inspection of construction; building-retrofitting services
3
RISK SHARING
Aids and Subsidies (credits, rent subsidies for dwellings and business premises)
Donations (national/ international, voluntary/ organized, cash/in kind donations)
Taxes (extra burdens on others than those suffered losses in the disaster)
Insurance (compulsory building insurance)
FINANCIAL MANAGEMENT SERVICES
mailding up funds for pre-disaster and post-disaster requirements; efficient allocation of funds;
maintaining equity between fund-providers and between fund-users

Figure 2.3 Priorities in Risk Management

Source: (Balamir, 2001) 
Consequently, we can say that hazard assessment is an important first step in reducing vulnerability, but in order to reduce future losses from natural hazards, hazard assessment studies must be coordinated with settlement level risk mitigation efforts and planning policies.

\subsection{Settlement Level Vulnerability and Risk Mitigation Policies}

Mitigation at all levels is the dominant paradigm today as promoted by international organizations and academic circles since 1990s, which changed the conventional mode of thinking focused on emergency and crisis management policies since 1940s (Balamir, 2006).

The scope of mitigation in the new approach is best expressed in questions directed during pre-Kobe Conference (2005) activities, to the national representatives;

1. Political Commitment and Institutional Aspects: as revealed by legislation addressing disaster risk reduction, incorporation of risk reduction concepts, annual budget allocated for disaster risk reduction and encouragement and active participation in disaster risk reduction efforts by the private sector, civil society, NGOs, academia and media;

2. Risk Identification: as evident in hazard mapping, vulnerability and capacity assessments, mechanisms for risk monitoring and risk mapping, socio-economic and environmental impact analyses;

3. Knowledge Management: as practiced in risk information management systems, academic and research communities dealing with disaster reduction, educational programs related to disaster risk reduction, training programs, indigenous knowledge and wisdom, and public awareness programs;

4. Risk Management Applications and Instruments: as implemented through environmental management and risk reduction practices, financial instruments to reduce the impact of disasters, and technical measures or programs on disaster risk reduction. (UNISDR, 2005).

The foregoing themes serve as a core set of principles to understand, guide and monitor current status of disaster risk reduction and the information provided by countries served as one of the main inputs for the "Review of the Yokohama Strategy and Plan of Action for a Safer World.

Information Reports on Disaster Reduction prepared by the governments for the WCDR reveals the approaches of 113 countries to risk assessment, risk reduction and risk mapping. Although these questions refer to activities at a national level, similar issues could be rephrased at other (regional, city, local) levels as well.

Anti-risk regulatory devices have been a priority issue for a considerable number of countries during the past few years either as new laws or amendments made to existing ones (Balamir, 2006). Among these are USA (Disaster Mitigation Law, 2000), New Zealand (Civil Defense Law, 2002), South Africa (Disasters Law, 2002), Australia (COAG Report, 2002), UK (Civil Mitigation Law, 2004), Canada (Risk Mitigation Projects Program, 2004), Greece (Civil Protection Law, 2003), Armenia (2002) and others, apart from Japan which had such regulation in effect since 1961. 
Following the Kobe Conference, the Hyogo Framework for Action 2005-2015 was announced which gave greater emphasis on mitigation and also in section four of the declaration pointed to the need for 'mainstreaming disaster risk considerations into planning procedures', and 'develop ... tools for the reduction of disaster risk in the context of land-use policy and planning ... at the national and local levels' (UNISDR, 2005).

Most relevant, but complicated and least studied among those is the city-level mitigation practices. Formal analyses of risks and action for mitigation in cities are the least mainstreamed of measures into the existing systems of city planning or disaster management.

Concepts and methods of urban mitigation planning are entirely different from those of conventional building-level risk mitigation. Earthquake engineering has during the past 40 years developed an area of expertise that deals with the risk of building collapse due lateral forces. The city however is not just an aggregate of buildings, but a complex system comprising its own nested sets of 'risk sectors', as well as buildings of various categories to acquire different functions and priorities in the context of urban mitigation planning. Cities are vulnerable therefore in very many different ways, and manifest a multitude of risks (Balamir, 2006).

On the other hand, mitigation is a most relevant and rewarding effort particularly at the level of settlements. Cities as distinct physical systems have their own complex functional integrity, and are subject to failure should any of the subcomponents receive a natural or man-made hazard impact.

Secondly, cities are usually managed in their totality by an authority explicitly responsible for its functioning and safety. Risk avoidance/ reduction/ sharing as part of such responsibilities is however, a recent awareness, and often an imposed obligation. These are some of the reasons why seismic risk mitigation should be streamlined into city planning functions and must have a formal basis (Balamir, 2006).

Observing the need, Coburn and Spence (1992) claims that: "Earthquake protection should be seen as an additional element of normal urban planning. It should not be a separate activity from other planning operations, but rather an integral part of the planning process..." Despite the statement, no specific method of mitigation planning in cities is offered by him in procedural or in content terms, apart from a general indication to a number of related issues like microzonation, building robustness, classification of uses at risk, etc.

However, awareness of the immense potential urban planning has for the reduction of risks at city-level is expanding. More recently, Wamsler (2006) indicated that city-level impacts of natural hazards could be worse than in environments of other levels, and therefore urban planning with its existing and potential tools could be developed as a proactive and preventive institution. Yet there are external and internal impediments (Balamir, 2006).

Despite the recent international declarations and determination in the new policy of mitigation, many of the international organizations still employ and fund conventional wisdom, depriving mitigation planning from resources necessary for explorations in city level risks. 
Examining the 'perceptions and practices of the international aid organizations', Wamsler (2006) concludes that there exists a significant incompatibility between the various professional disciplines. This is largely due to distinct tradition, education, and experiences of these disciplines; different working priorities, different concepts and terminologies, as well as separate legal-institutional structures and financial resources they operate within. It is necessary to 'create new institutional and organizational structures at all levels, which favour integrated risk reduction in urban planning' (Balamir, 2006).

City-level mitigation planning is therefore, universally at the stage of formulation and consolidation in its methods and tools. Experience and know-how related to seismic mitigation at city level is not widely recognized at the moment, nor mainstreamed into the professional modes of conduct and the legal system, despite a number of approaches in this area.

According to Balamir (2007), recent attempts at clarifying urban risks and develop methods for city mitigation could be categorized in a number approaches:

(a) Urban planning services are usually demanded for the post-disaster reconstruction stages and rehabilitation works. Methodological know-how is available in this area, based on case experiences and theoretical discourse (Spangle Assoc., 1991, 1997; Schwab, 1998).

(b) Turning to risk mitigation efforts prior to disasters, one basic approach seems to concentrate at macro assessments of loss. These usually focus at national level policies (Godschalk et. al., 1999). In general, most of pre-disaster management of seismic risks in settlements is either confined to engineering tactics at the individual building level, or to the simulation modeling efforts (as in the case of HAZUS) at system level (Coburn and Spence, 1992; Coburn, 1995). Both approaches rely on expert decision-making and DSS in the monitoring of city systems, rather than community action and local participatory processes (Balamir, 2007).

(c) A third category often implicitly assumes that city-level risks could be identified based on engineering concepts and tools employed in the analysis of risks in building structures. City-level risks are equated to the sum of risks of the urban building stock. The discourse to justify the approach claims that "after all it is the buildings that kill people" (Sucuoğlu, 2006). For this reason it is the robustness of buildings and life-lines in the city (engineering studies) that need be investigated, and mitigation efforts focused in these systems will suffice for the achievement of safety in the city (Scawthorn, et. al. 2006; Cozzi, Menoni, 2006 et. al.; Rosetto, 2006).

(d) Another set of pre-disaster efforts could be identified to fall closer to conventional land-use planning. Burby (1998) considers that land-use planning could provide sufficient means for mitigation by itself.

It is most relevant to survey and register geological attributes of land and local geographical features to determine the hazard zones and then the appropriate zoning of uses and designation of types of buildings for safer city development and functioning. Based on past experience, high hazard zones are avoided for residential purposes, but buildings for storage or animal husbandry could be permitted. Public buildings and emergency facilities must accordingly be allocated to less hazardous zones. 
Fault lines must have immediate strips of zones for total building ban, restricted zones for specific uses further away, constraints relaxed with distance. Mitigation decisions are confined to land-use impositions in this approach according to estimations of local hazards (Balamir, 2007).

(e) Cases that directly confront the problem of seismic mitigation, and intend to develop methods in comprehensive urban planning, rather than that of landuse planning tools alone, are few and recent.

Two exercises undertaken by the Columbia International Urban Planning Studio of the post-graduate program, in coordination with other research units, have been dedicated to the seismic problems of highly vulnerable cities of Caracas and Istanbul (Columbia University, 2001, 2002).

This approach does not only consider the city systems in their entirety, but develops also a multi-disciplinary framework, reveal a more comprehensive approach than conventional land-use planning, and define the boundaries of a new form of planning practice.

The Columbia University planning program, following a research format developed in the case of Caracas city, studied the earthquake prone Istanbul in 2002 with the intention of exploring planning and mitigation possibilities. The time and data constraints have largely constrained the Istanbul analyses, and reduced findings to a set of broad recommendations (Balamir, 2007).

Yet there are a number of significant elements within the scope of the study:

1. A post-event analysis focused on a prioritization of 'essential facilities': (a) medical, water, transportation, shelter, communication; (b) fuel, fire, hazardous materials, electricity, food; (c) reserved space, sanitary facilities, and identified the priority of urban activities that have greater contributions as: 'management', SAR, 'law enforcement/security' (Balamir, 2007).

2. Safety implications of various macro-form alternatives were explored. Comparisons were made between centralized metropolitan growth and satellite settlements configurations. The latter was preferred, taking into consideration also the impacts of alternatives on conservation policies (Balamir, 2007).

3. A sample of neighborhoods were investigated, followed by recommendations in infrastructure improvements, urban design propositions, social policies, 'resistance action plans', regulation of building densities and restrictions, and disaster response plans (Balamir, 2007).

Even if the attempts were inconclusive in developing a methodology in mitigation planning, the approach of the Columbia University is in the necessary direction. The study is not trapped in a simple understanding of equating city-level risks solely to those of the building stock. It is not either confined to the narrow scope of conventional land-use planning. The approach considers the urban mitigation issue in terms of a multi-disciplinary attitude in its determination of hazards, specifying an array of risks, assessments of loss, and in its propositions of policies. 
"The major deficiency in this approach lies in the implicit assumption that mitigation is a one-way technical and administrative project imposed by the local authorities. Participation methods and interactive involvement processes, which should have been the concomitant of each policy proposition, are omitted in the urban mitigation planning. Temporary public awareness-raising programs are obviously no substitutes for generating a total mobilization" (Balamir, 2007).

(f) The risk analyses and urban mitigation planning approach envisaged for the Earthquake Master Plan of Istanbul (EMPI, 2003) is still another alternative perhaps based on a methodology with wider implications (Balamir, 2006, 2004, 2001, 1999).

A survey of recent attempts in city-level mitigation reveals the nature of the gaps in understanding settlement safety, and the need for the development of a systematic response to risks in urban planning (Balamir, 2007).

The city however is not just an aggregate of buildings, but a complex system comprising its own nested sets of 'risk sectors', as well as buildings of various categories to acquire different functions and priorities in the context of urban mitigation planning. Sectors of risk are distinctly manageable clusters of vulnerabilities at the city-level for which a coordinated action is necessary.

Different levels of spatial units (national, regional, and city) could have entirely different sets of vulnerability and risk definitions, definitely different from risks at the building level (Balamir, 2007).

As cities have their own complex functional integrity, they are vulnerable in very different ways and very different risk sectors. Risk sectors are areas of causal relations on specific risks according to Earthquake Master Plan of Istanbul (EMPI). More than a dozen of city-level risk-sectors have been identified in Istanbul. Risk-Sectors of EMPI are given below;

- Risks in Macro-Form and Growth Tendencies (settlement configuration alternatives)

- Urban Fabric Risks (building height/proximity, plots, density, roads, carparks, etc.)

- Incompatible Land-Use Risks (buildings and districts)

- Risks of Productivity Loss (industrial plants)

- Risks in the Building Stock, Infrastructure and Lifelines

- Risks in Emergency Facilities and Lifelines (hospitals, schools, etc.)

- Special Risk Areas/ Special Buildings (landslide, flooding/historic buildings)

- Risks in Hazardous Uses (LPG and petrol stations, etc.)

- Open Space Deficiency Risks

\subsection{Settlement Level Vulnerability and Risk Assessment Studies in Turkey and Abroad}

Vulnerability assessment and seismic risk management using advanced methodologies are of major importance for the reduction of seismic risk in urban areas. Settlements are the most relevant geographical units for vulnerability and risk assessment studies, since greater densities of population occur and most intensive investments are made here, and most complex sets of vulnerabilities prevail in this context. 
Settlement vulnerabilities cannot be described simply in terms of robustness of individual buildings, but as a complex system structured with interdependent components. Urban stock texture, networks, distribution of land-uses, public facilities, their interaction with hazard prone locations, size of population served and many other factors have interdependent impacts on the vulnerabilities or resilience of settlements.

A number of risk assessment studies have been carried out in Turkey both at national and local levels after 1999. These studies that related to settlement level risks are given below;

1. The first one is the Earthquake Master Plan of Istanbul (EMPI) tendered by the Metropolitan Municipality of Istanbul and carried out by four universities in 2003 (ITU, METU, BU and Yıldız Tech. Un.).

Earthquake Master Plan of Istanbul (EMPI) developed a comprehensive framework for the determination of urban risks and methods of reducing them. More than a dozen of 'risk sectors' in the Metropolitan City were identified for DRR organization and action. A participatory framework was envisaged in each risk sector organizing the communications between stakeholders. Interrelated set of projects and action were identified in each risk sector with their budgets, responsible authorities, units, and NGOs within an overall implementation program. Within EMPI, a method of seismic risk mitigation model was developed for the high-risk sub-provinces of Istanbul.

Upon the request of the metropolitan municipality, this was followed by a detailed analysis and assessment of risk mitigation measures based on information obtained in extensive field surveys in the sub-province of Zeytinburnu. This approach indicated the viability of comprehensive planning of such high-risk areas, to incorporate the partial physical redevelopment of districts by means of partnerships, to exclude the options of density increases, gentrification, and excessive costs. The objective was to establish the possible set of conditions to maintain residents and tenants, self-financing social reorganization projects, testing the viability of physical rearrangements at higher safety standards and environmental quality. Communities of approximately 1000 dwellings proved to meet all possible constraints and economies required.

2. The second one was tendered by the World Bank for the investigation of risks in six different municipalities (Bakırköy, Bandırma, Eskişehir, Gemlik, Körfez and Tekirdag) and development of recommendations for improvement in their capacities for Disaster Risk Mitigation.

Research and recommendations for the sample of six municipalities followed a similar method in the determination of seismic risks in settlements of different size and character. Having established the hazard probabilities and their distribution in the city landscape by means of microzonation studies, the method described a 'community profile' followed by an identification of the high risk areas. Further to loss estimation and urban risk analyses, municipality capabilities are determined. The mitigation strategies for each of the municipalities are then developed, and some prioritization proposed according to needs for immediate attendance and effectiveness of action with reference to costs of mitigation measures. Both of these studies provide insight into identification of risks and methods of prioritization at settlement level (Prota, 2011). 
3. A national level earthquake risk assessment study was carried out in Boğaziçi University (Demircioglu, 2010). In this study, the national hazard maps according to the several ground motion parameters have been prepared and nationwide building damage; casualty and economic losses have been estimated. Both the hazard and risk assessments were grid based. These grids can be clustered into sub-provinces and provinces as per the needs of project. The hazard maps constitute an updated version of those associated with the infrastructure seismic design code published in 2007 for application to transportation structures officially administered by the Ministry of Transportation.

The risk maps produced in this thesis is analogous to the FEMA study entitled Estimated Annualized Earthquake Losses for the United States (FEMA, 2008).

4. An earthquake risk model for Turkey has been developed under the WB Turkish Emergency Flood and Earthquake Recovery Project (TEFER, 2000). An earthquake loss model for the Turkish Catastrophe Insurance Pools (TCIP-DASK) to serve a basis for the making decision process with respect to the pricing of its insure policy, risk control, the purchase of reinsure, and the transfer of seismic risk. The project concluded in 2001 and the software is used for TCIP.

5. At the local level, several earthquake risk assessment studies carried out by local municipalities can be cited. Further to the earthquake master plan for the city of Istanbul (EMPI) a study developed in the year 2009 included a very comprehensive local soil characteristics investigation as well as an updated building inventory development at geographical location level.

This study was preceded and also used the information provided by three other studies conducted for the city of Istanbul, these being:

- The earthquake microzonation study for the city of Istanbul conducted by JICA (JICA-IBB, 2002),

- Earthquake risk assessment study for the Istanbul Metropolitan Area conducted by Boğaziçi University (KOERI, 2002) and

- The earthquake risk assessment methodology employed in the Earthquake Master Plan of Istanbul (EMPI) study was updated in 2009.

6. At the local level, one of the recent projects is the Istanbul Seismic Risk Mitigation and Emergency Preparedness (ISMEP) Project. The aim of this project is to improve the city of Istanbul's preparedness for a potential earthquake through enhancing the institutional and technical capacity for disaster management and emergency response, strengthening critical public facilities for earthquake resistance, and supporting measures for better enforcement of building codes and land use plans. The Government of Turkey has initiated, ISMEP, to transform Istanbul into a city resilient to a major earthquake. The project is financed by a World Bank loan and implemented through the Istanbul Special Provincial Administration (ISMEP, 2010). 
7. An earthquake master plan was also developed for the city of Izmir in the year 2002 with the contribution of researchers from Boğaziçi and Istanbul Technical Universities as well as the Chamber of Civil Engineers in Izmir. During this study all the buildings in the Izmir metropolitan area were visited by engineers and classified according to their structural characteristics and vulnerability. The study also included risk assessment for the major lifeline systems in the city (KOERI, 2000).

8. In connection with the DRM-MERM Project, the assessment of the seismic hazard for Adapazarı, Gölcük, Değirmendere and İhsaniye regions have been conducted. The project has involved a probabilistic estimate of the expected ground motions at the sited locations for the next 50 years and the associated seismic microzonation essentially intended for the land use management for settlement (DRM, 2004).

9. Several academic researches were also carried out about settlement level vulnerability and risk assessment fields in Turkey. One of the most featured studies related to settlement level risks was carried out by Ezgi Orhan and examines post-disaster recovery processes and location choices of businesses in case of Adapazarı (Orhan, 2012). The second study about settlement level vulnerabilities and risks was carried out by Fikret Bayhan and examines the impacts of urban planning decisions on earthquake vulnerable cities in the case of Adapazarı (Bayhan, 2010).

Apart from estimations of rates of loss in the building stock for an expected seismic hazard, the world experience in this context is not rich with examples and precedents.

Similar risk assessment studies in foreign countries that have been carried out both at national and local levels related to settlement level risks are given below;

\section{United States of America}

The Disaster Mitigation Act 2000 (DMA-2000) encourages all units and city administrations in USA to develop DRR plans and projects and submit them to the Federal Administration. The Administration then decides whether there is a justifiable case, and whether it is worth to subsidize the plan/project based on a number of efficiency criteria. Such a competition environment demands and generates a ranking system in itself.

In 2008 US Federal Emergency Management Agency (FEMA) has prepared a study on the estimation of seismic risk in all regions of the United States by using two interrelated risk indicators:

1. Annualized Earthquake Loss (AEL), which is the estimated long-term value of earthquake losses to the general building stock in any single year in a specified geographic area; and

2. Annualized Earthquake Loss Ratio (AELR), which expresses estimated annualized loss as a fraction of the building inventory replacement value (FEMA, 2008). 
Similar and more detailed studies have also conducted by California Geological Survey (CGS) under the title "Estimation of Future Earthquake Losses in California".

In these studies losses from potential future earthquake are calculated both as scenarios of potential earthquakes and as annualized losses considering all the potential earthquake sources included in the national seismic hazard maps.

\section{Italy}

Crowley et al, (2008) have compared the various seismic risk maps which have been proposed in Italy over the past 10 years.

These maps have been updated over the years following the publication of more detailed seismic hazard and exposure data, and the updating of empirical vulnerability functions. The recent publication of updated seismic hazard maps in Italy has called for further seismic risk studies to be carried out using this stateof-the-art data. These seismic hazard maps are in terms of acceleration and displacement spectral ordinates and thus necessitate the use of more sophisticated models of the vulnerability such that the frequency content of the ground motion and the period of vibration of the building stock can be taken into account (Prota, 2011).

\section{Lisbon}

The LESSLOSS (Risk mitigation for earthquakes and landslides) project addressed natural disasters, risk and impact assessment, natural hazard monitoring, mapping and management strategies, improved disaster preparedness and mitigation, development of advanced methods for risk assessment, methods of appraising environmental quality and relevant prenormative research. In the frame work of project, earthquake disaster scenario prediction and loss modeling, finite-fault seismological models have been proposed to compute the earthquake scenarios for three urban areas, Istanbul (Turkey), Lisbon (Portugal), and Thessaloniki (Greece).

The overall aim of the project was to create a tool, based on state of the art modeling software, to provide strong quantified statement about the benefits and costs of a range of possible mitigation actions, to support decision-making by city and regional authorities for seismic risk mitigation strategies (LESSLOSS, 2004). 


\section{CHAPTER 3}

\section{SEISMIC LOSS ESTIMATIONS IN SETTLEMENTS OF TURKEY}

If vulnerability levels of settlements could be established with reference to seismic shake probabilities and levels of loss in the building stock, the question than is to explore the possible means of expressing this vulnerability in terms of asset of physical and social attributes of settlements.

This approach would identify vulnerabilities of settlements as dependent, and other explanatory attributes of cities as independent variables.

Quantitative information about a set of attributes of settlements is investigated statistically to determine which of the factors contribute most to risk levels described locally. The seismic hazard maps of the Kandilli Observatory and Earthquake Research Institute (KOERI), Erdik estimations of seismicity and statistics published by the Turkish Statistical Institute (TurkStat), like census and housing data have a leading contribution to make. These secondary sources of information help to compose the database for a series of comparisons in the seismic vulnerabilities and risk levels of cities.

In order to determine the seismic vulnerabilities and risks of settlements, disaster component that reveals the settlement level loss in building stock is examined on one side and the basic attributes of settlements and their effects on loss levels on the other side. This double sided process generates the dependent and independent variables of the research.

In the determination of seismic vulnerabilities and risks of settlements, loss levels in the building stock in each settlement will evaluate based on seismic hazard intensity via seismic hazard maps produced by KOERI and building stock vulnerability curves derived by Demircioglu (2010). Settlement level loss in the building stock is the basic indicator of assumed overall vulnerability (risk) and provides the dependent variables of the research.

The independent variables of the research are composed of building inventory data and related attributes of building stock on each settlement obtained from TurkStat. 'Building Construction Statistics', 'Building Census' and 'Population Census' prepared by TurkStat and 'Development Indexes' prepared by SPO is used within this research.

This study is expected to provide information about the critically vulnerable assets in cities, whether this could be considered as a function of hazardproneness. Otherwise, interpretations of the most effective attributes that could describe vulnerabilities best and be related to risk information in cities could be explored.

The basic question of the research is: "How do loss levels in building stock correlate to independent variables?" and regression analyses are used to examine this question. 


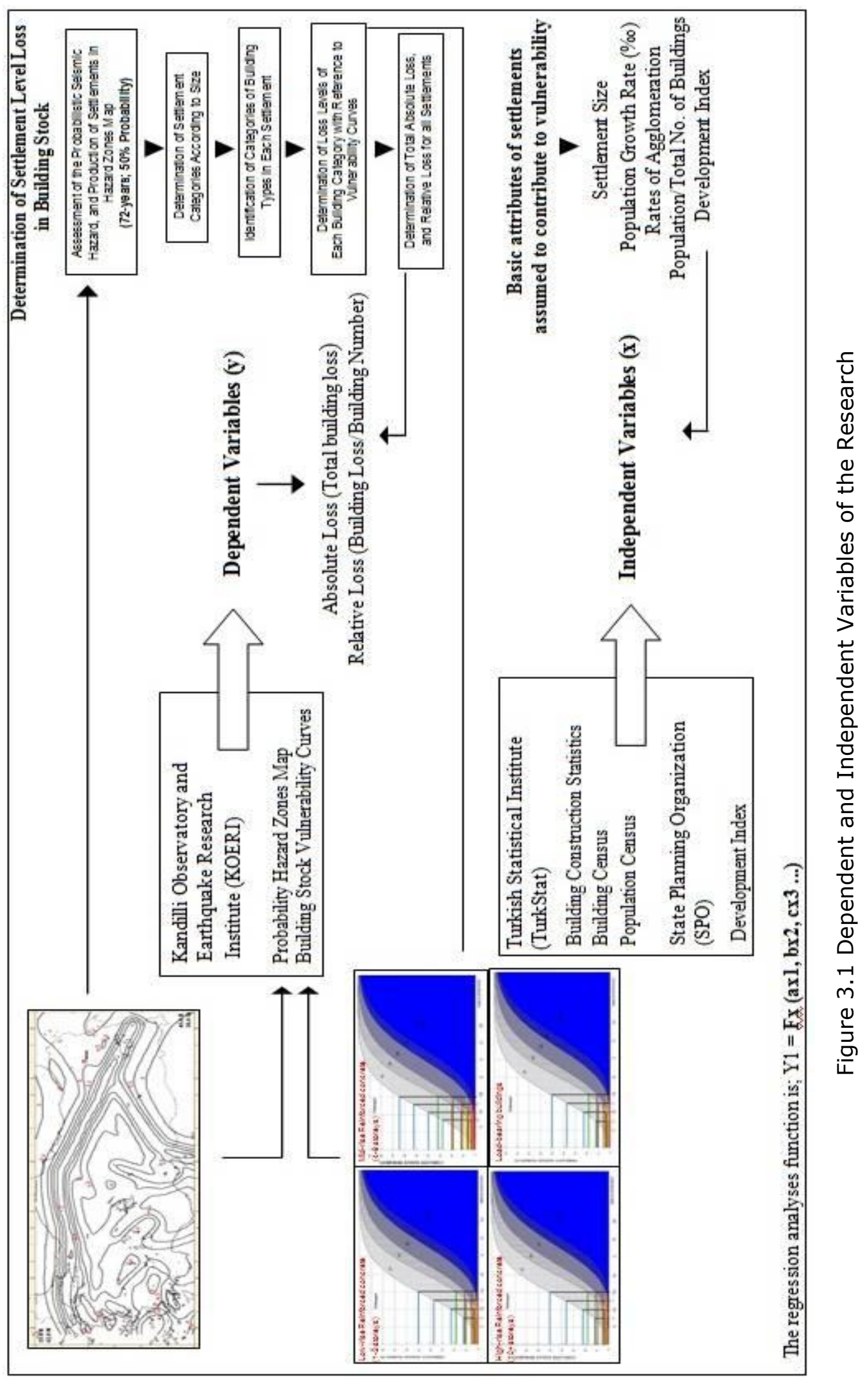




\subsection{Seismic Hazard Probabilities of Settlements}

Official Earthquake Hazard Map of Turkey is the basic premise of the disaster management system and the common source of earthquake hazard information in Turkey.

Earthquake Hazard Map of Turkey based on probabilistic considerations has been commissioned in 1996 and segments the country into five macro-level regions, as determined by the statistical occurrence of seismic events.

This Map is currently used for two purposes only. One of these is concerned with the building design standards and the other is the pricing of insurance premiums. Both purposes could have been better served if differentiations of locations were made on risk-basis. This demands the identification of relative risk categories of risks in settlements.

In this hazard-zone map essentially all the regions (with exception in East Anatolian Fault) with PGA $\geq 0.4 \mathrm{~g}$ were assigned Zone I and regions with PGA $\leq 0.1 \mathrm{~g}$ were assigned as Zone $\mathrm{V}$. This rounding off features and sub-province level resolution does not allow for its use in risk assessment purposes (Prota, 2011).

Earthquake Hazard Map of Turkey is a general zoning map that does not necessarily consider return periods, event frequencies and randomness of events. It only indicates hazard exposure levels of settlements without providing any information about risk levels and does not specify any quantitative earthquake hazard parameters for any zone. Besides it doesn't indicates any information about ordering and prioritization of settlements in the same hazard zones, all settlements located in the same hazard zones are accepted as of equal in risk apart from their physical settings and vulnerabilities.

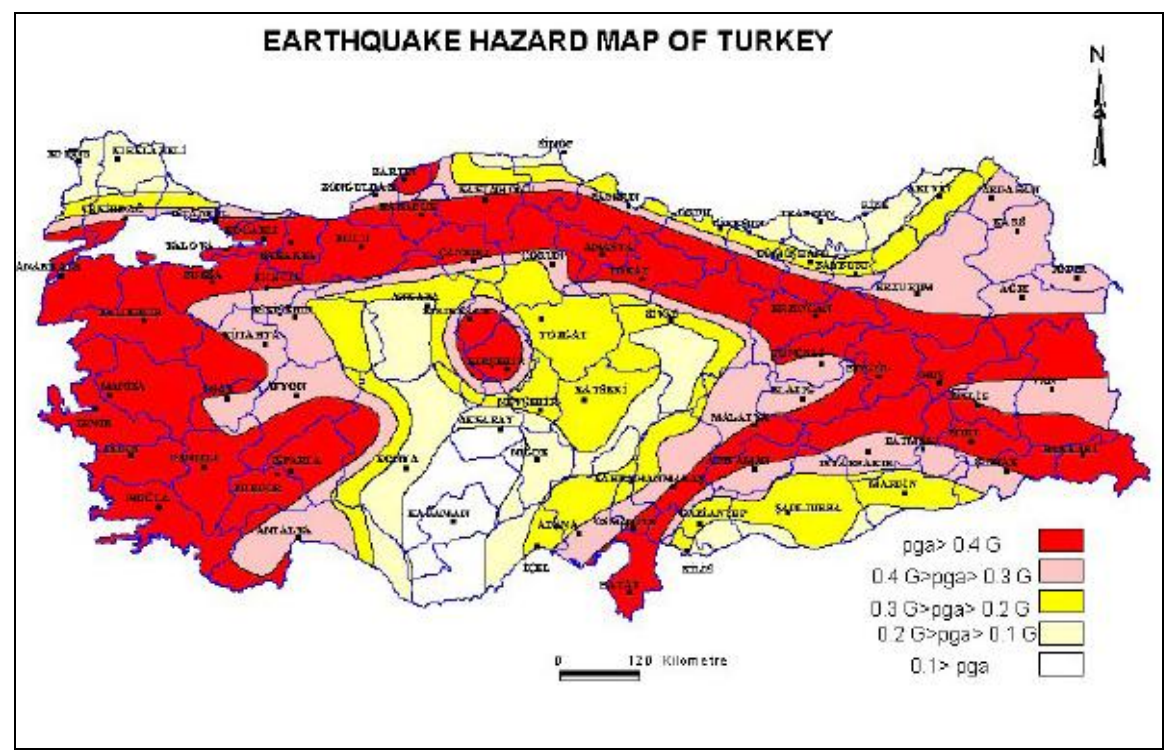

Figure 3.2 Earthquake Hazard Zoning Map of Turkey

(Source: GDDA, 1996) 
Due to these deficiencies of the Official Earthquake Hazard Map, it may be more appropriate to employ the probability hazard zones map provided by Erdik et al. (2002) for the identification of settlements under the higher threat of earthquake.

The intensity distribution map provided by Erdik et al. (2002) that is used for the purposes of prioritization of settlements according to their vulnerability levels, is representing $50 \%$ probability of occurrence in 72 years of return period.

This shorter - range estimation is more relevant for today's policy decisions rather than very long-term estimations of hazard. A second reason for this preference is the more accurate means of accounting for the recent hazards in a model with 'memory' (Balamir, 2011).

The intensity distribution map differentiates settlements into seven levels on the basis of expected hazard intensities from 5.0 to 8.0 , where 5.0 is the least and 8.0 is the highest level of expected hazard intensity.

Within this intensity distribution map, it is assumed that seismic energy along the line-segments is released by characteristic earthquakes; therefore the earthquakes with magnitude $\geq 6.5$ are associated with these line sources. Earthquakes with magnitude $<6.5$ are assumed to take place within limited areal zones around these linear segments. Smaller en-echelon and/or diffused faults were assumed to be encompassed in these zones. In addition to linear and areal source zones background seismicity zones are defined to model the floating earthquakes that are located outside these distinctly defined source zones and to delineate zones where no significant earthquake has taken place (Erdik et al., 2002).

Therefore expected hazard intensity level of 6.5 is accepted as the breakingpoint and all settlements with an expected hazard intensity level of 6.0 and less are excluded from the analyses assuming that insignificant damage is likely to take place in these settlements.

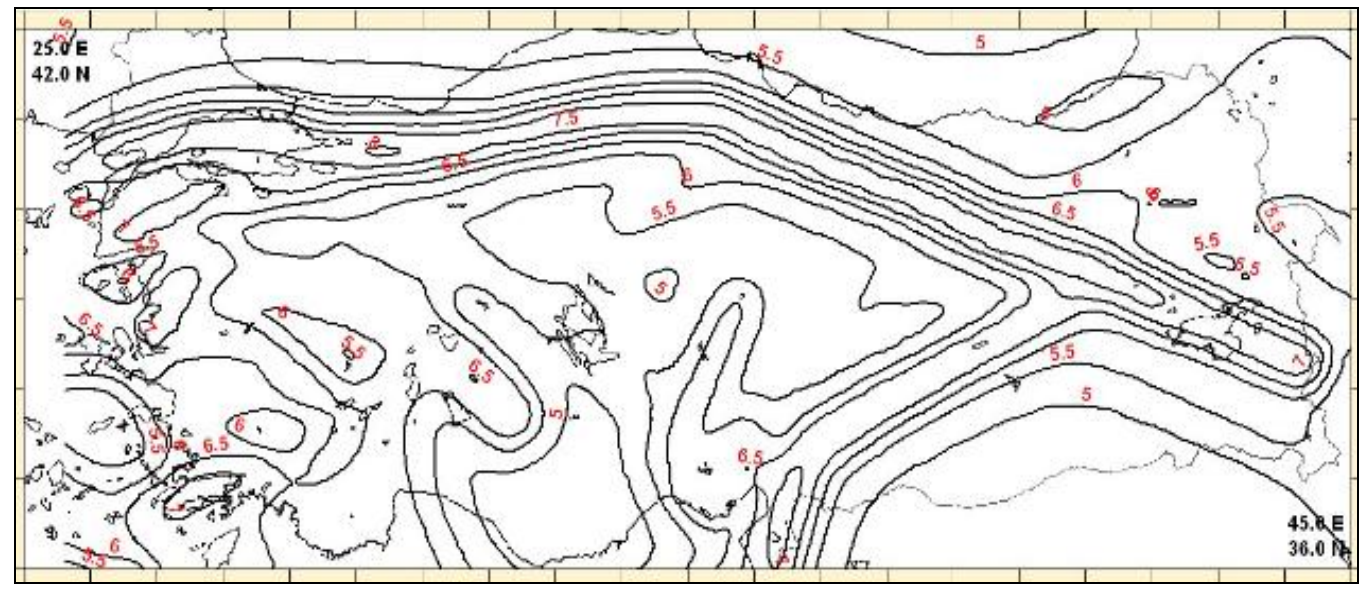

Figure 3.3 Intensity Distributions for 72 Years and \%50 Probability (Source: Erdik et al., 2002) 
In order to underline the discrepancies between the Official Earthquake Hazard Map and the Intensity Distribution Map provided by Erdik et al. (2002), the distribution of settlements subject to 6.5 and upper seismic intensities evaluated with respect to the Official Earthquake Hazard Map of Turkey.

When we examine the distribution of settlements according to the Official Earthquake Hazard Zone Map, we observe that 434 sub-provinces and province centers including those of metropolitan cities are located in the I. Degree Earthquake Zone that is the highest hazard probability zone. This is about \%50 of all sub-province and province centers of the country.

On the other hand, when we examine the distribution of settlements subject to $6.5+$ seismic intensities according to the Seismic Intensity Map, we observe that 498 of settlements are located in high hazard impact zone which is \%54, 8 of all settlements. As 6.5 and upper intensities can be classified as the high hazard impact zone, we can easily say that approximately two third of all population living under serious threat.

The distribution of sub-province and province centers according to both maps is as follows:

Table 3.1 Evaluation of Settlements Subject To 6.5+ Seismic Intensities According to the Seismic Intensity Map With Respect to the Official Earthquake Hazard Map

\begin{tabular}{|c|c|c|c|c|c|}
\hline \multicolumn{2}{|c|}{ Official Earthquake Hazard Map } & \multicolumn{3}{c|}{ Seismic Intensity Map } \\
\hline $\begin{array}{c}\text { Earthquake } \\
\text { Hazard Zone }\end{array}$ & $\begin{array}{c}\text { Number of } \\
\text { Settlements }\end{array}$ & $\%$ & $\begin{array}{c}\text { Expected } \\
\text { Seismic } \\
\text { Intensity }\end{array}$ & $\begin{array}{c}\text { Number of } \\
\text { Settlements }\end{array}$ & $\%$ \\
\hline 1 & 434 & 47,8 & 8 & 59 & 6,4 \\
\hline 2 & 203 & 22,3 & 7.5 & 79 & 8,7 \\
\hline 3 & 135 & 14,9 & 7 & 149 & 16,5 \\
\hline 4 & 115 & 12,7 & 6.5 & 211 & 23,2 \\
\hline 5 & 21 & 2,3 & $6<$ & 410 & 45,2 \\
\hline Total & $\mathbf{9 0 8}$ & $\mathbf{1 0 0}$ & Total & $\mathbf{9 0 8}$ & $\mathbf{1 0 0}$ \\
\hline
\end{tabular}




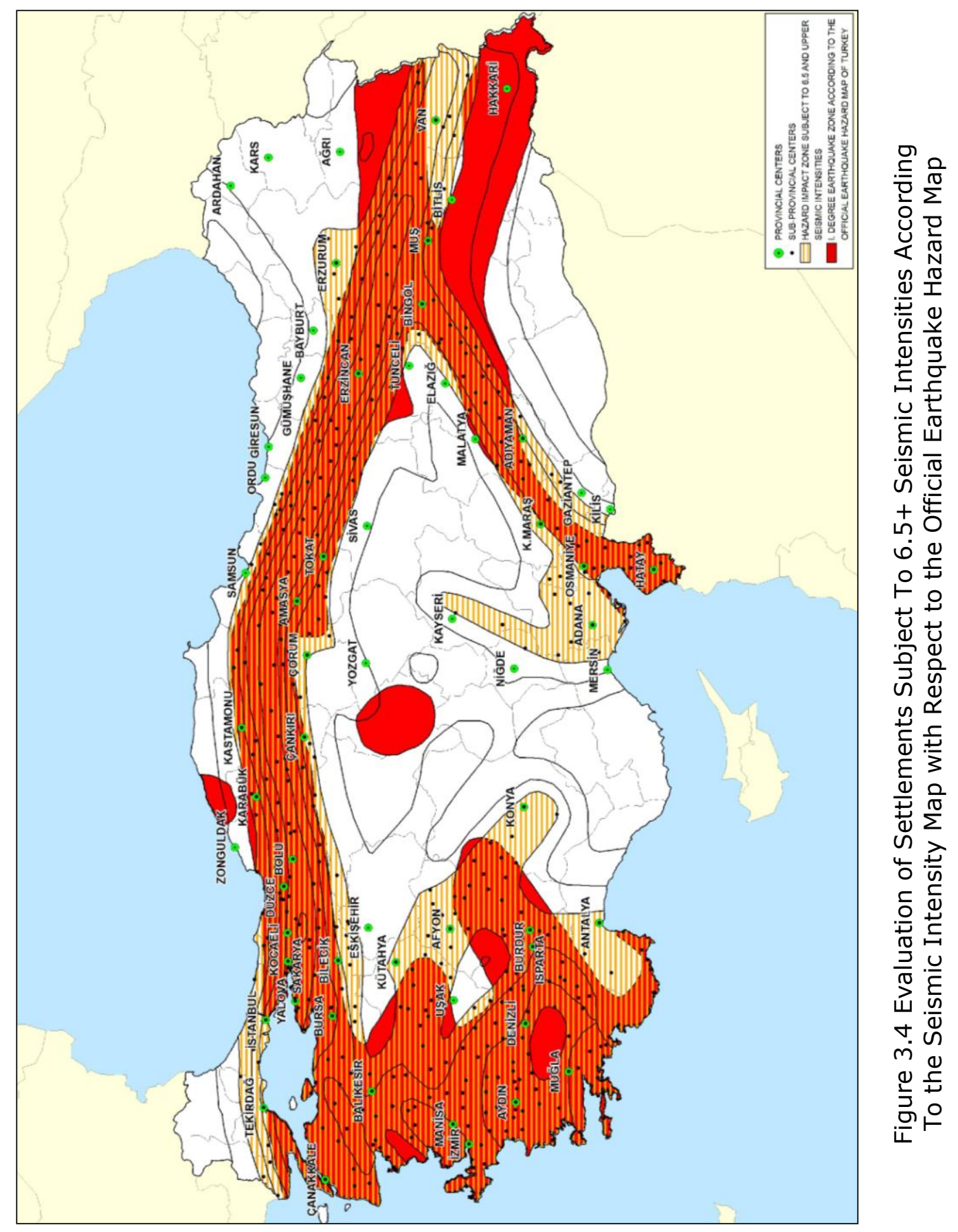




\subsubsection{Different Measures of Seismic Hazard}

Two different types of scales are commonly used to describe seismic hazards. The original force or energy of an earthquake is measured on a magnitude scale, while the intensity of shaking is measured on an intensity scale. However, these two scales are quite different they are often confused.

Magnitude scale is related to the amount of seismic energy released at the source/epicenter of the earthquake, is determined from measurements on seismographs and is a measurement of the size of the earthquake. Intensity scale measures the strength of shaking produced by the earthquake at a certain location, is determined from effects on people, buildings, human structures and the natural environment and is a measurement of the earthquake effects.

An earthquake has one magnitude, but many intensities, magnitude is a fixed value independent of distance from the epicenter of the earthquake, whereas intensity varies and is measured differently at different places depending upon its distance from the epicenter.

Magnitude is quantitative and exact and it is expressed as a number; intensity is qualitative and more subjective and it is expressed as a roman number.

\section{Magnitude Scales}

The Richter scale and The Moment Magnitude scale are both measures of the magnitude of earthquakes. Although, both scales are still used the Moment Magnitude scale is designed to overcome the problems of the Richter scale and is gradually replacing the Richter scale. The numbers generated by the two scales are usually very similar.

The Richter scale is used for the small size earthquakes while the Moment Magnitude scale is used for the medium to large earthquakes mostly.

\section{The Richter Magnitude Scale}

The Richter magnitude scale was developed in 1935 by Charles F. Richter to compare the size of earthquakes. It is a logarithmic scale and assigns values from 1-10 to the magnitude of any earthquake.

Because of the logarithmic basis of the scale, each whole number increase in magnitude represents a tenfold increase in measured amplitude; as an estimate of energy, each whole number step in the magnitude scale corresponds to the release of about 31 times more energy than the amount associated with the preceding whole number value.

The Richter scale is not used to express damage. An earthquake in a densely populated area which results in many deaths and considerable damage may have the same magnitude as a shock in a remote area that doesn't affect anything (USGS, 2012).

The following is an abbreviated description of the 10 levels of Richter Magnitude Scale. 
Table 3.2 Richter Magnitude Scale

(Source: Adapted from USGS, 2012)

\begin{tabular}{|c|c|c|}
\hline Magnitude & Description & Effects \\
\hline$<2.0$ & Micro & Micro earthquakes, not felt \\
\hline $2.0-2.9$ & \multirow{2}{*}{ Minor } & Generally not felt, but recorded \\
\hline $3.0-3.9$ & & Often Felt, but rarely causes damage \\
\hline $4.0-4.9$ & Light & $\begin{array}{l}\text { Noticeable shaking of indoor items, ratting noises. } \\
\text { Significant damage unlikely }\end{array}$ \\
\hline $5.0-5.9$ & Moderate & $\begin{array}{l}\text { Can cause major damage to poorly constructed } \\
\text { buildings over small regions. At most slightly } \\
\text { damage to well-designed buildings }\end{array}$ \\
\hline $6.0-6.9$ & Strong & $\begin{array}{l}\text { Can be destructive in areas up to about } 160 \\
\text { kilometers across in populated areas }\end{array}$ \\
\hline $7.0-7.9$ & Major & Can cause serious damage over larger areas \\
\hline $8.0-8.9$ & \multirow{2}{*}{ Great } & $\begin{array}{l}\text { Can cause serious damage in areas several hundred } \\
\text { kilometers across }\end{array}$ \\
\hline $9.0-9.9$ & & $\begin{array}{l}\text { Devastating in areas several thousand kilometers } \\
\text { across }\end{array}$ \\
\hline $10.0+$ & Massive & $\begin{array}{l}\text { Never recorded, widespread devastation across very } \\
\text { large areas }\end{array}$ \\
\hline
\end{tabular}

\section{The Moment Magnitude scale}

The Moment Magnitude scale was introduced in 1979 by Tom Hanks and Hiroo Kanamori as a successor to the Richter scale. It was developed to enable seismologists to better estimate the magnitude of large earthquakes, those greater than 7, as the Richter scale is not accurate at estimating earthquake magnitudes where the epicenter was greater than $600 \mathrm{~km}$ from the seismometer station or where the earthquake magnitude was greater than 7.0.

Thus, for medium-sized earthquakes, the moment magnitude values should be similar to Richter values. That is, a magnitude 5.0 earthquake will be about a 5.0 on both scales (Benton, 2012).

Unlike other scales, the moment magnitude scale does not saturate at the upper end; there is no upper limit to the possible measurable magnitudes. However, this has the side-effect that the scales diverge for smaller earthquakes. Therefore, Moment Magnitude scale is now the most common measure for medium to large earthquake magnitudes but breaks down for smaller quakes.

It's not based on instrumental recordings of an earthquake. It's based on the area of the fault that moved at the same moment as an earthquake.

\section{Intensity Scales}

The first widely adopted intensity scale, the Rossi-Forel scale, was introduced in the late 19th century. Since then numerous intensity scales have been developed and are used in different parts of the world. 
Although numerous intensity scales have been developed to evaluate the effects of earthquakes, the most commonly used intensity scales are; the European Macro seismic Scale that is used in Europe, the Modified Mercalli Intensity Scale that is used in USA and Hong Kong and the Medvedev-Sponheuer-Karnik that is used in India, Israel, Kazakhstan and Russia.

Unlike magnitude scales, intensity scales do not have a mathematical basis; instead they are an arbitrary ranking based on observed effects. Most of seismic intensity scales have twelve degrees of intensity and are roughly equivalent to one another in values but vary in the degree of sophistication employed in their formulation.

Values in the intensity scales depend upon the distance to the earthquake, with the highest intensities being around the epicenter. Data gathered from people who have experienced the quake are used to determine an intensity value for their location. The lower numbers of the intensity scale generally deal with the manner in which the earthquake is felt by people. The higher numbers of the scales are based on observed structural damage.

\section{The European Macro-seismic Scale (EMS)}

The European Macro seismic Scale (EMS) is the basis for evaluation of seismic intensity in European countries and is also used in a number of countries outside Europe. The scale is referred as EMS-98.

The history of the EMS began in 1988 when the European Seismological Commission decided to update the Medvedev-Sponheuer-Karnik scale (MSK-64), which was used in its basic form in Europe for almost a quarter of a century.

EMS-98 is the first seismic intensity scale designed to encourage co-operation between engineers and seismologists, rather than being for use by seismologists alone. Unlike the earthquake magnitude scales, which express the seismic energy released by an earthquake, EMS-98 intensity denotes how strongly an earthquake affects a specific place (SED, 2012).

The European Macro seismic Scale has 12 levels, as follows: 
Table 3.3 European Macro Seismic Scale (EMS-98)

(Source: SED, 2012)

\begin{tabular}{|c|c|c|}
\hline $\begin{array}{l}\text { EMS } \\
\text { intensity }\end{array}$ & Definition & $\begin{array}{c}\text { Description of typical observed effects } \\
\text { (abstracted) }\end{array}$ \\
\hline $\mathbf{I}$ & Not felt & Not felt. \\
\hline II & Scarcely felt & Felt only by very few individual people at rest in houses. \\
\hline III & Weak & $\begin{array}{l}\text { Felt indoors by a few people. People at rest feel a swaying or light } \\
\text { trembling. }\end{array}$ \\
\hline IV & $\begin{array}{l}\text { Largely } \\
\text { observed }\end{array}$ & $\begin{array}{l}\text { Felt indoors by many people, outdoors by very few. A few people } \\
\text { are awakened. Windows, doors and dishes rattle. }\end{array}$ \\
\hline $\mathbf{v}$ & Strong & $\begin{array}{l}\text { Felt indoors by most, outdoors by few. Many sleeping people } \\
\text { awake. A few are frightened. Buildings tremble throughout. } \\
\text { Hanging objects swing considerably. Small objects are shifted. } \\
\text { Doors and windows swing open or shut. }\end{array}$ \\
\hline VI & $\begin{array}{l}\text { Slightly } \\
\text { damaging }\end{array}$ & $\begin{array}{l}\text { Many people are frightened and run outdoors. Some objects fall. } \\
\text { Many houses suffer slight non-structural damage like hair-line } \\
\text { cracks and fall of small pieces of plaster. }\end{array}$ \\
\hline VII & Damaging & $\begin{array}{l}\text { Most people are frightened and run outdoors. Furniture is shifted } \\
\text { and objects fall from shelves in large numbers. Many well built } \\
\text { ordinary buildings suffer moderate damage: small cracks in walls, } \\
\text { fall of plaster, parts of chimneys fall down; older buildings may } \\
\text { show large cracks in walls and failure of fill-in walls. }\end{array}$ \\
\hline VIII & $\begin{array}{l}\text { Heavily } \\
\text { damaging }\end{array}$ & $\begin{array}{l}\text { Many people find it difficult to stand. Many houses have large } \\
\text { cracks in walls. A few well built ordinary buildings show serious } \\
\text { failure of walls, while weak older structures may collapse. }\end{array}$ \\
\hline IX & Destructive & $\begin{array}{l}\text { General panic. Many weak constructions collapse. Even well } \\
\text { built ordinary buildings show very heavy damage: serious failure } \\
\text { of walls and partial structural failure. }\end{array}$ \\
\hline $\mathbf{x}$ & $\begin{array}{l}\text { Very } \\
\text { destructive }\end{array}$ & Many ordinary well built buildings collapse. \\
\hline $\mathbf{X I}$ & Devastating & $\begin{array}{l}\text { Most ordinary well built buildings collapse, even some with good } \\
\text { earthquake resistant design are destroyed. }\end{array}$ \\
\hline XII & $\begin{array}{l}\text { Completely } \\
\text { devastating }\end{array}$ & Almost all buildings are destroyed. \\
\hline
\end{tabular}

\section{The Modified Mercalli Intensity Scale}

The Mercalli scale originated with the widely-used simple ten-degree Rossi-Forel scale which was revised by Giuseppe Mercalli in 1884. In 1931 it was modified by Harry Wood and Frank Neumann as the Mercalli-Wood-Neumann (MWN) scale. The scale is known today as the Modified Mercalli scale (MM) Intensity scale.

The Modified Mercalli Intensity scale quantifies the effects of an earthquake on the Earth's surface, humans, objects of nature and man-made structures on a scale from I (not felt) to XII (total destruction).

This scale, composed of 12 increasing levels of intensity that range from imperceptible shaking to catastrophic destruction, is designated by Roman numerals. It does not have a mathematical basis; instead it is an arbitrary ranking based on observed effects.

The following is an abbreviated description of the 12 levels of Modified Mercalli Intensity Scale. 
Table 3.4 Modified Mercalli Intensity Scale (MM)

(Source: Wood and Neumann, 1931)

\begin{tabular}{|c|c|}
\hline Intensity & Effects \\
\hline I & Not felt except by a very few under especially favorable conditions \\
\hline II & $\begin{array}{l}\text { Felt only by a few persons at rest, especially on upper floors of } \\
\text { buildings }\end{array}$ \\
\hline III & $\begin{array}{l}\text { Felt quite noticeably by persons indoors, especially on upper floors } \\
\text { of buildings. Many people do not recognize it as an earthquake. } \\
\text { Standing motor cars may rock slightly. Vibrations similar to the } \\
\text { passing of a truck. Duration estimated. }\end{array}$ \\
\hline IV & $\begin{array}{l}\text { Felt indoors by many, outdoors by few during the day. At night, } \\
\text { some awakened. Dishes, windows, doors disturbed; walls make } \\
\text { cracking sound. Sensation like heavy truck striking building. } \\
\text { Standing motor cars rocked noticeably. }\end{array}$ \\
\hline $\mathrm{V}$ & $\begin{array}{l}\text { Felt by nearly everyone; many awakened. Some dishes, windows } \\
\text { broken. Unstable objects overturned. Pendulum clocks may stop. }\end{array}$ \\
\hline VI & $\begin{array}{l}\text { Felt by all, many frightened. Some heavy furniture moved; a few } \\
\text { instances of fallen plaster. Damage slight. }\end{array}$ \\
\hline VII & $\begin{array}{l}\text { Damage negligible in buildings of good design and construction; } \\
\text { slight to moderate in well-built ordinary structures; considerable } \\
\text { damage in poorly built or badly designed structures; some } \\
\text { chimneys broken. }\end{array}$ \\
\hline VIII & $\begin{array}{l}\text { Damage slight in specially designed structures; considerable } \\
\text { damage in ordinary substantial buildings with partial collapse. } \\
\text { Damage great in poorly built structures. Fall of chimneys, factory } \\
\text { stacks, columns, monuments, walls. Heavy furniture overturned. }\end{array}$ \\
\hline IX & $\begin{array}{l}\text { Damage considerable in specially designed structures; well- } \\
\text { designed frame structures thrown out of plumb. Damage great in } \\
\text { substantial buildings, with partial collapse. Buildings shifted off } \\
\text { foundations. }\end{array}$ \\
\hline $\mathrm{x}$ & $\begin{array}{l}\text { Some well-built wooden structures destroyed; most masonry and } \\
\text { frame structures destroyed with foundations. Rails bent. }\end{array}$ \\
\hline XII & $\begin{array}{l}\begin{array}{l}\text { Few, if any (masonry) structures remain standing. Bridges } \\
\text { destroyed. Rails bent greatly. }\end{array} \\
\end{array}$ \\
\hline XII & $\begin{array}{l}\text { Damage total. Lines of sight and level are distorted. Objects } \\
\text { thrown into the air. }\end{array}$ \\
\hline
\end{tabular}

\section{The Medvedev-Sponheuer-Karnik Scale}

The Medvedev-Sponheuer-Karnik scale, also known as the MSK or MSK-64 was first proposed by Sergei Medvedev, Wilhelm Sponheuer and Vit Karnik in 1964. It was based on the experiences being available in the early 1960s from the application of the Modified Mercalli scale and the 1953 version of the Medvedev scale.

With minor modifications in the mid-1970s and early 1980s, the MSK scale became widely used in Europe and the USSR. In early 1990s, the European Seismological Commission used many of the principles formulated in the MSK in the development of the European Macro-seismic scale. The MedvedevSponheuer-Karnik scale has 12 intensity degrees and it is similar to the Modified Mercalli (MM) scale (See Table 3.4). 
The summarized table of the most featured magnitude and intensity scales are given below.

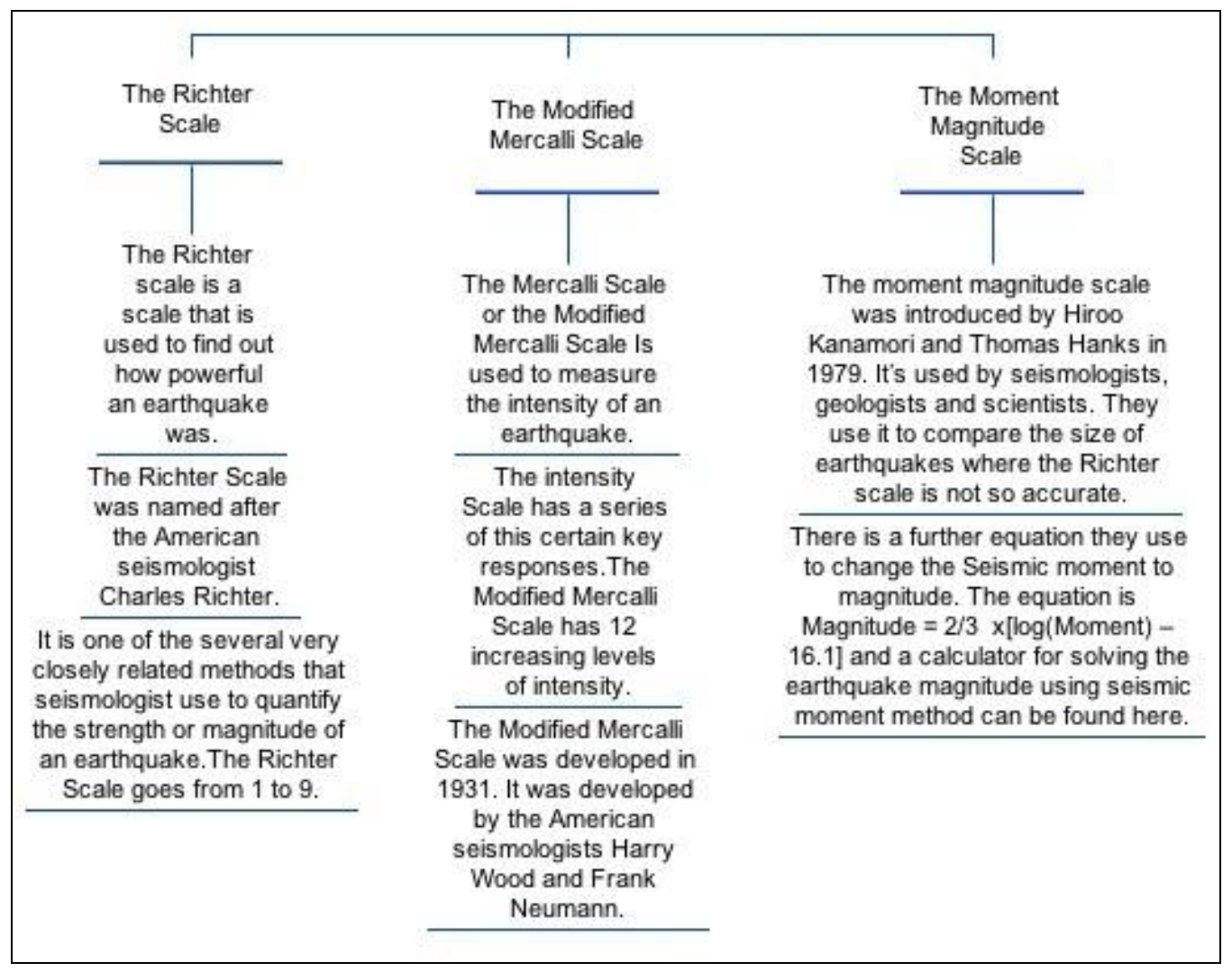

Figure 3.5 The Richter, Modified Mercalli and the Moment Magnitude Scales

(Source: Benton, 2012)

The following table gives intensities that are typically observed at locations near the epicenter of earthquakes of different magnitudes.

Table 3.5 Relationship between the Richter Magnitude Scale and Modified Mercalli Intensity Scale

(Source: USGS, 2012)

\begin{tabular}{|c|c|}
\hline Magnitude & $\begin{array}{c}\text { Modified Mercalli } \\
\text { Intensity }\end{array}$ \\
\hline $1.0-3.0$ & I \\
\hline $3.0-3.9$ & II - III \\
\hline $4.0-4.9$ & IV - V \\
\hline $5.0-5.9$ & VI - VII \\
\hline $6.0-6.9$ & VII - IX \\
\hline 7.0 and higher & VIII or higher \\
\hline
\end{tabular}




\subsubsection{Explanation of Erdik Rationale}

The technical approach used for the assessment and prioritization of the seismic vulnerabilities in Turkey employed within the study is based on the particular seismic intensity information derived by Erdik et al. (2002).

Two different methodologies have been used by Erdik et al. (2002) to compute the probabilistic hazard in Turkey. These are 'time-dependent approach' for the Marmara region and 'Poisson approach' for the remaining regions of the Turkey.

"Earthquake occurrence and fault segmentation data in the Marmara region are adequate to constrain a time dependent characteristic model for the region. The results of the study indicate a lower future hazard for the region of the 1999 earthquake and a higher hazard for the Central Marmara Sea region corresponding to the un-ruptured segments of the Main Marmara Fault in the Marmara Sea, when compared to Poisson, so-called memory-less models. This finding is also in accordance with (Parsons et al, 2000) indicating heightened probabilities for a major earthquake in the Marmara Sea region based on stress transfer approach" (Erdik at al., 2010).

"In time-dependent models, the probability of earthquake occurrence increases with the elapsed time since the last major earthquake on the fault that controls the regional earthquake hazard. In the case of the main Marmara Fault this earthquake is the 1999 Kocaeli event. This model is characterized by the recurrence-interval probability-density function of the characteristic earthquakes. Extensive paleoseismic and historical seismicity investigations on individual strike-slip faults (especially in California and Northwestern Turkey) indicate a quasi-periodic occurrence of characteristic earthquakes favoring the use of 'time dependent' stochastic models" (Erdik at al., 2010). The methodology, elaborated in Erdik et al., is essentially very similar to the one developed and used by United States Geological Survey - Working Group on California Earthquake Probabilities (WGCEP) for the preparation of US National Seismic Hazard Maps. The main physical ingredients of seismic hazard assessment are the tectonic setting of the region, the earthquake occurrences and the local site conditions.

"While the Poisson process seems to be applicable in a global sense in a regional scale, extensive paleoseismic and historical seismicity investigations on individual faults indicate a somewhat periodic occurrence of large magnitude earthquakes that necessitate the use of 'time dependent' (or 'renewal') stochastic models (Schwartz and Coppersmith, 1984). The time dependent model is based on the assumption that the occurrence of large earthquakes has some periodicity. The conditional probability that an earthquake occurs in the next $T$ years, given that it has not occurred in the last $T$ years is calculated by and integral function. For the renewal model, the conditional probabilities for each fault segment are calculated. These probabilities are said to be conditional since they change as a function of the time elapsed since the last earthquake" (Erdik at al., 2010).

The time-independent probabilistic 'Poissonian model' was used to assess the seismic hazard in the remaining regions of the Turkey. For the earthquake events to follow that model, the following assumptions are in order:

1- Earthquakes are spatially independent;

2- Earthquakes are temporally independent;

3- Probability that two seismic events will take place at the same time and at the same place approaches zero. 
"The historical and instrumental seismicity, tectonic models and the known slip rates along the faults constitute the main ingredients of the hazard analysis. Seismic Zonation has been implemented in three levels. The first level consists of linear faults representing the North Anatolian Fault (NAF), the north and east branches of NAF in the Marmara region, Bitlis - Zagros Suture Zone, Hatay Fault, Ezinepazari Fault, East-Anatolian Fault, Goksun Fault, Ecemis Fault, Tuzgolu Fault, Eskisehir Fault Zone, Simav-Sultandağ Fault Zone, Fethiye-Burdur Fault Zone, Gokova Fault Zone, Menderes Fault Zone, Gediz Fault Zone and Bergama Fault Zone. It is assumed that seismic energy along the line-segments is released by characteristic earthquakes; therefore the earthquakes with magnitude $M w \geq 6.5$ are associated with these line sources. The second level consists of limited areal zones around these linear segments assuming that earthquakes with magnitude $\mathrm{Mw}<6.5$ may take place within this zone. Smaller en-echelon and/or diffused faults were assumed to be encompassed in these zones. The third level considers the background seismicity, which represents the diffused seismicity that cannot be associated with known faults" (Erdik et al., 2010).

"Owing to the geological and geo-tectonic similarity of Anatolia to the California (strike slip faults similar to North, Northeast and East Anatolian Faults), the average of Boore et al. (1997), Sadigh et.al. (1997) and Campbell et al.(2003) ground motion prediction models for Peak Ground Acceleration (PGA) and the average of Boore et. al. (1997) and Sadigh et.al. (1997) ground motion prediction models for Spectral accelerations at $0.2 \mathrm{sec}$. and $1.0 \mathrm{sec}$. periods currently used for the assessment of earthquake hazard for the Western US were utilized. Another reason for the selection of these models was the good agreement between the instrumental intensities computed with these models with the observed macro seismic intensity distribution" (Erdik et al., 2002).

"The influence of the local geological structure on damage distribution due to ground-motion amplification (also called site effects) has been well known in the literature (Borcherdt, 1994). The construction of the design basis response spectrum for different Site Classes can be achieved through the modification of the spectral acceleration (SA at $0.2 \mathrm{~s}$ and at $1.0 \mathrm{sec}$ ) given by the hazard maps. The Uniform Hazard Response Spectrum presented in NEHRP (2003) that is employed as the appropriate spectral shape for a site is constructed with two parameters: the site-specific short period (SMS); and medium-period (SM1) spectral accelerations" (Erdik et al., 2002).

Site dependent peak ground acceleration (PGA) and peak ground velocities (PGV) for each return period (72, 475 and 2475 years) inferred from site dependent short and medium period spectral accelerations SMS and SM1 are calculated using the site dependent spectral accelerations for $T=0.2 \mathrm{sec}$ and $\mathrm{T}=1.0 \mathrm{sec}$. Based on the Wald et al (1999) methodology, the intensity distributions corresponding to $50 \%, 10 \%$ and $2 \%$ probabilities of exceedence in 50 years (return period of 72, 475, and 2475 years) have been obtained from both the site dependent PGA and PGV values (See Figure 3.7).

The intensity distribution of province and sub-province centers for 72 years return period and \%50 probability are thus determined with respect to this research derived by Erdik et al. (2002) and is employed for the assessment and prioritization of the seismic vulnerabilities in Turkey within the study. 


\subsection{Loss Levels in Building Stock}

Observed or estimated loss in settlements experiencing earthquakes could be measured by estimations with reference to the building stock. Risk in settlement units is defined as a function of material loss in the building stock with respect to the expected seismic event. It is assumed that loss in the building stock in each settlement can be used as a proxy to express the comparative loss of human life, economic loss, damages in infrastructural systems, as well as secondary and indirect levels of losses in the settlement. Therefore, settlement level loss in the building stock is the basic indicator of assumed risk and provides the dependent variables of the research.

In the estimation of building stock loss of settlements, three basic information components are employed:

1- The seismic hazard intensity of each settlement is likely to experience, based on a common set of assumptions is the first component. The particular seismic intensity information employed here is the 72-year return intensity with $50 \%$ probability and derived by Erdik et al. (2002). The map containing the spatial distribution of this information was used to determine the hazard level of all sub-provincial and provincial centers (See Figure 3.3).

2- Information concerning building stock properties in each settlement is obtained from TurkStat. The Building Census 2000 provides information on aspects of the building stock in each settlement. Following the categorization of the building stock provided in Demircioğlu (2010), four distinct groups of buildings have been identified in terms of number of buildings and number of storeys in each settlement (See Table 3.10).

3- Vulnerability/Fragility curves for each category of the building stock in Turkey, as empirically derived in Demircioğlu (2010) are employed here to determine the likely loss levels in settlements. According to this procedure, each of the four categories of the building stock in every settlement is separately evaluated in their likely response to the estimated intensity of shake (See Figures 3.17, 3.18 and 3.19).

By using three basic information components described above, determination of settlement level loss in the building stock has been realized by the following steps:

1. Assessment of the probabilistic seismic hazard and production of Settlements in Hazard Zones Map (72-years; 50\% probability),

2. Determination of Settlement Categories According to Size,

3. Identification of Categories of Building Types in Each Settlement,

4. Determination of Loss Levels of Each Building Category with reference to Vulnerability Curves,

5. Ordering of Settlements in Each Category According to Total Absolute Loss and Relative Loss

Following above described procedure, identification of most vulnerable settlements in each size-category and 'provinces with high-risk' are accomplished. 


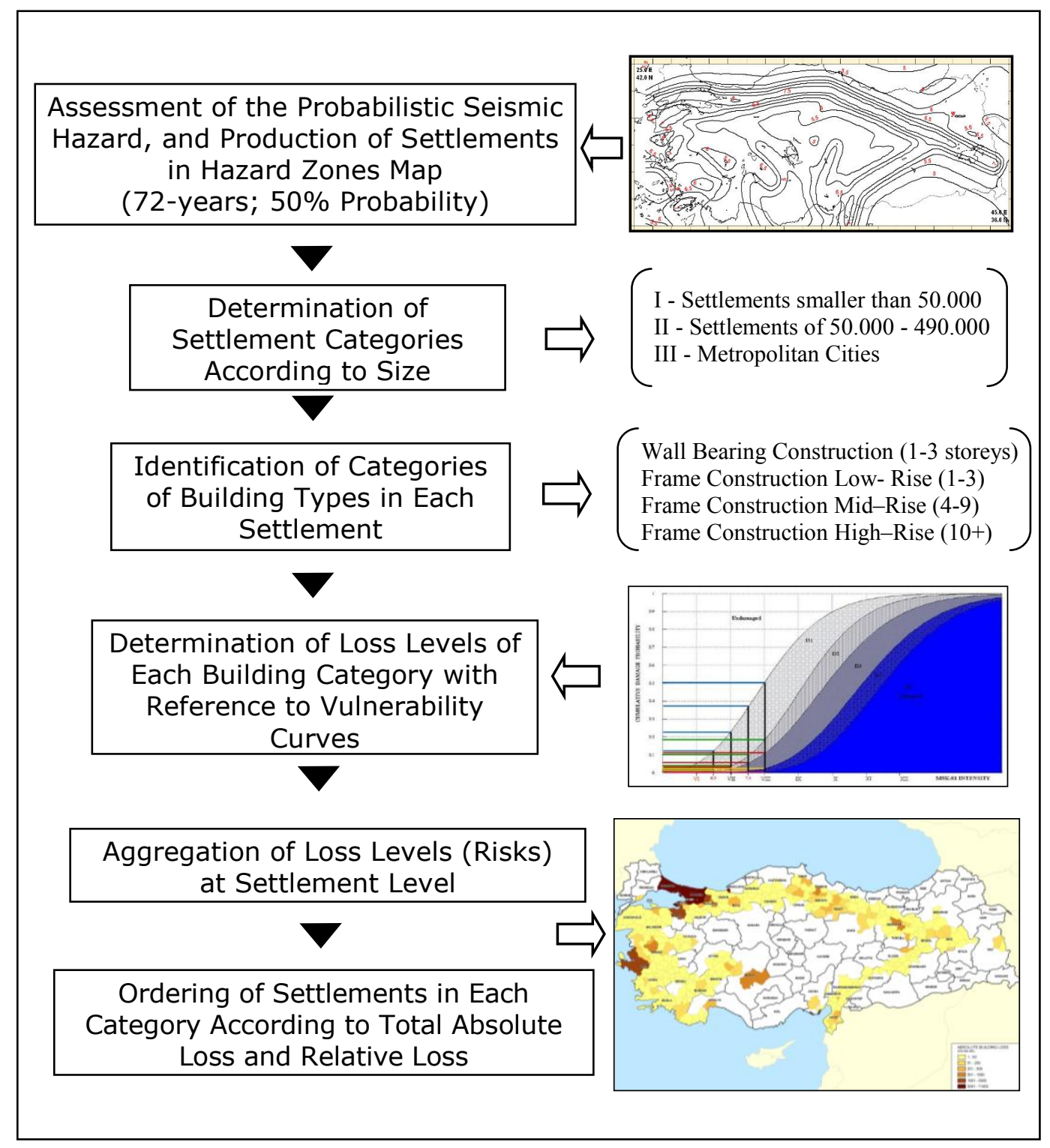

Figure 3.6 Flow Chart of Settlement Level Loss Determination 


\subsubsection{Loss Levels as a Function of Settlement Attributes}

Determination of settlement level loss in the building stock has been realized by the following steps:

1. Assessment of the probabilistic seismic hazard and production of Settlements in Hazard Zones Map

Seismic hazard intensities of each of the province and sub-province centers were determined with reference to the map produced by Erdik et al. (2002) and based on the assumption that such intensities will occur with a 72-year return period at $50 \%$ probability.

This shorter - range estimation is more relevant for today's policy decisions rather than very long-term estimations of hazard. A second reason for this preference is the more accurate means of accounting for the recent hazards in a model with 'memory' (Balamir, 2011).

The intensity distribution map with a 72 -year return period and $50 \%$ probability is digitized and used in the assessment of the probability seismic hazard and production of Settlements in Hazard Zones Map.

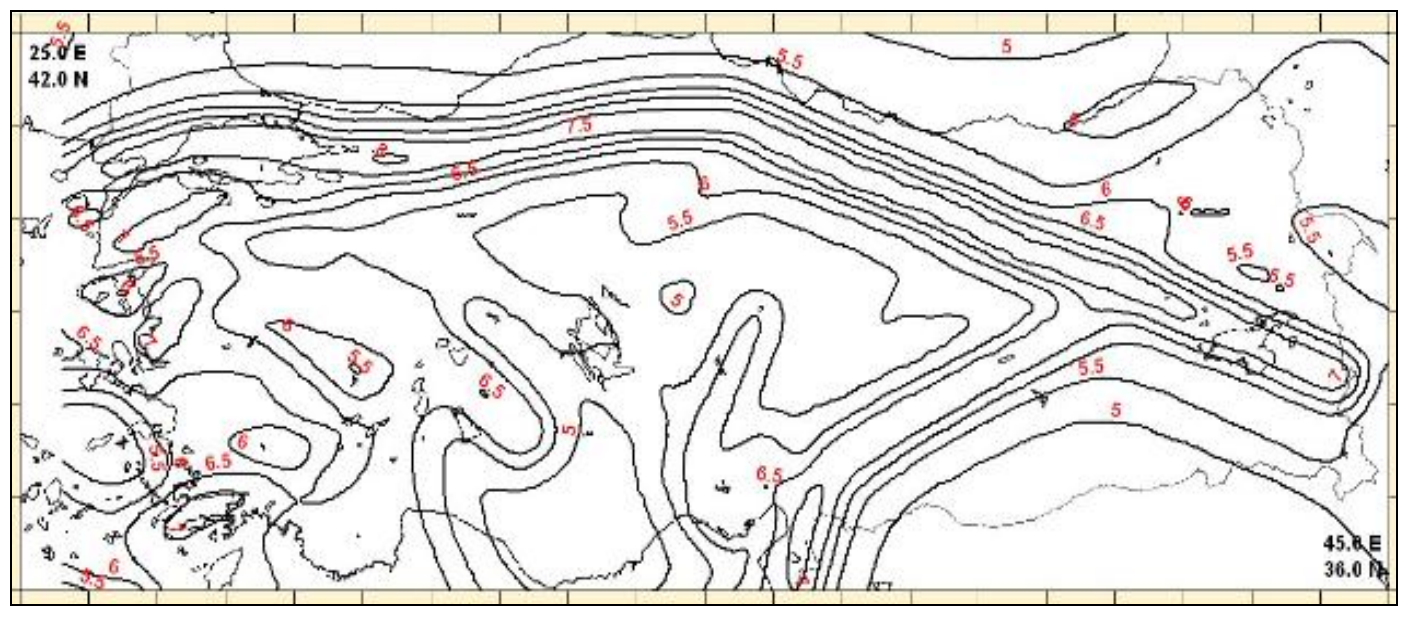

Figure 3.7 Intensity Distributions for 72 Years and \%50 Probability

(Source: Erdik et al., 2002) 


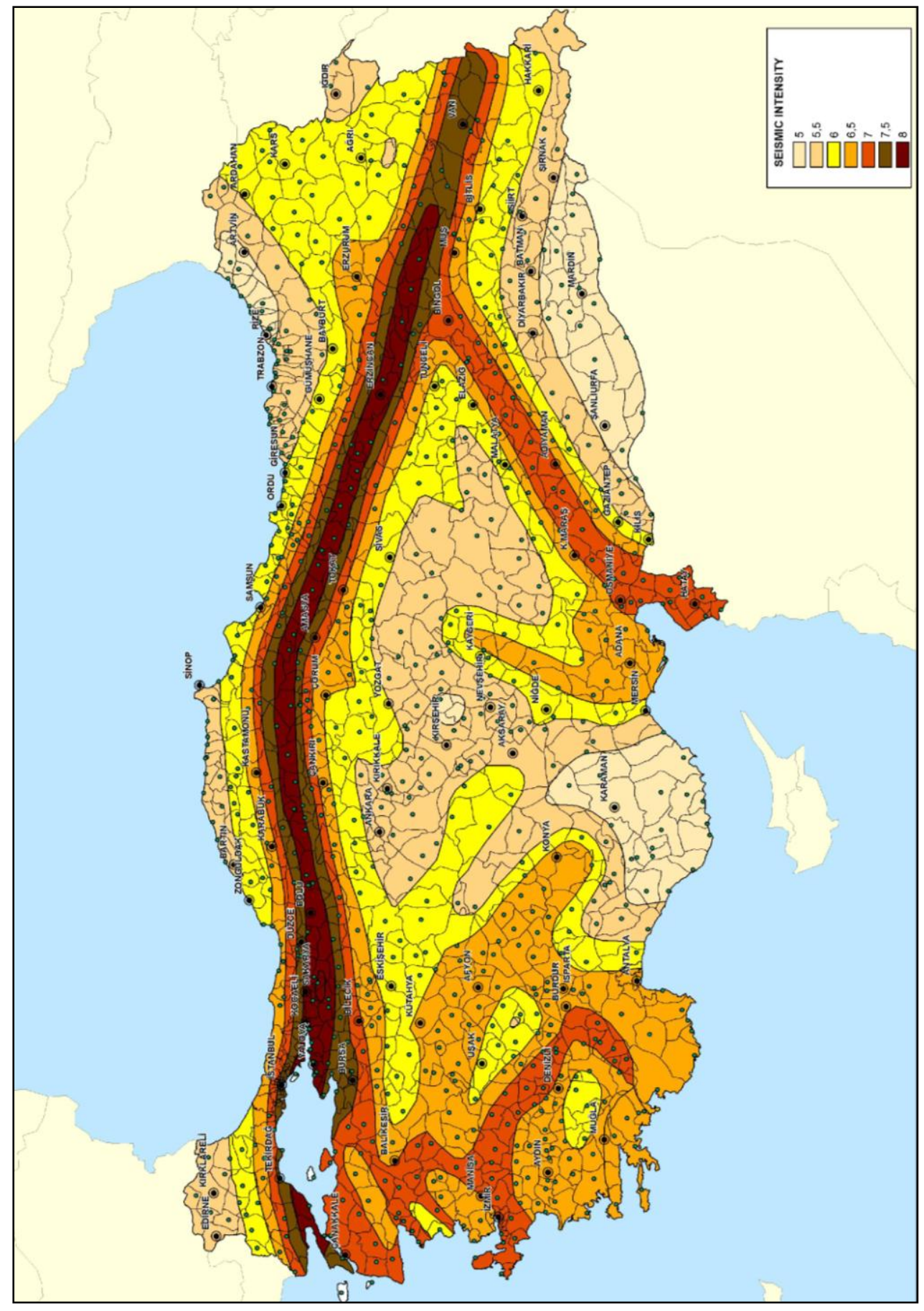

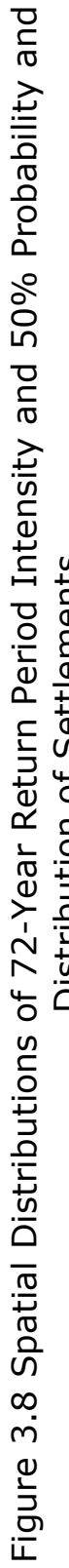


The distribution of province and sub-province centers according to expected hazard intensity levels within 72 years with a probability of $50 \%$ are given below in Table 3.6.

All settlements with an expected hazard intensity level of 6.0 and less are excluded from the analyses assuming that insignificant damage is likely to take place in these settlements.

Table 3.6 Expected Hazard Intensity Level Distribution of Province and SubProvince Centers

\begin{tabular}{|c|c|c|c|c|}
\hline Seismic Intensity & $\begin{array}{c}\text { Number of } \\
\text { Settlements }\end{array}$ & $\begin{array}{c}\text { Number of } \\
\text { Settlements } \\
\text { \% }\end{array}$ & $\begin{array}{c}\text { Total } \\
\text { Population }\end{array}$ & $\begin{array}{c}\text { Total } \\
\text { Population } \\
\text { \% }\end{array}$ \\
\hline 5.0 & 56 & 6,17 & 2.250 .086 & 4,11 \\
\hline 5.5 & 165 & 18,17 & 8.758 .017 & 15,98 \\
\hline 6.0 & 189 & 20,81 & 8.406 .916 & 15,34 \\
\hline 6.5 & 211 & 23,24 & 10.336 .721 & 18,86 \\
\hline 7.0 & 149 & 16,41 & 6.890 .125 & 12,57 \\
\hline 7.5 & 79 & 8,70 & 15.447 .702 & 28,19 \\
\hline 8.0 & 59 & 6,50 & 2.708 .513 & 4,94 \\
\hline Total & $\mathbf{9 0 8}$ & $\mathbf{1 0 0}$ & $\mathbf{5 4 . 7 9 8 . 0 8 0}$ & $\mathbf{1 0 0}$ \\
\hline
\end{tabular}

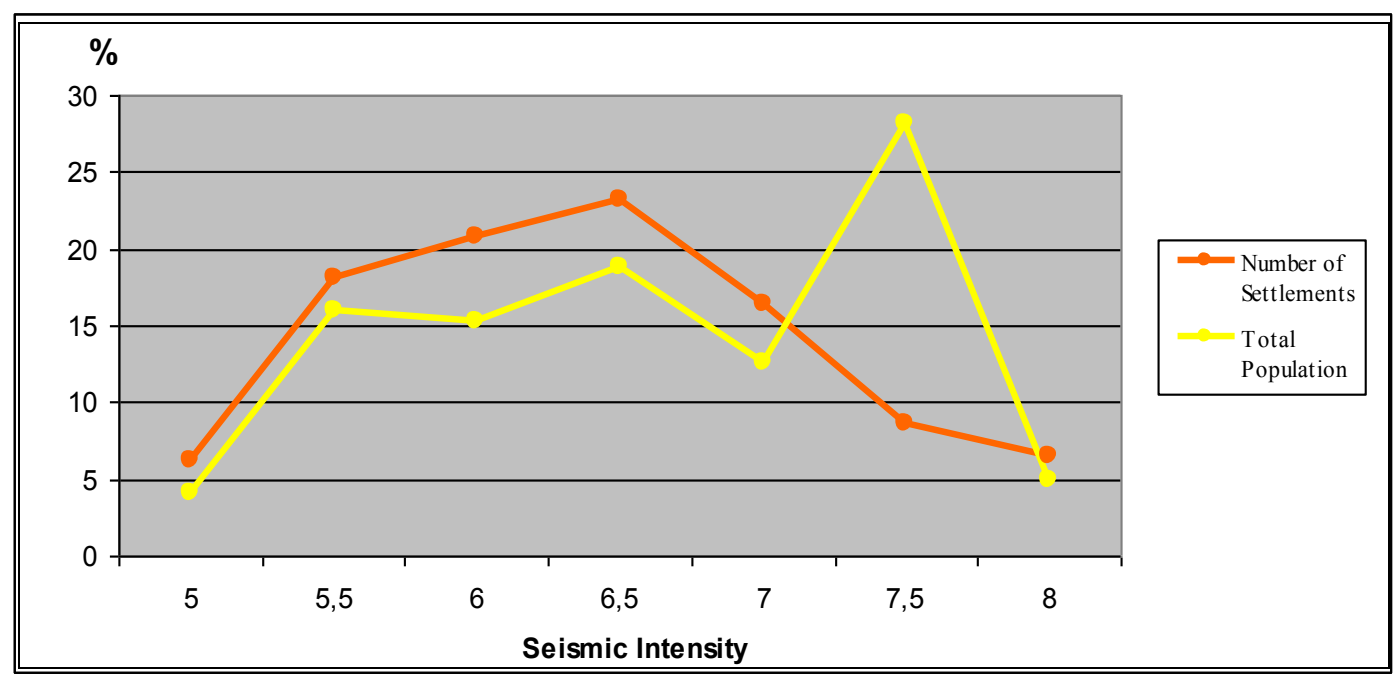

Figure 3.9 Expected Hazard Intensity Level Distributions of Province and SubProvince Centers 


\section{Determination of Settlement Categories According to Size}

Seeking for settlement attributes that can express overall vulnerability levels of cities could take into consideration the wide range of differences of settlements which could in the first instance be specified by size.

Metropolitan cities, large settlements and a multitude of smaller towns may be distinctly grouped both in terms of dependent and independent variables.

The rationale for categorization of settlements is the nature of vulnerabilities that is likely to vary in each settlement according to many interdependent components in physical and socio-economical terms. Yet settlements subject to similar intensities will have different levels of loss and cannot be described as of equal in vulnerabilities. One of the most featured reasons of this differentiation is the size of settlements.

If absolute vulnerabilities are measured in terms of likely loss levels, a bias for larger settlements and developed regions is inevitable. In order to avoid bias due to size of larger settlements and developed regions, a method of sub-grouping is to be employed. It may be appropriate to categorize the settlements in terms of population size and a categorization of settlements with reference to population is considered as an initial step.

Three groups of settlements are considered according to categorization of settlements with reference to population.

i- Metropolitan cities are identified as a separate category at the upper end. Irrespective of size and location, such province and sub-province centers are considered as a single settlement unit.

The remaining smaller cities are distinguished in two parts, almost identical in terms of total population. This marks the threshold size of 50.000 .

ii- Sub-provincial and provincial centers of 50.000-490.000 are identified as a second category of settlements. These are often well-established settlements with higher rates of growth and expanding economies.

iii- Smaller sub-provincial and provincial centers with a population less than 50.000 make the third group of urban centers. These are relatively stagnant settlements.

The frequency distributions of province and sub-province centers subject to seismic disturbance of $6.5+$ within 72 years with a probability of $50 \%$ are given below in terms of total population. The break-point of 50'000 is indicated in red.

Population distribution of settlements with reference to categories identified in the whole spectrum of seismic intensity levels is an overall indicator of exposure. The distributions of settlements within each size-category are given in the Figure 3.14 . 


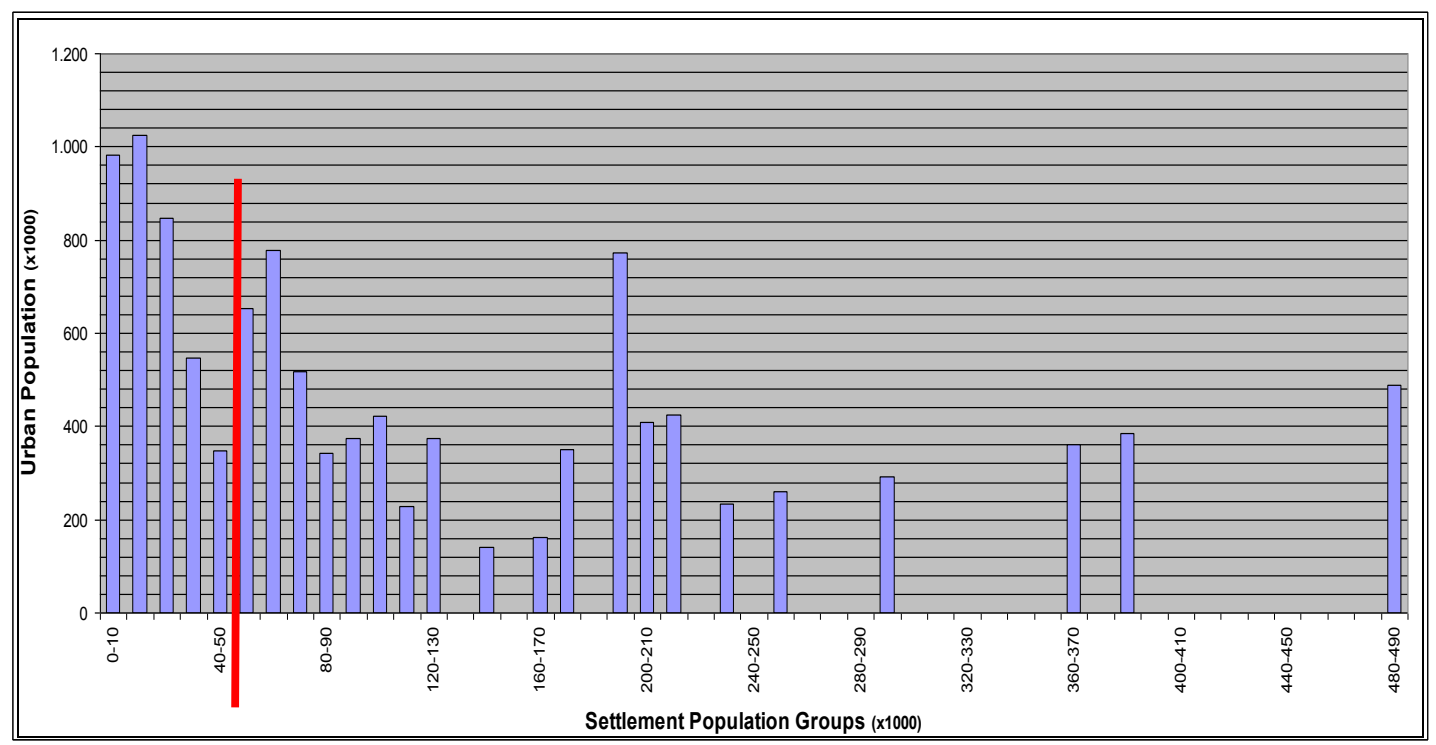

Figure 3.10 The Frequency Distribution of Province and Sub-Province Centers According to Population

The same distribution in terms of number of settlements indicates to a similar break-point.

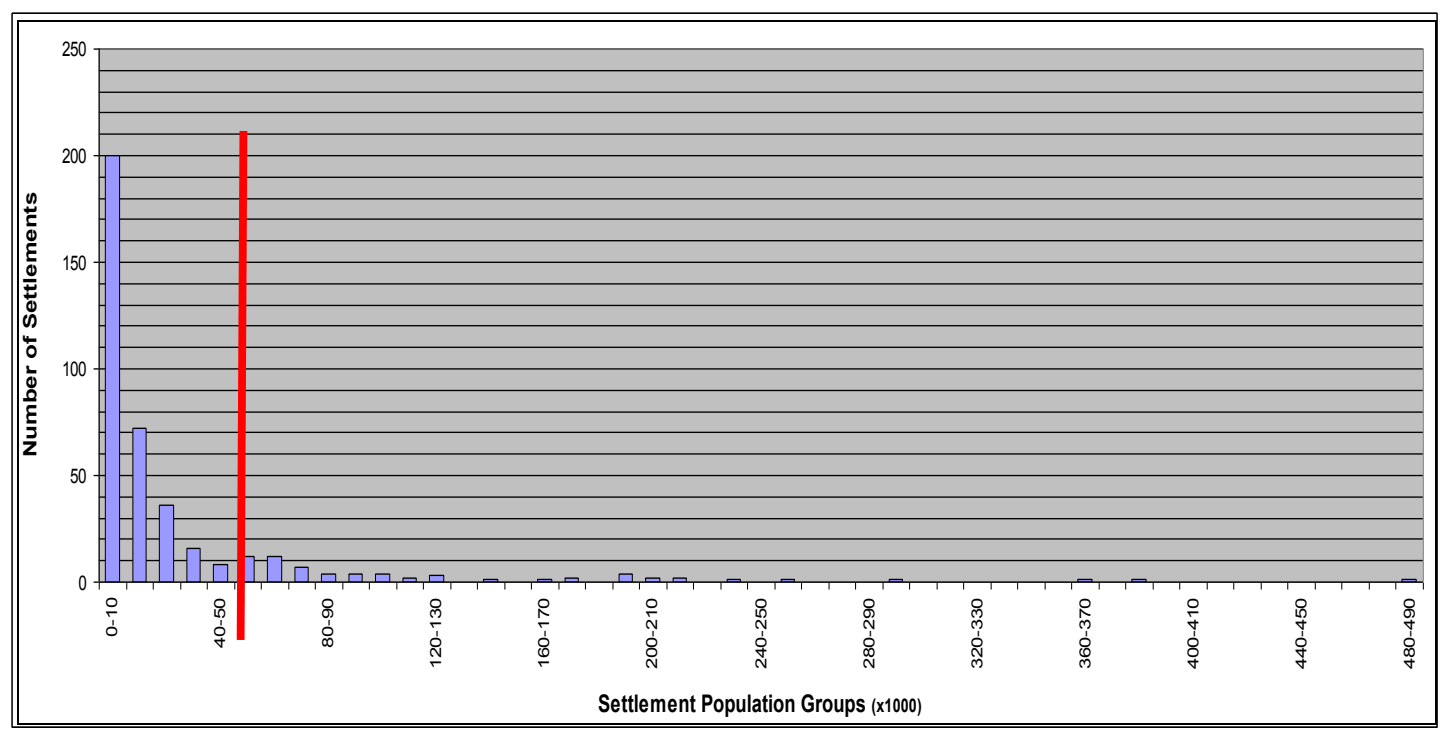

Figure 3.11 The Frequency Distribution of Province and Sub-Province Centers According to Number of Settlements

The overall distributions of settlements are as given in the table below: 
Table 3.7 Distribution of Settlements According to Number of Settlements and Total Population with Seismic Hazard Intensity Levels of 6.5 and Above

\begin{tabular}{|c|c|c|}
\hline $\begin{array}{c}\text { Settlement Size } \\
\text { Categories }\end{array}$ & $\begin{array}{c}\text { Number of } \\
\text { Settlements }\end{array}$ & Total Population \\
\hline $0-50.000$ & 332 & 3.748 .214 \\
\hline $50.000-490.000$ & 66 & 7.972 .548 \\
\hline Metropolitan provinces & 100 & 23.662 .299 \\
\hline Total & 498 & 35.383 .061 \\
\hline
\end{tabular}

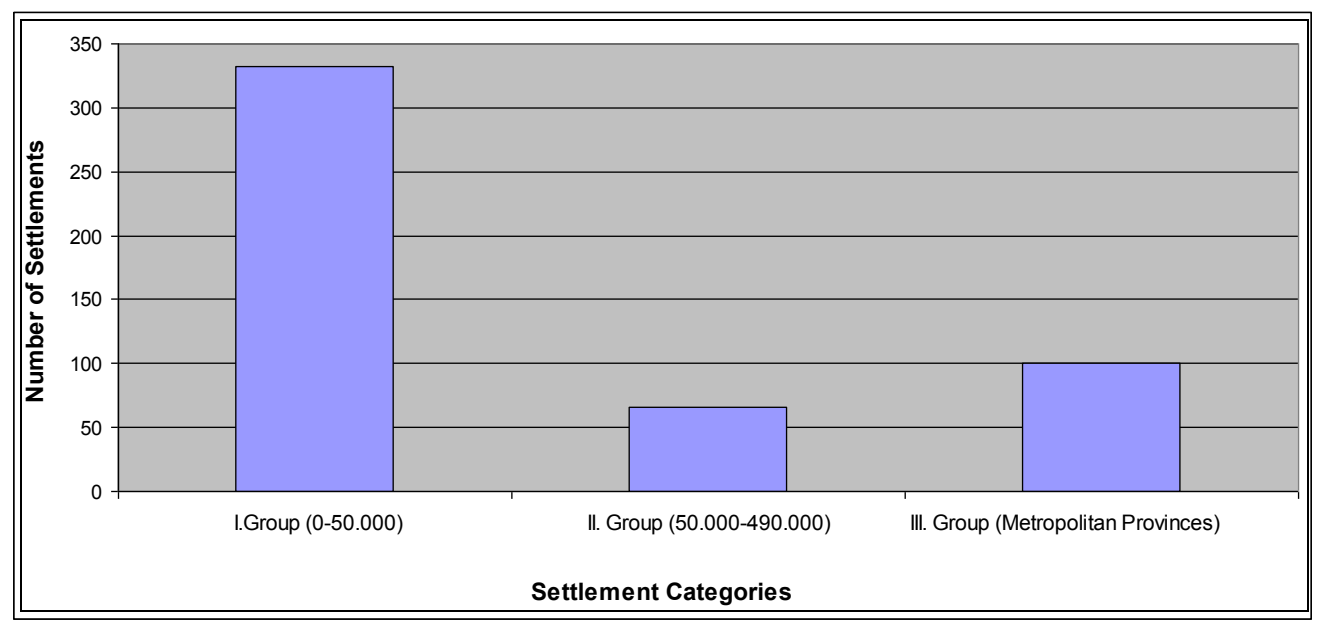

Figure 3.12 The Distribution of Province and Sub-Province Centers According to Number of Settlements

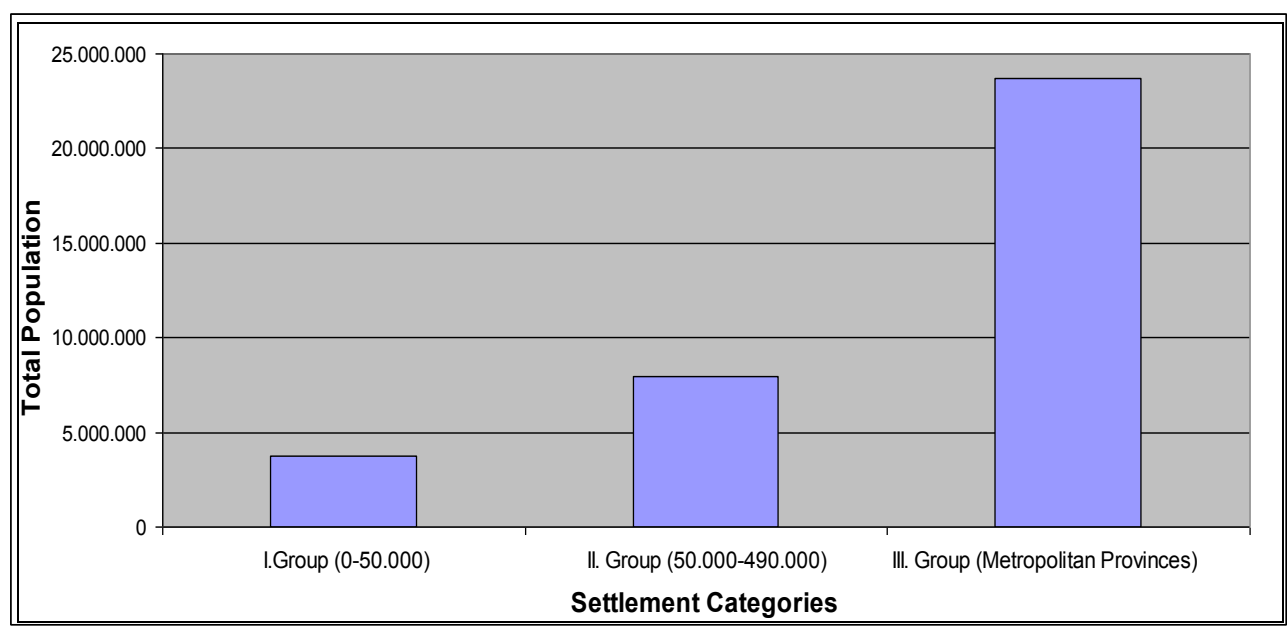

Figure 3.13 The Distribution of Province and Sub-Province Centers According to Total Population 


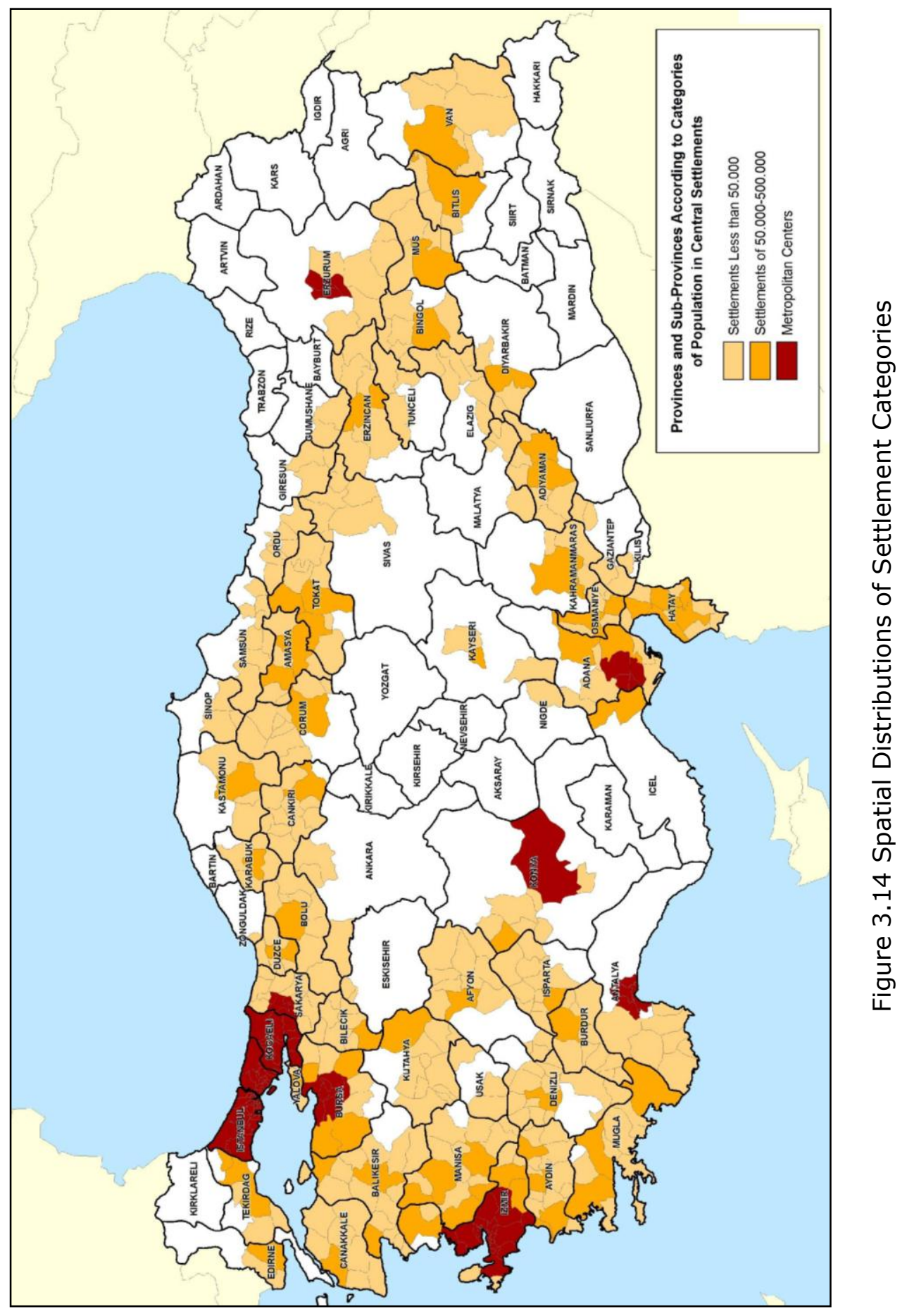


When settlements and population subject to $6.5+$ seismic hazards are compared with those subject to 6.0 and lower intensity seismic hazards, with reference to categories, the observed trend is a bias towards the higher end of the seismic scale both in terms of number of settlements and population.

When we examine the population distribution of settlements with reference to all seismic intensity levels, we saw that $35 \%$ of all urban population in the country lives in settlements subject to intensities lower than $6.0 .65 \%$ of settlement population in the country lives in settlements subject to intensities 6.5 and upper. As 6.5+ intensities can be classified as the high hazard impact zone, we can easily say that approximately two third of all population living under serious threat.

Table 3.8 The Distribution of Province and Sub-Province Centers with Reference to all Seismic Intensity Levels According to Total Population

\begin{tabular}{|c|c|c|c|c|c|c|c|c|}
\hline $\begin{array}{c}\text { Settlement } \\
\text { Size } \\
\text { Categories }\end{array}$ & $\begin{array}{c}\text { Total } \\
\text { Population }\end{array}$ & $\begin{array}{l}\text { Settlements } \\
\text { Subject to } \\
\text { Intensity of } \\
\mathbf{5 . 0}\end{array}$ & $\begin{array}{c}\text { Settlements } \\
\text { Subject to } \\
\text { Intensity of } \\
\mathbf{5 . 5}\end{array}$ & $\begin{array}{c}\text { Settlements } \\
\text { Subject to } \\
\text { Intensity of } \\
6\end{array}$ & $\begin{array}{c}\text { Settlements } \\
\text { Subject to } \\
\text { Intensity of } \\
\mathbf{6 . 5}\end{array}$ & $\begin{array}{l}\text { Settlements } \\
\text { Subject to } \\
\text { Intensity of } \\
7\end{array}$ & $\begin{array}{c}\text { Settlements } \\
\text { Subject to } \\
\text { Intensity of } \\
7.5\end{array}$ & $\begin{array}{l}\text { Settlements } \\
\text { Subject to } \\
\text { Intensity of } \\
\mathbf{8}\end{array}$ \\
\hline $0-5$ & & 578.0 & 1.256 & 1.520 .341 & 1.780 & 71 & 302 & 451.537 \\
\hline $\begin{array}{l}50.000- \\
490.000\end{array}$ & 14.823 .516 & 1.671 .998 & 2.360 .181 & 2.818 .789 & 4.339 .446 & 2.538 .841 & 678.810 & 415.451 \\
\hline $\begin{array}{c}\text { Metropolitan } \\
\text { provinces }\end{array}$ & 32.871 .044 & 0 & 5.140 .959 & 4.067 .916 & 4.216 .666 & 3.137 .913 & 14.466 .195 & 1.841 .525 \\
\hline Total & 080 & .250 .086 & 8.758 .017 & 8.406 .916 & 10.336 .721 & 6.890 .125 & 15.447 .702 & 2.708 .513 \\
\hline Total $\%$ & 100 & 4 & 16 & 15 & 19 & 13 & 28 & 5 \\
\hline
\end{tabular}

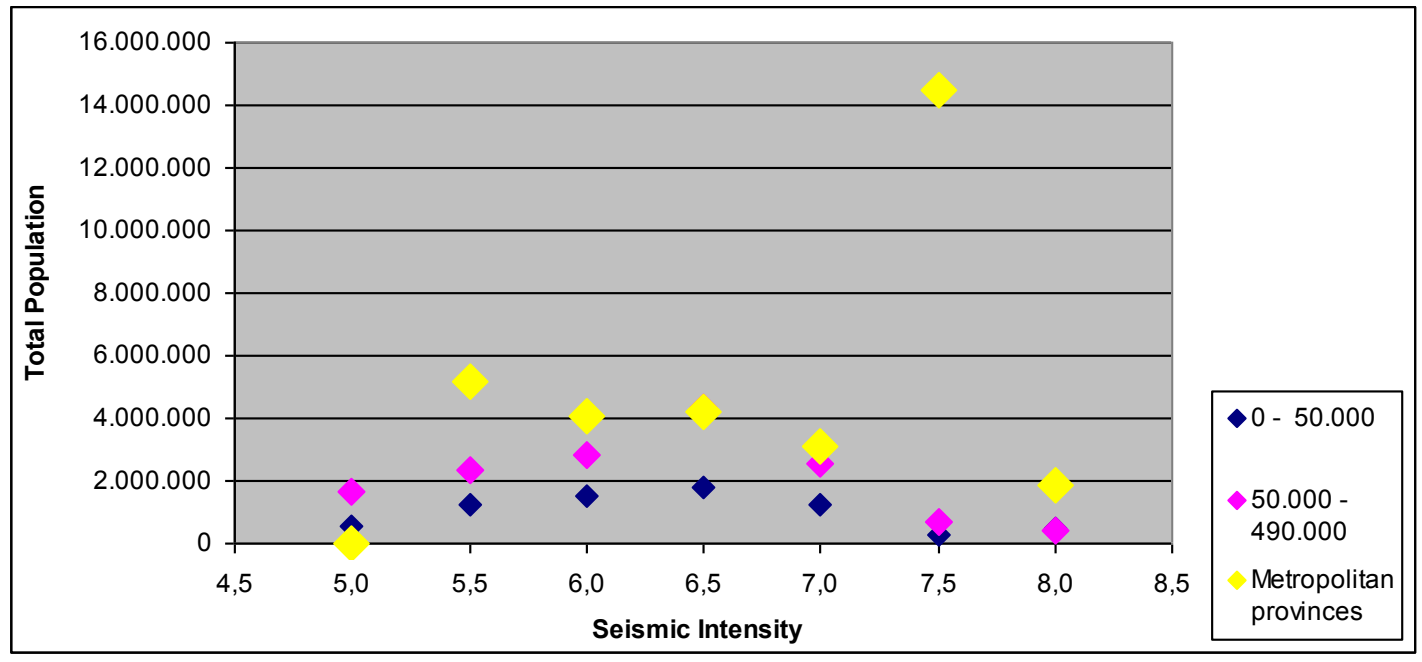

Figure 3.15 The Distribution of Province and Sub-Province Centers with Reference to all Seismic Intensity Levels According to Total Population 
When we examine the distribution of settlements with reference to all seismic intensity levels, we saw that $45 \%$ of settlements in the country are subject to intensities lower than 6.0 and $55 \%$ of settlements in the country is subject to intensities 6.5 and upper.

Table 3.9 The Distribution of Province and Sub-Province Centers with Reference to all Seismic Intensity Levels According to Number of Settlements

\begin{tabular}{|c|c|c|c|c|c|c|c|c|}
\hline $\begin{array}{c}\text { Settlement } \\
\text { Size } \\
\text { Categories }\end{array}$ & $\begin{array}{c}\text { Number } \\
\text { of } \\
\text { Settle- } \\
\text { ments }\end{array}$ & $\begin{array}{c}\text { Settlements } \\
\text { Subject to } \\
\text { Intensity of } \\
\mathbf{5 . 0}\end{array}$ & $\begin{array}{c}\text { Settlements } \\
\text { Subject to } \\
\text { Intensity of } \\
\mathbf{5 . 5}\end{array}$ & $\begin{array}{c}\text { Settlements } \\
\text { Subject to } \\
\text { Intensity of } \\
\mathbf{6}\end{array}$ & $\begin{array}{c}\text { Settlements } \\
\text { Subject to } \\
\text { Intensity of } \\
\mathbf{6 . 5}\end{array}$ & $\begin{array}{c}\text { Settlements } \\
\text { Subject to } \\
\text { Intensity of } \\
\mathbf{7}\end{array}$ & $\begin{array}{c}\text { Settlements } \\
\text { Subject to } \\
\text { Intensity of } \\
\mathbf{7 . 5}\end{array}$ & $\begin{array}{c}\text { Settlements } \\
\text { Subject to } \\
\text { Intensity of } \\
\mathbf{8}\end{array}$ \\
\hline $0-50.000$ & 677 & 43 & 142 & 160 & 154 & 108 & 32 & 38 \\
\hline $\begin{array}{c}50.000- \\
490.000\end{array}$ & 124 & 13 & 21 & 24 & 35 & 22 & 4 \\
\hline $\begin{array}{c}\text { Metropolitan } \\
\text { provinces }\end{array}$ & 107 & 0 & 2 & 5 & 22 & 19 & 43 & 16 \\
\hline Total & 908 & 56 & 165 & 189 & 211 & 149 & 79 & 59 \\
\hline Total \% & 100 & 6 & 18 & 21 & 23 & 17 & 9 & 6 \\
\hline
\end{tabular}

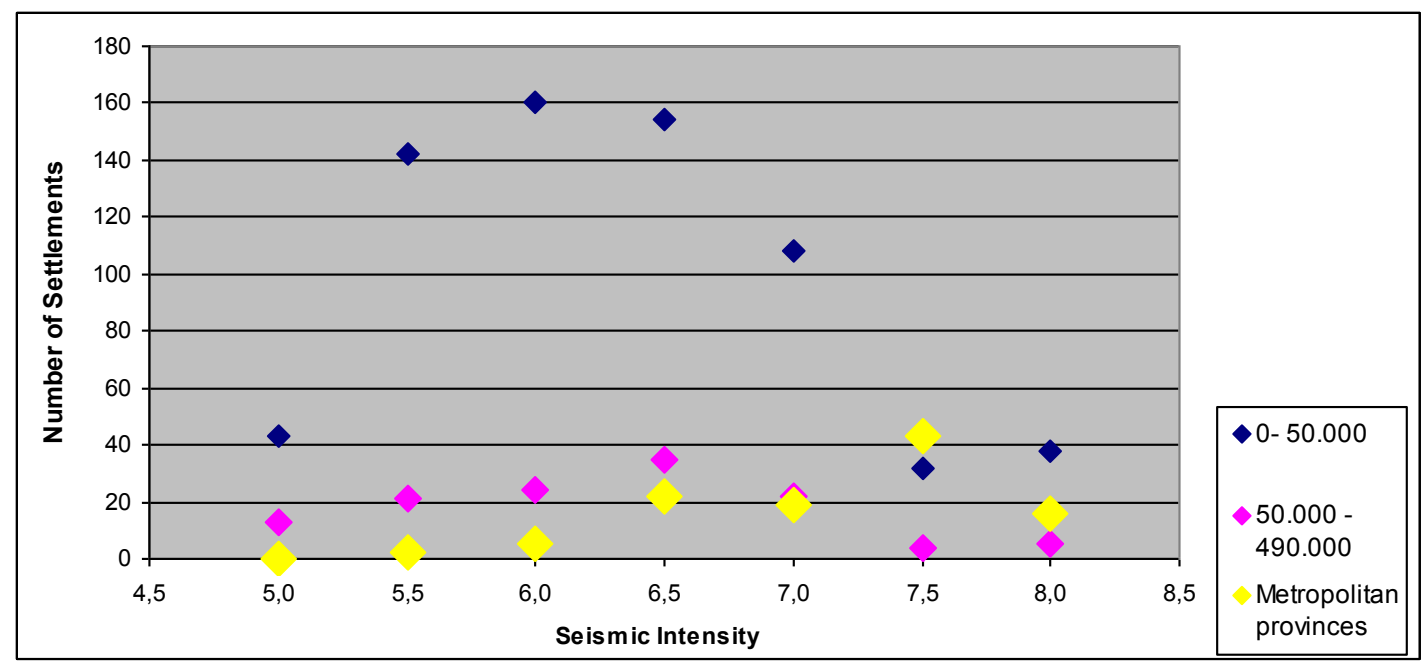

Figure 3.16 The Distribution of Province and Sub-Province Centers with Reference to all Seismic Intensity Levels According to Number of Settlements

Distribution of settlement categories indicates significant variation with reference to intensity of seismic hazard. Almost half of the smaller settlements prove take place at the lowest end of the seismic scale under consideration. This is reversed in the case of metropolitan centers as it can be seen in Table 3.4. This trend is observed to repeat itself with even greater shares in terms of population. 


\section{Identification of Categories of Building Types in Each Settlement}

Following the categorization of the building stock provided in Demircioğlu et al. (2010), four distinct groups of buildings have been identified. Load-bearing buildings, reinforced concrete structures of low-rise, medium-rise, and high-rise building categories are available in terms of number of buildings in each settlement.

Information concerning building stock properties in each settlement is obtained from Building Census-2000 produced by Turkish Statistical Institute. The publication however of this source of information was not aggregated at the settlement level. A special disaggregated version of the building census 2000 at the level of settlements was accessed for this research.

Data available for the building stock in the TurkStat statistics at settlement level provide information on number of buildings in each group separate from number of storey. These statistics provide information on the structural properties of buildings in Table 5 and the distribution of the number of storeys in Table 8 for the same building stock in every municipality.

These two tables were integrated on the basis that almost all buildings of 4+ storey's were frame structures, residual numbers of frame structures were attributed to lower storey buildings, and compositions of wall-bearing and frame structures established for each municipality corresponding to province and subprovince centers.

A re-aggregation based on number of storeys was necessary for an adjustment for the use of the vulnerability curves of buildings. The number of storey grouping has been organized so that 1-3 storey reinforced concrete buildings and load-bearing buildings have been combined. The mid-rise group was determined as 4-9 storey buildings. The $10+$ storey buildings were identified as the high-rise group of buildings.

The distribution of building stock attributes for all settlements according to construction type and number of storeys is given in the Appendix A.

In this minor re-appointment procedure of building categories special consideration was given to remain on the safer side, avoiding the likelihood of under-estimations of building vulnerabilities. The redistribution of the building stock thus maintained the compatibility with the definitions of the building vulnerability/fragility curves developed for Turkey (Balamir, 2011). 
Table 3.10 Building Stock Categories of Settlements According to Construction Type and Number of Storeys (6.5 + Seismic Intensity)

\begin{tabular}{|c|c|c|c|c|c|c|}
\hline $\begin{array}{c}\text { Settlement } \\
\text { Size } \\
\text { Categories }\end{array}$ & $\begin{array}{c}\text { Number } \\
\text { of } \\
\text { Settlements }\end{array}$ & $\begin{array}{c}\text { Wall Bearing } \\
\text { Construction } \\
(\mathbf{1 - 3} \text { storeys) }\end{array}$ & $\begin{array}{c}\text { Frame } \\
\text { Construction } \\
\text { Low- Rise } \\
\mathbf{( 1 - 3 )}\end{array}$ & $\begin{array}{c}\text { Frame } \\
\text { Construction } \\
\text { Mid-Rise } \\
\mathbf{( 4 - 9 )}\end{array}$ & $\begin{array}{c}\text { Frame } \\
\text { Construction } \\
\text { High-Rise } \\
(\mathbf{1 0 +})\end{array}$ & $\begin{array}{c}\text { Total } \\
\text { Number } \\
\text { of } \\
\text { Buildings }\end{array}$ \\
\hline $0-50.000$ & 332 & 440.905 & 341.875 & 54.309 & 80 & 843.188 \\
\hline $\begin{array}{c}50.000- \\
500.000\end{array}$ & 66 & 482.844 & 357.630 & 128.564 & 619 & 973.014 \\
\hline $\begin{array}{c}\text { Metropolitan } \\
\text { cities }\end{array}$ & 100 & 655.200 & 899.892 & 541.888 & 10.862 & 2.116 .296 \\
\hline Total & 498 & 1.578 .949 & 1.599 .397 & 724.761 & 11.561 & 3.932 .498 \\
\hline
\end{tabular}

Table 3.11 Building Stock Averages of Settlements According to Construction Type and Number of Storeys (6.5 + Seismic Intensity)

\begin{tabular}{|c|c|c|c|c|}
\hline $\begin{array}{c}\text { Settlement Size } \\
\text { Categories }\end{array}$ & $\begin{array}{c}\text { Wall Bearing } \\
\text { Construction } \\
(\mathbf{1 - 3} \text { storeys) }\end{array}$ & $\begin{array}{c}\text { Frame } \\
\text { Construction } \\
\text { Low- Rise } \\
(\mathbf{1 - 3})\end{array}$ & $\begin{array}{c}\text { Frame } \\
\text { Construction } \\
\text { Mid-Rise } \\
\mathbf{( 4 - 9 )}\end{array}$ & $\begin{array}{c}\text { Frame } \\
\text { Construction } \\
\text { High-Rise (10+) }\end{array}$ \\
\hline $0-50.000$ & 1328 & 1030 & 164 & 0,24 \\
\hline $50.000-500.000$ & 7316 & 5419 & 1948 & 9 \\
\hline Metropolitan cities & 72.800 & 99.988 & 60.210 & 1207 \\
\hline Turkey Total & 4.001 .954 & 2.735 .955 & 1.038 .730 & 17.407 \\
\hline Mean & 1246 & 852 & 323 & 5 \\
\hline
\end{tabular}

Table 3.12 Building Stock Categories of Settlements According to Construction Type and Number and Storeys by Percentages (6.5 + Seismic Intensity)

\begin{tabular}{|c|c|c|c|c|c|c|}
\hline $\begin{array}{c}\text { Settlement } \\
\text { Size } \\
\text { Categories }\end{array}$ & $\begin{array}{c}\text { Number } \\
\text { of } \\
\text { Settlements } \\
\mathbf{\%}\end{array}$ & $\begin{array}{c}\text { Wall } \\
\text { Bearing } \\
\text { Construction } \\
(\mathbf{1 - 3} \text { storeys) } \\
(\boldsymbol{\%})\end{array}$ & $\begin{array}{c}\text { Frame } \\
\text { Construction } \\
\text { Low- Rise } \\
\mathbf{( 1 - 3 )} \\
(\boldsymbol{\%})\end{array}$ & $\begin{array}{c}\text { Frame } \\
\text { Construction } \\
\text { Mid - Rise } \\
\mathbf{( 4 - 9 )} \\
(\boldsymbol{\%})\end{array}$ & $\begin{array}{c}\text { Frame } \\
\text { Construction } \\
\text { High - Rise } \\
(\mathbf{1 0 +}) \\
(\boldsymbol{\%})\end{array}$ & $\begin{array}{c}\text { Total } \\
\text { Number } \\
\text { of } \\
\text { Buildings } \\
\mathbf{\%}\end{array}$ \\
\hline $0-50.000$ & 67 & 28 & 21 & 8 & 1 & 21 \\
\hline $\begin{array}{c}50.000- \\
500.000\end{array}$ & 13 & 31 & 23 & 17 & 5 & 25 \\
\hline $\begin{array}{c}\text { Metropolitan } \\
\text { cities }\end{array}$ & 20 & 41 & 56 & 75 & 94 & 54 \\
\hline Total & 100 & 100 & 100 & 100 & 100 & 100 \\
\hline
\end{tabular}

Table 3.13 Building Stock Categories of Settlements According to Construction Type and Number and Storeys by Percentages (6.5 + Seismic Intensity)

\begin{tabular}{|c|c|c|c|c|}
\hline $\begin{array}{c}\text { Settlement Size } \\
\text { Categories }\end{array}$ & $\begin{array}{c}\text { Wall Bearing } \\
\text { Construction } \\
(\mathbf{1 - 3} \text { storeys) }\end{array}$ & $\begin{array}{c}\text { Frame } \\
\text { Construction } \\
\text { Low- Rise } \\
(\mathbf{1 - 3})\end{array}$ & $\begin{array}{c}\text { Frame } \\
\text { Construction } \\
\text { Mid - Rise } \\
\mathbf{( 4 - 9 )}\end{array}$ & $\begin{array}{c}\text { Frame } \\
\text { Construction } \\
\text { High - Rise } \\
(\mathbf{1 0 +})\end{array}$ \\
\hline $0-50.000(\%)$ & 53 & 41 & 6 & 0 \\
\hline $50.000-500.000(\%)$ & 50 & 37 & 13 & 0 \\
\hline Metropolitan cities (\%) & 31 & 43 & 26 & 1 \\
\hline Total (\%) & 40 & 41 & 19 & 0 \\
\hline
\end{tabular}




\section{Determination of Loss Levels of Each Building Category with Reference to Vulnerability Curves}

Vulnerability functions or fragility curves of an element at risk represent the probability that its response to earthquake excitation exceeds its various performance limit states based on physical and socioeconomic considerations (Erdik et al, 2002).

Vulnerability/fragility curves for each category of the building stock in Turkey, as empirically derived in Demircioğlu et al. (2010), are employed here to determine the likely loss levels therefore risks in settlements.

The horizontal axis indicates the range (uncertainty) of MSK intensities and the vertical scale indicates the percentage loss for the five different damage grades, D1 through D5, as described in EMS-98.

Building type categories are adjusted according to the definitions of the vulnerability curves based on empirical observations. These curves are devoted for low-rise reinforced concrete buildings, as well as mid-rise and high-rise reinforced concrete buildings. The vulnerability curve of the load-bearing category is assumed to approximate with the low-rise reinforced concrete type of buildings (See Figure 3.17, 3.18 and 3.19).

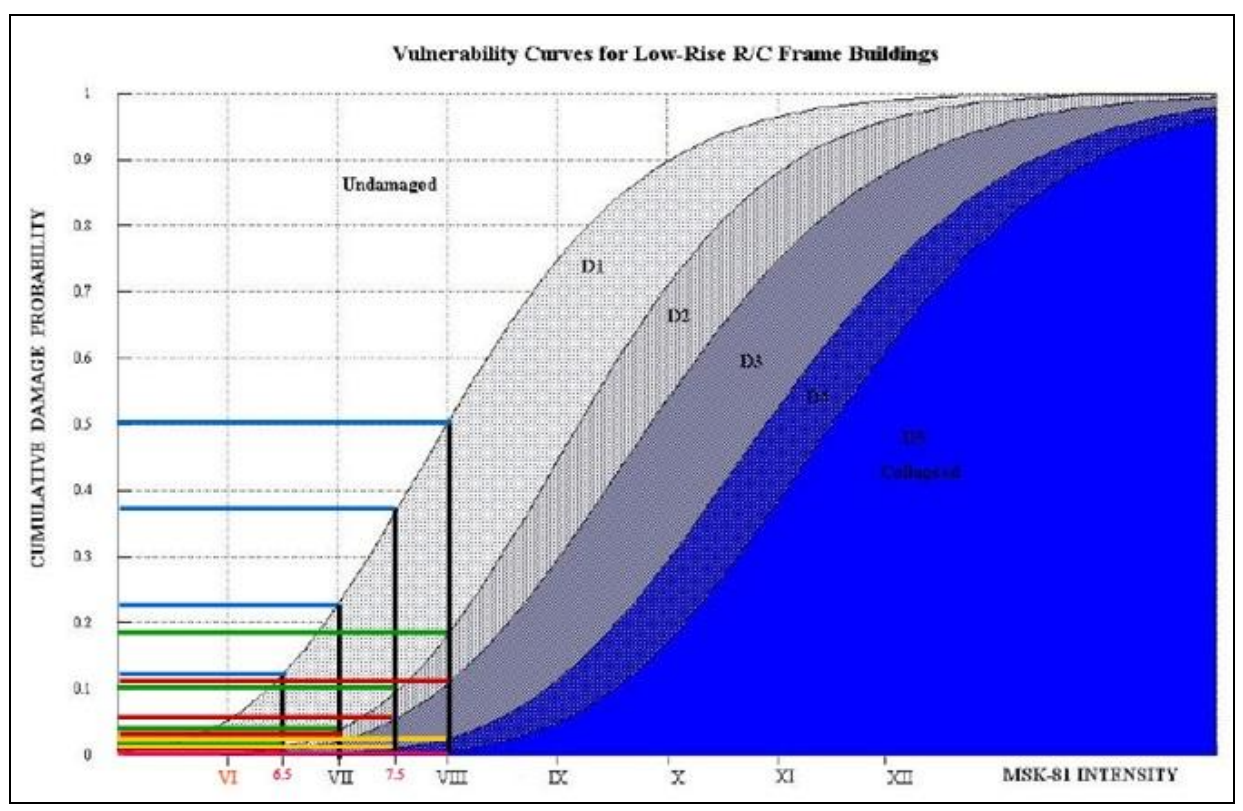

Figure 3.17 Intensity Based Vulnerability Curves for Load-Bearing and Low-Rise Reinforced Concrete Frame Type Buildings

(Source: Demircioğlu et al., 2010) 


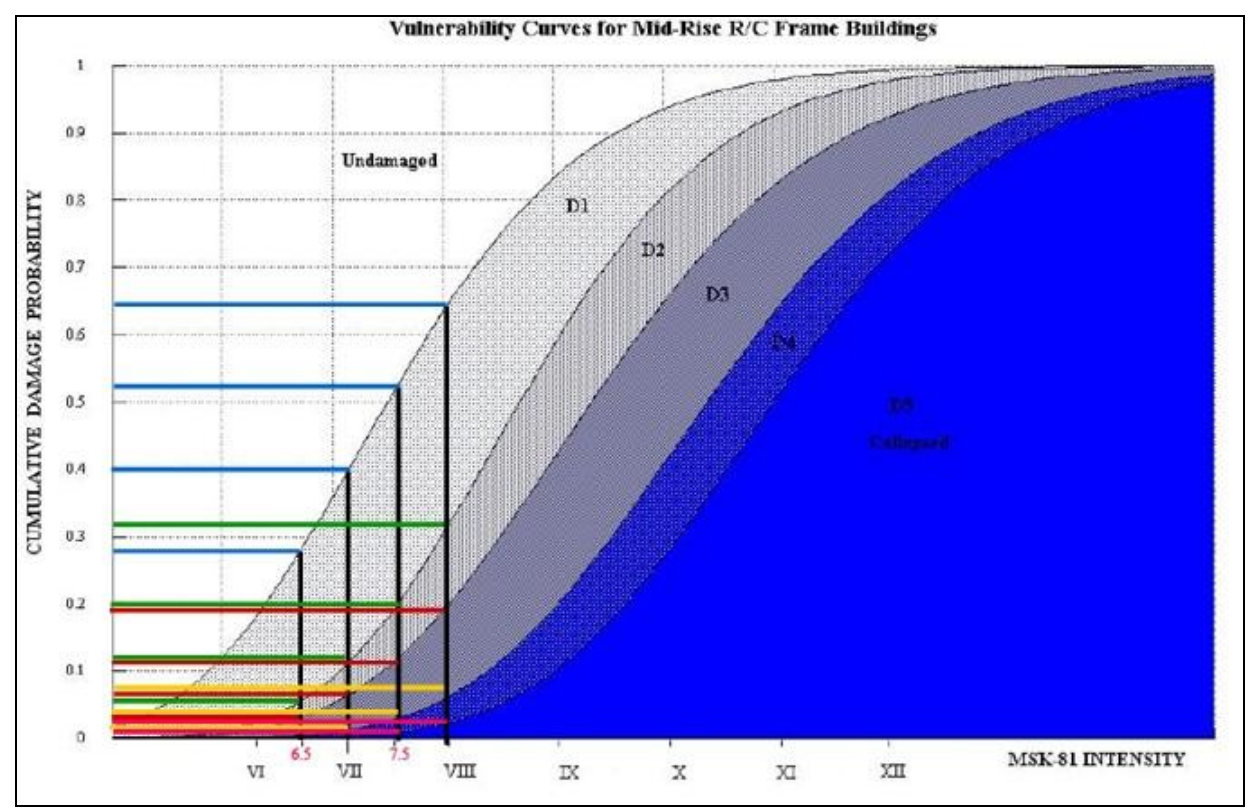

Figure 3.18 Intensity Based Vulnerability Curves for Mid-Rise Reinforced Concrete Frame Type Buildings

(Source: Demircioğlu et al., 2010)

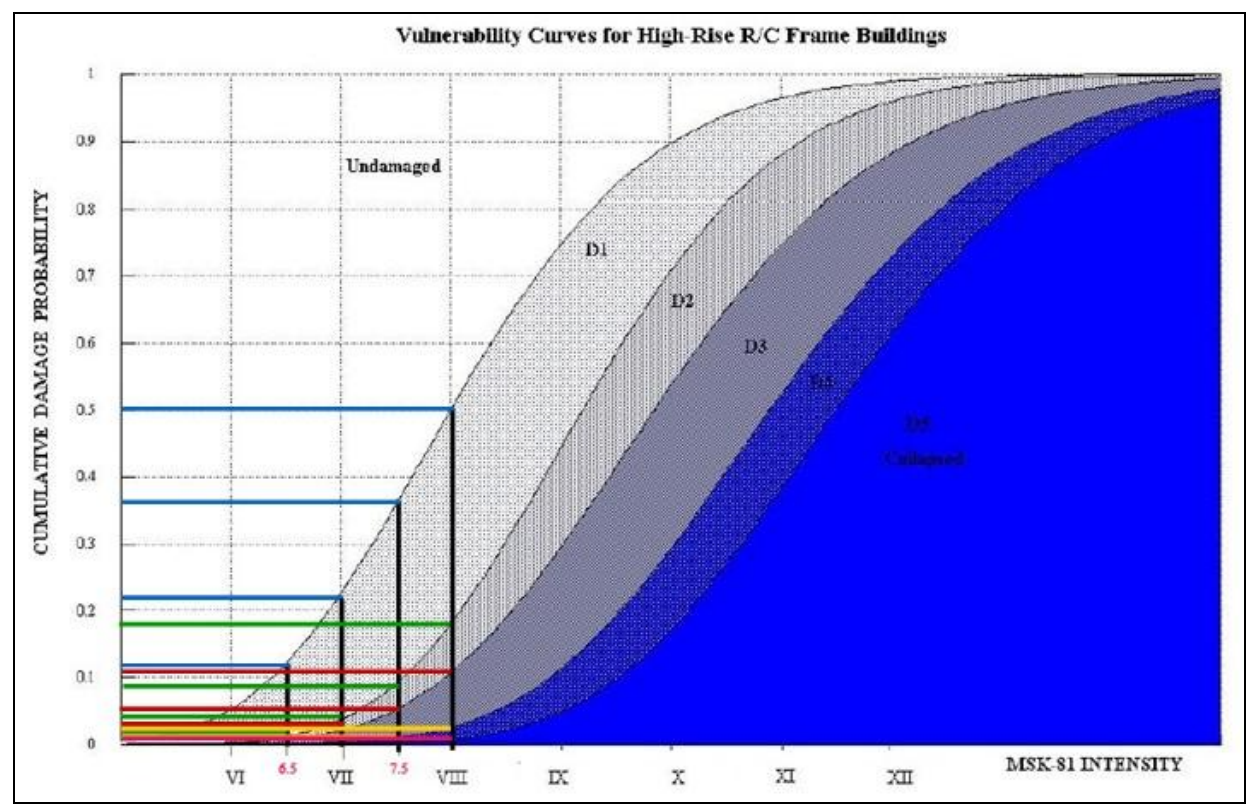

Figure 3.19 Intensity Based Vulnerability Curves for High-Rise Reinforced Concrete Frame Type Buildings

(Source: Demircioğlu et al., 2010) 
The 1998 European Macro seismic Scale (EMS, 1998) differentiates the structural vulnerabilities into six classes (A to F). Reinforced Concrete buildings with low levels of earthquake resistant design are assigned an average vulnerability class of C (Erdik et. al. 2002).

As illustrated in Figure 3.20 damage to reinforced concrete buildings are classified as: D1-Negligible to slight damage, D2-Moderate damage, D3Substantial to heavy damage, D4-Very heavy damage and D5-Destruction.

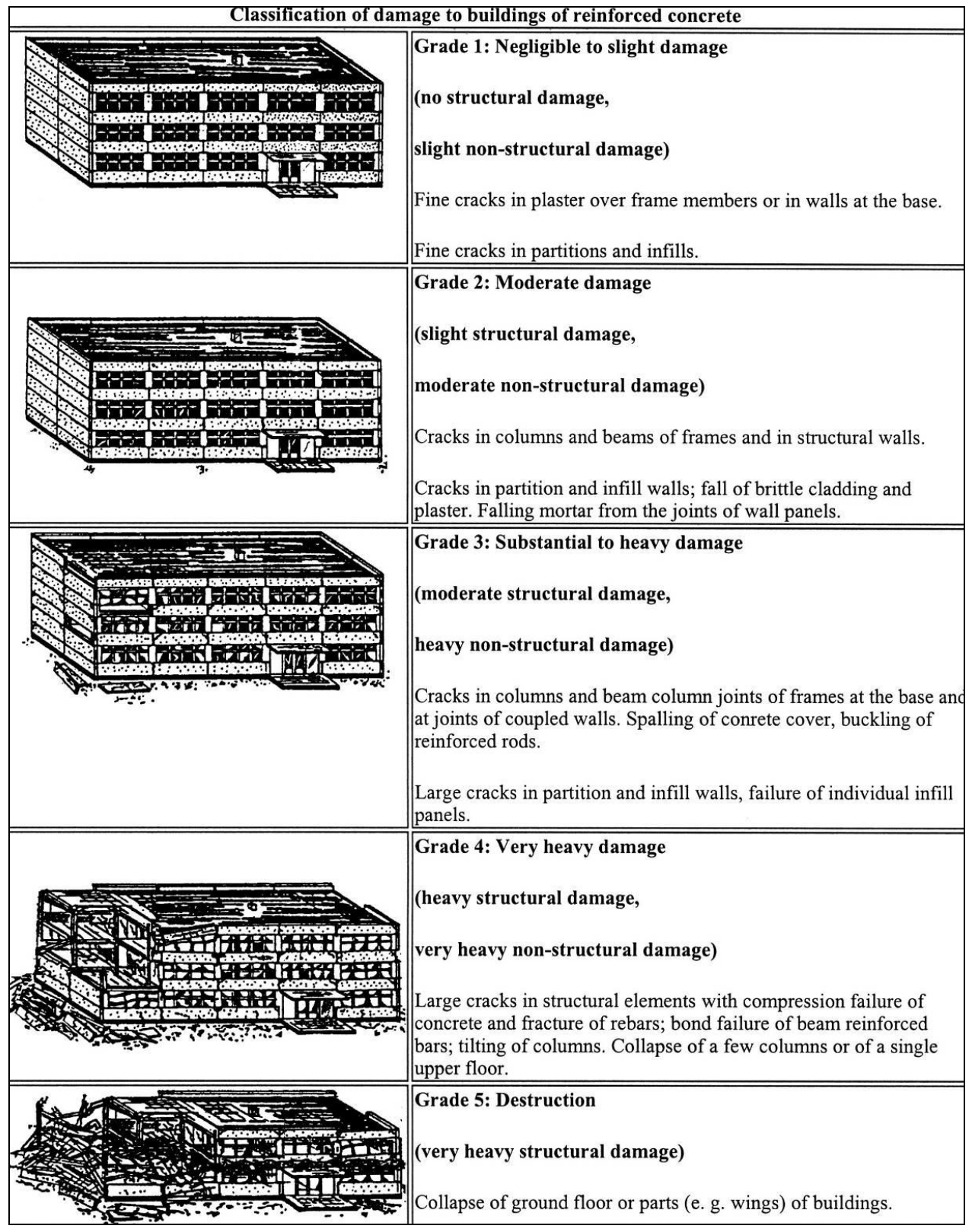

Figure 3.20 Classification of Damage to Reinforced Concrete Buildings (Source: EMS, 1998) 
Essentially using definitions from MSK-81 Scale, Coburn and Spence (1992) associates damage grades with following definitions:

Table 3.14 Description of Damage Grades in MSK-81 Intensity Scale (Source: Coburn \& Spence, 1992)

\begin{tabular}{|c|c|c|}
\hline Damage Grade & Masonry Buildings & $\begin{array}{c}\text { Reinforced Concrete } \\
\text { Buildings }\end{array}$ \\
\hline D1-Slight & Hairline cracks & $\begin{array}{c}\text { Panels cracked (Non- } \\
\text { structural) }\end{array}$ \\
\hline D2-Moderate & Cracks 0.5-2cm & Structural Cracks <1cm \\
\hline D3-Heavy & $\begin{array}{c}\text { Cracks }>2 \mathrm{~cm} \text {. or wall } \\
\text { material dislodged }\end{array}$ & $\begin{array}{c}\text { Heavy damage to structural } \\
\text { members, loss of concrete }\end{array}$ \\
\hline $\begin{array}{c}\text { D4-Partial } \\
\text { Destruction }\end{array}$ & $\begin{array}{c}\text { Complete collapse of } \\
\text { individual wall or roof } \\
\text { support }\end{array}$ & $\begin{array}{c}\text { Complete collapse of individual } \\
\text { structural member or major } \\
\text { deflection of structure }\end{array}$ \\
\hline D5-Collapse & \multicolumn{2}{|c}{$\begin{array}{c}\text { Failure of structural members } \\
\text { to allow fall of slabs. }\end{array}$} \\
\hline
\end{tabular}

The ratio of the cost of repair of the damage to the cost of reconstruction, expressed as the Repair-Cost Ratio, corresponding to the damage grades D1 through D5 can be approximately given as $0.05,0.20,0.50,0.80$ and 1.0 . Damage levels encompassing damages D3, D4 and D5 is an important descriptor of the earthquake damage since D3 represents an approximate borderline between repair and replacement of the building stock exposed to an earthquake (Erdik et. al., 2002).

EMS-98 differentiates buildings into 6 classes on the basis of their vulnerabilities from A to F. Rubble stone masonry constitutes the most vulnerable - A class. Properly built $\mathrm{R} / \mathrm{C}$ and steel buildings are in class $\mathrm{D}$ to $\mathrm{F}$. For the vulnerability class $C$, where the general R/C building stock in Turkey is located, EMS-98 provides the following definitions of intensity where 'few' describes less than $20 \%$ and 'many' describes between $20 \%$ and $60 \%$.

Intensity VI : A few buildings of vulnerability class C sustain Damage of Grade 1

Intensity VII : A few buildings of vulnerability class C sustain Damage of Grade 2

Intensity VIII : Many buildings of vulnerability class C suffer Damage of Grade 2, a few of grade 3

Intensity IX : Many buildings of vulnerability class $C$ suffer Damage of Grade 3, a few of grade 4

Intensity $X \quad$ : Many buildings of vulnerability class $C$ suffer damage of Grade 4, a few of grade 5 
The redistribution of the building stock maintained the compatibility with the definitions of the building vulnerability/fragility curves developed for Turkey. According to this procedure, each of the four categories of the building stock in every settlement is separately evaluated in their likely response to the estimated intensity of shake. As a statistical distribution, specific levels of loss from each category of the building stock can be determined by means of the vulnerability curves. The rationale behind the vulnerability curves is based on international taxonomies and the empirical findings of research on the experience in Turkey.

With reference to the seismic hazard intensity that any settlement is likely to experience, total loss in building stock with its various types and categories are estimated in each group of settlements relying on the vulnerability curves of each building type. The coefficients of damage in buildings with reference to seismic intensities were employed as in Table 3.15 below.

Table 3.15 Coefficients of Likely Forms of Loss in the Building Stock of Settlements Subject to Varying Levels of Seismic Intensity

\begin{tabular}{|c|c|c|c|c|c|}
\hline $\begin{array}{c}\text { Seismic } \\
\text { Intensity }\end{array}$ & $\begin{array}{c}\text { D1 } \\
\text { (Slight } \\
\text { Damage) }\end{array}$ & $\begin{array}{c}\text { D2 } \\
\text { (Medium } \\
\text { Damage) }\end{array}$ & $\begin{array}{c}\text { D3 } \\
\text { (Heavy } \\
\text { Damage) }\end{array}$ & $\begin{array}{c}\text { D4 } \\
\text { (Partial } \\
\text { Collapse) }\end{array}$ & $\begin{array}{c}\text { D5 } \\
\text { (Collapse } \\
\text { ) }\end{array}$ \\
\hline \multicolumn{6}{|c|}{ Low - Rise \& Load Bearing } \\
\hline 6.5 & 0,12 & 0,02 & 0,01 & 0 & 0 \\
\hline 7.0 & 0,22 & 0,04 & 0,03 & 0 & 0 \\
\hline 7.5 & 0,37 & 0,10 & 0,05 & 0,01 & 0 \\
\hline 8.0 & 0,50 & 0,18 & 0,11 & 0,03 & 0,01 \\
\hline \multicolumn{6}{|l|}{ Mid - Rise } \\
\hline 6.5 & 0,26 & 0,05 & 0,03 & 0 & 0 \\
\hline 7.0 & 0,40 & 0,12 & 0,05 & 0,01 & 0 \\
\hline 7.5 & 0,52 & 0,20 & 0,11 & 0,03 & 0,01 \\
\hline 8.0 & 0,65 & 0,32 & 0,19 & 0,05 & 0,03 \\
\hline \multicolumn{6}{|l|}{ High - Rise } \\
\hline 6.5 & 0,12 & 0,01 & 0 & 0 & 0 \\
\hline 7.0 & 0,22 & 0,03 & 0,02 & 0 & 0 \\
\hline 7.5 & 0,36 & 0,09 & 0,05 & 0,01 & 0 \\
\hline 8.0 & 0,50 & 0,18 & 0,11 & 0,02 & 0,01 \\
\hline
\end{tabular}

Building loss in each damage grade is obtained by multiplying the coefficients of damage in buildings with the distribution of building stock attributes according to construction type and number of storeys.

With the assumption that D3 represents an approximate borderline between repair and replacement of the building stock, total number of building lost is determined by the combined levels of loss, which means adding up the three categories of the most severe forms of damage in buildings. These are 'heavy damage' - D3, 'partial collapse' - D4 and 'total collapse' - D5 as identified in the building vulnerability curves for each type of building. 
Loss in each category of building types in each settlement is determined in absolute terms (total number of building loss) and relative terms (ratio of loss to the total building stock/ loss rate) with reference to the table above.

$$
\begin{array}{ll}
\text { Total number of building loss }=\mathrm{D} 3+\mathrm{D} 4+\mathrm{D} 5 & \longrightarrow \text { Absolute Loss } \\
\text { Loss Rate }=(\mathrm{D} 3+\mathrm{D} 4+\mathrm{D} 5) / \text { Total Building Stock } \longrightarrow \text { Relative Loss }
\end{array}
$$

The distribution of the total loss in building stock according to building types with reference to vulnerability curves in each settlement is given in the Appendix $B$.

It is then possible to have priority lists in each category of settlement-size in absolute and relative terms. Determination of loss could be interpreted by either of these criteria of absolute and relative loss. Even though these ratios may somewhat represent approximations, this may not represent a severe distortion in the estimations of loss in relative terms in the prioritization exercise carried out here.

\subsubsection{Building Loss Estimates as a Function of Likely Seismicity and Building Categories}

\section{Ordering of Settlements in Each Category According to Total Absolute Loss and Relative Loss}

Following above described procedure; loss in each settlement is determined, identification of most vulnerable settlements in each size-category and 'provinces with high-risk' are accomplished. This level of loss can be expressed in absolute terms (total number of buildings lost) or in relative terms (ratio of loss to the total building stock).

Although absolute loss may represent a concrete measure of loss, relative loss in settlements must also be taken into account. Small settlements with low values of absolute loss, but with high ratios may indicate greater impact and disturbance of hazard in urban life, than loss of similar or higher magnitude but smaller ratios in the larger cities or metropolitan agglomerations (Balamir, 2011).

Therefore the level of loss is expressed both in absolute terms (total number of buildings lost) and in relative terms (ratio of loss to the total building stock).

Total Lists of Categories of Settlements Prioritized According to Absolute Loss is given in the Appendix $C$ and Total Lists of Categories of Settlements Prioritized According to Relative Loss is given in the Appendix D.

The top-20 settlements of the complete lists in each size category according to absolute loss levels and relative loss levels are examined below. 


\section{Absolute Loss in Categories of Settlements}

The top-20 settlements (out of 332) of the complete list in each size category according to absolute loss levels (See Table 3.16, 3.17, 3.18) and the spatial distribution figures of settlements according to absolute loss is given below (See Figure 3.21). In the small-sized group of settlements, greatest loss is observed as in the Table 3.16, exhibiting the number of building loss.

The top 20 of the settlements of the complete list are significantly above the category averages in terms of absolute loss, total number of buildings and loss rates. Settlements subject to seismic intensities of 7.5 and 7.0 seem to have significantly and consistently lower rates of loss, even though absolute loss in these settlements are of comparable magnitude with those subject to the seismic intensity of 8.0 .

Almost half of the top 20 in the list are shrinking economies and are losing population. This implies least of care and maintenance in the privately owned property, and very low levels of public investments, and obviously higher risks (Balamir, 2011).

Table 3.16 Top-20 Settlements for 0-50.000 Population Prioritized According to Absolute Loss

\begin{tabular}{|c|c|c|c|c|c|c|}
\hline $\begin{array}{c}\text { CATEGORY } \\
\mathbf{0 - 5 0 . 0 0 0}\end{array}$ & $\begin{array}{c}\text { SUB- } \\
\text { PROVINCE }\end{array}$ & $\begin{array}{l}\text { Expected } \\
\text { Seismic } \\
\text { Intensity }\end{array}$ & $\begin{array}{c}\text { Absolute } \\
\text { Building } \\
\text { Loss }\end{array}$ & $\begin{array}{c}\text { Total } \\
\text { Building }\end{array}$ & $\begin{array}{l}\text { Loss } \\
\text { Rate }\end{array}$ & $\begin{array}{c}\text { Settlement } \\
\text { Population } \\
\text { (2009) }\end{array}$ \\
\hline TOKAT & NIKSAR & 8 & 1400 & 8343 & 0,17 & 33.682 \\
\hline KASTAMONU & TOSYA & 8 & 1364 & 8575 & 0,16 & 27.624 \\
\hline SAKARYA & HENDEK & 8 & 869 & 4969 & 0,17 & 44.418 \\
\hline CORUM & OSMANCIK & 8 & 786 & 5037 & 0,16 & 25.829 \\
\hline SAMSUN & HAVZA & 8 & 735 & 4620 & 0,16 & 20.204 \\
\hline TEKIRDAG & SARKOY & 8 & 712 & 4059 & 0,18 & 16.624 \\
\hline SAKARYA & AKYAZI & 8 & 681 & 3668 & 0,19 & 41.179 \\
\hline AMASYA & SULUOVA & 7,5 & 633 & 9653 & 0,07 & 37.151 \\
\hline ERZINCAN & UZUMLU & 8 & 631 & 4187 & 0,15 & 8.288 \\
\hline BOLU & GEREDE & 8 & 583 & 3439 & 0,17 & 23.808 \\
\hline SAKARYA & GEYVE & 8 & 543 & 3491 & 0,16 & 20.318 \\
\hline BALIKESIR & AYVALIK & 7 & 442 & 14115 & 0,03 & 35.986 \\
\hline SIVAS & SUSEHRI & 8 & 424 & 2589 & 0,16 & 15.304 \\
\hline BALIKESIR & BURHANIYE & 7 & 410 & 13164 & 0,03 & 38.156 \\
\hline SAKARYA & PAMUKOVA & 8 & 403 & 2600 & 0,15 & 16.047 \\
\hline MUS & VARTO & 8 & 384 & 2562 & 0,15 & 9.585 \\
\hline SAMSUN & LADIK & 8 & 377 & 2426 & 0,16 & 8.316 \\
\hline YALOVA & CINARCIK & 8 & 357 & 1675 & 0,21 & 11.080 \\
\hline IZMIR & CESME & 7 & 348 & 11532 & 0,03 & 20.455 \\
\hline BURSA & YENISEHIR & 7,5 & 339 & 5028 & 0,07 & 29.275 \\
\hline Group Average & & & 96 & 2540 & 0.04 & 11.290 \\
\hline
\end{tabular}


The second category of settlement with 50.000-490.000 inhabitants gives the following levels of building loss at top-20 of the list (out of 66) and rates of loss compared to the total building stock in the settlement (See Table 3.17, Figure 3.21).

In contrast to the previous category of settlements, many cases here prove high levels of absolute loss determined less dependently on strength of seismic shake and there are variations in seismic intensity levels and rates of loss. Apart from a very few of the cases here, rates of loss seem to be lower than observed in the previous category and almost half of the top 20 in the list have higher rates than the average rate for this category.

Table 3.17 Top-20 Settlements for 50.000-490.000 Population Prioritized According to Absolute Loss

\begin{tabular}{|c|c|c|c|c|c|c|}
\hline $\begin{array}{c}\text { CATEGORY } \\
\mathbf{5 0 . 0 0 0 - 4 9 0 . 0 0 0}\end{array}$ & $\begin{array}{c}\text { SUB- } \\
\text { PROVINCE }\end{array}$ & $\begin{array}{l}\text { Expected } \\
\text { Seismic } \\
\text { Intensity }\end{array}$ & $\begin{array}{c}\text { Absolute } \\
\text { Building } \\
\text { Loss }\end{array}$ & $\begin{array}{c}\text { Total } \\
\text { Building }\end{array}$ & $\begin{array}{l}\text { Loss } \\
\text { Rate }\end{array}$ & $\begin{array}{l}\text { Settlement } \\
\text { Population } \\
(\mathbf{2 0 0 9})\end{array}$ \\
\hline VAN & CENTRAL & 7,5 & 2285 & 36.235 & 0,06 & 360.810 \\
\hline ERZINCAN & CENTRAL & 8 & 2025 & 12.678 & 0,16 & 90.100 \\
\hline BOLU & CENTRAL & 8 & 1841 & 10.516 & 0,18 & 120.021 \\
\hline YALOVA & CENTRAL & 8 & 1507 & 8.302 & 0,18 & 92.166 \\
\hline TEKIRDAG & CENTRAL & 7,5 & 1347 & 15.683 & 0,09 & 140.535 \\
\hline TOKAT & ERBAA & 8 & 1251 & 7.895 & 0,16 & 58.845 \\
\hline BURSA & ORHANGAZİ & 8 & 945 & 5.313 & 0,18 & 54.319 \\
\hline MANISA & CENTRAL & 7 & 919 & 24.785 & 0,04 & 291.374 \\
\hline OSMANIYE & CENTRAL & 7 & 905 & 29.408 & 0,03 & 194.339 \\
\hline HATAY & ANTAKYA & 7 & 768 & 23.471 & 0,03 & 202.216 \\
\hline HATAY & ISKENDERUN & 7 & 705 & 21.169 & 0,03 & 190.279 \\
\hline ADIYAMAN & CENTRAL & 7 & 696 & 21.965 & 0,03 & 198.433 \\
\hline AMASYA & MERZIFON & 7,5 & 666 & 9.411 & 0,07 & 52.225 \\
\hline MANISA & TURGUTLU & 7 & 639 & 19.331 & 0,03 & 115.930 \\
\hline DUZCE & CENTRAL & 7,5 & 612 & 8.593 & 0,07 & 125.240 \\
\hline DENIZLI & CENTRAL & 6,5 & 586 & 41.993 & 0,01 & 488.768 \\
\hline MANISA & AKHİSAR & 7 & 585 & 17.775 & 0,03 & 100.897 \\
\hline BURSA & INEGOL & 7 & 536 & 14.095 & 0,04 & 161.541 \\
\hline TOKAT & CENTRAL & 7 & 528 & 15.371 & 0,03 & 129.879 \\
\hline MANISA & SALİHLİ & 7 & 483 & 13.639 & 0,04 & 96.503 \\
\hline Group Average & & & 454 & 14.743 & $\mathbf{0 , 0 3}$ & 120.796 \\
\hline
\end{tabular}

The third category of settlements as agglomerations of sub-provinces at metropolitan centers indicate the following set of priorities in Table 3.18. Ordering seems to follow seismic intensities rather than absolute size of the building stock in metropolitan provinces. 
Table 3.18 Metropolitan Provinces Prioritized According to Absolute Loss Levels

\begin{tabular}{|c|c|c|c|c|c|c|}
\hline $\begin{array}{c}\text { CATEGORY } \\
\text { Metropolitan } \\
\text { Cities }\end{array}$ & SUB-PROVINCE & $\begin{array}{c}\text { Expected } \\
\text { Seismic } \\
\text { Intensity }\end{array}$ & $\begin{array}{c}\text { Absolute } \\
\text { Building } \\
\text { Loss }\end{array}$ & $\begin{array}{c}\text { Total } \\
\text { Building }\end{array}$ & $\begin{array}{c}\text { Loss } \\
\text { Rate }\end{array}$ & $\begin{array}{c}\text { Settlement } \\
\text { Population } \\
\text { (2009) }\end{array}$ \\
\hline ISTANBUL & ISTANBUL (M) & 7,5 & 83824 & 864.540 & 0,10 & 12.782 .960 \\
\hline KOCAELI & KOCAELI (M) & 8 & 24077 & 139.423 & 0,17 & 1.422 .752 \\
\hline BURSA & BURSA (M) & 7,5 & 16506 & 204.907 & 0,08 & 1.854 .285 \\
\hline IZMIR & IZMIR (M) & 7 & 14531 & 421.397 & 0,03 & 3.276 .815 \\
\hline SAKARYA & SAKARYA (M) & 8 & 8070 & 49.609 & 0,16 & 442.157 \\
\hline ADANA & ADANA (M) & 6,5 & 1913 & 175.697 & 0,01 & 1.556 .238 \\
\hline ANTALYA & ANTALYA (M) & 6,5 & 1402 & 114.998 & 0,01 & 955.573 \\
\hline KONYA & KONYA (M) & 6,5 & 1355 & 113.267 & 0,01 & 1.003 .373 \\
\hline ERZURUM & ERZURUM (M) & 6,5 & 439 & 32.458 & 0,01 & 368.146 \\
\hline Group Average & & & $\mathbf{1 6 . 9 0 2}$ & $\mathbf{2 3 5 . 1 4 4}$ & $\mathbf{0 , 0 7}$ & $\mathbf{2 . 6 2 9 . 1 4 4}$ \\
\hline
\end{tabular}

Table 3.19 Average Absolute Loss According to the Settlement Categories

\begin{tabular}{|c|c|c|c|c|c|}
\hline $\begin{array}{c}\text { Settlement } \\
\text { Size } \\
\text { Categories }\end{array}$ & $\begin{array}{c}\text { Total } \\
\text { Absolute } \\
\text { Loss }\end{array}$ & $\begin{array}{c}\text { Total } \\
\text { Building }\end{array}$ & $\begin{array}{c}\text { Average } \\
\text { Absolute } \\
\text { Loss }\end{array}$ & $\begin{array}{c}\text { Minimum } \\
\text { Absolute } \\
\text { Loss }\end{array}$ & $\begin{array}{c}\text { Maximum } \\
\text { Absolute } \\
\text { Loss }\end{array}$ \\
\hline $0-50.000$ & 31.966 & 843.188 & 96 & 2 & 1400 \\
\hline $\begin{array}{c}50.000- \\
500.000\end{array}$ & 29.965 & 973.014 & 454 & 42 & 2285 \\
\hline $\begin{array}{c}\text { Metropolitan } \\
\text { cities }\end{array}$ & 152.115 & 2.116 .296 & 16.902 & 439 & 83.824 \\
\hline
\end{tabular}




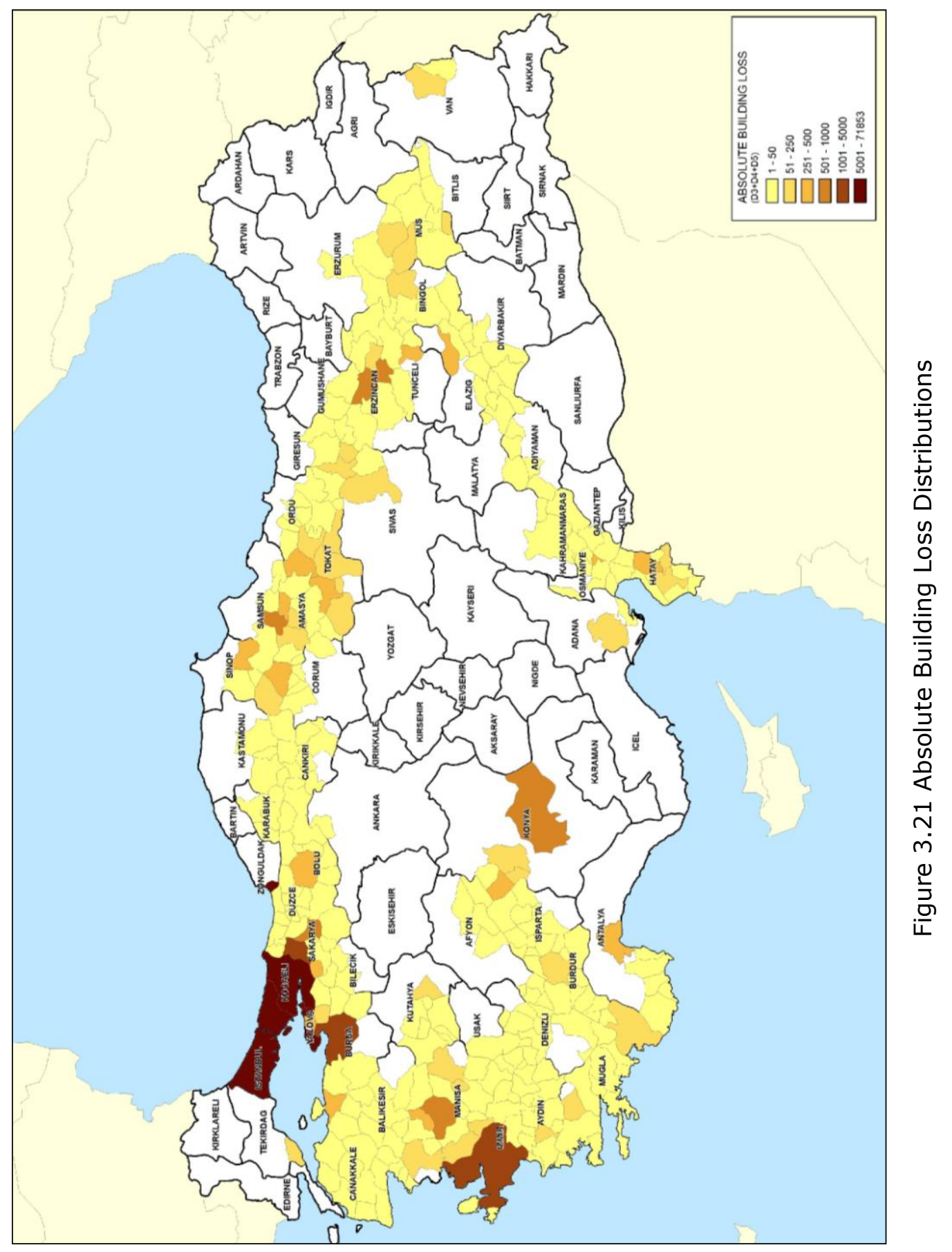




\section{Relative Loss in Categories of Settlements}

The top-20 settlements (out of 332) of the complete list in each size category according to relative loss levels (See Table 3.20, 3.21, 3.22) and the spatial distribution figures of settlements according to relative loss is given below (See Figure 3.22).

In the small-sized group of settlements, all cases prove high levels of relative loss determined dependently on strength of seismic shake and there are no variations in seismic intensity levels (See Table 3.20).

The top 20 of the settlements of the complete list are significantly above the category averages in terms of relative loss and absolute loss.

Table 3.20 Top-20 Settlements for 0-50.000 Population Prioritized According to Relative Loss

\begin{tabular}{|c|c|c|c|c|c|c|}
\hline $\begin{array}{c}\text { CATEGORY } \\
\mathbf{0 - 5 0 . 0 0 0}\end{array}$ & SUB-PROVINCE & $\begin{array}{c}\text { Expected } \\
\text { Seismic } \\
\text { Intensity }\end{array}$ & $\begin{array}{c}\text { Relative } \\
\text { Building } \\
\text { Loss }\end{array}$ & $\begin{array}{c}\text { Total } \\
\text { Building }\end{array}$ & $\begin{array}{c}\text { Absolute } \\
\text { Loss }\end{array}$ & $\begin{array}{c}\text { Sub-Province } \\
\text { Population } \\
\text { (2009) }\end{array}$ \\
\hline YALOVA & CINARCIK & 8 & 0,21 & 1675 & 357 & 11.080 \\
\hline SAKARYA & AKYAZI & 8 & 0,19 & 3668 & 681 & 41.179 \\
\hline YALOVA & CIFTLIKKOY & 8 & 0,19 & 1594 & 298 & 17.052 \\
\hline TEKIRDAG & SARKOY & 8 & 0,18 & 4059 & 712 & 16.624 \\
\hline TOKAT & NIKSAR & 8 & 0,17 & 8343 & 1400 & 33.682 \\
\hline SAKARYA & HENDEK & 8 & 0,17 & 4969 & 869 & 44.418 \\
\hline BOLU & GEREDE & 8 & 0,17 & 3439 & 583 & 23.808 \\
\hline AMASYA & TASOVA & 8 & 0,17 & 1677 & 282 & 10.821 \\
\hline YALOVA & TERMAL & 8 & 0,17 & 425 & 73 & 2.340 \\
\hline KASTAMONU & TOSYA & 8 & 0,16 & 8575 & 1364 & 27.624 \\
\hline CORUM & OSMANCIK & 8 & 0,16 & 5037 & 786 & 25.829 \\
\hline SAMSUN & HAVZA & 8 & 0,16 & 4620 & 735 & 20.204 \\
\hline SAKARYA & GEYVE & 8 & 0,16 & 3491 & 543 & 20.318 \\
\hline SIVAS & SUSEHRI & 8 & 0,16 & 2589 & 424 & 15.304 \\
\hline SAMSUN & LADIK & 8 & 0,16 & 2426 & 377 & 8.316 \\
\hline CANKIRI & ILGAZ & 8 & 0,16 & 1913 & 312 & 7.738 \\
\hline TOKAT & RESADIYE & 8 & 0,16 & 1941 & 309 & 9.027 \\
\hline BOLU & YENICAGA & 8 & 0,16 & 1120 & 183 & 5.175 \\
\hline GIRESUN & CAMOLUK & 8 & 0,16 & 859 & 133 & 2.023 \\
\hline TUNCELI & PULUMUR & 8 & 0,16 & 572 & 94 & 1.656 \\
\hline Group Average & & & $\mathbf{0 . 0 4}$ & $\mathbf{2 5 4 0}$ & $\mathbf{9 6}$ & $\mathbf{1 1 . 2 9 0}$ \\
\hline
\end{tabular}


The second category of settlement with 50.000-490.000 inhabitants gives the following levels of relative loss at top-20 of the list (See Table 3.21).

In contrast to the previous category of settlements, many cases here prove low levels of relative loss determined dependently on strength of seismic shake and there are variations in seismic intensity levels and relative loss.

Apart from a very few of the cases here, relative loss seem to be lower than observed in the previous category and more than half of the top 20 in the list have higher rates than the average rate for this category.

Table 3.21 Top-20 Settlements for 50.000-490.000 Population Prioritized According to Relative Loss

\begin{tabular}{|c|c|c|c|c|c|c|}
\hline $\begin{array}{c}\text { CATEGORY } \\
\mathbf{5 0 . 0 0 0 - 4 9 0 . 0 0 0}\end{array}$ & SUB-PROVINCE & $\begin{array}{c}\text { Expected } \\
\text { Seismic } \\
\text { Intensity }\end{array}$ & $\begin{array}{c}\text { Relative } \\
\text { Building } \\
\text { Loss }\end{array}$ & $\begin{array}{c}\text { Total } \\
\text { Building }\end{array}$ & $\begin{array}{c}\text { Absolute } \\
\text { Loss }\end{array}$ & $\begin{array}{c}\text { Sub- } \\
\text { Province } \\
\text { Population } \\
\text { (2009) }\end{array}$ \\
\hline BOLU & BOLU M. & 8 & 0,18 & 10516 & 1841 & 120.021 \\
\hline YALOVA & YALOVA M. & 8 & 0,18 & 8302 & 1507 & 92.166 \\
\hline BURSA & ORHANGAZI & 8 & 0,18 & 5313 & 945 & 54.319 \\
\hline ERZINCAN & ERZINCAN M. & 8 & 0,16 & 12678 & 2025 & 90.100 \\
\hline TOKAT & ERBAA & 8 & 0,16 & 7895 & 1251 & 58.845 \\
\hline TEKIRDAG & TEKİRDAĞ M. & 7,5 & 0,09 & 15683 & 1347 & 140.535 \\
\hline AMASYA & MERZIFON & 7,5 & 0,07 & 9411 & 666 & 52.225 \\
\hline DUZCE & DÜZCE M. & 7,5 & 0,07 & 8593 & 612 & 125.240 \\
\hline VAN & VAN M. & 7,5 & 0,06 & 36235 & 2285 & 360.810 \\
\hline MANISA & MANISA M. & 7 & 0,04 & 24785 & 919 & 291.374 \\
\hline BURSA & INEGOL & 7 & 0,04 & 14095 & 536 & 161.541 \\
\hline MANISA & SALIHLI & 7 & 0,04 & 13639 & 483 & 96.503 \\
\hline BALIKESIR & BANDIRMA & 7 & 0,04 & 12035 & 460 & 113.385 \\
\hline CANAKKALE & ÇANAKKALE M. & 7 & 0,04 & 9281 & 339 & 96.588 \\
\hline AMASYA & AMASYA M. & 7 & 0,04 & 9432 & 336 & 86.667 \\
\hline BURSA & M.KEMALPASA & 7 & 0,04 & 8460 & 304 & 57.097 \\
\hline OSMANIYE & OSMANIYE M. & 7 & 0,03 & 29408 & 905 & 194.339 \\
\hline HATAY & ANTAKYA & 7 & 0,03 & 23471 & 768 & 202.216 \\
\hline HATAY & ISKENDERUN & 7 & 0,03 & 21169 & 705 & 190.279 \\
\hline ADIYAMAN & ADIYAMAN M. & 7 & 0,03 & 21965 & 696 & 198.433 \\
\hline Group Average & & & $\mathbf{0 , 0 3}$ & $\mathbf{1 4 7 4 3}$ & $\mathbf{4 5 4}$ & $\mathbf{1 2 0 . 7 9 6}$ \\
\hline & & & & & \\
\hline
\end{tabular}

The third category of settlements as agglomerations of sub-provinces at metropolitan centers indicate the following set of priorities in Table 3.22.

Ordering seems to follow seismic intensities rather than absolute size of the building stock in metropolitan provinces and a very distinct group of four metropolitan cities with high ratio of loss are observed. 
Table 3.22 Metropolitan Provinces Prioritized According to Relative Loss Levels

\begin{tabular}{|c|c|c|c|c|c|c|}
\hline $\begin{array}{c}\text { CATEGORY III } \\
\text { Metropolitan } \\
\text { Provinces }\end{array}$ & SUB-PROVINCE & $\begin{array}{c}\text { Expected } \\
\text { Seismic } \\
\text { Intensity }\end{array}$ & $\begin{array}{c}\text { Relative } \\
\text { Building } \\
\text { Loss }\end{array}$ & $\begin{array}{c}\text { Total } \\
\text { Building }\end{array}$ & $\begin{array}{c}\text { Absolute } \\
\text { Loss }\end{array}$ & $\begin{array}{c}\text { Sub- } \\
\text { Province } \\
\text { Population } \\
\text { (2009) }\end{array}$ \\
\hline KOCAELI & KOCAELI & 8 & 0,17 & 139423 & 24077 & 1.422 .752 \\
\hline SAKARYA & SAKARYA & 8 & 0,16 & 49609 & 8070 & 442.157 \\
\hline ISTANBUL & ISTANBUL & 7,5 & 0,10 & 864540 & 83824 & 12.782 .960 \\
\hline BURSA & BURSA & 7,5 & 0,08 & 204907 & 16506 & 1.854 .285 \\
\hline IZMIR & IZMIR & 7 & 0,03 & 421397 & 14531 & 3.276 .815 \\
\hline ADANA & ADANA & 6,5 & 0,01 & 175697 & 1913 & 1.556 .238 \\
\hline ANTALYA & ANTALYA & 6,5 & 0,01 & 114998 & 1402 & 955.573 \\
\hline KONYA & KONYA & 6,5 & 0,01 & 113267 & 1355 & 1.003 .373 \\
\hline ERZURUM & ERZURUM & 6,5 & 0,01 & 32458 & 439 & 368.146 \\
\hline Group Average & & & $\mathbf{0 , 0 7}$ & $\mathbf{2 3 5 . 1 4 4}$ & $\mathbf{1 6 . 9 0 2}$ & $\mathbf{2 . 6 2 9 . 1 4 4}$ \\
\hline
\end{tabular}

Table 3.23 Average Relative Loss According to the Settlement Categories

\begin{tabular}{|c|c|c|c|c|}
\hline $\begin{array}{c}\text { Settlement Size } \\
\text { Categories }\end{array}$ & $\begin{array}{c}\text { Total } \\
\text { Building }\end{array}$ & $\begin{array}{c}\text { Average } \\
\text { Relative } \\
\text { Loss }\end{array}$ & $\begin{array}{c}\text { Minimum } \\
\text { Relative } \\
\text { Loss }\end{array}$ & $\begin{array}{c}\text { Maximum } \\
\text { Relative } \\
\text { Loss }\end{array}$ \\
\hline $0-50.000$ & 843.188 & 0,04 & 0 & 0,21 \\
\hline $\begin{array}{c}50.000- \\
500.000\end{array}$ & 973.014 & 0,03 & 0,01 & 0,18 \\
\hline $\begin{array}{c}\text { Metropolitan } \\
\text { cities }\end{array}$ & 2.116 .296 & 0,07 & 0,01 & 0,17 \\
\hline
\end{tabular}




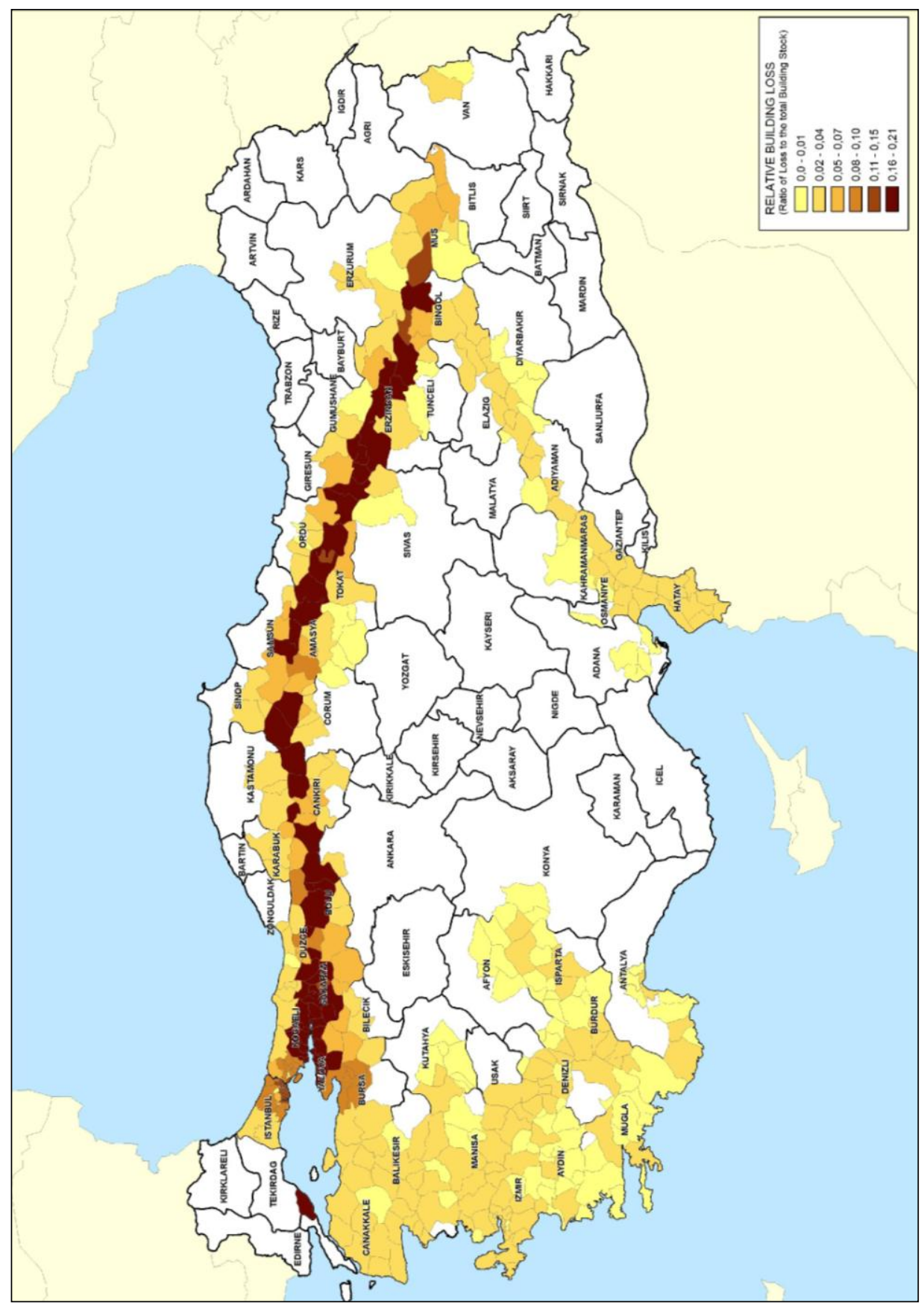

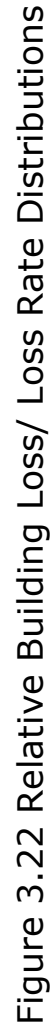


After determining the level of loss both in absolute terms (total number of buildings lost) and relative terms (ratio of loss to the total building stock), two dependent variables of the research is obtained.

$\mathrm{Y} 1$ that is determined as Absolute Loss is the first dependent variable of the research and composed of the total number of building loss.

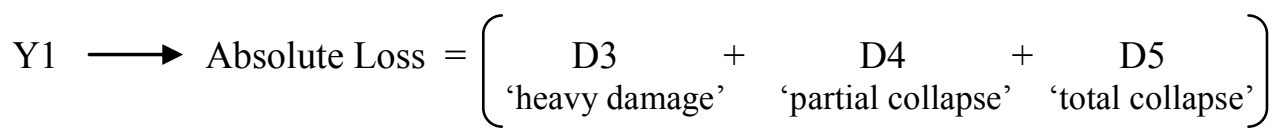

Y2 that is determined as Relative Loss is the other dependent variable of the research and composed of the ratio of loss to the total building stock.

$$
\mathrm{Y} 2 \longrightarrow \text { Relative Loss }=\left(\begin{array}{ccc}
\mathrm{D} 3+ & \mathrm{D} 4 \quad+\quad \begin{array}{c}
\mathrm{D} 5 \\
\text { heavy damage' }
\end{array} & \text { 'partial collapse' } \\
\text { Total Building Stock } & \text { 'total collapse' }
\end{array}\right)
$$

The distribution of dependent variables of the top-20 settlements for each sizecategory is given in the Table 3.24, Table 3.25, Table 3.26 and the distribution of dependent variables for all settlements in each size-category is given in the Appendix $\mathrm{E}$.

Table 3.24 Dependent Variables of the top-20 Settlements for $0-50.000$ Population

\begin{tabular}{|l|l|c|r|r|}
\cline { 4 - 5 } \multicolumn{1}{c}{$\begin{array}{c}\text { CATEGORY } \\
\mathbf{0 - 5 0 . 0 0 0}\end{array}$} & SUB-PROVINCE & Intensity & $\begin{array}{c}\text { Ybsolute } \\
\text { Loss }\end{array}$ & $\begin{array}{c}\text { Y2 } \\
\text { Relative Loss } \\
\text { Loss / Building) }\end{array}$ \\
\hline TOKAT & NIKSAR & 8 & 1400 & 0,17 \\
\hline KASTAMONU & TOSYA & 8 & 1364 & 0,16 \\
\hline SAKARYA & HENDEK & 8 & 869 & 0,17 \\
\hline CORUM & OSMANCIK & 8 & 786 & 0,16 \\
\hline SAMSUN & HAVZA & 8 & 735 & 0,16 \\
\hline TEKIRDAG & SARKOY & 8 & 712 & 0,18 \\
\hline SAKARYA & AKYAZI & 8 & 681 & 0,19 \\
\hline AMASYA & SULUOVA & 7,5 & 633 & 0,07 \\
\hline ERZINCAN & UZUMLU & 8 & 631 & 0,15 \\
\hline BOLU & GEREDE & 8 & 583 & 0,17 \\
\hline SAKARYA & GEYVE & 8 & 543 & 0,16 \\
\hline BALIKESIR & AYVALIK & 7 & 442 & 0,03 \\
\hline SIVAS & SUSEHRI & 8 & 424 & 0,16 \\
\hline BALIKESIR & BURHANIYE & 7 & 410 & 0,03 \\
\hline SAKARYA & PAMUKOVA & 8 & 403 & 0,15 \\
\hline MUS & VARTO & 8 & 384 & 0,15 \\
\hline SAMSUN & LADIK & 8 & 377 & 0,16 \\
\hline YALOVA & CINARCIK & 8 & 357 & 0,21 \\
\hline IZMIR & CESME & 7 & 348 & 0,03 \\
\hline BURSA & YENISEHIR & 7,5 & 339 & 0,07 \\
\hline Group Average & & & $\mathbf{9 6}$ & $\mathbf{0 , 0 4}$ \\
\hline
\end{tabular}


Table 3.25 Dependent Variables of the top-20 Settlements for $50.000-490.000$ Population

\begin{tabular}{|c|c|c|c|c|}
\hline & \multirow{3}{*}{$\begin{array}{c}\text { Y1 } \\
\begin{array}{c}\text { Absolute } \\
\text { Loss }\end{array}\end{array}$} & \multirow{3}{*}{$\begin{array}{c}\text { Y2 } \\
\text { Relative Loss } \\
\text { (Loss / Building) }\end{array}$} \\
\hline & & & & \\
\hline $\begin{array}{c}\text { CATEGORY } \\
\mathbf{5 0 . 0 0 0 - 4 9 0 . 0 0 0}\end{array}$ & SUB-PROVINCE & Intensity & & \\
\hline VAN & VAN C. & 7,5 & 2285 & 0,06 \\
\hline ERZINCAN & ERZİNCAN C. & 8 & 2025 & 0,16 \\
\hline BOLU & BOLU C. & 8 & 1841 & 0,18 \\
\hline YALOVA & YALOVA C. & 8 & 1507 & 0,18 \\
\hline TEKIRDAG & TEKİRDAĞ C. & 7,5 & 1347 & 0,09 \\
\hline TOKAT & ERBAA & 8 & 1251 & 0,16 \\
\hline BURSA & ORHANGAZI & 8 & 945 & 0,18 \\
\hline MANISA & MANISA C. & 7 & 919 & 0,04 \\
\hline OSMANIYE & OSMANIYE C. & 7 & 905 & 0,03 \\
\hline HATAY & ANTAKYA & 7 & 768 & 0,03 \\
\hline HATAY & ISKENDERUN & 7 & 705 & 0,03 \\
\hline ADIYAMAN & ADIYAMAN C. & 7 & 696 & 0,03 \\
\hline AMASYA & MERZIFON & 7,5 & 666 & 0,07 \\
\hline MANISA & TURGUTLU & 7 & 639 & 0,03 \\
\hline DUZCE & DÜZCE C. & 7,5 & 612 & 0,07 \\
\hline DENIZLI & DENİZLİ C. & 6,5 & 586 & 0,01 \\
\hline MANISA & AKHISAR & 7 & 585 & 0,03 \\
\hline BURSA & INEGOL & 7 & 536 & 0,04 \\
\hline TOKAT & TOKAT C. & 7 & 528 & 0,03 \\
\hline MANISA & SALIHLI & 7 & 483 & 0,04 \\
\hline Group Average & & & 454 & $\mathbf{0 , 0 3}$ \\
\hline
\end{tabular}

Table 3.26 Dependent Variables of the Research for Metropolitan Cities

\begin{tabular}{|c|c|c|c|c|}
\hline & & & Y1 & Y2 \\
\hline $\begin{array}{c}\text { CATEGORY } \\
\text { Metropolitan } \\
\text { Cities }\end{array}$ & SUB-PROVINCE & Intensity & $\begin{array}{l}\text { Absolute } \\
\text { Loss }\end{array}$ & $\begin{array}{c}\text { Relative Loss } \\
\text { (Loss / Building) }\end{array}$ \\
\hline ISTANBUL & ISTANBUL (M) & 7,5 & 83824 & 0,10 \\
\hline KOCAELI & KOCAELI (M) & 8 & 24077 & 0,17 \\
\hline BURSA & BURSA (M) & 7,5 & 16506 & 0,08 \\
\hline IZMIR & IZMIR (M) & 7 & 14531 & 0,03 \\
\hline SAKARYA & SAKARYA (M) & 8 & 8070 & 0,16 \\
\hline ADANA & ADANA (M) & 6,5 & 1913 & 0,01 \\
\hline ANTALYA & ANTALYA (M) & 6,5 & 1402 & 0,01 \\
\hline KONYA & KONYA (M) & 6,5 & 1355 & 0,01 \\
\hline ERZURUM & ERZURUM (M) & 6,5 & 439 & 0,01 \\
\hline Group Average & & & 16902 & $\mathbf{0 , 0 7}$ \\
\hline
\end{tabular}

Consequently, two dependent variables, $\mathrm{Y} 1$ and $\mathrm{Y} 2$ are determined for all settlements in each size category in order to examine the basic question of the research "How do loss levels in building stock correlate to independent variables?"

Therefore the next step of the study is to determine the independent variables of the research in order to be used in regression equations with dependent variables. 


\section{CHAPTER 4}

\section{ATTRIBUTES CONTRIBUTING TO VULNERABILITIES OF SETTLEMENTS}

Settlement vulnerabilities cannot be described simply in terms of robustness of individual buildings, but as a complex system structured with interdependent components. Urban stock texture, networks, distribution of land-uses, public facilities, their interaction with hazard prone locations, size of population served and many other factors have interdependent impacts on the vulnerabilities of settlements as mentioned in foregoing chapters.

Attributes of settlements that can be inferred to give rise to vulnerabilities are determined as the independent variables of research. These variables are composed of building inventory data and related attributes of building stock on each settlement obtained from Turkish Statistical Institute (TurkStat) and State Planning Organization (SPO).

'Building Construction Statistics', 'Building Census' and 'Population Census' prepared by TurkStat and 'Development Index' prepared by SPO were utilized to compose the building inventory data and related attributes on each settlement within this research.

Building Construction Statistics have been compiled by TurkStat annually since 1954 from information on building permits in cities and towns where municipalities exist. Information in this publication is obtained from construction permits and occupancy permits.

Building Census-2000 provided information on aspects of the building stock in each settlement and provided information for 3212 administrative units (provinces, districts and villages) in Turkey. Building inventory data on each settlement is provided in four separate sheets for the distributions of number of stories, the construction type, construction date and purpose of usage. The publication however of this source of information was not aggregated at the settlement level. A special disaggregated version of the building census 2000 at the level of settlements was accessed for this study.

Population Census-2000 provided urban and rural populations for 3212 administrative units (provinces, districts and villages) in Turkey. Urban and rural populations after the year 2000 are obtained from 'Address Based Population Registration System Database' prepared by TurkStat.

Development Index provided a wealth of socio-economic characteristics and covers demography, employment, education, infrastructure, construction and other welfare indicators.

In terms of available data independent variables of the research are determined as;

$$
\begin{aligned}
& \mathbf{X 1}=\text { Settlement Population } \\
& \mathbf{X} \mathbf{2}=\text { Population Growth Rate }(\% \circ) \\
& \mathbf{X} \mathbf{3}=\text { Rates of Agglomeration } \\
& \mathbf{X} \mathbf{4}=\text { Population/Total Number of Buildings } \\
& \mathbf{X 5}=\text { Development Index }
\end{aligned}
$$




\subsection{Settlement Population}

We can consider that as the settlement population increases, building densities will increase also and this will increase the potential loss in human life. Besides larger settlements in general have higher index of development implying greater likelihood of direct and indirect economic loss. So, we can say that larger the settlement population, greater is the risk for several reasons.

Population Distributions is obtained from 'Address Based Population Registration System Database' and 'Population Census' prepared by TurkStat and determined as the first independent variable (X1) of the study.

Table 4.1 Average Values of Population in Settlement Categories

\begin{tabular}{|c|c|c|c|c|c|}
\hline $\begin{array}{c}\text { Settlement Size } \\
\text { Categories }\end{array}$ & $\begin{array}{c}\text { Total } \\
\text { Number } \\
\text { of } \\
\text { Buildings }\end{array}$ & $\begin{array}{c}\text { Settlement } \\
\text { Population } \\
\mathbf{( 2 0 0 0 )}\end{array}$ & $\begin{array}{c}\text { Total } \\
\text { Population } \\
\text { (2000) }\end{array}$ & $\begin{array}{c}\text { Settlement } \\
\text { Population } \\
(\mathbf{2 0 0 9})\end{array}$ & $\begin{array}{c}\text { Total } \\
\text { Population } \\
\text { (2009) }\end{array}$ \\
\hline $0-50.000$ & 2540 & 12.292 & 32.033 & 11.290 & 27.276 \\
\hline $50.000-490.000$ & 14.743 & 96.999 & 152.395 & 120.796 & 169.592 \\
\hline Metropolitan Cities & 235.144 & 2.086 .170 & 187.9779 & 2.629 .144 & 2.697 .045 \\
\hline
\end{tabular}

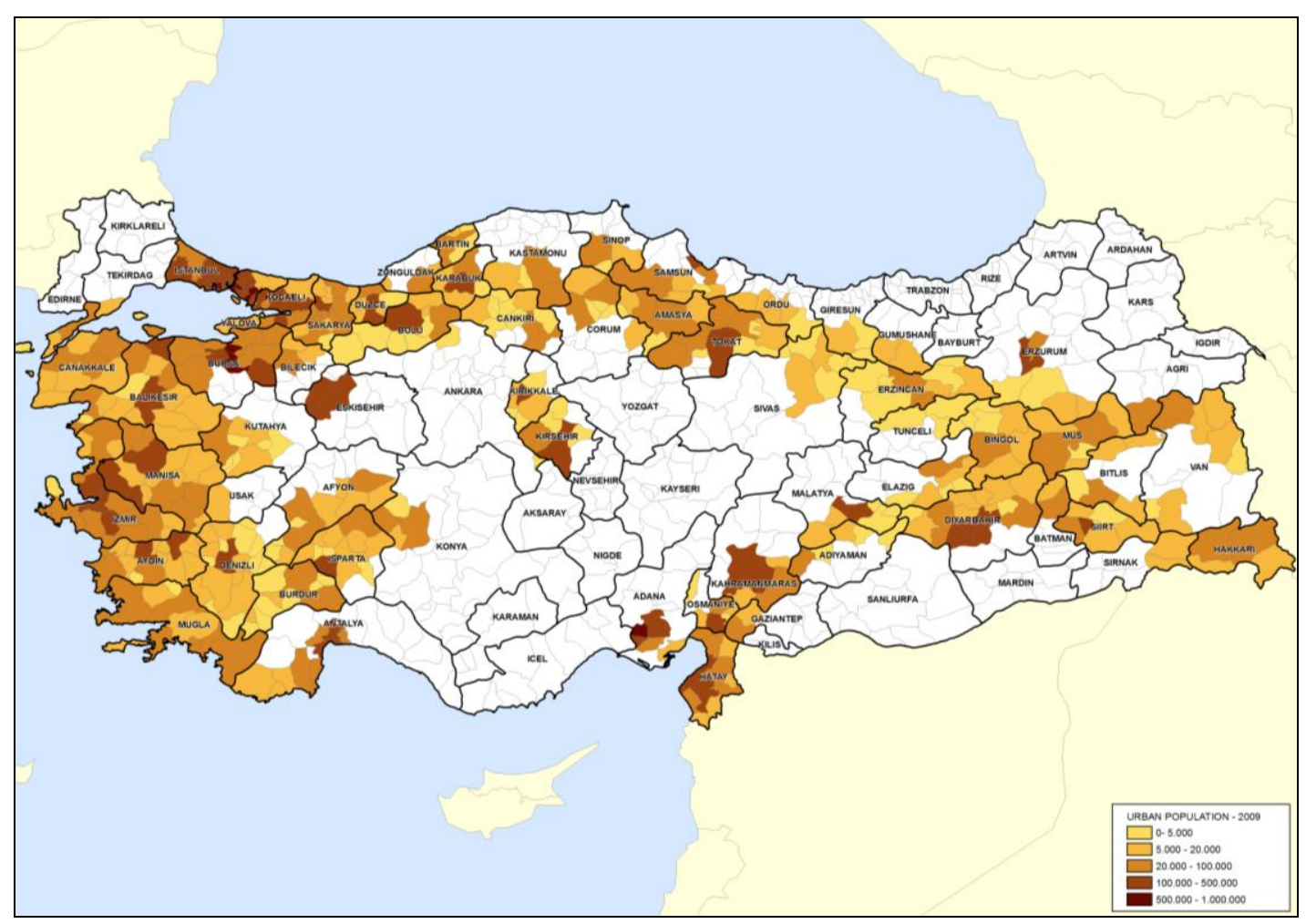

Figure 4.1 Urban Population Distributions 


\subsection{Population Growth Rate}

We can consider that as the rate of growth increases, control deficiencies will increase and this will increase the potential loss. Therefore, population growth rate is determined as the second independent variable (X2) of the study.

According to the Table 4.2; the smaller settlements in the average are either losing population or are stagnant. On the contrary larger cities and metropolitan cities are significantly growing and at the same pace.

Table 4.2 Average Values of Population Growth Rates in Settlement Categories

\begin{tabular}{|c|c|c|c|c|c|c|}
\hline $\begin{array}{c}\text { Settlement Size } \\
\text { Categories }\end{array}$ & $\begin{array}{c}\text { Total } \\
\text { Number } \\
\text { of } \\
\text { Buildings }\end{array}$ & $\begin{array}{c}\text { Settlement } \\
\text { Population } \\
\mathbf{( 2 0 0 0 )}\end{array}$ & $\begin{array}{c}\text { Total } \\
\text { Population } \\
\mathbf{( 2 0 0 0 )}\end{array}$ & $\begin{array}{c}\text { Settlement } \\
\text { Population } \\
\mathbf{( 2 0 0 9 )}\end{array}$ & $\begin{array}{c}\text { Total } \\
\text { Population } \\
\text { (2009) }\end{array}$ & $\begin{array}{c}\text { Population } \\
\text { Growth Rate } \\
\text { (Log-\%) }\end{array}$ \\
\hline $0-50.000$ & 2540 & 12.292 & 32.033 & 11.290 & 27.276 & $-0,945$ \\
\hline $50.000-490.000$ & 14.743 & 96.999 & 152.395 & 120.796 & 169.592 & 2,438 \\
\hline $\begin{array}{c}\text { Metropolitan } \\
\text { Cities }\end{array}$ & 235.144 & 2.086 .170 & 187.9779 & 2.629 .144 & 2.697 .045 & 2,570 \\
\hline
\end{tabular}

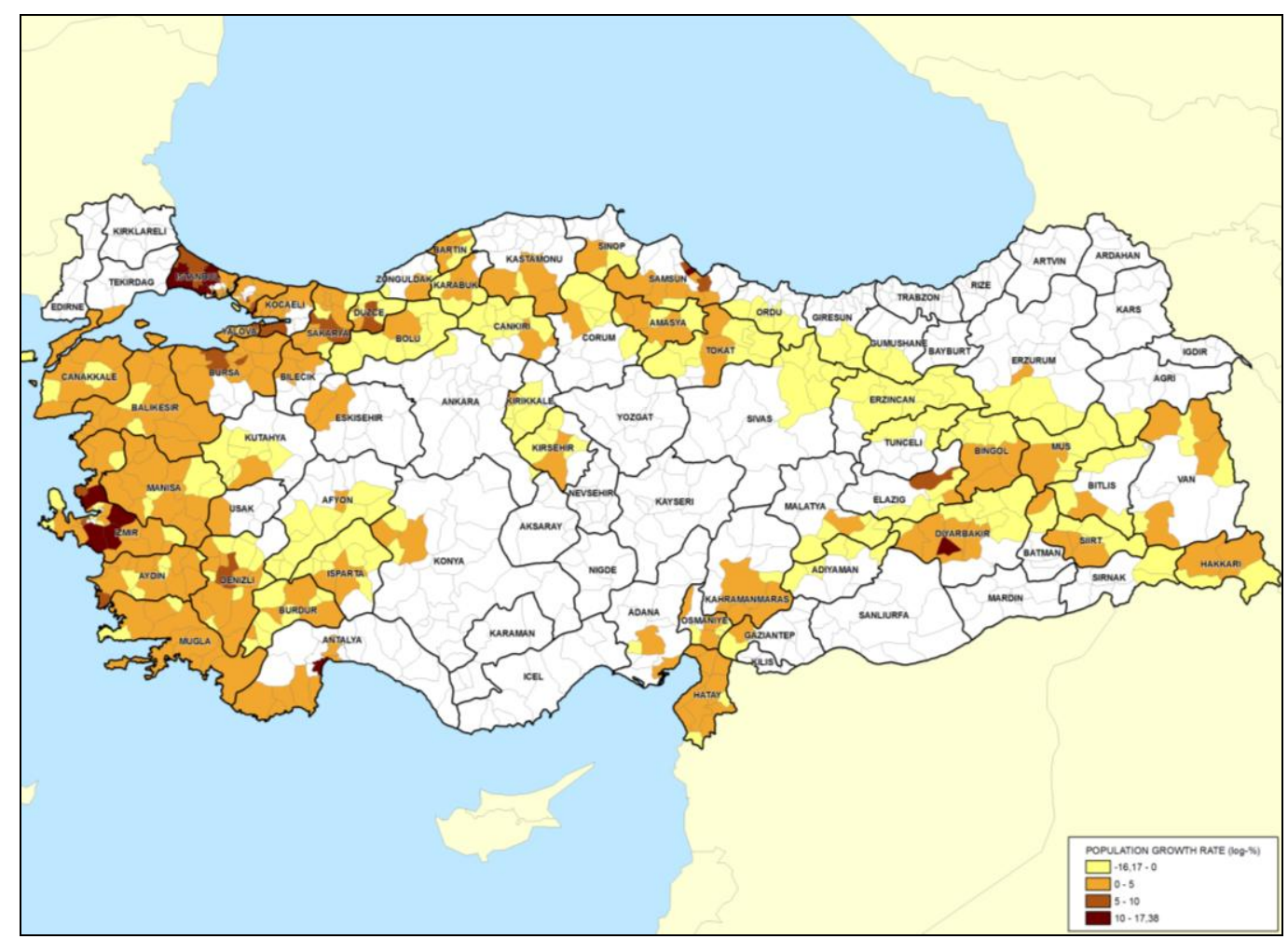

Figure 4.2 Population Growth Rates 


\subsection{Rates of Agglomeration}

Rate of agglomeration is the ratio of urban population to the total population and express the urbanization level of the settlement. Distinct rates of agglomeration are also a good indicator of how rural/urban natures of the sub-province or province differ. We can consider that as the rate of agglomeration increases, required urban services will increase and this will increase the potential loss. Therefore, rate of agglomeration is determined as the third independent variable (X3) of the study.

According to the Table 4.3; Metropolitan settlements seem to have absorbed almost all of the population into their area of jurisdiction. However in provinces with smaller central settlements, greater parts of population live in the rural area.

Table 4.3 Average Values of Agglomeration Rates in Settlement Categories

\begin{tabular}{|c|c|c|c|c|c|c|}
\hline $\begin{array}{c}\text { Settlement Size } \\
\text { Categories }\end{array}$ & $\begin{array}{c}\text { Total } \\
\text { Number } \\
\text { of } \\
\text { Buildings }\end{array}$ & $\begin{array}{c}\text { Settlement } \\
\text { Population } \\
\mathbf{( 2 0 0 0 )}\end{array}$ & $\begin{array}{c}\text { Total } \\
\text { Population } \\
\mathbf{( 2 0 0 0 )}\end{array}$ & $\begin{array}{c}\text { Settlement } \\
\text { Population } \\
\mathbf{( 2 0 0 9 )}\end{array}$ & $\begin{array}{c}\text { Total } \\
\text { Population } \\
\mathbf{( 2 0 0 9 )}\end{array}$ & $\begin{array}{c}\text { Rate of } \\
\text { Agglomeration }\end{array}$ \\
\hline $0-50.000$ & 2540 & 12.292 & 32.033 & 11.290 & 27.276 & 0,41 \\
\hline $50.000-490.000$ & 14.743 & 96.999 & 152.395 & 120.796 & 169.592 & 0,71 \\
\hline $\begin{array}{c}\text { Metropolitan } \\
\text { Cities }\end{array}$ & 235.144 & 2.086 .170 & 187.9779 & 2.629 .144 & 2.697 .045 & 0,97 \\
\hline
\end{tabular}

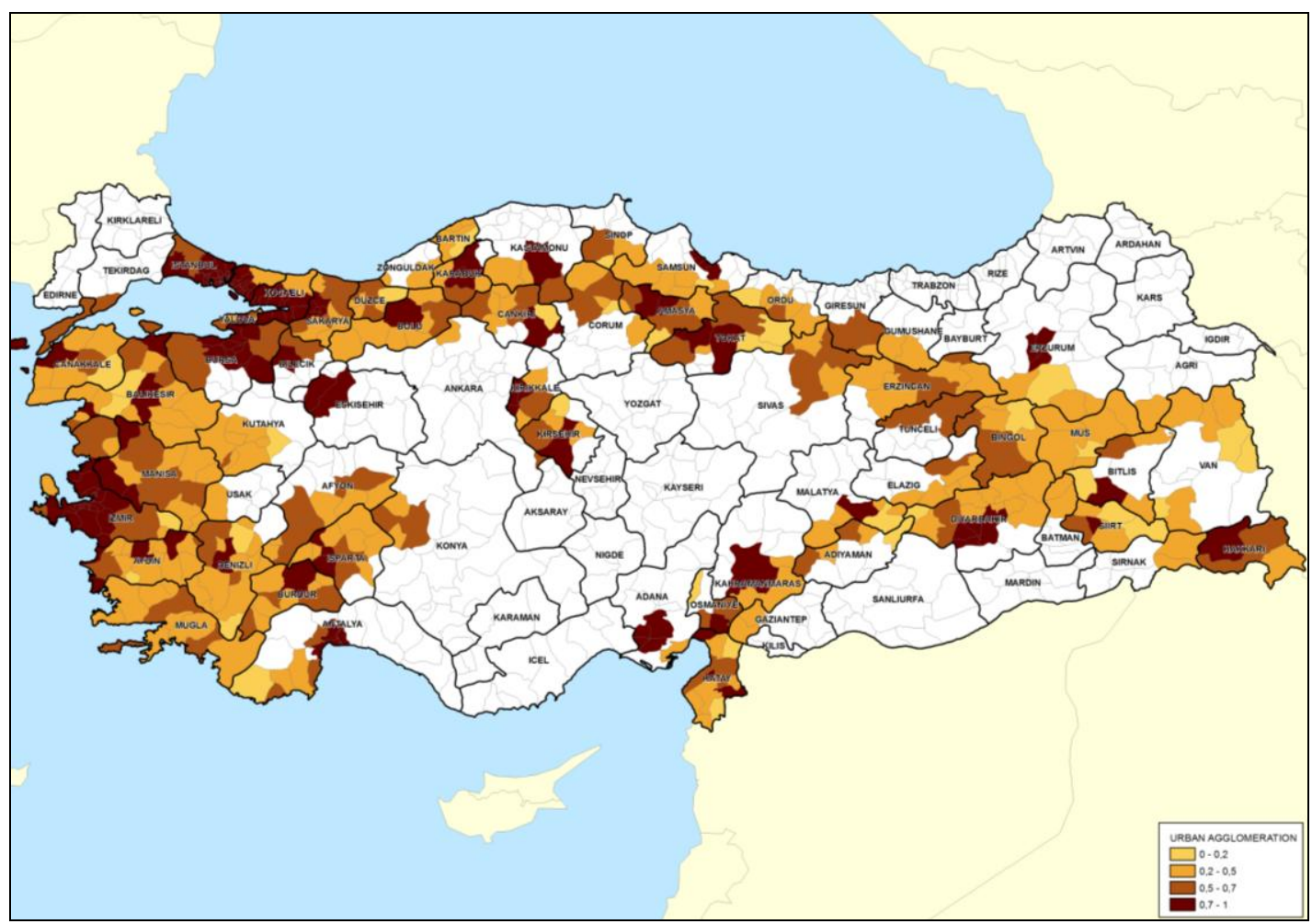

Figure 4.3 Urban Agglomeration 


\subsection{Population/Total Number of Buildings}

Average population density per building (2000) is significantly different in the categories identified. This is also a measure or indication of the increasing rate of human life losses in larger cities, another factor to reinforce the probable bias favoring larger settlements.

Therefore, population density is determined as the fourth independent variable (X4) of the study.

Table 4.4 Population Density in Settlement Categories

\begin{tabular}{|c|c|c|c|}
\hline $\begin{array}{c}\text { Settlement Size } \\
\text { Categories }\end{array}$ & $\begin{array}{c}\text { Population } \\
\text { (2000) }\end{array}$ & $\begin{array}{c}\text { Total Number of } \\
\text { Buildings }\end{array}$ & $\begin{array}{c}\text { Population / } \\
\text { Building }\end{array}$ \\
\hline $0-50.000$ & 4.080 .822 & 843.188 & 4,84 \\
\hline $50.000-490.000$ & 6.401 .962 & 973.014 & 6,58 \\
\hline Metropolitan Cities & 18.775 .534 & 2.116 .296 & 8,87 \\
\hline Total & 29.258 .318 & 3.932 .498 & 7.44 \\
\hline
\end{tabular}

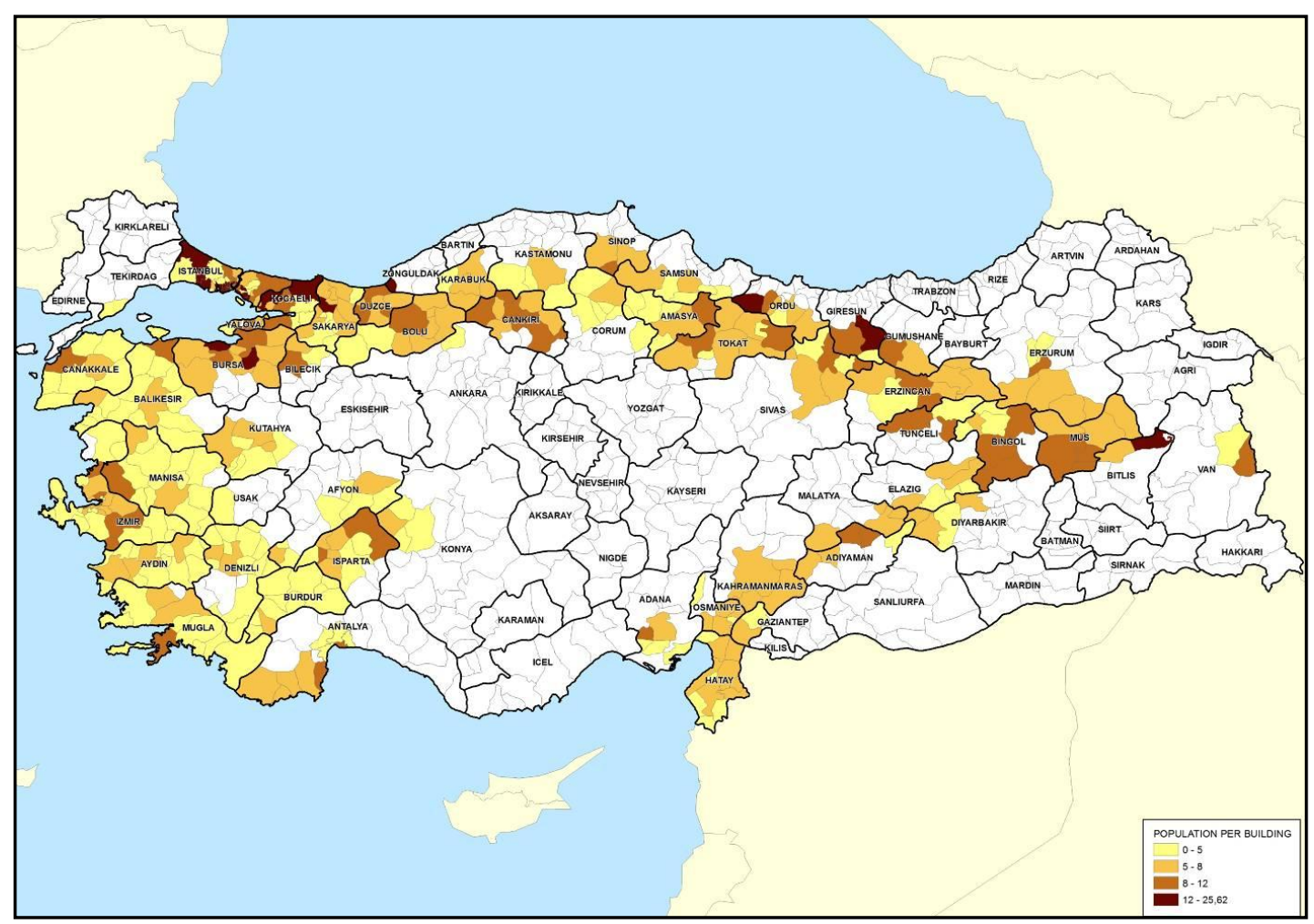

Figure 4.4 Population per Buildings 


\subsection{Development Index}

Socio-Economic Development Index (SEDI) prepared by SPO covers demography, employment, education, infrastructure, construction and other welfare indicators. SEDI use a large number of variables selected from economic and social fields that may best reflect the level of development (See Appendix $F$ for all SEDI variables). These variables determine the economic and social structural characteristics of settlements. Therefore, development index is determined as the fifth independent variable (X5) of the study.

The group of settlements with lower levels of population than 50.000 has a negative average development index of $(-0.171)$. The average development index of category of $50.000-490.000$ is 1.096 . The average development index available for the third group representing metropolitan settlements is distinctly higher (4.181).

Table 4.5 Average Values of Development Index in Settlement Categories

\begin{tabular}{|c|c|}
\hline $\begin{array}{c}\text { Settlement } \\
\text { Size Categories }\end{array}$ & $\begin{array}{c}\text { Average } \\
\text { Development index }\end{array}$ \\
\hline $0-50.000$ & $-0,171$ \\
\hline $50.000-490.000$ & 1,096 \\
\hline Metropolitan Cities & 4.181 \\
\hline
\end{tabular}

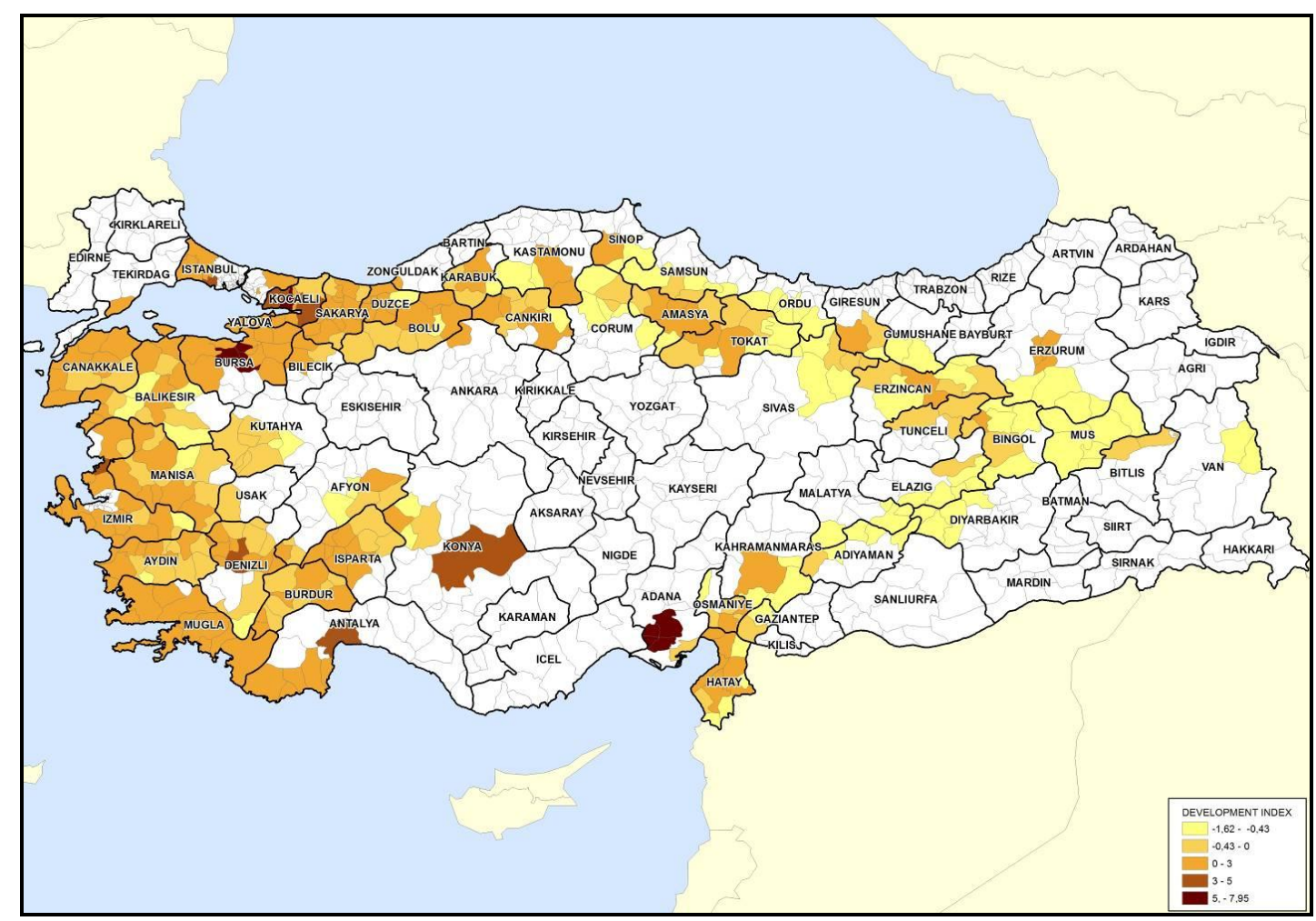

Figure 4.5 Development Index 
Consequently, all of the five independent variables of the research are obtained. The distribution of independent variables of the top-20 settlements for each sizecategory is given in the Table 4.6, Table 4.7, Table 4.8 and the distribution of independent variables for all settlements in each size-category is given in the Appendix E.

Table 4.6 Independent Variables of the Top-20 Settlements for 0-50.000 Population

\begin{tabular}{|c|c|c|c|c|c|c|}
\hline & & $\mathrm{X} 1$ & $\mathbf{X 2}$ & $\mathrm{X3}$ & $\mathrm{X} 4$ & $\mathrm{X5}$ \\
\hline $\begin{array}{c}\text { CATEGORY } \\
0-50.000\end{array}$ & $\begin{array}{l}\text { SUB- } \\
\text { PROVINCE }\end{array}$ & $\begin{array}{l}\text { Settlement } \\
\text { Population } \\
\text { (2009) }\end{array}$ & $\begin{array}{l}\text { Population } \\
\text { Growth } \\
\text { Rate }(\% 0)\end{array}$ & $\begin{array}{l}\text { Rates of } \\
\text { Agglome- } \\
\text { ration }\end{array}$ & $\begin{array}{l}\text { Population / } \\
\text { Total No. of } \\
\text { Buildings }\end{array}$ & $\begin{array}{c}\text { Development } \\
\text { Index }\end{array}$ \\
\hline TOKAT & NIKSAR & 33.682 & $-3,171$ & 0,52 & 5,37 & $-0,077$ \\
\hline KASTAMONU & TOSYA & 27.624 & 1,912 & 0,68 & 2,71 & 0,137 \\
\hline SAKARYA & HENDEK & 44.418 & 4,916 & 0,60 & 5,74 & 0,245 \\
\hline CORUM & OSMANCIK & 25.829 & $-1,063$ & 0,57 & 5,64 & $-0,038$ \\
\hline SAMSUN & HAVZA & 20.204 & 0,460 & 0,44 & 4,20 & $-0,374$ \\
\hline TEKIRDAG & SARKOY & 16.624 & 0,291 & 0,55 & 3,99 & 0,627 \\
\hline SAKARYA & AKYAZI & 41.179 & 6,379 & 0,49 & 6,32 & 0,264 \\
\hline AMASYA & SULUOVA & 37.151 & $-1,551$ & 0,78 & 4,43 & 0,581 \\
\hline ERZINCAN & UZUMLU & 8.288 & $-14,403$ & 0,52 & 7,24 & $-0,239$ \\
\hline BOLU & GEREDE & 23.808 & $-0,626$ & 0,69 & 7,32 & 0,374 \\
\hline SAKARYA & GEYVE & 20.318 & 1,775 & 0,44 & 4,96 & 0,144 \\
\hline BALIKESIR & AYVALIK & 35.986 & 1,309 & 0,58 & 2,27 & 1,459 \\
\hline SIVAS & SUSEHRI & 15.304 & $-5,514$ & 0,55 & 9,71 & $-0,212$ \\
\hline BALIKESIR & BURHANIYE & 38.156 & 2,227 & 0,77 & 2,37 & 1,127 \\
\hline SAKARYA & PAMUKOVA & 16.047 & 2,170 & 0,60 & 5,08 & 0,464 \\
\hline MUS & VARTO & 9.585 & $-5,955$ & 0,28 & 6,39 & $-1,038$ \\
\hline SAMSUN & LADIK & 8.316 & $-0,999$ & 0,46 & 3,75 & $-0,241$ \\
\hline YALOVA & CINARCIK & 11.080 & 2,368 & 0,43 & 5,35 & 1,174 \\
\hline IZMIR & CESME & 20.455 & $-2,343$ & 0,63 & 2,19 & 2,692 \\
\hline BURSA & YENISEHIR & 29.275 & 1,289 & 0,57 & 5,18 & 0,289 \\
\hline \multicolumn{2}{|l|}{ Group Average } & 11.290 & $-0,945$ & 0,41 & 4,84 & $-0,171$ \\
\hline
\end{tabular}

The top-20 settlements for $0-50.000$ population are significantly above the category averages in terms of 'settlement population' and 'rate of agglomeration'.

The average rates of growth and development indices are either negative or very small. Many of the settlements in this category are stagnant or in the process of negative growth.

Greater numbers of settlements that take place in the upper 20 in this category have relatively central status within their sub-province. Rates of agglomeration for these settlements are more or less leveled in the sub-province with the rural population.

Only a few of these settlements represent stronger agglomeration centers. These also indicate positive growth and development. 
Table 4.7 Independent Variables of the Top-20 Settlements for $50.000-490.000$ Population

\begin{tabular}{|c|c|c|c|c|c|c|}
\hline & \multirow{3}{*}{$\begin{array}{c}\text { X1 } \\
\text { Settlement } \\
\text { Population } \\
\text { (2009) } \\
\end{array}$} & \multirow{3}{*}{$\begin{array}{c}\text { X2 } \\
\text { Population } \\
\text { Growth } \\
\text { Rate }(\%) \\
\end{array}$} & \multirow{3}{*}{$\begin{array}{c}\text { X3 } \\
\text { Rates of } \\
\begin{array}{c}\text { Agglome- } \\
\text { ration }\end{array} \\
\end{array}$} & \multirow{3}{*}{$\begin{array}{c}\text { X4 } \\
\text { Population / } \\
\text { Total No. of } \\
\text { Buildings }\end{array}$} & \multirow{3}{*}{$\begin{array}{c}\text { X5 } \\
\begin{array}{c}\text { Development } \\
\text { Index }\end{array}\end{array}$} \\
\hline & & & & & & \\
\hline $\begin{array}{c}\text { CATEGORY } \\
50.000-490.000\end{array}$ & $\begin{array}{l}\text { SUB- } \\
\text { PROVINCE }\end{array}$ & & & & & \\
\hline VAN & VAN C. & 360.810 & 2,642 & 0,80 & 7,851 & 0,716 \\
\hline ERZINCAN & ERZINNCAN C. & 90.100 & $-1,928$ & 0,65 & 8,454 & 0,785 \\
\hline BOLU & BOLU C. & 120.021 & 3,891 & 0,75 & 8,042 & 1,795 \\
\hline YALOVA & YALOVA C. & 92.166 & 3,038 & 0,81 & 8,446 & 2,422 \\
\hline TEKIRDAG & TEKİRDAĞ C. & 140.535 & 3,009 & 0,82 & 6,835 & 1,864 \\
\hline TOKAT & ERBAA & 58.845 & 2,835 & 0,60 & 5,775 & $-0,252$ \\
\hline BURSA & ORHANGAZI & 54.319 & 2,234 & 0,72 & 8,362 & 1,130 \\
\hline MANISA & MANİSA C. & 291.374 & 3,411 & 0,86 & 8,648 & 2,465 \\
\hline OSMANIYE & OSMANIYE C. & 194.339 & 1,230 & 0,86 & 5,916 & 0,976 \\
\hline HATAY & ANTAKYA & 202.216 & 3,702 & 0,45 & 6,174 & 0,983 \\
\hline HATAY & ISKENDERUN & 190.279 & 1,985 & 0,60 & 7,518 & 2,562 \\
\hline ADIYAMAN & ADIYAMAN C. & 198.433 & 1,174 & 0,76 & 8,128 & 0,576 \\
\hline AMASYA & MERZIFON & 52.225 & 1,504 & 0,76 & 4,847 & 0,711 \\
\hline MANISA & TURGUTLU & 115.930 & 2,362 & 0,82 & 4,849 & 1,239 \\
\hline DUZCE & DÜZCE C. & 125.240 & 8,815 & 0,65 & 6,592 & 1,115 \\
\hline DENIZLI & DENIZLII C. & 488.768 & 6,371 & 0,94 & 6,560 & 3,691 \\
\hline MANISA & AKHISAR & 100.897 & 2,371 & 0,64 & 4,586 & 0,540 \\
\hline BURSA & INEGOL & 161.541 & 4,686 & 0,75 & 7,517 & 1,361 \\
\hline TOKAT & TOKAT C. & 129.879 & 1,537 & 0,71 & 7,358 & 0,817 \\
\hline MANISA & SALIHLI & 96.503 & 1,656 & 0,62 & 6,096 & 0,821 \\
\hline \multicolumn{2}{|l|}{ Group Average } & 120.796 & 2,438 & $\mathbf{0 , 7 1}$ & 6,582 & 1,096 \\
\hline
\end{tabular}

Rate of population increases in $50.000-490.00$ population category and almost identical rates of growth are observed. Apart from the province center of Erzincan, all settlements are in the process of growth, and half of the top 20 at higher rates than the average rate for this category.

This is further confirmed by the development index figures, again half of the top 20 at higher rates than the average development index for this category.

Stronger agglomeration is observed in this category of settlements, compared to the weak agglomeration rates of the previous category of settlements, even though growth is also an attribute of the rural context for settlements.

The top 20 of the settlements for metropolitan cities are significantly below the category averages in terms of 'settlement population' and 'development index'.

Apart from Sakarya, all settlements are in the process of growth, and half of the top-20 at higher rates than the average rate for this category.

Stronger agglomeration and population density is observed in metropolitan cities than the other two categories. 
Table 4.8 Independent Variables for Metropolitan Cities

\begin{tabular}{|l|l|r|r|r|r|c|}
\cline { 3 - 7 } \multicolumn{2}{c|}{} & \multicolumn{1}{c|}{ X1 } & \multicolumn{1}{c|}{ X2 } & \multicolumn{1}{c|}{ X3 } & \multicolumn{1}{c|}{ X4 } & \multicolumn{1}{|c|}{ X5 } \\
\hline $\begin{array}{l}\text { CATEGORY } \\
\text { Metropolitan } \\
\text { Cities }\end{array}$ & $\begin{array}{l}\text { SUB- } \\
\text { PROVINCE }\end{array}$ & $\begin{array}{c}\text { Settlement } \\
\text { Population } \\
\mathbf{( 2 0 0 9 )}\end{array}$ & $\begin{array}{c}\text { Population } \\
\text { Growth } \\
\text { Rate } \mathbf{( \% )}\end{array}$ & $\begin{array}{c}\text { Rates of } \\
\text { Agglome- } \\
\text { ration }\end{array}$ & $\begin{array}{c}\text { Population / } \\
\text { Total No. of } \\
\text { Buildings }\end{array}$ & $\begin{array}{c}\text { Development } \\
\text { Index }\end{array}$ \\
\hline ISTANBUL & ISTANBUL (M) & 12.782 .960 & 2,563 & 0,99 & 11,74 & N.A. \\
\hline KOCAELI & KOCAELI (M) & 1.422 .752 & 4,249 & 0,93 & 6,96 & 3,525 \\
\hline BURSA & BURSA (M) & 1.854 .285 & 2,239 & 0,96 & 7,40 & 7,953 \\
\hline IZMIR & IZMIR (M) & 3.276 .815 & 1,414 & 0,96 & 6,85 & N.A. \\
\hline SAKARYA & SAKARYA (M) & 442.157 & $-1,154$ & 0,91 & 9,89 & 2,607 \\
\hline ADANA & ADANA (M) & 1.556 .238 & 1,973 & 0,98 & 7,42 & 5,715 \\
\hline ANTALYA & ANTALYA (M) & 955.573 & 5,112 & 0,96 & 5,25 & 3,990 \\
\hline KONYA & KONYA (M) & 1.003 .373 & 3,343 & 0,95 & 6,56 & 3,549 \\
\hline ERZURUM & ERZURUM (M) & 368.146 & 12,976 & 0,96 & 3,53 & 1,924 \\
\hline Group Average & & $\mathbf{2 . 6 2 9 . 1 4 4}$ & $\mathbf{2 , 5 7 0}$ & $\mathbf{0 , 9 7}$ & $\mathbf{8 , 8 7}$ & $\mathbf{4 . 1 8 1}$ \\
\hline
\end{tabular}

Consequently, five independent variables, X1, X2, X3, X4 and X5 are determined for all settlements in each size category in order to examine the relationship between these attributes of settlements and measures of estimated loss in earthquakes.

Therefore the next step of the study is to investigate the relations between measures of vulnerability (dependent variables) and contributing attributes (independent variables) by means of regression methods. 


\section{CHAPTER 5}

\section{ANALYSIS OF MACRO INDICATORS OF SETTLEMENT VULNERABILITY}

Measures of vulnerability (dependent) and assumed contributing attributes (independent variables) are explained for each category of settlements in foregoing chapters. The distribution of dependent and independent variables of the research according to the each size-category is indicated here and for each settlement is given in the Appendix $\mathrm{E}$.

Relations between estimates of loss and contributing attributes are to be investigated as dependent and independent sets of variables of regression equations.

Best subsets regression analyses are employed to determine what combinations of the independent variables might best denote city-level risks.

The results of the best subsets analyses should give us the "most appropriate combination" for the regression analyses.

The regression analyses function is; $\mathrm{Y} 1=\mathrm{Fx}(\mathrm{ax} 1, \mathrm{bx} 2, \mathrm{cx} 3 \ldots)$

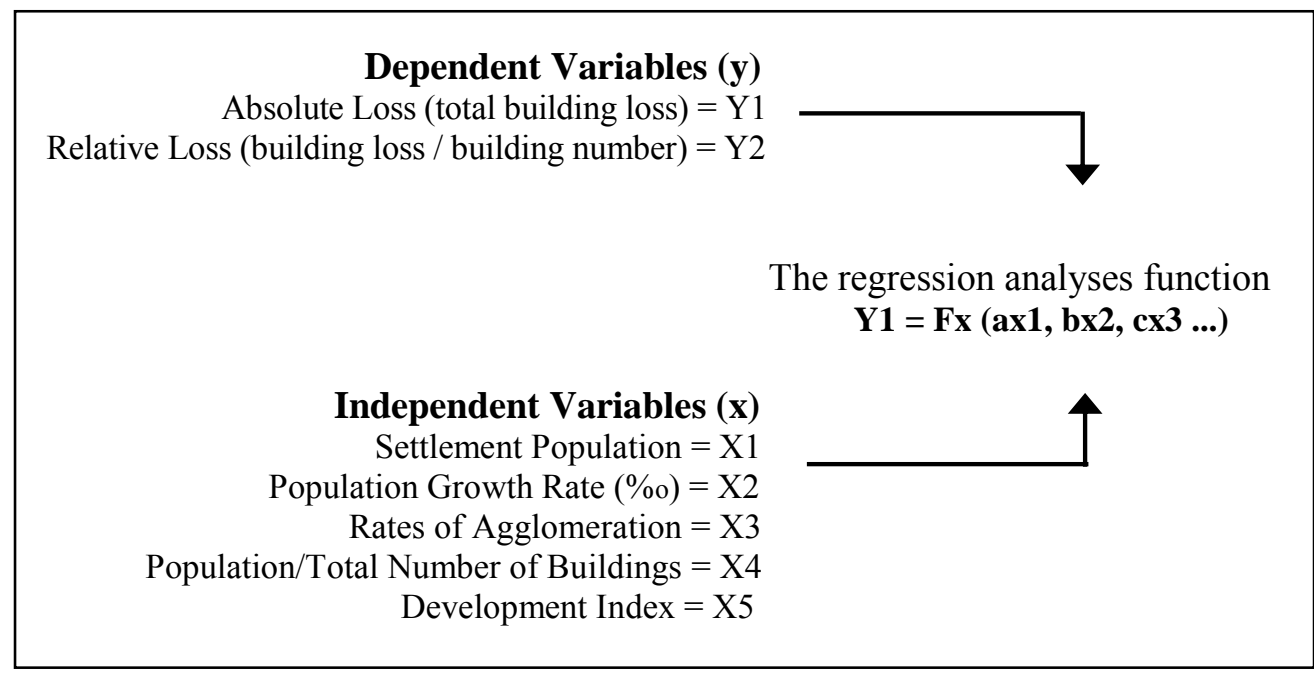

Figure 5.1 Vulnerability Measures and Assumed Contributing Attributes Overview 


\subsection{Best Subsets Regression Analyses}

Best Subsets regression analyses consider all possible combinations of predictors to find the best set to predict a variable. This procedure does not produce a regression equation but identifies the best combination of predictors to put into a regression equation.

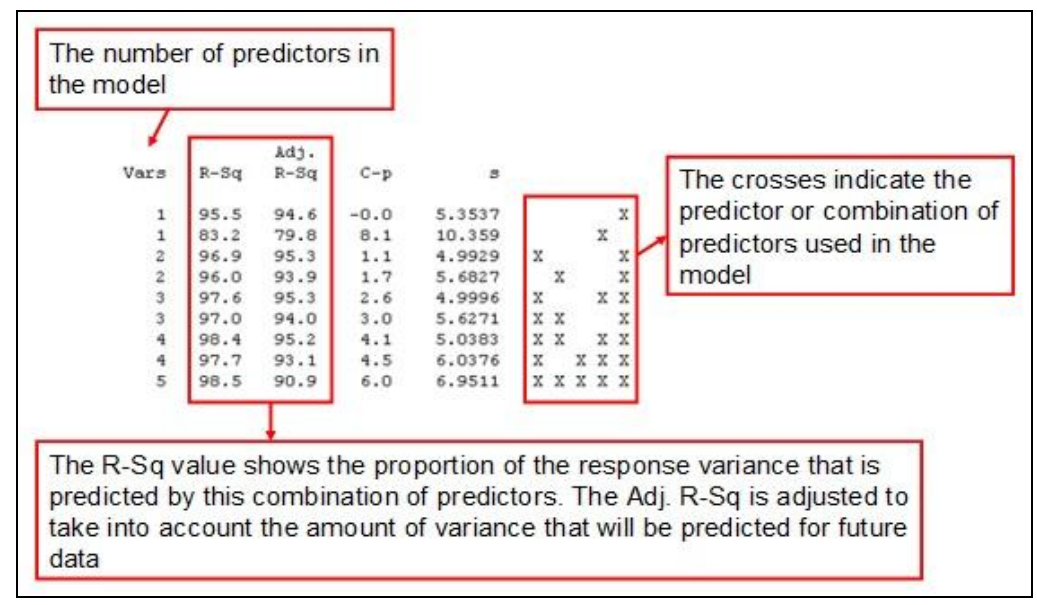

Figure 5.2 An Example For The Best Subset Regression Analyses

In best subsets regression analyses the more related variable is the one that have the biggest number of $\mathrm{R}-\mathrm{Sq}$ (adj.). Also the $\mathrm{C}-\mathrm{p}$ value shows which combination of predictors will make the best predictions, the smallest $C-p$ value shows the best combination.

Accordingly, the biggest number of R-Sq (adj.) and the smallest C-p value in the results of best subset regression analyses will give us the "most appropriate combination" for the regression analyses.

\subsubsection{Best Subsets Regression Analyses for Category I (0-50.000 Inhabitants)}

Best Subsets Regression Analyses for the first Category, that considers settlements having population up to 50.000 , is employed between the dependent and independent variables of the top-20 settlements in the first category prioritized according to absolute loss levels.

Dependent and independent variables of the top-20 settlements in the first category prioritized according to absolute loss levels are given below. 
Table 5.1 Dependent and Independent Variables of the Top-20 Settlements for Category I

\begin{tabular}{|c|c|c|c|c|c|c|c|c|c|}
\hline & & & Y1 & Y2 & $\mathbf{X 1}$ & $\mathbf{X} 2$ & $\mathbf{X 3}$ & $\mathrm{X4}$ & X5 \\
\hline $\begin{array}{c}\text { CATEGORY } \\
0-50.000\end{array}$ & $\begin{array}{l}\text { SUB- } \\
\text { PROVINCE }\end{array}$ & Intensity & $\begin{array}{l}\text { Absolute } \\
\text { Loss }\end{array}$ & $\begin{array}{l}\text { Relative } \\
\text { Loss (Loss } \\
\text { /Building) }\end{array}$ & $\begin{array}{c}\text { Settlement } \\
\text { Population } \\
\quad(2009)\end{array}$ & $\begin{array}{c}\text { Population } \\
\text { Growth } \\
\text { Rate }(\% \text { o) }\end{array}$ & $\begin{array}{c}\text { Rates of } \\
\text { Agglome } \\
\text {-ration }\end{array}$ & $\begin{array}{c}\text { Population } \\
/ \\
\text { Total No. } \\
\text { of } \\
\text { Buildings } \\
\end{array}$ & $\begin{array}{l}\text { Dev. } \\
\text { Index }\end{array}$ \\
\hline TOKAT & NIKSAR & 8 & 1400 & 0,17 & 33.682 & $-3,171$ & 0,52 & 5,37 & $-0,07744$ \\
\hline KASTAMONU & TOSYA & 8 & 1364 & 0,16 & 27.624 & 1,912 & 0,68 & 2,71 & 0,13718 \\
\hline SAKARYA & HENDEK & 8 & 869 & 0,17 & 44.418 & 4,916 & 0,60 & 5,74 & 0,24465 \\
\hline CORUM & OSMANCIK & 8 & 786 & 0,16 & 25.829 & $-1,063$ & 0,57 & 5,64 & $-0,03846$ \\
\hline SAMSUN & HAVZA & 8 & 735 & 0,16 & 20.204 & 0,460 & 0,44 & 4,20 & $-0,37355$ \\
\hline TEKIRDAG & SARKOY & 8 & 712 & 0,18 & 16.624 & 0,291 & 0,55 & 3,99 & 0,62666 \\
\hline SAKARYA & AKYAZI & 8 & 681 & 0,19 & 41.179 & 6,379 & 0,49 & 6,32 & 0,26360 \\
\hline AMASYA & SULUOVA & 7,5 & 633 & 0,07 & 37.151 & $-1,551$ & 0,78 & 4,43 & 0,58123 \\
\hline ERZINCAN & UZUMLU & 8 & 631 & 0,15 & 8.288 & $-14,403$ & 0,52 & 7,24 & $-0,23858$ \\
\hline BOLU & GEREDE & 8 & 583 & 0,17 & 23.808 & $-0,626$ & 0,69 & 7,32 & 0,37367 \\
\hline SAKARYA & GEYVE & 8 & 543 & 0,16 & 20.318 & 1,775 & 0,44 & 4,96 & 0,14350 \\
\hline BALIKESIR & AYVALIK & 7 & 442 & 0,03 & 35.986 & 1,309 & 0,58 & 2,27 & 1,45980 \\
\hline SIVAS & SUSEHRI & 8 & 424 & 0,16 & 15.304 & $-5,514$ & 0,55 & 9,71 & $-0,21177$ \\
\hline BALIKESIR & BURHANIYE & 7 & 410 & 0,03 & 38.156 & 2,227 & 0,77 & 2,37 & 1,12760 \\
\hline SAKARYA & PAMUKOVA & 8 & 403 & 0,15 & 16.047 & 2,170 & 0,60 & 5,08 & 0,46365 \\
\hline MUS & VARTO & 8 & 384 & 0,15 & 9.585 & $-5,955$ & 0,28 & 6,39 & $-1,03815$ \\
\hline SAMSUN & LADIK & 8 & 377 & 0,16 & 8.316 & $-0,999$ & 0,46 & 3,75 & $-0,24068$ \\
\hline YALOVA & CINARCIK & 8 & 357 & 0,21 & 11.080 & 2,368 & 0,43 & 5,35 & 1,17381 \\
\hline IZMIR & CESME & 7 & 348 & 0,03 & 20.455 & $-2,343$ & 0,63 & 2,19 & 2,69252 \\
\hline BURSA & YENISEHIR & 7,5 & 339 & 0,07 & 29.275 & 1,289 & 0,57 & 5,18 & 0,28969 \\
\hline
\end{tabular}

The first best subsets regression analyses is employed between the first dependent variable $Y 1$ (absolute loss) and independent variables (X1, X2, X3, $\mathrm{X} 4, \mathrm{X} 5)$ in order to see which independent variable is more related with $\mathrm{Y} 1$.

According to the Table 5.2 the biggest R-Sq (adj.) is 19, 1\% in the third line and this means that the most related variables with $Y 1$ is $X 1$ and $X 5$, which is settlement population and development index. 
Table 5.2 Best Subsets Regression 1 : Y1 versus $x 1 ; x 2 ; x 3 ; x 4 ; x 5$

\begin{tabular}{|c|c|c|c|c|c|c|c|c|c|}
\hline Best $\mathrm{S}$ & osets R & gression: Y1 & ersus X1; > & $2 ; \mathrm{X} 3 ; \mathrm{X}$ & X5 & & & & \\
\hline Resp & ise is & Y1 & & & & & & & \\
\hline & & & Mallows & & $\mathrm{x}$ & $\mathrm{x}$ & & & $\mathrm{x}$ \\
\hline Vars & $R-S q$ & $R-S q(a d j)$ & $\mathrm{Cp}$ & $\mathrm{S}$ & 1 & 2 & & 4 & 5 \\
\hline 1 & 13,4 & 8,6 & 2,6 & 292,87 & $\mathrm{X}$ & & & & \\
\hline 1 & 7,6 & 2,4 & 3,9 & 302,54 & & & & & $\mathrm{X}$ \\
\hline 2 & 27,7 & 19,1 & 1,6 & 275,42 & $\mathrm{x}$ & & & & $\mathrm{x}$ \\
\hline 2 & 18,1 & 8,4 & 3,6 & 293,09 & & & $\mathrm{x}$ & & $\mathrm{X}$ \\
\hline 3 & 31,5 & 18,7 & 2,7 & 276,18 & $\mathrm{X}$ & & & $\mathrm{X}$ & $\mathrm{X}$ \\
\hline 3 & 29,0 & 15,7 & 3,3 & 281,28 & $\mathrm{X}$ & $\mathrm{X}$ & & & $\mathrm{X}$ \\
\hline 4 & 34,4 & 16,9 & 4,1 & 279,26 & $\mathrm{X}$ & $\mathrm{X}$ & & $\mathrm{X}$ & $\mathrm{X}$ \\
\hline 4 & 33,0 & 15,2 & 4,4 & 282,10 & $\mathrm{X}$ & & $\mathrm{x}$ & $\mathrm{x}$ & $\mathrm{X}$ \\
\hline 5 & 35,0 & 11,7 & 6,0 & 287,76 & $\mathrm{X}$ & $\mathrm{X}$ & 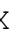 & $\mathrm{X}$ & $\mathrm{X}$ \\
\hline
\end{tabular}

As a result of this analysis we can say that;

$\mathrm{Y} 1$ that is determined as absolute loss is correlated with X1 and X5.

Accordingly, the regression analysis is performed with;

Y1 (Absolute loss) and X1 (Settlement Population)

Y1 (Absolute loss) and X5 (Development Index)

The second best subsets regression analysis is employed between the second dependent variable $\mathrm{Y} 2$ (rate of loss) and other independent variables (X1, X2, $\mathrm{X} 3, \mathrm{X} 4, \mathrm{X} 5)$.

Table 5.3 shows us that the biggest R-Sq (adj.) is $54,5 \%$ in the seventh line and this means that the most related variables with $Y 2$ is $X 1, X 3, X 4$ and $X 5$ that is settlement population, rate of agglomeration, ratio of population to the total number of building and development index.

Table 5.3 Best Subsets Regression 2 : Y2 versus $x 1 ; \times 2 ; \times 3 ; \times 4 ; \times 5$

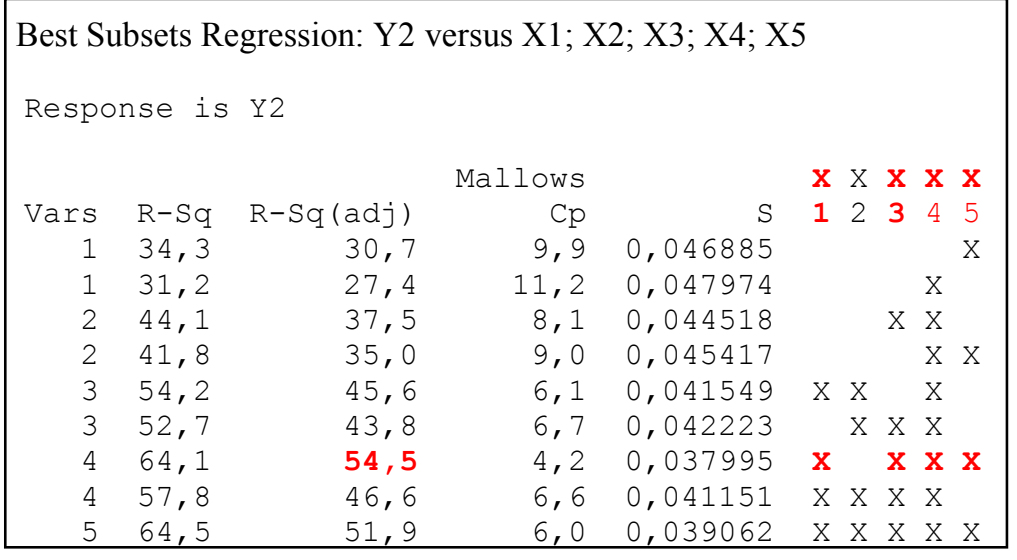


As a result of this analysis we can say that;

$\mathrm{Y} 2$ that is determined as rate of loss is correlated with $\mathrm{X} 1, \mathrm{X} 3, \mathrm{X} 4$ and $\mathrm{X} 5$.

Accordingly, regression analysis is performed with;

Y2 (Rate of Loss) and X1 (Settlement Population)

Y2 (Rate of Loss) and X3 (Rates of Agglomeration)

Y2 (Rate of Loss) and X4 (Population/Total Number of Buildings)

Y2 (Rate of Loss) and X5 (Development Index)

The results of best subsets regression analyses of top-20 settlements for the first category, that considers settlements having population up to 50.000 , shows that X1 (settlement population) and X5 (development index) are the most effective independent variables that correlates with both dependent variables.

Six regression analyses are performed according to the results of best subsets regression analyses for Category I, which considers settlements having population up to 50.000 . These are;

Regression Analysis: $\mathrm{Y} 1$ versus $\mathrm{X} 1$,

$Y 1$ versus $X 5$,

$Y 2$ versus $X 1$,

$Y 2$ versus $X 3$,

$Y 2$ versus $X 4$ and

$Y 2$ versus $X 5$.

\subsubsection{Best Subsets Regression Analyses for Category II (50.000- 490.000 Inhabitants)}

Best Subsets Regression Analyses for the second Category, that considers settlements having population between 50.000 and 490.000 , is employed between the dependent and independent variables of the top-20 settlements in the second category prioritized according to absolute loss levels.

Dependent and independent variables of the top-20 settlements in the second category prioritized according to absolute loss levels are given below. 
Table 5.4 Dependent and Independent Variables of the Top-20 Settlements for Category II

\begin{tabular}{|c|c|c|c|c|c|c|c|c|c|}
\hline & & & Y1 & Y2 & $\mathbf{X 1}$ & $\mathbf{X 2}$ & $\mathbf{X 3}$ & $\mathrm{X4}$ & $\mathrm{X} 5$ \\
\hline $\begin{array}{l}\text { CATEGORY } \\
50.000- \\
490.000\end{array}$ & $\begin{array}{l}\text { SUB- } \\
\text { PROVINCE }\end{array}$ & Intensity & $\begin{array}{l}\text { Absolute } \\
\text { Loss }\end{array}$ & $\begin{array}{l}\text { Relative } \\
\text { Loss (Loss } \\
\text { /Building) }\end{array}$ & $\begin{array}{c}\text { Settlement } \\
\text { Population } \\
\quad(2009)\end{array}$ & $\begin{array}{l}\text { Population } \\
\text { Growth } \\
\text { Rate }(\% \text { ) }\end{array}$ & $\begin{array}{l}\text { Rates of } \\
\text { Agglome } \\
\text {-ration }\end{array}$ & $\begin{array}{c}\text { Pop. / } \\
\text { Total No. } \\
\text { of } \\
\text { Buildings }\end{array}$ & $\begin{array}{l}\text { Dev. } \\
\text { Index }\end{array}$ \\
\hline VAN & VAN M. & 7,5 & 2285 & 0,06 & 360.810 & 2,642 & 0,80 & 7,851 & 0,71686 \\
\hline ERZINCAN & ERZINCAN M. & 8 & 2025 & 0,16 & 90.100 & $-1,928$ & 0,65 & 8,454 & 0,78524 \\
\hline BOLU & BOLU M. & 8 & 1841 & 0,18 & 120.021 & 3,891 & 0,75 & 8,042 & 1,79561 \\
\hline YALOVA & YALOVA M. & 8 & 1507 & 0,18 & 92.166 & 3,038 & 0,81 & 8,446 & 2,42273 \\
\hline TEKIRDAG & TEKİRDAĞ M. & 7,5 & 1347 & 0,09 & 140.535 & 3,009 & 0,82 & 6,835 & 1,86420 \\
\hline TOKAT & ERBAA & 8 & 1251 & 0,16 & 58.845 & 2,835 & 0,60 & 5,775 & $-0,25251$ \\
\hline BURSA & ORHANGAZI & 8 & 945 & 0,18 & 54.319 & 2,234 & 0,72 & 8,362 & 1,13050 \\
\hline MANISA & MANISA M. & 7 & 919 & 0,04 & 291.374 & 3,411 & 0,86 & 8,648 & 2,46533 \\
\hline OSMANIYE & OSMANIYE M. & 7 & 905 & 0,03 & 194.339 & 1,230 & 0,86 & 5,916 & 0,97609 \\
\hline HATAY & ANTAKYA & 7 & 768 & 0,03 & 202.216 & 3,702 & 0,45 & 6,174 & 0,98304 \\
\hline HATAY & ISKENDERUN & 7 & 705 & 0,03 & 190.279 & 1,985 & 0,60 & 7,518 & 2,56211 \\
\hline ADIYAMAN & ADIYAMAN M. & 7 & 696 & 0,03 & 198.433 & 1,174 & 0,76 & 8,128 & 0,57604 \\
\hline AMASYA & MERZIFON & 7,5 & 666 & 0,07 & 52.225 & 1,504 & 0,76 & 4,847 & 0,71109 \\
\hline MANISA & TURGUTLU & 7 & 639 & 0,03 & 115.930 & 2,362 & 0,82 & 4,849 & 1,23913 \\
\hline DUZCE & DÜZCE M. & 7,5 & 612 & 0,07 & 125.240 & 8,815 & 0,65 & 6,592 & 1,11568 \\
\hline DENIZLI & DENİLİ M. & 6,5 & 586 & 0,01 & 488.768 & 6,371 & 0,94 & 6,560 & 3,69197 \\
\hline MANISA & AKHISAR & 7 & 585 & 0,03 & 100.897 & 2,371 & 0,64 & 4,586 & 0,54044 \\
\hline BURSA & INEGOL & 7 & 536 & 0,04 & 161.541 & 4,686 & 0,75 & 7,517 & 1,36120 \\
\hline TOKAT & TOKAT M. & 7 & 528 & 0,03 & 129.879 & 1,537 & 0,71 & 7,358 & 0,81785 \\
\hline MANISA & SALIHLI & 7 & 483 & 0,04 & 96.503 & 1,656 & 0,62 & 6,096 & 0,82197 \\
\hline
\end{tabular}

Best subsets regression analyses is employed between the first dependent variable Y1 (absolute loss) and other independent variables in order to see which independent variable is more related with $\mathrm{Y} 1$.

According to the Table 5.5 the biggest R-Sq (adj.) is $19,3 \%$ in the third line and this means that the most related variables with $Y 1$ is $X 2$ and $X 4$, that is population growth rate and ratio of population to the total number of building. 
Table 5.5 Best Subsets Regression 3 : Y1 versus $x 1 ; x 2 ; \times 3 ; x 4 ; x 5$

\begin{tabular}{|c|c|c|c|c|c|c|c|c|}
\hline \multicolumn{9}{|c|}{ Best Subsets Regres } \\
\hline \multicolumn{9}{|c|}{ Response is Y1 } \\
\hline & & & Mallows & & & $\mathrm{X} X$ & $\mathrm{X}$ & \\
\hline Vars & $\mathrm{R}-\mathrm{Sq}$ & $R-S q(\operatorname{adj})$ & $\mathrm{Cp}$ & $\mathrm{S}$ & 1 & 23 & 4 & 5 \\
\hline 1 & 22,4 & 18,0 & 1,1 & 488,91 & & & $\mathrm{x}$ & \\
\hline 1 & 7,3 & 2,2 & 3,2 & 534,07 & & $\mathrm{X}$ & & \\
\hline 2 & 27,8 & 19,3 & 1,0 & 485,11 & & $\mathrm{x}$ & $\mathrm{x}$ & \\
\hline 2 & 27,6 & 19,1 & 1,0 & 485,88 & & & $\mathrm{X}$ & $\mathrm{X}$ \\
\hline 3 & 30,1 & 17,0 & 2,5 & 491,99 & & $\mathrm{X}$ & $\mathrm{X}$ & $\mathrm{X}$ \\
\hline 3 & 29,8 & 16,6 & 2,6 & 493,19 & & & $\mathrm{X}$ & $\mathrm{X}$ \\
\hline 4 & 31,9 & 13,7 & 4,1 & 501,71 & & $\mathrm{X} x$ & $\mathrm{X}$ & $\mathrm{X}$ \\
\hline 4 & 31,2 & 12,9 & 4,3 & 504,14 & $\mathrm{X}$ & & $\mathrm{X}$ & $\mathrm{X}$ \\
\hline 5 & 32,6 & 8,5 & 6,0 & 516,65 & $\mathrm{X}$ & $\mathrm{X} X$ & $\mathrm{X}$ & $\mathrm{X}$ \\
\hline
\end{tabular}

As a result of this analysis we can say that; $Y 1$ that is determined as absolute loss is correlated with $\mathrm{X} 2$ and $\mathrm{X} 4$. Accordingly, the regression analysis is performed with;

Y1 (Absolute loss) and X2 (Population Growth Rate)

Y1 (Absolute loss) and X4 (Population/Total Number of Buildings)

The second best subsets regression analysis is employed between the second dependent variable Y2 (rate of loss) and other independent variables, Table 5.6 shows us that the biggest R-Sq (adj.) is $45,8 \%$ in the third line and this means that the most related variables with $Y 2$ is $X 1$ and $X 4$, that is settlement population and ratio of population to the total number of building.

Table 5.6 Best Subsets Regression 4: Y2 versus $x 1 ; x 2 ; x 3 ; x 4 ; x 5$

\begin{tabular}{|c|c|c|c|c|c|c|c|}
\hline \multirow{2}{*}{\multicolumn{8}{|c|}{$\begin{array}{l}\text { Best Subsets Regress } \\
\text { Response is Y2 }\end{array}$}} \\
\hline & & & & & & & \\
\hline \multirow[b]{2}{*}{ Vars } & \multirow[b]{2}{*}{$R-S q$} & \multicolumn{2}{|r|}{ Mallows } & \multirow[b]{2}{*}{ S } & \multirow{2}{*}{$\begin{array}{ccc}x & x & X \\
1 & 2 & 3\end{array}$} & \multirow{2}{*}{$\begin{array}{l}x \\
4\end{array}$} & $\mathrm{X}$ \\
\hline & & $R-S q(a d j)$ & $\mathrm{Cp}$ & & & & 5 \\
\hline 1 & 25,6 & 21,5 & 6,7 & 0,053812 & $\mathrm{X}$ & & \\
\hline 1 & 16,3 & 11,7 & 9,6 & 0,057075 & & $\mathrm{X}$ & \\
\hline 2 & 51,5 & 45,8 & 0,8 & 0,044715 & $\mathrm{x}$ & $\mathrm{x}$ & \\
\hline 2 & 30,1 & 21,8 & 7,4 & 0,053701 & $\mathrm{X}$ & & $\mathrm{X}$ \\
\hline 3 & 53,1 & 44,3 & 2,4 & 0,045351 & $\mathrm{X}$ & $\mathrm{X} X$ & \\
\hline 3 & 52,6 & 43,7 & 2,5 & 0,045585 & X X & X & \\
\hline 4 & 54,2 & 42,0 & 4,0 & 0,046251 & $x \times 2$ & $X X$ & \\
\hline 4 & 53,2 & 40,7 & 4,3 & 0,046775 & $\mathrm{X}$ & & $\mathrm{x}$ \\
\hline 5 & 54,2 & 37,9 & 6,0 & 0,047874 & $x \times$ & & $\mathrm{X}$ \\
\hline
\end{tabular}


As a result of this analysis we can say that; $Y 2$ that is determined as rate of loss is correlated with X1 and X4. Accordingly, the regression analysis is performed with;

Y2 (Rate of Loss) and X1 (Settlement Population)

Y2 (Rate of Loss) and X4 (Population/Total Number of Buildings)

The results of best subsets regression analyses of top-20 settlements for the second category, that considers settlements having population between 50.000 and 490.000 , shows that $X 4$, the ratio of population to total number of buildings, is the most effective and only independent variable that correlates with both dependent variables.

Four regression analyses are performed according to the results of best subsets regression analyses for Category II that considers settlements having population between 50.000 and 490.000. These are;

$$
\begin{aligned}
& \text { Regression Analysis: } Y 1 \text { versus } X 2, \\
& Y 1 \text { versus } X 4, \\
& Y 2 \text { versus } X 1 \text { and } \\
& Y 2 \text { versus } X 4
\end{aligned}
$$

\subsubsection{Best Subsets Regression Analyses for Category III (Metropolitan Cities)}

Best Subsets Regression Analyses for the third Category, that considers metropolitan cities, is employed between the dependent and independent variables of the metropolitan cities prioritized according to absolute loss levels.

Dependent and independent variables of metropolitan cities in the third category

\begin{tabular}{|c|c|c|c|c|c|c|c|c|c|}
\hline & & & Y1 & Y2 & $\mathbf{X 1}$ & $\mathbf{X} 2$ & $\mathbf{X 3}$ & $\mathbf{X 4}$ & X5 \\
\hline $\begin{array}{c}\text { CATEGORY } \\
\text { Metropolitan } \\
\text { Cities }\end{array}$ & $\begin{array}{l}\text { SUB- } \\
\text { PROVINCE }\end{array}$ & Intensity & $\begin{array}{l}\text { Absolute } \\
\text { Loss }\end{array}$ & $\begin{array}{l}\text { Relative } \\
\text { Loss (Loss } \\
\text { /Building) }\end{array}$ & $\begin{array}{c}\text { Settlement } \\
\text { Population } \\
(2009)\end{array}$ & $\begin{array}{c}\text { Population } \\
\text { Growth } \\
\text { Rate }(\% 0)\end{array}$ & $\begin{array}{c}\text { Rates of } \\
\text { Agglome- } \\
\text { ration }\end{array}$ & $\begin{array}{c}\text { Population / } \\
\text { Total No. of } \\
\text { Buildings }\end{array}$ & $\begin{array}{l}\text { Dev. } \\
\text { Index }\end{array}$ \\
\hline ISTANBUL & ISTANBUL (M) & 7,5 & 83824 & 0,10 & 12.782 .960 & 2,563 & 0,99 & 11,74 & N.A. \\
\hline KOCAELI & KOCAELI (M) & 8 & 24077 & 0,17 & 1.422 .752 & 4,249 & 0,93 & 6,96 & \\
\hline BURSA & BURSA (M) & 7,5 & 16506 & 0,08 & 1.854 .285 & 2,239 & 0,96 & 7,40 & 7,95333 \\
\hline IZMIR & IZMIR (M) & 7 & 14531 & 0,03 & 3.276 .815 & 1,414 & 0,96 & 6,85 & N.A. \\
\hline SAKARYA & SAKARYA (M) & 8 & 8070 & 0,16 & 442.157 & $-1,154$ & 0,91 & 9,89 & \\
\hline ADANA & ADANA (M) & 6,5 & 1913 & 0,01 & 1.556 .238 & 1,973 & 0,98 & 7,42 & 5,71564 \\
\hline ANTALYA & ANTALYA (M) & 6,5 & 1402 & 0,01 & 955.573 & 5,112 & 0,96 & 5,25 & \\
\hline KONYA & KONYA (M) & 6,5 & 1355 & 0,01 & 1.003 .373 & 3,343 & 0,95 & 6,56 & 3,54941 \\
\hline ERZURUM & ERZURUM (M) & 6,5 & 439 & 0,01 & 368.146 & 12,976 & 0,96 & 3,53 & \\
\hline
\end{tabular}
prioritized according to absolute loss levels are given below.

Table 5.7 Dependent and Independent Variables of the Top-20 Settlements for Category II 
Best subsets regression analyses is employed between the first dependent variable $Y 1$ (absolute loss) and other independent variables in order to see which independent variable is more related with $\mathrm{Y} 1$.

According to the Table 5.8 the biggest R-Sq (adj.) is $95,5 \%$ in the seventh line and this means that the most related variables with $\mathrm{Y} 1$ is $\mathrm{X} 1, \mathrm{X} 3$ and $\mathrm{X} 4$ that is settlement population, rate of agglomeration and ratio of population to the total number of building.

Table 5.8 Best Subsets Regression 5: Y1 versus x1; x2; x3; x4; x5

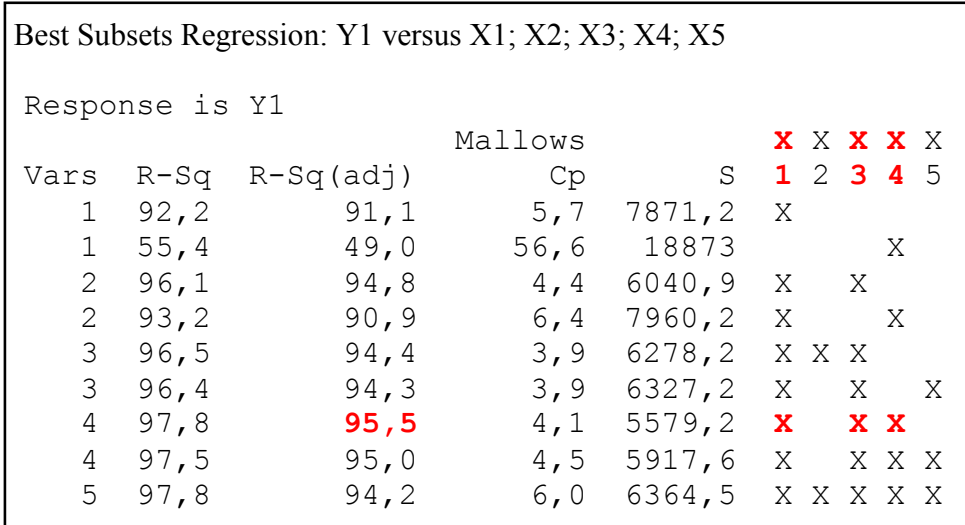

As a result of this analysis we can say that; $Y 1$ that is determined as absolute loss is correlated with $\mathrm{X} 1, \mathrm{X} 3$ and $\mathrm{X} 4$.

Accordingly, the regression analysis is performed with;

Y1 (Absolute loss) and X1 (Settlement Population)

$Y 1$ (Absolute loss) and X3 (Rates of Agglomeration)

Y1 (Absolute loss) and X4 (Population/Total Number of Buildings)

The second best subsets regression analysis is employed between the second dependent variable Y2 (rate of loss) and other independent variables, Table 5.9 shows us that the biggest R-Sq (adj.) is $68,6 \%$ in the fifth line and this means that the most related variables with $Y 2$ is $X 2, X 3$ and $X 4$, that is population growth rate, rate of agglomeration and ratio of population to the total number of buildings. 
Table 5.9 Best Subsets Regression 6 : Y2 versus $x 1 ; x 2 ; x 3 ; x 4 ; x 5$

\begin{tabular}{|c|c|c|c|c|c|c|c|c|c|}
\hline \multicolumn{10}{|c|}{ Best Subsets Regres } \\
\hline \multicolumn{10}{|c|}{$\begin{array}{l}\text { Best Subsets Regres } \\
\text { Response is Y2 }\end{array}$} \\
\hline Vars & $\mathrm{R}-\mathrm{Sq}$ & $R-S q(a d j)$ & $\begin{array}{r}\text { Mallows } \\
\mathrm{Cp}\end{array}$ & $\mathrm{S}$ & $\begin{array}{l}X \\
1\end{array}$ & $\begin{array}{l}X \\
2\end{array}$ & $\begin{array}{l}x \\
3\end{array}$ & & $\begin{array}{l}X \\
5\end{array}$ \\
\hline 1 & 34,2 & 24,8 & 6,0 & 0,057201 & & & $\mathrm{X}$ & & \\
\hline 1 & 34,1 & 24,7 & 6,0 & 0,057245 & & & & $\mathrm{X}$ & \\
\hline 2 & 75,4 & 67,2 & 2,4 & 0,037776 & $\mathrm{x}$ & & $\mathrm{X}$ & & \\
\hline 2 & 72,0 & 62,7 & 2,7 & 0,040316 & & & $\mathrm{X}$ & $\mathrm{X}$ & \\
\hline 3 & 80,4 & 68,6 & 2,3 & 0,036964 & & $x$ & $\mathrm{x}$ & $\mathrm{x}$ & \\
\hline 3 & 78,5 & 65,6 & 2,6 & 0,038679 & & $\mathrm{x}$ & $\mathrm{X}$ & $\mathrm{X}$ & \\
\hline 4 & 81,3 & 62,6 & 4,1 & 0,040366 & $\mathrm{X}$ & $\mathrm{X}$ & $\mathrm{X}$ & $x$ & X \\
\hline 4 & 80,4 & 60,8 & 4,3 & 0,041301 & $\mathrm{x}$ & & $\mathrm{X}$ & $x x$ & $\mathrm{X}$ \\
\hline 5 & 82,1 & 52,2 & 6,0 & 0,045637 & $\mathrm{x}$ & $\mathrm{X}$ & $X$ & $x x$ & \\
\hline
\end{tabular}

As a result of this analysis we can say that; $Y 2$ that is determined as rate of loss is correlated with $X 2, X 3$ and $X 4$. Accordingly, the regression analysis is performed with;

Y2 (Rate of Loss) and X2 (Population Growth Rate)

$Y 2$ (Rate of Loss) and X3 (Rates of Agglomeration)

Y2 (Rate of Loss) and X4 (Population/Total Number of Buildings)

The results of best subsets regression analyses for the third category, that considers metropolitan cities, shows that X3 (Rates of Agglomeration) and X4 (Population/Total Number of Buildings) are the most effective independent variables that correlates with both dependent variables.

Five regression analyses are performed according to the results of best subsets regression analyses for Category III that considers metropolitan cities. These are;

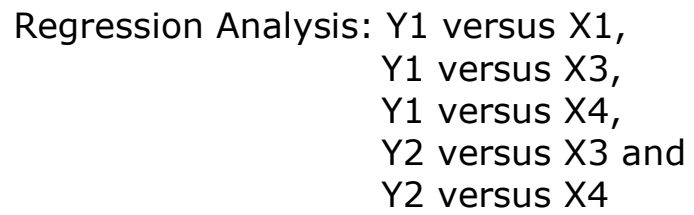

\subsubsection{Evaluation of Best Subsets Regression Analyses}

The results of best subsets regression analyses of top-20 settlements for the first category, that considers settlements having population up to 50.000 , shows that X1 (settlement population) and X5 (development index) are the most effective independent variables that correlates with both dependent variables. 
Six regression analyses are performed according to the results of best subsets regression analyses for Category I, which considers settlements having population up to 50.000. These are; Regression Analysis: $Y 1$ versus $X 1, Y 1$ versus $X 5, Y 2$ versus $X 1, Y 2$ versus $X 3, Y 2$ versus $X 4$ and $Y 2$ versus $X 5$.

The results of best subsets regression analyses of top-20 settlements for the second category, that considers settlements having population between 50.000 and 490.000 , shows that $X 4$, the ratio of population to total number of buildings, is the most effective and only independent variable that correlates with both dependent variables.

Four regression analyses are performed according to the results of best subsets regression analyses for Category II, which considers settlements having population between 50.000 and 490.000 . These are; Regression Analysis: Y1 versus $\mathrm{X} 2, \mathrm{Y} 1$ versus $\mathrm{X} 4, \mathrm{Y} 2$ versus $\mathrm{X} 1$ and $\mathrm{Y} 2$ versus $\mathrm{X} 4$.

The results of best subsets regression analyses for the third category, that considers metropolitan cities, shows that X3 (Rates of Agglomeration) and X4 (Population/Total Number of Buildings) are the most effective independent variables that correlates with both dependent variables.

Five regression analyses are performed according to the results of best subsets regression analyses for Category III that considers metropolitan cities. These are; Regression Analysis: $Y 1$ versus $X 1, Y 1$ versus $X 3, Y 1$ versus $X 4, Y 2$ versus $\mathrm{X} 3$ and $\mathrm{Y} 2$ versus $\mathrm{X} 4$.

Table 5.10 Evaluation of Best Subsets Regression Analyses

\begin{tabular}{|c|c|c|}
\hline $\begin{array}{c}\text { First Category } \\
\text { settlements having } \\
\text { population up to } 50.000\end{array}$ & $\begin{array}{l}Y 1 \text { versus } X 1 \\
Y 1 \text { versus } X 5 \\
Y 2 \text { versus } X 1 \\
Y 2 \text { versus } X 3 \\
Y 2 \text { versus } X 4 \\
Y 2 \text { versus } X 5\end{array}$ & $\begin{array}{l}\text { Six regression analyses } \\
\text { for Category I }\end{array}$ \\
\hline $\begin{array}{l}\text { Second Category } \\
\text { settlements having } \\
\text { population between } \\
50.000 \text { and } 490.000\end{array}$ & $\begin{array}{l}Y 1 \text { versus } X 2 \\
Y 1 \text { versus } X 4 \\
Y 2 \text { versus } X 1 \\
Y 2 \text { versus } X 4\end{array}$ & $\begin{array}{c}\text { Four regression analyses } \\
\text { for Category II }\end{array}$ \\
\hline $\begin{array}{l}\text { Third Category } \\
\text { metropolitan cities }\end{array}$ & $\begin{array}{l}Y 1 \text { versus } X 1 \\
Y 1 \text { versus } X 3 \\
Y 1 \text { versus } X 4 \\
Y 2 \text { versus } X 3 \\
Y 2 \text { versus } X 4\end{array}$ & $\begin{array}{c}\text { Five regression analyses } \\
\text { for Category III }\end{array}$ \\
\hline
\end{tabular}

*Y1 (absolute loss), Y2 (relative loss), X1 (settlement population), X2 (population growth rate), X3 (rates of agglomeration), X4 (population /total number of buildings), X5 (development index) 


\subsection{Analyses by Means of Regression Methods}

According to the results of best subsets regression analyses; six regression analyses for Category I, four regression analyses for Category II and five regression analyses for Category III are performed. Regression analyses are performed within top-20 settlements prioritized according to absolute loss in Category I and Category II and nine metropolitan cities in Category III.

In regression analyses in order to say that there is a relation between variables, the $\mathrm{R}-\mathrm{Sq}$ (adj.) must be minimum $64 \%$. The ratios lower than $64 \%$ is insufficient to verify the relationship between variables and we can say that there is a weak relation or there isn't any relation between variables. If the ratio is higher than $64 \%$ we can say that there is a strong relation between variables.

\subsubsection{Analyses by Means of Regression Methods for Category I (0- 50.000)}

Six regression analyses are performed according to the results of best subsets regression analyses for Category I that considers settlements having population up to 50.000. These are; Regression Analysis: $Y 1$ versus $X 1, Y 1$ versus $X 5, Y 2$ versus $X 1, Y 2$ versus $X 3, Y 2$ versus $X 4$ and $Y 2$ versus $X 5$.

\section{Regression Analysis 1:}

Regression Analysis 1 is performed with $\mathrm{Y} 1$ (absolute loss) and $\mathrm{X} 1$ (settlement population). As shown in the Table 5.11 , the $\mathrm{R}-\mathrm{Sq}$ (adj.) is $8,6 \%$. This ratio is insufficient to verify the relationship between $Y 1$ and $X 1$, so we can say that there is no relation between the regression equations of $Y 1$ versus $X 1$.

Table 5.11 Regression Analysis 1: Y1 versus $\mathrm{X} 1$

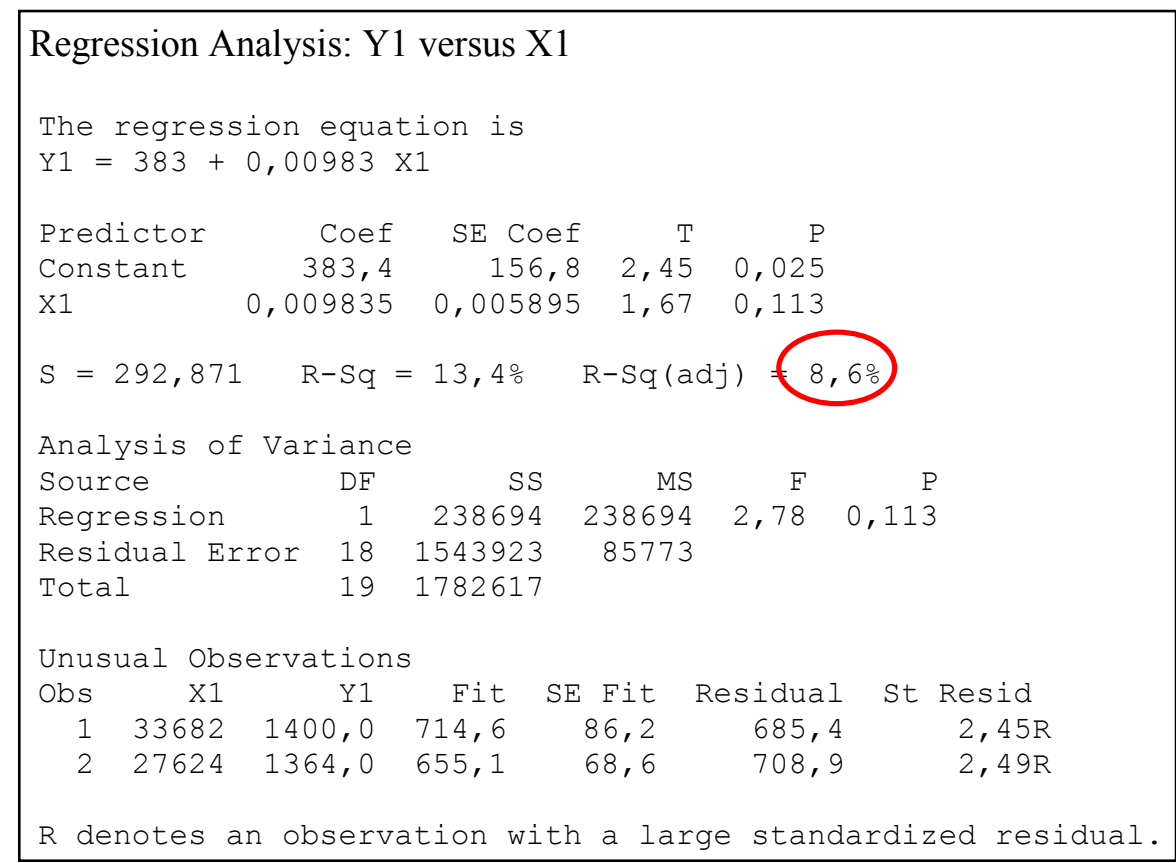




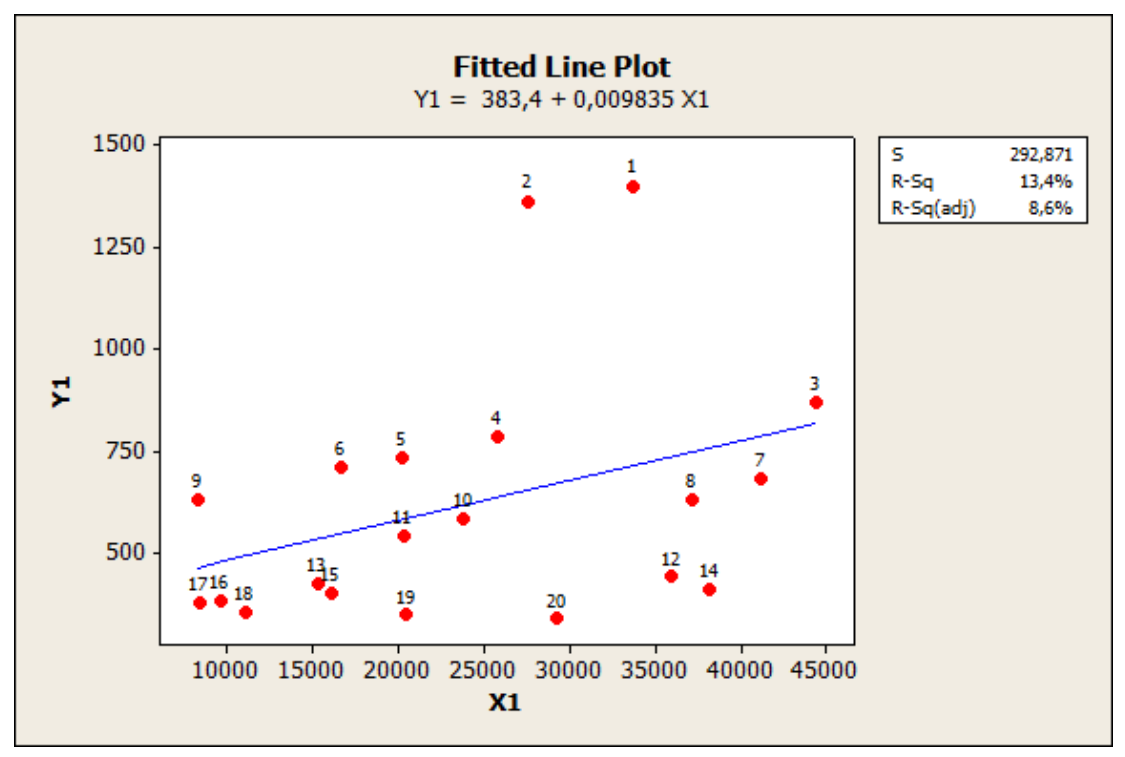

Figure 5.3 Regression Analysis 1: Y1 versus X1

Regression equation of $\mathrm{Y} 1$ versus $\mathrm{X} 1$ is; $\mathrm{Y} 1=383+0,00983 \mathrm{X} 1$ and

$$
\text { R-Sq (adj.) }=8,6 \%
$$

Consequently, we can say that there is no relation between Absolute Loss and Settlement Population for the top-20 settlements less than 50.000 inhabitants.

\section{Regression Analysis 2:}

Regression Analysis 2 is performed with Y1 (absolute loss) and X5 (development index). As shown in the Table 5.12, the R-Sq (adj.) is 2, 4\%.

This ratio is insufficient to verify the relationship between $Y 1$ and $X 5$, so we can say that there is no relation between the regression equations of $Y 1$ versus $X 5$. 
Table 5.12 Regression Analysis 2: Y1 versus X5

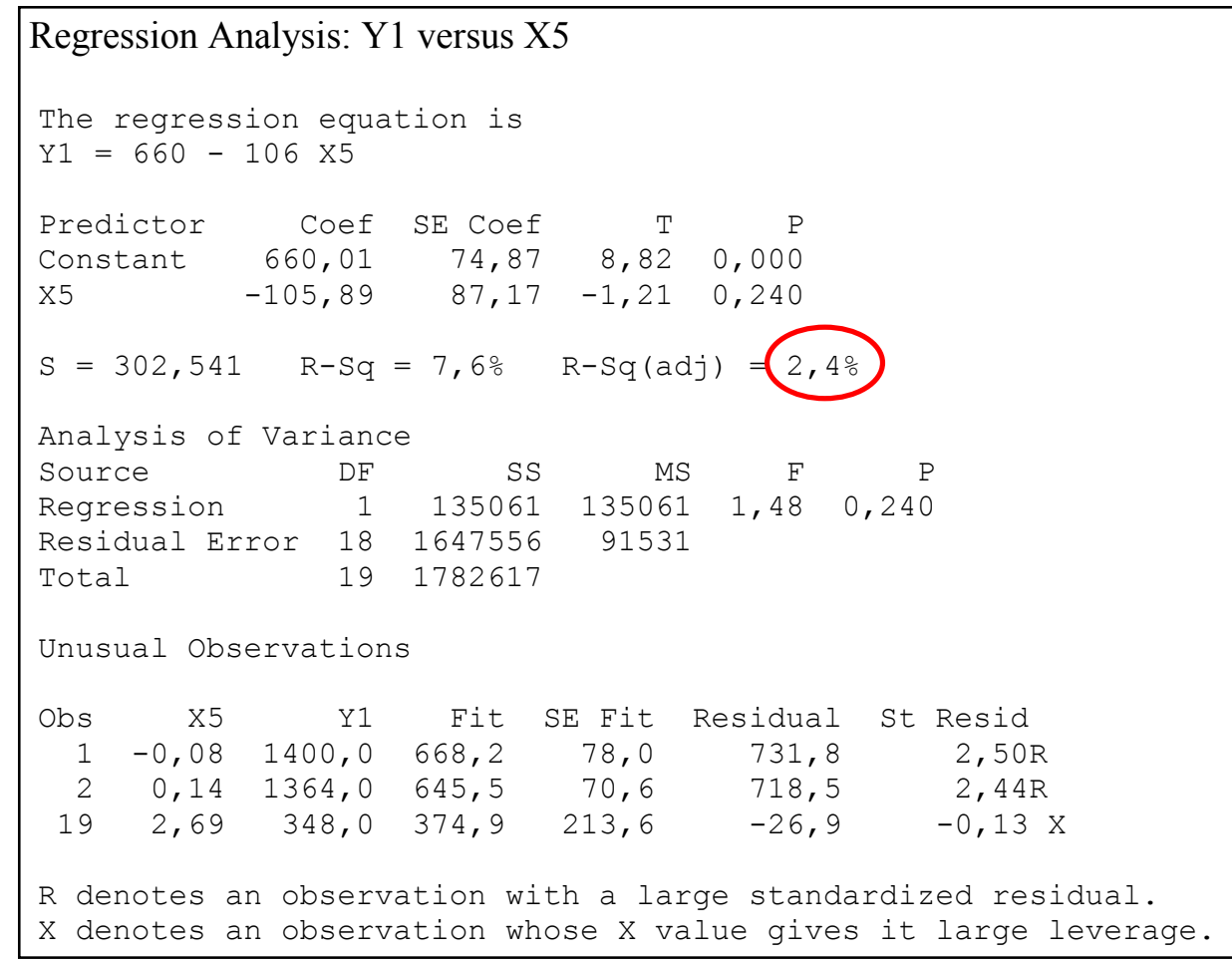

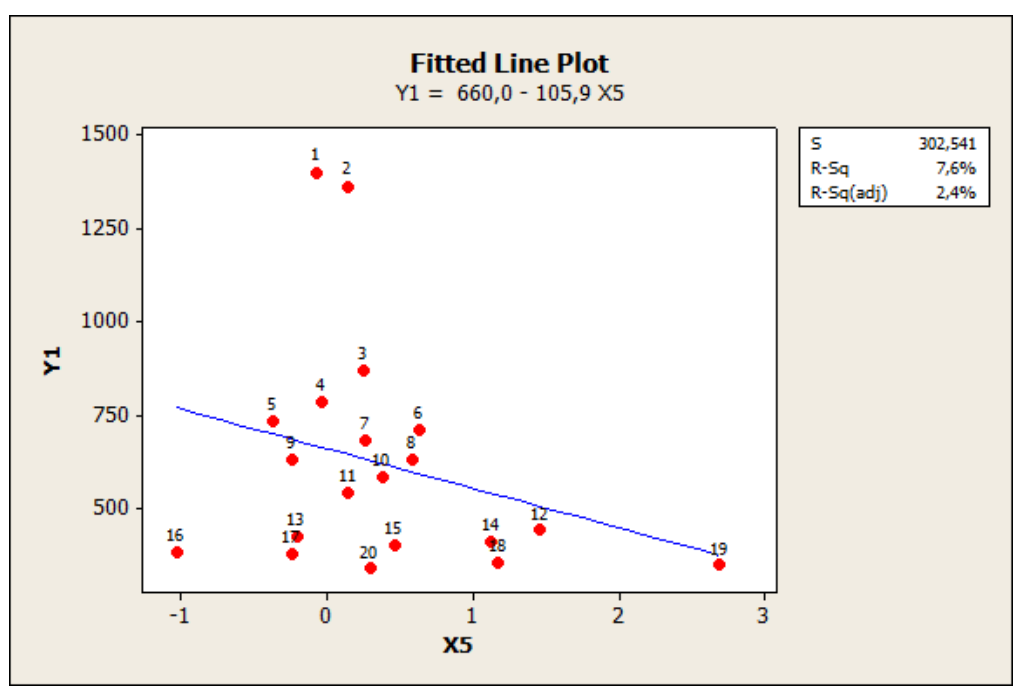

Figure 5.4 Regression Analysis 2: Y1 versus X5 
Regression equation of $\mathrm{Y} 1$ versus $\mathrm{X} 5$ is;

$$
\begin{aligned}
& \mathrm{Y} 1=660-106 \times 5 \text { and } \\
& \mathrm{R}-\mathrm{Sq} \text { (adj.) }=2,4 \%
\end{aligned}
$$

Consequently, we can say that there is no relation between Absolute Loss and Development Index for the top-20 settlements less than 50.000 inhabitants.

\section{Regression Analysis 3:}

Regression Analysis 3 is performed with Y2 (rate of loss) and X1 (settlement population). As shown in the Table 5.13, the R-Sq (adj.) is $6,5 \%$.

This ratio is insufficient to verify the relationship between $Y 2$ and $X 1$, so we can say that there is no relation between the regression equations of $Y 2$ versus $X 1$.

Table 5.13 Regression Analysis 3: Y2 versus X1

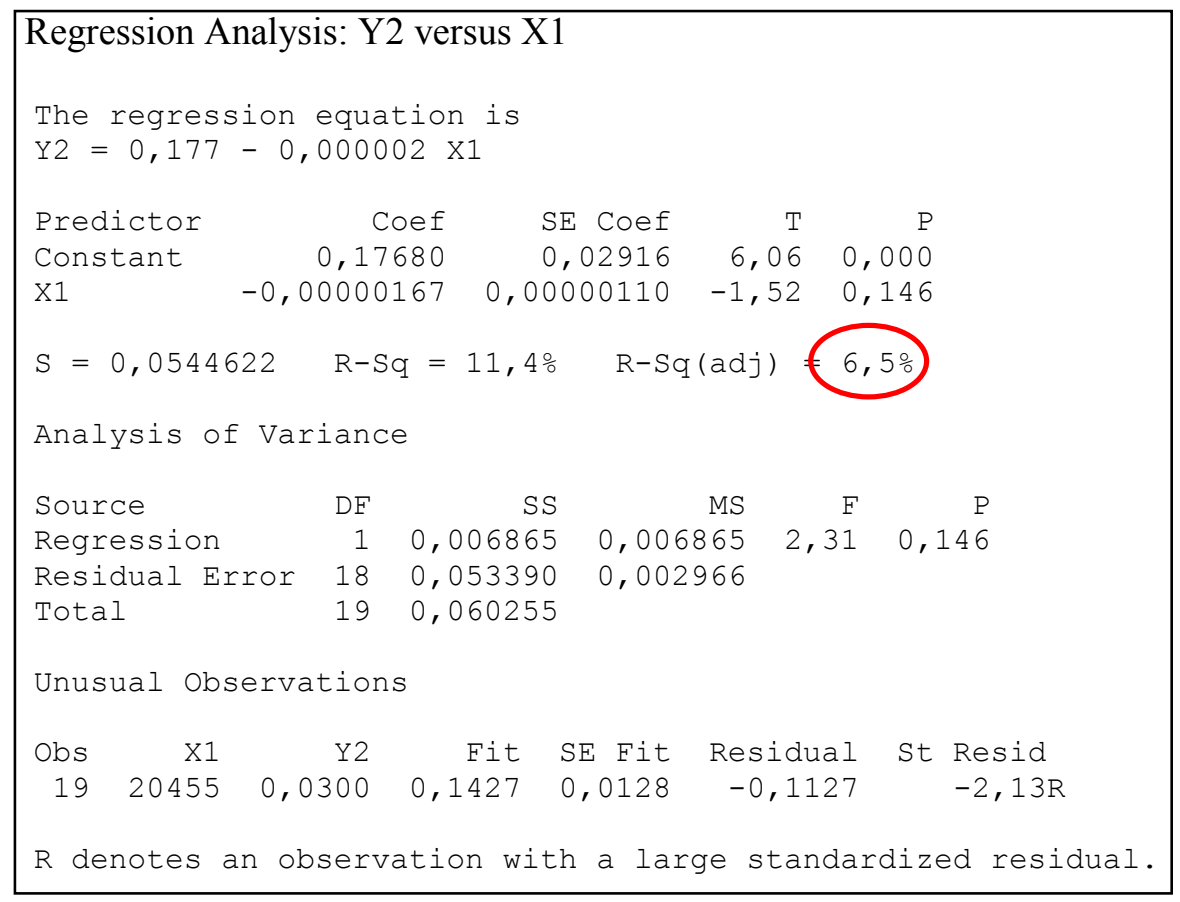




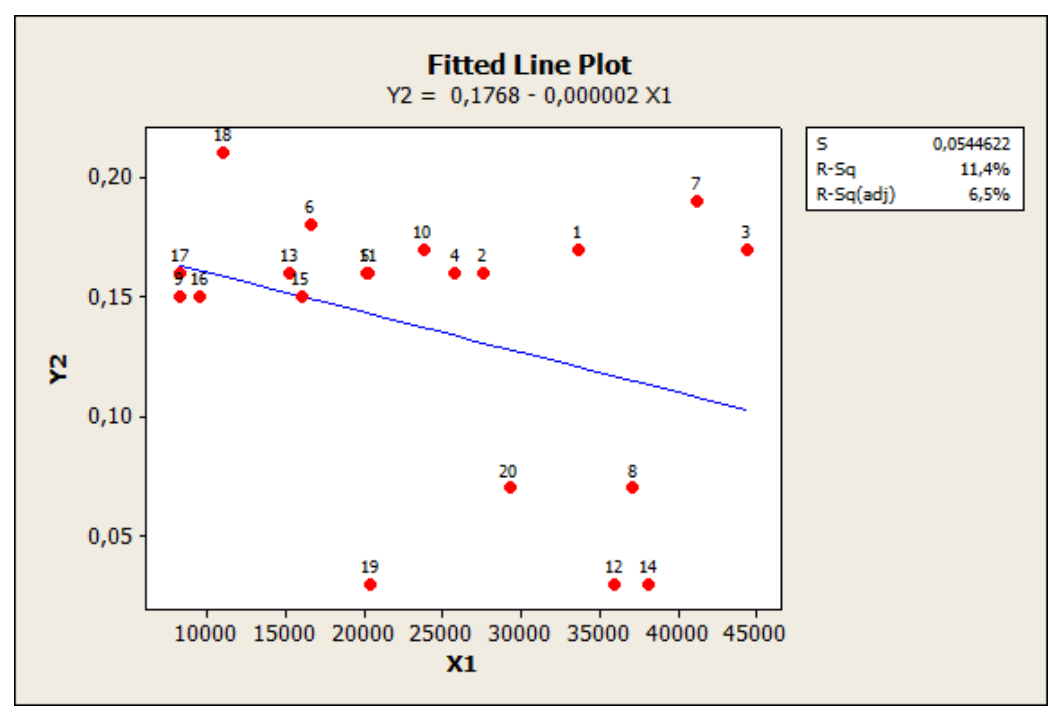

Figure 5.5 Regression Analysis 3: Y2 versus X1

Regression equation of $\mathrm{Y} 2$ versus $\mathrm{X} 1$ is;

$$
\begin{aligned}
& \mathrm{Y} 2=0,177-0,000002 \times 1 \\
& \mathrm{R}-\mathrm{Sq} \text { (adj.) }=6,5 \%
\end{aligned}
$$

Consequently, we can say that there is no relation between Rate of Loss and Settlement Population for the top-20 settlements less than 50.000 inhabitants.

\section{Regression Analysis 4:}

Regression Analysis 4 is performed with $\mathrm{Y} 2$ (rate of loss) and $\mathrm{X} 3$ (rates of agglomeration). As shown in the Table 5.14, the R-Sq (adj.) is $21,9 \%$.

Although this ratio isn't sufficient enough to verify the relationship between $Y 2$ and $X 3$, we can say that there is a weak relation between the regression equations of $\mathrm{Y} 2$ versus $\mathrm{X} 3$. 
Table 5.14 Regression Analysis 4: Y2 versus X3

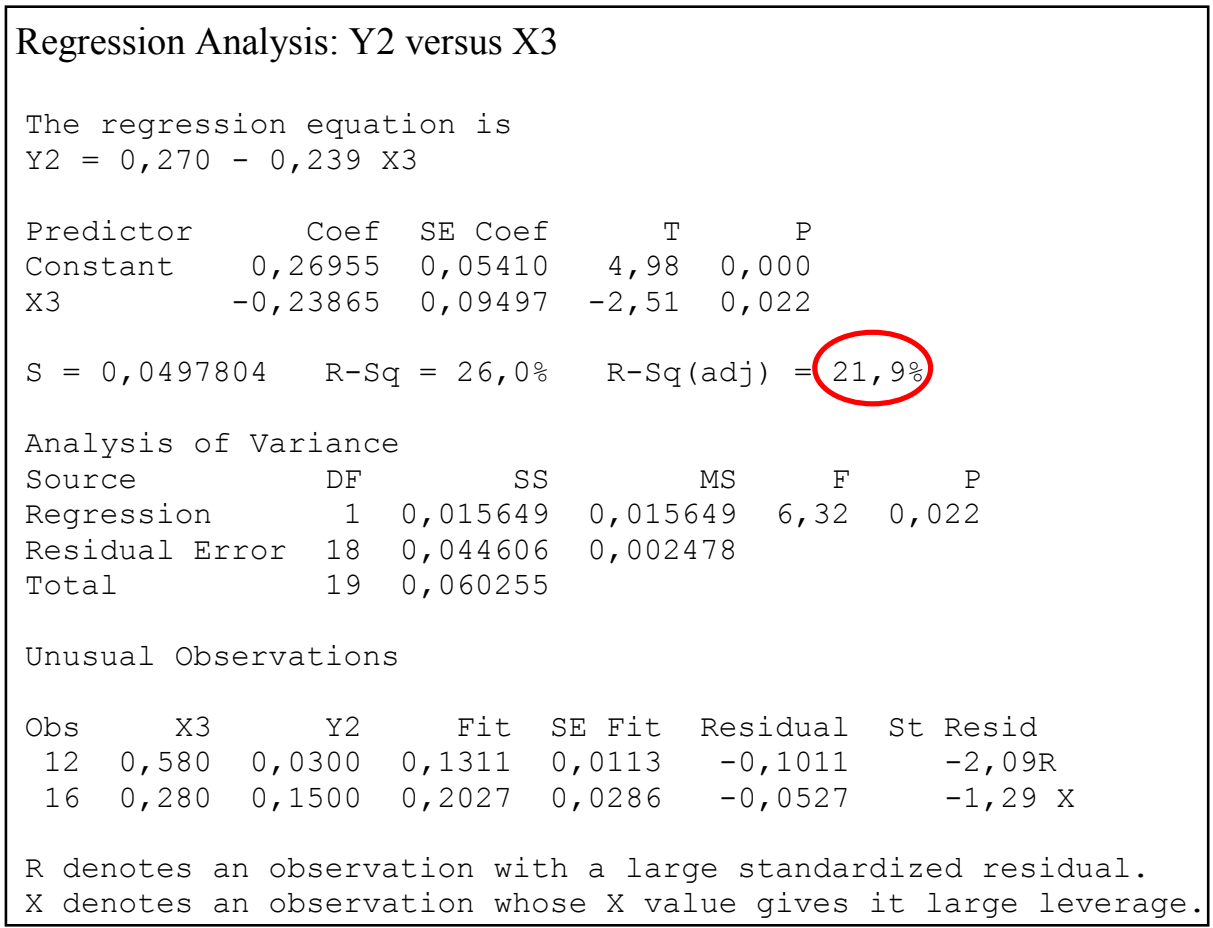

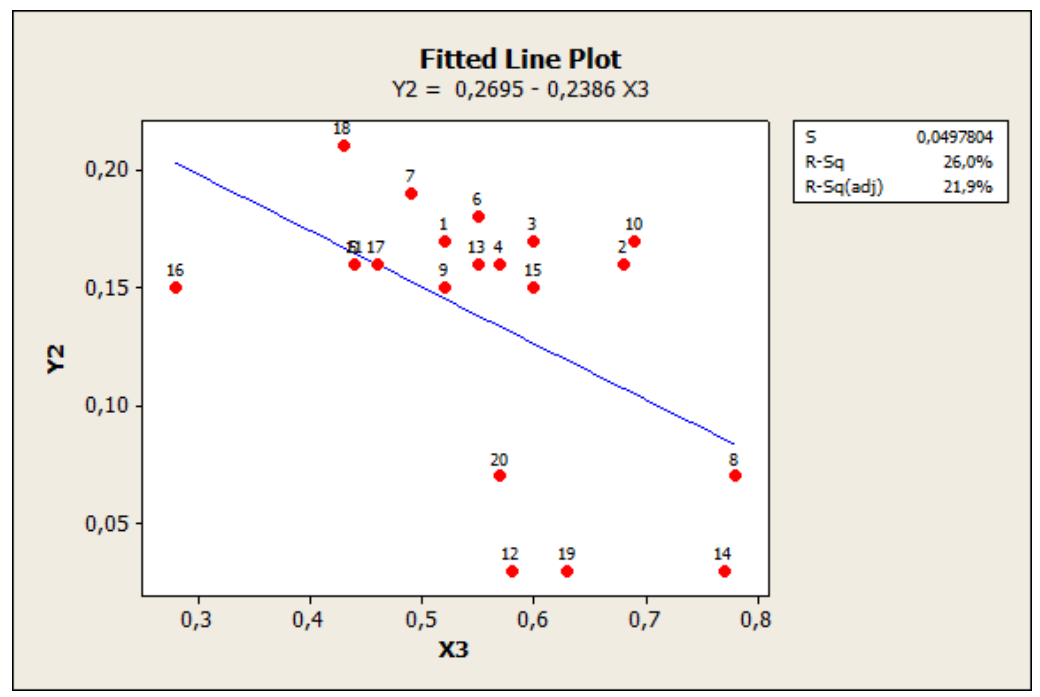

Figure 5.6 Regression Analysis 4: Y2 versus X3 
Regression equation of $\mathrm{Y} 2$ versus $\mathrm{X} 3$ is;

$$
\mathrm{Y} 2=0,270-0,239 \times 3
$$

$\mathrm{R}-\mathrm{Sq}($ adj. $)=21,9 \%$

Consequently, we can say that there is a weak relation between Rate of Loss and Rates of Agglomeration for the top-20 settlements less than 50.000 inhabitants.

\section{Regression Analysis 5:}

Regression Analysis 5 is performed with Y2 (rate of loss) and X4 (pop. /total number of buildings). As shown in the Table 5.15, the R-Sq (adj.) is 27, 4\%.

Although this ratio isn't sufficient enough to verify the relationship between $Y 2$ and $X 4$, we can say that there is a weak relation between the regression equations of $\mathrm{Y} 2$ versus $\mathrm{X} 4$.

Table 5.15 Regression Analysis 5: Y2 versus X4

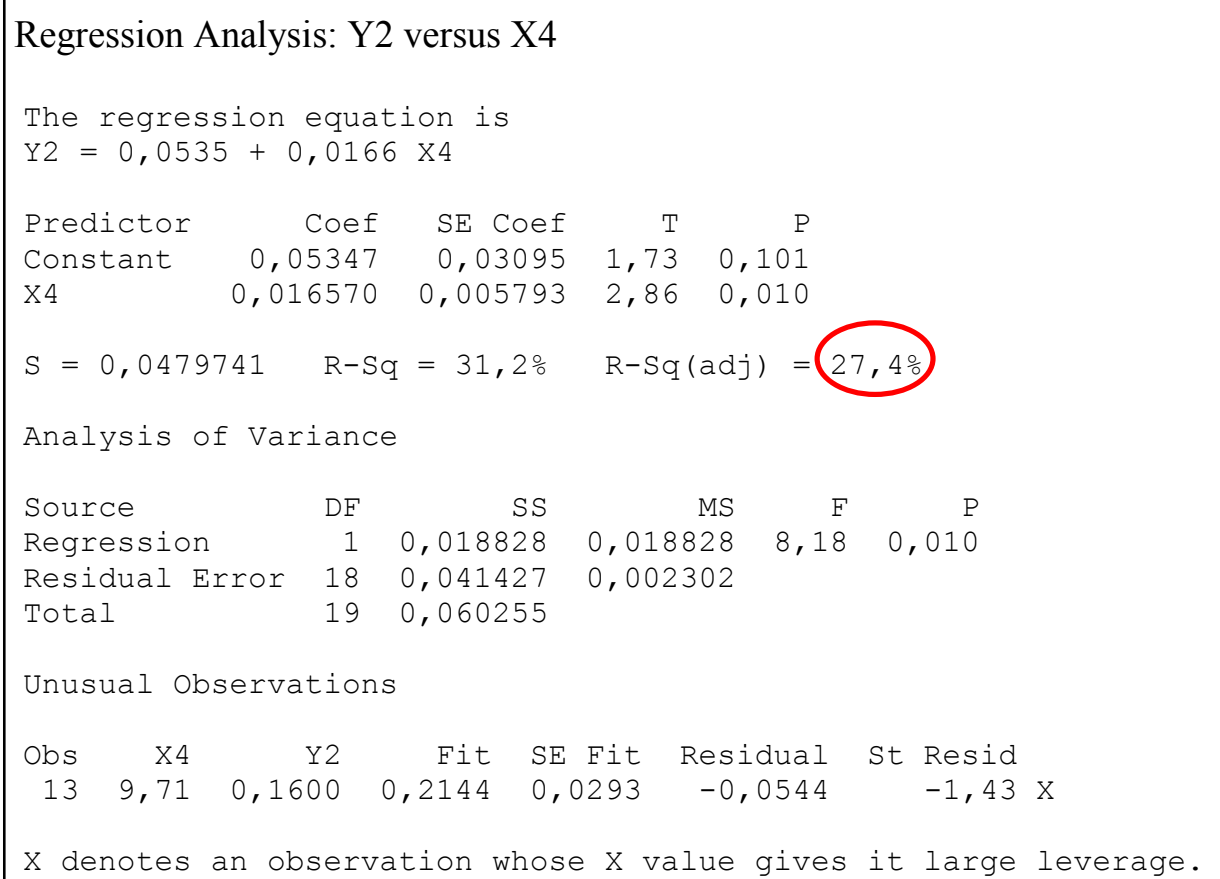




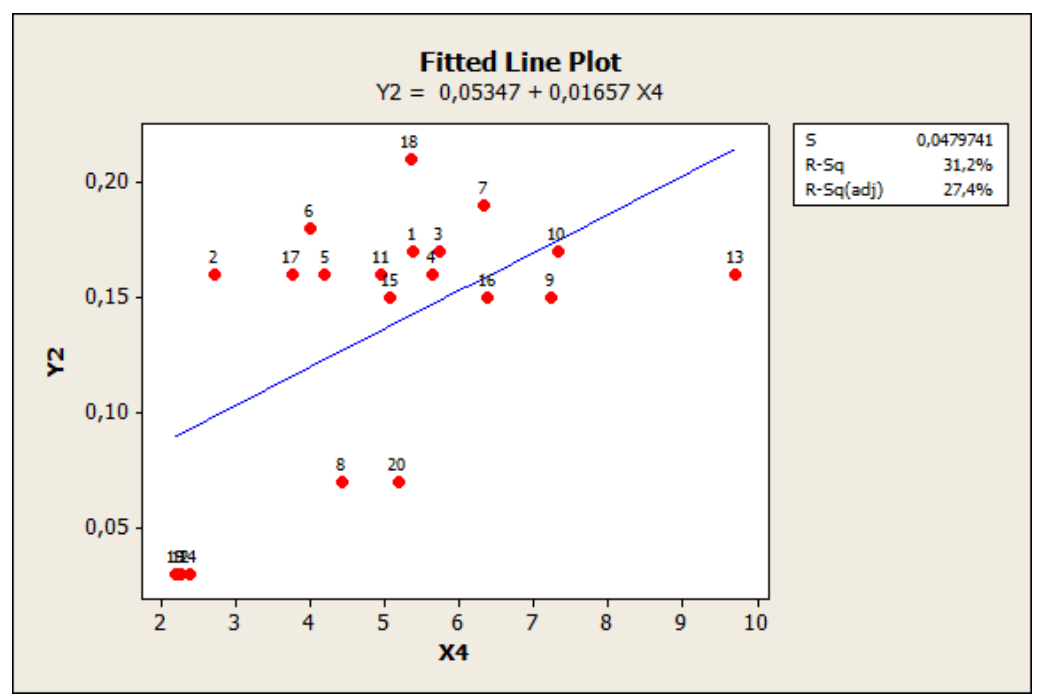

Figure 5.7 Regression Analysis 5: Y2 versus X4

Regression equation of $\mathrm{Y} 2$ versus $\mathrm{X} 4$ is;

$$
\begin{aligned}
& \mathrm{Y} 2=0,0535+0,0166 \times 4 \\
& \mathrm{R}-\mathrm{Sq} \text { (adj.) }=27,4 \%
\end{aligned}
$$

Consequently, we can say that there is a weak relation between Rate of Loss and the Ratio of Population to the Number of Buildings for the top-20 settlements less than 50.000 inhabitants.

\section{Regression Analysis 6:}

Regression Analysis 6 is performed with Y2 (rate of loss) and X5 (development index). As shown in the Table 5.16, the R-Sq (adj.) is 30, $7 \%$.

Although this ratio isn't sufficient enough to verify the relationship between $Y 2$ and $X 5,30,7 \%$ is a strong verification of relation for this type of datasets. So, we can say that there is a weak relation between the regression equations of $Y 2$ versus $X 5$. 
Table 5.16 Regression Analysis 6: Y2 versus X5

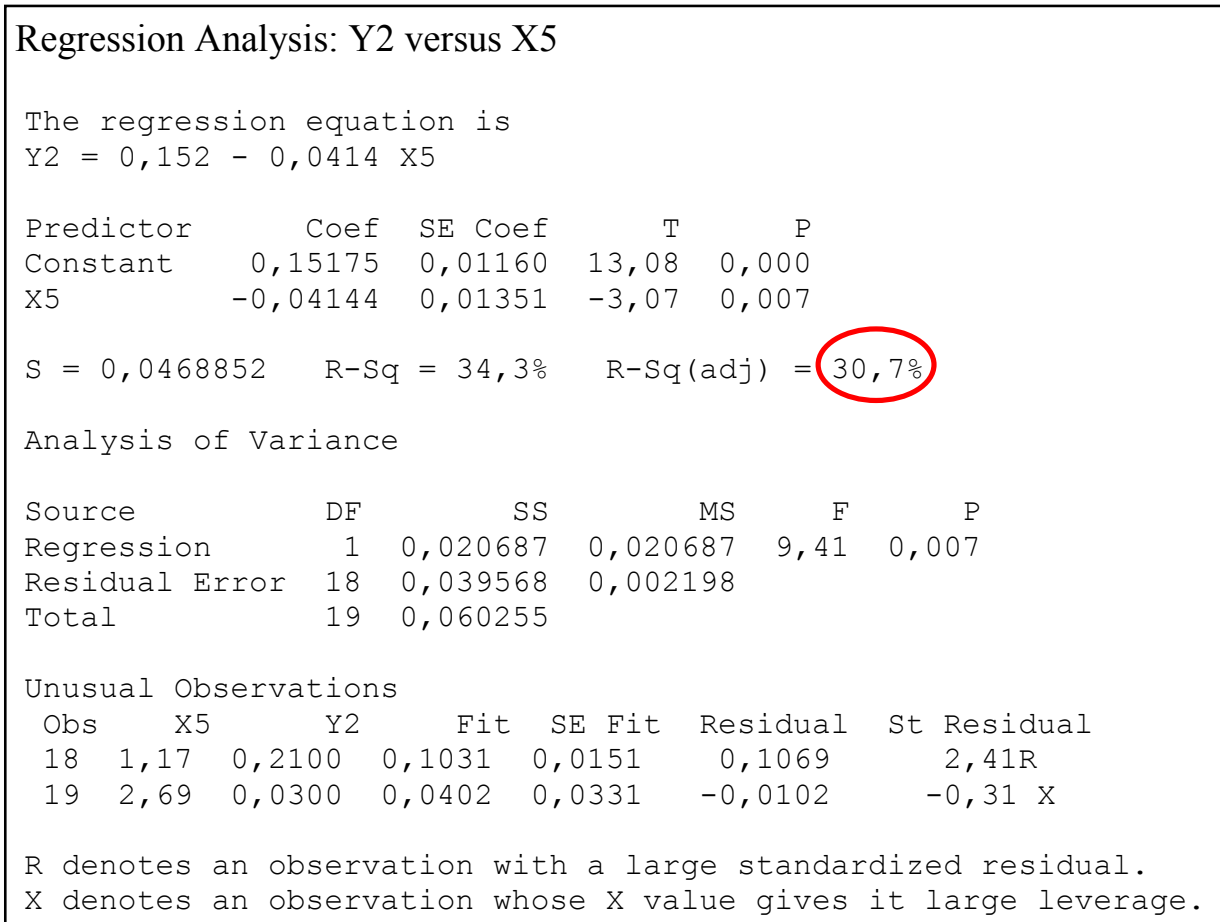

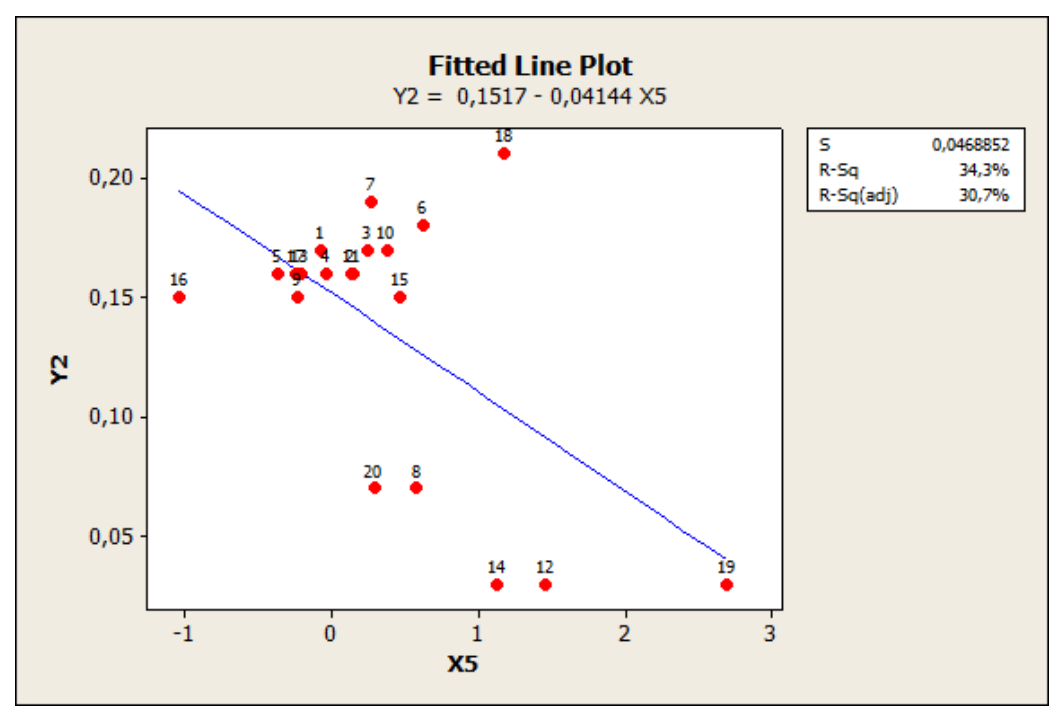

Figure 5.8 Regression Analysis 6: Y2 versus X5 
Regression equation of $\mathrm{Y} 2$ versus $\mathrm{X} 5$ is;

$$
\begin{aligned}
& \mathrm{Y} 2=0,152-0,0414 \times 5 \\
& \mathrm{R}-\mathrm{Sq} \text { (adj.) }=30,7 \%
\end{aligned}
$$

Consequently, we can say that there is a weak relation between Rate of Loss and Development Index for the top-20 settlements less than 50.000 inhabitants.

Six regression analyses are performed for top-20 settlements in the first category that considers settlements having populations up to 50.000 . The Results of these analyses show that;

Y1 (absolute loss) has no relation with independent variables and,

Y2 (rate of loss) has weak relations with X3 (Rates of Agglomeration)

X4 (Pop./Total Number of Buildings)

X5 (Development Index)

\subsubsection{Analyses by Means of Regression Methods for Category II (50.000-490.000)}

Four regression analyses are performed according to the results of best subsets regression analyses for Category II that considers settlements having population between $50.000-490.000$ inhabitants.

These are; Regression Analysis: $\mathrm{Y} 1$ versus $\mathrm{X} 2, \mathrm{Y} 1$ versus $\mathrm{X} 4, \mathrm{Y} 2$ versus $\mathrm{X} 1$ and Y2 versus $X 4$.

\section{Regression Analysis 7:}

Regression Analysis 7 is performed with $\mathrm{Y} 1$ (absolute loss) and $\mathrm{X} 2$ (population growth rate). As shown in the Table 5.17, the R-Sq (adj.) is 2, $2 \%$.

This ratio is insufficient to verify the relationship between $Y 1$ and $X 2$, so we can say that there is no relation between the regression equations of $Y 1$ versus $X 2$. 
Table 5.17 Regression Analysis 7: Y1 versus X2

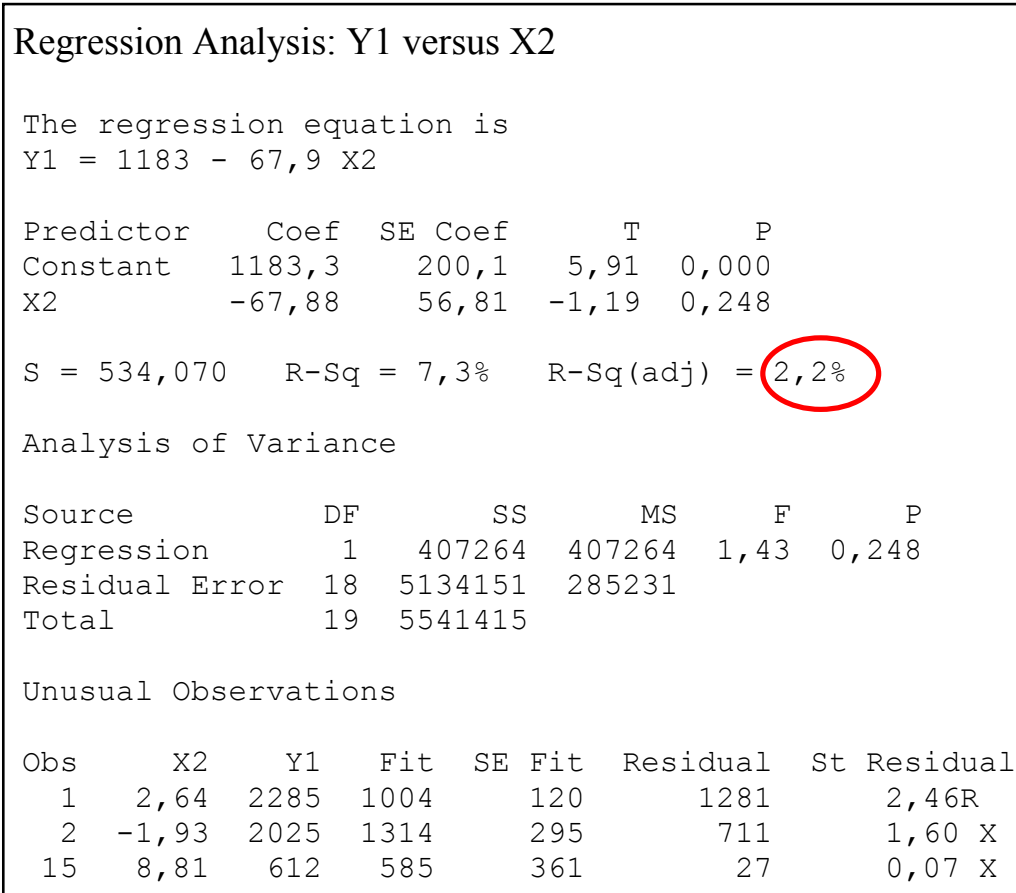

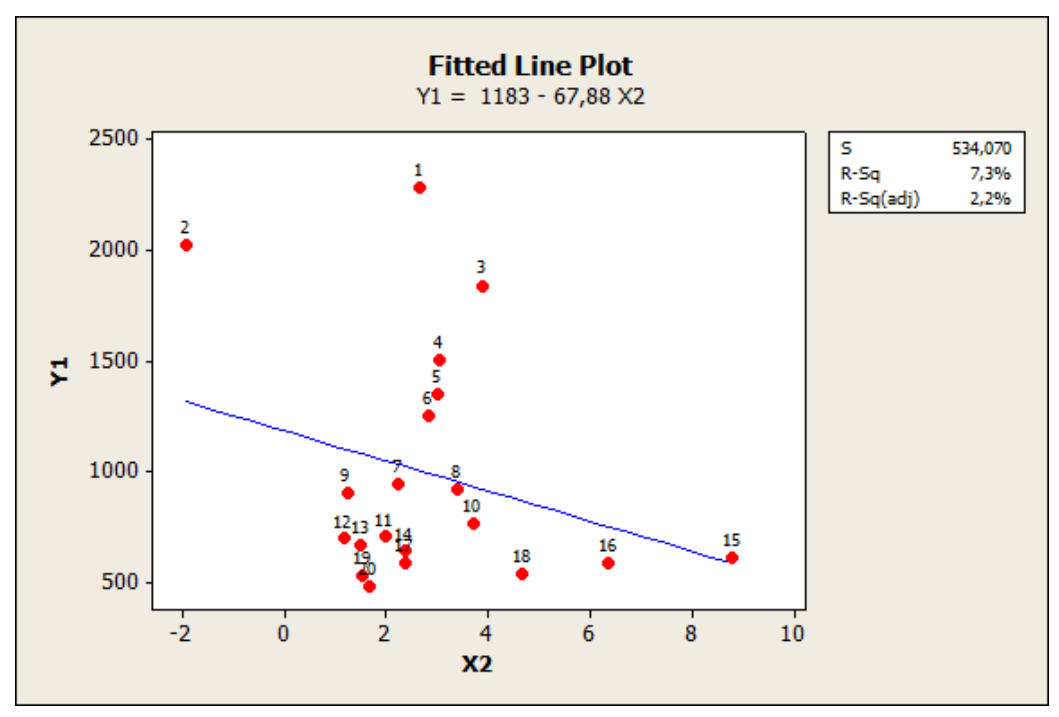

Figure 5.9 Regression Analysis 7: Y1 versus X2 
Regression equation of $\mathrm{Y} 1$ versus $\mathrm{X} 2$ is;

$$
\begin{aligned}
& \mathrm{Y} 1=1183-67,9 \times 2 \\
& \mathrm{R}-\mathrm{Sq} \text { (adj.) }=2,2 \%
\end{aligned}
$$

Consequently, we can say that there is no relation between Absolute Loss and Population Growth Rate for the top-20 settlements between 50.000-490.000 inhabitants.

\section{Regression Analysis 8:}

Regression Analysis 8 is performed with $Y 1$ (absolute loss) and $X 4$ (population/total number of buildings). As shown in the Table 5.18, the R-Sq (adj.) is $18,0 \%$.

Although this ratio isn't sufficient enough to verify the relationship between $Y 1$ and $X 4$, we can say that there is a weak relation between the regression equations of $\mathrm{Y} 1$ and $\mathrm{X} 4$.

Table 5.18 Regression Analysis 8: Y1 versus X4

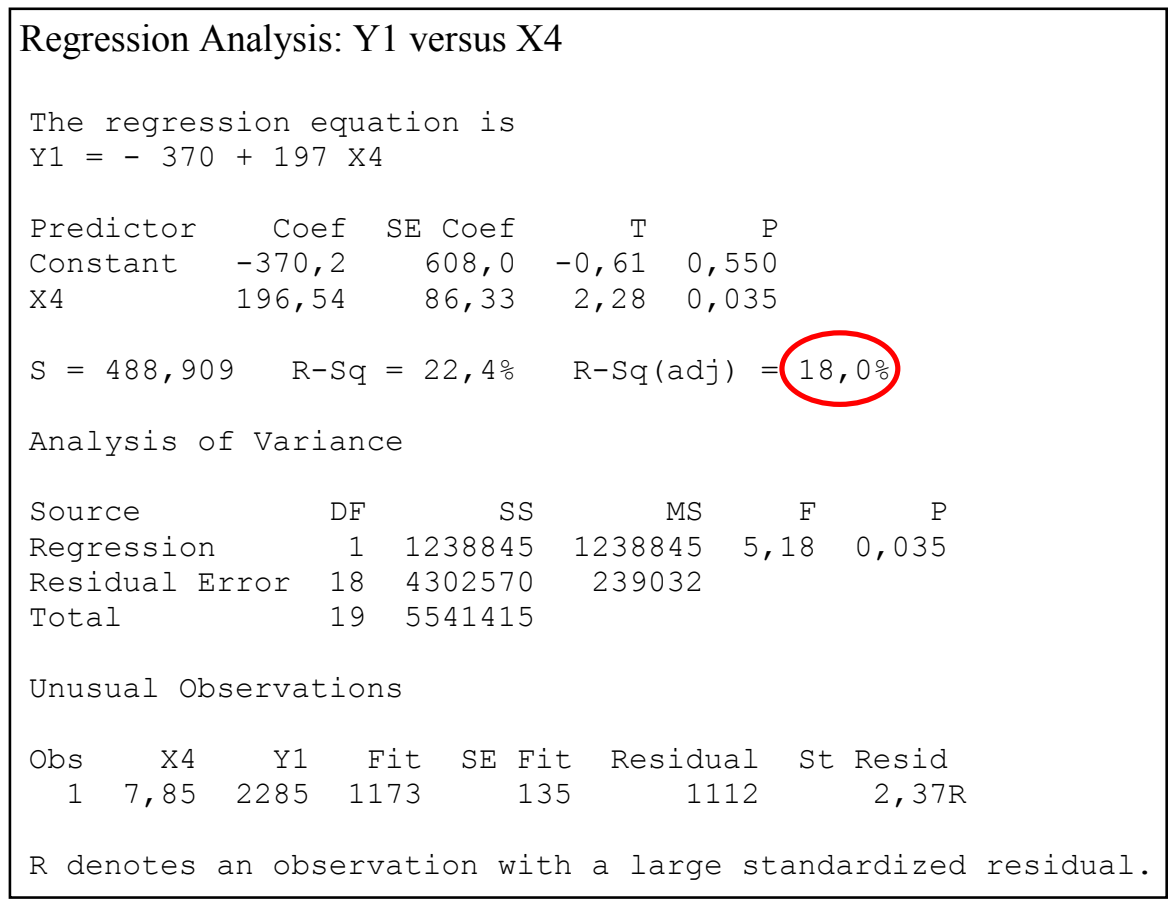




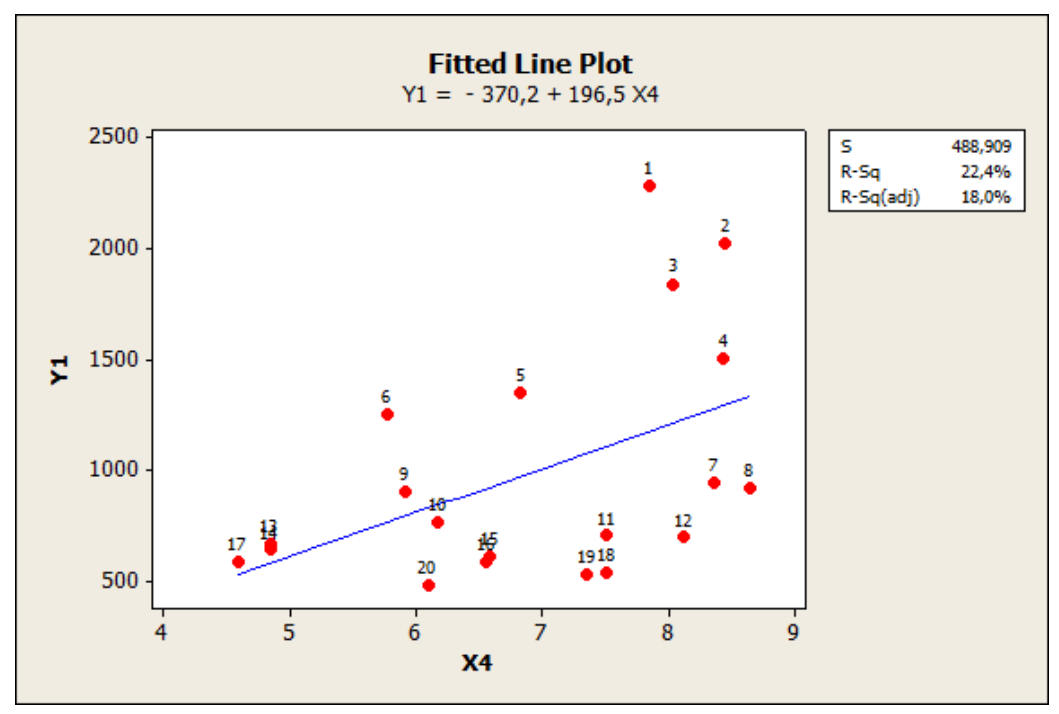

Figure 5.10 Regression Analysis 8: Y1 versus X4

Regression equation of $\mathrm{Y} 1$ versus $\mathrm{X} 4$ is;

$$
\begin{aligned}
& Y 1=-370+197 X 4 \\
& R-S q \text { (adj.) }=18,0 \%
\end{aligned}
$$

Consequently, we can say that there is a weak relation between Absolute Loss and the ratio of population to the number of buildings for the top-20 settlements between $50.000-490.000$ inhabitants.

\section{Regression Analysis 9:}

Regression Analysis 9 is performed with Y2 (rate of loss) and X1 (settlement population). As shown in the Table 5.19, the R-Sq (adj.) is $21,5 \%$.

Although this ratio isn't sufficient enough to verify the relationship, we can say that there is a weak relation between the regression equations of $\mathrm{Y} 2$ and $\mathrm{X} 1$. 
Table 5.19 Regression Analysis 9: Y2 versus X1

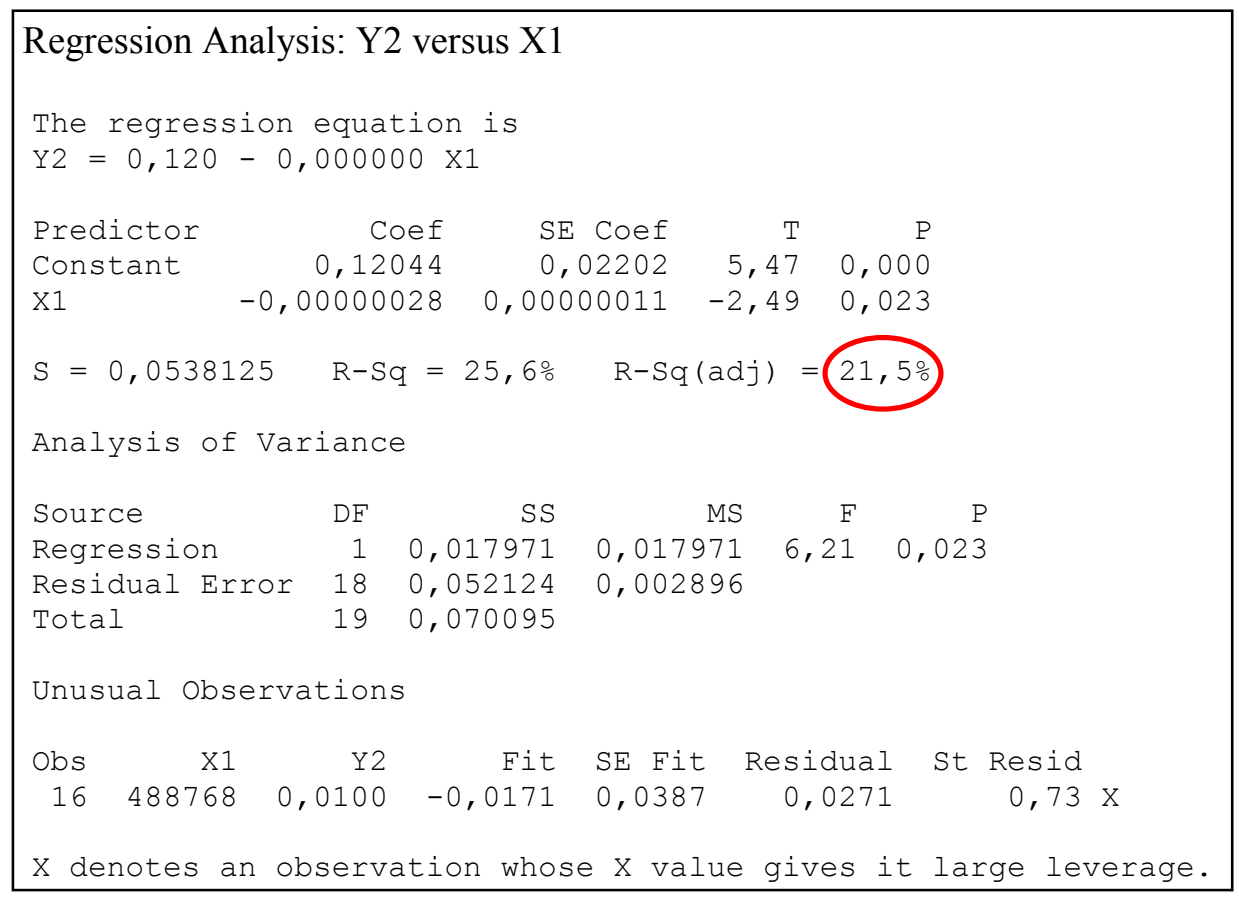

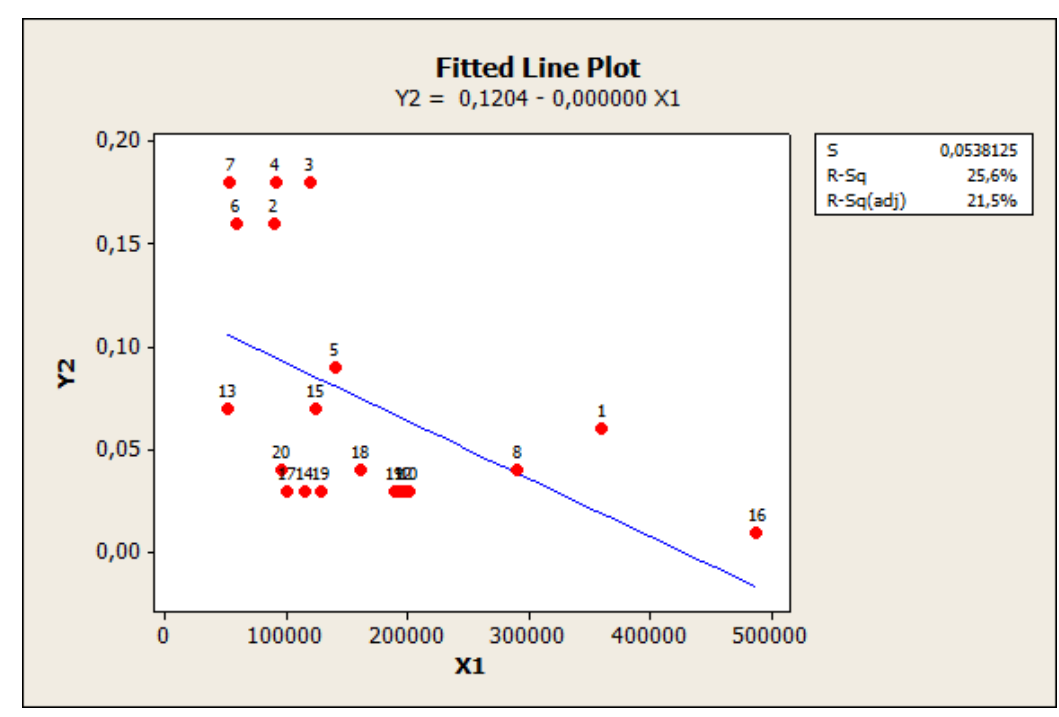

Figure 5.11 Regression Analysis 9: Y2 versus X1 
Regression equation of $\mathrm{Y} 2$ versus $\mathrm{X} 1$ is;

$$
\begin{aligned}
& \mathrm{Y} 2=0,120-0,000000 \times 1 \\
& \mathrm{R}-\mathrm{Sq} \text { (adj.) }=21,5 \%
\end{aligned}
$$

Consequently, we can say that there is a weak relation between Rate of Loss and Settlement Population for the top-20 settlements between 50.000-490.000 inhabitants.

\section{Regression Analysis 10:}

Regression Analysis 10 is performed with Y2 (rate of loss) and X4 (population/total number of buildings).

As shown in the Table 5.20 , the $\mathrm{R}-\mathrm{Sq}$ (adj.) is $11,7 \%$. This ratio is insufficient to verify the relationship, so we can say that there is no relation between the regression equations of $\mathrm{Y} 2$ versus $\mathrm{X} 4$.

Table 5.20 Regression Analysis 10: Y2 versus X4

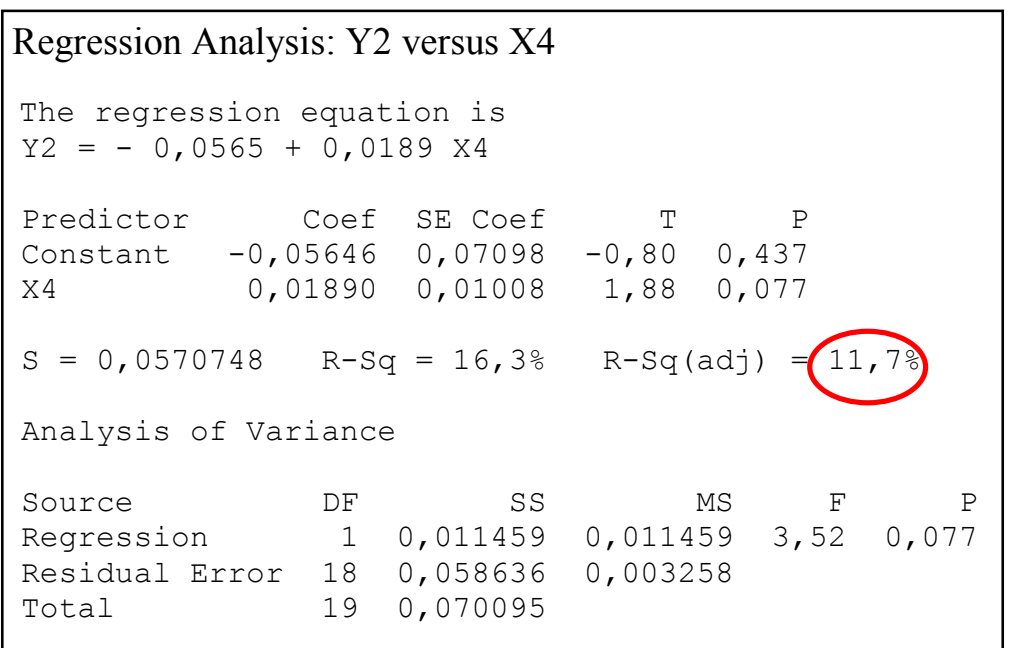




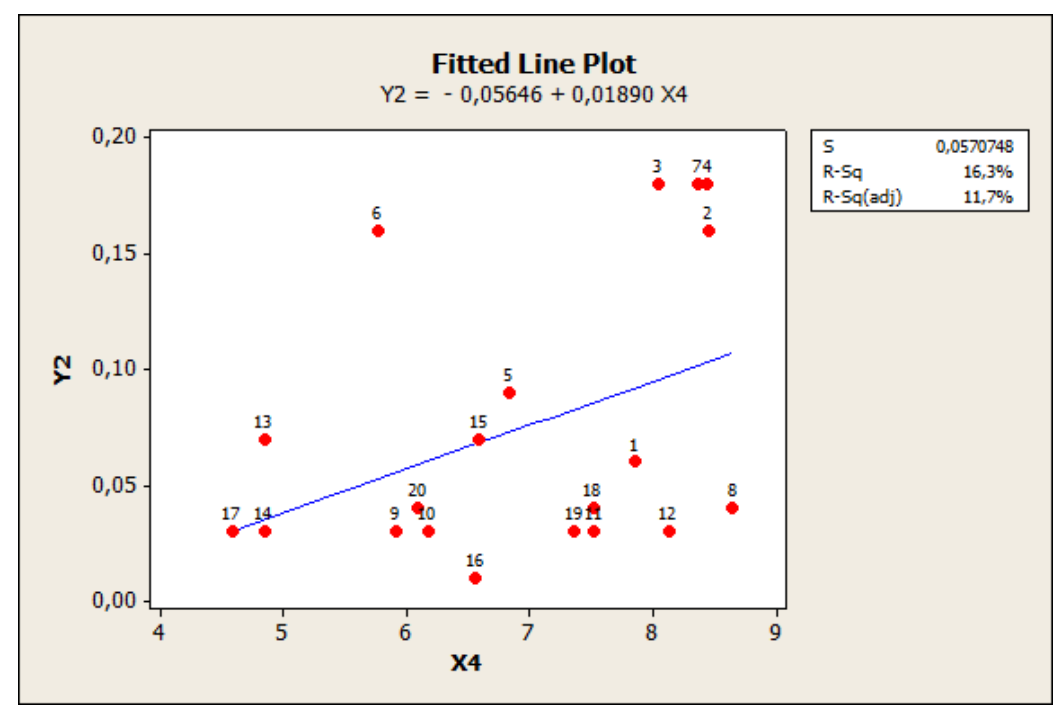

Figure 5.12 Regression Analysis 10: Y2 versus X4

Regression equation of $\mathrm{Y} 2$ versus $\mathrm{X} 4$ is;

$$
\begin{aligned}
& \mathrm{Y} 2=-0,0565+0,0189 \times 4 \\
& \mathrm{R}-\mathrm{Sq} \text { (adj.) }=11,7 \%
\end{aligned}
$$

Consequently, we can say that there is no relation between Rate of Loss and the Ratio of Population to the Number of Buildings for the top-20 settlements between $50.000-490.000$ inhabitants.

Four regression analyses are performed for top-20 settlements in the second category that considers settlements having population between 50.000-490.000 inhabitants.

The Results of these analyses show that;

Y1 (absolute loss) has no relation with $\mathrm{X} 2$ (population growth rate) and weak relations with $\mathrm{X} 4$ (Population/Total Number of Buildings).

Y2 (rate of loss) has weak relations with $X 1$ (settlement population) and no relation with X4 (Population/Total Number of Buildings).

\subsubsection{Analyses by Means of Regression Methods for Category III (Metropolitan Cities)}

Five regression analyses are performed according to the results of best subsets regression analyses for Category III that considers metropolitan cities.

These are; Regression Analysis: $Y 1$ versus $X 1, Y 1$ versus $X 3, Y 1$ versus $X 4, Y 2$ versus $\mathrm{X} 3$ and $\mathrm{Y} 2$ versus $\mathrm{X} 4$. 


\section{Regression Analysis 11:}

Regression Analysis 11 is performed with $\mathrm{Y} 1$ (absolute loss) and $\mathrm{X} 1$ (settlement population). As shown in the Table 5.21, the R-Sq (adj.) is $91,1 \%$.

This ratio is sufficient to verify the relationship and we can say that there is a strong relation between the regression equations of $\mathrm{Y} 1$ versus $\mathrm{X} 1$.

Table 5.21 Regression Analysis 11: Y1 versus X1

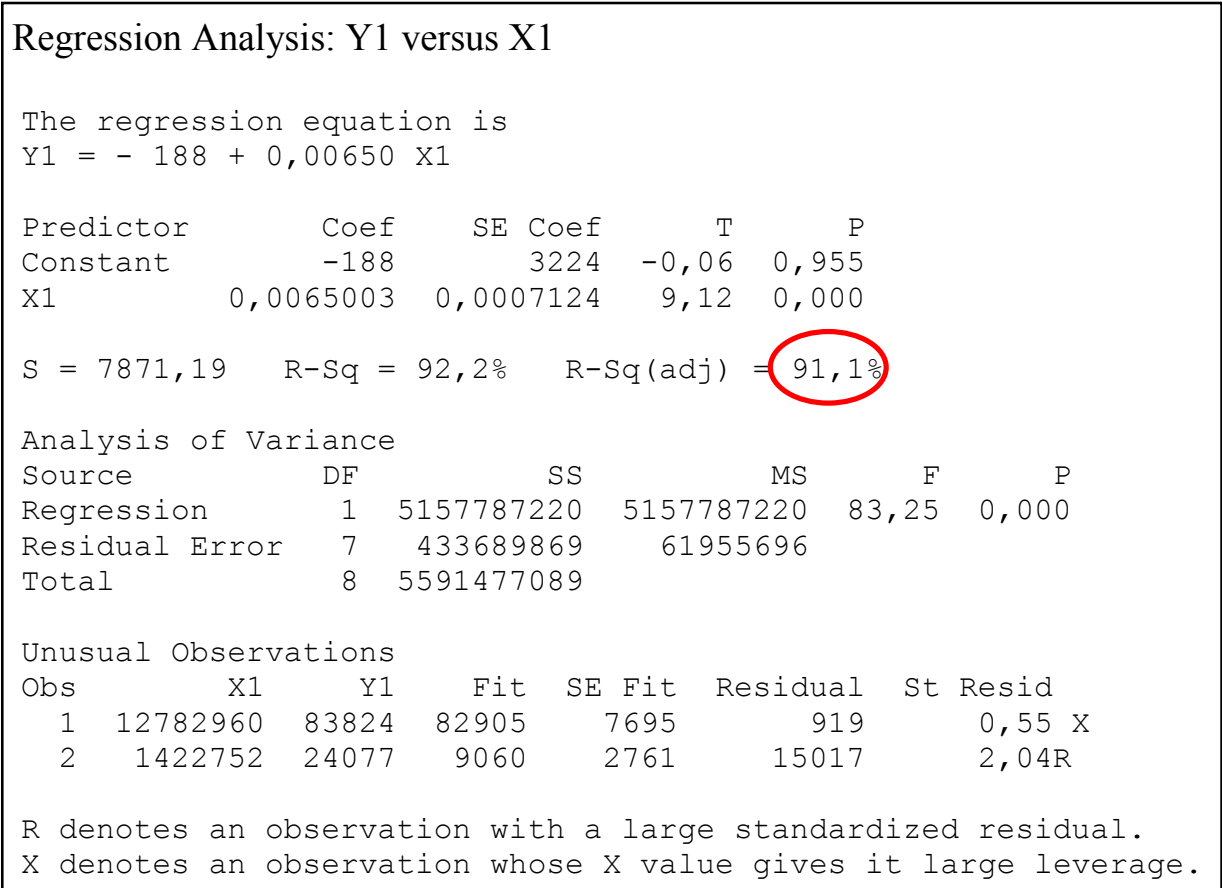

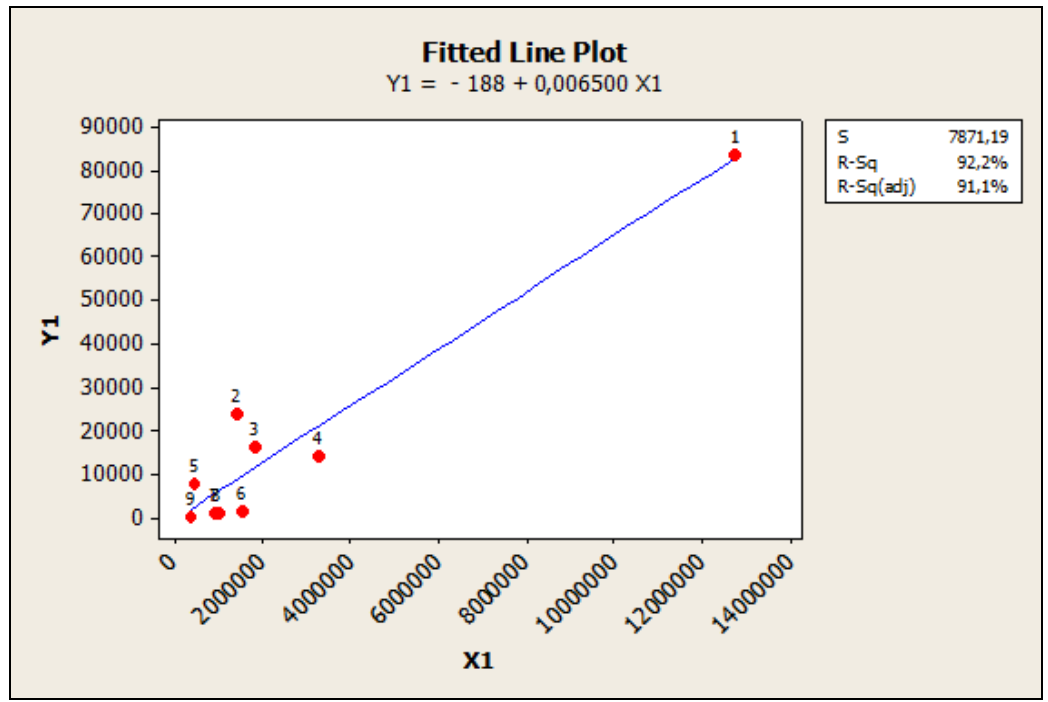

Figure 5.13 Regression Analysis 11: $\mathrm{Y} 1$ versus $\mathrm{X} 1$ 
Regression equation of $\mathrm{Y} 1$ versus $\mathrm{X} 1$ is;

$$
\begin{aligned}
& \mathrm{Y} 1=-188+0,00650 \times 1 \\
& \mathrm{R}-\mathrm{Sq} \text { (adj.) }=91,1 \%
\end{aligned}
$$

Consequently, we can say that there is a strong relation between Absolute Loss and Settlement Population for the metropolitan provinces.

\section{Regression Analysis 12:}

Regression Analysis 12 is performed with $\mathrm{Y} 1$ (absolute loss) and $\mathrm{X} 3$ (rates of agglomeration). As shown in the Table 5.22, the R-Sq (adj.) is 5, 0\%.

This ratio is insufficient to verify the relationship and we can say that there is no relation between the regression equations of $Y 1$ versus $X 3$.

Table 5.22 Regression Analysis 12: Y1 versus X3

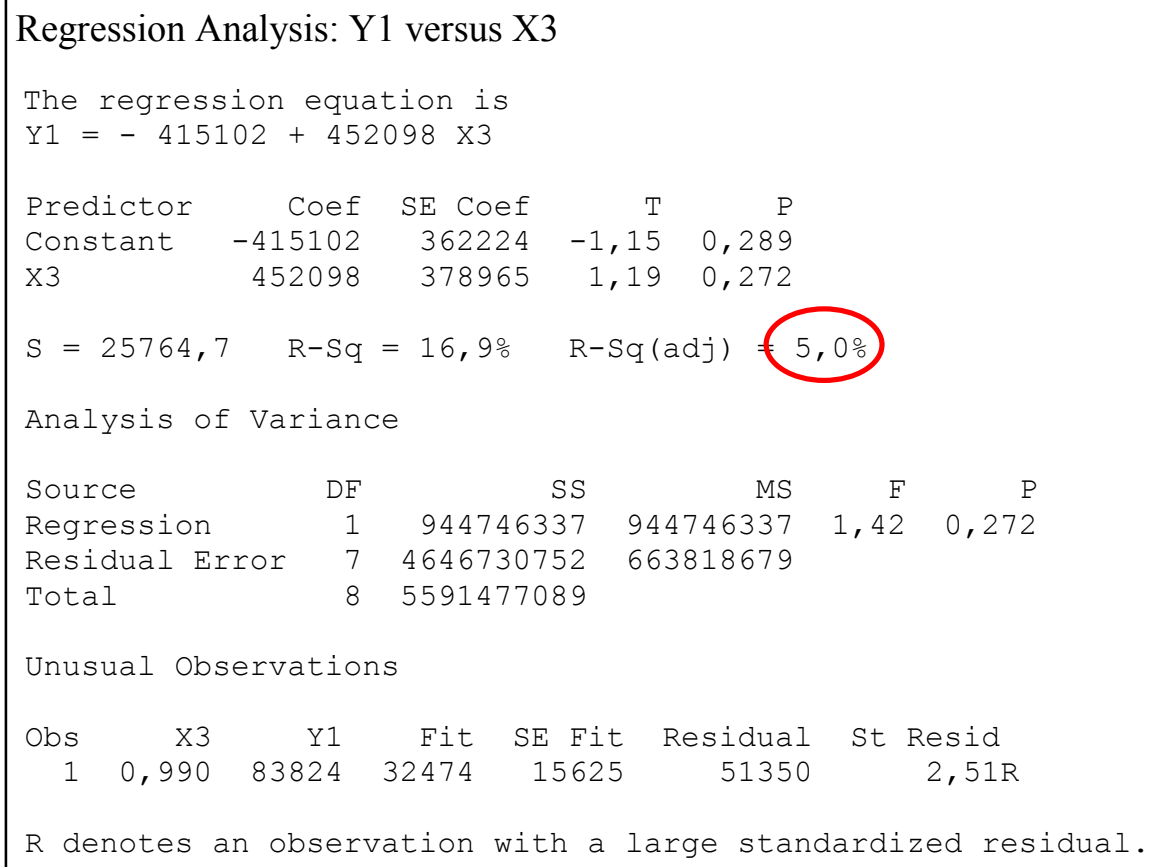




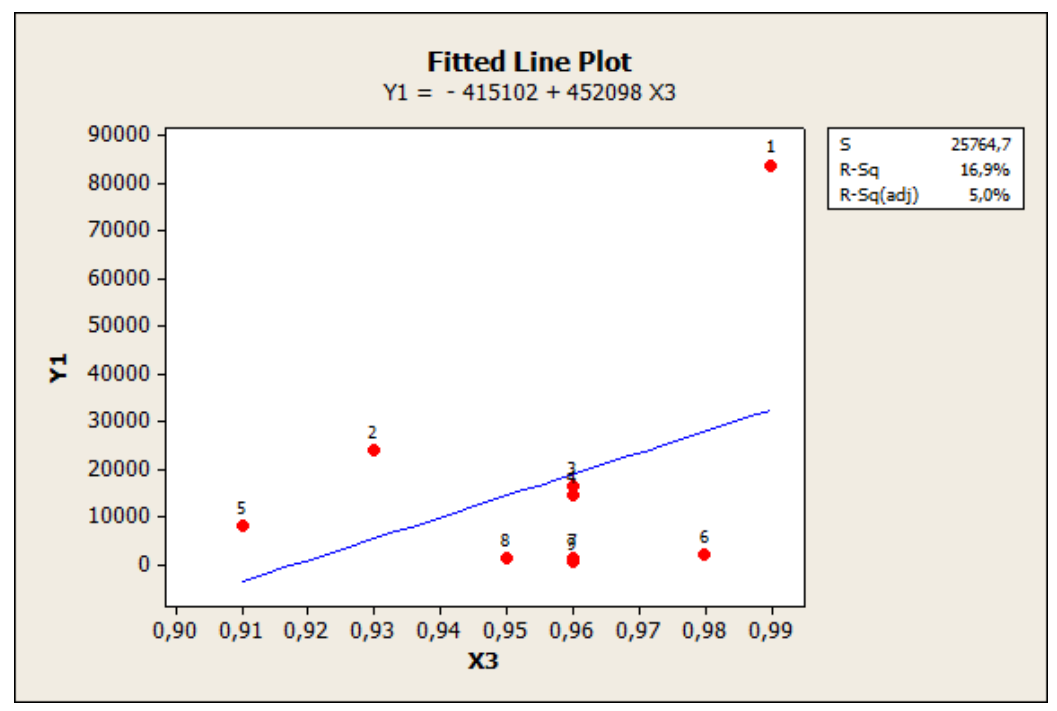

Figure 5.14 Regression Analysis 12: Y1 versus X3

Regression equation of $\mathrm{Y} 1$ versus $\mathrm{X} 3$ is;

$Y 1=-415102+452098 \times 3$

R-Sq (adj.) $=5,0 \%$

Consequently, we can say that there is no relation between Absolute Loss and Rates of Agglomeration for the metropolitan provinces.

\section{Regression Analysis 13:}

Regression Analysis 13 is performed with $\mathrm{Y} 1$ (absolute loss) and $\mathrm{X} 4$ (population/total number of buildings). As shown in the Table 5.23, the R-Sq (adj.) is $49,0 \%$.

Although this ratio isn't sufficient enough to verify the relationship, we can say that there is a weak relation between the regression equations of $Y 1$ versus X4. 
Table 5.23 Regression Analysis 13: Y1 versus X4
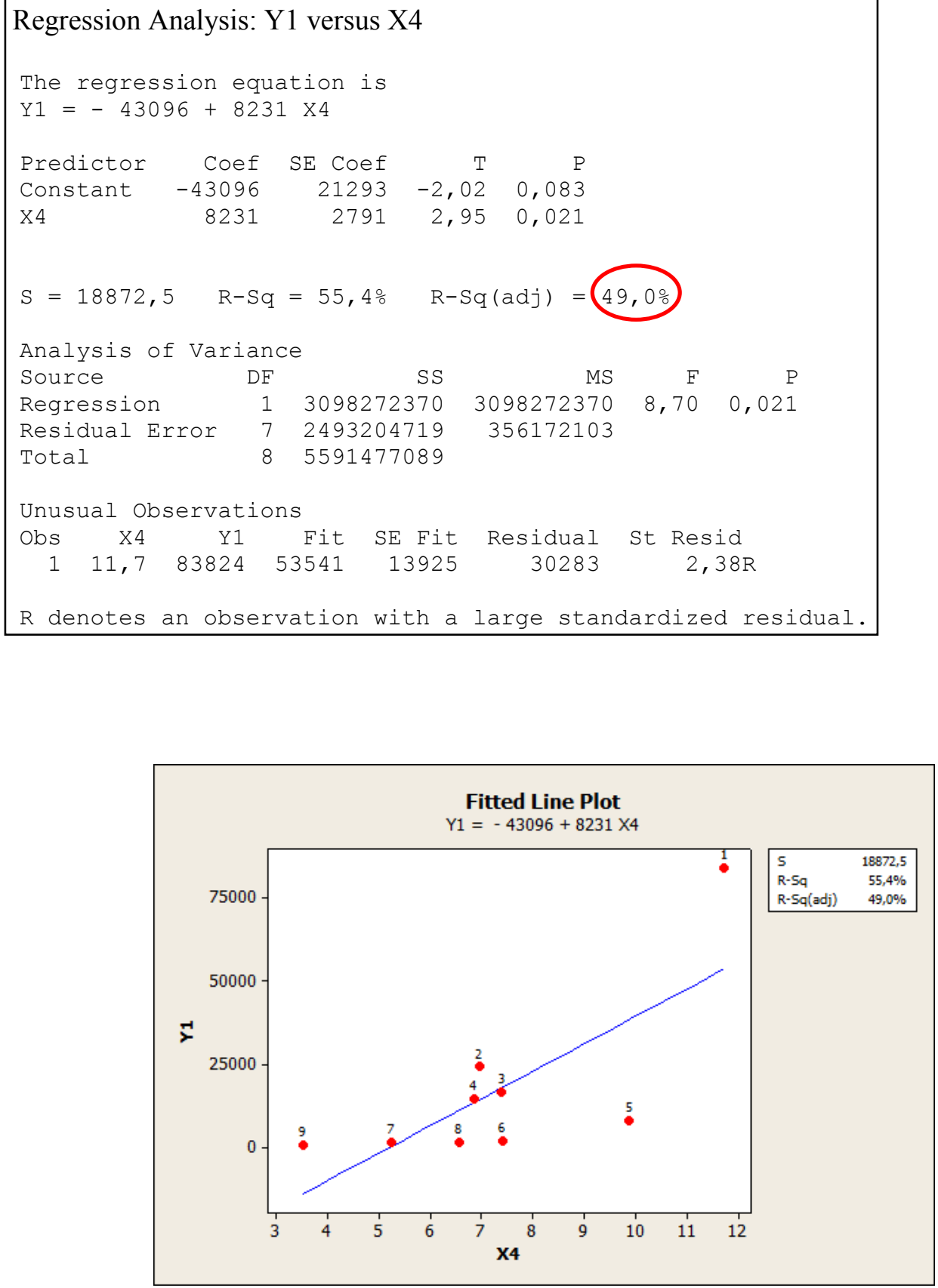

Figure 5.15 Regression Analysis 13: Y1 versus X4

Regression equation of $\mathrm{Y} 1$ versus $\mathrm{X} 4$ is;

$$
\begin{aligned}
& \mathrm{Y} 1=-43096+8231 \times 4 \\
& \mathrm{R}-\mathrm{Sq} \text { (adj.) }=49,0 \%
\end{aligned}
$$

Consequently, there is a weak relation between Absolute Loss and the Ratio of Population to the Number of Buildings for the metropolitan provinces. 


\section{Regression Analysis 14:}

Regression Analysis 14 is performed with $\mathrm{Y} 2$ (rate of loss) and $\mathrm{X} 3$ (rates of agglomeration). As shown in the Table 5.24, the R-Sq (adj.) is $24,8 \%$.

Although this ratio isn't sufficient enough to verify the relationship, we can say that there is a weak relation between the regression equations of $Y 2$ versus X3.

Table 5.24 Regression Analysis 14: Y2 versus X3

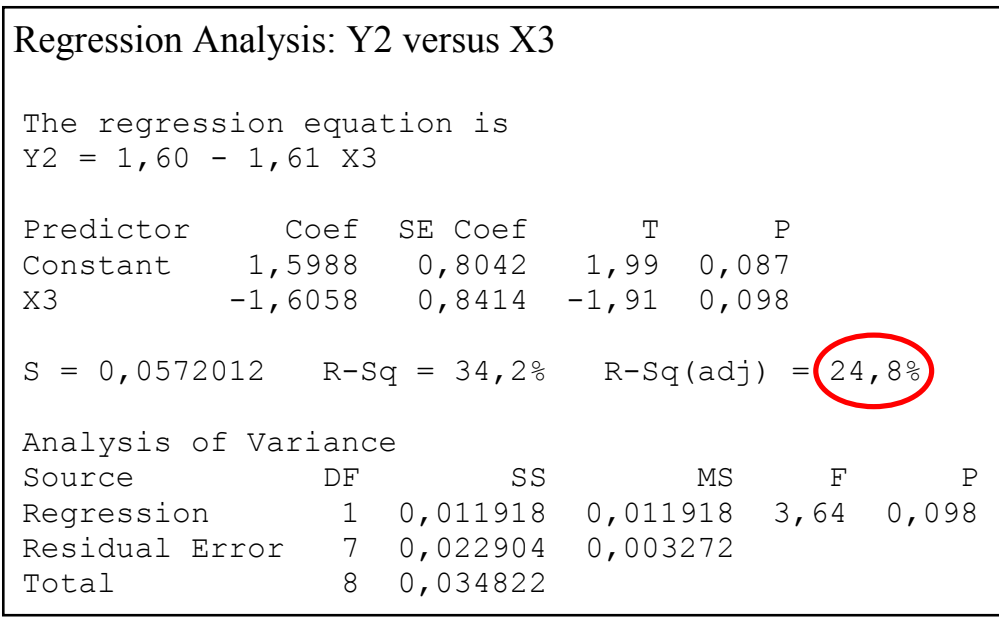

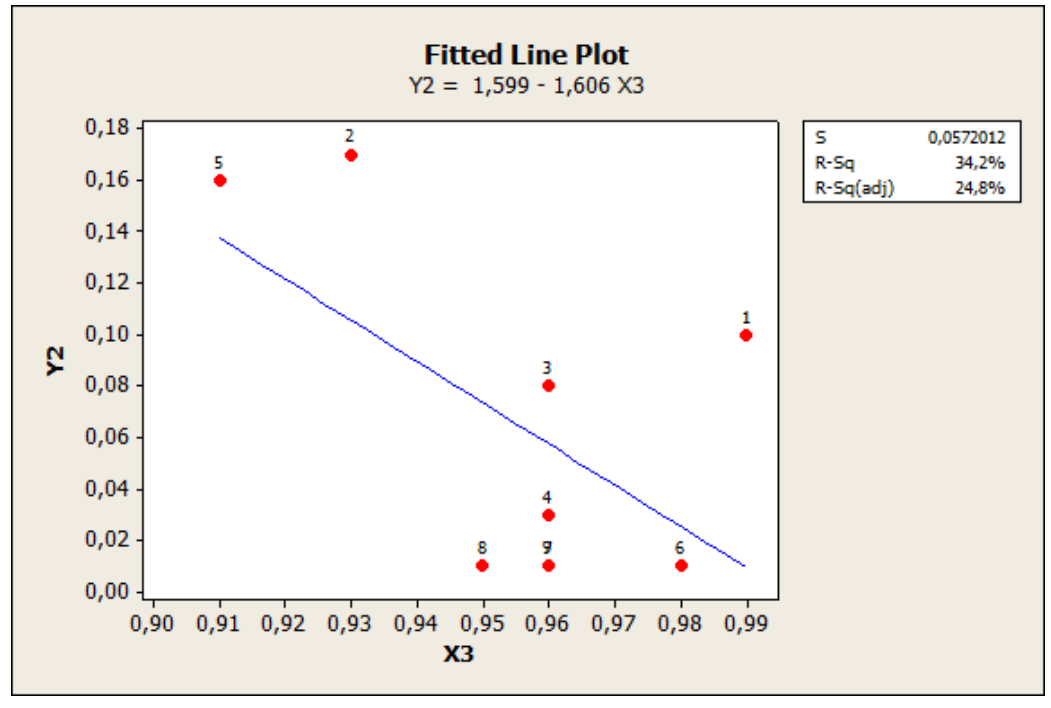

Figure 5.16 Regression Analysis 14: Y2 versus X3 
Regression equation of $\mathrm{Y} 2$ versus $\mathrm{X} 3$ is;

$$
\begin{aligned}
& Y 2=1,60-1,61 \times 3 \\
& R-S q \text { (adj.) }=24,8 \%
\end{aligned}
$$

Consequently, we can say that there is a weak relation between Rate of Loss and the Rates of Agglomeration for the metropolitan provinces.

\section{Regression Analysis 15:}

Regression Analysis 15 is performed with Y2 (rate of loss) and X4 (population/total number of buildings). As shown in the Table 5.25, the R-Sq (adj.) is $24,7 \%$.

Although this ratio isn't sufficient enough to verify the relationship, we can say that there is a weak relation between the regression equations of $Y 2$ versus $\mathrm{X} 4$.

Table 5.25 Regression Analysis 15: Y2 versus X4

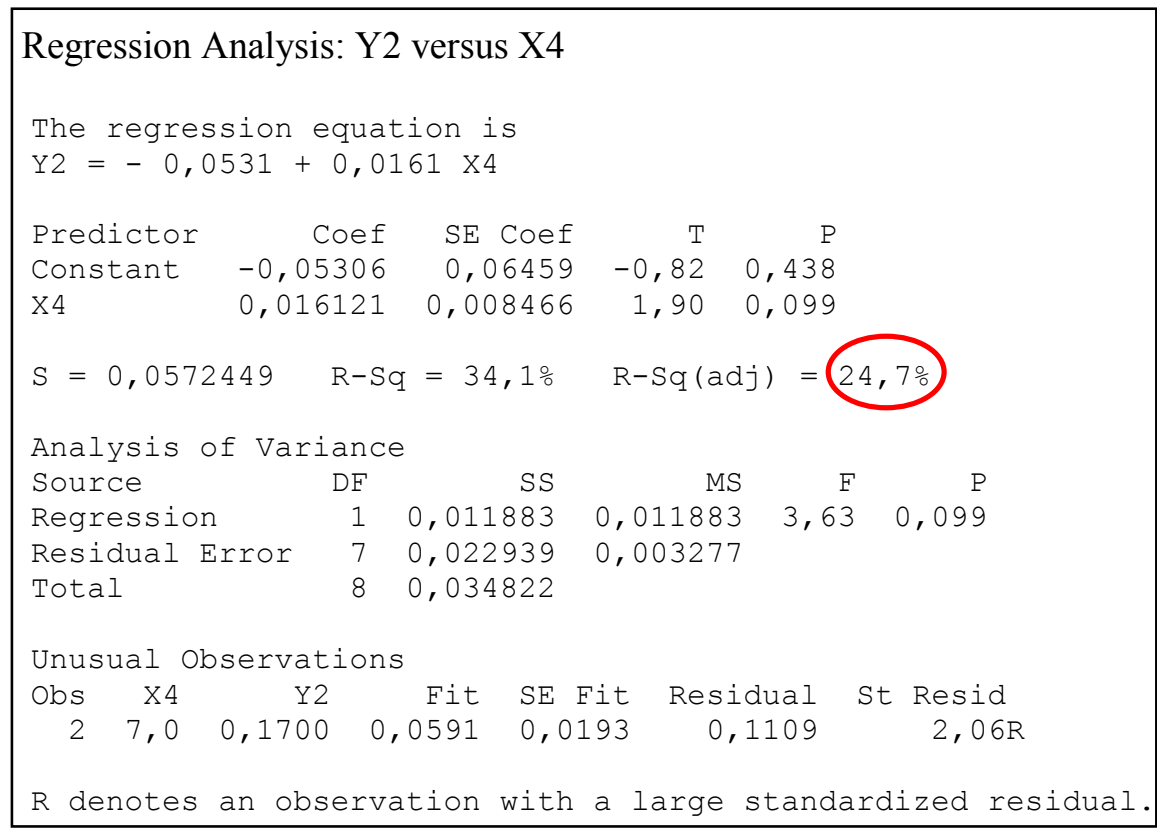




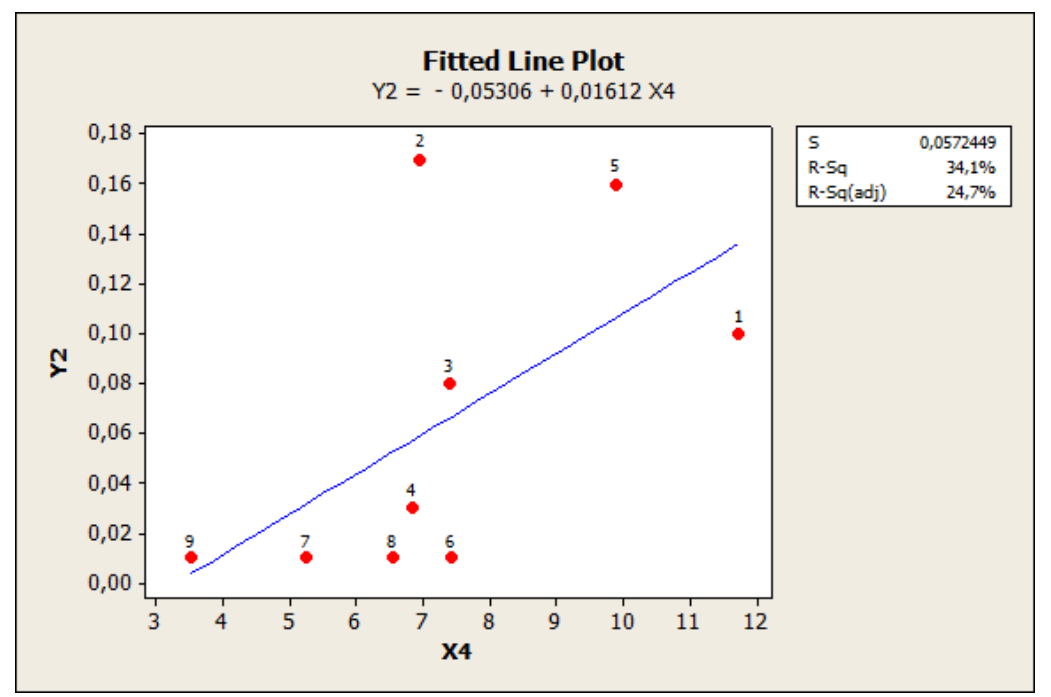

Figure 5.17 Regression Analysis 15: Y2 versus X4

Regression equation of $\mathrm{Y} 2$ versus $\mathrm{X} 4$ is;

$$
\begin{aligned}
& Y 2=-0,0531+0,0161 \times 4 \\
& R-S q \text { (adj.) }=24,7 \%
\end{aligned}
$$

Consequently, we can say that there is a weak relation between Rate of Loss and the Ratio of Population to the Number of Buildings for the metropolitan provinces.

Five regression analyses are performed for settlements in the third category that considers metropolitan cities. The Results of these analyses show that;

$Y 1$ (absolute loss) has strong relations with $\mathrm{X} 1$ (settlement population), no relation with X3 (Rates of Agglomeration) and weak relations with X4 (pop./ total number of buildings).

Y2 (rate of loss) has weak relations with $\mathrm{X} 3$ (rates of agglomeration) and X4 (pop./total number of buildings).

\subsection{Evaluation of Regression Analyses}

Six regression analyses are performed for top-20 settlements in Category I. The results of these analyses show that; $Y 1$ (absolute loss) has no relations with independent variables, Y2 (rate of loss) has weak relations with $X 3$ (rates of agglomeration), X4 (population /total number of buildings) and X5 (development index).

Four regression analyses are performed for top-20 settlements in Category II. The results of these analyses show that; $Y 1$ (absolute loss) has no relations with $\mathrm{X} 2$ (population growth rate) and weak relations with $\mathrm{X} 4$ (population /total number of buildings). Y2 (rate of loss) has weak relations with X1(settlement population) and no relations with X4 (population/ total number of buildings). 
Five regression analyses are performed for the top-20 settlements in Category III. The results of these analyses show that; $\mathrm{Y} 1$ (absolute loss) has strong relations with $X 1$ (settlement population), no relation with $X 3$ (rates of agglomeration) and weak relations with $X 4$ (population / total number of buildings). Y2 (rate of loss) has weak relations with X3 (rates of agglomeration) and $\mathrm{X} 4$ (population /total number of buildings).

As a result of these analyses we can say that Absolute Loss (YI) has no significant relations with independent variables of settlements in Category I that have populations up to 50.000 and settlements in Category II that have populations between 50.000 and 490.000 . Disparately, Absolute Loss is strongly related with settlement populations of metropolitan cities in Category III.

When we examine the results of analyses according to Relative Loss/Rate of Loss (Y2), we can say that Rate of Loss has weak relations both with independent variables of settlements in Category I that have populations up to 50.000, settlements in Category II that have populations between 50.000 and 490.000 and metropolitan cities in Category III.

Table 5.26 Evaluation of Regression Analyses

\begin{tabular}{|c|c|c|}
\hline Categories & $\begin{array}{c}\text { Relations with } \\
\text { Absolute Loss (Y1) }\end{array}$ & $\begin{array}{c}\text { Relations with } \\
\text { Relative Loss (Y2) }\end{array}$ \\
\hline $\begin{array}{c}\text { First Category } \\
\text { settlements having } \\
\text { population up to } \\
50.000\end{array}$ & $\begin{array}{c}\text { no relations with X1 } \\
\text { no relations with X5 }\end{array}$ & $\begin{array}{r}\text { weak relations with X3 } \\
\text { weak relations with X4 } \\
\text { weak relations with X5 }\end{array}$ \\
\hline $\begin{array}{c}\text { Second Category } \\
\text { settlements having } \\
\text { population between } \\
50.000 \text { and 490.000 }\end{array}$ & $\begin{array}{c}\text { no relations with X2 } \\
\text { weak relations with X4 }\end{array}$ & $\begin{array}{c}\text { weak relations with X1 } \\
\text { no relations with X4 }\end{array}$ \\
\hline $\begin{array}{c}\text { Third Category } \\
\text { Metropolitan Cities }\end{array}$ & $\begin{array}{c}\text { strong relations with X1 } \\
\text { no relations with X3 }\end{array}$ & $\begin{array}{l}\text { weak relations with X4 } \\
\text { weak relations with X3 }\end{array}$ \\
\hline
\end{tabular}

*X1(settlement population), X2(population growth rate), X3 (rates of agglomeration), X4 (population /total number of buildings), X5 (development index) 


\section{CHAPTER 6}

\section{FINDINGS and POLICY RECOMMENDATIONS}

The method and findings of this study may contribute to a more effective disaster policy and urban planning in several lines of policy development.

Suggestions and recommendations are briefly explored in this chapter indicating also areas of further research and policy development.

\subsection{Priorities for Mitigation Planning}

Mitigation planning is the process of figuring out how to reduce or eliminate the loss of life and property damage resulting from natural hazards and described by Kreimer et. al (1999) as an attempt to avoid, minimize, and share the costs of likely disasters. Mitigation planning is necessarily based on the identification and analysis of risks, and the development of methods for the management of urban risks. "An intensive collaboration of the disciplines is required, orchestrated preferably by the planners" (Balamir, 2006).

The purpose of mitigation planning is to identify policies and actions that can be implemented over the long term to reduce risk and future losses. Mitigation Plans form the foundation for a community's long-term strategy to reduce disaster losses and break the cycle of disaster damage, reconstruction, and repeated damage (FEMA, 2012).

The planning process is as important as the plan itself. It creates a framework for risk-based decision making to reduce damages to lives, property, and the economy from future disasters and help communities to become more sustainable and resilience by focusing efforts on the hazards, disaster-prone areas and identifying appropriate mitigation actions (FEMA, 2012).

Mitigation Planning identifies cost effective actions for risk reduction that are agreed upon by stakeholders and the public, focus resources on the greatest risks and vulnerabilities, builds partnerships by involving people and organizations, increases education and awareness of hazards and risk and aligns risk reduction with other community objectives.

Mitigation planning refers to a process that leads a planning committee through a framework of steps to develop a mitigation plan. The primary objective of the planning process is to facilitate development of strategies that will reduce damage, protect people and property, and improve resistance to natural hazards. 
According to FEMA (2012) this process involves four basic steps:

1. Organize Resources: communities should focus on the resources needed for a successful mitigation planning process. Essential steps include identifying and organizing interested members of the community as well as the technical expertise required during the planning process.

2. Identify Hazards and Assess Risks: communities need to identify the characteristics and potential consequences of hazards. It is important to understand how much of the community can be affected by specific hazards and what the impacts would be on important community assets.

3. Develop a Mitigation Plan: Armed with an understanding of the risks posed by hazards, communities need to determine what their priorities should be and then look at possible ways to avoid or minimize the undesired effects. The result is a hazard mitigation plan and strategy for implementation.

4. Implement Plan and Monitor Progress: Communities can bring the plan to life in a variety of ways, ranging from implementing specific mitigation projects to changes in day-to-day organizational operations. To ensure the success of an ongoing program, it is critical that the plan remains relevant. Thus, it is important to conduct periodic evaluations and make revisions as needed.

Consequently, mitigation planning at all levels is the dominant paradigm today as promoted by international organizations and academic circles since 1990s. Observations of this study provide guiding principles for effective mitigation practices in Turkey by ordering settlements and offer means of differential implementation.

The prioritized list of settlements according to their vulnerability levels should be accepted as the basis of the mitigation policies in higher-risk settlements and these cities within the highest hazard zone should obviously be the object of mitigation programs before those in areas of lower hazard.

Effective disaster mitigation strategies and more strict legal regulations about preparation of mitigation plans should be executed in higher-risk settlements and cities within the highest hazard zone.

Priorities of mitigation planning should be constituted with respect to the prioritized list of settlements according to their vulnerability levels and it should be compulsory to prepare mitigation plans for the settlements that have rank in the top-20 high risk lists.

The top-20 high risk settlements and metropolitan cities prioritized according to the absolute loss and relative loss that mitigation plans should be executed compulsorily are given below in the Table 6.1, Table 6.2, Table 6.3 and Table 6.4 . 
The top-20 of the settlements prioritized according to absolute loss are significantly above the category averages in terms of absolute loss and implementation of laws and regulations concerning mitigation policies and mitigation plans should be compulsory in these high-risk settlements.

Table 6.1 Top-20 Settlements Prioritized According to Absolute Loss that Mitigation Plans Should be Compulsory

\begin{tabular}{|l|l|c|c|c|}
\hline $\begin{array}{c}\text { Settlements of } \\
\mathbf{0}-\mathbf{4 9 0 . 0 0 0} \\
\text { Population }\end{array}$ & Sub-Province & $\begin{array}{c}\text { Expected } \\
\text { Intensity }\end{array}$ & $\begin{array}{c}\text { Absolute } \\
\text { Loss }\end{array}$ & $\begin{array}{c}\text { Relative Loss of } \\
\text { Settlements } \\
\text { (Loss Rate) }\end{array}$ \\
\hline VAN & VAN C. & 7,5 & 2285 & 0,06 \\
\hline ERZINCAN & ERZINCAN C. & 8 & 2025 & 0,16 \\
\hline BOLU & BOLU C. & 8 & 1841 & 0,18 \\
\hline YALOVA & YALOVA C. & 8 & 1507 & 0,18 \\
\hline TOKAT & NIKSAR & 8 & 1400 & 0,17 \\
\hline KASTAMONU & TOSYA & 8 & 1364 & 0,16 \\
\hline TEKIRDAG & TEKİRDAĞ C. & 7,5 & 1347 & 0,09 \\
\hline TOKAT & ERBAA & 8 & 1251 & 0,16 \\
\hline BURSA & ORHANGAZI & 8 & 945 & 0,18 \\
\hline MANISA & MANISA C. & 7 & 919 & 0,04 \\
\hline OSMANIYE & OSMANIYE C. & 7 & 905 & 0,03 \\
\hline SAKARYA & HENDEK & 8 & 869 & 0,17 \\
\hline CORUM & OSMANCIK & 8 & 786 & 0,16 \\
\hline HATAY & ANTAKYA & 7 & 768 & 0,03 \\
\hline SAMSUN & HAVZA & 8 & 735 & 0,16 \\
\hline TEKIRDAG & SARKOY & 8 & 712 & 0,18 \\
\hline HATAY & ISKENDERUN & 7 & 705 & 0,03 \\
\hline ADIYAMAN & ADIYAMAN C. & 7 & 696 & 0,03 \\
\hline SAKARYA & AKYAZI & 8 & 681 & 0,19 \\
\hline AMASYA & MERZIFON & 7,5 & 666 & 0,07 \\
\hline Group Average & & & $\mathbf{1 5 6}$ & $\mathbf{0 , 0 3}$ \\
\hline
\end{tabular}

Table 6.2 Metropolitan Provinces Prioritized According to Absolute Loss that Mitigation Plans Should be Compulsory

\begin{tabular}{|c|c|c|c|c|}
\hline $\begin{array}{c}\text { Metropolitan } \\
\text { Cities }\end{array}$ & Sub-Province & $\begin{array}{c}\text { Expected } \\
\text { Intensity }\end{array}$ & $\begin{array}{c}\text { Absolute } \\
\text { Loss }\end{array}$ & $\begin{array}{c}\text { Relative Loss of } \\
\text { Settlements } \\
\text { (Loss Rate) }\end{array}$ \\
\hline ISTANBUL & ISTANBUL (M) & 7,5 & 83824 & 0,10 \\
\hline KOCAELI & KOCAELI (M) & 8 & 24077 & 0,17 \\
\hline BURSA & BURSA (M) & 7,5 & 16506 & 0,08 \\
\hline IZMIR & IZMIR (M) & 7 & 14531 & 0,03 \\
\hline SAKARYA & SAKARYA (M) & 8 & 8070 & 0,16 \\
\hline ADANA & ADANA (M) & 6,5 & 1913 & 0,01 \\
\hline ANTALYA & ANTALYA (M) & 6,5 & 1402 & 0,01 \\
\hline KONYA & KONYA (M) & 6,5 & 1355 & 0,01 \\
\hline ERZURUM & ERZURUM (M) & 6,5 & 439 & 0,01 \\
\hline Group Average & & & $\mathbf{1 6 . 9 0 2}$ & $\mathbf{0 , 0 7}$ \\
\hline
\end{tabular}


The top-20 of the settlements prioritized according to relative loss are significantly above the category averages in terms of relative loss and implementation of laws and regulations concerning mitigation policies and mitigation plans should be compulsory in these high-risk settlements.

Table 6.3 Top-20 Settlements Prioritized According to Relative Loss that Mitigation Plans Should be Compulsory

\begin{tabular}{|l|l|c|c|c|}
\hline $\begin{array}{c}\text { Settlements of } \\
\mathbf{0}-\mathbf{4 9 0 . 0 0 0} \\
\text { Population }\end{array}$ & \multicolumn{1}{|c|}{ Sub-Province } & $\begin{array}{c}\text { Expected } \\
\text { Intensity }\end{array}$ & $\begin{array}{c}\text { Relative Loss of } \\
\text { Settlements } \\
\text { (Loss Rate) }\end{array}$ & $\begin{array}{c}\text { Absolute } \\
\text { Loss }\end{array}$ \\
\hline YALOVA & CINARCIK & 8 & 0,21 & 357 \\
\hline SAKARYA & AKYAZI & 8 & 0,19 & 681 \\
\hline YALOVA & CIFTLIKKOY & 8 & 0,19 & 298 \\
\hline BOLU & BOLU M. & 8 & 0,18 & 1841 \\
\hline YALOVA & YALOVA C. & 8 & 0,18 & 1507 \\
\hline BURSA & ORHANGAZI & 8 & 0,18 & 945 \\
\hline TEKIRDAG & SARKOY & 8 & 0,18 & 712 \\
\hline TOKAT & NIKSAR & 8 & 0,17 & 1400 \\
\hline SAKARYA & HENDEK & 8 & 0,17 & 869 \\
\hline BOLU & GEREDE & 8 & 0,17 & 583 \\
\hline AMASYA & TASOVA & 8 & 0,17 & 282 \\
\hline YALOVA & TERMAL & 8 & 0,17 & 73 \\
\hline ERZINCAN & ERZINCAN C. & 8 & 0,16 & 2025 \\
\hline KASTAMONU & TOSYA & 8 & 0,16 & 1364 \\
\hline TOKAT & ERBAA & 8 & 0,16 & 1251 \\
\hline CORUM & OSMANCIK & 8 & 0,16 & 786 \\
\hline SAMSUN & HAVZA & 8 & 0,16 & 735 \\
\hline SAKARYA & GEYVE & 8 & 0,16 & 543 \\
\hline SIVAS & SUSEHRI & 8 & 0,16 & 424 \\
\hline SAMSUN & LADIK & 8 & 0,16 & 377 \\
\hline Group Average & & & $\mathbf{0 , 0 3}$ & $\mathbf{1 5 6}$ \\
\hline
\end{tabular}

Table 6.4 Metropolitan Provinces Prioritized According to Relative Loss that Mitigation Plans Should be Compulsory

\begin{tabular}{|c|c|c|c|c|}
\hline $\begin{array}{c}\text { Metropolitan } \\
\text { Cities }\end{array}$ & Sub-Province & $\begin{array}{c}\text { Expected } \\
\text { Intensity }\end{array}$ & $\begin{array}{c}\text { Relative Loss } \\
\text { Of Settlements } \\
\text { (Loss Rate) }\end{array}$ & $\begin{array}{c}\text { Absolute } \\
\text { Loss }\end{array}$ \\
\hline KOCAELI & KOCAELI & 8 & 0,17 & 24077 \\
\hline SAKARYA & SAKARYA & 8 & 0,16 & 8070 \\
\hline ISTANBUL & ISTANBUL & 7,5 & 0,10 & 83824 \\
\hline BURSA & BURSA & 7,5 & 0,08 & 16506 \\
\hline IZMIR & IZMIR & 7 & 0,03 & 14531 \\
\hline ADANA & ADANA & 6,5 & 0,01 & 1913 \\
\hline ANTALYA & ANTALYA & 6,5 & 0,01 & 1402 \\
\hline KONYA & KONYA & 6,5 & 0,01 & 1355 \\
\hline ERZURUM & ERZURUM & 6,5 & 0,01 & 439 \\
\hline Group Average & & & $\mathbf{0 , 0 7}$ & $\mathbf{1 6 . 9 0 2}$ \\
\hline
\end{tabular}




\subsection{Urban Planning Standards and Principles}

One of the key elements in disaster risk reduction is effective management of land-use planning, urban planning standards and principles.

Global Assessment Report (GAR, 2011) recognized the opportunities of mainstreaming disaster risk reduction into land use planning and urban planning and the Hyogo Framework for Action 2005-2015 endorsed efforts in this field. Therefore, land use planning and urban planning standards became effective tools for disaster risk reduction by reducing risk factors, vulnerabilities and potential losses. Through land use planning, disaster risk factors can be modified to increase resilience.

"Land-use planning concerned with mitigation and equipped with the essential tools of implementation, does not only imply wider streets, lower densities, and larger open spaces in disaster-prone areas, but also a context in which individuals and institutions are alertly responsive and explicitly responsible for all eventualities" (Balamir, 2002).

Land use management is more than regulating development activities in the area with laws, ordinances and regulations. It should be linked to comprehensive land use plans and zoning ordinances to establish the bases for resilient development of the city. Land use management should seriously be taken into consideration, especially in cities with land use problems like high population density, high-rise buildings or vulnerable buildings in earthquake hazard-prone areas (Banba et. al, 2004).

Settlements in Turkey exceedingly perform all of these problems and it may be relevant to perform effective land-use planning and urban planning standards for the implementation of more effective disaster policies in Turkey.

Planning for resilient cities involves more than being occupied with minimum standards or widely-accepted spatial designs. Urban planning standards and principles together with risk-minimizing planning systems could effectively serve to mitigate risks and promote strict building supervision practices in disaster prone cities. To this end, urban planning standards and principles could be determined according to risk levels/zones determined by vulnerability maps and more strict planning standards could be executed in higher-risk settlements. Although, cities within the highest risk zones should obviously be the object of more strict inspection mechanisms than those of lower risks.

Urban standards for land use management as well as building construction are essential elements of disaster mitigation and it should be taken into consideration that different seismic intensity levels have different requirements of standards. Land-use planning and zoning, planning of open-spaces, transportation and infrastructure planning are all distinct aspects of disaster mitigation and all these systems are to be implemented at different standards according to risk levels. Rigorous implementation and enforcement of differentiated standards according to risk levels must be the highest priority for reducing risk factors, vulnerabilities and potential losses.

The regulations of land-use planning and urban planning standards can reduce the vulnerability of natural hazards by locational and/or design approaches. 
The locational approach is to avoid and restrict development in high-risk areas in order to reduce property loss and human casualties resulting from disasters. Determination of less hazardous areas for the expansion and direction of urban development is also used for reducing losses in this approach.

The design approach deals with the design and construction of buildings and infrastructure to resist expected earthquake loads and encourage safe design in order to make structures more resistant to disasters. Generally the locational and design strategies is used together to reduce urban risks.

An increasingly popular locational approach is public purchase of hazardous areas for use as recreational areas, parks and open spaces in high-risk settlements.

Adequate amounts of open and green areas systems have enormous value both during and after an earthquake event; they serve as potential evacuation places and temporary dwelling areas. After a major earthquake, the open space network becomes a kind of 'second city', providing multiple complex functions such as gathering and shelter, the distribution of goods and services and temporary inhabitation (McGregor, 1998, Middleton, 2007).

Another locational approach should be implemented for schools and health facilities not only because of the highly vulnerable population they accommodate, but also because they provide essential social services and serve as shelter sites for the community.

It is essential that these buildings function after a seismic event and special attention must be paid to their safety. Risk reduction efforts must focus on ensuring they can continue providing services when most needed. These facilities should be located on safest areas and follow current seismic codes in construction resistant to damage. These precautions should be implemented other public facilities also.

Critical infrastructure and lifelines services such as electricity, energy, telecommunication and water are systems that could serve for the emergency response and recovery of a community in the post-disaster context.

Protecting these utilities from damage and avoiding these services to be located in high-risk areas can minimize the economic and social disruptions caused by natural disasters.

Underground systems for critical infrastructure and lifelines services in high-risk settlements are effective measures against disaster. Another important point is the accessibility options, roads and sites are designed to be accessible in case of emergencies. 


\subsection{Law on Redevelopment of Areas under Disaster Risk (6306)}

The Law No. 6306 on "Redevelopment of Areas under Disaster Risk" put into force by publication at the Official Gazette dated May 31, 2012. The governing authority of the law is the Ministry of Environment and Urbanism (MEU). The Law has the objective of "determining the principles and methods of improvement, liquidation and renewal geared towards the constitution of healthy and safe living spaces in line with scientific and esthetic norms and standards in areas under disaster risk and in any high risk development".

The Redevelopment Law is intended to regulate the improvement, settlement and renovation of areas at risk of disaster and other lots which support riskbearing buildings, even if outside of a designated disaster risk area. The purpose of the Redevelopment Law which is defined in Article 1 is determining all kinds of principles, methods and processes in connection with rehabilitation, demolition and reconstruction at areas under disaster risk and at other areas, whether planned or not, where there are structures under risk, with the aim of providing habitats conforming to technical, health, environmental and zoning plan requirements.

The Law outlines the methods for the identification of such high risk areas and structures, evacuation and demolition processes, development of projects after demolition and it also lists the duties and responsibilities of public agencies.

The Law specifically focuses on the risk areas and defines "risk area" as areas that may cause loss of life or assets. These areas are identified by the Ministry, Housing Development Administration or municipalities, by taking the opinions of the Presidency of Management of Disaster and Emergency and decided by the Council of Ministers upon proposal of the Ministry.

According to the Law, the buildings that are at risk ("risky buildings") are defined as buildings within or outside risk areas that have completed their economic life, or which are scientifically and technically proven to be at risk of demolition or high damage. It should be underlined that if the Ministry deems necessary, a building that is not specified as a property at risk may also be subject to regeneration procedures for the purpose of maintaining the integrity of the enforceability of the Law.

Besides, there are various ambiguous and grey areas regarding this Law and it is likely that the Law is subject to objections in various aspects. The foremost of these objections about the Law is the restrictions imposed on the ownership rights and the granting of broad authority to the Ministry.

The Law noticeably brings all authorities under one institution - the Ministry of Environment and Urbanism. MEU is authorized to expropriate the immovable or exchange them with others; to transfer immovable property rights and zoning rights to other areas; to divide and to allocate shares forming the immovable's; and to establish rights on immovable's located within the risk areas" (Akalın and Sürel, 2012).

In addition to above mentioned deficiencies, another criticism about the Law is the Article 9. According to the Article 9 preventive provisions of other laws contrary to the implementation of this law shall not be applicable. 
These aspects of the law has already caused widespread protests from circles such as Professional chambers and current residents of redevelopment areas due to social, cultural and environmental concerns as it opens a way for new means of maximum use of land at centrally located urban land through higher floor area ratios which are to be determined by central and local administration institutions such as Housing Development Administration of Turkey, metropolitan municipalities and county municipalities (Akalın and Sürel, 2012).

Therefore, the law as proposed does not provide adequate protection mechanisms to individuals, inadequate to reduce the destructive effects of earthquakes and does not establish adequate and effective consultation mechanisms with the owners and/or tenants of the buildings which may be affected. Also, the language of the law is ambiguous and there are various points in the law which may be open to arbitrary interpretation besides giving immense powers to authorities.

The Union of Chambers of Turkish Engineers and Architects (UCTEA) stated their opinion about the Disaster Law as "All laws that protect the immunity of cities, habitats, nature and professional fields are getting scrapped. The government is rendering our cities more vulnerable to disasters through laws and administrative regulations that amount to plundering nature and history and which aim for 'profiteering' under the [disguise] of 'urban transformation'".

The contradictions of the Law with basic human rights and the Constitution are listed by the Chamber of City Planners under UCTEA as given below;

- The law penalizes any objection to an imposed agreement on disaster prevention

- Risk-free buildings can be brought under the scope of law for the sake of "practical coherence"

- The statement "Buildings in high risk areas are not to be provided power, water or natural gas, and all such services will be discontinued" is a clear violation of basic rights

- Obliging local residents to cover all infrastructure costs (including the cost of identification and demolition of high risk buildings) will increase the debt burden of these already impoverished populations

- The authorization of the Ministry of Environment and Urban Planning further enhances centralization

- The few plots remaining in the public sector could be Privatized Real estate owned by public agencies outside of the Treasury (schools, hospitals and public housing) could be transferred to the Ministry, whether prone to disasters or not

- Laws protecting natural and historical riches are made null and void, defined as "inapplicable legislation"

- Development of grazing land is made easier 
- The temporary ban on all zoning and construction in reserve building areas constitutes a violation of property rights

- The authority to impose "special" standards on planning resolutions could make the renewed areas unlivable

Aside from these arguments, it is suggested in some circles that high risk areas will be identified arbitrarily. Also, the Law on Disaster Prevention does not take into account any disaster other than earthquakes. The condition of tenants is not given due consideration, and no mechanism is designed for their protection, except for a one-off rent allowance.

Besides, there are no price-control measures to prevent impoverished residents from running into repayment problems or being obliged to sell their property for immediate gain, and thus be uprooted from their communities. The participation of local stakeholders was envisaged neither during the drafting of the law nor in the aftermath - aside from bearing its costs.

Finally, the law in question centered on demolition does not approach transformation comprehensively, in the light of healthy urban development, ecological sustainability and social justice - the indisputable principles of urban planning. Criticisms get only stronger once you add the fact that previous transformation projects were far from exemplary in many aspects not least design, and that market players focus on profit maximization and give a back seat to public interest (Adanalı, 2012).

Consequently, all of above mentioned deficiencies should be improved in order to provide adequate protection mechanisms to individuals, to reduce the destructive effects of earthquakes and establish adequate and effective consultation mechanisms with the owners and/or tenants of the buildings which may be affected.

Observations of this study provide guiding principles for effective mitigation practices in Turkey by ordering settlements and offer means of differential implementation. These could contribute to improved safety measures in Law (6306) on Redevelopment of Areas under Disaster Risk. 


\subsection{Building Codes and Development Regulations}

Regulatory frameworks for building and planning should be one of the key tools for reducing disaster risk in the built environment. Indeed, safer regulations, which define design loads, specify construction details and provide hazard zoning, have been shown to minimize damage and save lives. Many countries are developing good regulatory frameworks; however the difficulties lie in implementation (Johnson, 2012).

Among these are USA (Disaster Mitigation Law, 2000), New Zealand (Civil Defense Law, 2002), South Africa (Disasters Law, 2002), Australia (COAG Report, 2002), UK (Civil Mitigation Law, 2004), Canada (Risk Mitigation Projects Program, 2004), Greece (Civil Protection Law, 2003), Armenia (2002) and others, apart from Japan which had such regulation in effect since 1961.

Major earthquakes in Turkey have led to substantial changes in the practice of seismic design and construction. After the 1939 Erzincan earthquake, a committee formed to prepare a seismic zone map. The formation of this committee was the first step towards developing regulations for the seismic design of buildings in Turkey and since then specifications for construction in disaster areas have been changed many times.

The first seismic design code for buildings was published one year after the destructive Erzincan earthquake in 1940. Destructive earthquakes have usually resulted in revisions to the codes and the 1940's building code revised 9 times in the years of 1944, 1947, 1949, 1953, 1961, 1968, 1975, 1997 and 1998. Key events in the evolution of seismic codes in Turkey are listed below.

Table 6.5 Key events in the evolution of seismic design codes in Turkey (Source: PEER, 2000)

\begin{tabular}{|l|l|l|}
\hline Year & \multicolumn{1}{|c|}{ Event } & \multicolumn{1}{c|}{ Code development } \\
\hline 1939 & Erzincan earthquake (M7.9) & \\
\hline 1940 & $\begin{array}{l}\text { Committee formed to develop a seis- } \\
\text { mic zonation map for Turkey }\end{array}$ & First seismic code published \\
\hline 1942 & & $\begin{array}{l}\text { Earthquake zone map prepared; map promulgated } \\
\text { in } 1945\end{array}$ \\
\hline 1943 & Tosya earthquake (M7.2) & \\
\hline 1944 & Gerede earthquake (M7.2) & Seismic code revised \\
\hline 1947 & & Seismic code revised \\
\hline 1949 & & Seismic code revised \\
\hline 1953 & & Seismic code revised \\
\hline 1958 & $\begin{array}{l}\text { Ministry of Reconstruction and } \\
\text { Resettlement established }\end{array}$ & \\
\hline 1961 & & Seismic code revised \\
\hline 1963 & & Earthquake zone map revised \\
\hline 1966 & Varto earthquake (M7.1) & \\
\hline 1967 & Adapazari earthquake (M7.1) & \\
\hline 1968 & & Seismic code revised \\
\hline 1975 & & Seismic code revised; ductile detailing introduced \\
\hline 1992 & Erzincan earthquake (M6.9) & \\
\hline 1997 & & Seismic code revised; ductile detailing required \\
\hline 1999 & $\begin{array}{l}\text { Izmit earthquake (M7.4) } \\
\text { Düzce earthquake (M7.2) }\end{array}$ \\
\hline & & \\
\hline
\end{tabular}


Destructive earthquakes that occurred in 1999 have been a milestone in the improvement of seismic resistant design of structures and the latest Turkish building code, "Specification for Buildings to be built in Disaster Areas" (TEC2007) put into effect in March 2007.

"Specifications for Structures to be built in the Disaster Areas" that establish standards for building design and construction, refers to Official Earthquake Hazard Zoning Map of Turkey for the calculation of acceleration values that could affect the structure. Therefore, Earthquake Hazard Zoning Map of Turkey based on probabilistic considerations and divides the country into five macro-level regions as determined by the statistical occurrence of seismic events. This is currently used as a basis for engineering design safety of buildings with variant design standards imposed in each region.

Relevant building standards for a particular structure are defined by the location of the buildings according to earthquake hazard zones, soil conditions at the building site and construction type of the buildings.

The Earthquake Zoning Map shows the different macro-zones of Turkey, for which minimum effective acceleration coefficients and corresponding design spectra are defined in the Building Code. Seismic Zonation is based on ground acceleration values with $10 \%$ probability of exceedance in 50 years and 475 years mean return period. Five seismic zones are classified, as shown in the Table 6.6 due to expected acceleration values.

Table 6.6 The Effective Ground Acceleration Coefficient (Source: TEC-2007)

\begin{tabular}{|c|c|}
\hline Seismic Zone & $\begin{array}{c}\text { Acceleration Coefficient } \\
\text { (Ao) }\end{array}$ \\
\hline I & more than $0.4 \mathrm{~g}$ \\
\hline II & between $0.3 \mathrm{~g}-0.4 \mathrm{~g}$ \\
\hline III & between $0.2 \mathrm{~g}-0.3 \mathrm{~g}$ \\
\hline IV & between $0.2 \mathrm{~g}-0.1 \mathrm{~g}$ \\
\hline V & less than $0.1 \mathrm{~g}$ \\
\hline
\end{tabular}

However, this macro-zonation map does not specify any quantitative earthquake hazard parameters for any zone; it only indicates hazard exposure levels of provinces and settlements without providing any information about risk levels. The purpose could have been better served if differentiations of locations were made on risk-basis. This demands the identification of relative risk categories of risks in settlements.

Consequently, the official hazard map does not consider primary factors of risk, neither vulnerabilities nor attributes of the building stock. In order to underline this problem, the discrepancies between the location of settlements according to the hazard zones determined by the official earthquake hazard map and the prioritized lists of settlements according to the absolute and relative loss are examined in this research. 
To this end, first of all the top-20 settlements prioritized according to the absolute loss is compared with the location of these settlements according to the hazard zones determined by the official earthquake hazard map of Turkey (See Appendix $G$ for the total list).

When we examine the top-20 high risk settlements prioritized according to the absolute loss, we observe that three of these high risk settlements are located in the second hazard zone according to the official earthquake hazard map of Turkey. This shows that although these three settlements have rank in the top20 high risk list, they are classified in the second hazard zone and their acceleration values that will effect the construction of buildings are calculated according to the second hazard zone.

But the most remarkable result is seen in the city of Van that was struck by a devastating earthquake recently. Although centre of Van ranks in the first place of the high-risk settlements according to the absolute loss, it is classified in the second hazard zone according to the earthquake hazard map and its acceleration coefficient is calculated according to the second hazard level.

Appropriate locational differentiation is a crucial input in engineering design safety of buildings based on risk maps.

Table 6.7 Evaluation of the Top-20 Settlements Prioritized According to the Absolute Loss with respect to the Hazard Zones Determined by the Official Earthquake Hazard Map

\begin{tabular}{|l|l|c|c|c|c|}
\hline PROVINCE & SUB-PROVINCE & $\begin{array}{c}\text { Expected } \\
\text { Intensity }\end{array}$ & $\begin{array}{c}\text { Absolute } \\
\text { Loss }\end{array}$ & $\begin{array}{c}\text { Hazard } \\
\text { Zone }\end{array}$ & $\begin{array}{c}\text { Relative Loss } \\
\text { of Settlements } \\
\text { (Loss Rate) }\end{array}$ \\
\hline VAN & VAN C. & 7,5 & 2285 & 2 & 0,06 \\
\hline ERZINCAN & ERZINCAN C. & 8 & 2025 & 1 & 0,16 \\
\hline BOLU & BOLU C. & 8 & 1841 & 1 & 0,18 \\
\hline YALOVA & YALOVA C. & 8 & 1507 & 1 & 0,18 \\
\hline TOKAT & NIKSAR & 8 & 1400 & 1 & 0,17 \\
\hline KASTAMONU & TOSYA & 8 & 1364 & 1 & 0,16 \\
\hline TEKIRDAG & TEKIRDAĞ C. & 7,5 & 1347 & 2 & 0,09 \\
\hline TOKAT & ERBAA & 8 & 1251 & 1 & 0,16 \\
\hline BURSA & ORHANGAZI & 8 & 945 & 1 & 0,18 \\
\hline MANISA & MANISA C. & 7 & 919 & 1 & 0,04 \\
\hline OSMANIYE & OSMANIYE C. & 7 & 905 & 1 & 0,03 \\
\hline SAKARYA & HENDEK & 8 & 869 & 1 & 0,17 \\
\hline CORUM & OSMANCIK & 8 & 786 & 1 & 0,16 \\
\hline HATAY & ANTAKYA & 7 & 768 & 1 & 0,03 \\
\hline SAMSUN & HAVZA & 8 & 735 & 1 & 0,16 \\
\hline TEKIRDAG & SARKOY & 8 & 712 & 1 & 0,18 \\
\hline HATAY & ISKENDERUN & 7 & 705 & 1 & 0,03 \\
\hline ADIYAMAN & ADIYAMAN C. & 7 & 696 & 2 & 0,03 \\
\hline SAKARYA & AKYAZI & 8 & 681 & 1 & 0,19 \\
\hline AMASYA & MERZIFON & 7,5 & 666 & 1 & 0,07 \\
\hline
\end{tabular}




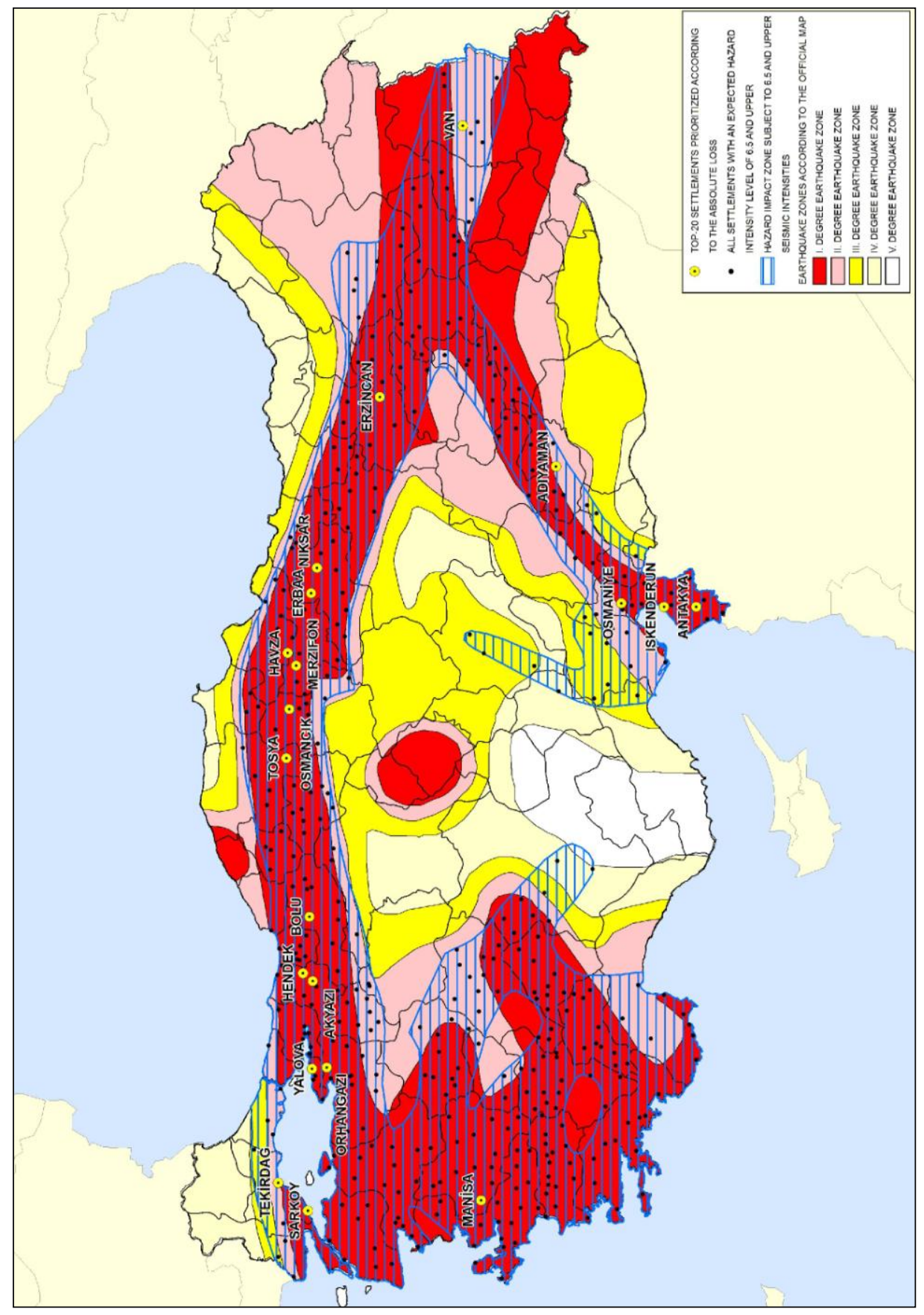

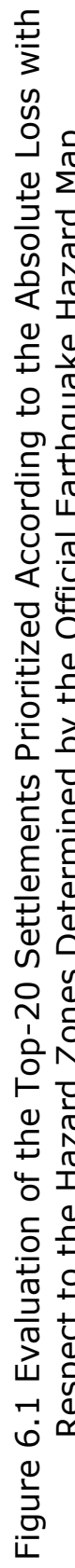


Other settlements rank in the Top-100 high risk list prioritized according to absolute loss that shows discrepancy with the hazard zones determined by the Official Earthquake Hazard Map are; centre of Kütahya that ranks in the 40th place, Tarsus that ranks in the 43rd place, Çorum that ranks in the 59th place, Keşan that ranks in the 65th place, Afyon that ranks in the 72 nd place, Çorlu that ranks in the 76th place, Kozan that ranks in the 85th place, Ceyhan that ranks in the 92nd place, Kadirli that ranks in the 94th place and Malkara that ranks in the 100th place (See Appendix G for the total list).

In the examination of the metropolitan cities prioritized according to the absolute loss, the most remarkable result is seen in the Istanbul metropolitan city. Although it ranks in the first place of the high-risk metropolitan cities, it is classified in the second hazard zone according to the earthquake hazard map.

As a result of this classification, acceleration coefficient of the most vulnerable metropolitan city of the country is calculated according to the second hazard level. This is another specific example that shows the inconsistency of using official earthquake hazard zoning map as a basis for calculating acceleration values for engineering design safety of buildings.

Other metropolitan cities prioritized according to the absolute loss are consistent with hazard zones determined by the official earthquake hazard map (See Appendix G).

Secondly, the top-20 settlements prioritized according to the relative loss is compared with the location of these settlements according to the hazard zones determined by the official earthquake hazard map of Turkey (See Appendix $\mathrm{H}$ for the total list).

When we examine the top-20 high risk settlements prioritized according to the relative loss, we observe that all of these high risk settlements are located in the first hazard zone according to the official earthquake hazard map of Turkey.

This shows that the prioritization of settlements according to relative loss is consistent with hazard zones determined by the official earthquake hazard map and this also makes their acceleration values calculation consistent with our prioritization. 
Table 6.8 Comparison of the Top-20 Settlements Prioritized According to the Relative Loss with the Hazard Zones Determined by the Official Earthquake Hazard Map

\begin{tabular}{|l|l|c|c|c|c|}
\hline PROVINCE & SUB-PROVINCE & $\begin{array}{c}\text { Expected } \\
\text { Intensity }\end{array}$ & $\begin{array}{c}\text { Relative Loss of } \\
\text { Settlements } \\
\text { (Loss Rate) }\end{array}$ & $\begin{array}{c}\text { Hazard } \\
\text { Zone }\end{array}$ & $\begin{array}{c}\text { Absolute } \\
\text { Loss }\end{array}$ \\
\hline YALOVA & CINARCIK & 8 & 0,21 & 1 & 357 \\
\hline SAKARYA & AKYAZI & 8 & 0,19 & 1 & 681 \\
\hline YALOVA & CIFTLIKKOY & 8 & 0,19 & 1 & 298 \\
\hline BOLU & BOLU M. & 8 & 0,18 & 1 & 1841 \\
\hline YALOVA & YALOVA C. & 8 & 0,18 & 1 & 1507 \\
\hline BURSA & ORHANGAZI & 8 & 0,18 & 1 & 945 \\
\hline TEKIRDAG & SARKOY & 8 & 0,18 & 1 & 712 \\
\hline TOKAT & NIKSAR & 8 & 0,17 & 1 & 1400 \\
\hline SAKARYA & HENDEK & 8 & 0,17 & 1 & 869 \\
\hline BOLU & GEREDE & 8 & 0,17 & 1 & 583 \\
\hline AMASYA & TASOVA & 8 & 0,17 & 1 & 282 \\
\hline YALOVA & TERMAL & 8 & 0,17 & 1 & 73 \\
\hline ERZINCAN & ERZİNCAN C. & 8 & 0,16 & 1 & 2025 \\
\hline KASTAMONU & TOSYA & 8 & 0,16 & 1 & 1364 \\
\hline TOKAT & ERBAA & 8 & 0,16 & 1 & 1251 \\
\hline CORUM & OSMANCIK & 8 & 0,16 & 1 & 786 \\
\hline SAMSUN & HAVZA & 8 & 0,16 & 1 & 735 \\
\hline SAKARYA & GEYVE & 8 & 0,16 & 1 & 543 \\
\hline SIVAS & SUSEHRI & 8 & 0,16 & 1 & 424 \\
\hline SAMSUN & LADIK & 8 & 0,16 & 1 & 377 \\
\hline
\end{tabular}

Other settlements rank in the Top-100 high risk list prioritized according to relative loss that shows discrepancy with the hazard zones determined by the Official Earthquake Hazard Map are; centre of Tekirdağ that ranks in the 44th place, centre of Van that ranks in the 59th place and centre of Adıyaman that ranks in the 94th place (See Appendix $\mathrm{H}$ for the total list).

The examination of the metropolitan cities prioritized according to the relative loss, shows parallel results with other prioritized settlements according to the relative loss. Metropolitan cities prioritized according to the absolute loss are consistent with hazard zones determined by the official earthquake hazard map with the exception of the Istanbul metropolitan city.

Consequently, the comparison of prioritized list of settlements according to both absolute and relative losses, with the hazard zones determined by the official earthquake hazard map shows us that the discrepancies between two approaches is seen more acute in absolute losses than relative losses.

The results of the evaluation of acceleration values for engineering design safety of buildings show that; absolute loss is a more distinctive factor than relative loss in the evaluation of building codes. 


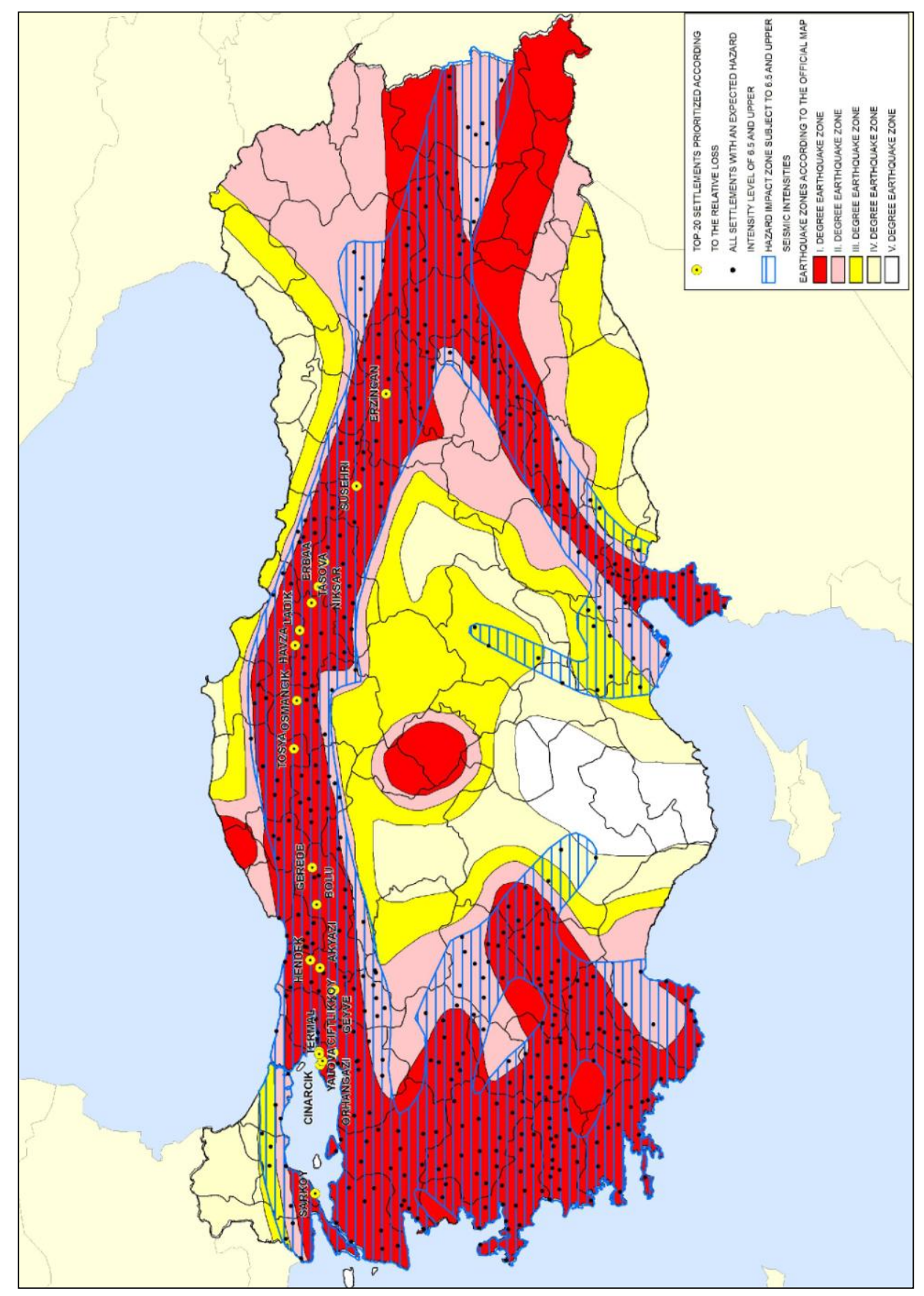

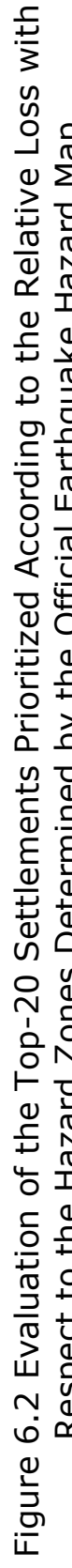




\subsection{Building Supervision Practices}

An effective disaster mitigation strategy must depend on two basic premises: One is the effective planning system that considers risk-basis regulatory frameworks and the second is the strict building supervision practices.

Many countries are developing good regulatory frameworks; however the difficulties lie in implementation (Johnson, 2012). Enforcement of related codes and standards during the construction of new buildings is as vital as devising appropriate building codes and legislation to support enforcement processes. Moreover, we must underline the fact that an effective construction supervision system can not be created through the legal text alone. It should be supported by such instruments as professional liability insurance, professional supervision and licensing.

Turkey has deficiencies in both the nature and implementation of laws and regulations concerning the planning system and the system of supervision. But the lack of implementation and control of current regulations resulted further devastating impacts than the regulations itself.

Although, the Turkish Building Code was updated in 1997 to include modern earthquake provisions, weaknesses in construction which were exposed in the 1999 Marmara earthquake, revealed that compliance with the intent of the code was poor and the effectiveness of the code enforcement was insufficient (Yüzügüllü et. al, 2004).

The devastating results of the 1999 East Marmara Earthquakes have provided tragic experiences of the ineffectiveness of the regulatory frameworks in implementing building standards and proved the need to review and reduce the deficiencies in the disaster management system and related legislations. Several steps were taken by the government in order to reduce deficiencies in the predisaster assessments.

Some of these steps are: the introduction of institutions of 'construction inspection functions' and provisions for the improvements in 'professional competence' (Keles, 2004; Balamir, 2001).

Within the scope of 'construction inspection functions' the supervision of building standards become mandatory and "The Building Supervision Law" (4708) put into force in 2001 "for the aim of assuring the safety of health and property, ensuring design and building inspection to construct buildings of good quality appropriate with improvement plans, science, art and health rules and standards and arranging the procedures and principles of building inspection".

"Specifications for Structures to be Built in the Disaster Areas" that established standards for building design and construction is used as a basis for construction inspection functions. As "Specifications for Structures to be built in the Disaster Areas" refers to Earthquake Hazard Zoning Map for the calculation of acceleration values that will effect the construction, same criticisms as mentioned in section 6.4 about the deficiencies of Hazard Zoning Map and the discrepancies between this map and the prioritized lists of settlements according to the absolute and relative loss are also valid for construction inspection functions. 
Therefore, the purpose of a strict inspection system could have been better served if construction inspections functions are differentiate according to the hazard zones determined by risk-basis maps.

Accordingly, more strict inspection mechanisms should be executed in high-risk settlements and cities within the highest hazard zone should obviously be the object of supervision programs before those in areas of lower hazard.

However, without appropriate means and tools of land-use planning that take into account seismic risks, individual building safety may have only little meaning (Balamir, 2001). Since current supervision is limited to buildings, it should be extended to control planning and implementation as well. Improvements in supervision are necessary for physical development which should be incorporated in the main body of the Development Law as a local government obligation (Balamir, 2004).

\subsection{Insurance System}

Following the 1999 Marmara Earthquake, one of the steps taken by the government has been the Obligatory Earthquake Insurance that became effective with the decree Law No. 587 "Decree Law Relating to Compulsory Earthquake Insurance". With this decree, the Turkish Catastrophe Insurance Pool (TCIP) was established and become responsible for the obligatory earthquake insurance.

"Compulsory Earthquake Insurance system has removed the conventional obligation of the state to provide dwellings to every disaster victim. With this insurance system, only households who have insured dwellings are entitled to compensation" (Balamir, 2004). Therefore, the state has no more responsibility to compensate any damage occurred due to earthquakes. The damages are to be compensated by the Compulsory Earthquake Insurance System.

Official Earthquake Hazard Zoning Map of Turkey is used as a basis for calculating insurance costs for the purchasers of obligatory earthquake insurance. Pricing takes into account the location of the buildings according to earthquake hazard zones and the construction type of the buildings. There are fifteen different rates determined according to five seismic hazard zones and three different building construction type.

Table 6.9 Rates of Compulsory Earthquake Insurance Scheme (Source: TCIP, 2012)

\begin{tabular}{|lccccc|}
\hline $\begin{array}{l}\text { REGION BASED RATES ACCORDING TO } \\
\text { Construction Type (\%o) }\end{array}$ & $\begin{array}{l}\text { ZONE } \\
\text { I }\end{array}$ & $\begin{array}{l}\text { ZONE } \\
\text { II }\end{array}$ & $\begin{array}{l}\text { ZONE } \\
\text { III }\end{array}$ & $\begin{array}{l}\text { ZONE } \\
\text { IV }\end{array}$ & $\begin{array}{l}\text { ZONE } \\
\text { V }\end{array}$ \\
\hline $\begin{array}{l}\text { A-Steel, Reinforced Concrete Frame } \\
\text { Structures }\end{array}$ & 2.20 & 1.55 & 0.83 & 0.55 & 0.44 \\
\hline $\begin{array}{l}\text { B-Masonry Stone Structures } \\
\text { C-Other Structures }\end{array}$ & 3.85 & 2.75 & 1.43 & 0.60 & 0.50 \\
\hline
\end{tabular}


"The system functions currently at a high cost since the probability of earthquakes are high, land use and location decisions do not take into account the findings of microzonation. All contribute to the intensification of risk" (Balamir, 2004).

The basic reason of this intensification of risk is the Earthquake Hazard Map of Turkey that only indicates hazard exposure levels of provinces and settlements without providing any information about risk levels. The purpose could have been better served if differentiations of locations were made on risk-basis. This demands the identification of relative risk categories of risks in settlements.

Consequently, the official hazard map considers only probabilities of seismic hazard not necessarily the vulnerabilities or attributes of the building stock. In order to underline this problem, we examine the discrepancies between the location of settlements according to the hazard zones determined by the official earthquake hazard map and the prioritized lists of settlements according to the absolute and relative loss.

To this end, first of all the top-20 settlements prioritized according to the absolute loss is compared with the location of these settlements according to the hazard zones determined by the official earthquake hazard map of Turkey (See Appendix $\mathrm{G}$ for the total list).

When we examine the top-20 high risk settlements prioritized according to the absolute loss, we observe that three of these high risk settlements Van Center, Tekirdağ Center and Adıyaman Center are located in the second hazard zone according to the official earthquake hazard map of Turkey.

Although these settlements have rank in the top-20 high risk list, they classified in the second hazard zone and their insurance rates are calculated according to the second hazard level.

But the most remarkable result is seen in the centre of Van that struck by a devastating earthquake recently. Although centre of Van ranks in the first place of the high-risk settlements according to the absolute loss, it is classified in the second hazard zone according to the earthquake hazard map and insurance rates are calculated according to the second hazard level.

This is a clear indication of the importance of both making differentiation of locations and calculating of insurance rates on risk-basis maps. 
Table 6.10 Comparison of the Top-20 Settlements Prioritized According to the Absolute Loss with the Hazard Zones Determined by the Official Earthquake Hazard Map

\begin{tabular}{|l|l|c|c|c|c|}
\hline PROVINCE & SUB-PROVINCE & $\begin{array}{c}\text { Expected } \\
\text { Intensity }\end{array}$ & \multicolumn{1}{c|}{$\begin{array}{c}\text { Absolute } \\
\text { Loss }\end{array}$} & $\begin{array}{c}\text { Hazard } \\
\text { Zone }\end{array}$ & $\begin{array}{c}\text { Relative Loss } \\
\text { of Settlements } \\
\text { (Loss Rate) }\end{array}$ \\
\hline VAN & VAN C. & 7,5 & 2285 & 2 & 0,06 \\
\hline ERZINCAN & ERZINCAN C. & 8 & 2025 & 1 & 0,16 \\
\hline BOLU & BOLU C. & 8 & 1841 & 1 & 0,18 \\
\hline YALOVA & YALOVA C. & 8 & 1507 & 1 & 0,18 \\
\hline TOKAT & NIKSAR & 8 & 1400 & 1 & 0,17 \\
\hline KASTAMONU & TOSYA & 8 & 1364 & 1 & 0,16 \\
\hline TEKIRDAG & TEKIRDAĞ C. & 7,5 & 1347 & 2 & 0,09 \\
\hline TOKAT & ERBAA & 8 & 1251 & 1 & 0,16 \\
\hline BURSA & ORHANGAZI & 8 & 945 & 1 & 0,18 \\
\hline MANISA & MANISA C. & 7 & 919 & 1 & 0,04 \\
\hline OSMANIYE & OSMANIYE C. & 7 & 905 & 1 & 0,03 \\
\hline SAKARYA & HENDEK & 8 & 869 & 1 & 0,17 \\
\hline CORUM & OSMANCIK & 8 & 786 & 1 & 0,16 \\
\hline HATAY & ANTAKYA & 7 & 768 & 1 & 0,03 \\
\hline SAMSUN & HAVZA & 8 & 735 & 1 & 0,16 \\
\hline TEKIRDAG & SARKOY & 8 & 712 & 1 & 0,18 \\
\hline HATAY & ISKENDERUN & 7 & 705 & 1 & 0,03 \\
\hline ADIYAMAN & ADIYAMAN C. & 7 & 696 & 2 & 0,03 \\
\hline SAKARYA & AKYAZI & 8 & 681 & 1 & 0,19 \\
\hline AMASYA & MERZIFON & 7,5 & 666 & 1 & 0,07 \\
\hline
\end{tabular}

Other settlements rank in the Top-100 high risk list prioritized according to absolute loss that shows discrepancy with the hazard zones determined by the Official Earthquake Hazard Map are; centre of Kütahya that ranks in the $40^{\text {th }}$ place, Tarsus that ranks in the 43 rd place, Corum that ranks in the $59^{\text {th }}$ place, Keşan that ranks in the $65^{\text {th }}$ place, Afyon that ranks in the $72^{\text {nd }}$ place, Çorlu that ranks in the $76^{\text {th }}$ place, Kozan that ranks in the $85^{\text {th }}$ place, Ceyhan that ranks in the $92^{\text {nd }}$ place, Kadirli that ranks in the $94^{\text {th }}$ place and Malkara that ranks in the $100^{\text {th }}$ place (See Appendix $\mathrm{G}$ for the total list).

In the examination of the metropolitan cities prioritized according to the absolute loss, the most remarkable result is seen in the Istanbul metropolitan city. Although it ranks in the first place of the high-risk metropolitan cities, it is classified in the second hazard zone according to the earthquake hazard map. As a result of this classification, insurance rate is calculated according to the second hazard level in the most vulnerable metropolitan city of the country.

This is another definite example that shows the inconsistency of using official earthquake hazard zoning map as a basis for calculating insurance costs for earthquake insurance.

Other metropolitan cities prioritized according to the absolute loss are consistent with hazard zones determined by the official earthquake hazard map (See Appendix G). 
Secondly, the top-20 settlements prioritized according to the relative loss is compared with the location of these settlements according to the hazard zones determined by the official earthquake hazard map of Turkey (See Appendix $\mathrm{H}$ for the total list).

When we examine the top-20 high risk settlements prioritized according to the relative loss, we observe that all of these high risk settlements are located in the first hazard zone according to the official earthquake hazard map of Turkey. This shows that the prioritization of settlements according to relative loss is consistent with hazard zones determined by the official earthquake hazard map and this also makes their insurance rate calculation consistent with our prioritization.

Table 6.11 Comparison of the Top-20 Settlements Prioritized According to the Relative Loss with the Hazard Zones Determined by the Official Earthquake Hazard Map

\begin{tabular}{|l|l|c|c|c|c|}
\hline PROVINCE & SUB-PROVINCE & $\begin{array}{c}\text { Expected } \\
\text { Intensity }\end{array}$ & $\begin{array}{c}\text { Relative Loss of } \\
\text { Settlements } \\
\text { (Loss Rate) }\end{array}$ & $\begin{array}{c}\text { Hazard } \\
\text { Zone }\end{array}$ & $\begin{array}{c}\text { Absolute } \\
\text { Loss }\end{array}$ \\
\hline YALOVA & CINARCIK & 8 & 0,21 & 1 & 357 \\
\hline SAKARYA & AKYAZI & 8 & 0,19 & 1 & 681 \\
\hline YALOVA & CIFTLIKKOY & 8 & 0,19 & 1 & 298 \\
\hline BOLU & BOLU M. & 8 & 0,18 & 1 & 1841 \\
\hline YALOVA & YALOVA C. & 8 & 0,18 & 1 & 1507 \\
\hline BURSA & ORHANGAZI & 8 & 0,18 & 1 & 945 \\
\hline TEKIRDAG & SARKOY & 8 & 0,18 & 1 & 712 \\
\hline TOKAT & NIKSAR & 8 & 0,17 & 1 & 1400 \\
\hline SAKARYA & HENDEK & 8 & 0,17 & 1 & 869 \\
\hline BOLU & GEREDE & 8 & 0,17 & 1 & 583 \\
\hline AMASYA & TASOVA & 8 & 0,17 & 1 & 282 \\
\hline YALOVA & TERMAL & 8 & 0,17 & 1 & 73 \\
\hline ERZINCAN & ERZINCAN C. & 8 & 0,16 & 1 & 2025 \\
\hline KASTAMONU & TOSYA & 8 & 0,16 & 1 & 1364 \\
\hline TOKAT & ERBAA & 8 & 0,16 & 1 & 1251 \\
\hline CORUM & OSMANCIK & 8 & 0,16 & 1 & 786 \\
\hline SAMSUN & HAVZA & 8 & 0,16 & 1 & 735 \\
\hline SAKARYA & GEYVE & 8 & 0,16 & 1 & 543 \\
\hline SIVAS & SUSEHRI & 8 & 0,16 & 1 & 424 \\
\hline SAMSUN & LADIK & 8 & 0,16 & 1 & 377 \\
\hline
\end{tabular}

Other settlements rank in the Top-100 high-risk list prioritized according to relative loss that shows discrepancy with the hazard zones determined by the Official Earthquake Hazard Map are; centre of Tekirdağ that ranks in the $44^{\text {th }}$ place, centre of Van that ranks in the $59^{\text {th }}$ place and centre of Adiyaman that ranks in the $94^{\text {th }}$ place (See Appendix $\mathrm{H}$ for the total list). 
The examination of the metropolitan cities prioritized according to the relative loss, shows parallel results with other prioritized settlements according to the relative loss. Metropolitan cities prioritized according to the absolute loss are consistent with hazard zones determined by the official earthquake hazard map with the exception of the Istanbul metropolitan city.

Consequently, the comparison of prioritized list of settlements according to both absolute and relative losses, with the hazard zones determined by the official earthquake hazard map shows us that the discrepancies is seen more in absolute losses than relative losses.

The results of the evaluation of insurance schemes show that; absolute loss is a more distinctive and important factor than relative loss in the evaluation of insurance schemes.

\subsection{National Investment Priorities and Regional Planning}

Regional inequalities have been one of the major problems of regional development policies in Turkey. Although various efforts have been made, socioeconomic disparities between regions have remained as an important development problem.

First efforts to reduce regional disparities within the country are started with the identification of Priority Provinces for Development (PPDs) in 1968. PPDs were defined to address regional inequalities by the State Planning Organization and over time its objectives have been revised and adjusted according to changing socio-economic conditions. The scope of PPDs was broadened in 1990 s and reached 49 provinces and 2 districts in 2003. The failure of the PPD policies to reduce regional inequalities is accepted in the 8th Five Year Development Plan (2000-2005) and a new investment package is created with Law No. 5084 in 2004 and improved in 2006.

A completely new incentive system was improved in 2009 and the provinces of Turkey were divided into four regions on the basis of NUTS 2 classification. This system that support amounts were differentiated among regional groups didn't solve the problems either. Accordingly the latest incentive system Degree No. 2012/3005 "Concerning State Encouragement to Investment" that increases the number of regions from four to six and differentiates the incentive amounts in order to provide advantageous schemes for less developed regions is devised in 2012.

The new investment incentive program differentiates from the previous ones with its province-based categorization. Provinces are divided into six regions in terms of priority of incentives where the provinces in the Region 6 will take the highest support and the provinces in Region 1 will take the lowest support. 


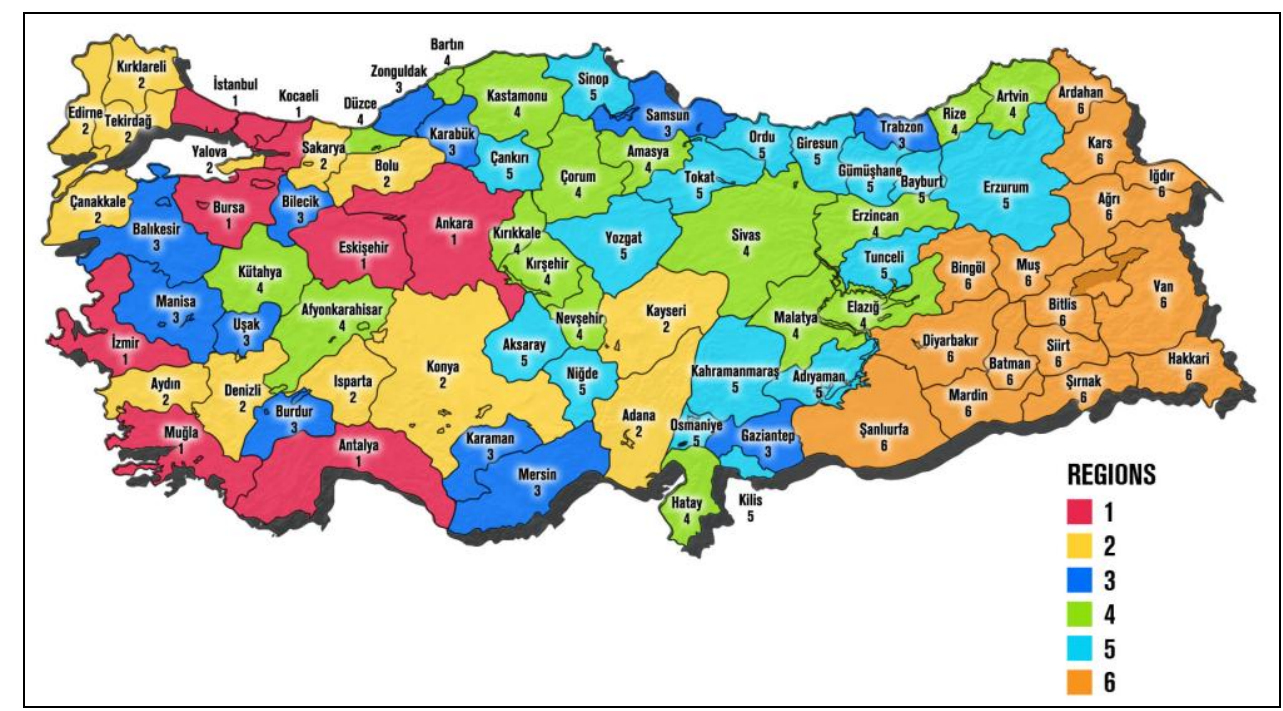

Figure 6.3 Investment Priority Regions

(Source: Ministry of Economy, 2012)

The core of these investment incentive system is to reduce socio-economic and regional inequalities by increasing the production and employment, providing economic growth and social improvement. But this drive in economic growth and social improvement will bring together rapid urbanization, informal settlements and unstable living environments that will increase the vulnerabilities of cities and raise the devastating effects of disaster risks.

Accordingly it is crucial to evaluate these investment incentives together with risk-sensitive planning systems, effective disaster mitigation strategies and strict building supervision practices in disaster prone cities. But neither the previous encouragements for investment nor the latest degree "Concerning State Encouragement to Investment" considers any risk-basis regulatory frameworks.

Another remarkable point of the latest degree is the priorities given to investments in industries such as defense, pharmaceuticals, mining, rail/sea transportation, education, tourism and test facilities for automotive/space industry.

Investments in these prioritized sectors will benefit from rates of the support measures of Region 5 even they are made in Regions 1, 2, 3 and 4. Most of these prioritized sectors can be classified as hazardous vulnerable facilities and should be coordinated with effective disaster mitigation strategies in the risk prone cities.

Besides, these sectoral priorities without discriminating disparities between regions are away from to overcome regional disparities and have only contributed the persistence of inequalities between regions despite the scope of the system. 
Considering all of these deficiencies of the latest investment system, the discrepancies between the location of settlements according to the investment priority regions and the prioritized lists of settlements according to the absolute and relative loss are examined.

To this end, first of all the top-20 settlements prioritized according to the absolute loss is compared with the location of these settlements according to the investment priority regions (See Appendix I for the total list).

Table 6.12 Comparisons of the Top-20 Settlements Prioritized According to the Absolute Loss with the Location of Settlements According to the Investment Priority Regions

\begin{tabular}{|l|c|c|c|}
\hline \multicolumn{1}{|c|}{ Province } & $\begin{array}{c}\text { Absolute } \\
\text { Loss }\end{array}$ & $\begin{array}{c}\text { Priority of } \\
\text { Incentives Region }\end{array}$ & $\begin{array}{c}\text { Relative Loss } \\
\text { of Settlements } \\
\text { (Loss Rate) }\end{array}$ \\
\hline ISTANBUL (M.) & 83824 & 1 & 0,10 \\
\hline KOCAELI (M.) & 24077 & 1 & 0,17 \\
\hline BURSA (M.) & 19168 & 1 & 0,08 \\
\hline IZMIR (M.) & 15727 & 1 & 0,03 \\
\hline SAKARYA (M.) & 10936 & 2 & 0,14 \\
\hline TOKAT & 3985 & 5 & 0,07 \\
\hline MANISA & 3875 & 3 & 0,03 \\
\hline HATAY & 3189 & 4 & 0,03 \\
\hline BALIKESIR & 3111 & 3 & 0,03 \\
\hline BOLU & 2990 & 2 & 0,14 \\
\hline ERZINCAN & 2925 & 4 & 0,14 \\
\hline TEKIRDAG & 2558 & 2 & 0,05 \\
\hline YALOVA & 2484 & 2 & 0,17 \\
\hline VAN & 2474 & 6 & 0,06 \\
\hline ADANA (M.) & 2343 & 2 & 0,01 \\
\hline AMASYA & 2210 & 4 & 0,06 \\
\hline CORUM & 1687 & 4 & 0,04 \\
\hline ANTALYA (M.) & 1644 & 1 & 0,01 \\
\hline KONYA (M.) & 1617 & 2 & 0,01 \\
\hline KASTAMONU & 1614 & 4 & 0,07 \\
\hline
\end{tabular}

When we examine the top-20 high risk settlements prioritized according to the absolute loss, we observe that two of these high risk settlements Tokat and Van are located in the region 5 and region 6 that will take the highest support in terms of priority of incentives (See Table 6.12 and Figure 6.4).

It can be evaluated so normal that less developed settlements needs investment incentives to increase production/employment in order to provide economic growth and the investment system gives the highest support to these less developed cities. 
But the specious point of the system is; although these settlements have rank in the top-20 high risk list, they classified in the highest support regions according to investment priority regions without taking any effective disaster mitigation and supervision strategies.

This inconsistent point of the system can be clearly seen in the example of Van, although the centre of Van is struck by a devastating earthquake recently and the city is highly vulnerable to seismic risks, the investors are supported especially in such industries mentioned above by the government without any mitigation and supervision strategies. This is a clear indication that the government didn't take any lessons from the devastating effects of earlier earthquakes. 


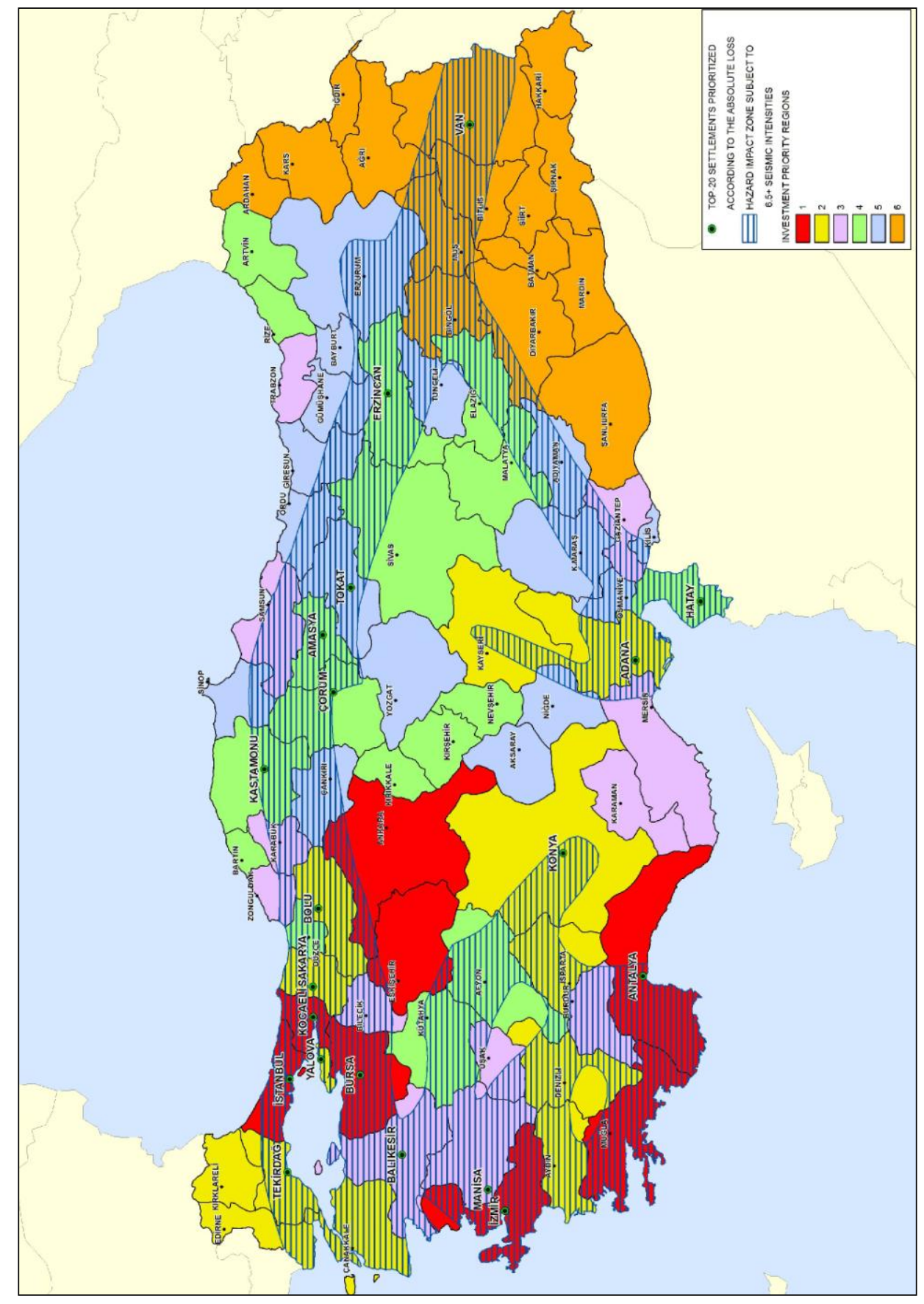

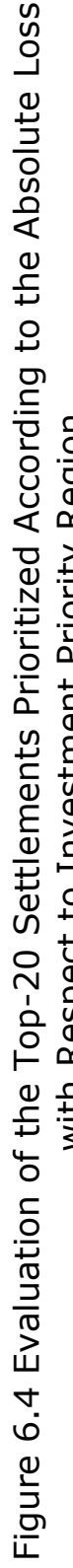


Other high-risk settlements located in the region 6 that will take the highest support in terms of priority of incentives are; Mus that ranks in the $30^{\text {th }}$ place, Bingöl that ranks in the $35^{\text {th }}$ place, Bitlis that ranks in the $40^{\text {th }}$ place and Diyarbakır that ranks in the $49^{\text {th }}$ place.

Settlements that are located in the Region 6 and assuming that insignificant damage is likely to take place in these settlements are also given below.

Table 6.13 High Risk Settlements Located in the Region Six Prioritized According to the Absolute Loss

\begin{tabular}{|c|c|c|c|}
\hline Province & $\begin{array}{c}\text { Absolute } \\
\text { Loss }\end{array}$ & $\begin{array}{c}\text { Priority of } \\
\text { Incentives } \\
\text { Region }\end{array}$ & $\begin{array}{c}\text { Relative Loss of } \\
\text { Settlements } \\
\text { (Loss Rate) }\end{array}$ \\
\hline 14-VAN & 2474 & 6 & 0,06 \\
\hline 30-MUS & 875 & 6 & 0,04 \\
\hline 35-BINGOL & 630 & 6 & 0,05 \\
\hline 40-BITLIS & 494 & 6 & 0,03 \\
\hline 49-DIYARBAKIR & 177 & 6 & 0,01 \\
\hline $\begin{array}{l}\text { 60-AĞRI, 62-ARDAHAN, } \\
\text { 65-BATMAN, 67-HAKKARİ, } \\
\text { 68-IĞDIR, 70-KARS, 74- } \\
\text { MARDİN, 77-SİİRT, 78- } \\
\text { ŞANLIURFA, } \\
\text { 79-ŞIRNAK, GÖKÇEADA AND } \\
\text { BOZCAADA DİSTRİCTS* }\end{array}$ & - & 6 & - \\
\hline
\end{tabular}

*All settlements with an expected hazard intensity level of 6.0 and less are excluded from the analyses assuming that insignificant damage is likely to take place in these settlements.

Secondly, the top-20 settlements prioritized according to the relative loss is compared with the location of these settlements according to the investment priority regions (See Appendix J for the total list).

When we examine the top-20 high risk settlements prioritized according to the relative loss, we observe that six of these high risk settlements; Tokat, Giresun, Tunceli and Çankırı are located in the region 5 and Van and Bingöl are located in the region 6 that will take the highest support in terms of priority of incentives (See Table 6.14 and Figure 6.5).

As mentioned above, although these settlements have rank in the top-20 high risk list, they classified in the highest support regions without taking any effective disaster mitigation and supervision strategies. This will raise the vulnerabilities of these settlements and the devastating effects of disaster risks. 
Table 6.14 Comparison of the Top-20 Settlements Prioritized According to the Relative Loss with the Location of Settlements According to the Investment Priority Regions

\begin{tabular}{|l|c|c|c|}
\hline \multicolumn{1}{|c|}{ Province } & $\begin{array}{c}\text { Relative Loss } \\
\text { of Settlements } \\
\text { (Loss Rate) }\end{array}$ & $\begin{array}{c}\text { Priority } \\
\text { of Incentives } \\
\text { Region }\end{array}$ & $\begin{array}{c}\text { Absolute } \\
\text { Loss }\end{array}$ \\
\hline KOCAELI (M.) & 0,17 & 1 & 24077 \\
\hline YALOVA & 0,17 & 2 & 2484 \\
\hline SAKARYA (M.) & 0,14 & 2 & 10936 \\
\hline BOLU & 0,14 & 2 & 2990 \\
\hline ERZINCAN & 0,14 & 4 & 2925 \\
\hline ISTANBUL (M.) & 0,10 & 1 & 83824 \\
\hline SIVAS & 0,10 & 4 & 1094 \\
\hline SAMSUN & 0,09 & 3 & 1614 \\
\hline BURSA (M.) & 0,08 & 1 & 19168 \\
\hline TOKAT & 0,07 & 5 & 3985 \\
\hline KASTAMONU & 0,07 & 4 & 1614 \\
\hline DUZCE & 0,07 & 4 & 1179 \\
\hline GIRESUN & 0,07 & 5 & 384 \\
\hline TUNCELI & 0,07 & 5 & 104 \\
\hline VAN & 0,06 & 6 & 2474 \\
\hline AMASYA & 0,06 & 4 & 2210 \\
\hline TEKIRDAG & 0,05 & 2 & 2558 \\
\hline CANKIRI & 0,05 & 5 & 957 \\
\hline BINGOL & 0,05 & 6 & 630 \\
\hline CORUM & 0,04 & 4 & 1687 \\
\hline
\end{tabular}

Other high risk settlements prioritized according to the Relative Loss and located in the region 6 that will take the highest support are; Muş, Bingöl, Bitlis and Diyarbakır as same as given in the Table 6.13. Investment incentives in these provinces should put into practice together with risk-sensitive planning systems, effective disaster mitigation and building supervision strategies.

Consequently, the comparison of prioritized list of settlements according to both absolute and relative losses, with the location of these settlements according to the investment priority regions shows us that the discrepancies is seen more in relative losses than absolute losses.

The results of the evaluation of investment incentives show that; relative loss is a more distinctive and important factor than absolute loss in the evaluation of investments. 


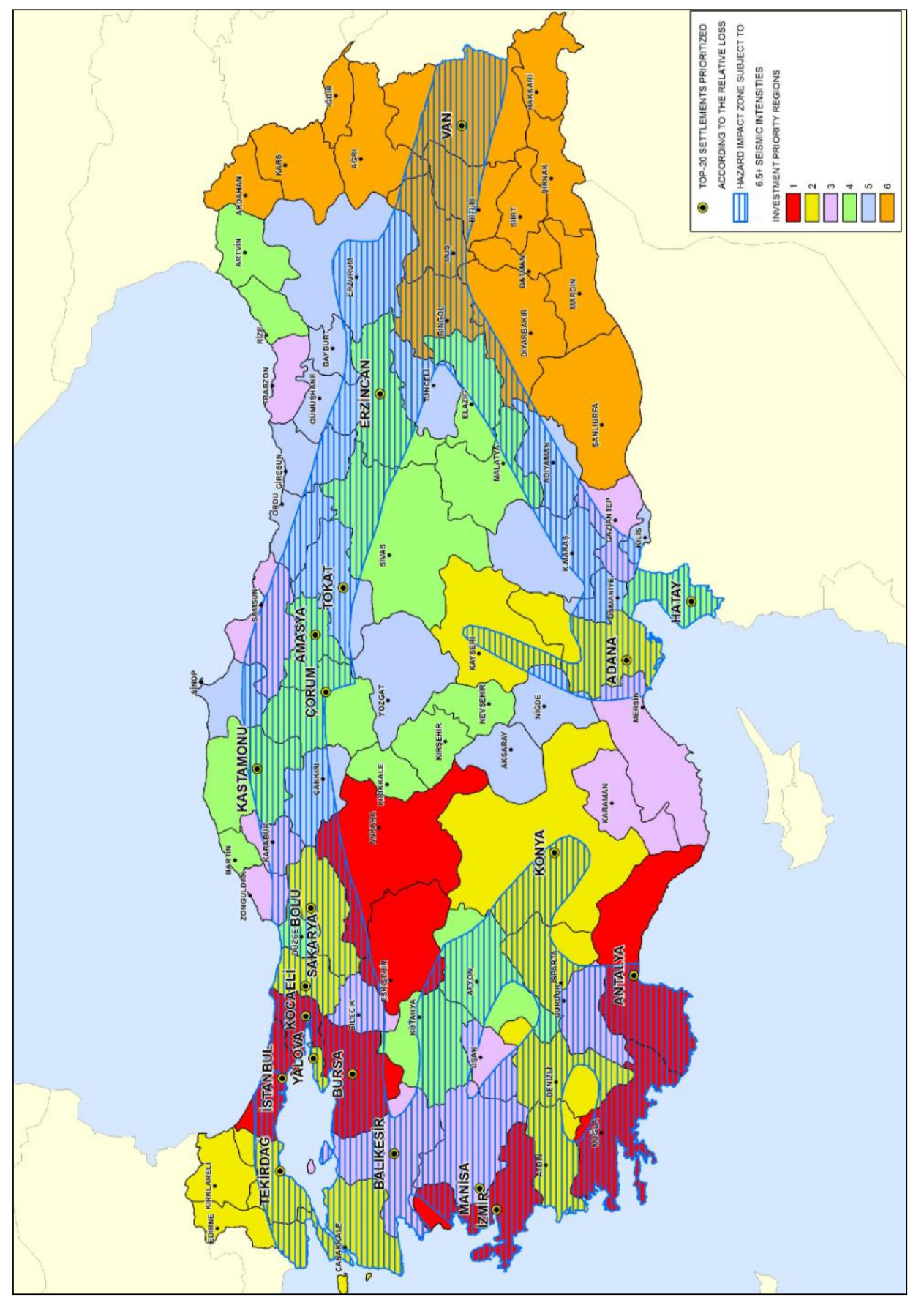

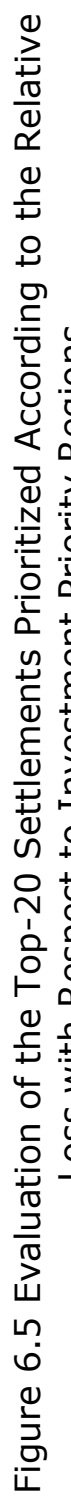




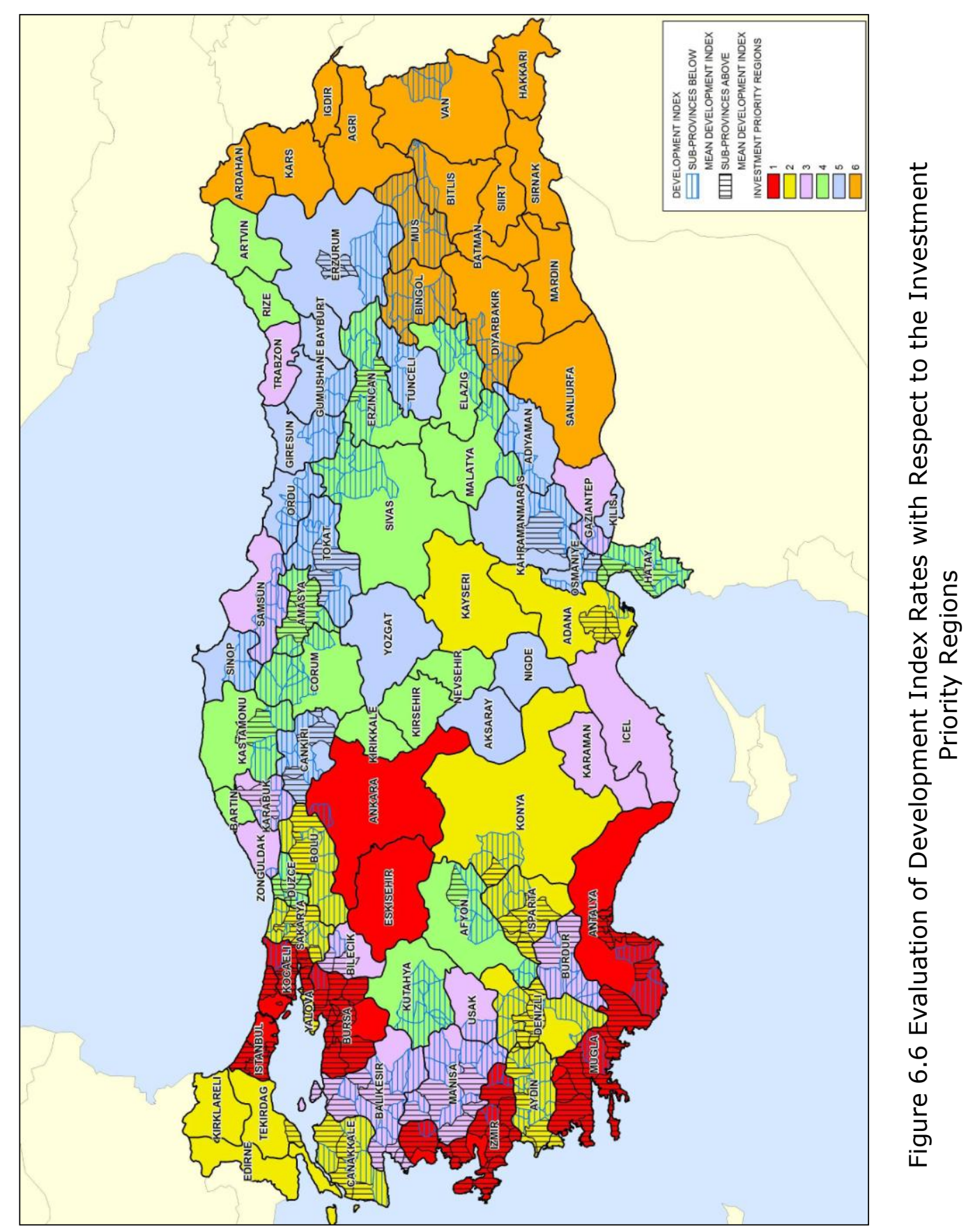




\section{CHAPTER 7}

\section{CONCLUSION AND FURTHER LINES OF INVESTIGATION}

Chronic seismic hazards and resulting secondary impacts as natural conditions of the country, and loss of robust building and prudent settlement practices as aggravated by rapid population growth make cities the most vulnerable geographical and social entities in Turkey. In contrast, Turkish disaster policy is solely focused on post-disaster issues and no incentives or provision exist to encourage risk analysis or risk mitigation approaches, despite current international efforts.

For the development of risk reduction policies an essential step is to prioritize settlements according to their vulnerability levels. This is determined by hazard probabilities and attributes of the building stock of each settlement. Measurement of vulnerability levels allows the ordering of settlements into risk categories.

Quantitative information about a set of attributes of settlements is investigated statistically to determine which of the factors contribute most to risk levels described locally. The seismic hazard maps of the Kandilli Observatory and Earthquake Research Institute (KOERI), Erdik estimations of seismicity and statistics published by the Turkish Statistical Institute (TurkStat), like census and housing data have a leading contribution to make.

In order to determine the seismic vulnerabilities and risks of settlements, disaster component that reveals the settlement level loss in building stock is examined on one side and the basic attributes of settlements and their effects on loss levels on the other side. This double sided process generates the dependent and independent variables of the research.

In the determination of seismic vulnerabilities and risks of settlements, loss levels in the building stock in each settlement evaluated based on seismic hazard intensity via seismic hazard maps produced by KOERI and building stock vulnerability curves derived by Demircioglu. Settlement level loss in the building stock is the basic indicator of assumed overall vulnerability (risk) and provides the dependent variables of the research.

Y1 that is determined as Absolute Loss is the first dependent variable of the research and composed of the total number of building loss. Y2 that is determined as Relative Loss is the other dependent variable of the research and composed of the ratio of loss to the total building stock

Vulnerability levels of settlements are then assumed to depend on a number of attributes of cities to explore if vulnerability could be related to a set of urban properties.

The basic attributes of settlements are composed of building inventory data and related attributes of building stock on each settlement obtained from TurkStat. 
'Building Construction Statistics', 'Building Census' and 'Population Census' prepared by TurkStat and 'Development Index' prepared by State Planning Organization is used within this research.

Attributes of settlements that are assumed to contribute to vulnerabilities and estimated loss are measurable indicators as independent variables. In terms of available data independent variables of the research are determined as; $\mathrm{X} 1=$ Settlement Population, X2 = Population Growth Rate $(\% 0), X 3=$ Rates of Agglomeration, $\mathrm{X} 4=$ Population/Total Number of Buildings, $\mathrm{X} 5=$ Development Index.

Although absolute loss may represent a concrete measure of loss, relative loss in settlements also is taken into account. Small settlements with low values of absolute loss, but with high ratios may indicate greater impact and disturbance of hazard in urban life, than loss of similar or higher magnitude but smaller ratios in the larger cities or metropolitan agglomerations. Therefore the level of loss in each category of building types in each settlement is expressed both in absolute terms (total number of buildings lost) and in relative terms (ratio of loss to the total building stock/loss rate).

After determining the level of loss both in absolute terms (total number of buildings lost) and relative terms (ratio of loss to the total building stock), and the attributes of settlements that are assumed to contribute to vulnerabilities, all settlements in each size category are prioritized according to absolute and relative losses.

The top-20 settlements for $0-50.000$ population are significantly above the category averages in terms of 'settlement population' and 'rate of agglomeration'. The average rates of growth and development indices are either negative or very small. Many of the settlements in this category are stagnant or in the process of negative growth.

Greater numbers of settlements that take place in the upper 20 in this category have relatively central status within their sub-province. Rates of agglomeration for these settlements are more or less leveled in the sub-province with the rural population. Only a few of these settlements represent stronger agglomeration centers. These also indicate positive growth and development.

Top-20 Settlements for 0-50.000 Population Prioritized According to Absolute Loss are; 1-Niksar (Tokat), 2-Tosya (Kastamonu), 3-Hendek (Sakarya), 4-Osmancık (Çorum), 5-Havza (Samsun), 6-Şarköy (Tekirdag), 7-Akyazı (Sakarya), 8-Suluova (Amasya), 9-Üzümlü (Erzincan), 10-Gerede (Bolu), 11Geyve (Sakarya), 12-Ayvalık (Balıkesir), 13-Suşehri (Sivas), 14-Burhaniye (Balıkesir), 15-Pamukova (Sakarya), 16-Varto (Mus), 17-Ladik (Samsun), 18Çınarcık (Yalova), 19-Çeşme (İzmir), 20-Yenişehir (Bursa).

Top-20 Settlements for 0-50.000 Population Prioritized According to Relative Loss are; 1-Çınarcık (Yalova), 2-Akyazı (Sakarya), 3-Çiftlikköy (Yalova), 4-Şarköy (Tekirdag), 5-Niksar (Tokat), 6-Hendek (Sakarya), 7-Gerede (Bolu), 8Taşova (Amasya), 9-Termal (Yalova), 10-Tosya (Kastamonu), 11-Osmancık (Corum), 12-Havza (Samsun), 13-Geyve (Sakarya), 14-Suşehri (Sivas), 15Ladik (Samsun), 16-Ilgaz (Çankırı), 17-Reşadiye (Tokat), 18-Yeniçağa (Bolu), 19-Çamoluk (Giresun), 20-Pülümür (Tunceli). 
In contrast to the previous category of settlements, many cases in 50.000490.00 population categories prove high levels of absolute loss determined less dependently on strength of seismic shake and there are variations in seismic intensity levels and rates of loss. Apart from a very few of the cases here, rates of loss seem to be lower than observed in the previous category and almost half of the top 20 in the list have higher rates than the average rate for this category.

Rate of population increases in $50.000-490.00$ population category and almost identical rates of growth are observed. Apart from the province center of Erzincan, all settlements are in the process of growth, and half of the top 20 at higher rates than the average rate for this category. This is further confirmed by the development index figures, again half of the top 20 at higher rates than the average development index for this category.

Stronger agglomeration is observed in this category of settlements, compared to the weak agglomeration rates of the previous category of settlements, even though growth is also an attribute of the rural context for settlements.

Top-20 Settlements for 50.000-490.000 Population Prioritized According to Absolute Loss are; 1-Van Central, 2-Erzincan Central, 3-Bolu Central, 4Yalova Central, 5-Tekirdag Central, 6-Erbaa (Tokat), 7-Orhangazi (Bursa), 8Manisa Central, 9-Osmaniye Central, 10-Antakya (Hatay), 11-İskenderun (Hatay), 12-Adiyaman Central, 13-Merzifon (Amasya), 14-Turgutlu (Manisa), 15Düzce Central, 16-Denizli Central, 17-Akhisar (Manisa), 18-İnegöl (Bursa), 19Tokat Central, 20-Salihli (Manisa).

Top-20 Settlements for 50.000-490.000 Population Prioritized According to Relative Loss are; 1-Bolu Central, 2-Yalova Central, 3-Orhangazi (Bursa), 4Erzincan Central, 5-Erbaa (Tokat), 6-Tekirdağ Central, 7-Merzifon (Amasya), 8Düzce Central, 9-Van Central, 10-Manisa Central, 11-İnegöl (Bursa), 12-Salihli (Manisa), 13-Bandirma (Balıkesir), 14-Çanakkale Central, 15-Amasya Central, 16-Mustafakemalpaşa (Bursa), 17- Osmaniye Central, 18-Antakya (Hatay), 19İskenderun (Hatay), 20-Adiyaman Central.

Ordering seems to follow seismic intensities rather than absolute size of the building stock in metropolitan provinces and a very distinct group of four metropolitan cities (Kocaeli, Sakarya, İstanbul, İzmir) with high ratio of loss are observed.

The top 20 of the settlements for metropolitan cities are significantly below the category averages in terms of 'settlement population' and 'development index'.

Metropolitan Provinces Prioritized According to Absolute Loss Levels are; İstanbul, Kocaeli Bursa, İzmir, Sakarya, Adana, Antalya, Konya, Erzurum.

Metropolitan Provinces Prioritized According to Relative Loss Levels are; Kocaeli, Sakarya, İstanbul, Bursa, İzmir, Adana, Antalya, Konya, Erzurum.

These prioritized lists of settlements according to their vulnerability levels should be accepted as the basis of the mitigation policies in higher-risk settlements and these cities within the highest hazard zone should obviously be the object of mitigation programs before those in areas of lower hazard. 
Priorities of mitigation planning should be constituted with respect to these prioritized lists of settlements according to their vulnerability levels and it should be compulsory to prepare mitigation plans for the settlements that have rank in the top-20 high risk lists.

Effective disaster mitigation strategies and more strict legal regulations about preparation of mitigation plans should be executed in these higher-risk settlements and cities within the highest hazard zone. Although, cities within the highest risk zones should obviously be the object of more strict inspection mechanisms than those of lower risks.

Urban standards for land use management as well as building construction are essential elements of disaster mitigation and it should be taken into consideration that different seismic intensity levels have different requirements of standards.

Land-use planning and zoning, planning of open-spaces, transportation and infrastructure planning are all distinct aspects of disaster mitigation and all these systems are to be implemented at different standards according to risk levels. Rigorous implementation and enforcement of differentiated standards according to risk levels must be the highest priority for reducing risk factors, vulnerabilities and potential losses.

Appropriate locational differentiation is a crucial input in engineering design safety of buildings based on risk maps. Urban planning standards and principles together with risk-minimizing planning systems could effectively serve to mitigate risks and promote strict building supervision practices in these disaster prone cities. To this end, urban planning standards and principles could be determined according to risk levels/zones determined by vulnerability maps and more strict planning standards could be executed in these higher-risk settlements. Although, it is crucial to evaluate investment incentives together with risk-sensitive planning systems, effective disaster mitigation strategies and strict building supervision practices in disaster prone cities.

Besides providing guiding principles for effective mitigation practices in Turkey by ordering settlements and offer means of differential implementation, another purpose of the study is to investigate the relations between measures of vulnerability (dependent variables) and contributing attributes (independent variables) by means of regression methods.

Best subsets regression analyses are employed to determine what combinations of the independent variables might best denote city-level risks. The results of the best subsets analyses give us the "most appropriate combination" for the regression analyses.

The results of best subsets regression analyses of top-20 settlements for the first category, that considers settlements having population up to 50.000, shows that X1 (settlement population) and X5 (development index) are the most effective independent variables that correlates with both dependent variables.

Six regression analyses are performed according to the results of best subsets regression analyses for Category I, which considers settlements having population up to 50.000 . 
These are; Regression Analysis: $Y 1$ (absolute loss) versus $X 1$ (settlement population), $Y 1$ versus $X 5$ (development index), $Y 2$ (rate of loss) versus $X 1$ (settlement population), $Y 2$ versus $X 3$ (rates of agglomeration), $Y 2$ versus $X 4$ (population /total number of buildings) and Y2 versus $X 5$ (development index).

The results of best subsets regression analyses of top-20 settlements for the second category, that considers settlements having population between 50.000 and 490.000 , shows that X4, the ratio of population to total number of buildings, is the most effective and only independent variable that correlates with both dependent variables.

Four regression analyses are performed according to the results of best subsets regression analyses for Category II that considers settlements having population between 50.000 and 490.000. These are; Regression Analysis: Y1 (absolute loss) versus $\mathrm{X} 2$ (population growth rate), $\mathrm{Y} 1$ versus $\mathrm{X} 4$ (population /total number of buildings), Y2 (rate of loss) versus $X 1$ (settlement population), and Y2 versus $\mathrm{X} 4$ (population /total number of buildings.

The results of best subsets regression analyses for the third category, that considers metropolitan cities, shows that X3 (Rates of Agglomeration) and X4 (Population/Total Number of Buildings) are the most effective independent variables that correlates with both dependent variables.

Five regression analyses are performed according to the results of best subsets regression analyses for Category III that considers metropolitan cities. These are; Regression Analysis: Y1 (absolute loss) versus X1 (settlement population), $Y 1$ versus $X 3$ (rates of agglomeration), Y1 versus $X 4$ (population /total number of buildings), Y2 (rate of loss) versus $X 3$ (rates of agglomeration) and $Y 2$ versus $\mathrm{X} 4$ (population /total number of buildings).

After obtaining the "most appropriate combinations" for the regression analyses by best subsets regression analyses, regression analyses are performed in all settlements in each size category.

Six regression analyses are performed according to the results of best subsets regression analyses for Category I, which considers settlements having population up to 50.000 . The results of these analyses show that; $Y 1$ (absolute loss) has no relations with independent variables, Y2 (rate of loss) has weak relations with X3 (rates of agglomeration), X4 (population /total number of buildings) and X5 (development index).

Four regression analyses are performed according to the results of best subsets regression analyses for Category II, which considers settlements having population between 50.000-490.000 inhabitants. The results of these analyses show that; $Y 1$ (absolute loss) has no relations with $X 2$ (population growth rate) and weak relations with $X 4$ (population /total number of buildings). Y2 (rate of loss) has weak relations with X1(settlement population) and no relations with $\mathrm{X} 4$ (population/ total number of buildings).

Five regression analyses are performed according to the results of best subsets regression analyses for Category III, which considers metropolitan cities. 
The results of these analyses show that; $Y 1$ (absolute loss) has strong relations with $\mathrm{X} 1$ (settlement population), no relation with $\mathrm{X} 3$ (rates of agglomeration) and weak relations with $X 4$ (population / total number of buildings). Y2 (rate of loss) has weak relations with X3 (rates of agglomeration) and X4 (population /total number of buildings).

As a result of these analyses we can say that Absolute Loss (YI) has no significant relations with independent variables of settlements in Category I that have populations up to 50.000 and settlements in Category II that have populations between 50.000 and 490.000 . Disparately, Absolute Loss is strongly related with settlement populations of metropolitan cities in Category III.

When we examine the results of analyses according to Relative Loss/Rate of Loss (Y2), we can say that Rate of Loss has weak relations both with independent variables of settlements in Category I that have populations up to 50.000, settlements in Category II that have populations between 50.000 and 490.000, and metropolitan cities in Category III.

Consequently, results of statistical analyses indicate that total building loss is related to the ratio of population over the total number of buildings in mid-range settlements, and directly related to population in metropolitan cities. Relative loss on the other hand is related with rate of agglomeration and development index in almost every size category of settlements.

For further lines of investigation, the results of this study can be converted into more precise information on actual volume of building stock by converting the loss in number of buildings by estimations of building floor area. Still further, it is possible to have an economic estimation of the loss in physical stock by taking into consideration the building costs and values. 


\section{REFERENCES}

Adanalı, Y.A., Urban transformation and law on disaster prevention: A pretext for lucrative investment, Perspectives - Political Analysis and Commentary from Turkey \#3, Heinrich Böll Stiftung - Turkey Representation, 2012.

African Development Bank (AFDB), Guidelines for Mainstreaming Disaster Risk Assessment in Development, 2004.

Akalın İ. and Sürel C.S., Turkey: The Biggest Construction Site on Earth: Turkey What to Expect From the Urban Regeneration Law, Newsletter on Turkish Law Developments - Hergüner Bilgen Özeke Attorney Partnership, 2012.

Asian Disaster Preparedness Centre (ADPC), Urban Governance and Community Resilience Guides, World Disaster Reduction Campaign on Making Cities Resilient, 2010.

Balamir M., Prioritization of High Seismic Risk Provinces and Public Buildings, 2011.

Balamir M., 1999 Depremlerinden 10 Yıl Sonra Türkiye Nerede? Uluslararası Afetler Politikasındaki Gelişmeler Açısından Bir İrdeleme, 2009.

Balamir M., Seismic Risks and Urban Mitigation Planning, chapter in the text book entitled; Tomorrow at Risk: Disasters in Europe and Greece, edited by Sapountzaki, HUA, TYPOTHETO - George Dardanos, Greece, 2007.

Balamir M., Seismic Mitigation Efforts in Istanbul: ISMEP Projects Short of Mitigation Planning, DPRI-IIASA Meeting, Istanbul, 2006.

Balamir M., Challenges and Methodology for Preventing Major Urban Risks: Designing a Prevention Policy, EUROPE-MENA Urban Network the Cities Meetings Preventing Major Urban Risks, Amman, 2005.

Balamir M., Local Administration and Risk Management, The Role of Local Governments in Reducing the Risk of Disasters, Demeter K., Guner A., Erkan N. E. (eds.), Center of Local Government Studies and Training, Marmara University, Istanbul, 2004. 
Balamir M., Urban Seismic Risk Management: The Earthquake Master Plan of Istanbul (EMPI), 13th World Conference on Earthquake Engineering, Vancouver, Canada, 2004.

Balamir M., Painful Steps of Progress from Crisis Planning to Contingency Planning: Proposed and Realized Changes for Disaster Preparedness in Turkey', The Journal of Contingencies and Crisis Management, Leiden 10: 1, 2002.

Balamir M., Recent Changes in Turkish Disasters Policy: A Strategic Reorientation, in Kleindorfer, Mitigation and Financing of Seismic Risks: Turkish and International Perspectives, Paul and Sertel (eds.), Dordrecht: Kluwer Academic Publishers, 2001.

Balamir M., Disaster Policies and Social Organisation, Disaster and Social Crisis Research Network sessions: 5th Conference of ESA, Helsinki, 2001.

Balamir M., Reproducing the Fatalist Society: An Evaluation of the Disasters and Development Laws and Regulations in Turkey, in Urban Settlements and Natural Disasters, ed. E. Komut, UIA and Chamber of Architects of Turkey, 1999.

Banba M, et al., Analysis of Land Use Management for Earthquake Disaster Reduction in the Asia Pacific Region, 2004.

Bayhan F., Impacts Of Planning Decisions in an Earthquake Vulnerable City: The Case of Adapazarı, Unpublished Master Thesis, Middle East Technical University, 2010.

Benton M., The Richter, The Modified Mercalli and The Moment Magnitude Scale, last accessed date December 2012.

Available at: http://studyoftheearth3.wikispaces.com/

Bogardi J.J., Measuring Vulnerability to Natural Hazards: Towards Disaster Resilient Societies, edited by Jörn Birkmann, United Nations University Press, 2006.

Boulle P., Luc V and Elina P., Vulnerability Reduction for Sustainable Urban Development, Disasters: 5, 1991.

Briceno S., Building Disaster Resilient Communities: The road to the World Conference on Disaster Reduction January 2005, Kobe, Hyogo, Japan, 2004.

Burby J. R., Cooperating with Nature: Confronting natural hazards with land-use planning for sustainable communities, Joseph Henry Press, Washington DC. 1998. 
Cardona O.D., The Need for Rethinking the Concepts of Vulnerability and Risk from a Holistic Perspective: A Necessary Review and Criticism for Effective Risk Management in Mapping Vulnerability: Disasters, Development and People, London, UK: Earthscan Publishers, 2004.

Centre for Research on the Epidemiology of Disasters (CRED), Annual Disaster Statistical Review-2010, The numbers and trends, 2010.

Coburn A. and R. Spence, Factors Determining Human Casualty Levels in Earthquakes: Mortality Prediction in Building Collapse, 10th World Conference on Earthquake Engineering, Spain, 1992.

Coburn A. and Spence R., Earthquake Protection, John Wiley and Sons Ltd., England, 1992.

Coburn A., Disaster Prevention and Mitigation in Metropolitan Areas: Reducing Urban Vulnerability in Turkey, in Informal Settlements, Environmental Degradation and Disaster Vulnerability: The Turkey Case Study, eds. R. Parker, A. Kreimer, M. Munasinghe, IDNDR and the World Bank, Washington, D.C., 1995.

Columbia University International Urban Planning Studio Disaster Resistant Istanbul, Urban Planning Studio of Graduate School of Architecture, Planning and Preservation, and Lamont-Doherty Earth Observatory, unpublished report, 2002.

Columbia University International Urban Planning Studio Disaster Resistant Caracas, Urban Planning Studio of Graduate School of Architecture, Planning and Preservation, and Lamont-Doherty Earth Observatory, unpublished report, 2001.

Cozzi S., Menoni S. et.al., Natural risk prevention and land-use planning in Italy: Strengths and weaknesses of a system stretched between centralized and decentralized authorities. In: Fleischhauer, M., Greiving, S. \& Wanczura, S. (editors), Natural hazards and planning in Europe, Dortmund, 2006.

Crowley H., Colombi M., Borzi B., Faravelli M., Onida M., Lopez M.,Polii D., Meroni F. and Pinho R., A Comparison of Seismic Risk Maps for Italy, BEE, 2008.

Demircioğlu M.B., Earthquake Hazard and Risk Assessment for Turkey, Unpublished PhD Thesis, Boğaziçi University, 2010.

DRM, Seismic Microzonation for Municipalities Manual, World Institute for Disaster Risk Management, last accessed date 22.09.2004

Available at: http://www.drmonline.net/drmlibrary. 
EM-DAT, The OFDA/CRED International Disaster Database, Université Catholique de Louvain, Brussels, Belgium, last accessed date 26.08.2011. Available at: http://www.emdat.be/

EMS-98, European macroseismic scale 1998, Cahiers du Centre Européen de Géodynamique et de Séismologie. Conseil de l'Europe. Luxembourg, Grünthal, G. (editor), 1998.

Erdik, M. and N. Aydınoglu, Earthquake Performance and Vulnerability of Buildings in Turkey, The World Bank Group Disaster Management Facility Report, 2002.

Earthquake Masterplan for Istanbul (EMPI), Bogazici University, Istanbul Technical University, Middle East Technical University and Yildiz Technical University, The Metropolitan Municipality of Istanbul, last accessed date 12.08.2003.

Available at: http://www.koeri.boun.edu.tr/depremmuh/IBB.IDMP.ENG.pdf

FEMA, Estimated Annualized Earthquake Losses for the United States, Federal Emergency Management Agency, Washington DC, USA, 2008.

FEMA, Federal Emergency Management Agency, last accessed date December 2012. Available at: http://www.fema.gov/

Gencer E., Vulnerability in Hazard-Prone Megacities: An Overview of Global Trends and the Case of the Istanbul Metropolitan Area, Summer Academy for Social Vulnerability, 2007.

Global Assessment Report on Disaster Risk Reduction (GAR), United Nations Inter-Agency Secretariat of the International Strategy for Disaster Reduction UNISDR, 2011.

Global Assessment Report on Disaster Risk Reduction (GAR), United Nations Inter-Agency Secretariat of the International Strategy for Disaster Reduction UNISDR, 2009.

Godschalk D. R., Beatley T., Berke P., Brower D. J., Kaiser E. J., Natural Hazard Mitigation: Recasting Disaster Policy and Planning, Island Press, Washington, D. C. , 1999 .

Greene A., A Process Approach to Project Risk Management, Doctoral research workshop: Construction Process Research, Loughborough University, 2000. 
Istanbul Seismic Risk Mitigation and Emergency Preparedness Project (ISMEP), 2010.

JICA, Country Strategy Paper for Natural Disasters in Turkey, Final Report, Ankara, 2004.

JICA-IBB, The Study on A Disaster Prevention / Mitigation Basic Plan in Istanbul including Seismic Microzonation in the Republic of Turkey, 2002.

Johnson C., Regulatory frameworks for reducing disaster risk through planning and building, 2012.

Kandilli Observatory and Earthquake Research Institute (KOERI), Earthquake Risk Assessment for Istanbul Metropolitan Area, Report prepared for American Red Cross and Turkish Red Crescent, Bogaziçi University, 2002.

Kandilli Observatory and Earthquake Research Institute (KOERI), An Earthquake Damage Scenario and Earthquake Master Plan for the city of Izmir, last accessed date September 2000, Available at:

http://www.koeri.boun.edu.tr/depremmuh/izmir/izmirrapor2002.htm

Keles R., Turkish Government Structure from a Disaster Management Perspective, The Role of Local Governments in Reducing the Risk of Disasters, Demeter K., Guner A., Erkan N. E., (eds.), Center of Local Government Studies and Training, Marmara University, İstanbul, 2004.

Kreimer et. al., Managing Disaster Risk in Mexico, Market Incentives for Mitigation Investment, The World Bank, Washington, DC, 1999.

LESSLOSS, Risk Mitigation for Earthquakes and Landslides Project, last accessed date November 2004. Available at: http://www.lessloss.org/

Lewis, D. and Mioch J., Urban Vulnerability and Good Governance, Journal of Contingencies and Crisis Management, 2005.

McBean G. and Henstra D., Climate Change, Natural Hazards and Cities for Natural Resources Canada, Institute for Catastrophic Loss Reduction (ICLR) Research, Paper Series No. 31, 2003.

McEntire David A., Triggering Agents, Vulnerabilities and Disaster Reduction, Disaster Prevention and Management, Volume 10, Number 3, 2001. 
McGregor R., The Hawke's Bay earthquake: New Zealand's greatest natural disaster, Napier, N.Z., Art Deco Trust, 1998.

Middleton D., A roof over their heads: The challenge of accommodation following disasters, Emergency Management Conference, New Zealand, 2007.

Ministry of Economy, Investment Priority Regions, 2012.

Orhan E., Post-Disaster Recovery Processes and Location Choices of Businesses In Case Of Adapazarı, Unpublished Doctorate Thesis, Middle East Technical University, 2012

PEER (Pasific Earthquake Engineering Research Center), Structural Engineering Reconnaissance of the August 17, 1999 Earthquake: Kocaeli (Izmit), Turkey, University of California, Berkeley, 2000.

Pelling M., The Vulnerability of Cities: Natural Disaster and Social Resilience, Earthscan Publications, 2003.

Pelling M., Urbanization and Disaster Risk, Population-Environment Research Network Cyber seminar on Population and Natural Hazards, 2007.

Prota Engineering, Prioritization of High Seismic Risk Provinces and Public Buildings, 2011.

Quarantelli, E L., Urban Vulnerability to Disasters in Developing Countries: Managing Risks. In Building Safer Cities: The Future of Disaster Risk, edited by A. Kreimer, M. Arnold and A. Carlin. Washington, DC: World Bank, 2003.

Rosetto, T. Construction Design, Building Standards and Land Use Planning, Guidance Note No. 12, 2006.

Scawthorn, C. et.al. Earthquake Risk Reduction, developed for WBI DL, Course by Kyoto University, Unpublished Report, 2006.

Schwab, J. et. al., Planning for Post-Disaster Recovery and Reconstruction, FEMA and American Planning Association, Planning Advisory Service Report 483/484, Chicago, 1998.

Siegel B., No Regrets Approach to Decision-Making in a Changing Climate: Toward Adaptive Social Protection and Spatially Enabled Governance, World Bank, 2011. 
Spangle Associates, Rebuilding After Earthquakes: Lessons from Planners, International Symposium on Rebuilding After Earthquakes, Stanford University, August 12-15 1990, California. Spangle and Associates Inc., 1991.

Spangle Associates, The Recovery and Reconstruction Plan of the City of Los Angeles: Evaluation of Its Use after the Northridge Earthquake, research report, Portola Valley, 1997.

State Planning Organization (SPO), İlçelerin Sosyo-Ekonomik Gelişmişlik Sıralaması Araştırması, 2004.

Sucuoğlu H., Seismic risk mitigation studies in Istanbul, 8th National Conference on Earthquake Engineering (8NCEE), 2006.

SED, The Swiss Seismological Service, last accessed date December 2012. Available at: http://www.seismo.ethz.ch/index

TCIP, Turkish Compulsory Insurance Pool, last accessed date December 2012. Available at: http://www.dask.gov.tr.

TEFER (Turkey Emergency Flood and Earthquake Recovery), A Probabilistic Seismic Hazard Assessment For Turkey, Report prepared in connection with the Improvement Of Natural Hazard Insurance And Disaster Funding Strategy Project, 2000.

Thiruppugazh V., Urban Vulnerability Reduction: Regulations and Beyond, ASARC Working Paper, 2007.

TURKSTAT, Building Census, 2000.

TURKSTAT, Building Construction Statistics, 2000.

TURKSTAT, Address Based Population Registration System Database, last accessed date December 2012. Available at: http://www.turkstat.gov.tr/

UNISDR Terminology on Disaster Risk Reduction, United Nations Inter-Agency Secretariat of the International Strategy for Disaster Reduction UNISDR, 2009.

United Nations Development Program UNDP, Reducing Disaster Risk: A Challenge for Development, A Global Report, UNDP-Bureau for Crisis Prevention and Recovery (BRCP), New York, last accessed date February 2004.

Available at: http://www.undp.org/bcpr/disred/rdr.htm. 
United Nations Human Settlement Program UNDP, Urbanization: Facts and Figures, 2002.

United Nations International Strategy for Disaster Reduction (UN/ISDR), Living with Risk, A Global Review of Disaster Reduction Initiatives, 2004.

United Nations International Strategy for Disaster Reduction, UNISDR, Yokohama Strategy and Plan of Action for a Safer World: Guidelines for Natural Disaster Prevention, Preparedness and Mitigation, Resolution adopted by delegates of the World Conference on Natural disaster Reduction, Yokohama, Japan, 23-27 May, 1994.

United Nations International Strategy for Disaster Reduction, UNISDR, Hyogo Declaration, Resolution adopted by delegates of the World Conference on Disaster Reduction, Kobe, Hyogo, Japan, 18-22 January, 2005.

United States Geological Survey, USGS, last accessed date December 2012. Available at: http://www.usgs.gov

Wamsler, C. Mainstreaming Risk Reduction in Urban Planning and Housing: A Challenge for International Aid Organizations, Disasters (30:2), 2006.

Wisner B, Blaikie P, Cannon T, Davis I, At Risk: Natural Hazards, People's Vulnerability and Disasters, London: Routledge, 2003.

Wood, H.O., and Neumann F., Modified Mercalli Intensity Scale, Seismological Society of America Bulletin - 21, 1931.

Yüzügüllü Ö., Barbarosoglu G., Erdik M., Seismic Risk Mitigation Practices In School Buildings In Istanbul, Turkey, Kandilli Observatory and Earthquake Research Institute Bogaziçi University, Turkey, 2004. 


\section{APPENDIX A}

\section{BUILDING STOCK ATTRIBUTES ACCORDING TO CONSTRUCTION TYPE AND NUMBER OF STOREYS}

\begin{tabular}{|c|c|c|c|c|c|c|}
\hline Provinces & Sub-Provinces & Intensity & $\begin{array}{c}\text { Load } \\
\text { Bearing } \\
\text { Construction } \\
(1-3 \text { storeys })\end{array}$ & $\begin{array}{c}\text { Frame } \\
\text { Construction } \\
\text { Low- Rise } \\
(1-3)\end{array}$ & $\begin{array}{c}\text { Frame } \\
\text { Construction } \\
\text { Mid-Rise } \\
(4-9)\end{array}$ & \begin{tabular}{|c} 
Frame \\
Construction \\
High-Rise \\
$(10+)$
\end{tabular} \\
\hline ADANA & YUMURTALIK & 6,5 & 1377 & 194 & 74 & 1 \\
\hline ADANA & KARAISALI & 6,5 & 2187 & 54 & 42 & 0 \\
\hline ADANA & KARATAS & 6,5 & 17 & 2144 & 79 & 0 \\
\hline ADANA & POZANTI & 6,5 & 115 & 2346 & 33 & 0 \\
\hline ADANA & IMAMOGLU & 6,5 & 1513 & 3553 & 44 & 0 \\
\hline ADANA & KOZAN & 6,5 & 15750 & 1461 & 412 & 15 \\
\hline ADANA & CEYHAN & 6,5 & 14967 & 374 & 589 & 13 \\
\hline ADIYAMAN & GERGER & 6,5 & 875 & 1 & 0 & 0 \\
\hline ADIYAMAN & KAHTA & 6,5 & 2415 & 4397 & 180 & 0 \\
\hline AFYON & IHSANIYE & 6,5 & 574 & 123 & 9 & 0 \\
\hline AFYON & EVCILER & 6,5 & 846 & 207 & 18 & 0 \\
\hline AFYON & DAZKIRI & 6,5 & 1014 & 71 & 74 & 0 \\
\hline AFYON & BAYAT & 6,5 & 1484 & 144 & 17 & 0 \\
\hline AFYON & BASMAKCI & 6,5 & 1395 & 634 & 44 & 0 \\
\hline AFYON & SULTANDAGI & 6,5 & 865 & 839 & 108 & 0 \\
\hline AFYON & COBANLAR & 6,5 & 1652 & 145 & 25 & 0 \\
\hline AFYON & \begin{tabular}{|l|} 
ISCEHISAR \\
\end{tabular} & 6,5 & 2177 & 397 & 115 & 0 \\
\hline AFYON & \begin{tabular}{|l} 
SUHUT \\
\end{tabular} & 6,5 & 2821 & 233 & 110 & 0 \\
\hline AFYON & CAY & 6,5 & 3837 & 916 & 373 & 0 \\
\hline AFYON & EMIRDAG & 6,5 & 3236 & 1505 & 515 & 0 \\
\hline AFYON & BOLVADIN & 6,5 & 8322 & 929 & 409 & 0 \\
\hline AFYON & AFYON M. & 6,5 & 14832 & 115 & 3005 & 5 \\
\hline AMASYA & GOYNUCEK & 6,5 & 440 & 156 & 23 & 0 \\
\hline ANKARA & NALLIHAN & 6,5 & 642 & 1357 & 278 & 1 \\
\hline ANKARA & KIZILCAHAMAM & 6,5 & 999 & 496 & 402 & 0 \\
\hline ANTALYA & KAS & 6,5 & 739 & 313 & 173 & 0 \\
\hline ANTALYA & FINIKE & 6,5 & 603 & 838 & 292 & 2 \\
\hline ANTALYA & ELMALI & 6,5 & 1833 & 1527 & 278 & 1 \\
\hline ANTALYA & KALE (DEMRE) & 6,5 & 1313 & 898 & 145 & 0 \\
\hline ANTALYA & KORKUTELI & 6,5 & 2738 & 876 & 604 & 0 \\
\hline ANTALYA & KEMER & 6,5 & 971 & 962 & 156 & 0 \\
\hline ANTALYA & KUMLUCA & 6,5 & 3249 & 968 & 476 & 0 \\
\hline AYDIN & \begin{tabular}{|l|} 
KARPUZLU \\
\end{tabular} & 6,5 & 592 & 250 & 17 & 2 \\
\hline AYDIN & KARACASU & 6,5 & 2096 & 276 & 105 & 0 \\
\hline AYDIN & SULTANHISAR & 6,5 & 1319 & 270 & 106 & 0 \\
\hline AYDIN & YENIPAZAR & 6,5 & 2349 & 714 & 62 & 0 \\
\hline AYDIN & KOCARLI & 6,5 & 1026 & 605 & 65 & 0 \\
\hline AYDIN & BUHARKENT & 6,5 & 1123 & 465 & 141 & 0 \\
\hline AYDIN & KUYUCAK & 6,5 & 1338 & 622 & 123 & 0 \\
\hline AYDIN & BOZDOGAN & 6,5 & 3698 & 258 & 171 & 0 \\
\hline AYDIN & KOSK & 6,5 & 1054 & 836 & 104 & 0 \\
\hline AYDIN & GERMENCIK & 6,5 & 2044 & 908 & 129 & 0 \\
\hline AYDIN & INCIRLIOVA & 6,5 & 2295 & 1374 & 350 & 0 \\
\hline AYDIN & CINE & 6,5 & 3432 & 1814 & 375 & 0 \\
\hline AYDIN & DİDİM & 6,5 & 1144 & 16706 & 835 & 1 \\
\hline
\end{tabular}




\begin{tabular}{|c|c|c|c|c|c|c|}
\hline Provinces & Sub-Provinces & Intensity & $\begin{array}{c}\text { Load } \\
\text { Bearing } \\
\text { Construction } \\
\text { (1-3 storeys) }\end{array}$ & $\begin{array}{c}\text { Frame } \\
\text { Construction } \\
\text { Low- Rise } \\
(1-3)\end{array}$ & $\begin{array}{c}\text { Frame } \\
\text { Construction } \\
\text { Mid-Rise } \\
(4-9)\end{array}$ & $\begin{array}{c}\text { Frame } \\
\text { Construction } \\
\text { High-Rise } \\
(10+)\end{array}$ \\
\hline AYDIN & KUSADASI & 6,5 & 2261 & 13730 & 1690 & 4 \\
\hline AYDIN & SOKE & 6,5 & 7167 & 1565 & 1687 & 1 \\
\hline AYDIN & NAZILLI & 6,5 & 9704 & 4610 & 2224 & 6 \\
\hline AYDIN & AYDIN C. & 6,5 & 7877 & 5837 & 5533 & 21 \\
\hline BALIKESIR & KEPSUT & 6,5 & 1655 & 390 & 133 & 0 \\
\hline BALIKESIR & GONEN & 6,5 & 3409 & 3187 & 911 & 1 \\
\hline BALIKESIR & BALIKESİR C. & 6,5 & 14168 & 8515 & 8074 & 21 \\
\hline BILECIK & INHISAR & 6,5 & 476 & 28 & 12 & 0 \\
\hline BILECIK & YENIPAZAR & 6,5 & 383 & 62 & 26 & 0 \\
\hline BILECIK & PAZARYERI & 6,5 & 1600 & 168 & 40 & 0 \\
\hline BILECIK & SOGUT & 6,5 & 1009 & 787 & 373 & 0 \\
\hline BILECIK & BOZUYUK & 6,5 & 6720 & 266 & 873 & 1 \\
\hline BITLIS & GUROYMAK & 6,5 & 2134 & 103 & 35 & 0 \\
\hline BITLIS & TATVAN & 6,5 & 1150 & 4329 & 340 & 1 \\
\hline BURDUR & CELTIKCI & 6,5 & 385 & 456 & 12 & 0 \\
\hline BURDUR & AGLASUN & 6,5 & 1321 & 70 & 38 & 0 \\
\hline BURDUR & BUCAK & 6,5 & 5515 & 1196 & 674 & 0 \\
\hline BURDUR & BURDUR C. & 6,5 & 7925 & 3775 & 1287 & 0 \\
\hline BURSA & KELES & 6,5 & 258 & 580 & 34 & 0 \\
\hline BURSA & ORHANELI & 6,5 & 1470 & 106 & 132 & 0 \\
\hline CANAKKALE & YENICE & 6,5 & 900 & 492 & 58 & 0 \\
\hline CANKIRI & ELDIVAN & 6,5 & 1280 & 29 & 19 & 0 \\
\hline CANKIRI & SABANOZU & 6,5 & 588 & 283 & 17 & 0 \\
\hline CANKIRI & ÇANKIRI C. & 6,5 & 2553 & 3486 & 995 & 2 \\
\hline CORUM & ORTAKOY & 6,5 & 534 & 266 & 28 & 0 \\
\hline CORUM & MECITOZU & 6,5 & 860 & 615 & 47 & 0 \\
\hline CORUM & BAYAT & 6,5 & 588 & 846 & 94 & 0 \\
\hline CORUM & ÇORUM C. & 6,5 & 15849 & 1330 & 3809 & 27 \\
\hline DENIZLI & BEYAGAC & 6,5 & 700 & 89 & 17 & 0 \\
\hline DENIZLI & CAMELI & 6,5 & 601 & 198 & 50 & 0 \\
\hline DENIZLI & BEKILLI & 6,5 & 1419 & 378 & 25 & 0 \\
\hline DENIZLI & BABADAG & 6,5 & 1342 & 300 & 35 & 0 \\
\hline DENIZLI & HONAZ & 6,5 & 1205 & 489 & 51 & 0 \\
\hline DENIZLI & ACIPAYAM & 6,5 & 982 & 647 & 369 & 1 \\
\hline DENIZLI & SARAYKOY & 6,5 & 1879 & 962 & 477 & 0 \\
\hline DENIZLI & DENİZLİ C. & 6,5 & 14680 & 18818 & 8365 & 48 \\
\hline DIYARBAKIR & DICLE & 6,5 & 1442 & 0 & 9 & 0 \\
\hline DIYARBAKIR & CERMIK & 6,5 & 2668 & 0 & 41 & 0 \\
\hline DIYARBAKIR & ERGANI & 6,5 & 4623 & 5700 & 152 & 0 \\
\hline DUZCE & AKCAKOCA & 6,5 & 1014 & 972 & 748 & 1 \\
\hline EDIRNE & IPSALA & 6,5 & 1802 & 457 & 55 & 0 \\
\hline ELAZIG & KARAKOCAN & 6,5 & 1319 & 553 & 118 & 0 \\
\hline ERZURUM & TEKMAN & 6,5 & 882 & 146 & 9 & 0 \\
\hline ERZURUM & ASKALE & 6,5 & 1318 & 1309 & 71 & 2 \\
\hline ERZURUM & PASINLER & 6,5 & 3164 & 965 & 73 & 0 \\
\hline ESKISEHIR & MIHALGAZI & 6,5 & 471 & 265 & 29 & 0 \\
\hline ESKISEHIR & SARICAKAYA & 6,5 & 271 & 163 & 24 & 0 \\
\hline GAZIANTEP & YAVUZELI & 6,5 & 320 & 569 & 20 & 0 \\
\hline GAZIANTEP & ARABAN & 6,5 & 1882 & 178 & 8 & 0 \\
\hline GUMUSHANE & KELKIT & 6,5 & 1022 & 1265 & 153 & 0 \\
\hline ICEL(MERSIN) & TARSUS & 6,5 & 6652 & 25176 & 1413 & 2 \\
\hline ISPARTA & GONEN & 6,5 & 1049 & 95 & 35 & 0 \\
\hline ISPARTA & ATABEY & 6,5 & 1334 & 74 & 47 & 2 \\
\hline ISPARTA & GELENDOST & 6,5 & 1630 & 73 & 26 & 0 \\
\hline ISPARTA & ULUBORLU & 6,5 & 1950 & 53 & 48 & 0 \\
\hline ISPARTA & SENIRKENT & 6,5 & 1455 & 682 & 160 & 0 \\
\hline
\end{tabular}




\begin{tabular}{|c|c|c|c|c|c|c|}
\hline Provinces & Sub-Provinces & Intensity & $\begin{array}{c}\text { Load } \\
\text { Bearing } \\
\text { Construction } \\
(1-3 \text { storeys })\end{array}$ & $\begin{array}{c}\text { Frame } \\
\text { Construction } \\
\text { Low- Rise } \\
(1-3)\end{array}$ & $\begin{array}{c}\text { Frame } \\
\text { Construction } \\
\text { Mid-Rise } \\
(4-9)\end{array}$ & \begin{tabular}{|c} 
Frame \\
Construction \\
High-Rise \\
$(10+)$
\end{tabular} \\
\hline ISPARTA & KECIBORLU & 6,5 & 2228 & 187 & 81 & 0 \\
\hline ISPARTA & S.KARAAĞAÇ & 6,5 & 2286 & 397 & 258 & 0 \\
\hline ISPARTA & EGIRDIR & 6,5 & 2754 & 762 & 493 & 0 \\
\hline ISPARTA & YALVAC & 6,5 & 1773 & 896 & 656 & 0 \\
\hline ISPARTA & ISPARTA C. & 6,5 & 16760 & 4958 & 4569 & 9 \\
\hline IZMIR & BEYDAG & 6,5 & 1384 & 580 & 128 & 0 \\
\hline IZMIR & KIRAZ & 6,5 & 1571 & 628 & 80 & 0 \\
\hline IZMIR & KINIK & 6,5 & 3375 & 458 & 35 & 0 \\
\hline IZMIR & TIRE & 6,5 & 7784 & 1677 & 963 & 0 \\
\hline IZMIR & ODEMIS & 6,5 & 9711 & 2729 & 2195 & 1 \\
\hline K.MARAS & CAGLAYANCERIT & 6,5 & 2234 & 202 & 13 & 0 \\
\hline K.MARAS & K.MARAŞ C. & 6,5 & 17205 & 21891 & 2190 & 36 \\
\hline KARABUK & YENICE & 6,5 & 646 & 1149 & 518 & 1 \\
\hline KARABUK & SAFRANBOLU & 6,5 & 2642 & 2547 & 794 & 0 \\
\hline KARABUK & KARABÜK C. & 6,5 & 9520 & 1981 & 2182 & 1 \\
\hline KASTAMONU & TASKOPRU & 6,5 & 664 & 1440 & 524 & 0 \\
\hline KASTAMONU & KASTAMONU C. & 6,5 & 726 & 6958 & 1474 & 1 \\
\hline KAYSERI & BUNYAN & 6,5 & 2321 & 381 & 109 & 0 \\
\hline KAYSERI & YAHYALI & 6,5 & 3241 & 1111 & 154 & 0 \\
\hline KAYSERI & TALAS & 6,5 & 1555 & 604 & 690 & 52 \\
\hline KILIS & MUSABEYLI & 6,5 & 103 & 68 & 3 & 0 \\
\hline KONYA & DERBENT & 6,5 & 1523 & 174 & 15 & 0 \\
\hline KONYA & AKOREN & 6,5 & 524 & 0 & 11 & 0 \\
\hline KONYA & HUYUK & 6,5 & 1414 & 32 & 65 & 0 \\
\hline KONYA & TUZLUKCU & 6,5 & 1179 & 35 & 3 & 0 \\
\hline KONYA & DOGANHISAR & 6,5 & 1798 & 342 & 199 & 0 \\
\hline KONYA & \begin{tabular}{|l|} 
ILGIN \\
\end{tabular} & 6,5 & 3053 & 2079 & 349 & 0 \\
\hline KONYA & AKSEHIR & 6,5 & 5944 & 1180 & 1663 & 0 \\
\hline KUTAHYA & DUMLUPINAR & 6,5 & 491 & 89 & 19 & 0 \\
\hline KUTAHYA & ASLANAPA & 6,5 & 101 & 372 & 8 & 0 \\
\hline KUTAHYA & CAVDARHISAR & 6,5 & 32 & 756 & 20 & 1 \\
\hline KUTAHYA & SAPHANE & 6,5 & 314 & 1136 & 39 & 0 \\
\hline KUTAHYA & PAZARLAR & 6,5 & 853 & 198 & 51 & 0 \\
\hline KUTAHYA & HISARCIK & 6,5 & 876 & 324 & 189 & 0 \\
\hline KUTAHYA & ALTINTAS & 6,5 & 699 & 429 & 60 & 0 \\
\hline KUTAHYA & EMET & 6,5 & 95 & 2469 & 191 & 0 \\
\hline KUTAHYA & GEDIZ & 6,5 & 124 & 4295 & 51 & 0 \\
\hline KUTAHYA & SIMAV & 6,5 & 1701 & 1925 & 1229 & 2 \\
\hline KUTAHYA & KÜTAHYA C. & 6,5 & 20105 & 1829 & 5474 & 41 \\
\hline MALATYA & KALE & 6,5 & 632 & 35 & 6 & 1 \\
\hline MALATYA & DOGANSEHIR & 6,5 & 1480 & 292 & 69 & 0 \\
\hline MANISA & KOPRUBASI & 6,5 & 915 & 611 & 51 & 0 \\
\hline MANISA & GORDES & 6,5 & 2158 & 882 & 209 & 0 \\
\hline MANISA & DEMIRCI & 6,5 & 3791 & 425 & 206 & 0 \\
\hline MANISA & KIRKAGAC & 6,5 & 3707 & 1177 & 228 & 0 \\
\hline MANISA & SOMA & 6,5 & 6200 & 1954 & 1713 & 0 \\
\hline MUGLA & ULA & 6,5 & 2044 & 98 & 4 & 0 \\
\hline MUGLA & KOYCEGIZ & 6,5 & 1627 & 670 & 13 & 0 \\
\hline MUGLA & DATCA & 6,5 & 2297 & 1169 & 78 & 0 \\
\hline MUGLA & YATAGAN & 6,5 & 2099 & 457 & 249 & 0 \\
\hline MUGLA & DALAMAN & 6,5 & 3022 & 1004 & 209 & 0 \\
\hline MUGLA & ORTACA & 6,5 & 2642 & 1495 & 280 & 0 \\
\hline MUGLA & MARMARIS & 6,5 & 1018 & 1553 & 958 & 0 \\
\hline MUGLA & BODRUM & 6,5 & 1583 & 11195 & 68 & 0 \\
\hline MUGLA & MILAS & 6,5 & 3298 & 4270 & 533 & 1 \\
\hline MUGLA & MUĞLA C. & 6,5 & 5797 & 1801 & 1084 & 3 \\
\hline
\end{tabular}




\begin{tabular}{|c|c|c|c|c|c|c|}
\hline Provinces & Sub-Provinces & Intensity & $\begin{array}{c}\text { Load } \\
\text { Bearing } \\
\text { Construction } \\
\text { (1-3 storeys) } \\
\end{array}$ & $\begin{array}{c}\text { Frame } \\
\text { Construction } \\
\text { Low- Rise } \\
(1-3) \\
\end{array}$ & \begin{tabular}{|c|} 
Frame \\
Construction \\
Mid-Rise \\
$(4-9)$ \\
\end{tabular} & $\begin{array}{c}\text { Frame } \\
\text { Construction } \\
\text { High-Rise } \\
(10+)\end{array}$ \\
\hline MUGLA & FETHIYE & 6,5 & 3709 & 8242 & 822 & 8 \\
\hline MUS & HASKOY & 6,5 & 1096 & 1184 & 33 & 0 \\
\hline MUS & MUŞ C. & 6,5 & 2189 & 3862 & 545 & 0 \\
\hline NIGDE & CAMARDI & 6,5 & 1316 & 4 & 29 & 0 \\
\hline ORDU & CATALPINAR & 6,5 & 127 & 793 & 71 & 0 \\
\hline ORDU & GURGENTEPE & 6,5 & 292 & 2027 & 151 & 0 \\
\hline ORDU & KUMRU & 6,5 & 566 & 1249 & 311 & 1 \\
\hline ORDU & KORGAN & 6,5 & 1074 & 1624 & 236 & 0 \\
\hline OSMANIYE & SUMBAS & 6,5 & 690 & 43 & 0 & 0 \\
\hline OSMANIYE & DUZICI & 6,5 & 2118 & 5368 & 36 & 0 \\
\hline OSMANIYE & KADIRLI & 6,5 & 15757 & 66 & 289 & 3 \\
\hline SAKARYA & KAYNARCA & 6,5 & 506 & 292 & 111 & 0 \\
\hline SAKARYA & KOCAALI & 6,5 & 1087 & 2146 & 221 & 0 \\
\hline SAKARYA & KARASU & 6,5 & 1683 & 1797 & 730 & 1 \\
\hline SAMSUN & SALIPAZARI & 6,5 & 231 & 801 & 125 & 0 \\
\hline SAMSUN & TEKKEKÖY & 6,5 & 883 & 1256 & 308 & 3 \\
\hline SINOP & DURAGAN & 6,5 & 547 & 725 & 316 & 0 \\
\hline SINOP & BOYABAT & 6,5 & 1045 & 1878 & 686 & 1 \\
\hline SIVAS & ZARA & 6,5 & 2855 & 275 & 118 & 0 \\
\hline TEKIRDAG & MURATLI & 6,5 & 1427 & 1958 & 167 & 0 \\
\hline TEKIRDAG & CERKEZKOY & 6,5 & 1958 & 2021 & 1100 & 57 \\
\hline TEKIRDAG & CORLU & 6,5 & 5293 & 6389 & 3781 & 41 \\
\hline TOKAT & PAZAR & 6,5 & 858 & 461 & 38 & 0 \\
\hline TOKAT & ZILE & 6,5 & 143 & 8771 & 358 & 1 \\
\hline TOKAT & TURHAL & 6,5 & 7569 & 2322 & 868 & 0 \\
\hline TUNCELI & NAZIMIYE & 6,5 & 247 & 34 & 30 & 0 \\
\hline TUNCELI & OVACIK & 6,5 & 443 & 172 & 27 & 0 \\
\hline USAK & ULUBEY & 6,5 & 665 & 937 & 113 & 0 \\
\hline USAK & BANAZ & 6,5 & 991 & 1683 & 555 & 1 \\
\hline VAN & SARAY & 6,5 & 469 & 104 & 2 & 0 \\
\hline VAN & GEVAS & 6,5 & 1055 & 1001 & 18 & 0 \\
\hline ZONGULDAK & ALAPLI & 6,5 & 483 & 192 & 774 & 0 \\
\hline ADANA & ADANA (M.) & 6,5 & 27107 & 137530 & 8880 & 1955 \\
\hline ANTALYA & ANTALYA (M.) & 6,5 & 69699 & 30230 & 13410 & 878 \\
\hline ERZURUM & ERZURUM (M.) & 6,5 & 18261 & 8426 & 5732 & 23 \\
\hline KONYA & KONYA (M.) & 6,5 & 88979 & 11939 & 11516 & 280 \\
\hline ADIYAMAN & TUT & 7 & 592 & 489 & 22 & 0 \\
\hline ADIYAMAN & SINCIK & 7 & 494 & 139 & 4 & 0 \\
\hline ADIYAMAN & CELIKHAN & 7 & 669 & 563 & 24 & 0 \\
\hline ADIYAMAN & BESNI & 7 & 977 & 2900 & 169 & 1 \\
\hline ADIYAMAN & GOLBASI & 7 & 1005 & 2995 & 275 & 0 \\
\hline ADIYAMAN & ADIYAMAN C. & 7 & 5668 & 14695 & 1412 & 9 \\
\hline AMASYA & HAMAMOZU & 7 & 373 & 83 & 23 & 0 \\
\hline AMASYA & AMASYA C. & 7 & 4782 & 2787 & 1821 & 1 \\
\hline ANKARA & CAMLIDERE & 7 & 1909 & 327 & 44 & 0 \\
\hline BALIKESIR & BALYA & 7 & 532 & 105 & 15 & 0 \\
\hline BALIKESIR & GOMEC & 7 & 1549 & 1355 & 5 & 0 \\
\hline BALIKESIR & IVRINDI & 7 & 970 & 464 & 101 & 0 \\
\hline BALIKESIR & MANYAS & 7 & 1154 & 354 & 95 & 0 \\
\hline BALIKESIR & SAVASTEPE & 7 & 1473 & 713 & 113 & 2 \\
\hline BALIKESIR & HAVRAN & 7 & 2600 & 590 & 195 & 0 \\
\hline BALIKESIR & SINDIRGI & 7 & 2021 & 884 & 217 & 0 \\
\hline BALIKESIR & BIGADIC & 7 & 1801 & 1404 & 297 & 0 \\
\hline BALIKESIR & ERDEK & 7 & 1896 & 1150 & 1124 & 0 \\
\hline BALIKESIR & SUSURLUK & 7 & 4046 & 990 & 653 & 0 \\
\hline BALIKESIR & AYVALIK & 7 & 7027 & 6407 & 650 & 0 \\
\hline
\end{tabular}




\begin{tabular}{|c|c|c|c|c|c|c|}
\hline Provinces & Sub-Provinces & Intensity & $\begin{array}{c}\text { Load } \\
\text { Bearing } \\
\text { Construction } \\
(1-3 \text { storeys })\end{array}$ & $\begin{array}{c}\text { Frame } \\
\text { Construction } \\
\text { Low- Rise } \\
(1-3)\end{array}$ & $\begin{array}{c}\text { Frame } \\
\text { Construction } \\
\text { Mid-Rise } \\
(4-9)\end{array}$ & \begin{tabular}{|c} 
Frame \\
Construction \\
High-Rise \\
$(10+)$
\end{tabular} \\
\hline BALIKESIR & BURHANIYE & 7 & 6182 & 6478 & 497 & 0 \\
\hline BALIKESIR & EDREMIT & 7 & 5153 & 1318 & 1133 & 0 \\
\hline BALIKESIR & BANDIRMA & 7 & 3658 & 5002 & 3320 & 31 \\
\hline BILECIK & GOLPAZARI & 7 & 911 & 862 & 86 & 0 \\
\hline BILECIK & BİLECİK C. & 7 & 2955 & 233 & 828 & 1 \\
\hline BINGOL & YAYLADERE & 7 & 776 & 9 & 27 & 0 \\
\hline BINGOL & GENC & 7 & 1086 & 480 & 109 & 0 \\
\hline BINGOL & BİNGÖL C. & 7 & 3143 & 2903 & 1157 & 1 \\
\hline BOLU & KIBRISCIK & 7 & 392 & 6 & 7 & 0 \\
\hline BOLU & SEBEN & 7 & 15 & 715 & 22 & 0 \\
\hline BURDUR & KEMER & 7 & 666 & 115 & 17 & 0 \\
\hline BURDUR & CAVDIR & 7 & 633 & 203 & 43 & 0 \\
\hline BURDUR & ALTINYAYLA & 7 & 1087 & 30 & 30 & 0 \\
\hline BURDUR & TEFENNI & 7 & 1417 & 124 & 61 & 0 \\
\hline BURDUR & YESILOVA & 7 & 920 & 595 & 67 & 0 \\
\hline BURDUR & KARAMANLI & 7 & 1575 & 222 & 109 & 0 \\
\hline BURDUR & GOLHISAR & 7 & 2773 & 536 & 179 & 0 \\
\hline BURSA & KARACABEY & 7 & 3772 & 2915 & 956 & 0 \\
\hline BURSA & M.KEMALPASA & 7 & 4386 & 2368 & 1688 & 0 \\
\hline BURSA & INEGOL & 7 & 3845 & 6469 & 3770 & 0 \\
\hline CANAKKALE & AYVACIK & 7 & 1242 & 556 & 50 & 0 \\
\hline CANAKKALE & LAPSEKI & 7 & 1330 & 539 & 301 & 0 \\
\hline CANAKKALE & EZINE & 7 & 2507 & 1120 & 209 & 3 \\
\hline CANAKKALE & BAYRAMIC & 7 & 2703 & 1293 & 154 & 0 \\
\hline CANAKKALE & CAN & 7 & 2022 & 2632 & 357 & 0 \\
\hline CANAKKALE & BIGA & 7 & 2363 & 2300 & 809 & 0 \\
\hline CANAKKALE & ÇANAKKALE C. & 7 & 3620 & 3533 & 2067 & 11 \\
\hline CANKIRI & YAPRAKLI & 7 & 218 & 538 & 18 & 0 \\
\hline CANKIRI & ORTA & 7 & 680 & 215 & 29 & 0 \\
\hline CORUM & LACIN & 7 & 505 & 6 & 8 & 0 \\
\hline CORUM & OGUZLAR & 7 & 193 & 1211 & 39 & 0 \\
\hline CORUM & ISKILIP & 7 & 1222 & 3407 & 470 & 0 \\
\hline DENIZLI & BAKLAN & 7 & 803 & 131 & 8 & 0 \\
\hline DENIZLI & AKKOY & 7 & 376 & 252 & 6 & 0 \\
\hline DENIZLI & CAL & 7 & 1456 & 256 & 24 & 0 \\
\hline DENIZLI & BOZKURT & 7 & 692 & 253 & 50 & 0 \\
\hline DENIZLI & CARDAK & 7 & 720 & 568 & 65 & 0 \\
\hline DENIZLI & GUNEY & 7 & 1178 & 629 & 40 & 0 \\
\hline DENIZLI & BULDAN & 7 & 2206 & 1718 & 324 & 1 \\
\hline DIYARBAKIR & CUNGUS & 7 & 787 & 65 & 13 & 0 \\
\hline DUZCE & YIGILCA & 7 & 77 & 368 & 110 & 0 \\
\hline EDIRNE & ENEZ & 7 & 1131 & 2322 & 31 & 0 \\
\hline EDIRNE & KESAN & 7 & 5460 & 1641 & 940 & 0 \\
\hline ELAZIG & ALACAKAYA & 7 & 626 & 193 & 7 & 0 \\
\hline ELAZIG & ARICAK & 7 & 513 & 0 & 19 & 0 \\
\hline ELAZIG & SIVRICE & 7 & 947 & 48 & 13 & 0 \\
\hline ELAZIG & MADEN & 7 & 1333 & 263 & 48 & 0 \\
\hline ELAZIG & PALU & 7 & 1619 & 142 & 38 & 0 \\
\hline ELAZIG & KOVANCILAR & 7 & 1500 & 99 & 428 & 16 \\
\hline ERZINCAN & OTLUKBELI & 7 & 341 & 81 & 9 & 0 \\
\hline ERZINCAN & KEMAH & 7 & 458 & 191 & 22 & 0 \\
\hline ERZINCAN & TERCAN & 7 & 1249 & 144 & 29 & 0 \\
\hline ERZURUM & CAT & 7 & 1101 & 122 & 9 & 0 \\
\hline ERZURUM & KARACOBAN & 7 & 2190 & 205 & 17 & 0 \\
\hline ERZURUM & HINIS & 7 & 1058 & 2467 & 17 & 1 \\
\hline GAZIANTEP & NURDAGI & 7 & 125 & 2132 & 14 & 0 \\
\hline
\end{tabular}




\begin{tabular}{|c|c|c|c|c|c|c|}
\hline Provinces & Sub-Provinces & Intensity & $\begin{array}{c}\text { Load } \\
\text { Bearing } \\
\text { Construction } \\
\text { (1-3 storeys) }\end{array}$ & $\begin{array}{c}\text { Frame } \\
\text { Construction } \\
\text { Low- Rise } \\
(1-3)\end{array}$ & $\begin{array}{c}\text { Frame } \\
\text { Construction } \\
\text { Mid-Rise } \\
(4-9)\end{array}$ & $\begin{array}{c}\text { Frame } \\
\text { Construction } \\
\text { High-Rise } \\
(10+)\end{array}$ \\
\hline GAZIANTEP & ISLAHIYE & 7 & 2350 & 2254 & 162 & 8 \\
\hline GIRESUN & ALUCRA & 7 & 574 & 315 & 37 & 0 \\
\hline GUMUSHANE & SIRAN & 7 & 756 & 276 & 89 & 0 \\
\hline HATAY & KUMLU & 7 & 1096 & 0 & 3 & 0 \\
\hline HATAY & YAYLADAGI & 7 & 859 & 885 & 23 & 0 \\
\hline HATAY & ALTINOZU & 7 & 288 & 1025 & 23 & 0 \\
\hline HATAY & HASSA & 7 & 1076 & 583 & 12 & 0 \\
\hline HATAY & BELEN & 7 & 2588 & 2246 & 237 & 2 \\
\hline HATAY & ERZIN & 7 & 5650 & 26 & 48 & 0 \\
\hline HATAY & SAMANDAG & 7 & 1615 & 5083 & 512 & 1 \\
\hline HATAY & REYHANLI & 7 & 3588 & 5405 & 175 & 0 \\
\hline HATAY & KIRIKHAN & 7 & 3824 & 7711 & 237 & 1 \\
\hline HATAY & DORTYOL & 7 & 3431 & 6712 & 485 & 0 \\
\hline HATAY & ISKENDERUN & 7 & 5491 & 13296 & 2354 & 2 \\
\hline HATAY & \begin{tabular}{|l|} 
ANTAKYA \\
\end{tabular} & 7 & 7589 & 13344 & 2330 & 20 \\
\hline IZMIR & KARABURUN & 7 & 814 & 649 & 14 & 0 \\
\hline IZMIR & CESME & 7 & 666 & 10711 & 116 & 1 \\
\hline IZMIR & BERGAMA & 7 & 7971 & 3337 & 1041 & 4 \\
\hline K.MARAS & TURKOGLU & 7 & 386 & 1842 & 18 & 0 \\
\hline K.MARAS & PAZARCIK & 7 & 592 & 3267 & 65 & 0 \\
\hline KASTAMONU & IHSANGAZI & 7 & 874 & 476 & 121 & 0 \\
\hline KASTAMONU & ARAC & 7 & 718 & 554 & 120 & 0 \\
\hline MALATYA & DOGANYOL & 7 & 822 & 3 & 2 & 0 \\
\hline MALATYA & PUTURGE & 7 & 789 & 101 & 20 & 0 \\
\hline MANISA & GOLMARMARA & 7 & 2439 & 479 & 52 & 0 \\
\hline MANISA & AHMETLI & 7 & 1839 & 784 & 76 & 0 \\
\hline MANISA & SARIGOL & 7 & 2740 & 1393 & 101 & 0 \\
\hline MANISA & SARUHANLI & 7 & 2795 & 696 & 128 & 0 \\
\hline MANISA & KULA & 7 & 4676 & 2836 & 182 & 0 \\
\hline MANISA & ALASEHIR & 7 & 6240 & 2619 & 667 & 1 \\
\hline MANISA & SALIHLI & 7 & 5707 & 5420 & 2484 & 1 \\
\hline MANISA & AKHISAR & 7 & 13022 & 2956 & 1760 & 0 \\
\hline MANISA & TURGUTLU & 7 & 9088 & 8193 & 2017 & 1 \\
\hline MANISA & MANISA C. & 7 & 13664 & 5204 & 5873 & 6 \\
\hline MUS & KORKUT & 7 & 406 & 213 & 4 & 0 \\
\hline MUS & MALAZGIRT & 7 & 2305 & 1778 & 47 & 0 \\
\hline ORDU & AKKUS & 7 & 208 & 272 & 86 & 0 \\
\hline ORDU & AYBASTI & 7 & 440 & 2773 & 469 & 0 \\
\hline ORDU & GOLKOY & 7 & 2586 & 1416 & 234 & 2 \\
\hline OSMANIYE & HASANBEYLI & 7 & 798 & 644 & 0 & 0 \\
\hline OSMANIYE & TOPRAKKALE & 7 & 67 & 1590 & 2 & 0 \\
\hline OSMANIYE & BAHCE & 7 & 353 & 1912 & 32 & 1 \\
\hline OSMANIYE & OSMANIYE C. & 7 & 5283 & 23167 & 827 & 79 \\
\hline SAKARYA & FERIZLI & 7 & 779 & 1032 & 111 & 0 \\
\hline SAMSUN & AYVACIK & 7 & 369 & 782 & 37 & 0 \\
\hline SINOP & SARAYDUZU & 7 & 192 & 173 & 19 & 0 \\
\hline SIVAS & IMRANLI & 7 & 572 & 707 & 24 & 0 \\
\hline TEKIRDAG & MALKARA & 7 & 2236 & 1533 & 733 & 0 \\
\hline TOKAT & TOKAT C. & 7 & 4506 & 8516 & 2295 & 2 \\
\hline USAK & ESME & 7 & 3047 & 570 & 176 & 0 \\
\hline VAN & GURPINAR & 7 & 814 & 25 & 11 & 0 \\
\hline VAN & OZALP & 7 & 1051 & 313 & 41 & 0 \\
\hline VAN & EDREMIT & 7 & 929 & 145 & 12 & 0 \\
\hline VAN & BASKALE & 7 & 1373 & 586 & 18 & 0 \\
\hline IZMIR & IZMIR (M.) & 7 & 138577 & 216090 & 64466 & 1171 \\
\hline AMASYA & GUMUSHACIKOY & 7,5 & 3164 & 775 & 234 & 0 \\
\hline
\end{tabular}




\begin{tabular}{|c|c|c|c|c|c|c|}
\hline Provinces & Sub-Provinces & Intensity & $\begin{array}{c}\text { Load } \\
\text { Bearing } \\
\text { Construction } \\
\text { (1-3 storeys) }\end{array}$ & $\begin{array}{c}\text { Frame } \\
\text { Construction } \\
\text { Low- Rise } \\
(1-3)\end{array}$ & \begin{tabular}{c|} 
Frame \\
Construction \\
Mid-Rise \\
$(4-9)$ \\
\end{tabular} & $\begin{array}{c}\text { Frame } \\
\text { Construction } \\
\text { High-Rise } \\
(10+)\end{array}$ \\
\hline AMASYA & SULUOVA & 7,5 & 4768 & 4253 & 610 & 0 \\
\hline AMASYA & MERZIFON & 7,5 & 6112 & 2164 & 1126 & 2 \\
\hline BILECIK & OSMANELI & 7,5 & 1459 & 762 & 163 & 0 \\
\hline BINGOL & ADAKLI & 7,5 & 833 & 7 & 9 & 0 \\
\hline BINGOL & KIGI & 7,5 & 601 & 88 & 9 & 0 \\
\hline BITLIS & ADILCEVAZ & 7,5 & 2025 & 629 & 82 & 0 \\
\hline BITLIS & AHLAT & 7,5 & 2000 & 1721 & 71 & 0 \\
\hline BOLU & GOYNUK & 7,5 & 221 & 984 & 18 & 0 \\
\hline BOLU & MUDURNU & 7,5 & 170 & 1422 & 56 & 2 \\
\hline BOLU & MENGEN & 7,5 & 297 & 587 & 151 & 0 \\
\hline BURSA & IZNIK & 7,5 & 1483 & 2324 & 158 & 0 \\
\hline BURSA & YENISEHIR & 7,5 & 3093 & 1509 & 419 & 0 \\
\hline CANKIRI & KORGUN & 7,5 & 580 & 106 & 18 & 0 \\
\hline CANKIRI & ATKARACALAR & 7,5 & 319 & 373 & 21 & 0 \\
\hline CANKIRI & KURSUNLU & 7,5 & 1094 & 159 & 57 & 0 \\
\hline CORUM & DODURGA & 7,5 & 907 & 74 & 10 & 0 \\
\hline DUZCE & CILIMLI & 7,5 & 38 & 733 & 16 & 0 \\
\hline DUZCE & GUMUSOVA & 7,5 & 207 & 979 & 100 & 0 \\
\hline DUZCE & CUMAYERI & 7,5 & 55 & 961 & 38 & 0 \\
\hline DUZCE & DÜZCE M. & 7,5 & 1957 & 5446 & 1121 & 0 \\
\hline ERZINCAN & CAYIRLI & 7,5 & 889 & 63 & 27 & 0 \\
\hline GIRESUN & S.KARAHISAR & 7,5 & 1453 & 1627 & 247 & 0 \\
\hline KARABUK & OVACIK & 7,5 & 68 & 152 & 9 & 0 \\
\hline KARABUK & ESKIPAZAR & 7,5 & 931 & 314 & 141 & 0 \\
\hline MUS & BULANIK & 7,5 & 2701 & 1296 & 42 & 0 \\
\hline ORDU & MESUDIYE & 7,5 & 200 & 726 & 31 & 0 \\
\hline SAKARYA & TARAKLI & 7,5 & 129 & 940 & 16 & 0 \\
\hline SAMSUN & ASARCIK & 7,5 & 149 & 205 & 30 & 0 \\
\hline SAMSUN & KAVAK & 7,5 & 507 & 737 & 146 & 0 \\
\hline SAMSUN & VEZIRKOPRU & 7,5 & 502 & 3539 & \begin{tabular}{|l|l|}
369 \\
\end{tabular} & 0 \\
\hline SIVAS & DOGANSAR & 7,5 & 409 & 177 & 14 & 0 \\
\hline TEKIRDAG & TEKİRDAĞ C. & 7,5 & 3040 & 7989 & 4560 & 15 \\
\hline TOKAT & ALMUS & 7,5 & 768 & 186 & 113 & 0 \\
\hline VAN & VAN C. & 7,5 & 34404 & 243 & 1372 & 1 \\
\hline YALOVA & ARMUTLU & 7,5 & 862 & 778 & 440 & 0 \\
\hline BURSA & BURSA (M.) & 7,5 & 55416 & 101949 & 47028 & 158 \\
\hline ISTANBUL & ISTANBUL (M.) & 7,5 & 200025 & 295927 & 357937 & 6271 \\
\hline AMASYA & TASOVA & 8 & 874 & 535 & 263 & 0 \\
\hline BINGOL & YEDISU & 8 & 432 & 11 & 7 & 0 \\
\hline BINGOL & KARLIOVA & 8 & 754 & 142 & 12 & 0 \\
\hline BOLU & DORTDIVAN & 8 & 161 & 381 & 44 & 0 \\
\hline BOLU & YENICAGA & 8 & 623 & 362 & 129 & 0 \\
\hline BOLU & GEREDE & 8 & 1011 & 1841 & 576 & 0 \\
\hline BOLU & BOLU C. & 8 & 3362 & 4846 & 2257 & 2 \\
\hline BURSA & ORHANGAZI & 8 & 1818 & 2246 & 1241 & 1 \\
\hline CANKIRI & BAYRAMOREN & 8 & 1 & 268 & 11 & 0 \\
\hline CANKIRI & ILGAZ & 8 & 791 & 893 & 219 & 5 \\
\hline CANKIRI & CERKES & 8 & 214 & 1474 & 38 & 0 \\
\hline CORUM & KARGI & 8 & 1750 & 95 & 29 & 0 \\
\hline CORUM & OSMANCIK & 8 & 4026 & 720 & 275 & 1 \\
\hline DUZCE & GOLYAKA & 8 & 111 & 671 & 33 & 0 \\
\hline DUZCE & KAYNASLI & 8 & 345 & 814 & 11 & 0 \\
\hline ERZINCAN & REFAHIYE & 8 & 624 & 189 & 30 & 0 \\
\hline ERZINCAN & UZUMLU & 8 & 2817 & 1341 & 28 & 0 \\
\hline ERZINCAN & ERZINCAN C. & 8 & 8815 & 2637 & 1138 & 0 \\
\hline GIRESUN & CAMOLUK & 8 & 547 & 275 & 37 & 0 \\
\hline
\end{tabular}




\begin{tabular}{|c|c|c|c|c|c|c|}
\hline Provinces & Sub-Provinces & Intensity & $\begin{array}{c}\text { Load } \\
\text { Bearing } \\
\text { Construction } \\
\text { (1-3 storeys) }\end{array}$ & $\begin{array}{c}\text { Frame } \\
\text { Construction } \\
\text { Low- Rise } \\
(1-3)\end{array}$ & $\begin{array}{c}\text { Frame } \\
\text { Construction } \\
\text { Mid-Rise } \\
(4-9) \\
\end{array}$ & $\begin{array}{c}\text { Frame } \\
\text { Construction } \\
\text { High-Rise } \\
(10+)\end{array}$ \\
\hline KASTAMONU & TOSYA & 8 & 586 & 7299 & 669 & 1 \\
\hline MUS & VARTO & 8 & 1673 & 848 & 22 & 0 \\
\hline SAKARYA & KARAPURCEK & 8 & 0 & 892 & 8 & 0 \\
\hline SAKARYA & PAMUKOVA & 8 & 1642 & 810 & 129 & 1 \\
\hline SAKARYA & GEYVE & 8 & 720 & 2552 & 194 & 0 \\
\hline SAKARYA & AKYAZI & 8 & 1212 & 2710 & 342 & 1 \\
\hline SAKARYA & HENDEK & 8 & 277 & 4795 & 401 & 0 \\
\hline SAMSUN & LADIK & 8 & 1168 & 1114 & 130 & 0 \\
\hline SAMSUN & HAVZA & 8 & 2052 & 2189 & 366 & 0 \\
\hline SIVAS & GOLOVA & 8 & 185 & 250 & 34 & 0 \\
\hline SIVAS & AKINCILAR & 8 & 1039 & 309 & 31 & 0 \\
\hline SIVAS & KOYULHISAR & 8 & 1106 & 666 & 28 & 0 \\
\hline SIVAS & SUSEHRI & 8 & 1173 & 1115 & 298 & 0 \\
\hline TEKIRDAG & SARKOY & 8 & 787 & 2394 & 871 & 0 \\
\hline TOKAT & BASCIFTLIK & 8 & 726 & 477 & 7 & 0 \\
\hline TOKAT & RESADIYE & 8 & 976 & 806 & 156 & 0 \\
\hline TOKAT & NIKSAR & 8 & 1774 & 5316 & 1248 & 0 \\
\hline TOKAT & ERBAA & 8 & 3859 & 3402 & 598 & 1 \\
\hline TUNCELI & PULUMUR & 8 & 455 & 51 & 66 & 0 \\
\hline YALOVA & TERMAL & 8 & 61 & 283 & 79 & 0 \\
\hline YALOVA & ALTINOVA & 8 & 205 & 280 & 41 & 0 \\
\hline YALOVA & CINARCIK & 8 & 289 & 496 & 886 & 0 \\
\hline YALOVA & CIFTLIKKOY & 8 & 381 & 703 & 502 & 0 \\
\hline YALOVA & YALOVA C. & 8 & 2453 & 3547 & 2246 & 7 \\
\hline KOCAELI & KOCAELI (M.) & 8 & 37086 & 74363 & 27196 & 117 \\
\hline SAKARYA & SAKARYA (M.) & 8 & 20050 & 23438 & 5723 & 9 \\
\hline
\end{tabular}

C: Central

M: Metropolitan 


\section{APPENDIX B}

\section{TOTAL LOSS IN BUILDING STOCK ACCORDING TO BUILDING TYPES WITH REFERENCE TO VULNERABILITY CURVES}

\begin{tabular}{|c|c|c|c|c|c|c|c|}
\hline Provinces & Sub-Provinces & Intensity & \begin{tabular}{|c|} 
Load \\
Bearing \\
Construction \\
(1-3 storeys) \\
Combined \\
levels of loss \\
(D3+D4+D5)
\end{tabular} & $\begin{array}{c}\text { Frame } \\
\text { Construction } \\
\text { Low-Rise } \\
(\mathbf{1 - 3}) \\
\text { Combined } \\
\text { levels of loss } \\
\text { (D3+D4+D5) }\end{array}$ & $\begin{array}{c}\text { Frame } \\
\text { Construction } \\
\text { Mid-Rise } \\
(\mathbf{4 - 9 )} \\
\text { Combined } \\
\text { levels of loss } \\
\text { (D3+D4+D5) }\end{array}$ & $\begin{array}{c}\text { Frame } \\
\text { Construction } \\
\text { High-Rise } \\
(\mathbf{1 0 +}) \\
\text { Combined } \\
\text { levels of loss } \\
\text { (D3+D4+D5) }\end{array}$ & $\begin{array}{c}\text { TOTAL } \\
\text { LOST }\end{array}$ \\
\hline ADANA & YUMURTALIK & 6,5 & 13,77 & 1,94 & 2,22 & 0 & 18 \\
\hline ADANA & KARAISALI & 6,5 & 21,87 & 0,54 & 1,26 & 0 & 24 \\
\hline ADANA & KARATAS & 6,5 & 0,17 & 21,44 & 2,37 & 0 & 24 \\
\hline ADANA & POZANTI & 6,5 & 1,15 & 23,46 & 0,99 & 0 & 26 \\
\hline ADANA & IMAMOGLU & 6,5 & 15,13 & 35,53 & 1,32 & 0 & 52 \\
\hline \begin{tabular}{|l} 
ADANA \\
\end{tabular} & KOZAN & 6,5 & 157,5 & 14,61 & 12,36 & 0 & 184 \\
\hline ADANA & CEYHAN & 6,5 & 149,67 & 3,74 & 17,67 & 0 & 171 \\
\hline ADIYAMAN & GERGER & 6,5 & 8,75 & \begin{tabular}{l|l|}
0,01 & \\
\end{tabular} & 0 & 0 & 9 \\
\hline ADIYAMAN & KAHTA & 6,5 & 24,15 & 43,97 & 5,4 & 0 & 74 \\
\hline AFYON & IHSANIYE & 6,5 & 5,74 & 1,23 & 0,27 & 0 & 7 \\
\hline AFYON & EVCILER & 6,5 & 8,46 & 2,07 & 0,54 & 0 & 11 \\
\hline AFYON & DAZKIRI & 6,5 & 10,14 & 0,71 & 2,22 & 0 & 13 \\
\hline AFYON & BAYAT & 6,5 & 14,84 & 1,44 & 0,51 & 0 & 17 \\
\hline AFYON & BASMAKCI & 6,5 & 13,95 & 6,34 & 1,32 & 0 & 22 \\
\hline AFYON & SULTANDAGI & 6,5 & 8,65 & 8,39 & 3,24 & 0 & 20 \\
\hline AFYON & COBANLAR & 6,5 & 16,52 & 1,45 & 0,75 & 0 & 19 \\
\hline AFYON & ISCEHISAR & 6,5 & 21,77 & 3,97 & 3,45 & 0 & 29 \\
\hline AFYON & SUHUT & 6,5 & 28,21 & 2,33 & 3,3 & 0 & 34 \\
\hline AFYON & CAY & 6,5 & 38,37 & 9,16 & 11,19 & 0 & 59 \\
\hline AFYON & EMIRDAG & 6,5 & 32,36 & 15,05 & 15,45 & 0 & 63 \\
\hline AFYON & BOLVADIN & 6,5 & 83,22 & 9,29 & 12,27 & 0 & 105 \\
\hline AFYON & AFYON M. & 6,5 & 148,32 & 1,15 & 90,15 & 0 & 240 \\
\hline AMASYA & GOYNUCEK & 6,5 & 4,4 & 1,56 & 0,69 & 0 & 7 \\
\hline ANKARA & NALLIHAN & 6,5 & 6,42 & 13,57 & 8,34 & 0 & 28 \\
\hline ANKARA & K.HAMAM & 6,5 & 9,99 & 4,96 & 12,06 & 0 & 27 \\
\hline ANTALYA & KAS & 6,5 & 7,39 & 3,13 & 5,19 & 0 & 16 \\
\hline ANTALYA & FINIKE & 6,5 & 6,03 & 8,38 & 8,76 & 0 & 23 \\
\hline ANTALYA & ELMALI & 6,5 & 18,33 & 15,27 & 8,34 & 0 & 42 \\
\hline ANTALYA & KALE (DEMRE) & 6,5 & 13,13 & 8,98 & 4,35 & 0 & 26 \\
\hline ANTALYA & KORKUTELI & 6,5 & 27,38 & 8,76 & 18,12 & 0 & 54 \\
\hline ANTALYA & KEMER & 6,5 & 9,71 & 9,62 & 4,68 & 0 & 24 \\
\hline ANTALYA & KUMLUCA & 6,5 & 32,49 & 9,68 & 14,28 & 0 & 56 \\
\hline AYDIN & KARPUZLU & 6,5 & 5,92 & 2,5 & 0,51 & 0 & 9 \\
\hline AYDIN & KARACASU & 6,5 & 20,96 & 2,76 & 3,15 & 0 & 27 \\
\hline AYDIN & SULTANHISAR & 6,5 & 13,19 & 2,7 & 3,18 & 0 & 19 \\
\hline AYDIN & YENIPAZAR & 6,5 & 23,49 & 7,14 & 1,86 & 0 & 32 \\
\hline AYDIN & KOCARLI & 6,5 & 10,26 & 6,05 & 1,95 & 0 & 18 \\
\hline AYDIN & BUHARKENT & 6,5 & 11,23 & 4,65 & 4,23 & 0 & 20 \\
\hline AYDIN & KUYUCAK & 6,5 & 13,38 & 6,22 & 3,69 & 0 & 23 \\
\hline AYDIN & BOZDOGAN & 6,5 & 36,98 & 2,58 & 5,13 & 0 & 45 \\
\hline AYDIN & KOSK & 6,5 & 10,54 & 8,36 & 3,12 & 0 & 22 \\
\hline
\end{tabular}




\begin{tabular}{|c|c|c|c|c|c|c|c|}
\hline Provinces & Sub-Provinces & Intensity & \begin{tabular}{|c|} 
Load \\
Bearing \\
Construction \\
$(\mathbf{1 - 3}$ storeys $)$ \\
Combined \\
levels of loss \\
(D3+D4+D5)
\end{tabular} & \begin{tabular}{|c|} 
Frame \\
Construction \\
Low-Rise \\
$(\mathbf{1 - 3})$ \\
Combined \\
levels of loss \\
(D3+D4+D5)
\end{tabular} & $\begin{array}{c}\text { Frame } \\
\text { Construction } \\
\text { Mid-Rise } \\
\mathbf{( 4 - 9 )} \\
\text { Combined } \\
\text { levels of loss } \\
\text { (D3+D4+D5) }\end{array}$ & \begin{tabular}{|c|} 
Frame \\
Construction \\
High-Rise \\
$(\mathbf{1 0 +})$ \\
Combined \\
levels of loss \\
(D3+D4+D5)
\end{tabular} & $\begin{array}{c}\text { TOTAL } \\
\text { LOST }\end{array}$ \\
\hline AYDIN & GERMENCIK & 6,5 & 20,44 & 9,08 & 3,87 & 0 & 33 \\
\hline AYDIN & INCIRLIOVA & 6,5 & 22,95 & 13,74 & 10,5 & 0 & 47 \\
\hline \begin{tabular}{|l} 
AYDIN \\
\end{tabular} & CINE & 6,5 & 34,32 & 18,14 & 11,25 & 0 & 64 \\
\hline \begin{tabular}{|l} 
AYDIN \\
\end{tabular} & DİDİM & 6,5 & 11,44 & 167,06 & 25,05 & 0 & 204 \\
\hline AYDIN & KUSADASI & 6,5 & 22,61 & 137,3 & 50,7 & 0 & 211 \\
\hline AYDIN & SOKE & 6,5 & 71,67 & 15,65 & 50,61 & 0 & 138 \\
\hline AYDIN & NAZILLI & 6,5 & 97,04 & 46,1 & 66,72 & 0 & 210 \\
\hline \begin{tabular}{|l} 
AYDIN \\
\end{tabular} & AYDIN C. & 6,5 & 78,77 & 58,37 & 165,99 & 0 & 303 \\
\hline BALIKESIR & KEPSUT & 6,5 & 16,55 & 3,9 & 3,99 & 0 & 24 \\
\hline \begin{tabular}{|l|} 
BALIKESIR \\
\end{tabular} & GONEN & 6,5 & 34,09 & 31,87 & 27,33 & 0 & 93 \\
\hline BALIKESIR & BALIKESİR C. & 6,5 & 141,68 & 85,15 & 242,22 & 0 & 469 \\
\hline BILECIK & INHISAR & 6,5 & 4,76 & 0,28 & 0,36 & 0 & 5 \\
\hline BILECIK & YENIPAZAR & 6,5 & 3,83 & 0,62 & 0,78 & 0 & 5 \\
\hline BILECIK & PAZARYERI & 6,5 & 16 & 1,68 & 1,2 & 0 & 19 \\
\hline BILECIK & SOGUT & 6,5 & 10,09 & 7,87 & 11,19 & 0 & 29 \\
\hline BILECIK & BOZUYUK & 6,5 & 67,2 & 2,66 & 26,19 & 0 & 96 \\
\hline BITLIS & GUROYMAK & 6,5 & 21,34 & 1,03 & 1,05 & 0 & 23 \\
\hline BITLIS & TATVAN & 6,5 & 11,5 & 43,29 & 10,2 & 0 & 65 \\
\hline BURDUR & CELTIKCI & 6,5 & 3,85 & 4,56 & 0,36 & 0 & 9 \\
\hline BURDUR & AGLASUN & 6,5 & 13,21 & 0,7 & 1,14 & 0 & 15 \\
\hline BURDUR & BUCAK & 6,5 & 55,15 & 11,96 & 20,22 & 0 & 87 \\
\hline BURDUR & BURDUR C. & 6,5 & 79,25 & 37,75 & 38,61 & 0 & 156 \\
\hline BURSA & KELES & 6,5 & 2,58 & 5,8 & 1,02 & 0 & 9 \\
\hline BURSA & ORHANELI & 6,5 & 14,7 & 1,06 & 3,96 & 0 & 20 \\
\hline CANAKKALE & YENICE & 6,5 & 9 & 4,92 & 1,74 & 0 & 16 \\
\hline CANKIRI & ELDIVAN & 6,5 & 12,8 & 0,29 & 0,57 & 0 & 14 \\
\hline \begin{tabular}{|l|} 
CANKIRI \\
\end{tabular} & SABANOZU & 6,5 & 5,88 & 2,83 & 0,51 & 0 & 9 \\
\hline CANKIRI & ÇANKIRI C. & 6,5 & 25,53 & 34,86 & 29,85 & 0 & 90 \\
\hline CORUM & ORTAKOY & 6,5 & 5,34 & 2,66 & 0,84 & 0 & 9 \\
\hline CORUM & MECITOZU & 6,5 & 8,6 & 6,15 & 1,41 & 0 & 16 \\
\hline CORUM & BAYAT & 6,5 & 5,88 & 8,46 & 2,82 & 0 & 17 \\
\hline CORUM & ÇORUM C. & 6,5 & 158,49 & 13,3 & 114,27 & 0 & 286 \\
\hline DENIZLI & BEYAGAC & 6,5 & 7 & 0,89 & 0,51 & 0 & 8 \\
\hline DENIZLI & CAMELI & 6,5 & 6,01 & 1,98 & 1,5 & 0 & 9 \\
\hline DENIZLI & BEKILLI & 6,5 & 14,19 & 3,78 & 0,75 & 0 & 19 \\
\hline DENIZLI & BABADAG & 6,5 & 13,42 & 3 & 1,05 & 0 & 17 \\
\hline DENIZLI & HONAZ & 6,5 & 12,05 & 4,89 & 1,53 & 0 & 18 \\
\hline \begin{tabular}{|l|} 
DENIZLI \\
\end{tabular} & ACIPAYAM & 6,5 & 9,82 & 6,47 & 11,07 & 0 & 27 \\
\hline DENIZLI & SARAYKOY & 6,5 & 18,79 & 9,62 & 14,31 & 0 & 43 \\
\hline DENIZLI & DENIZLII C. & 6,5 & 146,8 & 188,18 & 250,95 & 0 & 586 \\
\hline DIYARBAKIR & DICLE & 6,5 & 14,42 & 0 & 0,27 & 0 & 15 \\
\hline DIYARBAKIR & CERMIK & 6,5 & 26,68 & 0 & 1,23 & 0 & 28 \\
\hline DIYARBAKIR & ERGANI & 6,5 & 46,23 & 57 & 4,56 & 0 & 108 \\
\hline \begin{tabular}{|l|} 
DUZCE \\
\end{tabular} & AKCAKOCA & 6,5 & 10,14 & 9,72 & 22,44 & 0 & 42 \\
\hline EDIRNE & IPSALA & 6,5 & 18,02 & 4,57 & 1,65 & 0 & 24 \\
\hline ELAZIG & KARAKOCAN & 6,5 & 13,19 & 5,53 & 3,54 & 0 & 22 \\
\hline ERZURUM & TEKMAN & 6,5 & 8,82 & 1,46 & 0,27 & 0 & 11 \\
\hline ERZURUM & ASKALE & 6,5 & 13,18 & 13,09 & 2,13 & 0 & 28 \\
\hline ERZURUM & PASINLER & 6,5 & 31,64 & 9,65 & 2,19 & 0 & 43 \\
\hline ESKISEHIR & MIHALGAZI & 6,5 & 4,71 & 2,65 & 0,87 & 0 & 8 \\
\hline ESKISEHIR & SARICAKAYA & 6,5 & 2,71 & 1,63 & 0,72 & 0 & 5 \\
\hline
\end{tabular}




\begin{tabular}{|c|c|c|c|c|c|c|c|}
\hline Provinces & Sub-Provinces & Intensity & \begin{tabular}{|c|} 
Load \\
Bearing \\
Construction \\
(1-3 storeys) \\
Combined \\
levels of loss \\
(D3+D4+D5)
\end{tabular} & 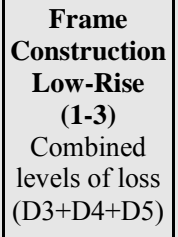 & $\begin{array}{c}\text { Frame } \\
\text { Construction } \\
\text { Mid-Rise } \\
(\mathbf{4 - 9 )} \\
\text { Combined } \\
\text { levels of loss } \\
\text { (D3+D4+D5) }\end{array}$ & \begin{tabular}{|c|} 
Frame \\
Construction \\
High-Rise \\
$(\mathbf{1 0 +})$ \\
Combined \\
levels of loss \\
(D3+D4+D5)
\end{tabular} & $\begin{array}{l}\text { TOTAL } \\
\text { LOST }\end{array}$ \\
\hline GAZIANTEP & YAVUZELI & 6,5 & 3,2 & 5,69 & 0,6 & 0 & $\overline{9}$ \\
\hline GAZIANTEP & ARABAN & 6,5 & 18,82 & 1,78 & 0,24 & 0 & 21 \\
\hline GUMUSHANE & KELKIT & 6,5 & 10,22 & 12,65 & 4,59 & 0 & 27 \\
\hline ICEL(MERSIN) & TARSUS & 6,5 & 66,52 & 251,76 & 42,39 & 0 & 361 \\
\hline ISPARTA & GONEN & 6,5 & 10,49 & 0,95 & 1,05 & 0 & 12 \\
\hline ISPARTA & ATABEY & 6,5 & 13,34 & 0,74 & 1,41 & 0 & 15 \\
\hline ISPARTA & GELENDOST & 6,5 & 16,3 & 0,73 & 0,78 & 0 & 18 \\
\hline ISPARTA & ULUBORLU & 6,5 & 19,5 & 0,53 & 1,44 & 0 & 21 \\
\hline ISPARTA & SENIRKENT & 6,5 & 14,55 & 6,82 & 4,8 & 0 & 26 \\
\hline \begin{tabular}{|l} 
ISPARTA \\
\end{tabular} & KECIBORLU & 6,5 & 22,28 & 1,87 & 2,43 & 0 & 27 \\
\hline ISPARTA & S.KARAAGAC & 6,5 & 22,86 & 3,97 & 7,74 & 0 & 35 \\
\hline ISPARTA & EGIRDIR & 6,5 & 27,54 & 7,62 & 14,79 & 0 & 50 \\
\hline ISPARTA & YALVAC & 6,5 & 17,73 & 8,96 & 19,68 & 0 & 46 \\
\hline ISPARTA & ISPARTA C. & 6,5 & 167,6 & 49,58 & 137,07 & 0 & 354 \\
\hline IZMIR & BEYDAG & 6,5 & 13,84 & 5,8 & 3,84 & 0 & 23 \\
\hline IZMIR & KIRAZ & 6,5 & 15,71 & 6,28 & 2,4 & 0 & 24 \\
\hline IZMIR & KINIK & 6,5 & 33,75 & 4,58 & 1,05 & 0 & 39 \\
\hline IZMIR & TIRE & 6,5 & 77,84 & 16,77 & 28,89 & 0 & 124 \\
\hline IZMIR & ODEMIS & 6,5 & 97,11 & 27,29 & 65,85 & 0 & 190 \\
\hline K.MARAS & CAG.CERIT & 6,5 & 22,34 & 2,02 & 0,39 & 0 & 25 \\
\hline K.MARAS & K.MARAŞ C. & 6,5 & 172,05 & 218,91 & 65,7 & 0 & 457 \\
\hline KARABUK & YENICE & 6,5 & 6,46 & 11,49 & 15,54 & 0 & 33 \\
\hline KARABUK & SAFRANBOLU & 6,5 & 26,42 & 25,47 & 23,82 & 0 & 76 \\
\hline KARABUK & KARABÜK C. & 6,5 & 95,2 & 19,81 & 65,46 & 0 & 180 \\
\hline KASTAMONU & TASKOPRU & 6,5 & 6,64 & 14,4 & 15,72 & 0 & 37 \\
\hline KASTAMONU & KASTAMONU C. & 6,5 & 7,26 & 69,58 & 44,22 & 0 & 121 \\
\hline KAYSERI & BUNYAN & 6,5 & 23,21 & 3,81 & 3,27 & 0 & 30 \\
\hline KAYSERI & YAHYALI & 6,5 & 32,41 & 11,11 & 4,62 & 0 & 48 \\
\hline KAYSERI & TALAS & 6,5 & 15,55 & 6,04 & 20,7 & 0 & 42 \\
\hline KILIS & MUSABEYLI & 6,5 & 1,03 & 0,68 & 0,09 & 0 & 2 \\
\hline KONYA & DERBENT & 6,5 & 15,23 & 1,74 & 0,45 & 0 & 17 \\
\hline KONYA & AKOREN & 6,5 & 5,24 & 0 & 0,33 & 0 & 6 \\
\hline KONYA & HUYUK & 6,5 & 14,14 & 0,32 & 1,95 & 0 & 16 \\
\hline KONYA & TUZLUKCU & 6,5 & 11,79 & 0,35 & 0,09 & 0 & 12 \\
\hline KONYA & DOGANHISAR & 6,5 & 17,98 & 3,42 & 5,97 & 0 & 27 \\
\hline KONYA & ILGIN & 6,5 & 30,53 & 20,79 & 10,47 & 0 & 62 \\
\hline KONYA & AKSEHIR & 6,5 & 59,44 & 11,8 & 49,89 & 0 & 121 \\
\hline KUTAHYA & DUMLUPINAR & 6,5 & 4,91 & 0,89 & 0,57 & 0 & 6 \\
\hline KUTAHYA & ASLANAPA & 6,5 & 1,01 & 3,72 & 0,24 & 0 & 5 \\
\hline KUTAHYA & CAVDARHISAR & 6,5 & 0,32 & 7,56 & 0,6 & 0 & 8 \\
\hline KUTAHYA & SAPHANE & 6,5 & 3,14 & 11,36 & 1,17 & 0 & 16 \\
\hline KUTAHYA & PAZARLAR & 6,5 & 8,53 & 1,98 & 1,53 & 0 & 12 \\
\hline KUTAHYA & HISARCIK & 6,5 & 8,76 & 3,24 & 5,67 & 0 & 18 \\
\hline KUTAHYA & ALTINTAS & 6,5 & 6,99 & 4,29 & 1,8 & 0 & 13 \\
\hline KUTAHYA & EMET & 6,5 & 0,95 & 24,69 & 5,73 & 0 & 31 \\
\hline KUTAHYA & GEDIZ & 6,5 & 1,24 & 42,95 & 1,53 & 0 & 46 \\
\hline KUTAHYA & SIMAV & 6,5 & 17,01 & 19,25 & 36,87 & 0 & 73 \\
\hline KUTAHYA & KÜTAHYA C. & 6,5 & 201,05 & 18,29 & 164,22 & 0 & 384 \\
\hline MALATYA & KALE & 6,5 & 6,32 & 0,35 & 0,18 & 0 & 7 \\
\hline MALATYA & DOGANSEHIR & 6,5 & 14,8 & 2,92 & 2,07 & 0 & 20 \\
\hline MANISA & KOPRUBASI & 6,5 & 9,15 & 6,11 & 1,53 & 0 & 17 \\
\hline
\end{tabular}




\begin{tabular}{|c|c|c|c|c|c|c|c|}
\hline Provinces & Sub-Provinces & Intensity & \begin{tabular}{|c|} 
Load \\
Bearing \\
Construction \\
(1-3 storeys) \\
Combined \\
levels of loss \\
(D3+D4+D5)
\end{tabular} & \begin{tabular}{|c|} 
Frame \\
Construction \\
Low-Rise \\
$(\mathbf{1 - 3})$ \\
Combined \\
levels of loss \\
(D3+D4+D5)
\end{tabular} & $\begin{array}{c}\text { Frame } \\
\text { Construction } \\
\text { Mid-Rise } \\
\mathbf{( 4 - 9 )} \\
\text { Combined } \\
\text { levels of loss } \\
\text { (D3+D4+D5) }\end{array}$ & \begin{tabular}{|c|} 
Frame \\
Construction \\
High-Rise \\
$(\mathbf{1 0 +})$ \\
Combined \\
levels of loss \\
(D3+D4+D5)
\end{tabular} & $\begin{array}{l}\text { TOTAL } \\
\text { LOST }\end{array}$ \\
\hline MANISA & GORDES & 6,5 & 21,58 & 8,82 & 6,27 & 0 & 37 \\
\hline MANISA & DEMIRCI & 6,5 & 37,91 & 4,25 & 6,18 & 0 & 48 \\
\hline MANISA & KIRKAGAC & 6,5 & 37,07 & 11,77 & 6,84 & 0 & 56 \\
\hline MANISA & SOMA & 6,5 & 62 & 19,54 & 51,39 & 0 & 133 \\
\hline MUGLA & ULA & 6,5 & 20,44 & 0,98 & 0,12 & 0 & 22 \\
\hline MUGLA & KOYCEGIZ & 6,5 & 16,27 & 6,7 & 0,39 & 0 & 23 \\
\hline MUGLA & DATCA & 6,5 & 22,97 & 11,69 & 2,34 & 0 & 37 \\
\hline \begin{tabular}{|l|} 
MUGLA \\
\end{tabular} & YATAGAN & 6,5 & 20,99 & 4,57 & 7,47 & 0 & 33 \\
\hline MUGLA & DALAMAN & 6,5 & 30,22 & 10,04 & 6,27 & 0 & 47 \\
\hline MUGLA & ORTACA & 6,5 & 26,42 & 14,95 & 8,4 & 0 & 50 \\
\hline MUGLA & MARMARIS & 6,5 & 10,18 & 15,53 & 28,74 & 0 & 54 \\
\hline MUGLA & BODRUM & 6,5 & 15,83 & 111,95 & 2,04 & 0 & 130 \\
\hline MUGLA & MILAS & 6,5 & 32,98 & 42,7 & 15,99 & 0 & 92 \\
\hline MUGLA & MUĞLA C. & 6,5 & 57,97 & 18,01 & 32,52 & 0 & 109 \\
\hline MUGLA & FETHIYE & 6,5 & 37,09 & 82,42 & 24,66 & 0 & 144 \\
\hline MUS & HASKOY & 6,5 & 10,96 & 11,84 & 0,99 & 0 & 24 \\
\hline MUS & MUŞ C. & 6,5 & 21,89 & 38,62 & 16,35 & 0 & 77 \\
\hline NIGDE & CAMARDI & 6,5 & 13,16 & 0,04 & 0,87 & 0 & 14 \\
\hline ORDU & CATALPINAR & 6,5 & 1,27 & 7,93 & 2,13 & 0 & 11 \\
\hline ORDU & GURGENTEPE & 6,5 & 2,92 & 20,27 & 4,53 & 0 & 28 \\
\hline ORDU & KUMRU & 6,5 & 5,66 & 12,49 & 9,33 & 0 & 27 \\
\hline ORDU & KORGAN & 6,5 & 10,74 & 16,24 & 7,08 & 0 & 34 \\
\hline OSMANIYE & SUMBAS & 6,5 & 6,9 & 0,43 & 0 & 0 & 7 \\
\hline OSMANIYE & DUZICI & 6,5 & 21,18 & 53,68 & 1,08 & 0 & 76 \\
\hline OSMANIYE & KADIRLI & 6,5 & 157,57 & 0,66 & 8,67 & 0 & 167 \\
\hline SAKARYA & KAYNARCA & 6,5 & 5,06 & 2,92 & 3,33 & 0 & 11 \\
\hline SAKARYA & KOCAALI & 6,5 & 10,87 & 21,46 & 6,63 & 0 & 39 \\
\hline SAKARYA & KARASU & 6,5 & 16,83 & 17,97 & 21,9 & 0 & 57 \\
\hline SAMSUN & SALIPAZARI & 6,5 & 2,31 & 8,01 & 3,75 & 0 & 14 \\
\hline SAMSUN & TEKKEKÖY & 6,5 & 8,83 & 12,56 & 9,24 & 0 & 31 \\
\hline SINOP & DURAGAN & 6,5 & 5,47 & 7,25 & 9,48 & 0 & 22 \\
\hline SINOP & BOYABAT & 6,5 & 10,45 & 18,78 & 20,58 & 0 & 50 \\
\hline SIVAS & ZARA & 6,5 & 28,55 & 2,75 & 3,54 & 0 & 35 \\
\hline TEKIRDAG & MURATLI & 6,5 & 14,27 & 19,58 & 5,01 & 0 & 39 \\
\hline TEKIRDAG & CERKEZKOY & 6,5 & 19,58 & 20,21 & 33 & 0 & 73 \\
\hline TEKIRDAG & CORLU & 6,5 & 52,93 & 63,89 & 113,43 & 0 & 230 \\
\hline TOKAT & PAZAR & 6,5 & 8,58 & 4,61 & 1,14 & 0 & 14 \\
\hline TOKAT & ZILE & 6,5 & 1,43 & 87,71 & 10,74 & 0 & 100 \\
\hline TOKAT & TURHAL & 6,5 & 75,69 & 23,22 & 26,04 & 0 & 125 \\
\hline \begin{tabular}{|l} 
TUNCELI \\
\end{tabular} & NAZIMIYE & 6,5 & 2,47 & 0,34 & 0,9 & 0 & 4 \\
\hline TUNCELI & OVACIK & 6,5 & 4,43 & 1,72 & 0,81 & 0 & 7 \\
\hline USAK & ULUBEY & 6,5 & 6,65 & 9,37 & 3,39 & 0 & 19 \\
\hline USAK & BANAZ & 6,5 & 9,91 & 16,83 & 16,65 & 0 & 43 \\
\hline VAN & SARAY & 6,5 & 4,69 & 1,04 & 0,06 & 0 & 6 \\
\hline VAN & GEVAS & 6,5 & 10,55 & 10,01 & 0,54 & 0 & 21 \\
\hline ZONGULDAK & ALAPLI & 6,5 & 4,83 & 1,92 & 23,22 & 0 & 30 \\
\hline ADANA & ADANA (M.) & 6,5 & 271,07 & 1375,3 & 266,4 & 0 & 1913 \\
\hline ANTALYA & ANTALYA (M.) & 6,5 & 696,99 & 302,3 & 402,3 & 0 & 1402 \\
\hline ERZURUM & ERZURUM (M.) & 6,5 & 182,61 & 84,26 & 171,96 & 0 & 439 \\
\hline KONYA & KONYA (M.) & 6,5 & 889,79 & 119,39 & 345,48 & 0 & 1355 \\
\hline ADIYAMAN & TUT & 7 & 17,76 & 14,67 & 1,32 & 0 & 34 \\
\hline
\end{tabular}




\begin{tabular}{|c|c|c|c|c|c|c|c|}
\hline Provinces & Sub-Provinces & Intensity & \begin{tabular}{|c|} 
Load \\
Bearing \\
Construction \\
(1-3 storeys) \\
Combined \\
levels of loss \\
(D3+D4+D5)
\end{tabular} & 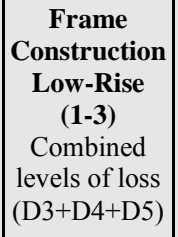 & $\begin{array}{c}\text { Frame } \\
\text { Construction } \\
\text { Mid-Rise } \\
(\mathbf{4 - 9 )} \\
\text { Combined } \\
\text { levels of loss } \\
\text { (D3+D4+D5) }\end{array}$ & \begin{tabular}{|c|} 
Frame \\
Construction \\
High-Rise \\
$(\mathbf{1 0 +})$ \\
Combined \\
levels of loss \\
(D3+D4+D5)
\end{tabular} & $\begin{array}{c}\text { TOTAL } \\
\text { LOST }\end{array}$ \\
\hline ADIYAMAN & SINCIK & 7 & 14,82 & 4,17 & 0,24 & 0 & 19 \\
\hline \begin{tabular}{|l|} 
ADIYAMAN \\
\end{tabular} & CELIKHAN & 7 & 20,07 & 16,89 & 1,44 & 0 & 38 \\
\hline ADIYAMAN & BESNI & 7 & 29,31 & 87 & 10,14 & 0,02 & 126 \\
\hline ADIYAMAN & GOLBASI & 7 & 30,15 & 89,85 & 16,5 & 0 & 137 \\
\hline ADIYAMAN & ADIYAMAN C. & 7 & 170,04 & 440,85 & 84,72 & 0,18 & 696 \\
\hline AMASYA & HAMAMOZU & 7 & 11,19 & 2,49 & 1,38 & 0 & 15 \\
\hline AMASYA & AMASYA C. & 7 & 143,46 & 83,61 & 109,26 & 0,02 & 336 \\
\hline ANKARA & CAMLIDERE & 7 & 57,27 & 9,81 & 2,64 & 0 & 70 \\
\hline BALIKESIR & BALYA & 7 & 15,96 & 3,15 & 0,9 & 0 & 20 \\
\hline \begin{tabular}{|l|} 
BALIKESIR \\
\end{tabular} & GOMEC & 7 & 46,47 & 40,65 & 0,3 & 0 & 87 \\
\hline BALIKESIR & IVRINDI & 7 & 29,1 & 13,92 & 6,06 & 0 & 49 \\
\hline BALIKESIR & MANYAS & 7 & 34,62 & 10,62 & 5,7 & 0 & 51 \\
\hline BALIKESIR & SAVASTEPE & 7 & 44,19 & 21,39 & 6,78 & 0,04 & 72 \\
\hline BALIKESIR & HAVRAN & 7 & 78 & 17,7 & 11,7 & 0 & 107 \\
\hline BALIKESIR & SINDIRGI & 7 & 60,63 & 26,52 & 13,02 & 0 & 100 \\
\hline BALIKESIR & BIGADIC & 7 & 54,03 & 42,12 & 17,82 & 0 & 114 \\
\hline BALIKESIR & ERDEK & 7 & 56,88 & 34,5 & 67,44 & 0 & 159 \\
\hline BALIKESIR & SUSURLUK & 7 & 121,38 & 29,7 & 39,18 & 0 & 190 \\
\hline BALIKESIR & AYVALIK & 7 & 210,81 & 192,21 & 39 & 0 & 442 \\
\hline BALIKESIR & BURHANIYE & 7 & 185,46 & 194,34 & 29,82 & 0 & 410 \\
\hline BALIKESIR & EDREMIT & 7 & 154,59 & 39,54 & 67,98 & 0 & 262 \\
\hline BALIKESIR & BANDIRMA & 7 & 109,74 & 150,06 & 199,2 & 0,62 & 460 \\
\hline BILECIK & GOLPAZARI & 7 & 27,33 & 25,86 & 5,16 & 0 & 58 \\
\hline BILECIK & BİLECIK C. & 7 & 88,65 & 6,99 & 49,68 & 0,02 & 145 \\
\hline \begin{tabular}{|l|} 
BINGOL \\
\end{tabular} & YAYLADERE & 7 & 23,28 & 0,27 & 1,62 & 0 & 25 \\
\hline BINGOL & GENC & 7 & 32,58 & 14,4 & 6,54 & 0 & 54 \\
\hline BINGOL & BİNGÖL C. & 7 & 94,29 & 87,09 & 69,42 & 0,02 & 251 \\
\hline BOLU & KIBRISCIK & 7 & 11,76 & 0,18 & 0,42 & 0 & 12 \\
\hline BOLU & SEBEN & 7 & 0,45 & 21,45 & 1,32 & 0 & 23 \\
\hline BURDUR & KEMER & 7 & 19,98 & 3,45 & 1,02 & 0 & 24 \\
\hline BURDUR & CAVDIR & 7 & 18,99 & 6,09 & 2,58 & 0 & 28 \\
\hline BURDUR & ALTINYAYLA & 7 & 32,61 & 0,9 & 1,8 & 0 & 35 \\
\hline BURDUR & TEFENNI & 7 & 42,51 & 3,72 & 3,66 & 0 & 50 \\
\hline BURDUR & YESILOVA & 7 & 27,6 & 17,85 & 4,02 & 0 & 49 \\
\hline BURDUR & KARAMANLI & 7 & 47,25 & 6,66 & 6,54 & 0 & 60 \\
\hline \begin{tabular}{|l|} 
BURDUR \\
\end{tabular} & GOLHISAR & 7 & 83,19 & 16,08 & 10,74 & 0 & 110 \\
\hline BURSA & KARACABEY & 7 & 113,16 & 87,45 & 57,36 & 0 & 258 \\
\hline BURSA & M.KEMALPASA & 7 & 131,58 & 71,04 & 101,28 & 0 & 304 \\
\hline BURSA & INEGOL & 7 & 115,35 & 194,07 & 226,2 & 0 & 536 \\
\hline CANAKKALE & AYVACIK & 7 & 37,26 & 16,68 & 3 & 0 & 57 \\
\hline CANAKKALE & LAPSEKI & 7 & 39,9 & 16,17 & 18,06 & 0 & 74 \\
\hline CANAKKALE & EZINE & 7 & 75,21 & 33,6 & 12,54 & 0,06 & 121 \\
\hline CANAKKALE & BAYRAMIC & 7 & 81,09 & 38,79 & 9,24 & 0 & 129 \\
\hline CANAKKALE & $\mathrm{CAN}$ & 7 & 60,66 & 78,96 & 21,42 & 0 & 161 \\
\hline CANAKKALE & BIGA & 7 & 70,89 & 69 & 48,54 & 0 & 188 \\
\hline CANAKKALE & ÇANAKKALE C. & 7 & 108,6 & 105,99 & 124,02 & 0,22 & 339 \\
\hline CANKIRI & YAPRAKLI & 7 & 6,54 & 16,14 & 1,08 & 0 & 24 \\
\hline CANKIRI & ORTA & 7 & 20,4 & 6,45 & 1,74 & 0 & 29 \\
\hline CORUM & LACIN & 7 & 15,15 & 0,18 & 0,48 & 0 & 16 \\
\hline CORUM & OGUZLAR & 7 & 5,79 & 36,33 & 2,34 & 0 & 44 \\
\hline CORUM & ISKILIP & 7 & 36,66 & 102,21 & 28,2 & 0 & 167 \\
\hline
\end{tabular}




\begin{tabular}{|c|c|c|c|c|c|c|c|}
\hline Provinces & Sub-Provinces & Intensity & \begin{tabular}{|c|} 
Load \\
Bearing \\
Construction \\
$(\mathbf{1 - 3}$ storeys $)$ \\
Combined \\
levels of loss \\
(D3+D4+D5)
\end{tabular} & \begin{tabular}{|c|} 
Frame \\
Construction \\
Low-Rise \\
$(\mathbf{1 - 3})$ \\
Combined \\
levels of loss \\
(D3+D4+D5)
\end{tabular} & \begin{tabular}{|c|} 
Frame \\
Construction \\
Mid-Rise \\
$\mathbf{( 4 - 9 )}$ \\
Combined \\
levels of loss \\
(D3+D4+D5)
\end{tabular} & \begin{tabular}{|c|} 
Frame \\
Construction \\
High-Rise \\
$(\mathbf{1 0 +})$ \\
Combined \\
levels of loss \\
(D3+D4+D5)
\end{tabular} & \begin{tabular}{|l} 
TOTAL \\
LOST
\end{tabular} \\
\hline DENIZLI & BAKLAN & 7 & 24,09 & 3,93 & 0,48 & 0 & 29 \\
\hline \begin{tabular}{|l} 
DENIZLI \\
\end{tabular} & AKKOY & 7 & 11,28 & 7,56 & 0,36 & 0 & 19 \\
\hline \begin{tabular}{|l} 
DENIZLI \\
\end{tabular} & $\mathrm{CAL}$ & 7 & 43,68 & 7,68 & 1,44 & 0 & 53 \\
\hline \begin{tabular}{|l} 
DENIZLI \\
\end{tabular} & BOZKURT & 7 & 20,76 & 7,59 & 3 & 0 & 31 \\
\hline \begin{tabular}{|l} 
DENIZLI \\
\end{tabular} & CARDAK & 7 & 21,6 & 17,04 & 3,9 & 0 & 43 \\
\hline \begin{tabular}{|l} 
DENIZLI \\
\end{tabular} & GUNEY & 7 & 35,34 & 18,87 & 2,4 & 0 & 57 \\
\hline \begin{tabular}{|l} 
DENIZLI \\
\end{tabular} & BULDAN & 7 & 66,18 & 51,54 & 19,44 & 0,02 & 137 \\
\hline DIYARBAKIR & CUNGUS & 7 & 23,61 & 1,95 & 0,78 & 0 & 26 \\
\hline DUZCE & YIGILCA & 7 & 2,31 & 11,04 & 6,6 & 0 & 20 \\
\hline EDIRNE & ENEZ & 7 & 33,93 & 69,66 & 1,86 & 0 & 105 \\
\hline EDIRNE & KESAN & 7 & 163,8 & 49,23 & 56,4 & 0 & 269 \\
\hline ELAZIG & ALACAKAYA & 7 & 18,78 & 5,79 & 0,42 & 0 & 25 \\
\hline ELAZIG & ARICAK & 7 & 15,39 & 0 & 1,14 & 0 & 17 \\
\hline ELAZIG & SIVRICE & 7 & 28,41 & 1,44 & 0,78 & 0 & 31 \\
\hline ELAZIG & MADEN & 7 & 39,99 & 7,89 & 2,88 & 0 & 51 \\
\hline ELAZIG & PALU & 7 & 48,57 & 4,26 & 2,28 & 0 & $\overline{55}$ \\
\hline \begin{tabular}{|l} 
ELAZIG \\
\end{tabular} & KOVANCILAR & 7 & 45 & 2,97 & 25,68 & 0,32 & 74 \\
\hline $\begin{array}{l}\text { ERZINCAN } \\
\end{array}$ & OTLUKBELI & 7 & 10,23 & 2,43 & 0,54 & 0 & $\overline{13}$ \\
\hline ERZINCAN & KEMAH & 7 & 13,74 & 5,73 & 1,32 & 0 & 21 \\
\hline ERZINCAN & TERCAN & 7 & 37,47 & 4,32 & 1,74 & 0 & $\overline{44}$ \\
\hline ERZURUM & CAT & 7 & 33,03 & 3,66 & 0,54 & 0 & 37 \\
\hline ERZURUM & KARACOBAN & 7 & 65,7 & 6,15 & 1,02 & 0 & 73 \\
\hline ERZURUM & HINIS & 7 & 31,74 & 74,01 & 1,02 & 0,02 & 107 \\
\hline GAZIANTEP & NURDAGI & 7 & 3,75 & 63,96 & 0,84 & 0 & 69 \\
\hline \begin{tabular}{|l} 
GAZIANTEP \\
\end{tabular} & ISLAHIYE & 7 & 70,5 & 67,62 & 9,72 & 0,16 & 148 \\
\hline GIRESUN & ALUCRA & 7 & 17,22 & 9,45 & 2,22 & 0 & 29 \\
\hline GUMUSHANE & SIRAN & 7 & 22,68 & 8,28 & 5,34 & 0 & 36 \\
\hline HATAY & KUMLU & 7 & 32,88 & 0 & 0,18 & 0 & 33 \\
\hline \begin{tabular}{|l} 
HATAY \\
\end{tabular} & YAYLADAGI & 7 & 25,77 & 26,55 & 1,38 & 0 & 54 \\
\hline HATAY & ALTINOZU & 7 & 8,64 & 30,75 & 1,38 & 0 & 41 \\
\hline \begin{tabular}{|l} 
HATAY \\
\end{tabular} & HASSA & 7 & 32,28 & 17,49 & 0,72 & 0 & 50 \\
\hline HATAY & BELEN & 7 & 77,64 & 67,38 & 14,22 & 0,04 & 159 \\
\hline \begin{tabular}{|l} 
HATAY \\
\end{tabular} & ERZIN & 7 & 169,5 & 0,78 & 2,88 & 0 & 173 \\
\hline HATAY & SAMANDAG & 7 & 48,45 & 152,49 & 30,72 & 0,02 & 232 \\
\hline HATAY & REYHANLI & 7 & 107,64 & 162,15 & 10,5 & 0 & 280 \\
\hline HATAY & KIRIKHAN & 7 & 114,72 & 231,33 & 14,22 & 0,02 & 360 \\
\hline HATAY & DORTYOL & 7 & 102,93 & 201,36 & 29,1 & 0 & 333 \\
\hline HATAY & ISKENDERUN & 7 & 164,73 & 398,88 & 141,24 & 0,04 & 705 \\
\hline HATAY & ANTAKYA & 7 & 227,67 & 400,32 & 139,8 & 0,4 & 768 \\
\hline IZMIR & KARABURUN & 7 & 24,42 & 19,47 & 0,84 & 0 & 45 \\
\hline IZMIR & CESME & 7 & 19,98 & 321,33 & 6,96 & 0,02 & 348 \\
\hline IZMIR & BERGAMA & 7 & 239,13 & 100,11 & 62,46 & 0,08 & 402 \\
\hline K.MARAS & TURKOGLU & 7 & 11,58 & 55,26 & 1,08 & 0 & 68 \\
\hline K.MARAS & PAZARCIK & 7 & 17,76 & 98,01 & 3,9 & 0 & 120 \\
\hline KASTAMONU & IHSANGAZI & 7 & 26,22 & 14,28 & 7,26 & 0 & 48 \\
\hline KASTAMONU & ARAC & 7 & 21,54 & 16,62 & 7,2 & 0 & 45 \\
\hline MALATYA & DOGANYOL & 7 & 24,66 & 0,09 & 0,12 & 0 & 25 \\
\hline MALATYA & PUTURGE & 7 & 23,67 & 3,03 & 1,2 & 0 & 28 \\
\hline MANISA & GOLMARMARA & 7 & 73,17 & 14,37 & 3,12 & 0 & 91 \\
\hline MANISA & AHMETLI & 7 & 55,17 & 23,52 & 4,56 & 0 & 83 \\
\hline MANISA & SARIGOL & 7 & 82,2 & 41,79 & 6,06 & 0 & 130 \\
\hline
\end{tabular}




\begin{tabular}{|c|c|c|c|c|c|c|c|}
\hline Provinces & Sub-Provinces & Intensity & \begin{tabular}{|c|} 
Load \\
Bearing \\
Construction \\
$(\mathbf{1 - 3}$ storeys $)$ \\
Combined \\
levels of loss \\
(D3+D4+D5)
\end{tabular} & $\begin{array}{c}\text { Frame } \\
\text { Construction } \\
\text { Low-Rise } \\
(\mathbf{1 - 3}) \\
\text { Combined } \\
\text { levels of loss } \\
\text { (D3+D4+D5) }\end{array}$ & $\begin{array}{c}\text { Frame } \\
\text { Construction } \\
\text { Mid-Rise } \\
\mathbf{( 4 - 9 )} \\
\text { Combined } \\
\text { levels of loss } \\
\text { (D3+D4+D5) }\end{array}$ & $\begin{array}{c}\text { Frame } \\
\text { Construction } \\
\text { High-Rise } \\
(\mathbf{1 0 +}) \\
\text { Combined } \\
\text { levels of loss } \\
\text { (D3+D4+D5) }\end{array}$ & $\begin{array}{c}\text { TOTAL } \\
\text { LOST }\end{array}$ \\
\hline MANISA & SARUHANLI & 7 & 83,85 & 20,88 & 7,68 & 0 & 112 \\
\hline MANISA & KULA & 7 & 140,28 & 85,08 & 10,92 & 0 & 236 \\
\hline MANISA & ALASEHIR & 7 & 187,2 & 78,57 & 40,02 & 0,02 & 306 \\
\hline MANISA & SALIHLI & 7 & 171,21 & 162,6 & 149,04 & 0,02 & 483 \\
\hline MANISA & AKHISAR & 7 & 390,66 & 88,68 & 105,6 & 0 & 585 \\
\hline MANISA & TURGUTLU & 7 & 272,64 & 245,79 & 121,02 & 0,02 & 639 \\
\hline MANISA & MANISA C. & 7 & 409,92 & 156,12 & 352,38 & 0,12 & 919 \\
\hline MUS & KORKUT & 7 & 12,18 & 6,39 & 0,24 & 0 & 19 \\
\hline MUS & MALAZGIRT & 7 & 69,15 & 53,34 & 2,82 & 0 & 125 \\
\hline ORDU & AKKUS & 7 & 6,24 & 8,16 & 5,16 & 0 & 20 \\
\hline ORDU & AYBASTI & 7 & 13,2 & 83,19 & 28,14 & 0 & 125 \\
\hline ORDU & GOLKOY & 7 & 77,58 & 42,48 & 14,04 & 0,04 & 134 \\
\hline OSMANIYE & HASANBEYLI & 7 & 23,94 & 19,32 & 0 & 0 & 43 \\
\hline OSMANIYE & TOPRAKKALE & 7 & 2,01 & 47,7 & 0,12 & 0 & 50 \\
\hline OSMANIYE & BAHCE & 7 & 10,59 & 57,36 & 1,92 & 0,02 & 70 \\
\hline OSMANIYE & OSMANIYE C. & 7 & 158,49 & 695,01 & 49,62 & 1,58 & 905 \\
\hline SAKARYA & FERIZLI & 7 & 23,37 & 30,96 & 6,66 & 0 & 61 \\
\hline SAMSUN & AYVACIK & 7 & 11,07 & 23,46 & 2,22 & 0 & 37 \\
\hline SINOP & SARAYDUZU & 7 & 5,76 & 5,19 & 1,14 & 0 & 12 \\
\hline SIVAS & IMRANLI & 7 & 17,16 & 21,21 & 1,44 & 0 & 40 \\
\hline TEKIRDAG & MALKARA & 7 & 67,08 & 45,99 & 43,98 & 0 & 157 \\
\hline TOKAT & TOKAT C. & 7 & 135,18 & 255,48 & 137,7 & 0,04 & 528 \\
\hline USAK & ESME & 7 & 91,41 & 17,1 & 10,56 & 0 & 119 \\
\hline VAN & GURPINAR & 7 & 24,42 & 0,75 & 0,66 & 0 & 26 \\
\hline VAN & OZALP & 7 & 31,53 & 9,39 & 2,46 & 0 & 43 \\
\hline VAN & EDREMIT & 7 & 27,87 & 4,35 & 0,72 & 0 & 33 \\
\hline VAN & BASKALE & 7 & 41,19 & 17,58 & 1,08 & 0 & 60 \\
\hline IZMIR & IZMIR (M.) & 7 & 4157,31 & 6482,7 & 3867,96 & 23,42 & 14531 \\
\hline AMASYA & GUMSHACIKOY & 7,5 & 189,84 & 46,5 & 35,1 & 0 & 271 \\
\hline AMASYA & SULUOVA & 7,5 & 286,08 & 255,18 & 91,5 & 0 & 633 \\
\hline AMASYA & MERZIFON & 7,5 & 366,72 & 129,84 & 168,9 & 0,12 & 666 \\
\hline BILECIK & OSMANELI & 7,5 & 87,54 & 45,72 & 24,45 & 0 & 158 \\
\hline BINGOL & ADAKLI & 7,5 & 49,98 & 0,42 & 1,35 & 0 & 52 \\
\hline BINGOL & KIGI & 7,5 & 36,06 & 5,28 & 1,35 & 0 & 43 \\
\hline BITLIS & ADILCEVAZ & 7,5 & 121,5 & 37,74 & 12,3 & 0 & 172 \\
\hline BITLIS & AHLAT & 7,5 & 120 & 103,26 & 10,65 & 0 & 234 \\
\hline BOLU & GOYNUK & 7,5 & 13,26 & 59,04 & 2,7 & 0 & 75 \\
\hline BOLU & MUDURNU & 7,5 & 10,2 & 85,32 & 8,4 & 0,12 & 104 \\
\hline BOLU & MENGEN & 7,5 & 17,82 & 35,22 & 22,65 & 0 & 76 \\
\hline BURSA & IZNIK & 7,5 & 88,98 & 139,44 & 23,7 & 0 & 252 \\
\hline BURSA & YENISEHIR & 7,5 & 185,58 & 90,54 & 62,85 & 0 & 339 \\
\hline CANKIRI & KORGUN & 7,5 & 34,8 & 6,36 & 2,7 & 0 & 44 \\
\hline CANKIRI & ATKARACALAR & 7,5 & 19,14 & 22,38 & 3,15 & 0 & 45 \\
\hline CANKIRI & KURSUNLU & 7,5 & 65,64 & 9,54 & 8,55 & 0 & 84 \\
\hline CORUM & DODURGA & 7,5 & 54,42 & 4,44 & 1,5 & 0 & 60 \\
\hline DUZCE & CILIMLI & 7,5 & 2,28 & 43,98 & 2,4 & 0 & 49 \\
\hline DUZCE & GUMUSOVA & 7,5 & 12,42 & 58,74 & 15 & 0 & 86 \\
\hline DUZCE & CUMAYERI & 7,5 & 3,3 & 57,66 & 5,7 & 0 & 67 \\
\hline DUZCE & DÜZCE M. & 7,5 & 117,42 & 326,76 & 168,15 & 0 & 612 \\
\hline ERZINCAN & CAYIRLI & 7,5 & 53,34 & 3,78 & 4,05 & 0 & 61 \\
\hline GIRESUN & S.KARAHISAR & 7,5 & 87,18 & 97,62 & 37,05 & 0 & 222 \\
\hline
\end{tabular}




\begin{tabular}{|c|c|c|c|c|c|c|c|}
\hline Provinces & Sub-Provinces & Intensity & \begin{tabular}{|c|} 
Load \\
Bearing \\
Construction \\
$(\mathbf{1 - 3}$ storeys $)$ \\
Combined \\
levels of loss \\
(D3+D4+D5)
\end{tabular} & \begin{tabular}{|c|} 
Frame \\
Construction \\
Low-Rise \\
$(\mathbf{1 - 3})$ \\
Combined \\
levels of loss \\
(D3+D4+D5)
\end{tabular} & $\begin{array}{c}\text { Frame } \\
\text { Construction } \\
\text { Mid-Rise } \\
\mathbf{( 4 - 9 )} \\
\text { Combined } \\
\text { levels of loss } \\
\text { (D3+D4+D5) }\end{array}$ & \begin{tabular}{|c|} 
Frame \\
Construction \\
High-Rise \\
$(\mathbf{1 0 +})$ \\
Combined \\
levels of loss \\
(D3+D4+D5)
\end{tabular} & $\begin{array}{l}\text { TOTAL } \\
\text { LOST }\end{array}$ \\
\hline KARABUK & OVACIK & 7,5 & 4,08 & 9,12 & 1,35 & 0 & 15 \\
\hline KARABUK & ESKIPAZAR & 7,5 & 55,86 & 18,84 & 21,15 & 0 & 96 \\
\hline MUS & BULANIK & 7,5 & 162,06 & 77,76 & 6,3 & 0 & 246 \\
\hline ORDU & MESUDIYE & 7,5 & 12 & 43,56 & 4,65 & 0 & 60 \\
\hline SAKARYA & TARAKLI & 7,5 & 7,74 & 56,4 & 2,4 & 0 & 67 \\
\hline SAMSUN & ASARCIK & 7,5 & 8,94 & 12,3 & 4,5 & 0 & 26 \\
\hline SAMSUN & KAVAK & 7,5 & 30,42 & 44,22 & 21,9 & 0 & 97 \\
\hline SAMSUN & VEZIRKOPRU & 7,5 & 30,12 & 212,34 & 55,35 & 0 & 298 \\
\hline SIVAS & DOGANSAR & 7,5 & 24,54 & 10,62 & 2,1 & 0 & 37 \\
\hline TEKIRDAG & TEKİRDAĞ C. & 7,5 & 182,4 & 479,34 & 684 & 0,9 & 1347 \\
\hline TOKAT & ALMUS & 7,5 & 46,08 & 11,16 & 16,95 & 0 & 74 \\
\hline VAN & VAN C. & 7,5 & 2064,24 & 14,58 & 205,8 & 0,06 & 2285 \\
\hline YALOVA & ARMUTLU & 7,5 & 51,72 & 46,68 & 66 & 0 & 164 \\
\hline BURSA & BURSA (M.) & 7,5 & 3324,96 & 6116,94 & 7054,2 & 9,48 & 16506 \\
\hline ISTANBUL & ISTANBUL (M.) & 7,5 & 12001,5 & 17755,62 & 53690,55 & 376,26 & 83824 \\
\hline AMASYA & TASOVA & 8 & 131,1 & 80,25 & 71,01 & 0 & 282 \\
\hline BINGOL & YEDISU & 8 & 64,8 & 1,65 & 1,89 & 0 & 68 \\
\hline BINGOL & KARLIOVA & 8 & 113,1 & 21,3 & 3,24 & 0 & 138 \\
\hline BOLU & DORTDIVAN & 8 & 24,15 & 57,15 & 11,88 & 0 & 93 \\
\hline BOLU & YENICAGA & 8 & 93,45 & 54,3 & 34,83 & 0 & 183 \\
\hline BOLU & GEREDE & 8 & 151,65 & 276,15 & 155,52 & 0 & 583 \\
\hline BOLU & BOLU M. & 8 & 504,3 & 726,9 & 609,39 & 0,28 & 1841 \\
\hline BURSA & ORHANGAZI & 8 & 272,7 & 336,9 & 335,07 & 0,14 & 945 \\
\hline CANKIRI & BAYRAMOREN & 8 & 0,15 & 40,2 & 2,97 & 0 & 43 \\
\hline CANKIRI & ILGAZ & 8 & 118,65 & 133,95 & 59,13 & 0,7 & 312 \\
\hline CANKIRI & CERKES & 8 & 32,1 & 221,1 & 10,26 & 0 & 263 \\
\hline CORUM & KARGI & 8 & 262,5 & 14,25 & 7,83 & 0 & 285 \\
\hline CORUM & OSMANCIK & 8 & 603,9 & 108 & 74,25 & 0,14 & 786 \\
\hline \begin{tabular}{|l|} 
DUZCE \\
\end{tabular} & GOLYAKA & 8 & 16,65 & 100,65 & 8,91 & 0 & 126 \\
\hline DUZCE & KAYNASLI & 8 & 51,75 & 122,1 & 2,97 & 0 & 177 \\
\hline ERZINCAN & REFAHIYE & 8 & 93,6 & 28,35 & 8,1 & 0 & 130 \\
\hline ERZINCAN & UZUMLU & 8 & 422,55 & 201,15 & 7,56 & 0 & 631 \\
\hline ERZINCAN & ERZINCAN C. & 8 & 1322,25 & 395,55 & 307,26 & 0 & 2025 \\
\hline GIRESUN & CAMOLUK & 8 & 82,05 & 41,25 & 9,99 & 0 & 133 \\
\hline KASTAMONU & TOSYA & 8 & 87,9 & 1094,85 & 180,63 & 0,14 & 1364 \\
\hline MUS & VARTO & 8 & 250,95 & 127,2 & 5,94 & 0 & 384 \\
\hline SAKARYA & KARAPURCEK & 8 & 0 & 133,8 & 2,16 & 0 & 136 \\
\hline SAKARYA & PAMUKOVA & 8 & 246,3 & 121,5 & 34,83 & 0,14 & 403 \\
\hline SAKARYA & GEYVE & 8 & 108 & 382,8 & 52,38 & 0 & 543 \\
\hline SAKARYA & AKYAZI & 8 & 181,8 & 406,5 & 92,34 & 0,14 & 681 \\
\hline$\overline{\text { SAKARYA }}$ & HENDEK & 8 & 41,55 & 719,25 & 108,27 & 0 & 869 \\
\hline \begin{tabular}{|l} 
SAMSUN \\
\end{tabular} & LADIK & 8 & 175,2 & 167,1 & 35,1 & 0 & 377 \\
\hline SAMSUN & HAVZA & 8 & 307,8 & 328,35 & 98,82 & 0 & 735 \\
\hline SIVAS & GOLOVA & 8 & 27,75 & 37,5 & 9,18 & 0 & 74 \\
\hline SIVAS & AKINCILAR & 8 & 155,85 & 46,35 & 8,37 & 0 & 211 \\
\hline SIVAS & KOYULHISAR & 8 & 165,9 & 99,9 & 7,56 & 0 & 273 \\
\hline SIVAS & SUSEHRI & 8 & 175,95 & 167,25 & 80,46 & 0 & 424 \\
\hline TEKIRDAG & SARKOY & 8 & 118,05 & 359,1 & 235,17 & 0 & 712 \\
\hline TOKAT & BASCIFTLIK & 8 & 108,9 & 71,55 & 1,89 & 0 & 182 \\
\hline TOKAT & RESADIYE & 8 & 146,4 & 120,9 & 42,12 & 0 & 309 \\
\hline TOKAT & NIKSAR & 8 & 266,1 & 797,4 & 336,96 & 0 & 1400 \\
\hline
\end{tabular}




\begin{tabular}{|l|l|r|r|r|r|r|r|}
\hline Provinces & Sub-Provinces & Intensity & $\begin{array}{c}\text { Load } \\
\text { Bearing } \\
\text { Construction } \\
\mathbf{( 1 - 3} \text { storeys) } \\
\text { Combined } \\
\text { levels of loss } \\
\text { (D3+D4+D5) }\end{array}$ & $\begin{array}{c}\text { Frame } \\
\text { Construction } \\
\text { Low-Rise } \\
\mathbf{1 - 3}) \\
\text { Combined } \\
\text { levels of loss } \\
\text { (D3+D4+D5) }\end{array}$ & $\begin{array}{c}\text { Frame } \\
\text { Construction } \\
\text { Mid-Rise } \\
\mathbf{4}-\mathbf{9}) \\
\text { Combined } \\
\text { levels of loss } \\
\text { (D3+D4+D5) }\end{array}$ & $\begin{array}{c}\text { Frame } \\
\text { Construction } \\
\text { High-Rise } \\
\mathbf{( 1 0 + )} \\
\text { Combined } \\
\text { levels of loss } \\
\text { (D3+D4+D5) }\end{array}$ & $\begin{array}{c}\text { TOTAL } \\
\text { LOST }\end{array}$ \\
\hline TOKAT & ERBAA & 8 & 578,85 & 510,3 & 161,46 & 0,14 & 1251 \\
\hline TUNCELI & PULUMUR & 8 & 68,25 & 7,65 & 17,82 & 0 & 94 \\
\hline YALOVA & TERMAL & 8 & 9,15 & 42,45 & 21,33 & 0 & 73 \\
\hline YALOVA & ALTINOVA & 8 & 30,75 & 42 & 11,07 & 0 & 84 \\
\hline YALOVA & CINARCIK & 8 & 43,35 & 74,4 & 239,22 & 0 & 357 \\
\hline YALOVA & CIFTLIKKOY & 8 & 57,15 & 105,45 & 135,54 & 0 & 298 \\
\hline YALOVA & YALOVA C. & 8 & 367,95 & 532,05 & 606,42 & 0,98 & 1507 \\
\hline KOCAELI & KOCAELI (M.) & 8 & 5562,9 & 11154,45 & 7342,92 & 16,38 & 24077 \\
\hline SAKARYA & SAKARYA (M.) & 8 & 3007,5 & 3515,7 & 1545,21 & 1,26 & 8070 \\
\hline
\end{tabular}

C: Central

M: Metropolitan 


\section{APPENDIX C}

\section{TOTAL LISTS OF CATEGORIES OF SETTLEMENTS PRIORITIZED}

ACCORDING TO ABSOLUTE LOSS

CATEGORY I - SETTLEMENTS HAVING POPULATION UP TO 50.000

\begin{tabular}{|c|c|c|c|c|c|c|}
\hline $\begin{array}{c}\text { CATEGORY } \\
0-50.000\end{array}$ & SUB-PROVINCE & Intensity & $\begin{array}{l}\text { Absolute } \\
\text { Loss }\end{array}$ & $\begin{array}{c}\text { Total } \\
\text { Building }\end{array}$ & $\begin{array}{l}\text { Relative Loss, } \\
\text { Loss Rate }\end{array}$ & $\begin{array}{c}\text { Settlement } \\
\text { Population } \\
(2009) \\
\end{array}$ \\
\hline TOKAT & NIKSAR & 8 & 1400 & 8343 & 0,17 & 33.682 \\
\hline KASTAMONU & TOSYA & 8 & 1364 & 8575 & 0,16 & 27.624 \\
\hline SAKARYA & HENDEK & 8 & 869 & 4969 & 0,17 & 44.418 \\
\hline CORUM & OSMANCIK & 8 & 786 & 5037 & 0,16 & 25.829 \\
\hline SAMSUN & HAVZA & 8 & 735 & 4620 & 0,16 & 20.204 \\
\hline TEKIRDAG & SARKOY & 8 & 712 & 4059 & 0,18 & 16.624 \\
\hline SAKARYA & AKYAZI & 8 & 681 & 3668 & 0,19 & 41.179 \\
\hline AMASYA & SULUOVA & 7,5 & 633 & 9653 & 0,07 & 37.151 \\
\hline ERZINCAN & UZUMLU & 8 & 631 & 4187 & 0,15 & 8.288 \\
\hline BOLU & GEREDE & 8 & \begin{tabular}{l|l}
583 \\
\end{tabular} & 3439 & 0,17 & 23.808 \\
\hline SAKARYA & GEYVE & 8 & 543 & 3491 & 0,16 & 20.318 \\
\hline BALIKESIR & AYVALIK & 7 & \begin{tabular}{l|l}
442 \\
\end{tabular} & 14115 & 0,03 & 35.986 \\
\hline SIVAS & SUSEHRI & 8 & 424 & 2589 & 0,16 & 15.304 \\
\hline BALIKESIR & BURHANIYE & 7 & $\begin{array}{ll}410 \\
\end{array}$ & 13164 & 0,03 & 38.156 \\
\hline SAKARYA & PAMUKOVA & 8 & \begin{tabular}{l|l}
403 \\
\end{tabular} & 2600 & 0,15 & 16.047 \\
\hline MUS & VARTO & 8 & \begin{tabular}{|l|}
384 \\
\end{tabular} & 2562 & 0,15 & 9.585 \\
\hline SAMSUN & LADIK & 8 & 377 & 2426 & 0,16 & 8.316 \\
\hline YALOVA & CINARCIK & 8 & 357 & 1675 & 0,21 & 11.080 \\
\hline IZMIR & CESME & 7 & 348 & 11532 & 0,03 & 20.455 \\
\hline BURSA & YENISEHIR & 7,5 & 339 & 5028 & 0,07 & 29.275 \\
\hline CANKIRI & ILGAZ & 8 & 312 & 1913 & 0,16 & 7.738 \\
\hline TOKAT & RESADIYE & 8 & 309 & 1941 & 0,16 & 9.027 \\
\hline MANISA & ALASEHIR & 7 & 306 & 9553 & 0,03 & 47.942 \\
\hline YALOVA & CIFTLIKKOY & 8 & 298 & 1594 & 0,19 & 17.052 \\
\hline SAMSUN & VEZIRKOPRU & 7,5 & 298 & 4455 & 0,07 & 26.724 \\
\hline CORUM & KARGI & 8 & 285 & 1878 & 0,15 & 5.226 \\
\hline AMASYA & TASOVA & 8 & 282 & 1677 & 0,17 & 10.821 \\
\hline SIVAS & KOYULHISAR & 8 & 273 & 1806 & 0,15 & 4.426 \\
\hline AMASYA & GUMUSHACIKOY & 7,5 & 271 & 4176 & 0,07 & 14.620 \\
\hline CANKIRI & CERKES & 8 & 263 & 1728 & 0,15 & 9.404 \\
\hline BURSA & IZNIK & 7,5 & 252 & 3968 & 0,06 & 22.574 \\
\hline MUS & BULANIK & 7,5 & 246 & 4278 & 0,06 & 21.352 \\
\hline MANISA & KULA & 7 & 236 & 7694 & 0,03 & 24.241 \\
\hline BITLIS & AHLAT & 7,5 & 234 & 5609 & 0,04 & 19.078 \\
\hline HATAY & SAMANDAG & 7 & 232 & 7232 & 0,03 & 44.137 \\
\hline GIRESUN & SEBINKARAHISAR & 7,5 & 222 & 3441 & 0,06 & 11.921 \\
\hline SIVAS & AKINCILAR & 8 & 211 & 1379 & 0,15 & 2.775 \\
\hline AYDIN & DİDİM(YENİHİSAR) & 6,5 & 204 & 18697 & 0,01 & 41.246 \\
\hline BALIKESIR & SUSURLUK & 7 & 190 & 5693 & 0,03 & 23.952 \\
\hline CANAKKALE & BIGA & 7 & 188 & 5654 & 0,03 & 36.520 \\
\hline BOLU & YENICAGA & 8 & 183 & 1120 & 0,16 & 5.175 \\
\hline TOKAT & BASCIFTLIK & 8 & 182 & 1225 & 0,15 & 3.840 \\
\hline DUZCE & KAYNASLI & 8 & 177 & 1171 & 0,15 & 9.418 \\
\hline
\end{tabular}




\begin{tabular}{|c|c|c|c|c|c|c|}
\hline $\begin{array}{c}\text { CATEGORY } \\
0-50.000\end{array}$ & SUB-PROVINCE & Intensity & $\begin{array}{c}\text { Absolute } \\
\text { Loss }\end{array}$ & $\begin{array}{c}\text { Total } \\
\text { Building }\end{array}$ & $\begin{array}{c}\text { Relative Loss, } \\
\text { Loss Rate }\end{array}$ & $\begin{array}{c}\text { Settlement } \\
\text { Population } \\
\text { (2009) }\end{array}$ \\
\hline HATAY & ERZIN & 7 & 173 & 5749 & 0,03 & 30.356 \\
\hline BITLIS & ADILCEVAZ & 7,5 & 172 & 2866 & 0,06 & 14.428 \\
\hline CORUM & ISKILIP & 7 & 167 & 5106 & 0,03 & 20.724 \\
\hline YALOVA & ARMUTLU & 7,5 & 164 & 2083 & 0,08 & 5.223 \\
\hline \begin{tabular}{|l|} 
CANAKKALE \\
\end{tabular} & CAN & 7 & 161 & 5016 & 0,03 & 28.769 \\
\hline HATAY & BELEN & 7 & 159 & 5093 & 0,03 & 20.892 \\
\hline BALIKESIR & ERDEK & 7 & 159 & 4193 & 0,04 & 20.876 \\
\hline BILECIK & OSMANELI & 7,5 & 158 & 2390 & 0,07 & 13.760 \\
\hline TEKIRDAG & MALKARA & 7 & 157 & 4518 & 0,03 & 27.371 \\
\hline GAZIANTEP & ISLAHIYE & 7 & 148 & 4949 & 0,03 & 30.904 \\
\hline BILECIK & BİLECİK C. & 7 & 145 & 4025 & 0,04 & 46.403 \\
\hline BINGOL & KARLIOVA & 8 & 138 & 911 & 0,15 & 6.202 \\
\hline DENIZLI & BULDAN & 7 & 137 & 4282 & 0,03 & 15.197 \\
\hline ADIYAMAN & GOLBASI & 7 & 137 & 4284 & 0,03 & 27.800 \\
\hline SAKARYA & KARAPURCEK & 8 & 136 & 910 & 0,15 & 7.452 \\
\hline ORDU & GOLKOY & 7 & 134 & 4246 & 0,03 & 16.410 \\
\hline GIRESUN & CAMOLUK & 8 & 133 & 859 & 0,16 & 2.023 \\
\hline ERZINCAN & REFAHIYE & 8 & 130 & 849 & 0,15 & 3.563 \\
\hline MANISA & SARIGOL & 7 & 130 & 4250 & 0,03 & 13.406 \\
\hline \begin{tabular}{|l|} 
MUGLA \\
\end{tabular} & BODRUM & 6,5 & 130 & 12850 & 0,01 & 31.590 \\
\hline CANAKKALE & BAYRAMIC & 7 & 129 & 4157 & 0,03 & 13.290 \\
\hline ADIYAMAN & BESNI & 7 & 126 & 4254 & 0,03 & 26.788 \\
\hline DUZCE & GOLYAKA & 8 & 126 & 819 & 0,15 & 8.793 \\
\hline MUS & MALAZGIRT & 7 & 125 & 4146 & 0,03 & 19.130 \\
\hline ORDU & AYBASTI & 7 & 125 & 3742 & 0,03 & 14.175 \\
\hline CANAKKALE & EZINE & 7 & 121 & 3901 & 0,03 & 13.202 \\
\hline K.MARAS & PAZARCIK & 7 & 120 & 3944 & 0,03 & 28.713 \\
\hline USAK & ESME & 7 & 119 & 3797 & 0,03 & 13.532 \\
\hline BALIKESIR & BIGADIC & 7 & 114 & 3533 & 0,03 & 16.062 \\
\hline MANISA & SARUHANLI & 7 & 112 & 3637 & 0,03 & 15.336 \\
\hline BURDUR & GOLHISAR & 7 & 110 & 3496 & 0,03 & 13.424 \\
\hline BALIKESIR & HAVRAN & 7 & 107 & 3389 & 0,03 & 10.671 \\
\hline ERZURUM & HINIS & 7 & 107 & 3551 & 0,03 & 9.654 \\
\hline EDIRNE & ENEZ & 7 & 105 & 3484 & 0,03 & 3.820 \\
\hline AFYON & BOLVADIN & 6,5 & 105 & 9687 & 0,01 & 31.284 \\
\hline \begin{tabular}{|l|l} 
BOLU \\
\end{tabular} & MUDURNU & 7,5 & 104 & 1656 & 0,06 & 4.596 \\
\hline BALIKESIR & SINDIRGI & 7 & 100 & 3141 & 0,03 & 12.672 \\
\hline TOKAT & ZILE & 6,5 & 100 & 9275 & 0,01 & 35.417 \\
\hline SAMSUN & KAVAK & 7,5 & 97 & 1393 & 0,07 & 8.435 \\
\hline KARABUK & ESKIPAZAR & 7,5 & 96 & 1394 & 0,07 & 6.916 \\
\hline \begin{tabular}{|l} 
TUNCELI \\
\end{tabular} & PULUMUR & 8 & 94 & 572 & 0,16 & 1.656 \\
\hline BALIKESIR & GONEN & 6,5 & 93 & 7512 & 0,01 & 42.939 \\
\hline BOLU & DORTDIVAN & 8 & 93 & 589 & 0,16 & 2.952 \\
\hline MANISA & GOLMARMARA & 7 & 91 & 2983 & 0,03 & 9.840 \\
\hline BALIKESIR & GOMEC & 7 & 87 & 2927 & 0,03 & 4.788 \\
\hline BURDUR & BUCAK & 6,5 & 87 & 7405 & 0,01 & 36.370 \\
\hline \begin{tabular}{|l} 
DUZCE \\
\end{tabular} & GUMUSOVA & 7,5 & 86 & 1294 & 0,07 & 6.483 \\
\hline YALOVA & ALTINOVA & 8 & 84 & 534 & 0,16 & 4.942 \\
\hline CANKIRI & KURSUNLU & 7,5 & 84 & 1312 & 0,06 & 3.939 \\
\hline MANISA & AHMETLI & 7 & 83 & 2704 & 0,03 & 9.916 \\
\hline OSMANIYE & DUZICI & 6,5 & 76 & 7540 & 0,01 & 40.823 \\
\hline KARABUK & SAFRANBOLU & 6,5 & 76 & 6030 & 0,01 & 39.669 \\
\hline BOLU & MENGEN & 7,5 & 76 & 1038 & 0,07 & 5.170 \\
\hline BOLU & GOYNUK & 7,5 & 75 & 1223 & 0,06 & 4.182 \\
\hline SIVAS & GOLOVA & 8 & 74 & 469 & 0,16 & 2.174 \\
\hline
\end{tabular}




\begin{tabular}{|c|c|c|c|c|c|c|}
\hline $\begin{array}{c}\text { CATEGORY } \\
0-50.000\end{array}$ & SUB-PROVINCE & Intensity & $\begin{array}{l}\text { Absolute } \\
\text { Loss }\end{array}$ & $\begin{array}{c}\text { Total } \\
\text { Building }\end{array}$ & $\begin{array}{l}\text { Relative Loss, } \\
\text { Loss Rate }\end{array}$ & $\begin{array}{l}\text { Settlement } \\
\text { Population } \\
(2009)\end{array}$ \\
\hline TOKAT & ALMUS & 7,5 & 74 & 1070 & \begin{tabular}{l|l|}
0,07 \\
\end{tabular} & 4.408 \\
\hline CANAKKALE & LAPSEKI & 7 & 74 & 2184 & 0,03 & 10.624 \\
\hline ELAZIG & KOVANCILAR & 7 & 74 & 2060 & 0,04 & 20.246 \\
\hline KUTAHYA & SIMAV & 6,5 & 73 & 4870 & 0,02 & 24.799 \\
\hline YALOVA & TERMAL & 8 & 73 & 425 & 0,17 & 2.340 \\
\hline ERZURUM & KARACOBAN & 7 & 73 & 2423 & 0,03 & 8.804 \\
\hline BALIKESIR & SAVASTEPE & 7 & 72 & 2307 & 0,03 & 9.368 \\
\hline OSMANIYE & BAHCE & 7 & 70 & 2305 & 0,03 & 12.917 \\
\hline ANKARA & CAMLIDERE & 7 & 70 & 2285 & 0,03 & 3.747 \\
\hline GAZIANTEP & NURDAGI & 7 & 69 & 2273 & 0,03 & 16.328 \\
\hline BINGOL & YEDISU & 8 & 68 & 460 & 0,15 & 1.352 \\
\hline K.MARAS & TURKOGLU & 7 & 68 & 2262 & 0,03 & 14.274 \\
\hline DUZCE & CUMAYERI & 7,5 & 67 & 1056 & 0,06 & 7.824 \\
\hline SAKARYA & TARAKLI & 7,5 & 67 & 1087 & 0,06 & 3.055 \\
\hline AYDIN & CINE & 6,5 & 64 & 5631 & 0,01 & 20.416 \\
\hline AFYON & EMIRDAG & 6,5 & 63 & 5372 & \begin{tabular}{l|l|}
0,01 \\
\end{tabular} & 20.253 \\
\hline KONYA & ILGIN & 6,5 & 62 & 5510 & 0,01 & 31.171 \\
\hline ERZINCAN & CAYIRLI & 7,5 & 61 & 1000 & 0,06 & 3.089 \\
\hline SAKARYA & FERIZLI & 7 & 61 & 1924 & 0,03 & 12.914 \\
\hline BURDUR & KARAMANLI & 7 & 60 & 1914 & \begin{tabular}{l|l|}
0,03 \\
\end{tabular} & 5.251 \\
\hline \begin{tabular}{|l|} 
CORUM \\
\end{tabular} & DODURGA & 7,5 & 60 & 991 & 0,06 & 3.065 \\
\hline ORDU & MESUDIYE & 7,5 & 60 & 965 & 0,06 & 3.031 \\
\hline \begin{tabular}{|l} 
VAN \\
\end{tabular} & BASKALE & 7 & 60 & 1986 & 0,03 & 12.562 \\
\hline AFYON & CAY & 6,5 & 59 & 5129 & 0,01 & 14.592 \\
\hline \begin{tabular}{|l} 
BILECIK \\
\end{tabular} & GOLPAZARI & 7 & 58 & 1862 & 0,03 & 7.697 \\
\hline CANAKKALE & AYVACIK & 7 & 57 & 1849 & 0,03 & 7.538 \\
\hline SAKARYA & KARASU & 6,5 & 57 & 4218 & 0,01 & 27.914 \\
\hline DENIZLI & GUNEY & 7 & 57 & 1857 & 0,03 & 5.908 \\
\hline ANTALYA & KUMLUCA & 6,5 & 56 & 4711 & 0,01 & 30.939 \\
\hline MANISA & KIRKAGAC & 6,5 & 56 & 5152 & 0,01 & 26.660 \\
\hline ELAZIG & PALU & 7 & 55 & 1812 & 0,03 & 8.837 \\
\hline \begin{tabular}{|l|} 
MUGLA \\
\end{tabular} & MARMARIS & 6,5 & 54 & 3545 & \begin{tabular}{l|l|l}
0,02 \\
\end{tabular} & 30.101 \\
\hline \begin{tabular}{|l|} 
ANTALYA \\
\end{tabular} & KORKUTELI & 6,5 & 54 & 4225 & 0,01 & 20.109 \\
\hline HATAY & YAYLADAGI & 7 & 54 & 1774 & 0,03 & 5.843 \\
\hline BINGOL & GENC & 7 & 54 & 1676 & 0,03 & 18.691 \\
\hline \begin{tabular}{|l} 
DENIZLI \\
\end{tabular} & CAL & 7 & 53 & 1738 & 0,03 & 3.887 \\
\hline ADANA & IMAMOGLU & 6,5 & 52 & 5136 & 0,01 & 20.636 \\
\hline \begin{tabular}{|l|} 
BINGOL \\
\end{tabular} & ADAKLI & 7,5 & 52 & 851 & 0,06 & 3.143 \\
\hline BALIKESIR & MANYAS & 7 & 51 & 1607 & 0,03 & 6.578 \\
\hline \begin{tabular}{|l|} 
ELAZIG \\
\end{tabular} & MADEN & 7 & 51 & 1653 & 0,03 & 5.314 \\
\hline HATAY & HASSA & 7 & 50 & 1673 & \begin{tabular}{l|l|}
0,03 \\
\end{tabular} & 9.207 \\
\hline ISPARTA & EGIRDIR & 6,5 & 50 & 4014 & 0,01 & 18.402 \\
\hline \begin{tabular}{|l} 
BURDUR \\
\end{tabular} & TEFENNI & 7 & 50 & 1606 & \begin{tabular}{l|l|}
0,03 \\
\end{tabular} & 4.626 \\
\hline OSMANIYE & TOPRAKKALE & 7 & 50 & 1661 & 0,03 & 7.843 \\
\hline \begin{tabular}{|l|} 
SINOP \\
\end{tabular} & BOYABAT & 6,5 & 50 & 3732 & 0,01 & 25.271 \\
\hline MUGLA & ORTACA & 6,5 & 50 & 4427 & \begin{tabular}{l|l|}
0,01 \\
\end{tabular} & 25.816 \\
\hline \begin{tabular}{|l} 
BURDUR \\
\end{tabular} & YESILOVA & 7 & 49 & 1587 & 0,03 & 4.724 \\
\hline BALIKESIR & IVRINDI & 7 & 49 & 1537 & \begin{tabular}{l|l|}
0,03 \\
\end{tabular} & 6.514 \\
\hline DUZCE & CILIMLI & 7,5 & 49 & 794 & 0,06 & 6.348 \\
\hline MANISA & DEMIRCI & 6,5 & 48 & 4448 & 0,01 & 19.550 \\
\hline KAYSERI & YAHYALI & 6,5 & 48 & 4513 & 0,01 & 20.066 \\
\hline KASTAMONU & IHSANGAZI & 7 & 48 & 1473 & 0,03 & 2.715 \\
\hline AYDIN & INCIRLIOVA & 6,5 & 47 & 4029 & 0,01 & 19.438 \\
\hline MUGLA & DALAMAN & 6,5 & 47 & 4248 & 0,01 & 22.956 \\
\hline ISPARTA & YALVAC & 6,5 & 46 & 3371 & \begin{tabular}{ll|}
0,01 \\
\end{tabular} & 20.448 \\
\hline
\end{tabular}




\begin{tabular}{|c|c|c|c|c|c|c|}
\hline $\begin{array}{c}\text { CATEGORY } \\
0-50.000\end{array}$ & SUB-PROVINCE & Intensity & $\begin{array}{c}\text { Absolute } \\
\text { Loss }\end{array}$ & $\begin{array}{c}\text { Total } \\
\text { Building }\end{array}$ & $\begin{array}{c}\text { Relative Loss, } \\
\text { Loss Rate }\end{array}$ & $\begin{array}{c}\text { Settlement } \\
\text { Population } \\
\text { (2009) }\end{array}$ \\
\hline KUTAHYA & GEDIZ & 6,5 & 46 & 4525 & 0,01 & 19.546 \\
\hline KASTAMONU & ARAC & 7 & 45 & 1393 & 0,03 & 5.776 \\
\hline IZMIR & KARABURUN & 7 & 45 & 1485 & 0,03 & 2.785 \\
\hline AYDIN & BOZDOGAN & 6,5 & 45 & 4128 & 0,01 & 9.713 \\
\hline CANKIRI & ATKARACALAR & 7,5 & 45 & 713 & 0,06 & 2.730 \\
\hline CORUM & OGUZLAR & 7 & 44 & 1463 & 0,03 & 3.741 \\
\hline CANKIRI & KORGUN & 7,5 & 44 & 704 & 0,06 & 2.129 \\
\hline ERZINCAN & TERCAN & 7 & 44 & 1430 & 0,03 & 5.416 \\
\hline ERZURUM & PASINLER & 6,5 & 43 & 4237 & 0,01 & 13.969 \\
\hline USAK & BANAZ & 6,5 & 43 & 3252 & 0,01 & 15.395 \\
\hline VAN & OZALP & 7 & 43 & 1417 & 0,03 & 10.166 \\
\hline CANKIRI & BAYRAMOREN & 8 & 43 & 282 & 0,15 & 880 \\
\hline OSMANIYE & HASANBEYLI & 7 & 43 & 1446 & 0,03 & 2.559 \\
\hline \begin{tabular}{|l|} 
DENIZLI \\
\end{tabular} & SARAYKOY & 6,5 & 43 & 3360 & 0,01 & 18.526 \\
\hline BINGOL & KIGI & 7,5 & 43 & 698 & 0,06 & 3.220 \\
\hline \begin{tabular}{|l} 
DENIZLI \\
\end{tabular} & CARDAK & 7 & 43 & 1360 & 0,03 & 4.634 \\
\hline \begin{tabular}{|l|} 
DUZCE \\
\end{tabular} & AKCAKOCA & 6,5 & 42 & 2751 & 0,02 & 23.378 \\
\hline ANTALYA & ELMALI & 6,5 & 42 & 3649 & 0,01 & 14.478 \\
\hline HATAY & ALTINOZU & 7 & 41 & 1345 & 0,03 & 7.458 \\
\hline SIVAS & IMRANLI & 7 & 40 & 1304 & 0,03 & 3.303 \\
\hline IZMIR & KINIK & 6,5 & 39 & 3869 & 0,01 & 11.919 \\
\hline SAKARYA & KOCAALI & 6,5 & 39 & 3461 & 0,01 & 12.560 \\
\hline TEKIRDAG & MURATLI & 6,5 & 39 & 3558 & 0,01 & 19.107 \\
\hline ADIYAMAN & CELIKHAN & 7 & 38 & 1265 & 0,03 & 8.224 \\
\hline SIVAS & DOGANSAR & 7,5 & 37 & 600 & 0,06 & 1.508 \\
\hline ERZURUM & CAT & 7 & 37 & 1234 & 0,03 & 4.527 \\
\hline MUGLA & DATCA & 6,5 & 37 & 3566 & 0,01 & 9.958 \\
\hline KASTAMONU & TASKOPRU & 6,5 & 37 & 2643 & 0,01 & 16.385 \\
\hline SAMSUN & AYVACIK & 7 & 37 & 1189 & 0,03 & 6.702 \\
\hline MANISA & GORDES & 6,5 & 37 & 3263 & 0,01 & 10.812 \\
\hline GUMUSHANE & SIRAN & 7 & 36 & 1124 & 0,03 & 6.854 \\
\hline \begin{tabular}{|l|} 
BURDUR \\
\end{tabular} & ALTINYAYLA & 7 & 35 & 1149 & 0,03 & 3.240 \\
\hline SIVAS & ZARA & 6,5 & 35 & 3296 & 0,01 & 11.996 \\
\hline ISPARTA & SARKIKARAAGAC & 6,5 & 35 & 2955 & 0,01 & 10.473 \\
\hline ORDU & KORGAN & 6,5 & 34 & 2958 & 0,01 & 13.018 \\
\hline AFYON & SUHUT & 6,5 & 34 & 3171 & 0,01 & 12.479 \\
\hline \begin{tabular}{|l} 
ADIYAMAN \\
\end{tabular} & TUT & 7 & 34 & 1104 & 0,03 & 4.101 \\
\hline KARABUK & YENICE & 6,5 & 33 & 2332 & 0,01 & 9.772 \\
\hline AYDIN & GERMENCIK & 6,5 & 33 & 3082 & 0,01 & 12.588 \\
\hline HATAY & KUMLU & 7 & 33 & 1101 & 0,03 & 5.167 \\
\hline MUGLA & YATAGAN & 6,5 & 33 & 2808 & 0,01 & 17.707 \\
\hline VAN & EDREMIT & 7 & 33 & 1088 & 0,03 & 12.426 \\
\hline AYDIN & YENIPAZAR & 6,5 & 32 & 3125 & 0,01 & 6.609 \\
\hline KUTAHYA & EMET & 6,5 & 31 & 2759 & 0,01 & 10.547 \\
\hline DENIZLI & BOZKURT & 7 & 31 & 995 & 0,03 & 4.360 \\
\hline ELAZIG & SIVRICE & 7 & 31 & 1011 & 0,03 & 4.236 \\
\hline SAMSUN & TEKKEKÖY & 6,5 & 31 & 2451 & 0,01 & 36.728 \\
\hline KAYSERI & BUNYAN & 6,5 & 30 & 2833 & 0,01 & 12.431 \\
\hline ZONGULDAK & ALAPLI & 6,5 & 30 & 1457 & 0,02 & 18.194 \\
\hline AFYON & ISCEHISAR & 6,5 & 29 & 2692 & 0,01 & 11.910 \\
\hline BILECIK & SOGUT & 6,5 & 29 & 2169 & 0,01 & 15.007 \\
\hline GIRESUN & ALUCRA & 7 & 29 & 928 & 0,03 & 4.970 \\
\hline CANKIRI & ORTA & 7 & 29 & 925 & 0,03 & 3.815 \\
\hline DENIZLI & BAKLAN & 7 & 29 & 942 & 0,03 & 2.062 \\
\hline ERZURUM & ASKALE & 6,5 & 28 & 2705 & 0,01 & 12.447 \\
\hline
\end{tabular}




\begin{tabular}{|c|c|c|c|c|c|c|}
\hline $\begin{array}{c}\text { CATEGORY } \\
0-50.000\end{array}$ & SUB-PROVINCE & Intensity & $\begin{array}{l}\text { Absolute } \\
\text { Loss }\end{array}$ & $\begin{array}{c}\text { Total } \\
\text { Building }\end{array}$ & $\begin{array}{l}\text { Relative Loss, } \\
\text { Loss Rate }\end{array}$ & $\begin{array}{c}\text { Settlement } \\
\text { Population } \\
(2009)\end{array}$ \\
\hline ANKARA & NALLIHAN & 6,5 & 28 & 2373 & \begin{tabular}{l|l|}
0,01 \\
\end{tabular} & 12.585 \\
\hline DIYARBAKIR & CERMIK & 6,5 & 28 & 2819 & 0,01 & 17.389 \\
\hline MALATYA & POTURGE & 7 & 28 & 910 & 0,03 & 2.751 \\
\hline ORDU & GURGENTEPE & 6,5 & 28 & 2479 & 0,01 & 7.844 \\
\hline BURDUR & CAVDIR & 7 & 28 & 882 & 0,03 & 3.112 \\
\hline \begin{tabular}{|l|} 
ORDU \\
\end{tabular} & KUMRU & 6,5 & 27 & 2138 & 0,01 & 11.948 \\
\hline GUMUSHANE & KELKIT & 6,5 & 27 & 2452 & 0,01 & 14.012 \\
\hline KONYA & DOGANHISAR & 6,5 & 27 & 2349 & 0,01 & 6.233 \\
\hline DENIZLI & ACIPAYAM & 6,5 & 27 & 2009 & 0,01 & 12.588 \\
\hline ANKARA & KIZILCAHAMAM & 6,5 & 27 & 1910 & 0,01 & 16.810 \\
\hline AYDIN & KARACASU & 6,5 & 27 & 2488 & 0,01 & 6.154 \\
\hline ISPARTA & KECIBORLU & 6,5 & 27 & 2503 & 0,01 & 7.134 \\
\hline ANTALYA & KALE (DEMRE) & 6,5 & 26 & 2358 & 0,01 & 15.574 \\
\hline DIYARBAKIR & CUNGUS & 7 & 26 & 868 & 0,03 & 2.544 \\
\hline ISPARTA & SENIRKENT & 6,5 & 26 & 2301 & 0,01 & 6.932 \\
\hline VAN & GURPINAR & 7 & 26 & 858 & 0,03 & 5.166 \\
\hline SAMSUN & ASARCIK & 7,5 & 26 & 386 & 0,07 & 2.537 \\
\hline \begin{tabular}{|l} 
ADANA \\
\end{tabular} & POZANTI & 6,5 & 26 & 2496 & 0,01 & 9.880 \\
\hline BINGOL & YAYLADERE & 7 & 25 & 818 & 0,03 & 989 \\
\hline ELAZIG & ALACAKAYA & 7 & 25 & 830 & 0,03 & 2.598 \\
\hline MALATYA & DOGANYOL & 7 & 25 & 827 & 0,03 & 1.774 \\
\hline K.MARAS & CAGLAYANCERIT & 6,5 & 25 & 2453 & 0,01 & 12.428 \\
\hline BURDUR & KEMER & 7 & 24 & 799 & 0,03 & 2.012 \\
\hline BALIKESIR & KEPSUT & 6,5 & 24 & 2183 & 0,01 & 5.763 \\
\hline IZMIR & KIRAZ & 6,5 & 24 & 2303 & 0,01 & 8.469 \\
\hline \begin{tabular}{|l} 
EDIRNE \\
\end{tabular} & IPSALA & 6,5 & 24 & 2325 & 0,01 & 8.033 \\
\hline ANTALYA & KEMER & 6,5 & 24 & 2091 & 0,01 & 20.110 \\
\hline ADANA & KARATAS & 6,5 & 24 & 2240 & 0,01 & 8.504 \\
\hline \begin{tabular}{|l} 
MUS \\
\end{tabular} & HASKOY & 6,5 & 24 & 2332 & 0,01 & 13.389 \\
\hline CANKIRI & YAPRAKLI & 7 & 24 & 776 & 0,03 & 1.771 \\
\hline ADANA & KARAISALI & 6,5 & 24 & 2284 & 0,01 & 7.307 \\
\hline IZMIR & BEYDAG & 6,5 & 23 & 2098 & 0,01 & 5.710 \\
\hline \begin{tabular}{|l|} 
BITLIS \\
\end{tabular} & GUROYMAK & 6,5 & 23 & 2288 & 0,01 & 20.226 \\
\hline MUGLA & KOYCEGIZ & 6,5 & 23 & 2317 & 0,01 & 8.677 \\
\hline AYDIN & KUYUCAK & 6,5 & 23 & 2091 & 0,01 & 7.701 \\
\hline BOLU & SEBEN & 7 & 23 & 755 & 0,03 & 2.822 \\
\hline ANTALYA & FINIKE & 6,5 & 23 & 1752 & 0,01 & 11.199 \\
\hline \begin{tabular}{|l|} 
ELAZIG \\
\end{tabular} & KARAKOCAN & 6,5 & 22 & 2016 & 0,01 & 12.708 \\
\hline SINOP & DURAGAN & 6,5 & 22 & 1592 & 0,01 & 7.442 \\
\hline AYDIN & KOSK & 6,5 & 22 & 2006 & 0,01 & 9.854 \\
\hline AFYON & BASMAKCI & 6,5 & 22 & 2080 & 0,01 & 5.681 \\
\hline \begin{tabular}{|l|} 
MUGLA \\
\end{tabular} & ULA & 6,5 & 22 & 2151 & 0,01 & 5.602 \\
\hline ISPARTA & ULUBORLU & 6,5 & 21 & 2051 & 0,01 & 6.520 \\
\hline VAN & GEVAS & 6,5 & 21 & 2080 & 0,01 & 10.432 \\
\hline GAZIANTEP & ARABAN & 6,5 & 21 & 2075 & 0,01 & 9.758 \\
\hline ERZINCAN & KEMAH & 7 & 21 & 674 & \begin{tabular}{l|l|}
0,03 \\
\end{tabular} & 1.929 \\
\hline \begin{tabular}{|l} 
AFYON \\
\end{tabular} & SULTANDAGI & 6,5 & 20 & 1822 & 0,01 & 6.288 \\
\hline AYDIN & BUHARKENT & 6,5 & 20 & 1744 & \begin{tabular}{l|l|}
0,01 \\
\end{tabular} & 6.891 \\
\hline BALIKESIR & BALYA & 7 & 20 & 653 & 0,03 & 1.901 \\
\hline DUZCE & YIGILCA & 7 & 20 & 555 & 0,04 & 3.141 \\
\hline MALATYA & DOGANSEHIR & 6,5 & 20 & 1843 & 0,01 & 10.800 \\
\hline BURSA & ORHANELI & 6,5 & 20 & 1714 & 0,01 & 7.934 \\
\hline ORDU & AKKUS & 7 & 20 & 572 & 0,03 & 5.746 \\
\hline USAK & ULUBEY & 6,5 & 19 & 1716 & 0,01 & 4.945 \\
\hline ADIYAMAN & SINCIK & 7 & 19 & 638 & \begin{tabular}{l|l|}
0,03 \\
\end{tabular} & 4.331 \\
\hline
\end{tabular}




\begin{tabular}{|c|c|c|c|c|c|c|}
\hline \begin{tabular}{|c} 
CATEGORY \\
$0-50.000$
\end{tabular} & SUB-PROVINCE & Intensity & $\begin{array}{c}\text { Absolute } \\
\text { Loss }\end{array}$ & $\begin{array}{c}\text { Total } \\
\text { Building }\end{array}$ & $\begin{array}{c}\text { Relative Loss, } \\
\text { Loss Rate }\end{array}$ & $\begin{array}{c}\text { Settlement } \\
\text { Population } \\
\text { (2009) }\end{array}$ \\
\hline \begin{tabular}{|l|} 
DENIZLI \\
\end{tabular} & AKKOY & 7 & 19 & 634 & 0,03 & 2.755 \\
\hline AYDIN & SULTANHISAR & 6,5 & 19 & 1695 & 0,01 & 6.229 \\
\hline BILECIK & PAZARYERI & 6,5 & 19 & 1810 & 0,01 & 6.481 \\
\hline MUS & KORKUT & 7 & 19 & 625 & 0,03 & 3.102 \\
\hline AFYON & COBANLAR & 6,5 & 19 & 1831 & 0,01 & 8.774 \\
\hline DENIZLI & BEKILLI & 6,5 & 19 & 1823 & 0,01 & 3.481 \\
\hline \begin{tabular}{|l} 
DENIZLI \\
\end{tabular} & HONAZ & 6,5 & 18 & 1757 & 0,01 & 9.788 \\
\hline AYDIN & KOCARLI & 6,5 & 18 & 1697 & 0,01 & 6.822 \\
\hline ADANA & YUMURTALIK & 6,5 & 18 & 1650 & 0,01 & 5.220 \\
\hline ISPARTA & GELENDOST & 6,5 & 18 & 1730 & 0,01 & 5.351 \\
\hline KUTAHYA & HISARCIK & 6,5 & 18 & 1395 & 0,01 & 4.877 \\
\hline \begin{tabular}{|l} 
DENIZLI \\
\end{tabular} & BABADAG & 6,5 & 17 & 1684 & 0,01 & 4.185 \\
\hline KONYA & DERBENT & 6,5 & 17 & 1713 & 0,01 & 2.922 \\
\hline CORUM & BAYAT & 6,5 & 17 & 1531 & 0,01 & 8.828 \\
\hline AFYON & BAYAT & 6,5 & 17 & 1654 & 0,01 & 4.489 \\
\hline \begin{tabular}{|l} 
MANISA \\
\end{tabular} & KOPRUBASI & 6,5 & 17 & 1587 & 0,01 & 5.283 \\
\hline \begin{tabular}{|l} 
ELAZIG \\
\end{tabular} & ARICAK & 7 & 17 & 538 & 0,03 & 3.380 \\
\hline KONYA & HUYUK & 6,5 & 16 & 1513 & 0,01 & 3.695 \\
\hline CORUM & MECITOZU & 6,5 & 16 & 1522 & 0,01 & 5.261 \\
\hline CORUM & LACIN & 7 & 16 & 521 & 0,03 & 1.227 \\
\hline ANTALYA & KAS & 6,5 & 16 & 1126 & 0,01 & 6.857 \\
\hline KUTAHYA & SAPHANE & 6,5 & 16 & 1491 & 0,01 & 3.623 \\
\hline CANAKKALE & YENICE & 6,5 & 16 & 1463 & 0,01 & 6.830 \\
\hline ISPARTA & ATABEY & 6,5 & 15 & 1462 & 0,01 & 4.355 \\
\hline AMASYA & HAMAMOZU & 7 & 15 & 481 & 0,03 & 1.405 \\
\hline BURDUR & AGLASUN & 6,5 & 15 & 1443 & 0,01 & 4.414 \\
\hline DIYARBAKIR & DICLE & 6,5 & 15 & 1482 & 0,01 & 8.610 \\
\hline KARABUK & OVACIK & 7,5 & 15 & 229 & 0,06 & 783 \\
\hline TOKAT & PAZAR & 6,5 & 14 & 1358 & 0,01 & 4.986 \\
\hline NIGDE & CAMARDI & 6,5 & 14 & 1353 & 0,01 & 3.480 \\
\hline SAMSUN & SALIPAZARI & 6,5 & 14 & 1162 & 0,01 & 6.156 \\
\hline CANKIRI & ELDIVAN & 6,5 & 14 & 1329 & 0,01 & 3.034 \\
\hline ERZINCAN & OTLUKBELI & 7 & 13 & 435 & 0,03 & 1.630 \\
\hline KUTAHYA & ALTINTAS & 6,5 & 13 & 1192 & 0,01 & 5.538 \\
\hline AFYON & DAZKIRI & 6,5 & 13 & 1162 & 0,01 & 4.470 \\
\hline ISPARTA & GONEN & 6,5 & 12 & 1185 & 0,01 & 3.663 \\
\hline BOLU & KIBRISCIK & 7 & 12 & 405 & 0,03 & 1.345 \\
\hline KONYA & TUZLUKCU & 6,5 & 12 & 1218 & 0,01 & 3.912 \\
\hline SINOP & SARAYDUZU & 7 & 12 & 388 & 0,03 & 951 \\
\hline KUTAHYA & PAZARLAR & 6,5 & 12 & 1103 & 0,01 & 3.660 \\
\hline ORDU & CATALPINAR & 6,5 & 11 & 999 & 0,01 & 5.333 \\
\hline \begin{tabular}{|l} 
SAKARYA \\
\end{tabular} & KAYNARCA & 6,5 & 11 & 911 & 0,01 & 5.144 \\
\hline AFYON & EVCILER & 6,5 & 11 & 1071 & 0,01 & 4.142 \\
\hline ERZURUM & TEKMAN & 6,5 & 11 & 1040 & 0,01 & 3.957 \\
\hline DENIZLI & CAMELI & 6,5 & 9 & 854 & 0,01 & 2.837 \\
\hline GAZIANTEP & YAVUZELI & 6,5 & 9 & 909 & 0,01 & 4.093 \\
\hline BURSA & KELES & 6,5 & 9 & 873 & 0,01 & 3.681 \\
\hline CANKIRI & SABANOZU & 6,5 & 9 & 897 & 0,01 & 5.124 \\
\hline AYDIN & KARPUZLU & 6,5 & 9 & 863 & 0,01 & 2.116 \\
\hline CORUM & ORTAKOY & 6,5 & 9 & 834 & 0,01 & 2.945 \\
\hline BURDUR & CELTIKCI & 6,5 & 9 & 856 & 0,01 & 2.374 \\
\hline \begin{tabular}{|l} 
ADIYAMAN \\
\end{tabular} & GERGER & 6,5 & 9 & 901 & 0,01 & 3.242 \\
\hline KUTAHYA & CAVDARHISAR & 6,5 & 8 & 809 & 0,01 & 2.412 \\
\hline DENIZLI & BEYAGAC & 6,5 & 8 & 807 & 0,01 & 2.664 \\
\hline ESKISEHIR & MIHALGAZI & 6,5 & 8 & 765 & 0,01 & 1.951 \\
\hline
\end{tabular}




\begin{tabular}{|l|l|r|r|r|r|r|}
\hline $\begin{array}{c}\text { CATEGORY } \\
\mathbf{0 - 5 0 . 0 0 0}\end{array}$ & SUB-PROVINCE & Intensity & $\begin{array}{c}\text { Absolute } \\
\text { Loss }\end{array}$ & $\begin{array}{c}\text { Total } \\
\text { Building }\end{array}$ & $\begin{array}{c}\text { Relative Loss, } \\
\text { Loss Rate }\end{array}$ & $\begin{array}{c}\text { Settlement } \\
\text { Population } \\
(\mathbf{2 0 0 9})\end{array}$ \\
\hline OSMANIYE & SUMBAS & 6,5 & 7 & 733 & 0,01 & 2.114 \\
\hline AFYON & IHSANIYE & 6,5 & 7 & 711 & 0,01 & 2.341 \\
\hline TUNCELI & OVACIK & 6,5 & 7 & 642 & 0,01 & 3.227 \\
\hline MALATYA & KALE & 6,5 & 7 & 675 & 0,01 & 2.030 \\
\hline AMASYA & GOYNUCEK & 6,5 & 7 & 620 & 0,01 & 2.421 \\
\hline KUTAHYA & DUMLUPINAR & 6,5 & 6 & 599 & 0,01 & 1.438 \\
\hline VAN & SARAY & 6,5 & 6 & 585 & 0,01 & 3.591 \\
\hline KONYA & AKOREN & 6,5 & 6 & 1214 & 0,00 & 3.442 \\
\hline BILECIK & INHISAR & 6,5 & 5 & 516 & 0,01 & 1.085 \\
\hline BILECIK & YENIPAZAR & 6,5 & 5 & 473 & 0,01 & 1.115 \\
\hline ESKISEHIR & SARICAKAYA & 6,5 & 5 & 971 & 0,01 & 2.150 \\
\hline KUTAHYA & ASLANAPA & 6,5 & 5 & 483 & 0,01 & 1.893 \\
\hline TUNCELI & NAZIMIYE & 6,5 & 4 & 313 & 0,01 & 1.636 \\
\hline KILIS & MUSABEYLI & 6,5 & 2 & 175 & 0,01 & 856 \\
\hline
\end{tabular}

\section{C: Central}

CATEGORY II - SETTLEMENTS HAVING POPULATION BETWEEN 50.000 AND 490.000

\begin{tabular}{|l|l|r|r|r|r|r|}
\hline $\begin{array}{c}\text { CATEGORY } \\
\text { 50.000-490.000 }\end{array}$ & SUB-PROVINCE & Intensity & $\begin{array}{c}\text { Absolute } \\
\text { Loss }\end{array}$ & $\begin{array}{c}\text { Total } \\
\text { Building }\end{array}$ & $\begin{array}{c}\text { Relative Loss, } \\
\text { Loss Rate }\end{array}$ & $\begin{array}{c}\text { Settlement } \\
\text { Population } \\
\text { (2009) }\end{array}$ \\
\hline VAN & VAN C. & 7,5 & 2285 & 36235 & 0,06 & 360.810 \\
\hline ERZINCAN & ERZINCAN C. & 8 & 2025 & 12678 & 0,16 & 90.100 \\
\hline BOLU & BOLU C. & 8 & 1841 & 10516 & 0,18 & 120.021 \\
\hline YALOVA & YALOVA C. & 8 & 1507 & 8302 & 0,18 & 92.166 \\
\hline TEKIRDAG & TEKİRDAĞ C. & 7,5 & 1347 & 15683 & 0,09 & 140.535 \\
\hline TOKAT & ERBAA & 8 & 1251 & 7895 & 0,16 & 58.845 \\
\hline BURSA & ORHANGAZI & 8 & 945 & 5313 & 0,18 & 54.319 \\
\hline MANISA & MANISA C. & 7 & 919 & 24785 & 0,04 & 291.374 \\
\hline OSMANIYE & OSMANIYE C. & 7 & 905 & 29408 & 0,03 & 194.339 \\
\hline HATAY & ANTAKYA & 7 & 768 & 23471 & 0,03 & 202.216 \\
\hline HATAY & ISKENDERUN & 7 & 705 & 21169 & 0,03 & 190.279 \\
\hline ADIYAMAN & ADIYAMAN C. & 7 & 696 & 21965 & 0,03 & 198.433 \\
\hline AMASYA & MERZIFON & 7,5 & 666 & 9411 & 0,07 & 52.225 \\
\hline MANISA & TURGUTLU & 7 & 639 & 19331 & 0,03 & 115.930 \\
\hline DUZCE & DÜZCE C. & 7,5 & 612 & 8593 & 0,07 & 125.240 \\
\hline DENIZLI & DENIZLI C. & 6,5 & 586 & 41993 & 0,01 & 488.768 \\
\hline MANISA & AKHISAR & 7 & 585 & 17775 & 0,03 & 100.897 \\
\hline BURSA & INEGOL & 7 & 536 & 14095 & 0,04 & 161.541 \\
\hline TOKAT & TOKAT C. & 7 & 528 & 15371 & 0,03 & 129.879 \\
\hline MANISA & SALIHLI & 7 & 483 & 13639 & 0,04 & 96.503 \\
\hline BALIKESIR & BALIKESIR C. & 6,5 & 469 & 30918 & 0,02 & 259.157 \\
\hline BALIKESIR & BANDIRMA & 7 & 460 & 12035 & 0,04 & 113.385 \\
\hline K.MARAS & K.MARAŞ C. & 6,5 & 457 & 41470 & 0,01 & 384.953 \\
\hline IZMIR & BERGAMA & 7 & 402 & 12446 & 0,03 & 58.570 \\
\hline KUTAHYA & KÜTAHYA C. & 6,5 & 384 & 27490 & 0,01 & 212.444 \\
\hline ICEL(MERSIN) & TARSUS & 6,5 & 361 & 33303 & 0,01 & 233.436 \\
\hline HATAY & KIRIKHAN & 7 & 360 & 11860 & 0,03 & 69.285 \\
\hline ISPARTA & ISPARTA C. & 6,5 & 354 & 26357 & 0,01 & 190.084 \\
\hline CANAKKALE & ÇANAKKALE C. & 7 & 339 & 9281 & 0,04 & 96.588 \\
\hline
\end{tabular}




\begin{tabular}{|c|c|c|c|c|c|c|}
\hline $\begin{array}{c}\text { CATEGORY } \\
50.000-490.000\end{array}$ & SUB-PROVINCE & Intensity & $\begin{array}{c}\text { Absolute } \\
\text { Loss }\end{array}$ & $\begin{array}{c}\text { Total } \\
\text { Building }\end{array}$ & $\begin{array}{l}\text { Relative Loss, } \\
\text { Loss Rate }\end{array}$ & $\begin{array}{c}\text { Settlement } \\
\text { Population } \\
(\mathbf{2 0 0 9 )}\end{array}$ \\
\hline AMASYA & AMASYA C. & 7 & 336 & 9432 & 0,04 & 86.667 \\
\hline HATAY & DORTYOL & 7 & 333 & 10708 & 0,03 & 69.507 \\
\hline BURSA & M.KEMALPASA & 7 & 304 & 8460 & 0,04 & 57.097 \\
\hline AYDIN & AYDIN C. & 6,5 & 303 & 19320 & 0,02 & 179.425 \\
\hline CORUM & ÇORUM C. & 6,5 & 286 & 21086 & 0,01 & 212.418 \\
\hline HATAY & REYHANLI & 7 & 280 & 9267 & 0,03 & 61.306 \\
\hline EDIRNE & \begin{tabular}{|l} 
KESAN \\
\end{tabular} & 7 & 269 & 8056 & 0,03 & 53.391 \\
\hline BALIKESIR & EDREMIT & 7 & 262 & 7636 & 0,03 & 50.523 \\
\hline BURSA & KARACABEY & 7 & 258 & 7657 & 0,03 & 51.907 \\
\hline BINGOL & BİNGÖL C. & 7 & 251 & 7211 & 0,03 & 89.224 \\
\hline AFYON & AFYON C. & 6,5 & 240 & 17973 & 0,01 & 170.455 \\
\hline TEKIRDAG & CORLU & 6,5 & 230 & 15526 & 0,01 & 206.134 \\
\hline AYDIN & KUSADASI & 6,5 & 211 & 17726 & 0,01 & 61.648 \\
\hline AYDIN & NAZILLI & 6,5 & 210 & 16583 & 0,01 & 109.800 \\
\hline IZMIR & \begin{tabular}{|l} 
ODEMIS \\
\end{tabular} & 6,5 & 190 & 14665 & 0,01 & 73.310 \\
\hline ADANA & KOZAN & 6,5 & 184 & 17670 & 0,01 & 74.521 \\
\hline KARABUK & KARABÜK C. & 6,5 & 180 & 13714 & 0,01 & 108.167 \\
\hline ADANA & CEYHAN & 6,5 & 171 & 16033 & 0,01 & 104.572 \\
\hline OSMANIYE & KADIRLI & 6,5 & 167 & 16164 & 0,01 & 78.964 \\
\hline BURDUR & BURDUR C. & 6,5 & 156 & 13011 & 0,01 & 71.611 \\
\hline MUGLA & FETHIYE & 6,5 & 144 & 12810 & 0,01 & 72.003 \\
\hline AYDIN & SOKE & 6,5 & 138 & 10442 & 0,01 & 67.234 \\
\hline MANISA & SOMA & 6,5 & 133 & 9885 & 0,01 & 74.158 \\
\hline TOKAT & TURHAL & 6,5 & 125 & 10797 & 0,01 & 64.090 \\
\hline IZMIR & TIRE & 6,5 & 124 & 10443 & 0,01 & 50.900 \\
\hline KONYA & AKSEHIR & 6,5 & 121 & 8790 & 0,01 & 61.196 \\
\hline KASTAMONU & KASTAMONU C. & 6,5 & 121 & 9197 & 0,01 & 86.085 \\
\hline MUGLA & MUĞLA C. & 6,5 & 109 & 8723 & 0,01 & 61.550 \\
\hline DIYARBAKIR & ERGANI & 6,5 & 108 & 10522 & 0,01 & 63.065 \\
\hline BILECIK & BOZUYUK & 6,5 & 96 & 7901 & 0,01 & 56.782 \\
\hline MUGLA & MILAS & 6,5 & 92 & 8112 & 0,01 & 50.975 \\
\hline CANKIRI & ÇANKIRI C. & 6,5 & 90 & 7084 & 0,01 & 69.087 \\
\hline MUS & MUŞ C. & 6,5 & 77 & 6631 & 0,01 & 72.774 \\
\hline ADIYAMAN & KAHTA & 6,5 & 74 & 7031 & 0,01 & 61.243 \\
\hline TEKIRDAG & CERKEZKOY & 6,5 & 73 & 5172 & 0,01 & 69.875 \\
\hline BITLIS & TATVAN & 6,5 & 65 & 5864 & 0,01 & 56.996 \\
\hline KAYSERI & TALAS & 6,5 & 42 & 2924 & 0,01 & 81.566 \\
\hline
\end{tabular}

C: Central

\section{CATEGORY III - METROPOLITAN CITIES}

\begin{tabular}{|l|l|r|r|r|r|r|}
\hline $\begin{array}{c}\text { CATEGORY } \\
\text { Metropolitan } \\
\text { Cities }\end{array}$ & SUB-PROVINCE & Intensity & $\begin{array}{c}\text { Absolute } \\
\text { Loss }\end{array}$ & $\begin{array}{c}\text { Total } \\
\text { Building }\end{array}$ & $\begin{array}{c}\text { Relative Loss, } \\
\text { Loss Rate }\end{array}$ & $\begin{array}{c}\text { Settlement } \\
\text { Population } \\
(\mathbf{2 0 0 9})\end{array}$ \\
\hline ISTANBUL & ISTANBUL (M.) & 7,5 & 83824 & 864540 & 0,10 & 12.782 .960 \\
\hline KOCAELI & KOCAELI (M.) & 8 & 24077 & 139423 & 0,17 & 1.422 .752 \\
\hline BURSA & BURSA (M.) & 7,5 & 16506 & 204907 & 0,08 & 1.854 .285 \\
\hline IZMIR & IZMIR (M.) & 7 & 14531 & 421397 & 0,03 & 3.276 .815 \\
\hline SAKARYA & SAKARYA (M.) & 8 & 8070 & 49609 & 0,16 & 442.157 \\
\hline ADANA & ADANA (M.) & 6,5 & 1913 & 175697 & 0,01 & 1.556 .238 \\
\hline ANTALYA & ANTALYA (M.) & 6,5 & 1402 & 114998 & 0,01 & 955.573 \\
\hline KONYA & KONYA (M.) & 6,5 & 1355 & 113267 & 0,01 & 1.003 .373 \\
\hline ERZURUM & ERZURUM (M.) & 6,5 & 439 & 32458 & 0,01 & 368.146 \\
\hline
\end{tabular}

M: Metropolitan 
APPENDIX D

TOTAL LISTS OF CATEGORIES OF SETTLEMENTS PRIORITIZED ACCORDING TO RELATIVE LOSS

CATEGORY I - SETTLEMENTS HAVING POPULATION UP TO 50.000

\begin{tabular}{|c|c|c|c|c|c|c|}
\hline $\begin{array}{c}\text { CATEGORY } \\
\mathbf{0 - 5 0 . 0 0 0}\end{array}$ & SUB-PROVINCE & Intensity & $\begin{array}{c}\text { Relative Loss, } \\
\text { Loss Rate }\end{array}$ & $\begin{array}{c}\text { Total } \\
\text { Building }\end{array}$ & $\begin{array}{c}\text { Absolute } \\
\text { Loss }\end{array}$ & $\begin{array}{l}\text { Settlement } \\
\text { Population } \\
\text { (2009) }\end{array}$ \\
\hline YALOVA & CINARCIK & 8 & 0,21 & 1675 & 357 & 11.080 \\
\hline SAKARYA & AKYAZI & 8 & 0,19 & 3668 & 681 & 41.179 \\
\hline YALOVA & CIFTLIKKOY & 8 & 0,19 & 1594 & 298 & 17.052 \\
\hline TEKIRDAG & SARKOY & 8 & 0,18 & 4059 & 712 & 16.624 \\
\hline TOKAT & NIKSAR & 8 & 0,17 & 8343 & 1400 & 33.682 \\
\hline SAKARYA & HENDEK & 8 & 0,17 & 4969 & 869 & 44.418 \\
\hline BOLU & GEREDE & 8 & 0,17 & 3439 & 583 & 23.808 \\
\hline AMASYA & TASOVA & 8 & 0,17 & 1677 & 282 & 10.821 \\
\hline YALOVA & TERMAL & 8 & 0,17 & 425 & 73 & 2.340 \\
\hline KASTAMONU & TOSYA & 8 & 0,16 & 8575 & 1364 & 27.624 \\
\hline CORUM & OSMANCIK & 8 & 0,16 & 5037 & 786 & 25.829 \\
\hline SAMSUN & HAVZA & 8 & 0,16 & 4620 & 735 & 20.204 \\
\hline SAKARYA & GEYVE & 8 & 0,16 & 3491 & 543 & 20.318 \\
\hline SIVAS & SUSEHRI & 8 & 0,16 & 2589 & 424 & 15.304 \\
\hline SAMSUN & LADIK & 8 & 0,16 & 2426 & 377 & 8.316 \\
\hline CANKIRI & ILGAZ & 8 & 0,16 & 1913 & 312 & 7.738 \\
\hline TOKAT & RESADIYE & 8 & 0,16 & 1941 & 309 & 9.027 \\
\hline BOLU & YENICAGA & 8 & 0,16 & 1120 & 183 & 5.175 \\
\hline GIRESUN & CAMOLUK & 8 & 0,16 & 859 & 133 & 2.023 \\
\hline TUNCELI & PULUMUR & 8 & 0,16 & 572 & 94 & 1.656 \\
\hline BOLU & DORTDIVAN & 8 & 0,16 & 589 & 93 & 2.952 \\
\hline YALOVA & ALTINOVA & 8 & 0,16 & 534 & 84 & 4.942 \\
\hline SIVAS & GOLOVA & 8 & 0,16 & 469 & 74 & 2.174 \\
\hline ERZINCAN & UZUMLU & 8 & 0,15 & 4187 & 631 & 8.288 \\
\hline SAKARYA & PAMUKOVA & 8 & 0,15 & 2600 & 403 & 16.047 \\
\hline MUS & VARTO & 8 & 0,15 & 2562 & 384 & 9.585 \\
\hline CORUM & KARGI & 8 & 0,15 & 1878 & 285 & 5.226 \\
\hline SIVAS & KOYULHISAR & 8 & 0,15 & 1806 & 273 & 4.426 \\
\hline CANKIRI & CERKES & 8 & 0,15 & 1728 & 263 & 9.404 \\
\hline SIVAS & AKINCILAR & 8 & 0,15 & 1379 & 211 & 2.775 \\
\hline TOKAT & BASCIFTLIK & 8 & 0,15 & 1225 & 182 & 3.840 \\
\hline DUZCE & KAYNASLI & 8 & 0,15 & 1171 & 177 & 9.418 \\
\hline BINGOL & KARLIOVA & 8 & 0,15 & 911 & 138 & 6.202 \\
\hline SAKARYA & KARAPURCEK & 8 & 0,15 & 910 & 136 & 7.452 \\
\hline ERZINCAN & REFAHIYE & 8 & 0,15 & 849 & 130 & 3.563 \\
\hline DUZCE & GOLYAKA & 8 & 0,15 & 819 & 126 & 8.793 \\
\hline BINGOL & YEDISU & 8 & 0,15 & 460 & 68 & 1.352 \\
\hline CANKIRI & BAYRAMOREN & 8 & 0,15 & 282 & 43 & 880 \\
\hline YALOVA & ARMUTLU & 7,5 & 0,08 & 2083 & 164 & 5.223 \\
\hline AMASYA & SULUOVA & 7,5 & 0,07 & 9653 & 633 & 37.151 \\
\hline BURSA & YENISEHIR & 7,5 & 0,07 & 5028 & 339 & 29.275 \\
\hline SAMSUN & VEZIRKOPRU & 7,5 & 0,07 & 4455 & 298 & 26.724 \\
\hline AMASYA & GUMUSHACIKOY & 7,5 & 0,07 & 4176 & 271 & 14.620 \\
\hline
\end{tabular}




\begin{tabular}{|c|c|c|c|c|c|c|}
\hline $\begin{array}{c}\text { CATEGORY } \\
0-50.000\end{array}$ & SUB-PROVINCE & Intensity & $\begin{array}{c}\text { Relative Loss, } \\
\text { Loss Rate }\end{array}$ & $\begin{array}{c}\text { Total } \\
\text { Building }\end{array}$ & $\begin{array}{c}\text { Absolute } \\
\text { Loss }\end{array}$ & $\begin{array}{l}\text { Settlement } \\
\text { Population } \\
\text { (2009) }\end{array}$ \\
\hline \begin{tabular}{|l} 
BILECIK \\
\end{tabular} & OSMANELI & 7,5 & 0,07 & 2390 & 158 & 13.760 \\
\hline SAMSUN & KAVAK & 7,5 & 0,07 & 1393 & 97 & 8.435 \\
\hline KARABUK & ESKIPAZAR & 7,5 & 0,07 & 1394 & 96 & 6.916 \\
\hline \begin{tabular}{|l} 
DUZCE \\
\end{tabular} & GUMUSOVA & 7,5 & 0,07 & 1294 & 86 & 6.483 \\
\hline BOLU & MENGEN & 7,5 & 0,07 & 1038 & 76 & 5.170 \\
\hline TOKAT & ALMUS & 7,5 & 0,07 & 1070 & 74 & 4.408 \\
\hline SAMSUN & ASARCIK & 7,5 & 0,07 & 386 & 26 & 2.537 \\
\hline BURSA & IZNIK & 7,5 & 0,06 & 3968 & 252 & 22.574 \\
\hline MUS & BULANIK & 7,5 & 0,06 & 4278 & 246 & 21.352 \\
\hline GIRESUN & SEBINKARAHISAR & 7,5 & 0,06 & 3441 & 222 & 11.921 \\
\hline BITLIS & ADILCEVAZ & 7,5 & 0,06 & 2866 & 172 & 14.428 \\
\hline BOLU & MUDURNU & 7,5 & 0,06 & 1656 & 104 & 4.596 \\
\hline \begin{tabular}{|l|} 
CANKIRI \\
\end{tabular} & KURSUNLU & 7,5 & 0,06 & 1312 & 84 & 3.939 \\
\hline BOLU & GOYNUK & 7,5 & 0,06 & 1223 & 75 & 4.182 \\
\hline DUZCE & CUMAYERI & 7,5 & 0,06 & 1056 & 67 & 7.824 \\
\hline SAKARYA & TARAKLI & 7,5 & 0,06 & 1087 & 67 & 3.055 \\
\hline ERZINCAN & CAYIRLI & 7,5 & 0,06 & 1000 & 61 & 3.089 \\
\hline CORUM & DODURGA & 7,5 & 0,06 & 991 & 60 & 3.065 \\
\hline ORDU & MESUDIYE & 7,5 & 0,06 & 965 & 60 & 3.031 \\
\hline BINGOL & ADAKLI & 7,5 & 0,06 & 851 & 52 & 3.143 \\
\hline DUZCE & CILIMLI & 7,5 & 0,06 & 794 & 49 & 6.348 \\
\hline CANKIRI & ATKARACALAR & 7,5 & 0,06 & 713 & 45 & 2.730 \\
\hline CANKIRI & KORGUN & 7,5 & 0,06 & 704 & 44 & 2.129 \\
\hline BINGOL & KIGI & 7,5 & 0,06 & 698 & 43 & 3.220 \\
\hline SIVAS & DOGANSAR & 7,5 & 0,06 & 600 & 37 & 1.508 \\
\hline KARABUK & OVACIK & 7,5 & 0,06 & 229 & 15 & 783 \\
\hline \begin{tabular}{|l} 
BITLIS \\
\end{tabular} & AHLAT & 7,5 & 0,04 & 5609 & 234 & 19.078 \\
\hline \begin{tabular}{|l|} 
BALIKESIR \\
\end{tabular} & ERDEK & 7 & 0,04 & 4193 & 159 & 20.876 \\
\hline BILECIK & BİLECİK C. & 7 & 0,04 & 4025 & 145 & 46.403 \\
\hline ELAZIG & KOVANCILAR & 7 & 0,04 & 2060 & 74 & 20.246 \\
\hline DUZCE & YIGILCA & 7 & 0,04 & 555 & 20 & 3.141 \\
\hline \begin{tabular}{|l|} 
BALIKESIR \\
\end{tabular} & AYVALIK & 7 & 0,03 & 14115 & 442 & 35.986 \\
\hline BALIKESIR & BURHANIYE & 7 & 0,03 & 13164 & 410 & 38.156 \\
\hline IZMIR & CESME & 7 & 0,03 & 11532 & 348 & 20.455 \\
\hline MANISA & ALASEHIR & 7 & 0,03 & 9553 & 306 & 47.942 \\
\hline MANISA & KULA & 7 & 0,03 & 7694 & 236 & 24.241 \\
\hline HATAY & SAMANDAG & 7 & 0,03 & 7232 & 232 & 44.137 \\
\hline BALIKESIR & SUSURLUK & 7 & 0,03 & 5693 & 190 & 23.952 \\
\hline CANAKKALE & BIGA & 7 & 0,03 & 5654 & 188 & 36.520 \\
\hline HATAY & ERZIN & 7 & 0,03 & 5749 & 173 & 30.356 \\
\hline CORUM & ISKILIP & 7 & 0,03 & 5106 & 167 & 20.724 \\
\hline CANAKKALE & CAN & 7 & 0,03 & 5016 & 161 & 28.769 \\
\hline HATAY & BELEN & 7 & 0,03 & 5093 & 159 & 20.892 \\
\hline TEKIRDAG & MALKARA & 7 & 0,03 & 4518 & 157 & 27.371 \\
\hline GAZIANTEP & ISLAHIYE & 7 & 0,03 & 4949 & 148 & 30.904 \\
\hline DENIZLI & BULDAN & 7 & 0,03 & 4282 & 137 & 15.197 \\
\hline ADIYAMAN & GOLBASI & 7 & 0,03 & 4284 & 137 & 27.800 \\
\hline ORDU & GOLKOY & 7 & 0,03 & 4246 & 134 & 16.410 \\
\hline MANISA & SARIGOL & 7 & 0,03 & 4250 & 130 & 13.406 \\
\hline CANAKKALE & BAYRAMIC & 7 & 0,03 & 4157 & 129 & 13.290 \\
\hline ADIYAMAN & BESNI & 7 & 0,03 & 4254 & 126 & 26.788 \\
\hline MUS & MALAZGIRT & 7 & 0,03 & 4146 & 125 & 19.130 \\
\hline ORDU & AYBASTI & 7 & 0,03 & 3742 & 125 & 14.175 \\
\hline CANAKKALE & EZINE & 7 & 0,03 & 3901 & 121 & 13.202 \\
\hline K.MARAS & PAZARCIK & 7 & 0,03 & 3944 & 120 & 28.713 \\
\hline
\end{tabular}




\begin{tabular}{|c|c|c|c|c|c|c|}
\hline $\begin{array}{c}\text { CATEGORY } \\
0-50.000\end{array}$ & SUB-PROVINCE & Intensity & $\begin{array}{c}\text { Relative Loss, } \\
\text { Loss Rate }\end{array}$ & $\begin{array}{c}\text { Total } \\
\text { Building }\end{array}$ & $\begin{array}{c}\text { Absolute } \\
\text { Loss }\end{array}$ & $\begin{array}{c}\text { Settlement } \\
\text { Population } \\
\text { (2009) }\end{array}$ \\
\hline USAK & ESME & 7 & 0,03 & 3797 & 119 & 13.532 \\
\hline BALIKESIR & BIGADIC & 7 & 0,03 & 3533 & 114 & 16.062 \\
\hline MANISA & SARUHANLI & 7 & 0,03 & 3637 & 112 & 15.336 \\
\hline BURDUR & GOLHISAR & 7 & 0,03 & 3496 & 110 & 13.424 \\
\hline BALIKESIR & HAVRAN & 7 & 0,03 & 3389 & 107 & 10.671 \\
\hline ERZURUM & HINIS & 7 & 0,03 & 3551 & 107 & 9.654 \\
\hline EDIRNE & ENEZ & 7 & 0,03 & 3484 & 105 & 3.820 \\
\hline BALIKESIR & SINDIRGI & 7 & 0,03 & 3141 & 100 & 12.672 \\
\hline MANISA & GOLMARMARA & 7 & 0,03 & 2983 & 91 & 9.840 \\
\hline BALIKESIR & GOMEC & 7 & 0,03 & 2927 & 87 & 4.788 \\
\hline MANISA & AHMETLI & 7 & 0,03 & 2704 & 83 & 9.916 \\
\hline CANAKKALE & LAPSEKI & 7 & 0,03 & 2184 & 74 & 10.624 \\
\hline ERZURUM & KARACOBAN & 7 & 0,03 & 2423 & 73 & 8.804 \\
\hline BALIKESIR & SAVASTEPE & 7 & 0,03 & 2307 & 72 & 9.368 \\
\hline OSMANIYE & BAHCE & 7 & 0,03 & 2305 & 70 & 12.917 \\
\hline ANKARA & CAMLIDERE & 7 & 0,03 & 2285 & 70 & 3.747 \\
\hline \begin{tabular}{|l|} 
GAZIANTEP \\
\end{tabular} & NURDAGI & 7 & 0,03 & 2273 & 69 & 16.328 \\
\hline K.MARAS & TURKOGLU & 7 & 0,03 & 2262 & 68 & 14.274 \\
\hline SAKARYA & FERIZLI & 7 & 0,03 & 1924 & 61 & 12.914 \\
\hline BURDUR & KARAMANLI & 7 & 0,03 & 1914 & 60 & 5.251 \\
\hline VAN & BASKALE & 7 & 0,03 & 1986 & 60 & 12.562 \\
\hline BILECIK & GOLPAZARI & 7 & 0,03 & 1862 & 58 & 7.697 \\
\hline CANAKKALE & AYVACIK & 7 & 0,03 & 1849 & 57 & 7.538 \\
\hline DENIZLI & GUNEY & 7 & 0,03 & 1857 & 57 & 5.908 \\
\hline \begin{tabular}{|l} 
ELAZIG \\
\end{tabular} & PALU & 7 & 0,03 & 1812 & 55 & 8.837 \\
\hline HATAY & YAYLADAGI & 7 & 0,03 & 1774 & 54 & 5.843 \\
\hline \begin{tabular}{|l|} 
BINGOL \\
\end{tabular} & GENC & 7 & 0,03 & 1676 & 54 & 18.691 \\
\hline DENIZLI & CAL & 7 & 0,03 & 1738 & 53 & 3.887 \\
\hline BALIKESIR & MANYAS & 7 & 0,03 & 1607 & 51 & 6.578 \\
\hline ELAZIG & MADEN & 7 & 0,03 & 1653 & 51 & 5.314 \\
\hline HATAY & HASSA & 7 & 0,03 & 1673 & 50 & 9.207 \\
\hline BURDUR & TEFENNI & 7 & 0,03 & 1606 & 50 & 4.626 \\
\hline OSMANIYE & TOPRAKKALE & 7 & 0,03 & 1661 & 50 & 7.843 \\
\hline BURDUR & YESILOVA & 7 & 0,03 & 1587 & 49 & 4.724 \\
\hline BALIKESIR & IVRINDI & 7 & 0,03 & 1537 & 49 & 6.514 \\
\hline KASTAMONU & IHSANGAZI & 7 & 0,03 & 1473 & 48 & 2.715 \\
\hline KASTAMONU & ARAC & 7 & 0,03 & 1393 & 45 & 5.776 \\
\hline IZMIR & KARABURUN & 7 & 0,03 & 1485 & 45 & 2.785 \\
\hline CORUM & OGUZLAR & 7 & 0,03 & 1463 & 44 & 3.741 \\
\hline ERZINCAN & TERCAN & 7 & 0,03 & 1430 & 44 & 5.416 \\
\hline VAN & OZALP & 7 & 0,03 & 1417 & 43 & 10.166 \\
\hline OSMANIYE & HASANBEYLI & 7 & 0,03 & 1446 & 43 & 2.559 \\
\hline DENIZLI & CARDAK & 7 & 0,03 & 1360 & 43 & 4.634 \\
\hline HATAY & ALTINOZU & 7 & 0,03 & 1345 & 41 & 7.458 \\
\hline SIVAS & IMRANLI & 7 & 0,03 & 1304 & 40 & 3.303 \\
\hline ADIYAMAN & CELIKHAN & 7 & 0,03 & 1265 & 38 & 8.224 \\
\hline ERZURUM & CAT & 7 & 0,03 & 1234 & 37 & 4.527 \\
\hline SAMSUN & AYVACIK & 7 & 0,03 & 1189 & 37 & 6.702 \\
\hline GUMUSHANE & SIRAN & 7 & 0,03 & 1124 & 36 & 6.854 \\
\hline \begin{tabular}{|l} 
BURDUR \\
\end{tabular} & ALTINYAYLA & 7 & 0,03 & 1149 & 35 & 3.240 \\
\hline ADIYAMAN & TUT & 7 & 0,03 & 1104 & 34 & 4.101 \\
\hline HATAY & KUMLU & 7 & 0,03 & 1101 & 33 & 5.167 \\
\hline VAN & EDREMIT & 7 & 0,03 & 1088 & 33 & 12.426 \\
\hline DENIZLI & BOZKURT & 7 & 0,03 & 995 & 31 & 4.360 \\
\hline ELAZIG & SIVRICE & 7 & 0,03 & 1011 & 31 & 4.236 \\
\hline
\end{tabular}




\begin{tabular}{|c|c|c|c|c|c|c|}
\hline $\begin{array}{c}\text { CATEGORY } \\
0-50.000\end{array}$ & SUB-PROVINCE & Intensity & $\begin{array}{c}\text { Relative Loss, } \\
\text { Loss Rate }\end{array}$ & $\begin{array}{c}\text { Total } \\
\text { Building }\end{array}$ & $\begin{array}{c}\text { Absolute } \\
\text { Loss }\end{array}$ & $\begin{array}{l}\text { Settlement } \\
\text { Population } \\
\text { (2009) }\end{array}$ \\
\hline GIRESUN & ALUCRA & 7 & 0,03 & 928 & 29 & 4.970 \\
\hline CANKIRI & ORTA & 7 & 0,03 & 925 & 29 & 3.815 \\
\hline DENIZLI & BAKLAN & 7 & 0,03 & 942 & 29 & 2.062 \\
\hline MALATYA & POTURGE & 7 & 0,03 & 910 & 28 & 2.751 \\
\hline BURDUR & CAVDIR & 7 & 0,03 & 882 & 28 & 3.112 \\
\hline DIYARBAKIR & CUNGUS & 7 & 0,03 & 868 & 26 & 2.544 \\
\hline VAN & GURPINAR & 7 & 0,03 & 858 & 26 & 5.166 \\
\hline BINGOL & YAYLADERE & 7 & 0,03 & 818 & 25 & 989 \\
\hline ELAZIG & ALACAKAYA & 7 & 0,03 & 830 & 25 & 2.598 \\
\hline MALATYA & DOGANYOL & 7 & 0,03 & 827 & 25 & 1.774 \\
\hline BURDUR & KEMER & 7 & 0,03 & 799 & 24 & 2.012 \\
\hline CANKIRI & YAPRAKLI & 7 & 0,03 & 776 & 24 & 1.771 \\
\hline BOLU & SEBEN & 7 & 0,03 & 755 & 23 & 2.822 \\
\hline ERZINCAN & KEMAH & 7 & 0,03 & 674 & 21 & 1.929 \\
\hline BALIKESIR & BALYA & 7 & 0,03 & 653 & 20 & 1.901 \\
\hline ORDU & AKKUS & 7 & 0,03 & 572 & 20 & 5.746 \\
\hline ADIYAMAN & SINCIK & 7 & 0,03 & 638 & 19 & 4.331 \\
\hline DENIZLI & AKKOY & 7 & 0,03 & 634 & 19 & 2.755 \\
\hline MUS & KORKUT & 7 & 0,03 & 625 & 19 & 3.102 \\
\hline ELAZIG & ARICAK & 7 & 0,03 & 538 & 17 & 3.380 \\
\hline CORUM & LACIN & 7 & 0,03 & 521 & 16 & 1.227 \\
\hline AMASYA & HAMAMOZU & 7 & 0,03 & 481 & 15 & 1.405 \\
\hline ERZINCAN & OTLUKBELI & 7 & 0,03 & 435 & 13 & 1.630 \\
\hline BOLU & KIBRISCIK & 7 & 0,03 & 405 & 12 & 1.345 \\
\hline SINOP & SARAYDUZU & 7 & 0,03 & 388 & 12 & 951 \\
\hline KUTAHYA & SIMAV & 6,5 & 0,02 & 4870 & 73 & 24.799 \\
\hline MUGLA & MARMARIS & 6,5 & 0,02 & 3545 & 54 & 30.101 \\
\hline \begin{tabular}{|l|} 
DUZCE \\
\end{tabular} & AKCAKOCA & 6,5 & 0,02 & 2751 & 42 & 23.378 \\
\hline ZONGULDAK & ALAPLI & 6,5 & 0,02 & 1457 & 30 & 18.194 \\
\hline \begin{tabular}{|l|} 
AYDIN \\
\end{tabular} & DİDİM(YENIHİSAR) & 6,5 & 0,01 & 18697 & 204 & 41.246 \\
\hline MUGLA & BODRUM & 6,5 & 0,01 & 12850 & 130 & 31.590 \\
\hline AFYON & BOLVADIN & 6,5 & 0,01 & 9687 & 105 & 31.284 \\
\hline TOKAT & ZILE & 6,5 & 0,01 & 9275 & 100 & 35.417 \\
\hline BALIKESIR & GONEN & 6,5 & 0,01 & 7512 & 93 & 42.939 \\
\hline BURDUR & BUCAK & 6,5 & 0,01 & 7405 & 87 & 36.370 \\
\hline OSMANIYE & DUZICI & 6,5 & 0,01 & 7540 & 76 & 40.823 \\
\hline KARABUK & SAFRANBOLU & 6,5 & 0,01 & 6030 & 76 & 39.669 \\
\hline AYDIN & CINE & 6,5 & 0,01 & 5631 & 64 & 20.416 \\
\hline AFYON & EMIRDAG & 6,5 & 0,01 & 5372 & 63 & 20.253 \\
\hline KONYA & ILGIN & 6,5 & 0,01 & 5510 & 62 & 31.171 \\
\hline AFYON & CAY & 6,5 & 0,01 & 5129 & 59 & 14.592 \\
\hline \begin{tabular}{|l} 
SAKARYA \\
\end{tabular} & KARASU & 6,5 & 0,01 & 4218 & 57 & 27.914 \\
\hline ANTALYA & KUMLUCA & 6,5 & 0,01 & 4711 & 56 & 30.939 \\
\hline MANISA & KIRKAGAC & 6,5 & 0,01 & 5152 & 56 & 26.660 \\
\hline \begin{tabular}{|l|} 
ANTALYA \\
\end{tabular} & KORKUTELI & 6,5 & 0,01 & 4225 & 54 & 20.109 \\
\hline ADANA & IMAMOGLU & 6,5 & 0,01 & 5136 & 52 & 20.636 \\
\hline ISPARTA & EGIRDIR & 6,5 & 0,01 & 4014 & 50 & 18.402 \\
\hline \begin{tabular}{|l} 
SINOP \\
\end{tabular} & BOYABAT & 6,5 & 0,01 & 3732 & 50 & 25.271 \\
\hline MUGLA & ORTACA & 6,5 & 0,01 & 4427 & 50 & 25.816 \\
\hline MANISA & DEMIRCI & 6,5 & 0,01 & 4448 & 48 & 19.550 \\
\hline KAYSERI & YAHYALI & 6,5 & 0,01 & 4513 & 48 & 20.066 \\
\hline AYDIN & INCIRLIOVA & 6,5 & 0,01 & 4029 & 47 & 19.438 \\
\hline MUGLA & DALAMAN & 6,5 & 0,01 & 4248 & 47 & 22.956 \\
\hline ISPARTA & YALVAC & 6,5 & 0,01 & 3371 & 46 & 20.448 \\
\hline KUTAHYA & GEDIZ & 6,5 & 0,01 & 4525 & 46 & 19.546 \\
\hline
\end{tabular}




\begin{tabular}{|c|c|c|c|c|c|c|}
\hline $\begin{array}{c}\text { CATEGORY } \\
0-50.000\end{array}$ & SUB-PROVINCE & Intensity & $\begin{array}{c}\text { Relative Loss, } \\
\text { Loss Rate }\end{array}$ & $\begin{array}{c}\text { Total } \\
\text { Building }\end{array}$ & $\begin{array}{c}\text { Absolute } \\
\text { Loss }\end{array}$ & $\begin{array}{c}\text { Settlement } \\
\text { Population } \\
\text { (2009) }\end{array}$ \\
\hline AYDIN & BOZDOGAN & 6,5 & 0,01 & 4128 & 45 & 9.713 \\
\hline ERZURUM & PASINLER & 6,5 & 0,01 & 4237 & 43 & 13.969 \\
\hline USAK & BANAZ & 6,5 & 0,01 & 3252 & 43 & 15.395 \\
\hline DENIZLI & SARAYKOY & 6,5 & 0,01 & 3360 & 43 & 18.526 \\
\hline ANTALYA & ELMALI & 6,5 & 0,01 & 3649 & 42 & 14.478 \\
\hline IZMIR & KINIK & 6,5 & 0,01 & 3869 & 39 & 11.919 \\
\hline SAKARYA & KOCAALI & 6,5 & 0,01 & 3461 & 39 & 12.560 \\
\hline TEKIRDAG & MURATLI & 6,5 & 0,01 & 3558 & 39 & 19.107 \\
\hline MUGLA & DATCA & 6,5 & 0,01 & 3566 & 37 & 9.958 \\
\hline KASTAMONU & TASKOPRU & 6,5 & 0,01 & 2643 & 37 & 16.385 \\
\hline MANISA & GORDES & 6,5 & 0,01 & 3263 & 37 & 10.812 \\
\hline SIVAS & ZARA & 6,5 & 0,01 & 3296 & 35 & 11.996 \\
\hline ISPARTA & SARKIKARAAGAC & 6,5 & 0,01 & 2955 & 35 & 10.473 \\
\hline ORDU & KORGAN & 6,5 & 0,01 & 2958 & 34 & 13.018 \\
\hline AFYON & SUHUT & 6,5 & 0,01 & 3171 & 34 & 12.479 \\
\hline KARABUK & YENICE & 6,5 & 0,01 & 2332 & 33 & 9.772 \\
\hline \begin{tabular}{|l} 
AYDIN \\
\end{tabular} & GERMENCIK & 6,5 & 0,01 & 3082 & 33 & 12.588 \\
\hline MUGLA & YATAGAN & 6,5 & 0,01 & 2808 & 33 & 17.707 \\
\hline \begin{tabular}{|l} 
AYDIN \\
\end{tabular} & YENIPAZAR & 6,5 & 0,01 & 3125 & 32 & 6.609 \\
\hline KUTAHYA & EMET & 6,5 & 0,01 & 2759 & 31 & 10.547 \\
\hline SAMSUN & TEKKEKÖY & 6,5 & 0,01 & 2451 & 31 & 36.728 \\
\hline KAYSERI & BUNYAN & 6,5 & 0,01 & 2833 & 30 & 12.431 \\
\hline AFYON & ISCEHISAR & 6,5 & 0,01 & 2692 & 29 & 11.910 \\
\hline BILECIK & SOGUT & 6,5 & 0,01 & 2169 & 29 & 15.007 \\
\hline ERZURUM & ASKALE & 6,5 & 0,01 & 2705 & 28 & 12.447 \\
\hline ANKARA & NALLIHAN & 6,5 & 0,01 & 2373 & 28 & 12.585 \\
\hline DIYARBAKIR & CERMIK & 6,5 & 0,01 & 2819 & 28 & 17.389 \\
\hline ORDU & GURGENTEPE & 6,5 & 0,01 & 2479 & 28 & 7.844 \\
\hline ORDU & KUMRU & 6,5 & 0,01 & 2138 & 27 & 11.948 \\
\hline GUMUSHANE & KELKIT & 6,5 & 0,01 & 2452 & 27 & 14.012 \\
\hline KONYA & DOGANHISAR & 6,5 & 0,01 & 2349 & 27 & 6.233 \\
\hline DENIZLI & ACIPAYAM & 6,5 & 0,01 & 2009 & 27 & 12.588 \\
\hline ANKARA & KIZILCAHAMAM & 6,5 & 0,01 & 1910 & 27 & 16.810 \\
\hline AYDIN & KARACASU & 6,5 & 0,01 & 2488 & 27 & 6.154 \\
\hline ISPARTA & KECIBORLU & 6,5 & 0,01 & 2503 & 27 & 7.134 \\
\hline ANTALYA & KALE (DEMRE) & 6,5 & 0,01 & 2358 & 26 & 15.574 \\
\hline ISPARTA & SENIRKENT & 6,5 & 0,01 & 2301 & 26 & 6.932 \\
\hline ADANA & POZANTI & 6,5 & 0,01 & 2496 & 26 & 9.880 \\
\hline K.MARAS & CAGLAYANCERIT & 6,5 & 0,01 & 2453 & 25 & 12.428 \\
\hline BALIKESIR & KEPSUT & 6,5 & 0,01 & 2183 & 24 & 5.763 \\
\hline IZMIR & KIRAZ & 6,5 & 0,01 & 2303 & 24 & 8.469 \\
\hline \begin{tabular}{|l} 
EDIRNE \\
\end{tabular} & IPSALA & 6,5 & 0,01 & 2325 & 24 & 8.033 \\
\hline ANTALYA & KEMER & 6,5 & 0,01 & 2091 & 24 & 20.110 \\
\hline ADANA & KARATAS & 6,5 & 0,01 & 2240 & 24 & 8.504 \\
\hline MUS & HASKOY & 6,5 & 0,01 & 2332 & 24 & 13.389 \\
\hline ADANA & KARAISALI & 6,5 & 0,01 & 2284 & 24 & 7.307 \\
\hline IZMIR & BEYDAG & 6,5 & 0,01 & 2098 & 23 & 5.710 \\
\hline BITLIS & GUROYMAK & 6,5 & 0,01 & 2288 & 23 & 20.226 \\
\hline MUGLA & KOYCEGIZ & 6,5 & 0,01 & 2317 & 23 & 8.677 \\
\hline AYDIN & KUYUCAK & 6,5 & 0,01 & 2091 & 23 & 7.701 \\
\hline ANTALYA & FINIKE & 6,5 & 0,01 & 1752 & 23 & 11.199 \\
\hline ELAZIG & KARAKOCAN & 6,5 & 0,01 & 2016 & 22 & 12.708 \\
\hline SINOP & DURAGAN & 6,5 & 0,01 & 1592 & 22 & 7.442 \\
\hline AYDIN & KOSK & 6,5 & 0,01 & 2006 & 22 & 9.854 \\
\hline AFYON & BASMAKCI & 6,5 & 0,01 & 2080 & 22 & 5.681 \\
\hline
\end{tabular}




\begin{tabular}{|c|c|c|c|c|c|c|}
\hline $\begin{array}{c}\text { CATEGORY } \\
0-50.000\end{array}$ & SUB-PROVINCE & Intensity & $\begin{array}{c}\text { Relative Loss, } \\
\text { Loss Rate }\end{array}$ & $\begin{array}{c}\text { Total } \\
\text { Building }\end{array}$ & $\begin{array}{c}\text { Absolute } \\
\text { Loss }\end{array}$ & $\begin{array}{l}\text { Settlement } \\
\text { Population } \\
\text { (2009) }\end{array}$ \\
\hline MUGLA & ULA & 6,5 & 0,01 & 2151 & 22 & 5.602 \\
\hline ISPARTA & ULUBORLU & 6,5 & 0,01 & 2051 & 21 & 6.520 \\
\hline \begin{tabular}{|l|} 
VAN \\
\end{tabular} & GEVAS & 6,5 & 0,01 & 2080 & 21 & 10.432 \\
\hline GAZIANTEP & ARABAN & 6,5 & 0,01 & 2075 & 21 & 9.758 \\
\hline AFYON & SULTANDAGI & 6,5 & 0,01 & 1822 & 20 & 6.288 \\
\hline AYDIN & BUHARKENT & 6,5 & 0,01 & 1744 & 20 & 6.891 \\
\hline MALATYA & DOGANSEHIR & 6,5 & 0,01 & 1843 & 20 & 10.800 \\
\hline BURSA & ORHANELI & 6,5 & 0,01 & 1714 & 20 & 7.934 \\
\hline USAK & ULUBEY & 6,5 & 0,01 & 1716 & 19 & 4.945 \\
\hline AYDIN & SULTANHISAR & 6,5 & 0,01 & 1695 & 19 & 6.229 \\
\hline BILECIK & PAZARYERI & 6,5 & 0,01 & 1810 & 19 & 6.481 \\
\hline AFYON & COBANLAR & 6,5 & 0,01 & 1831 & 19 & 8.774 \\
\hline DENIZLI & BEKILLI & 6,5 & 0,01 & 1823 & 19 & 3.481 \\
\hline DENIZLI & HONAZ & 6,5 & 0,01 & 1757 & 18 & 9.788 \\
\hline AYDIN & KOCARLI & 6,5 & 0,01 & 1697 & 18 & 6.822 \\
\hline \begin{tabular}{|l|} 
ADANA \\
\end{tabular} & YUMURTALIK & 6,5 & 0,01 & 1650 & 18 & 5.220 \\
\hline ISPARTA & GELENDOST & 6,5 & 0,01 & 1730 & 18 & 5.351 \\
\hline KUTAHYA & HISARCIK & 6,5 & 0,01 & 1395 & 18 & 4.877 \\
\hline DENIZLI & BABADAG & 6,5 & 0,01 & 1684 & 17 & 4.185 \\
\hline KONYA & DERBENT & 6,5 & 0,01 & 1713 & 17 & 2.922 \\
\hline CORUM & BAYAT & 6,5 & 0,01 & 1531 & 17 & 8.828 \\
\hline \begin{tabular}{|l} 
AFYON \\
\end{tabular} & BAYAT & 6,5 & 0,01 & 1654 & 17 & 4.489 \\
\hline MANISA & KOPRUBASI & 6,5 & 0,01 & 1587 & 17 & 5.283 \\
\hline KONYA & HUYUK & 6,5 & 0,01 & 1513 & 16 & 3.695 \\
\hline CORUM & MECITOZU & 6,5 & 0,01 & 1522 & 16 & 5.261 \\
\hline ANTALYA & KAS & 6,5 & 0,01 & 1126 & 16 & 6.857 \\
\hline KUTAHYA & SAPHANE & 6,5 & 0,01 & 1491 & 16 & 3.623 \\
\hline CANAKKALE & YENICE & 6,5 & 0,01 & 1463 & 16 & 6.830 \\
\hline ISPARTA & ATABEY & 6,5 & 0,01 & 1462 & 15 & 4.355 \\
\hline \begin{tabular}{|l|} 
BURDUR \\
\end{tabular} & AGLASUN & 6,5 & 0,01 & 1443 & 15 & 4.414 \\
\hline DIYARBAKIR & DICLE & 6,5 & 0,01 & 1482 & 15 & 8.610 \\
\hline TOKAT & PAZAR & 6,5 & 0,01 & 1358 & 14 & 4.986 \\
\hline NIGDE & CAMARDI & 6,5 & 0,01 & 1353 & 14 & 3.480 \\
\hline SAMSUN & SALIPAZARI & 6,5 & 0,01 & 1162 & 14 & 6.156 \\
\hline CANKIRI & ELDIVAN & 6,5 & 0,01 & 1329 & 14 & 3.034 \\
\hline KUTAHYA & ALTINTAS & 6,5 & 0,01 & 1192 & 13 & 5.538 \\
\hline \begin{tabular}{|l|} 
AFYON \\
\end{tabular} & DAZKIRI & 6,5 & 0,01 & 1162 & 13 & 4.470 \\
\hline ISPARTA & GONEN & 6,5 & 0,01 & 1185 & 12 & 3.663 \\
\hline KONYA & TUZLUKCU & 6,5 & 0,01 & 1218 & 12 & 3.912 \\
\hline KUTAHYA & PAZARLAR & 6,5 & 0,01 & 1103 & 12 & 3.660 \\
\hline ORDU & CATALPINAR & 6,5 & 0,01 & 999 & 11 & 5.333 \\
\hline \begin{tabular}{|l} 
SAKARYA \\
\end{tabular} & KAYNARCA & 6,5 & 0,01 & 911 & 11 & 5.144 \\
\hline \begin{tabular}{|l|} 
AFYON \\
\end{tabular} & EVCILER & 6,5 & 0,01 & 1071 & 11 & 4.142 \\
\hline ERZURUM & TEKMAN & 6,5 & 0,01 & 1040 & 11 & 3.957 \\
\hline DENIZLI & CAMELI & 6,5 & 0,01 & 854 & 9 & 2.837 \\
\hline GAZIANTEP & YAVUZELI & 6,5 & 0,01 & 909 & 9 & 4.093 \\
\hline \begin{tabular}{|l|} 
BURSA \\
\end{tabular} & KELES & 6,5 & 0,01 & 873 & 9 & 3.681 \\
\hline \begin{tabular}{|l|} 
CANKIRI \\
\end{tabular} & SABANOZU & 6,5 & 0,01 & 897 & 9 & 5.124 \\
\hline AYDIN & KARPUZLU & 6,5 & 0,01 & 863 & 9 & 2.116 \\
\hline CORUM & ORTAKOY & 6,5 & 0,01 & 834 & 9 & 2.945 \\
\hline BURDUR & CELTIKCI & 6,5 & 0,01 & 856 & 9 & 2.374 \\
\hline \begin{tabular}{|l} 
ADIYAMAN \\
\end{tabular} & GERGER & 6,5 & 0,01 & 901 & 99 & 3.242 \\
\hline KUTAHYA & CAVDARHISAR & 6,5 & 0,01 & 809 & 8 & 2.412 \\
\hline DENIZLI & BEYAGAC & 6,5 & 0,01 & 807 & 8 & 2.664 \\
\hline ESKISEHIR & MIHALGAZI & 6,5 & 0,01 & 765 & 8 & 1.951 \\
\hline
\end{tabular}




\begin{tabular}{|l|l|r|r|r|r|r|}
\hline $\begin{array}{c}\text { CATEGORY } \\
\mathbf{0 - 5 0 . 0 0 0}\end{array}$ & SUB-PROVINCE & Intensity & $\begin{array}{c}\text { Relative Loss, } \\
\text { Loss Rate }\end{array}$ & $\begin{array}{c}\text { Total } \\
\text { Building }\end{array}$ & $\begin{array}{c}\text { Absolute } \\
\text { Loss }\end{array}$ & $\begin{array}{c}\text { Settlement } \\
\text { Population } \\
\text { (2009) }\end{array}$ \\
\hline OSMANIYE & SUMBAS & 6,5 & 0,01 & 733 & 7 & 2.114 \\
\hline AFYON & IHSANIYE & 6,5 & 0,01 & 711 & 7 & 2.341 \\
\hline TUNCELI & OVACIK & 6,5 & 0,01 & 642 & 7 & 3.227 \\
\hline MALATYA & KALE & 6,5 & 0,01 & 675 & 7 & 2.030 \\
\hline AMASYA & GOYNUCEK & 6,5 & 0,01 & 620 & 7 & 2.421 \\
\hline KUTAHYA & DUMLUPINAR & 6,5 & 0,01 & 599 & 6 & 1.438 \\
\hline VAN & SARAY & 6,5 & 0,01 & 585 & 6 & 3.591 \\
\hline BILECIK & INHISAR & 6,5 & 0,01 & 516 & 5 & 1.085 \\
\hline BILECIK & YENIPAZAR & 6,5 & 0,01 & 473 & 5 & 1.115 \\
\hline ESKISEHIR & SARICAKAYA & 6,5 & 0,01 & 971 & 5 & 2.150 \\
\hline KUTAHYA & ASLANAPA & 6,5 & 0,01 & 483 & 5 & 1.893 \\
\hline TUNCELI & NAZIMIYE & 6,5 & 0,01 & 313 & 4 & 1.636 \\
\hline KILIS & MUSABEYLI & 6,5 & 0,01 & 175 & 2 & 856 \\
\hline KONYA & AKOREN & 6,5 & 0,00 & 1214 & 6 & 3.442 \\
\hline
\end{tabular}

C: Central

CATEGORY II - SETTLEMENTS HAVING POPULATION BETWEEN 50.000 AND 490.000

\begin{tabular}{|l|l|r|r|r|r|r|}
\hline $\begin{array}{c}\text { CATEGORY } \\
\text { 50.000-490.000 }\end{array}$ & SUB-PROVINCE & Intensity & $\begin{array}{c}\text { Relative Loss, } \\
\text { Loss Rate }\end{array}$ & $\begin{array}{c}\text { Total } \\
\text { Building }\end{array}$ & $\begin{array}{c}\text { Absolute } \\
\text { Loss }\end{array}$ & $\begin{array}{c}\text { Settlement } \\
\text { Population } \\
\text { (2009) }\end{array}$ \\
\hline BOLU & BOLU C. & 8 & 0,18 & 10516 & 1841 & 120.021 \\
\hline YALOVA & YALOVA C. & 8 & 0,18 & 8302 & 1507 & 92.166 \\
\hline BURSA & ORHANGAZI & 8 & 0,18 & 5313 & 945 & 54.319 \\
\hline ERZINCAN & ERZINCAN C. & 8 & 0,16 & 12678 & 2025 & 90.100 \\
\hline TOKAT & ERBAA & 8 & 0,16 & 7895 & 1251 & 58.845 \\
\hline TEKIRDAG & TEKİRDAĞ C. & 7,5 & 0,09 & 15683 & 1347 & 140.535 \\
\hline AMASYA & MERZIFON & 7,5 & 0,07 & 9411 & 666 & 52.225 \\
\hline DUZCE & DÜZCE C. & 7,5 & 0,07 & 8593 & 612 & 125.240 \\
\hline VAN & VAN C. & 7,5 & 0,06 & 36235 & 2285 & 360.810 \\
\hline MANISA & MANISA C. & 7 & 0,04 & 24785 & 919 & 291.374 \\
\hline BURSA & INEGOL & 7 & 0,04 & 14095 & 536 & 161.541 \\
\hline MANISA & SALIHLI & 7 & 0,04 & 13639 & 483 & 96.503 \\
\hline BALIKESIR & BANDIRMA & 7 & 0,04 & 12035 & 460 & 113.385 \\
\hline CANAKKALE & ÇANAKKALE C. & 7 & 0,04 & 9281 & 339 & 96.588 \\
\hline AMASYA & AMASYA C. & 7 & 0,04 & 9432 & 336 & 86.667 \\
\hline BURSA & M.KEMALPASA & 7 & 0,04 & 8460 & 304 & 57.097 \\
\hline OSMANIYE & OSMANIYE C. & 7 & 0,03 & 29408 & 905 & 194.339 \\
\hline HATAY & ANTAKYA & 7 & 0,03 & 23471 & 768 & 202.216 \\
\hline HATAY & ISKENDERUN & 7 & 0,03 & 21169 & 705 & 190.279 \\
\hline ADIYAMAN & ADIYAMAN C. & 7 & 0,03 & 21965 & 696 & 198.433 \\
\hline MANISA & TURGUTLU & 7 & 0,03 & 19331 & 639 & 115.930 \\
\hline MANISA & AKHISAR & 7 & 0,03 & 17775 & 585 & 100.897 \\
\hline TOKAT & TOKAT C. & 7 & 0,03 & 15371 & 528 & 129.879 \\
\hline IZMIR & BERGAMA & 7 & 0,03 & 12446 & 402 & 58.570 \\
\hline HATAY & KIRIKHAN & 7 & 0,03 & 11860 & 360 & 69.285 \\
\hline HATAY & DORTYOL & 7 & 0,03 & 10708 & 333 & 69.507 \\
\hline HATAY & REYHANLI & 7 & 0,03 & 9267 & 280 & 61.306 \\
\hline EDIRNE & KESAN & 7 & 0,03 & 8056 & 269 & 53.391 \\
\hline BALIKESIR & EDREMIT & 7 & 0,03 & 7636 & 262 & 50.523 \\
\hline BURSA & KARACABEY & 7 & 0,03 & 7657 & 258 & 51.907 \\
\hline BINGOL & BİNGÖL C. & 7 & 0,03 & 7211 & 251 & 89.224 \\
\hline & & & & & & \\
\hline
\end{tabular}




\begin{tabular}{|c|c|c|c|c|c|c|}
\hline $\begin{array}{c}\text { CATEGORY } \\
\mathbf{5 0 . 0 0 0 - 4 9 0 . 0 0 0}\end{array}$ & SUB-PROVINCE & Intensity & $\begin{array}{l}\text { Relative Loss, } \\
\text { Loss Rate }\end{array}$ & $\begin{array}{c}\text { Total } \\
\text { Building }\end{array}$ & $\begin{array}{c}\text { Absolute } \\
\text { Loss }\end{array}$ & $\begin{array}{c}\text { Settlement } \\
\text { Population } \\
(2009)\end{array}$ \\
\hline BALIKESIR & BALIKESİR C. & 6,5 & 0,02 & 30918 & 469 & 259.157 \\
\hline AYDIN & AYDIN C. & 6,5 & 0,02 & 19320 & 303 & 179.425 \\
\hline DENIZLI & DENIZLİ C. & 6,5 & 0,01 & 41993 & 586 & 488.768 \\
\hline K.MARAS & K.MARAŞ C. & 6,5 & 0,01 & 41470 & 457 & 384.953 \\
\hline KUTAHYA & KÜTAHYA C. & 6,5 & 0,01 & 27490 & 384 & 212.444 \\
\hline ICEL(MERSIN) & TARSUS & 6,5 & 0,01 & 33303 & 361 & 233.436 \\
\hline ISPARTA & $\begin{array}{l}\text { ISPARTA C. } \\
\end{array}$ & 6,5 & 0,01 & 26357 & 354 & 190.084 \\
\hline CORUM & ÇORUM C. & 6,5 & 0,01 & 21086 & 286 & 212.418 \\
\hline AFYON & AFYON C. & 6,5 & 0,01 & 17973 & 240 & 170.455 \\
\hline TEKIRDAG & CORLU & 6,5 & 0,01 & 15526 & 230 & 206.134 \\
\hline AYDIN & KUSADASI & 6,5 & 0,01 & 17726 & 211 & 61.648 \\
\hline AYDIN & \begin{tabular}{|l|} 
NAZILLI \\
\end{tabular} & 6,5 & 0,01 & 16583 & 210 & 109.800 \\
\hline IZMIR & ODEMIS & 6,5 & 0,01 & 14665 & 190 & 73.310 \\
\hline ADANA & KOZAN & 6,5 & 0,01 & 17670 & 184 & 74.521 \\
\hline KARABUK & KARABÜK C. & 6,5 & 0,01 & 13714 & 180 & 108.167 \\
\hline ADANA & CEYHAN & 6,5 & 0,01 & 16033 & 171 & 104.572 \\
\hline OSMANIYE & KADIRLI & 6,5 & 0,01 & 16164 & 167 & 78.964 \\
\hline BURDUR & \begin{tabular}{|l} 
BURDUR C. \\
\end{tabular} & 6,5 & 0,01 & 13011 & 156 & 71.611 \\
\hline MUGLA & \begin{tabular}{|l} 
FETHIYE \\
\end{tabular} & 6,5 & 0,01 & 12810 & 144 & 72.003 \\
\hline AYDIN & SOKE & 6,5 & 0,01 & 10442 & 138 & 67.234 \\
\hline MANISA & SOMA & 6,5 & 0,01 & 9885 & 133 & 74.158 \\
\hline TOKAT & TURHAL & 6,5 & 0,01 & 10797 & 125 & 64.090 \\
\hline IZMIR & TIRE & 6,5 & 0,01 & 10443 & 124 & 50.900 \\
\hline KONYA & AKSEHIR & 6,5 & 0,01 & 8790 & 121 & 61.196 \\
\hline KASTAMONU & KASTAMONU C. & 6,5 & 0,01 & 9197 & 121 & 86.085 \\
\hline MUGLA & MUĞLA C. & 6,5 & 0,01 & 8723 & 109 & 61.550 \\
\hline DIYARBAKIR & ERGANI & 6,5 & 0,01 & 10522 & 108 & 63.065 \\
\hline BILECIK & BOZUYUK & 6,5 & 0,01 & 7901 & 96 & 56.782 \\
\hline MUGLA & \begin{tabular}{|l|} 
MILAS \\
\end{tabular} & 6,5 & 0,01 & 8112 & 92 & 50.975 \\
\hline CANKIRI & ÇANKIRI C. & 6,5 & 0,01 & 7084 & 90 & 69.087 \\
\hline MUS & MUŞ C. & 6,5 & 0,01 & 6631 & 77 & 72.774 \\
\hline ADIYAMAN & KAHTA & 6,5 & 0,01 & 7031 & 74 & 61.243 \\
\hline TEKIRDAG & CERKEZKOY & 6,5 & 0,01 & 5172 & 73 & 69.875 \\
\hline BITLIS & TATVAN & 6,5 & 0,01 & 5864 & 65 & 56.996 \\
\hline KAYSERI & TALAS & 6,5 & 0,01 & 2924 & 42 & 81.566 \\
\hline
\end{tabular}

C: Central

\section{CATEGORY III - METROPOLITAN CITIES}

\begin{tabular}{|l|l|c|r|r|r|r|}
\hline $\begin{array}{l}\text { CATEGORY } \\
\text { Metropolitan } \\
\text { Cities }\end{array}$ & SUB-PROVINCE & Intensity & $\begin{array}{c}\text { Relative Loss, } \\
\text { Loss Rate }\end{array}$ & $\begin{array}{c}\text { Total } \\
\text { Building }\end{array}$ & $\begin{array}{c}\text { Absolute } \\
\text { Loss }\end{array}$ & $\begin{array}{c}\text { Settlement } \\
\text { Population } \\
\text { (2009) }\end{array}$ \\
\hline KOCAELI & KOCAELI (M.) & 8 & 0,17 & 139423 & 24077 & 1.422 .752 \\
\hline SAKARYA & SAKARYA (M.) & 8 & 0,16 & 49609 & 8070 & 442.157 \\
\hline ISTANBUL & ISTANBUL (M.) & 7,5 & 0,10 & 864540 & 83824 & 12.782 .960 \\
\hline BURSA & BURSA (M.) & 7,5 & 0,08 & 204907 & 16506 & 1.854 .285 \\
\hline IZMIR & IZMIR (M.) & 7 & 0,03 & 421397 & 14531 & 3.276 .815 \\
\hline ADANA & ADANA (M.) & 6,5 & 0,01 & 175697 & 1913 & 1.556 .238 \\
\hline ANTALYA & ANTALYA (M.) & 6,5 & 0,01 & 114998 & 1402 & 955.573 \\
\hline KONYA & KONYA (M.) & 6,5 & 0,01 & 113267 & 1355 & 1.003 .373 \\
\hline ERZURUM & ERZURUM (M.) & 6,5 & 0,01 & 32458 & 439 & 368.146 \\
\hline
\end{tabular}

M: Metropolitan 


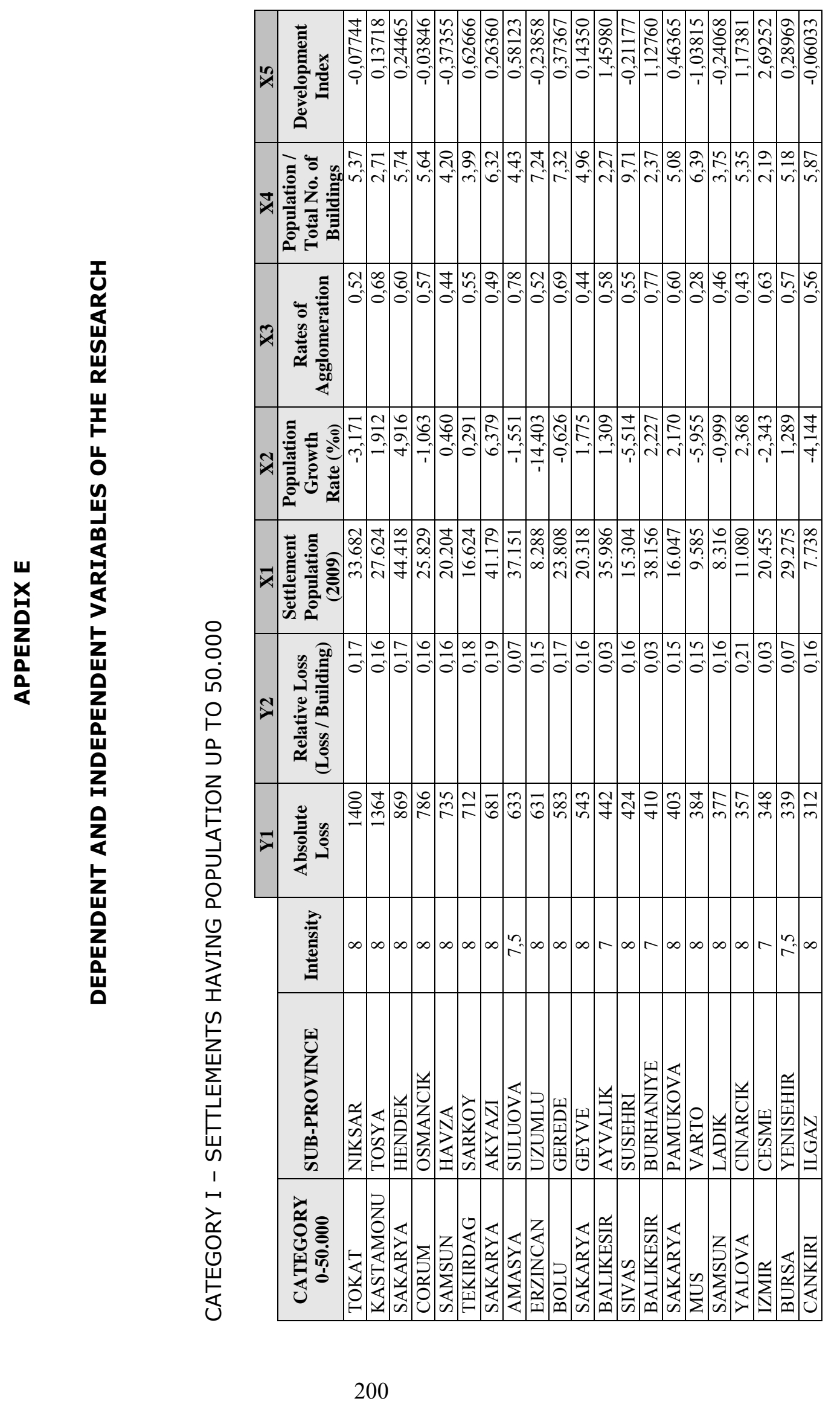




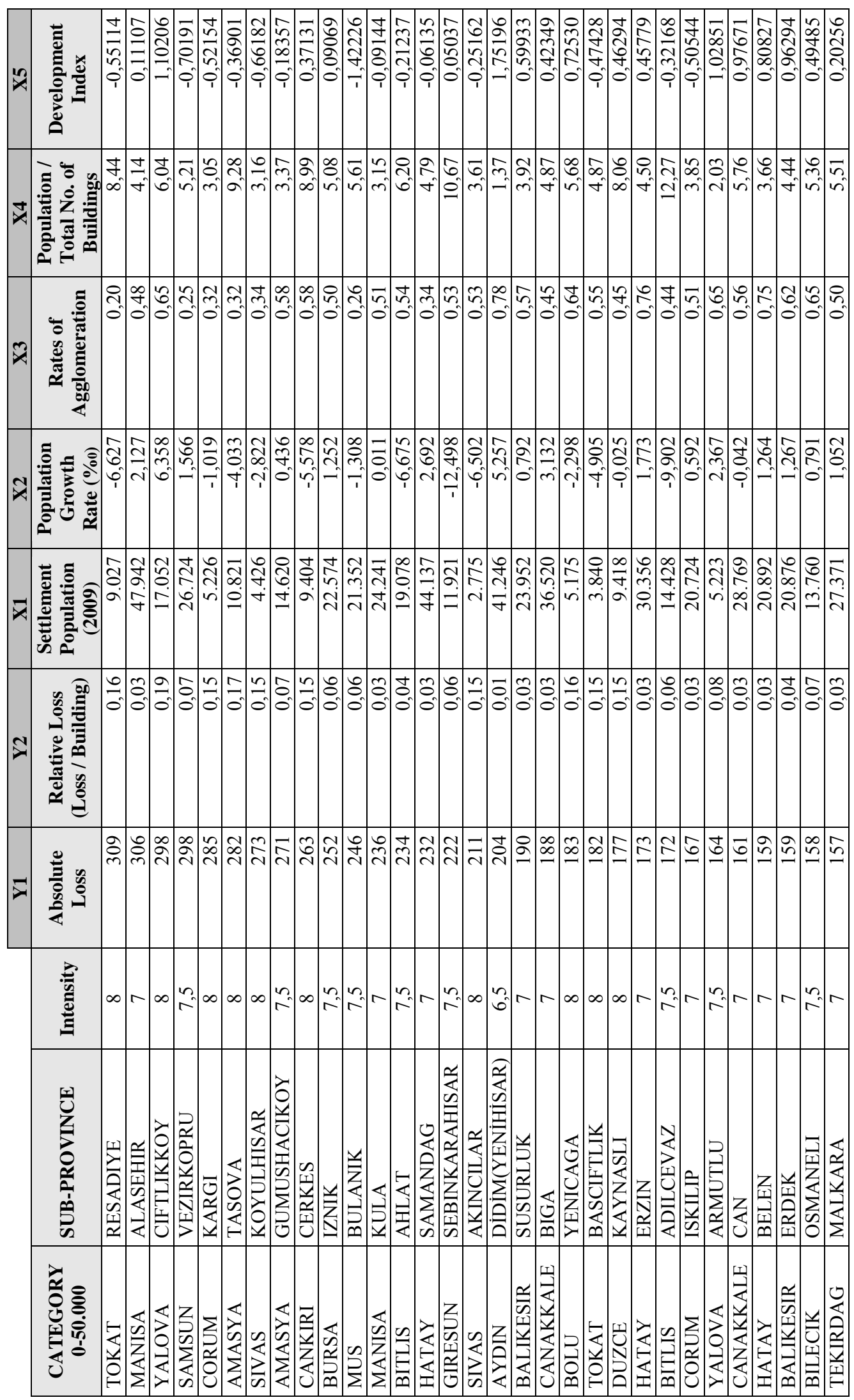




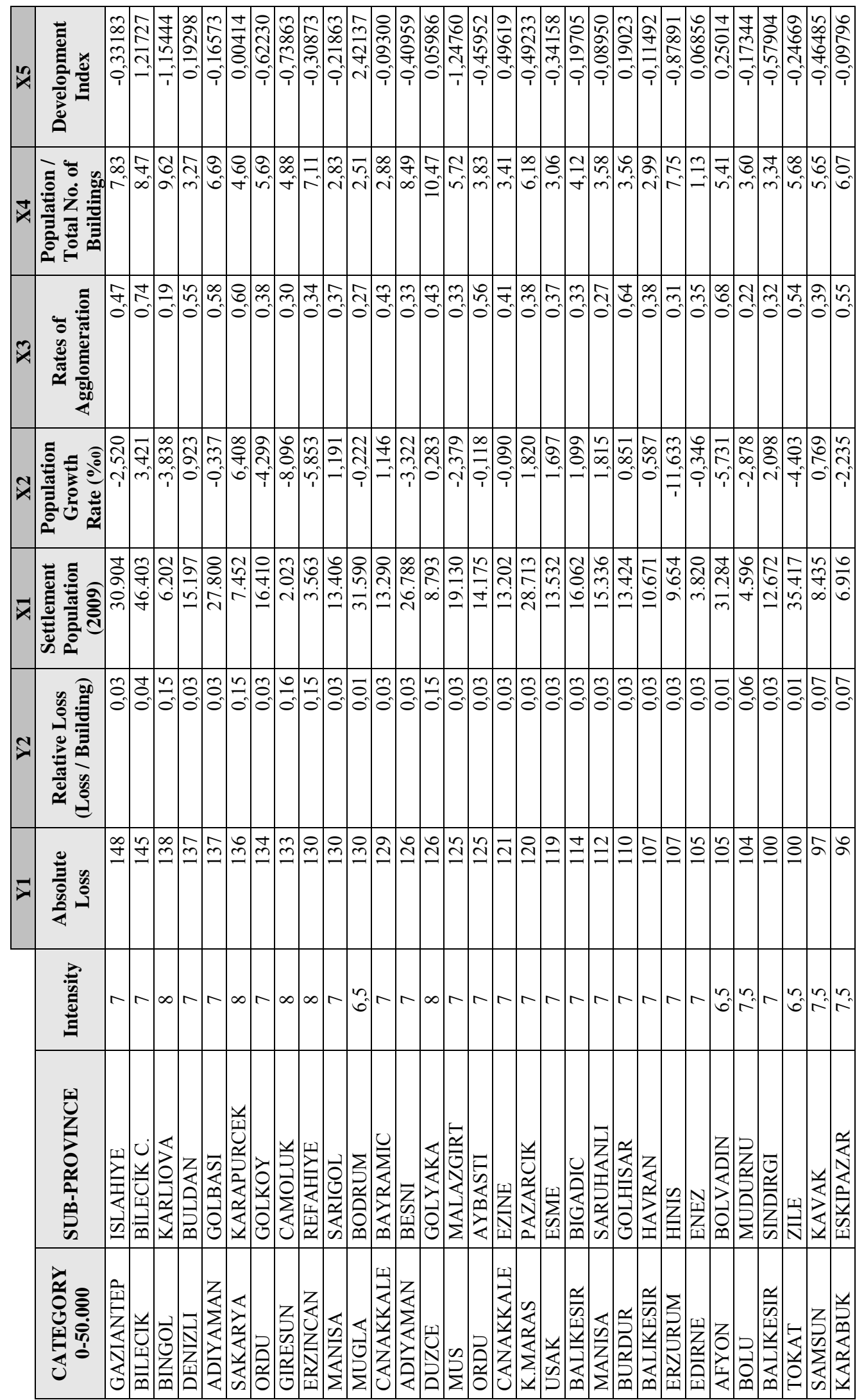




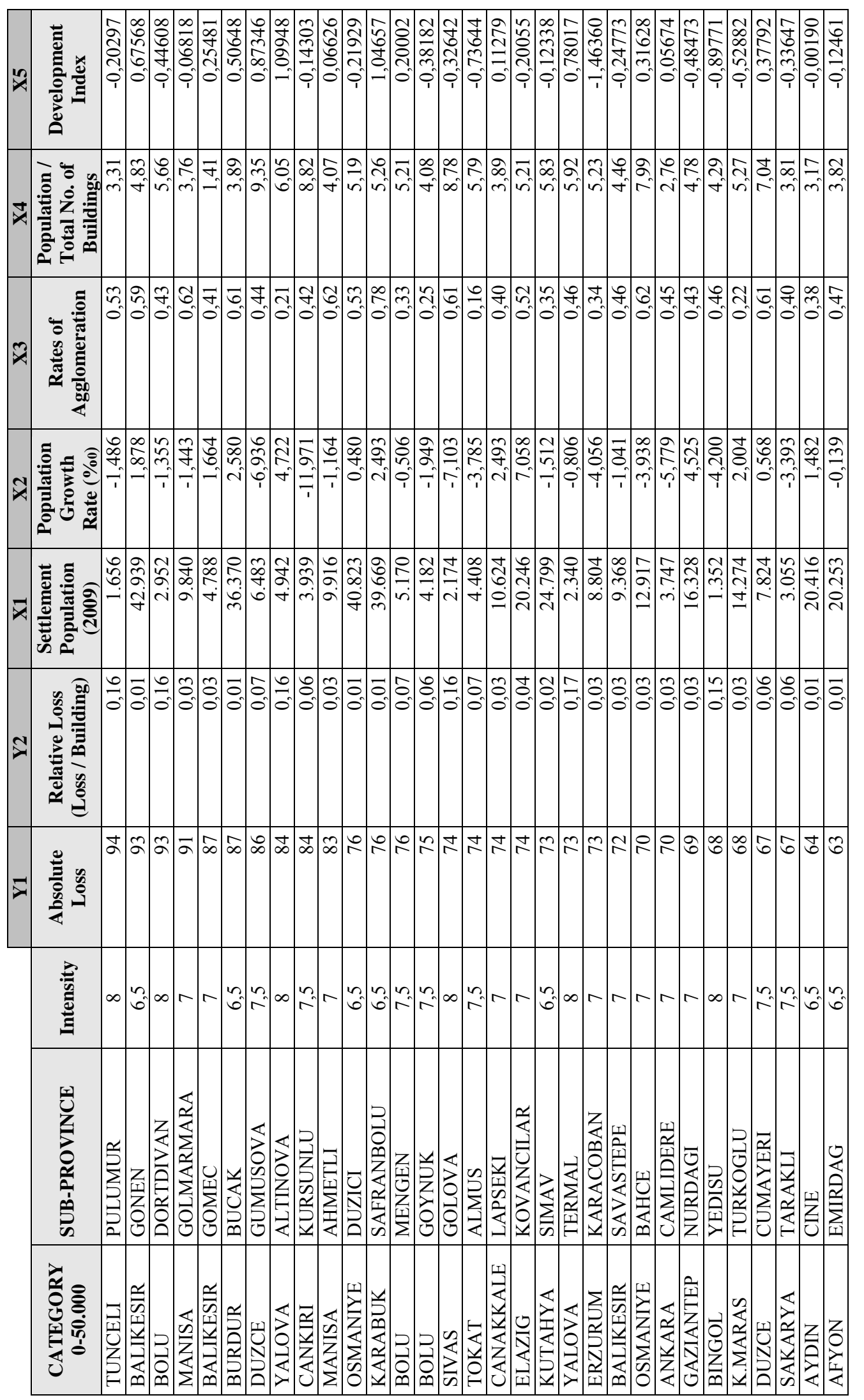




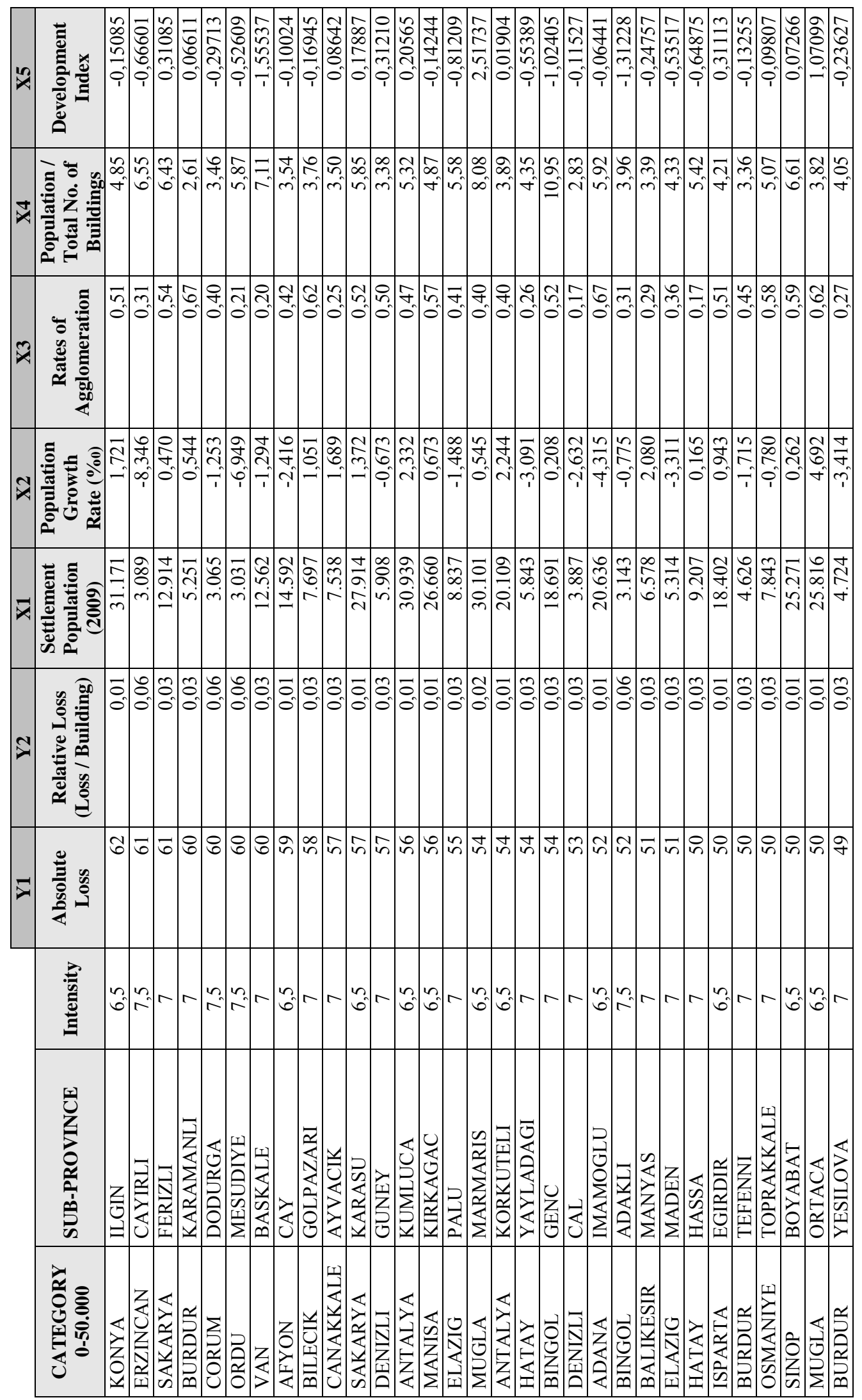




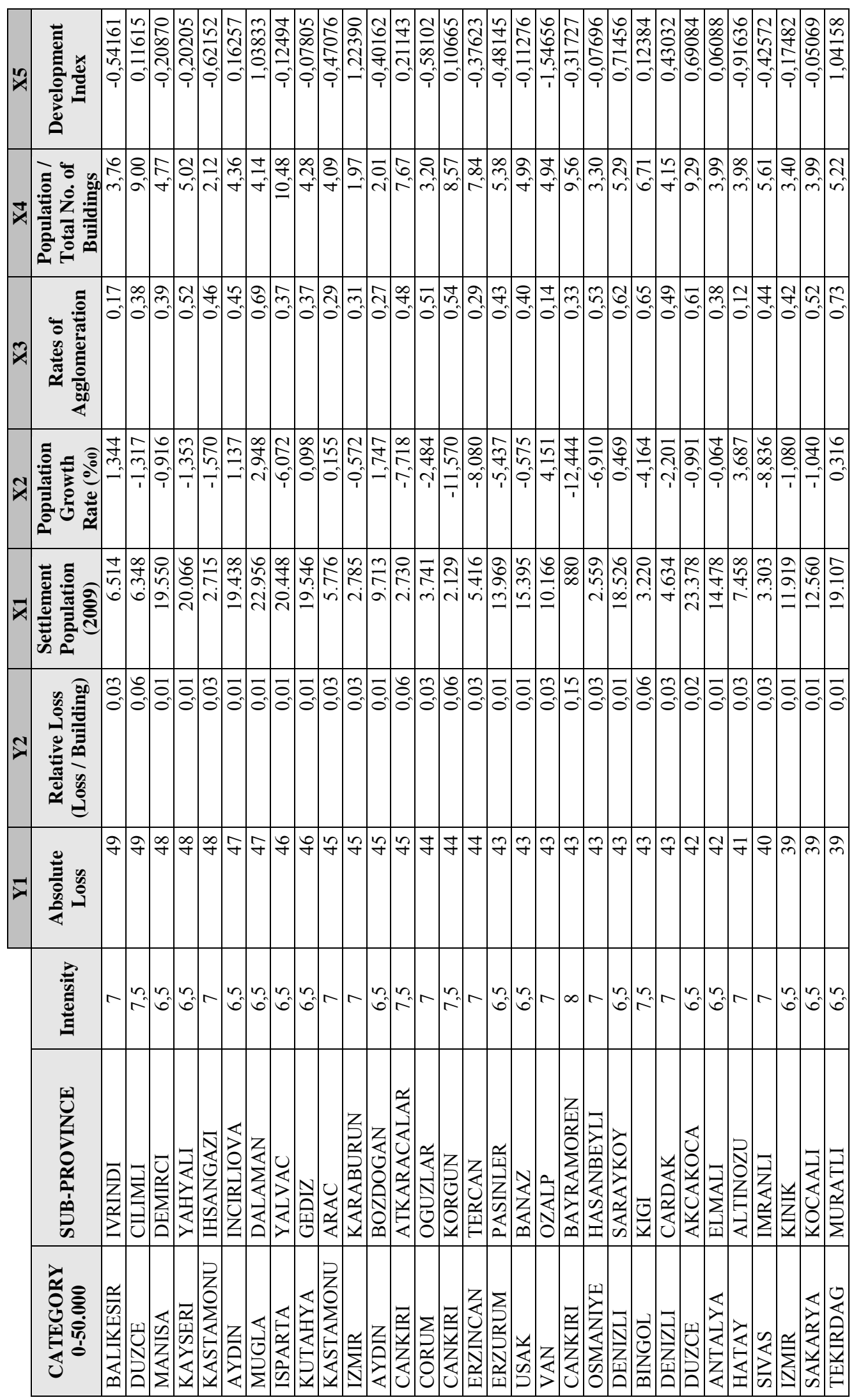




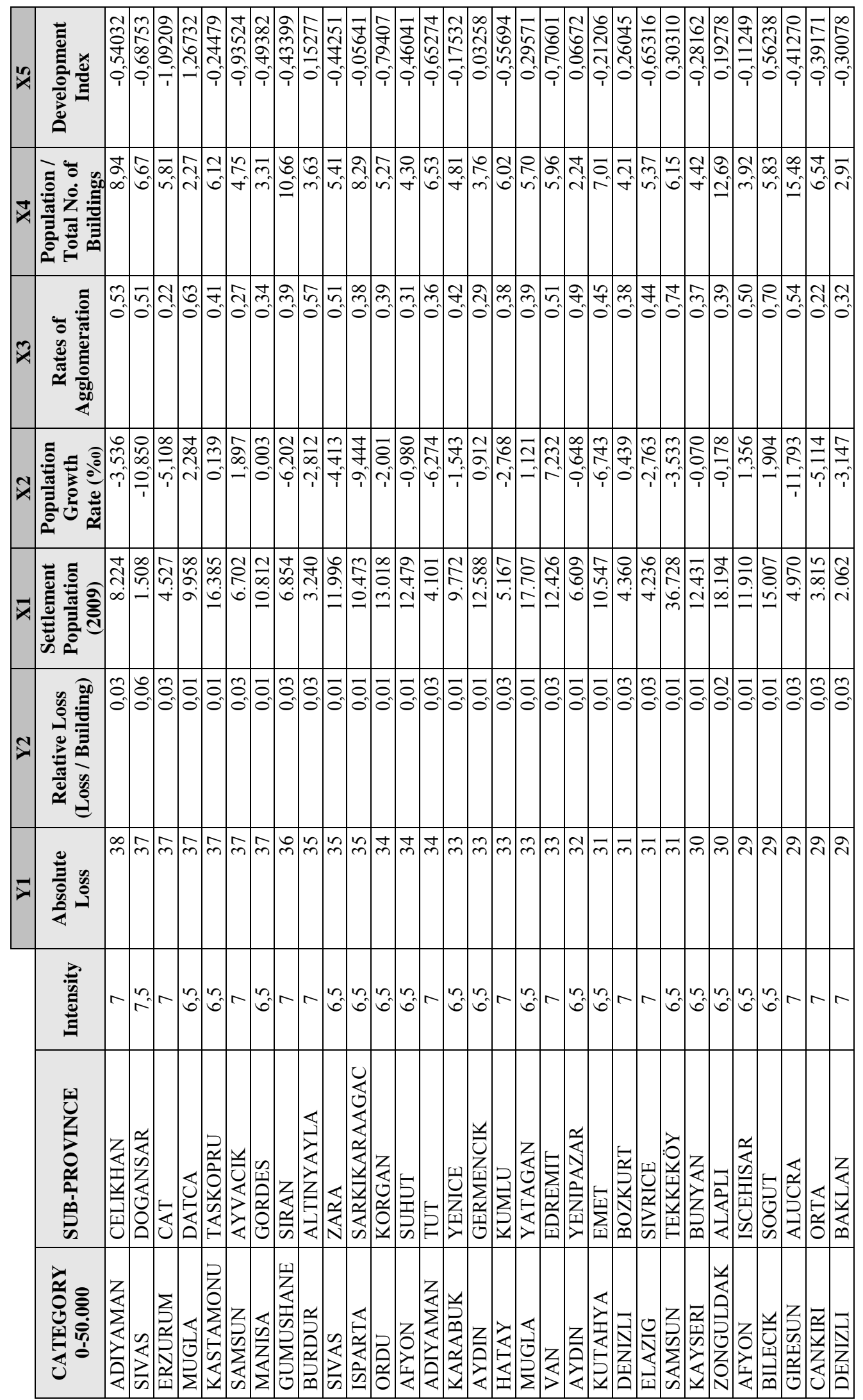




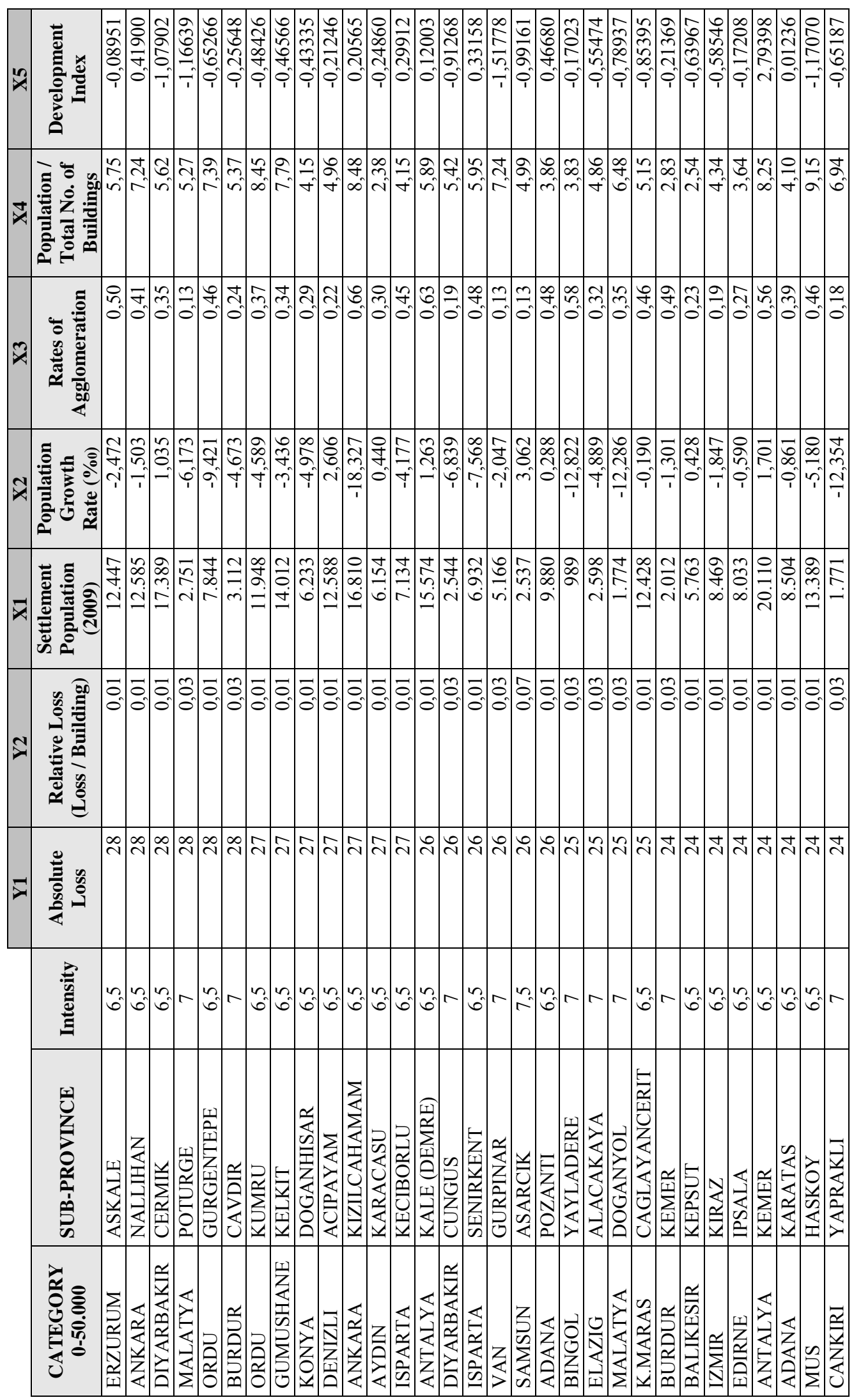




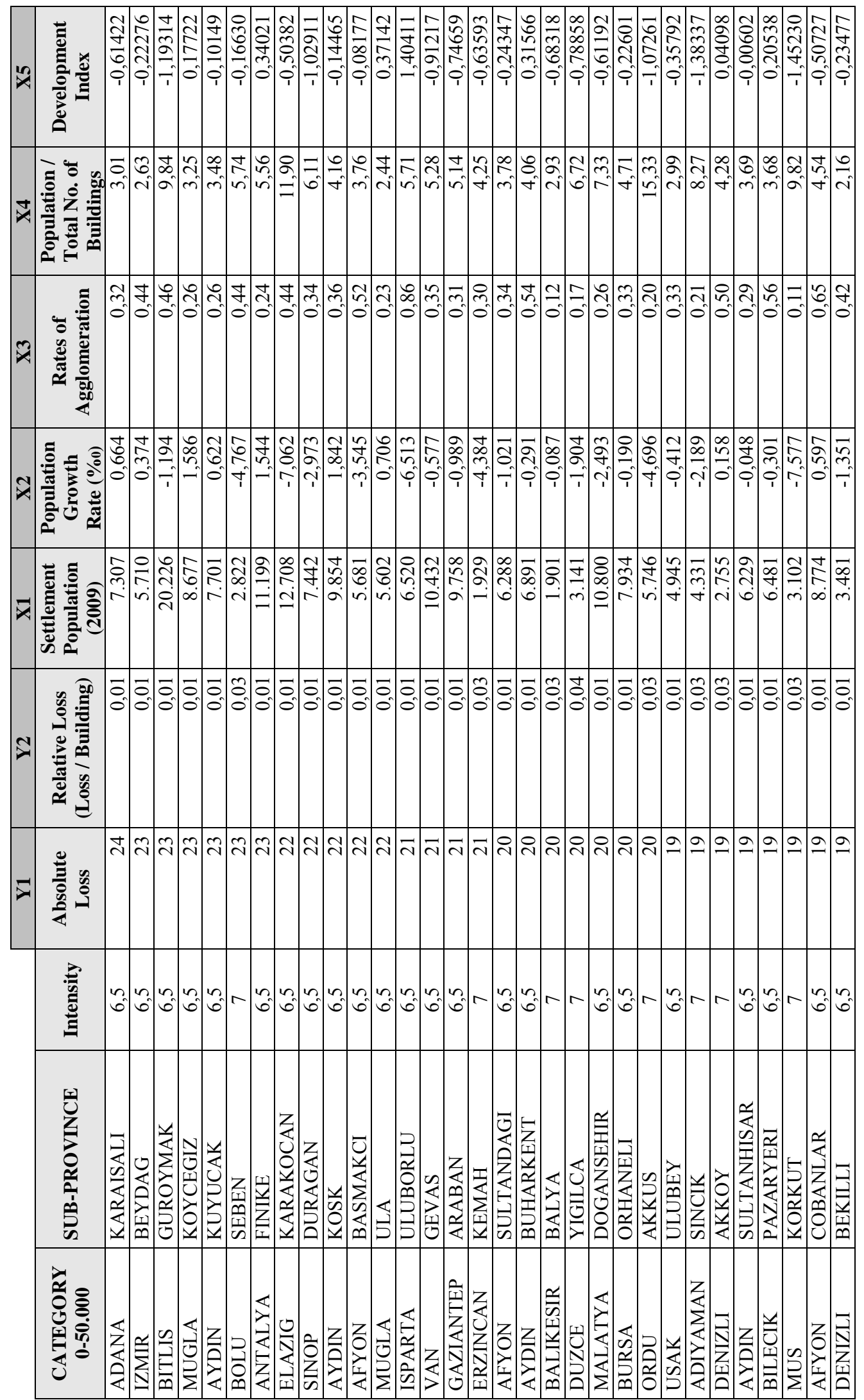




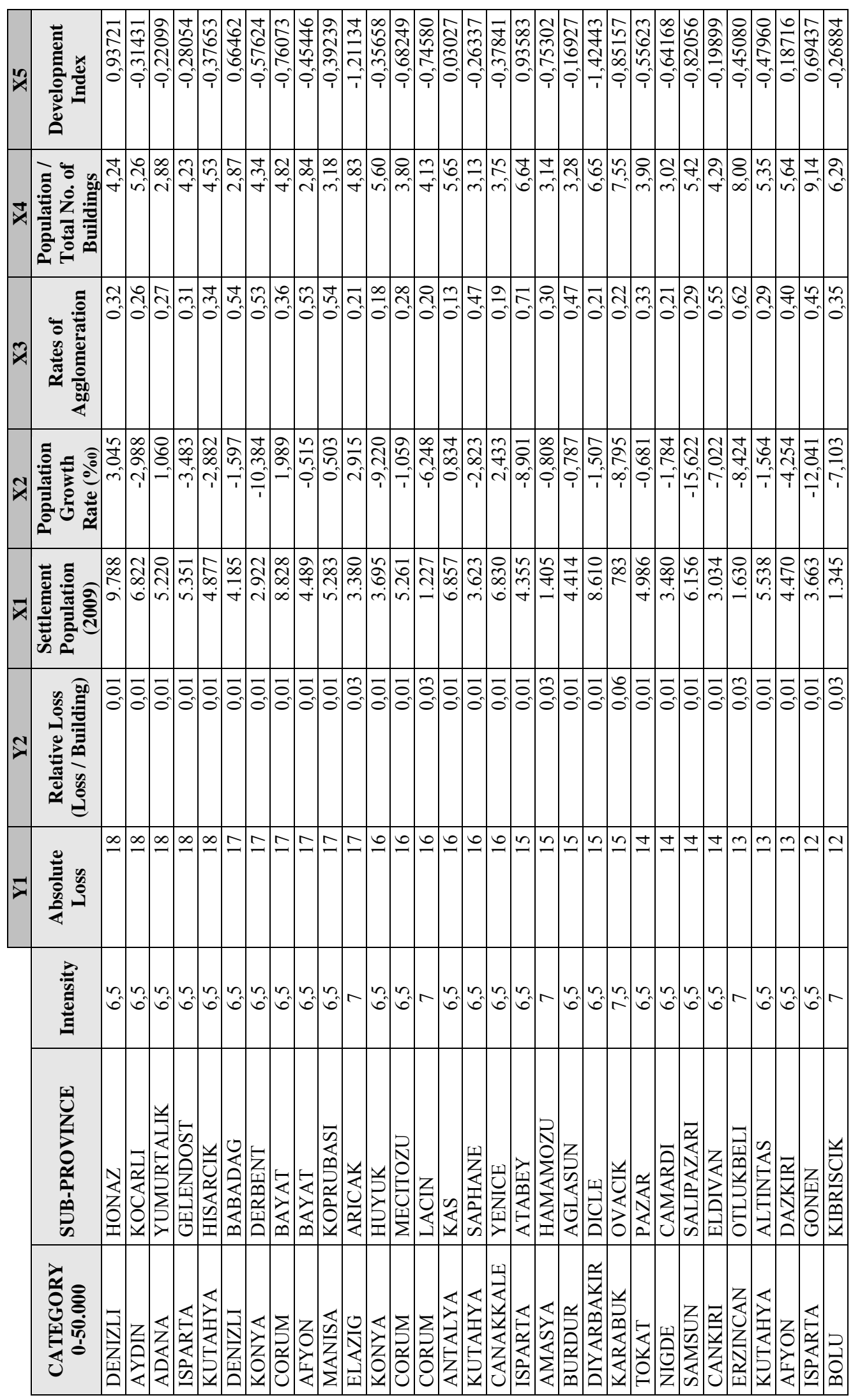




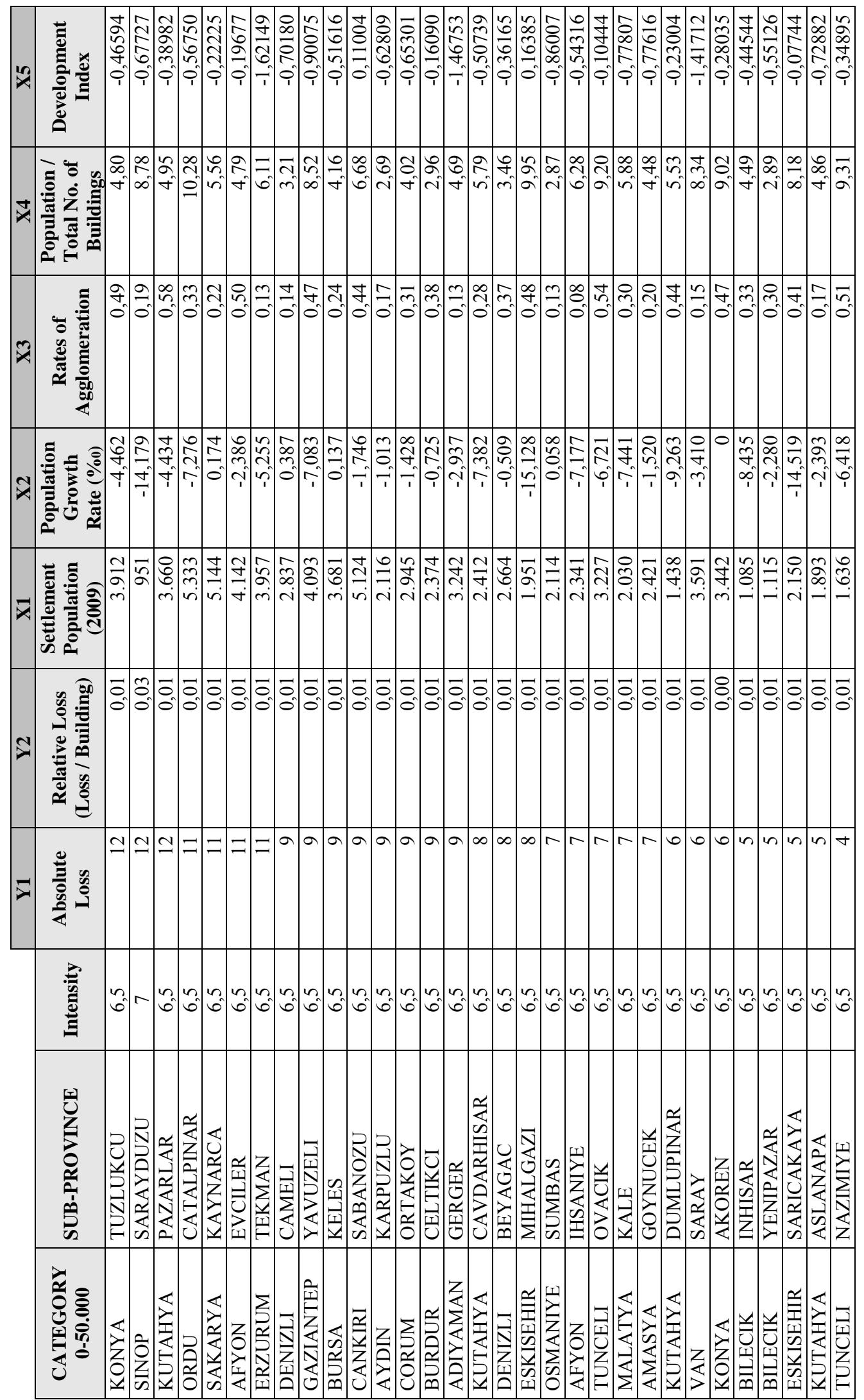



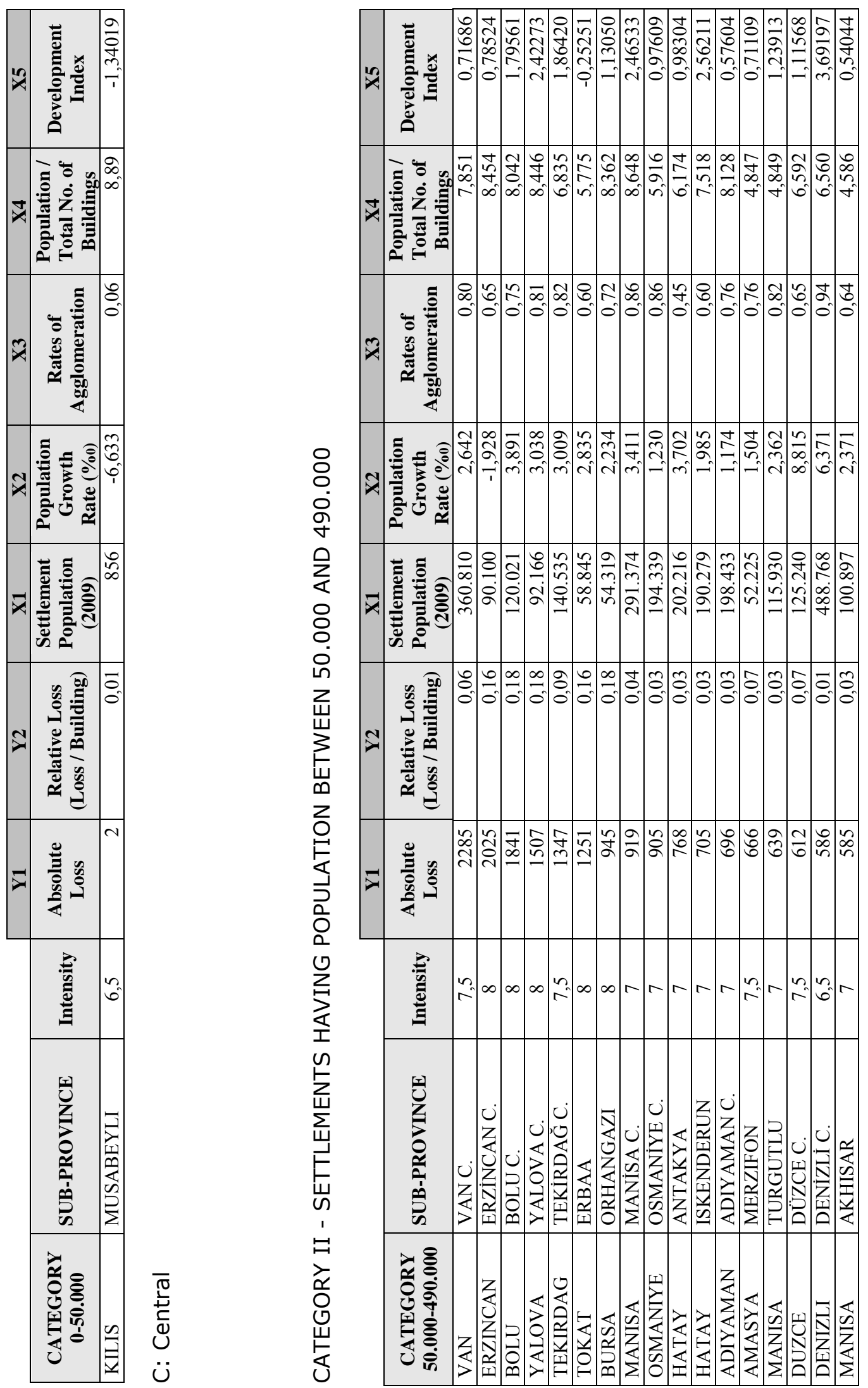


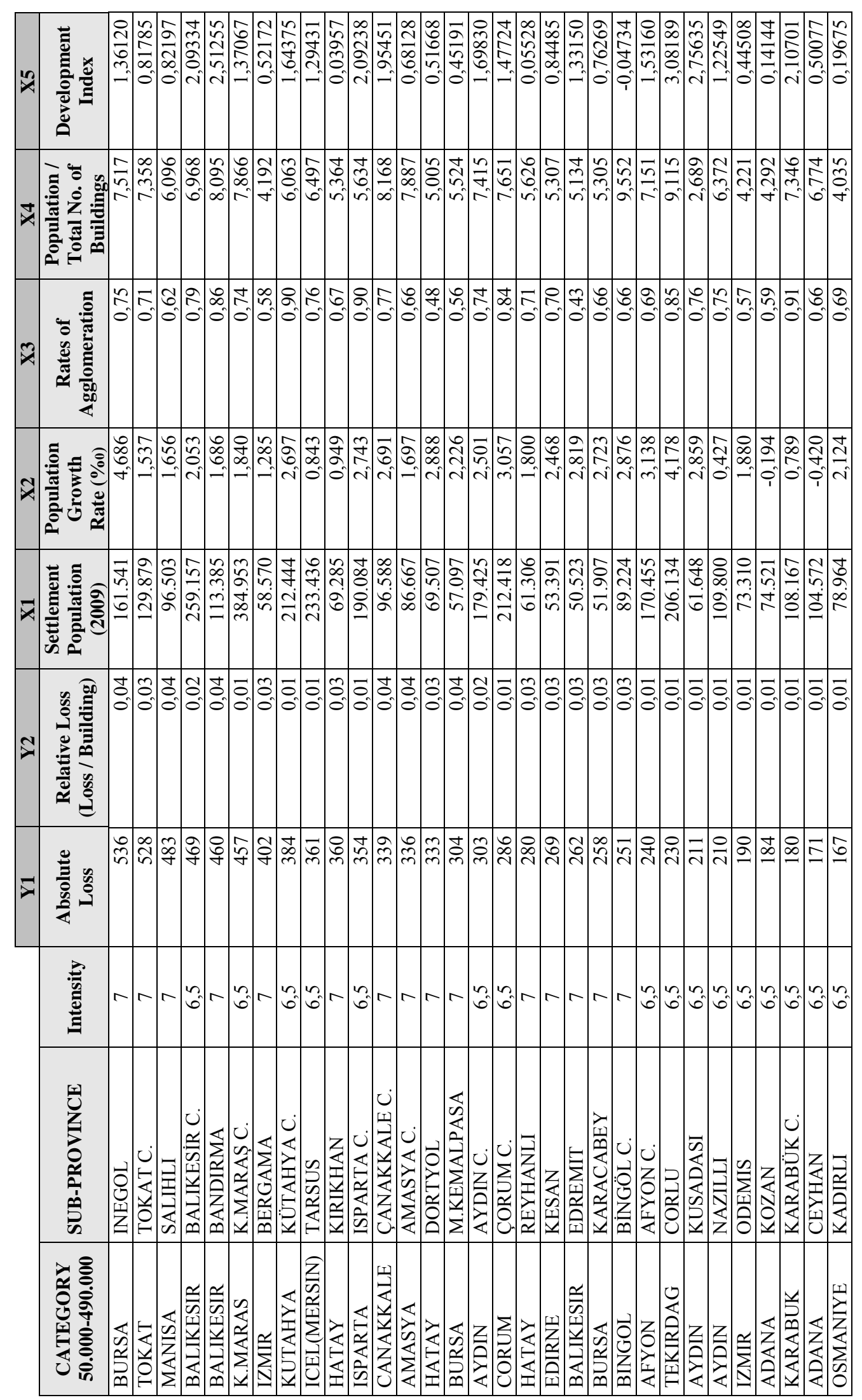




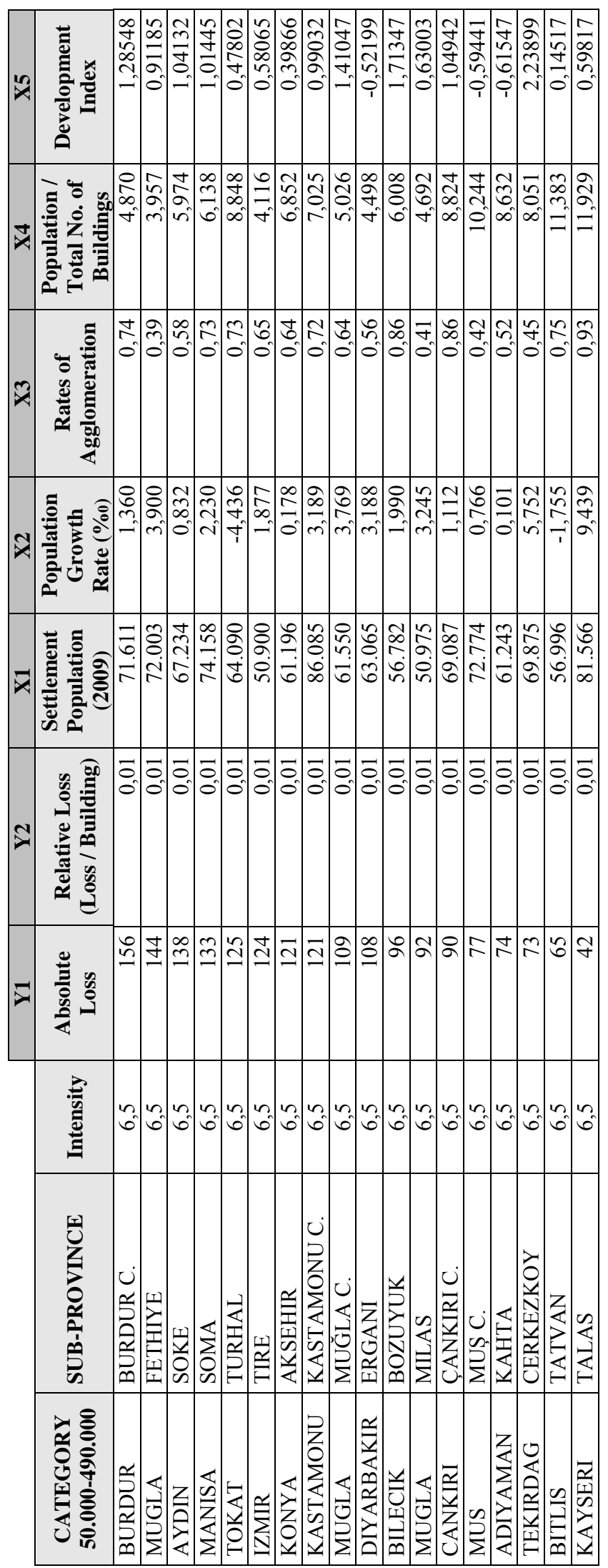

$\frac{\pi}{2}$
$\frac{1}{0}$
0
$ن$ 


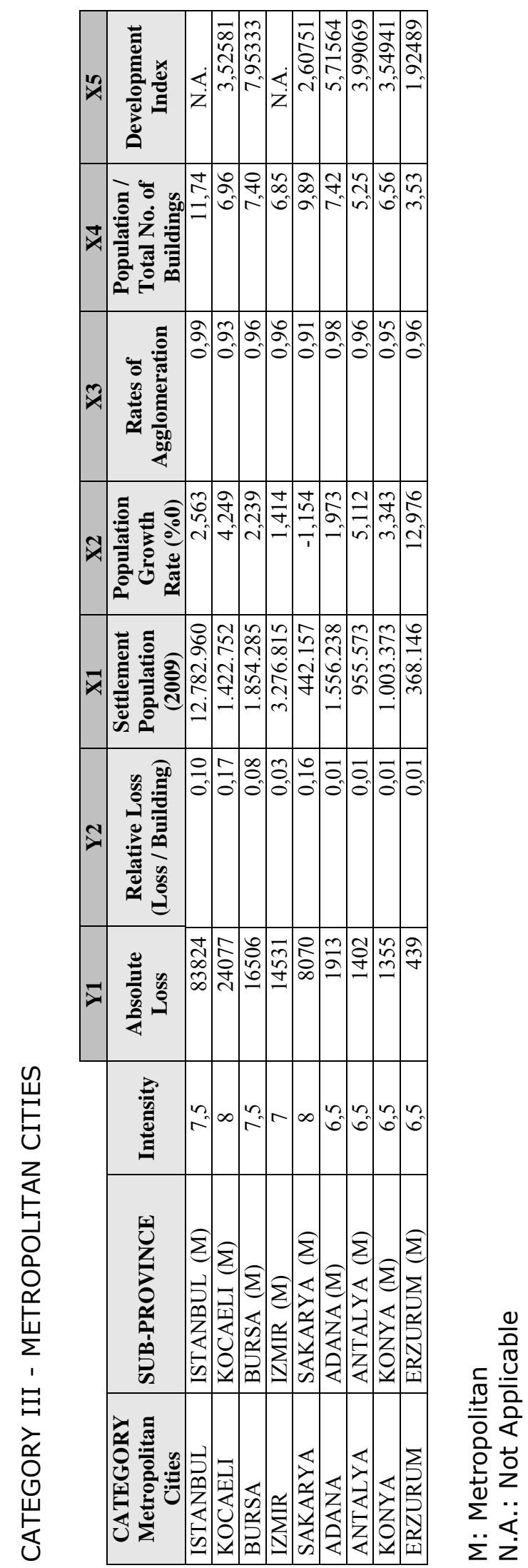


APPENDIX F

SOCIO-ECONOMIC DEVELOPMENT INDEX (SEDI) VARIABLES

\begin{tabular}{|c|c|}
\hline YEAR & VARIABLES \\
\hline & DEMOGRAPHIC INDICATORS \\
\hline 2000 & Total Population \\
\hline 2000 & Urbanization Rate \\
\hline $1990-2000$ & Annual Population Growth Rate \\
\hline 2000 & Population Density \\
\hline \multirow[t]{2}{*}{2000} & Average Household Size \\
\hline & EMPLOYMENT INDICATORS \\
\hline 2000 & Ratio of people employed in industrial sector to the total employment \\
\hline 2000 & Ratio of people employed in commercial sector to the total employment \\
\hline 2000 & Ratio of people employed in agricultural sector to the total employment \\
\hline 2000 & Ratio of people employed in financial sector to the total employment \\
\hline 2000 & Proportion of regular or casual employee \\
\hline 2000 & Proportion of regular or casual woman employee \\
\hline \multirow[t]{2}{*}{2000} & Proportion of employer \\
\hline & EDUCATION INDICATORS \\
\hline 2000 & Literacy rate \\
\hline 2000 & Woman literate rate \\
\hline \multirow[t]{2}{*}{2000} & Proportion of higher education graduate population \\
\hline & HEALTH INDICATORS \\
\hline 2000 & Infant mortality rate \\
\hline 2000 & Number of medical doctors per 10000 person \\
\hline 2000 & Number of dentists per 10000 person \\
\hline 2000 & Number of pharmacies per 10000 person \\
\hline \multirow[t]{2}{*}{2000} & Number of hospital beds per 10000 person \\
\hline & INDUSTRY INDICATORS \\
\hline 2000 & Number of plots in organized industrial estates \\
\hline 2000 & Annual average number of employees in manufacturing industry \\
\hline 2000 & Total capacity of power equipment installed at the end of year \\
\hline 2000 & Per capita value added in manufacturing industry \\
\hline \multirow[t]{2}{*}{2000} & Per capita electricity consumption in manufacturing industry \\
\hline & AGRICULTURE INDICATORS \\
\hline \multirow[t]{2}{*}{2000} & Share of agricultural production value in national production \\
\hline & FINANCIAL INDICATORS \\
\hline 2000 & Number of bank branches \\
\hline 2000 & Total exports per capita \\
\hline 2000 & Total imports per capita \\
\hline 2000 & Amount of income and corporation tax per capita \\
\hline 2000 & Total public expenditures per capita \\
\hline 2000 & Per capita gross domestic product \\
\hline \multirow[t]{2}{*}{2000} & Share in total gross domestic product \\
\hline & INFRASTRUCTURE \\
\hline 2000 & Proportion of asphalt road in rural settlements \\
\hline 2000 & Proportion of total asphalt road \\
\hline 2000 & Proportion of population in rural settlements with adequate drinking water \\
\hline
\end{tabular}


OTHER WEALTH INDICATORS

\begin{tabular}{|l|l|} 
& OTHER WEALTH INDICATORS \\
\hline 2000 & Total telephone counters per person \\
\hline 2000 & Total electricity consumption per capita \\
\hline 2000 & Number of private cars per 10000 population \\
\hline 2000 & Number of motor vehicles per 10000 population \\
\hline 2000 & Proportion of population having a card for free health services \\
\hline
\end{tabular}




\section{APPENDIX G}

\section{COMPARISON OF THE SETTLEMENTS PRIORITIZED ACCORDING TO THE ABSOLUTE LOSS WITH THE HAZARD ZONES DETERMINED BY THE OFFICIAL EARTHQUAKE HAZARD MAP}

\begin{tabular}{|c|c|c|c|c|c|}
\hline & SUB-PROVINCE & Intensity & $\begin{array}{c}\text { Absolute } \\
\text { Loss }\end{array}$ & $\begin{array}{c}\text { Hazard } \\
\text { Zone }\end{array}$ & \begin{tabular}{|c|} 
Relative Loss \\
(Loss / Building) \\
\end{tabular} \\
\hline VAN & VAN C. & 7,5 & 2285 & 2 & 0,06 \\
\hline ERZINCAN & ERZINNCAN C. & 8 & 2025 & 1 & 0,16 \\
\hline BOLU & BOLU C. & 8 & 1841 & 1 & 0,18 \\
\hline YALOVA & YALOVA C. & 8 & 1507 & 1 & 0,18 \\
\hline TOKAT & NIKSAR & 8 & 1400 & 1 & 0,17 \\
\hline KASTAMONU & TOSYA & 8 & 1364 & 1 & 0,16 \\
\hline TEKIRDAG & TEKİRDAĞ C. & 7,5 & 1347 & 2 & 0,09 \\
\hline TOKAT & ERBAA & 8 & 1251 & 1 & 0,16 \\
\hline BURSA & ORHANGAZI & 8 & 945 & 1 & 0,18 \\
\hline MANISA & MANISA C. & 7 & 919 & 1 & 0,04 \\
\hline OSMANIYE & OSMANIYE C. & 7 & 905 & 1 & 0,03 \\
\hline SAKARYA & HENDEK & 8 & 869 & 1 & 0,17 \\
\hline CORUM & OSMANCIK & 8 & 786 & 1 & 0,16 \\
\hline HATAY & ANTAKYA & 7 & 768 & 1 & 0,03 \\
\hline SAMSUN & HAVZA & 8 & 735 & 1 & 0,16 \\
\hline TEKIRDAG & SARKOY & 8 & 712 & 1 & 0,18 \\
\hline HATAY & ISKENDERUN & 7 & 705 & 1 & 0,03 \\
\hline ADIYAMAN & ADIYAMAN C. & 7 & 696 & 2 & 0,03 \\
\hline SAKARYA & AKYAZI & 8 & 681 & 1 & 0,19 \\
\hline AMASYA & MERZIFON & 7,5 & 666 & 1 & 0,07 \\
\hline MANISA & TURGUTLU & 7 & 639 & 1 & 0,03 \\
\hline AMASYA & SULUOVA & 7,5 & 633 & 1 & 0,07 \\
\hline ERZINCAN & UZUMLU & 8 & 631 & 1 & 0,15 \\
\hline DUZCE & DÜZCE C. & 7,5 & 612 & 1 & 0,07 \\
\hline DENIZLI & DENİZLİ C. & 6,5 & 586 & 1 & 0,01 \\
\hline MANISA & AKHISAR & 7 & 585 & 1 & 0,03 \\
\hline BOLU & GEREDE & 8 & 583 & 1 & 0,17 \\
\hline SAKARYA & GEYVE & 8 & 543 & 1 & 0,16 \\
\hline BURSA & INEGOL & 7 & 536 & 1 & 0,04 \\
\hline TOKAT & TOKAT C. & 7 & 528 & 1 & 0,03 \\
\hline MANISA & SALIHLI & 7 & 483 & 1 & 0,04 \\
\hline BALIKESIR & BALIKESİR C. & 6,5 & 469 & 1 & 0,02 \\
\hline BALIKESIR & BANDIRMA & 7 & 460 & 1 & 0,04 \\
\hline K.MARAS & K.MARAŞ C. & 6,5 & 457 & 1 & 0,01 \\
\hline BALIKESIR & AYVALIK & 7 & 442 & 1 & 0,03 \\
\hline SIVAS & SUSEHRI & 8 & 424 & 1 & 0,16 \\
\hline BALIKESIR & BURHANIYE & 7 & 410 & 1 & 0,03 \\
\hline SAKARYA & PAMUKOVA & 8 & 403 & 1 & 0,15 \\
\hline IZMIR & BERGAMA & 7 & 402 & 1 & 0,03 \\
\hline KUTAHYA & KÜTAHYA C. & 6,5 & 384 & 2 & 0,01 \\
\hline MUS & VARTO & 8 & 384 & 1 & 0,15 \\
\hline SAMSUN & LADIK & 8 & 377 & 1 & 0,16 \\
\hline ICEL(MERSIN) & TARSUS & 6,5 & 361 & 3 & 0,01 \\
\hline HATAY & KIRIKHAN & 7 & 360 & 1 & 0,03 \\
\hline YALOVA & CINARCIK & 8 & 357 & 1 & 0,21 \\
\hline ISPARTA & ISPARTA C. & 6,5 & 354 & 1 & 0,01 \\
\hline
\end{tabular}




\begin{tabular}{|c|c|c|c|c|c|}
\hline & SUB-PROVINCE & Intensity & $\begin{array}{c}\text { Absolute } \\
\text { Loss }\end{array}$ & $\begin{array}{c}\text { Hazard } \\
\text { Zone }\end{array}$ & $\begin{array}{c}\text { Relative Loss } \\
\text { (Loss / Building) }\end{array}$ \\
\hline IZMIR & CESME & 7 & 348 & 1 & 0,03 \\
\hline BURSA & YENISEHIR & 7,5 & 339 & 1 & 0,07 \\
\hline CANAKKALE & ÇANAKKALE C. & 7 & 339 & 1 & 0,04 \\
\hline AMASYA & AMASYA C. & 7 & 336 & 1 & 0,04 \\
\hline HATAY & DORTYOL & 7 & 333 & 1 & 0,03 \\
\hline CANKIRI & ILGAZ & 8 & 312 & 1 & 0,16 \\
\hline TOKAT & RESADIYE & 8 & 309 & 1 & 0,16 \\
\hline MANISA & ALASEHIR & 7 & 306 & 1 & 0,03 \\
\hline BURSA & M.KEMALPASA & 7 & 304 & 1 & 0,04 \\
\hline AYDIN & AYDIN C. & 6,5 & 303 & 1 & 0,02 \\
\hline SAMSUN & VEZIRKOPRU & 7,5 & 298 & 1 & 0,07 \\
\hline YALOVA & CIFTLIKKOY & 8 & 298 & 1 & 0,19 \\
\hline CORUM & ÇORUM C. & 6,5 & 286 & 2 & 0,01 \\
\hline CORUM & KARGI & 8 & 285 & 1 & 0,15 \\
\hline AMASYA & TASOVA & 8 & 282 & 1 & 0,17 \\
\hline HATAY & REYHANLI & 7 & 280 & 1 & 0,03 \\
\hline SIVAS & KOYULHISAR & 8 & 273 & 1 & 0,15 \\
\hline AMASYA & GUMUSHACIKOY & 7,5 & 271 & 1 & 0,07 \\
\hline EDIRNE & KESAN & 7 & 269 & 2 & 0,03 \\
\hline CANKIRI & CERKES & 8 & 263 & 1 & 0,15 \\
\hline BALIKESIR & EDREMIT & 7 & 262 & 1 & 0,03 \\
\hline BURSA & KARACABEY & 7 & 258 & 1 & 0,03 \\
\hline BURSA & IZNIK & 7,5 & 252 & 1 & 0,06 \\
\hline BINGOL & BİNGÖL C. & 7 & 251 & 1 & 0,03 \\
\hline MUS & BULANIK & 7,5 & 246 & 1 & 0,06 \\
\hline AFYON & AFYON C. & 6,5 & 240 & 2 & 0,01 \\
\hline MANISA & KULA & 7 & 236 & 1 & 0,03 \\
\hline BITLIS & AHLAT & 7,5 & 234 & 1 & 0,04 \\
\hline HATAY & SAMANDAG & 7 & 232 & 1 & 0,03 \\
\hline TEKIRDAG & CORLU & 6,5 & 230 & 3 & 0,01 \\
\hline GIRESUN & SEBINKARAHISAR & 7,5 & 222 & 1 & 0,06 \\
\hline AYDIN & KUSADASI & 6,5 & 211 & 1 & 0,01 \\
\hline SIVAS & AKINCILAR & 8 & 211 & 1 & 0,15 \\
\hline AYDIN & NAZILLI & 6,5 & 210 & 1 & 0,01 \\
\hline AYDIN & DİDİM(YENİHİSAR) & 6,5 & 204 & 1 & 0,01 \\
\hline BALIKESIR & SUSURLUK & 7 & 190 & 1 & 0,03 \\
\hline IZMIR & ODEMIS & 6,5 & 190 & 1 & 0,01 \\
\hline CANAKKALE & BIGA & 7 & 188 & 1 & 0,03 \\
\hline ADANA & KOZAN & 6,5 & 184 & 3 & 0,01 \\
\hline BOLU & YENICAGA & 8 & 183 & 1 & 0,16 \\
\hline TOKAT & BASCIFTLIK & 8 & 182 & 1 & 0,15 \\
\hline KARABUK & KARABÜK C. & 6,5 & 180 & 1 & 0,01 \\
\hline DUZCE & KAYNASLI & 8 & 177 & 1 & 0,15 \\
\hline HATAY & ERZIN & 7 & 173 & 1 & 0,03 \\
\hline BITLIS & ADILCEVAZ & 7,5 & 172 & 1 & 0,06 \\
\hline ADANA & CEYHAN & 6,5 & 171 & 2 & 0,01 \\
\hline CORUM & ISKILIP & 7 & 167 & 1 & 0,03 \\
\hline OSMANIYE & KADIRLI & 6,5 & 167 & 2 & 0,01 \\
\hline YALOVA & ARMUTLU & 7,5 & 164 & 1 & 0,08 \\
\hline CANAKKALE & CAN & 7 & 161 & 1 & 0,03 \\
\hline BALIKESIR & ERDEK & 7 & 159 & 1 & 0,04 \\
\hline HATAY & BELEN & 7 & 159 & 1 & 0,03 \\
\hline BILECIK & OSMANELI & 7,5 & 158 & 1 & 0,07 \\
\hline TEKIRDAG & MALKARA & 7 & 157 & 2 & 0,03 \\
\hline BURDUR & BURDUR C. & 6,5 & 156 & 1 & 0,01 \\
\hline GAZIANTEP & ISLAHIYE & 7 & 148 & 1 & 0,03 \\
\hline BILECIK & BİLECİK C. & 7 & 145 & 1 & 0,04 \\
\hline
\end{tabular}




\begin{tabular}{|c|c|c|c|c|c|}
\hline & SUB-PROVINCE & Intensity & $\begin{array}{c}\text { Absolute } \\
\text { Loss }\end{array}$ & $\begin{array}{c}\text { Hazard } \\
\text { Zone }\end{array}$ & $\begin{array}{c}\text { Relative Loss } \\
\text { (Loss / Building) }\end{array}$ \\
\hline MUGLA & FETHIYE & 6,5 & 144 & 1 & 0,01 \\
\hline AYDIN & SOKE & 6,5 & 138 & 1 & 0,01 \\
\hline BINGOL & KARLIOVA & 8 & 138 & 1 & 0,15 \\
\hline ADIYAMAN & GOLBASI & 7 & 137 & 1 & 0,03 \\
\hline DENIZLI & BULDAN & 7 & 137 & 1 & 0,03 \\
\hline SAKARYA & KARAPURCEK & 8 & 136 & 1 & 0,15 \\
\hline ORDU & GOLKOY & 7 & 134 & 1 & 0,03 \\
\hline GIRESUN & CAMOLUK & 8 & 133 & 1 & 0,16 \\
\hline MANISA & SOMA & 6,5 & 133 & 1 & 0,01 \\
\hline ERZINCAN & REFAHIYE & 8 & 130 & 1 & 0,15 \\
\hline MANISA & SARIGOL & 7 & 130 & 1 & 0,03 \\
\hline MUGLA & BODRUM & 6,5 & 130 & 1 & 0,01 \\
\hline CANAKKALE & BAYRAMIC & 7 & 129 & 1 & 0,03 \\
\hline ADIYAMAN & BESNI & 7 & 126 & 2 & 0,03 \\
\hline DUZCE & GOLYAKA & 8 & 126 & 1 & 0,15 \\
\hline MUS & MALAZGIRT & 7 & 125 & 1 & 0,03 \\
\hline ORDU & AYBASTI & 7 & 125 & 1 & 0,03 \\
\hline TOKAT & TURHAL & 6,5 & 125 & 1 & 0,01 \\
\hline IZMIR & TIRE & 6,5 & 124 & 1 & 0,01 \\
\hline CANAKKALE & EZINE & 7 & 121 & 1 & 0,03 \\
\hline KASTAMONU & KASTAMONU C. & 6,5 & 121 & 1 & 0,01 \\
\hline KONYA & AKSEHIR & 6,5 & 121 & 1 & 0,01 \\
\hline K.MARAS & PAZARCIK & 7 & 120 & 1 & 0,03 \\
\hline USAK & ESME & 7 & 119 & 1 & 0,03 \\
\hline BALIKESIR & BIGADIC & 7 & 114 & 1 & 0,03 \\
\hline MANISA & SARUHANLI & 7 & 112 & 1 & 0,03 \\
\hline BURDUR & GOLHISAR & 7 & 110 & 1 & 0,03 \\
\hline MUGLA & MUĞLA C. & 6,5 & 109 & 1 & 0,01 \\
\hline DIYARBAKIR & ERGANI & 6,5 & 108 & 1 & 0,01 \\
\hline BALIKESIR & HAVRAN & 7 & 107 & 1 & 0,03 \\
\hline ERZURUM & HINIS & 7 & 107 & 1 & 0,03 \\
\hline AFYON & \begin{tabular}{|l|} 
BOLVADIN \\
\end{tabular} & 6,5 & 105 & 1 & 0,01 \\
\hline EDIRNE & ENEZ & 7 & 105 & 2 & 0,03 \\
\hline BOLU & MUDURNU & 7,5 & 104 & 1 & 0,06 \\
\hline BALIKESIR & SINDIRGI & 7 & 100 & 1 & 0,03 \\
\hline TOKAT & ZILE & 6,5 & 100 & 1 & 0,01 \\
\hline SAMSUN & \begin{tabular}{|l|} 
KAVAK \\
\end{tabular} & 7,5 & 97 & 1 & 0,07 \\
\hline BILECIK & BOZUYUK & 6,5 & 96 & 2 & 0,01 \\
\hline KARABUK & ESKIPAZAR & 7,5 & 96 & 1 & 0,07 \\
\hline TUNCELI & PULUMUR & 8 & 94 & 1 & 0,16 \\
\hline BALIKESIR & GONEN & 6,5 & 93 & 1 & 0,01 \\
\hline BOLU & DORTDIVAN & 8 & 93 & 1 & 0,16 \\
\hline MUGLA & MILAS & 6,5 & 92 & 1 & 0,01 \\
\hline MANISA & GOLMARMARA & 7 & 91 & 1 & 0,03 \\
\hline CANKIRI & ÇANKIRI C. & 6,5 & 90 & 1 & 0,01 \\
\hline BALIKESIR & GOMEC & 7 & 87 & 1 & 0,03 \\
\hline BURDUR & BUCAK & 6,5 & 87 & 1 & 0,01 \\
\hline DUZCE & GUMUSOVA & 7,5 & 86 & 1 & 0,07 \\
\hline CANKIRI & KURSUNLU & 7,5 & 84 & 1 & 0,06 \\
\hline YALOVA & \begin{tabular}{|l|} 
ALTINOVA \\
\end{tabular} & 8 & 84 & 1 & 0,16 \\
\hline MANISA & AHMETLI & 7 & 83 & 1 & 0,03 \\
\hline MUS & MUŞ C. & 6,5 & 77 & 1 & 0,01 \\
\hline BOLU & MENGEN & 7,5 & 76 & 1 & 0,07 \\
\hline KARABUK & SAFRANBOLU & 6,5 & 76 & 1 & 0,01 \\
\hline OSMANIYE & DUZICI & 6,5 & 76 & 1 & 0,01 \\
\hline BOLU & GOYNUK & 7,5 & 75 & 1 & 0,06 \\
\hline ADIYAMAN & KAHTA & 6,5 & 74 & 2 & 0,01 \\
\hline
\end{tabular}




\begin{tabular}{|c|c|c|c|c|c|}
\hline & SUB-PROVINCE & Intensity & $\begin{array}{c}\text { Absolute } \\
\text { Loss }\end{array}$ & $\begin{array}{c}\text { Hazard } \\
\text { Zone }\end{array}$ & $\begin{array}{c}\text { Relative Loss } \\
\text { (Loss / Building) }\end{array}$ \\
\hline CANAKKALE & \begin{tabular}{|l|} 
LAPSEKI \\
\end{tabular} & 7 & 74 & 1 & 0,03 \\
\hline ELAZIG & KOVANCILAR & 7 & 74 & 1 & 0,04 \\
\hline SIVAS & GOLOVA & 8 & 74 & 1 & 0,16 \\
\hline TOKAT & ALMUS & 7,5 & 74 & 1 & 0,07 \\
\hline ERZURUM & KARACOBAN & 7 & 73 & 1 & 0,03 \\
\hline KUTAHYA & SIMAV & 6,5 & 73 & 1 & 0,02 \\
\hline TEKIRDAG & CERKEZKOY & 6,5 & 73 & 3 & 0,01 \\
\hline YALOVA & TERMAL & 8 & 73 & 1 & 0,17 \\
\hline BALIKESIR & SAVASTEPE & 7 & 72 & 1 & 0,03 \\
\hline ANKARA & CAMLIDERE & 7 & 70 & 1 & 0,03 \\
\hline OSMANIYE & BAHCE & 7 & 70 & 1 & 0,03 \\
\hline GAZIANTEP & NURDAGI & 7 & 69 & 1 & 0,03 \\
\hline BINGOL & YEDISU & 8 & 68 & 1 & 0,15 \\
\hline K.MARAS & TURKOGLU & 7 & 68 & 1 & 0,03 \\
\hline DUZCE & CUMAYERI & 7,5 & 67 & 1 & 0,06 \\
\hline SAKARYA & TARAKLI & 7,5 & 67 & 1 & 0,06 \\
\hline BITLIS & TATVAN & 6,5 & 65 & 2 & 0,01 \\
\hline AYDIN & CINE & 6,5 & 64 & 1 & 0,01 \\
\hline AFYON & EMIRDAG & 6,5 & 63 & 2 & 0,01 \\
\hline KONYA & ILGIN & 6,5 & 62 & 1 & 0,01 \\
\hline ERZINCAN & CAYIRLI & 7,5 & 61 & 1 & 0,06 \\
\hline SAKARYA & FERIZLI & 7 & 61 & 1 & 0,03 \\
\hline BURDUR & KARAMANLI & 7 & 60 & 1 & 0,03 \\
\hline CORUM & DODURGA & 7,5 & 60 & 1 & 0,06 \\
\hline ORDU & MESUDIYE & 7,5 & 60 & 1 & 0,06 \\
\hline VAN & BASKALE & 7 & 60 & 2 & 0,03 \\
\hline AFYON & CAY & 6,5 & 59 & 1 & 0,01 \\
\hline BILECIK & GOLPAZARI & 7 & 58 & 1 & 0,03 \\
\hline CANAKKALE & AYVACIK & 7 & 57 & 1 & 0,03 \\
\hline DENIZLI & GUNEY & 7 & 57 & 1 & 0,03 \\
\hline SAKARYA & KARASU & 6,5 & 57 & 1 & 0,01 \\
\hline ANTALYA & KUMLUCA & 6,5 & 56 & 1 & 0,01 \\
\hline MANISA & KIRKAGAC & 6,5 & 56 & 1 & 0,01 \\
\hline ELAZIG & PALU & 7 & 55 & 1 & 0,03 \\
\hline ANTALYA & KORKUTELI & 6,5 & 54 & 2 & 0,01 \\
\hline BINGOL & GENC & 7 & 54 & 1 & 0,03 \\
\hline HATAY & YAYLADAGI & 7 & 54 & 1 & 0,03 \\
\hline MUGLA & MARMARIS & 6,5 & 54 & 1 & 0,02 \\
\hline DENIZLI & CAL & 7 & 53 & 1 & 0,03 \\
\hline ADANA & IMAMOGLU & 6,5 & 52 & 3 & 0,01 \\
\hline BINGOL & ADAKLI & 7,5 & 52 & 1 & 0,06 \\
\hline BALIKESIR & MANYAS & 7 & 51 & 1 & 0,03 \\
\hline ELAZIG & MADEN & 7 & 51 & 1 & 0,03 \\
\hline BURDUR & TEFENNI & 7 & 50 & 1 & 0,03 \\
\hline HATAY & HASSA & 7 & 50 & 1 & 0,03 \\
\hline ISPARTA & EGIRDIR & 6,5 & 50 & 1 & 0,01 \\
\hline MUGLA & ORTACA & 6,5 & 50 & 1 & 0,01 \\
\hline OSMANIYE & TOPRAKKALE & 7 & 50 & 1 & 0,03 \\
\hline SINOP & BOYABAT & 6,5 & 50 & 1 & 0,01 \\
\hline BALIKESIR & \begin{tabular}{|l|} 
IVRINDI \\
\end{tabular} & 7 & 49 & 1 & 0,03 \\
\hline BURDUR & YESILOVA & 7 & 49 & 1 & 0,03 \\
\hline DUZCE & CILIMLI & 7,5 & 49 & 1 & 0,06 \\
\hline KASTAMONU & IHSANGAZI & 7 & 48 & 1 & 0,03 \\
\hline KAYSERI & YAHYALI & 6,5 & 48 & 3 & 0,01 \\
\hline MANISA & DEMIRCI & 6,5 & 48 & 1 & 0,01 \\
\hline AYDIN & INCIRLIOVA & 6,5 & 47 & 1 & 0,01 \\
\hline MUGLA & DALAMAN & 6,5 & 47 & 1 & 0,01 \\
\hline
\end{tabular}




\begin{tabular}{|c|c|c|c|c|c|}
\hline & SUB-PROVINCE & Intensity & $\begin{array}{c}\text { Absolute } \\
\text { Loss }\end{array}$ & $\begin{array}{c}\text { Hazard } \\
\text { Zone }\end{array}$ & $\begin{array}{c}\text { Relative Loss } \\
\text { (Loss / Building) }\end{array}$ \\
\hline ISPARTA & YALVAC & 6,5 & 46 & 1 & 0,01 \\
\hline KUTAHYA & GEDIZ & 6,5 & 46 & 1 & 0,01 \\
\hline AYDIN & BOZDOGAN & 6,5 & 45 & 1 & 0,01 \\
\hline CANKIRI & ATKARACALAR & 7,5 & 45 & 1 & 0,06 \\
\hline IZMIR & KARABURUN & 7 & 45 & 1 & 0,03 \\
\hline KASTAMONU & ARAC & 7 & 45 & 1 & 0,03 \\
\hline CANKIRI & KORGUN & 7,5 & 44 & 1 & 0,06 \\
\hline CORUM & OGUZLAR & 7 & 44 & 1 & 0,03 \\
\hline ERZINCAN & TERCAN & 7 & 44 & 1 & 0,03 \\
\hline BINGOL & KIGI & 7,5 & 43 & 1 & 0,06 \\
\hline CANKIRI & BAYRAMOREN & 8 & 43 & 1 & 0,15 \\
\hline DENIZLI & SARAYKOY & 6,5 & 43 & 1 & 0,01 \\
\hline DENIZLI & CARDAK & 7 & 43 & 1 & 0,03 \\
\hline ERZURUM & PASINLER & 6,5 & 43 & 2 & 0,01 \\
\hline OSMANIYE & HASANBEYLI & 7 & 43 & 1 & 0,03 \\
\hline USAK & BANAZ & 6,5 & 43 & 2 & 0,01 \\
\hline VAN & OZALP & 7 & 43 & 1 & 0,03 \\
\hline ANTALYA & ELMALI & 6,5 & 42 & 2 & 0,01 \\
\hline DUZCE & AKCAKOCA & 6,5 & 42 & 1 & 0,02 \\
\hline KAYSERI & \begin{tabular}{|l|} 
TALAS \\
\end{tabular} & 6,5 & 42 & 3 & 0,01 \\
\hline HATAY & \begin{tabular}{|l|} 
ALTINOZU \\
\end{tabular} & 7 & 41 & 1 & 0,03 \\
\hline SIVAS & IMRANLI & 7 & 40 & 1 & 0,03 \\
\hline IZMIR & KINIK & 6,5 & 39 & 1 & 0,01 \\
\hline SAKARYA & KOCAALI & 6,5 & 39 & 1 & 0,01 \\
\hline TEKIRDAG & MURATLI & 6,5 & 39 & 3 & 0,01 \\
\hline ADIYAMAN & CELIKHAN & 7 & 38 & 1 & 0,03 \\
\hline ERZURUM & CAT & 7 & 37 & 1 & 0,03 \\
\hline KASTAMONU & TASKOPRU & 6,5 & 37 & 2 & 0,01 \\
\hline MANISA & GORDES & 6,5 & 37 & 1 & 0,01 \\
\hline MUGLA & DATCA & 6,5 & 37 & 1 & 0,01 \\
\hline SAMSUN & AYVACIK & 7 & 37 & 1 & 0,03 \\
\hline SIVAS & \begin{tabular}{|l} 
DOGANSAR \\
\end{tabular} & 7,5 & 37 & 1 & 0,06 \\
\hline GUMUSHANE & SIRAN & 7 & 36 & 1 & 0,03 \\
\hline BURDUR & ALTINYAYLA & 7 & 35 & 1 & 0,03 \\
\hline ISPARTA & SARKIKARAAGAC & 6,5 & 35 & 1 & 0,01 \\
\hline SIVAS & ZARA & 6,5 & 35 & 1 & 0,01 \\
\hline ADIYAMAN & \begin{tabular}{|l|} 
TUT \\
\end{tabular} & 7 & 34 & 1 & 0,03 \\
\hline AFYON & \begin{tabular}{|l|} 
SUHUT \\
\end{tabular} & 6,5 & 34 & 1 & 0,01 \\
\hline ORDU & KORGAN & 6,5 & 34 & 1 & 0,01 \\
\hline AYDIN & GERMENCIK & 6,5 & 33 & 1 & 0,01 \\
\hline HATAY & KUMLU & 7 & 33 & 1 & 0,03 \\
\hline KARABUK & YENICE & 6,5 & 33 & 1 & 0,01 \\
\hline MUGLA & YATAGAN & 6,5 & 33 & 1 & 0,01 \\
\hline VAN & EDREMIT & 7 & 33 & 2 & 0,03 \\
\hline AYDIN & \begin{tabular}{|l|} 
YENIPAZAR \\
\end{tabular} & 6,5 & 32 & 1 & 0,01 \\
\hline DENIZLI & BOZKURT & 7 & 31 & 1 & 0,03 \\
\hline ELAZIG & SIVRICE & 7 & 31 & 1 & 0,03 \\
\hline KUTAHYA & EMET & 6,5 & 31 & 1 & 0,01 \\
\hline SAMSUN & TEKKEKÖY & 6,5 & 31 & 2 & 0,01 \\
\hline KAYSERI & BUNYAN & 6,5 & 30 & 3 & 0,01 \\
\hline ZONGULDAK & ALAPLI & 6,5 & 30 & 1 & 0,02 \\
\hline AFYON & ISCEHISAR & 6,5 & 29 & 2 & 0,01 \\
\hline BILECIK & \begin{tabular}{|l|} 
SOGUT \\
\end{tabular} & 6,5 & 29 & 2 & 0,01 \\
\hline CANKIRI & ORTA & 7 & 29 & 1 & 0,03 \\
\hline DENIZLI & BAKLAN & 7 & 29 & 1 & 0,03 \\
\hline GIRESUN & ALUCRA & 7 & 29 & 1 & 0,03 \\
\hline ANKARA & NALLIHAN & 6,5 & 28 & 2 & 0,01 \\
\hline
\end{tabular}




\begin{tabular}{|c|c|c|c|c|c|}
\hline & SUB-PROVINCE & Intensity & $\begin{array}{c}\text { Absolute } \\
\text { Loss }\end{array}$ & $\begin{array}{c}\text { Hazard } \\
\text { Zone }\end{array}$ & $\begin{array}{c}\text { Relative Loss } \\
\text { (Loss / Building) }\end{array}$ \\
\hline BURDUR & $\begin{array}{l}\text { CAVDIR } \\
\text { CAVD }\end{array}$ & 7 & 28 & 1 & 0,03 \\
\hline DIYARBAKIR & CERMIK & 6,5 & 28 & 1 & 0,01 \\
\hline ERZURUM & ASKALE & 6,5 & 28 & 2 & 0,01 \\
\hline MALATYA & POTURGE & 7 & 28 & 1 & 0,03 \\
\hline ORDU & GURGENTEPE & 6,5 & 28 & 1 & 0,01 \\
\hline ANKARA & KIZILCAHAMAM & 6,5 & 27 & 2 & 0,01 \\
\hline AYDIN & KARACASU & 6,5 & 27 & 1 & 0,01 \\
\hline DENIZLI & ACIPAYAM & 6,5 & 27 & 1 & 0,01 \\
\hline GUMUSHANE & KELKIT & 6,5 & 27 & 1 & 0,01 \\
\hline ISPARTA & KECIBORLU & 6,5 & 27 & 1 & 0,01 \\
\hline KONYA & DOGANHISAR & 6,5 & 27 & 1 & 0,01 \\
\hline ORDU & KUMRU & 6,5 & 27 & 1 & 0,01 \\
\hline ADANA & POZANTI & 6,5 & 26 & 3 & 0,01 \\
\hline ANTALYA & KALE (DEMRE) & 6,5 & 26 & 1 & 0,01 \\
\hline DIYARBAKIR & CUNGUS & 7 & 26 & 1 & 0,03 \\
\hline ISPARTA & SENIRKENT & 6,5 & 26 & 1 & 0,01 \\
\hline SAMSUN & ASARCIK & 7,5 & 26 & 1 & 0,07 \\
\hline VAN & GURPINAR & 7 & 26 & 2 & 0,03 \\
\hline BINGOL & YAYLADERE & 7 & 25 & 1 & 0,03 \\
\hline ELAZIG & ALACAKAYA & 7 & 25 & 1 & 0,03 \\
\hline K.MARAS & CAGLAYANCERIT & 6,5 & 25 & 1 & 0,01 \\
\hline MALATYA & DOGANYOL & 7 & 25 & 1 & 0,03 \\
\hline ADANA & KARATAS & 6,5 & 24 & 2 & 0,01 \\
\hline ADANA & KARAISALI & 6,5 & 24 & 3 & 0,01 \\
\hline ANTALYA & KEMER & 6,5 & 24 & 1 & 0,01 \\
\hline BALIKESIR & KEPSUT & 6,5 & 24 & 1 & 0,01 \\
\hline BURDUR & KEMER & 7 & 24 & 1 & 0,03 \\
\hline CANKIRI & YAPRAKLI & 7 & 24 & 1 & 0,03 \\
\hline EDIRNE & \begin{tabular}{|l} 
IPSALA \\
\end{tabular} & 6,5 & 24 & 3 & 0,01 \\
\hline IZMIR & KIRAZ & 6,5 & 24 & 1 & 0,01 \\
\hline MUS & HASKOY & 6,5 & 24 & 1 & 0,01 \\
\hline ANTALYA & FINIKE & 6,5 & 23 & 1 & 0,01 \\
\hline AYDIN & KUYUCAK & 6,5 & 23 & 1 & 0,01 \\
\hline BITLIS & GUROYMAK & 6,5 & 23 & 2 & 0,01 \\
\hline BOLU & SEBEN & 7 & 23 & 1 & 0,03 \\
\hline IZMIR & BEYDAG & 6,5 & 23 & 1 & 0,01 \\
\hline MUGLA & \begin{tabular}{|l|} 
KOYCEGIZ \\
\end{tabular} & 6,5 & 23 & 1 & 0,01 \\
\hline AFYON & BASMAKCI & 6,5 & 22 & 1 & 0,01 \\
\hline AYDIN & KOSK & 6,5 & 22 & 1 & 0,01 \\
\hline ELAZIG & KARAKOCAN & 6,5 & 22 & 2 & 0,01 \\
\hline MUGLA & ULA & 6,5 & 22 & 1 & 0,01 \\
\hline SINOP & \begin{tabular}{|l} 
DURAGAN \\
\end{tabular} & 6,5 & 22 & 1 & 0,01 \\
\hline ERZINCAN & KEMAH & 7 & 21 & 1 & 0,03 \\
\hline GAZIANTEP & ARABAN & 6,5 & 21 & 3 & 0,01 \\
\hline ISPARTA & ULUBORLU & 6,5 & 21 & 1 & 0,01 \\
\hline VAN & GEVAS & 6,5 & 21 & 2 & 0,01 \\
\hline AFYON & SULTANDAGI & 6,5 & 20 & 1 & 0,01 \\
\hline AYDIN & BUHARKENT & 6,5 & 20 & 1 & 0,01 \\
\hline BALIKESIR & BALYA & 7 & 20 & 1 & 0,03 \\
\hline BURSA & \begin{tabular}{|l|} 
ORHANELI \\
\end{tabular} & 6,5 & 20 & 2 & 0,01 \\
\hline DUZCE & YIGILCA & 7 & 20 & 1 & 0,04 \\
\hline MALATYA & DOGANSEHIR & 6,5 & 20 & 1 & 0,01 \\
\hline ORDU & AKKUS & 7 & 20 & 1 & 0,03 \\
\hline ADIYAMAN & SINCIK & 7 & 19 & 1 & 0,03 \\
\hline AFYON & \begin{tabular}{|l|} 
COBANLAR \\
\end{tabular} & 6,5 & 19 & 1 & 0,01 \\
\hline AYDIN & \begin{tabular}{|l} 
SULTANHISAR \\
\end{tabular} & 6,5 & 19 & 1 & 0,01 \\
\hline BILECIK & PAZARYERI & 6,5 & 19 & 2 & 0,01 \\
\hline
\end{tabular}




\begin{tabular}{|c|c|c|c|c|c|}
\hline & SUB-PROVINCE & Intensity & $\begin{array}{l}\text { Absolute } \\
\text { Loss }\end{array}$ & $\begin{array}{c}\text { Hazard } \\
\text { Zone }\end{array}$ & $\begin{array}{c}\text { Relative Loss } \\
\text { (Loss / Building) }\end{array}$ \\
\hline DENIZLI & AKKOY & 7 & 19 & 1 & 0,03 \\
\hline DENIZLI & BEKILLI & 6,5 & 19 & 1 & 0,01 \\
\hline MUS & KORKUT & 7 & 19 & 1 & 0,03 \\
\hline USAK & ULUBEY & 6,5 & 19 & 2 & 0,01 \\
\hline ADANA & YUMURTALIK & 6,5 & 18 & 1 & 0,01 \\
\hline AYDIN & KOCARLI & 6,5 & 18 & 1 & 0,01 \\
\hline DENIZLI & \begin{tabular}{|l|} 
HONAZ \\
\end{tabular} & 6,5 & 18 & 1 & 0,01 \\
\hline ISPARTA & GELENDOST & 6,5 & 18 & 1 & 0,01 \\
\hline KUTAHYA & HISARCIK & 6,5 & 18 & 1 & 0,01 \\
\hline AFYON & \begin{tabular}{|l|} 
BAYAT \\
\end{tabular} & 6,5 & 17 & 2 & 0,01 \\
\hline CORUM & BAYAT & 6,5 & 17 & 2 & 0,01 \\
\hline DENIZLI & BABADAG & 6,5 & 17 & 1 & 0,01 \\
\hline ELAZIG & ARICAK & 7 & 17 & 1 & 0,03 \\
\hline KONYA & DERBENT & 6,5 & 17 & 3 & 0,01 \\
\hline MANISA & KOPRUBASI & 6,5 & 17 & 1 & 0,01 \\
\hline ANTALYA & KAS & 6,5 & 16 & 1 & 0,01 \\
\hline CANAKKALE & YENICE & 6,5 & 16 & 1 & 0,01 \\
\hline CORUM & MECITOZU & 6,5 & 16 & 1 & 0,01 \\
\hline CORUM & LACIN & 7 & 16 & 1 & 0,03 \\
\hline KONYA & HUYUK & 6,5 & 16 & 2 & 0,01 \\
\hline KUTAHYA & SAPHANE & 6,5 & 16 & 1 & 0,01 \\
\hline AMASYA & HAMAMOZU & 7 & 15 & 1 & 0,03 \\
\hline BURDUR & AGLASUN & 6,5 & 15 & 1 & 0,01 \\
\hline DIYARBAKIR & DICLE & 6,5 & 15 & 1 & 0,01 \\
\hline ISPARTA & ATABEY & 6,5 & 15 & 1 & 0,01 \\
\hline KARABUK & OVACIK & 7,5 & 15 & 1 & 0,06 \\
\hline CANKIRI & ELDIVAN & 6,5 & 14 & 2 & 0,01 \\
\hline NIGDE & CAMARDI & 6,5 & 14 & 4 & 0,01 \\
\hline SAMSUN & \begin{tabular}{|l} 
SALIPAZARI \\
\end{tabular} & 6,5 & 14 & 2 & 0,01 \\
\hline TOKAT & PAZAR & 6,5 & 14 & 1 & 0,01 \\
\hline AFYON & DAZKIRI & 6,5 & 13 & 1 & 0,01 \\
\hline ERZINCAN & OTLUKBELI & 7 & 13 & 1 & 0,03 \\
\hline KUTAHYA & \begin{tabular}{|l} 
ALTINTAS \\
\end{tabular} & 6,5 & 13 & 2 & 0,01 \\
\hline BOLU & \begin{tabular}{|l|} 
KIBRISCIK \\
\end{tabular} & 7 & 12 & 1 & 0,03 \\
\hline ISPARTA & GONEN & 6,5 & 12 & 1 & 0,01 \\
\hline KONYA & TUZLUKCU & 6,5 & 12 & 1 & 0,01 \\
\hline KUTAHYA & PAZARLAR & 6,5 & 12 & 1 & 0,01 \\
\hline SINOP & SARAYDUZU & 7 & 12 & 1 & 0,03 \\
\hline AFYON & EVCILER & 6,5 & 11 & 1 & 0,01 \\
\hline ERZURUM & TEKMAN & 6,5 & 11 & 1 & 0,01 \\
\hline ORDU & CATALPINAR & 6,5 & 11 & 2 & 0,01 \\
\hline SAKARYA & KAYNARCA & 6,5 & 11 & 1 & 0,01 \\
\hline ADIYAMAN & GERGER & 6,5 & 9 & 1 & 0,01 \\
\hline AYDIN & KARPUZLU & 6,5 & 9 & 1 & 0,01 \\
\hline BURDUR & CELTIKCI & 6,5 & 9 & 1 & 0,01 \\
\hline BURSA & KELES & 6,5 & 9 & 2 & 0,01 \\
\hline CANKIRI & SABANOZU & 6,5 & 9 & 2 & 0,01 \\
\hline CORUM & ORTAKOY & 6,5 & 9 & 2 & 0,01 \\
\hline DENIZLI & CAMELI & 6,5 & 9 & 1 & 0,01 \\
\hline GAZIANTEP & \begin{tabular}{|l|} 
YAVUZELI \\
\end{tabular} & 6,5 & 9 & 3 & 0,01 \\
\hline DENIZLI & BEYAGAC & 6,5 & 8 & 1 & 0,01 \\
\hline ESKISEHIR & MIHALGAZI & 6,5 & 8 & 2 & 0,01 \\
\hline KUTAHYA & CAVDARHISAR & 6,5 & 8 & 1 & 0,01 \\
\hline AFYON & IHSANIYE & 6,5 & 7 & 2 & 0,01 \\
\hline AMASYA & GOYNUCEK & 6,5 & 7 & 1 & 0,01 \\
\hline MALATYA & KALE & 6,5 & 7 & 1 & 0,01 \\
\hline OSMANIYE & \begin{tabular}{|l} 
SUMBAS \\
\end{tabular} & 6,5 & 7 & 1 & 0,01 \\
\hline
\end{tabular}




\begin{tabular}{|l|l|c|r|r|r|}
\hline & \multicolumn{1}{|c|}{ SUB-PROVINCE } & Intensity & \multicolumn{1}{c|}{$\begin{array}{c}\text { Absolute } \\
\text { Loss }\end{array}$} & $\begin{array}{c}\text { Hazard } \\
\text { Zone }\end{array}$ & $\begin{array}{c}\text { Relative Loss } \\
\text { (Loss / Building) }\end{array}$ \\
\hline TUNCELI & OVACIK & 6,5 & 7 & 1 & 0,01 \\
\hline KONYA & AKOREN & 6,5 & 6 & 4 & 0 \\
\hline KUTAHYA & DUMLUPINAR & 6,5 & 6 & 2 & 0,01 \\
\hline VAN & SARAY & 6,5 & 6 & 1 & 0,01 \\
\hline BILECIK & INHISAR & 6,5 & 5 & 2 & 0,01 \\
\hline BILECIK & YENIPAZAR & 6,5 & 5 & 1 & 0,01 \\
\hline ESKISEHIR & SARICAKAYA & 6,5 & 5 & 2 & 0,01 \\
\hline KUTAHYA & ASLANAPA & 6,5 & 5 & 1 & 0,01 \\
\hline TUNCELI & NAZIMIYE & 6,5 & 4 & 1 & 0,01 \\
\hline KILIS & MUSABEYLI & 6,5 & 2 & 3 & 0,01 \\
\hline
\end{tabular}

C: Central

Comparison of the Metropolitan Cities Prioritized According to the Absolute Loss with the Hazard Zones Determined by the Official Earthquake Hazard Map

\begin{tabular}{|l|l|c|r|r|r|}
\hline $\begin{array}{c}\text { Metropolitan } \\
\text { Cities }\end{array}$ & SUB-PROVINCE & Intensity & $\begin{array}{c}\text { Absolute } \\
\text { Loss }\end{array}$ & Hazard Zone & $\begin{array}{c}\text { Relative Loss } \\
\text { (Loss / Building) }\end{array}$ \\
\hline ISTANBUL & ISTANBUL (M) & 7,5 & 83824 & $2 *$ & 0,10 \\
\hline KOCAELI & KOCAELI (M) & 8 & 24077 & 1 & 0,17 \\
\hline BURSA & BURSA (M) & 7,5 & 16506 & 1 & 0,08 \\
\hline IZMIR & IZMIR (M) & 7 & 14531 & 1 & 0,03 \\
\hline SAKARYA & SAKARYA (M) & 8 & 8070 & 1 & 0,16 \\
\hline ADANA & ADANA (M) & 6,5 & 1913 & 2 & 0,01 \\
\hline ANTALYA & ANTALYA (M) & 6,5 & 1402 & 2 & 0,01 \\
\hline KONYA & KONYA (M) & 6,5 & 1355 & 4 & 0,01 \\
\hline ERZURUM & ERZURUM (M) & 6,5 & 439 & 2 & 0,01 \\
\hline
\end{tabular}

M: Metropolitan

* 22 settlements are located in the second degree hazard zone, 15 settlements are located in the first degree hazard zone and 2 settlements are located in the third degree hazard zone in Istanbul. Therefore, the hazard zone of Istanbul Metropolitan city is accepted as second degree hazard zone. 


\section{APPENDIX H}

\section{COMPARISON OF THE SETTLEMENTS PRIORITIZED ACCORDING TO THE RELATIVE LOSS WITH THE HAZARD ZONES DETERMINED BY THE OFFICIAL EARTHQUAKE HAZARD MAP}

\begin{tabular}{|c|c|c|c|c|c|}
\hline & SUB-PROVINCE & Intensity & $\begin{array}{c}\text { Relative Loss/ } \\
\text { Loss Rate }\end{array}$ & Hazard Zone & Absolute Loss \\
\hline YALOVA & CINARCIK & 8 & 0,21 & 1 & 357 \\
\hline SAKARYA & AKYAZI & 8 & 0,19 & 1 & 681 \\
\hline YALOVA & CIFTLIKKOY & 8 & 0,19 & 1 & 298 \\
\hline BOLU & BOLU C. & 8 & 0,18 & 1 & 1841 \\
\hline YALOVA & YALOVA C. & 8 & 0,18 & 1 & 1507 \\
\hline \begin{tabular}{|l|} 
BURSA \\
\end{tabular} & ORHANGAZI & 8 & 0,18 & 1 & 945 \\
\hline TEKIRDAG & SARKOY & 8 & 0,18 & 1 & 712 \\
\hline TOKAT & NIKSAR & 8 & 0,17 & 1 & 1400 \\
\hline SAKARYA & HENDEK & 8 & 0,17 & 1 & 869 \\
\hline BOLU & GEREDE & 8 & 0,17 & 1 & 583 \\
\hline AMASYA & TASOVA & 8 & 0,17 & 1 & 282 \\
\hline YALOVA & TERMAL & 8 & 0,17 & 1 & 73 \\
\hline ERZINCAN & ERZINCAN C. & 8 & 0,16 & 1 & 2025 \\
\hline KASTAMONU & TOSYA & 8 & 0,16 & 1 & 1364 \\
\hline TOKAT & ERBAA & 8 & 0,16 & 1 & 1251 \\
\hline CORUM & OSMANCIK & 8 & 0,16 & 1 & 786 \\
\hline SAMSUN & HAVZA & 8 & 0,16 & 1 & 735 \\
\hline SAKARYA & GEYVE & 8 & 0,16 & 1 & 543 \\
\hline SIVAS & SUSEHRI & 8 & 0,16 & 1 & 424 \\
\hline SAMSUN & LADIK & 8 & 0,16 & 1 & 377 \\
\hline CANKIRI & ILGAZ & 8 & 0,16 & 1 & 312 \\
\hline \begin{tabular}{|l|} 
TOKAT \\
\end{tabular} & RESADIYE & 8 & 0,16 & 1 & 309 \\
\hline BOLU & YENICAGA & 8 & 0,16 & 1 & 183 \\
\hline GIRESUN & CAMOLUK & 8 & 0,16 & 1 & 133 \\
\hline TUNCELI & PULUMUR & 8 & 0,16 & 1 & 94 \\
\hline BOLU & DORTDIVAN & 8 & 0,16 & 1 & 93 \\
\hline YALOVA & ALTINOVA & 8 & 0,16 & 1 & 84 \\
\hline SIVAS & GOLOVA & 8 & 0,16 & 1 & 74 \\
\hline ERZINCAN & UZUMLU & 8 & 0,15 & 1 & 631 \\
\hline SAKARYA & PAMUKOVA & 8 & 0,15 & 1 & 403 \\
\hline MUS & VARTO & 8 & 0,15 & 1 & 384 \\
\hline CORUM & KARGI & 8 & 0,15 & 1 & 285 \\
\hline SIVAS & KOYULHISAR & 8 & 0,15 & 1 & 273 \\
\hline CANKIRI & CERKES & 8 & 0,15 & 1 & 263 \\
\hline SIVAS & AKINCILAR & 8 & 0,15 & 1 & 211 \\
\hline TOKAT & BASCIFTLIK & 8 & 0,15 & 1 & 182 \\
\hline DUZCE & KAYNASLI & 8 & 0,15 & 1 & 177 \\
\hline BINGOL & KARLIOVA & 8 & 0,15 & 1 & 138 \\
\hline SAKARYA & KARAPURCEK & 8 & 0,15 & 1 & 136 \\
\hline ERZINCAN & REFAHIYE & 8 & 0,15 & 1 & 130 \\
\hline DUZCE & GOLYAKA & 8 & 0,15 & 1 & 126 \\
\hline BINGOL & YEDISU & 8 & 0,15 & 1 & 68 \\
\hline CANKIRI & BAYRAMOREN & 8 & 0,15 & 1 & 43 \\
\hline TEKIRDAG & TEKİRDAĞ C. & 7,5 & 0,09 & 2 & 1347 \\
\hline YALOVA & ARMUTLU & 7,5 & 0,08 & 1 & 164 \\
\hline AMASYA & MERZIFON & 7,5 & 0,07 & 1 & 666 \\
\hline
\end{tabular}




\begin{tabular}{|c|c|c|c|c|c|}
\hline & SUB-PROVINCE & Intensity & $\begin{array}{c}\text { Relative Loss/ } \\
\text { Loss Rate } \\
\end{array}$ & Hazard Zone & Absolute Loss \\
\hline AMASYA & SULUOVA & 7,5 & 0,07 & 1 & 633 \\
\hline DUZCE & DÜZCE C. & 7,5 & 0,07 & 1 & 612 \\
\hline BURSA & YENISEHIR & 7,5 & 0,07 & 1 & 339 \\
\hline SAMSUN & VEZIRKOPRU & 7,5 & 0,07 & 1 & 298 \\
\hline AMASYA & GUMUSHACIKOY & 7,5 & 0,07 & 1 & 271 \\
\hline BILECIK & OSMANELI & 7,5 & 0,07 & 1 & 158 \\
\hline SAMSUN & KAVAK & 7,5 & 0,07 & 1 & 97 \\
\hline KARABUK & ESKIPAZAR & 7,5 & 0,07 & 1 & 96 \\
\hline DUZCE & GUMUSOVA & 7,5 & 0,07 & 1 & 86 \\
\hline BOLU & MENGEN & 7,5 & 0,07 & 1 & 76 \\
\hline TOKAT & ALMUS & 7,5 & 0,07 & 1 & 74 \\
\hline SAMSUN & ASARCIK & 7,5 & 0,07 & 1 & 26 \\
\hline VAN & VAN C. & 7,5 & 0,06 & 2 & 2285 \\
\hline BURSA & IZNIK & 7,5 & 0,06 & 1 & 252 \\
\hline MUS & BULANIK & 7,5 & 0,06 & 1 & 246 \\
\hline GIRESUN & SEBINKARAHISAR & 7,5 & 0,06 & 1 & 222 \\
\hline BITLIS & ADILCEVAZ & 7,5 & 0,06 & 1 & 172 \\
\hline BOLU & MUDURNU & 7,5 & 0,06 & 1 & 104 \\
\hline CANKIRI & KURSUNLU & 7,5 & 0,06 & 1 & 84 \\
\hline BOLU & GOYNUK & 7,5 & 0,06 & 1 & 75 \\
\hline DUZCE & CUMAYERI & 7,5 & 0,06 & 1 & 67 \\
\hline SAKARYA & TARAKLI & 7,5 & 0,06 & 1 & 67 \\
\hline ERZINCAN & CAYIRLI & 7,5 & 0,06 & 1 & 61 \\
\hline CORUM & DODURGA & 7,5 & 0,06 & 1 & 60 \\
\hline ORDU & MESUDIYE & 7,5 & 0,06 & 1 & 60 \\
\hline BINGOL & ADAKLI & 7,5 & 0,06 & 1 & 52 \\
\hline DUZCE & CILIMLI & 7,5 & 0,06 & 1 & 49 \\
\hline CANKIRI & ATKARACALAR & 7,5 & 0,06 & 1 & 45 \\
\hline CANKIRI & KORGUN & 7,5 & 0,06 & 1 & 44 \\
\hline BINGOL & KIGI & 7,5 & 0,06 & 1 & 43 \\
\hline SIVAS & DOGANSAR & 7,5 & 0,06 & 1 & 37 \\
\hline KARABUK & OVACIK & 7,5 & 0,06 & 1 & 15 \\
\hline MANISA & MANISA C. & 7 & 0,04 & 1 & 919 \\
\hline BURSA & INEGOL & 7 & 0,04 & 1 & 536 \\
\hline MANISA & SALIHLI & 7 & 0,04 & 1 & 483 \\
\hline BALIKESIR & BANDIRMA & 7 & 0,04 & 1 & 460 \\
\hline CANAKKALE & ÇANAKKALE C. & 7 & 0,04 & 1 & 339 \\
\hline AMASYA & AMASYA C. & 7 & 0,04 & 1 & 336 \\
\hline BURSA & M.KEMALPASA & 7 & 0,04 & 1 & 304 \\
\hline BITLIS & AHLAT & 7,5 & 0,04 & 1 & 234 \\
\hline BALIKESIR & ERDEK & 7 & 0,04 & 1 & 159 \\
\hline BILECIK & BİLECİK C. & 7 & 0,04 & 1 & 145 \\
\hline ELAZIG & KOVANCILAR & 7 & 0,04 & 1 & 74 \\
\hline DUZCE & YIGILCA & 7 & 0,04 & 1 & 20 \\
\hline OSMANIYE & OSMANIYE C. & 7 & 0,03 & 1 & 905 \\
\hline HATAY & ANTAKYA & 7 & 0,03 & 1 & 768 \\
\hline HATAY & ISKENDERUN & 7 & 0,03 & 1 & 705 \\
\hline ADIYAMAN & ADIYAMAN C. & 7 & 0,03 & 2 & 696 \\
\hline MANISA & TURGUTLU & 7 & 0,03 & 1 & 639 \\
\hline MANISA & AKHISAR & 7 & 0,03 & 1 & 585 \\
\hline TOKAT & TOKAT C. & 7 & 0,03 & 1 & 528 \\
\hline BALIKESIR & AYVALIK & 7 & 0,03 & 1 & 442 \\
\hline BALIKESIR & BURHANIYE & 7 & 0,03 & 1 & 410 \\
\hline IZMIR & BERGAMA & 7 & 0,03 & 1 & 402 \\
\hline HATAY & KIRIKHAN & 7 & 0,03 & 1 & 360 \\
\hline IZMIR & CESME & 7 & 0,03 & 1 & 348 \\
\hline HATAY & DORTYOL & 7 & 0,03 & 1 & 333 \\
\hline
\end{tabular}




\begin{tabular}{|c|c|c|c|c|c|}
\hline & SUB-PROVINCE & Intensity & $\begin{array}{c}\text { Relative Loss/ } \\
\text { Loss Rate }\end{array}$ & Hazard Zone & Absolute Loss \\
\hline MANISA & ALASEHIR & 7 & 0,03 & 1 & 306 \\
\hline HATAY & REYHANLI & 7 & 0,03 & 1 & 280 \\
\hline EDIRNE & KESAN & 7 & 0,03 & 2 & 269 \\
\hline BALIKESIR & EDREMIT & 7 & 0,03 & 1 & 262 \\
\hline BURSA & KARACABEY & 7 & 0,03 & 1 & 258 \\
\hline BINGOL & BİNGÖL C. & 7 & 0,03 & 1 & 251 \\
\hline MANISA & KULA & 7 & 0,03 & 1 & 236 \\
\hline HATAY & SAMANDAG & 7 & 0,03 & 1 & 232 \\
\hline BALIKESIR & SUSURLUK & 7 & 0,03 & 1 & 190 \\
\hline CANAKKALE & BIGA & 7 & 0,03 & 1 & 188 \\
\hline HATAY & ERZIN & 7 & 0,03 & 1 & 173 \\
\hline CORUM & ISKILIP & 7 & 0,03 & 1 & 167 \\
\hline CANAKKALE & CAN & 7 & 0,03 & 1 & 161 \\
\hline HATAY & BELEN & 7 & 0,03 & 1 & 159 \\
\hline \begin{tabular}{|l|} 
TEKIRDAG \\
\end{tabular} & MALKARA & 7 & 0,03 & 2 & 157 \\
\hline GAZIANTEP & ISLAHIYE & 7 & 0,03 & 1 & 148 \\
\hline ADIYAMAN & GOLBASI & 7 & 0,03 & 1 & 137 \\
\hline DENIZLI & BULDAN & 7 & 0,03 & 1 & 137 \\
\hline ORDU & GOLKOY & 7 & 0,03 & 1 & 134 \\
\hline MANISA & SARIGOL & 7 & 0,03 & 1 & 130 \\
\hline CANAKKALE & BAYRAMIC & 7 & 0,03 & 1 & 129 \\
\hline ADIYAMAN & BESNI & 7 & 0,03 & 2 & 126 \\
\hline MUS & MALAZGIRT & 7 & 0,03 & 1 & 125 \\
\hline ORDU & AYBASTI & 7 & 0,03 & 1 & 125 \\
\hline CANAKKALE & EZINE & 7 & 0,03 & 1 & 121 \\
\hline K.MARAS & PAZARCIK & 7 & 0,03 & 1 & 120 \\
\hline USAK & ESME & 7 & 0,03 & 1 & 119 \\
\hline BALIKESIR & BIGADIC & 7 & 0,03 & 1 & 114 \\
\hline MANISA & SARUHANLI & 7 & 0,03 & 1 & 112 \\
\hline \begin{tabular}{|l|} 
BURDUR \\
\end{tabular} & GOLHISAR & 7 & 0,03 & 1 & 110 \\
\hline BALIKESIR & HAVRAN & 7 & 0,03 & 1 & 107 \\
\hline ERZURUM & HINIS & 7 & 0,03 & 1 & 107 \\
\hline EDIRNE & ENEZ & 7 & 0,03 & 2 & 105 \\
\hline BALIKESIR & SINDIRGI & 7 & 0,03 & 1 & 100 \\
\hline MANISA & GOLMARMARA & 7 & 0,03 & 1 & 91 \\
\hline \begin{tabular}{|l|} 
BALIKESIR \\
\end{tabular} & GOMEC & 7 & 0,03 & 1 & 87 \\
\hline MANISA & AHMETLI & 7 & 0,03 & 1 & 83 \\
\hline CANAKKALE & LAPSEKI & 7 & 0,03 & 1 & 74 \\
\hline ERZURUM & KARACOBAN & 7 & 0,03 & 1 & 73 \\
\hline BALIKESIR & SAVASTEPE & 7 & 0,03 & 1 & 72 \\
\hline ANKARA & CAMLIDERE & 7 & 0,03 & 1 & 70 \\
\hline OSMANIYE & BAHCE & 7 & 0,03 & 1 & 70 \\
\hline GAZIANTEP & NURDAGI & 7 & 0,03 & 1 & 69 \\
\hline K.MARAS & TURKOGLU & 7 & 0,03 & 1 & 68 \\
\hline SAKARYA & FERIZLI & 7 & 0,03 & 1 & 61 \\
\hline BURDUR & KARAMANLI & 7 & 0,03 & 1 & 60 \\
\hline VAN & BASKALE & 7 & 0,03 & 2 & 60 \\
\hline BILECIK & GOLPAZARI & 7 & 0,03 & 1 & 58 \\
\hline CANAKKALE & AYVACIK & 7 & 0,03 & 1 & 57 \\
\hline DENIZLI & GUNEY & 7 & 0,03 & 1 & 57 \\
\hline ELAZIG & PALU & 7 & 0,03 & 1 & 55 \\
\hline \begin{tabular}{|l|} 
BINGOL \\
\end{tabular} & GENC & 7 & 0,03 & 1 & 54 \\
\hline HATAY & YAYLADAGI & 7 & 0,03 & 1 & 54 \\
\hline \begin{tabular}{|l|} 
DENIZLI \\
\end{tabular} & CAL & 7 & 0,03 & 1 & 53 \\
\hline BALIKESIR & MANYAS & 7 & 0,03 & 1 & 51 \\
\hline ELAZIG & MADEN & 7 & 0,03 & 1 & 51 \\
\hline \begin{tabular}{|l} 
BURDUR \\
\end{tabular} & TEFENNI & 7 & 0,03 & 1 & 50 \\
\hline
\end{tabular}




\begin{tabular}{|c|c|c|c|c|c|}
\hline & SUB-PROVINCE & Intensity & $\begin{array}{c}\text { Relative Loss/ } \\
\text { Loss Rate } \\
\end{array}$ & Hazard Zone & Absolute Loss \\
\hline HATAY & HASSA & 7 & 0,03 & 1 & 50 \\
\hline OSMANIYE & TOPRAKKALE & 7 & 0,03 & 1 & 50 \\
\hline BALIKESIR & IVRINDI & 7 & 0,03 & 1 & 49 \\
\hline BURDUR & YESILOVA & 7 & 0,03 & 1 & 49 \\
\hline KASTAMONU & IHSANGAZI & 7 & 0,03 & 1 & 48 \\
\hline IZMIR & KARABURUN & 7 & 0,03 & 1 & 45 \\
\hline KASTAMONU & ARAC & 7 & 0,03 & 1 & 45 \\
\hline CORUM & OGUZLAR & 7 & 0,03 & 1 & 44 \\
\hline ERZINCAN & TERCAN & 7 & 0,03 & 1 & 44 \\
\hline \begin{tabular}{|l} 
DENIZLI \\
\end{tabular} & CARDAK & 7 & 0,03 & 1 & 43 \\
\hline OSMANIYE & HASANBEYLI & 7 & 0,03 & 1 & 43 \\
\hline VAN & OZALP & 7 & 0,03 & 1 & 43 \\
\hline HATAY & ALTINOZU & 7 & 0,03 & 1 & 41 \\
\hline SIVAS & IMRANLI & 7 & 0,03 & 1 & 40 \\
\hline ADIYAMAN & CELIKHAN & 7 & 0,03 & 1 & 38 \\
\hline ERZURUM & CAT & 7 & 0,03 & 1 & 37 \\
\hline \begin{tabular}{|l} 
SAMSUN \\
\end{tabular} & AYVACIK & 7 & 0,03 & 1 & 37 \\
\hline GUMUSHANE & SIRAN & 7 & 0,03 & 1 & 36 \\
\hline BURDUR & ALTINYAYLA & 7 & 0,03 & 1 & 35 \\
\hline ADIYAMAN & TUT & 7 & 0,03 & 1 & 34 \\
\hline HATAY & KUMLU & 7 & 0,03 & 1 & 33 \\
\hline VAN & EDREMIT & 7 & 0,03 & 2 & 33 \\
\hline DENIZLI & BOZKURT & 7 & 0,03 & 1 & 31 \\
\hline ELAZIG & SIVRICE & 7 & 0,03 & 1 & 31 \\
\hline CANKIRI & ORTA & 7 & 0,03 & 1 & 29 \\
\hline \begin{tabular}{|l} 
DENIZLI \\
\end{tabular} & BAKLAN & 7 & 0,03 & 1 & 29 \\
\hline GIRESUN & ALUCRA & 7 & 0,03 & 1 & 29 \\
\hline BURDUR & CAVDIR & 7 & 0,03 & 1 & 28 \\
\hline MALATYA & POTURGE & 7 & 0,03 & 1 & 28 \\
\hline DIYARBAKIR & CUNGUS & 7 & 0,03 & 1 & 26 \\
\hline VAN & GURPINAR & 7 & 0,03 & 2 & 26 \\
\hline BINGOL & YAYLADERE & 7 & 0,03 & 1 & 25 \\
\hline ELAZIG & ALACAKAYA & 7 & 0,03 & 1 & 25 \\
\hline MALATYA & DOGANYOL & 7 & 0,03 & 1 & 25 \\
\hline BURDUR & KEMER & 7 & 0,03 & 1 & 24 \\
\hline \begin{tabular}{|l} 
CANKIRI \\
\end{tabular} & YAPRAKLI & 7 & 0,03 & 1 & 24 \\
\hline BOLU & SEBEN & 7 & 0,03 & 1 & 23 \\
\hline ERZINCAN & KEMAH & 7 & 0,03 & 1 & 21 \\
\hline BALIKESIR & BALYA & 7 & 0,03 & 1 & 20 \\
\hline ORDU & AKKUS & 7 & 0,03 & 1 & 20 \\
\hline \begin{tabular}{|l} 
ADIYAMAN \\
\end{tabular} & SINCIK & 7 & 0,03 & 1 & 19 \\
\hline \begin{tabular}{|l} 
DENIZLI \\
\end{tabular} & AKKOY & 7 & 0,03 & 1 & 19 \\
\hline \begin{tabular}{|l} 
MUS \\
\end{tabular} & KORKUT & 7 & 0,03 & 1 & 19 \\
\hline \begin{tabular}{|l|} 
ELAZIG \\
\end{tabular} & ARICAK & 7 & 0,03 & 1 & 17 \\
\hline CORUM & LACIN & 7 & 0,03 & 1 & 16 \\
\hline AMASYA & HAMAMOZU & 7 & 0,03 & 1 & 15 \\
\hline ERZINCAN & OTLUKBELI & 7 & 0,03 & 1 & 13 \\
\hline BOLU & KIBRISCIK & 7 & 0,03 & 1 & 12 \\
\hline SINOP & SARAYDUZU & 7 & 0,03 & 1 & 12 \\
\hline BALIKESIR & BALIKESİR C. & 6,5 & 0,02 & 1 & 469 \\
\hline \begin{tabular}{|l} 
AYDIN \\
\end{tabular} & AYDIN C. & 6,5 & 0,02 & 1 & 303 \\
\hline KUTAHYA & SIMAV & 6,5 & 0,02 & 1 & 73 \\
\hline MUGLA & MARMARIS & 6,5 & 0,02 & 1 & 54 \\
\hline DUZCE & AKCAKOCA & 6,5 & 0,02 & 1 & 42 \\
\hline ZONGULDAK & ALAPLI & 6,5 & 0,02 & 1 & 30 \\
\hline DENIZLI & DENIZZLİ C. & 6,5 & 0,01 & 1 & 586 \\
\hline K.MARAS & K.MARAŞ C. & 6,5 & 0,01 & 1 & 457 \\
\hline
\end{tabular}




\begin{tabular}{|c|c|c|c|c|c|}
\hline & SUB-PROVINCE & Intensity & $\begin{array}{c}\text { Relative Loss/ } \\
\text { Loss Rate }\end{array}$ & Hazard Zone & Absolute Loss \\
\hline KUTAHYA & KÜTAHYA C. & 6,5 & 0,01 & 2 & 384 \\
\hline ICEL(MERSIN) & TARSUS & 6,5 & 0,01 & 3 & 361 \\
\hline ISPARTA & ISPARTA C. & 6,5 & 0,01 & 1 & 354 \\
\hline CORUM & ÇORUM C. & 6,5 & 0,01 & 2 & 286 \\
\hline AFYON & AFYON C. & 6,5 & 0,01 & 2 & 240 \\
\hline TEKIRDAG & CORLU & 6,5 & 0,01 & 3 & 230 \\
\hline AYDIN & KUSADASI & 6,5 & 0,01 & 1 & 211 \\
\hline AYDIN & NAZILLI & 6,5 & 0,01 & 1 & 210 \\
\hline AYDIN & DİDİM(YENİHİSAR) & 6,5 & 0,01 & 1 & 204 \\
\hline IZMIR & ODEMIS & 6,5 & 0,01 & 1 & 190 \\
\hline ADANA & KOZAN & 6,5 & 0,01 & 3 & 184 \\
\hline KARABUK & KARABÜK C. & 6,5 & 0,01 & 1 & 180 \\
\hline ADANA & CEYHAN & 6,5 & 0,01 & 2 & 171 \\
\hline OSMANIYE & KADIRLI & 6,5 & 0,01 & 2 & 167 \\
\hline BURDUR & BURDUR C. & 6,5 & 0,01 & 1 & 156 \\
\hline MUGLA & FETHIYE & 6,5 & 0,01 & 1 & 144 \\
\hline AYDIN & SOKE & 6,5 & 0,01 & 1 & 138 \\
\hline MANISA & SOMA & 6,5 & 0,01 & 1 & 133 \\
\hline MUGLA & BODRUM & 6,5 & 0,01 & 1 & 130 \\
\hline TOKAT & TURHAL & 6,5 & 0,01 & 1 & 125 \\
\hline IZMIR & TIRE & 6,5 & 0,01 & 1 & 124 \\
\hline KASTAMONU & KASTAMONU C. & 6,5 & 0,01 & 1 & 121 \\
\hline KONYA & AKSEHIR & 6,5 & 0,01 & 1 & 121 \\
\hline MUGLA & MUĞLA C. & 6,5 & 0,01 & 1 & 109 \\
\hline DIYARBAKIR & ERGANI & 6,5 & 0,01 & 1 & 108 \\
\hline AFYON & BOLVADIN & 6,5 & 0,01 & 1 & 105 \\
\hline TOKAT & ZILE & 6,5 & 0,01 & 1 & 100 \\
\hline BILECIK & BOZUYUK & 6,5 & 0,01 & 2 & 96 \\
\hline BALIKESIR & GONEN & 6,5 & 0,01 & 1 & 93 \\
\hline MUGLA & MILAS & 6,5 & 0,01 & 1 & 92 \\
\hline CANKIRI & ÇANKIRI C. & 6,5 & 0,01 & 1 & 90 \\
\hline BURDUR & BUCAK & 6,5 & 0,01 & 1 & 87 \\
\hline MUS & MUŞ C. & 6,5 & 0,01 & 1 & 77 \\
\hline KARABUK & SAFRANBOLU & 6,5 & 0,01 & 1 & 76 \\
\hline OSMANIYE & DUZICI & 6,5 & 0,01 & 1 & 76 \\
\hline ADIYAMAN & KAHTA & 6,5 & 0,01 & 2 & 74 \\
\hline TEKIRDAG & CERKEZKOY & 6,5 & 0,01 & 3 & 73 \\
\hline BITLIS & TATVAN & 6,5 & 0,01 & 2 & 65 \\
\hline AYDIN & CINE & 6,5 & 0,01 & 1 & 64 \\
\hline AFYON & EMIRDAG & 6,5 & 0,01 & 2 & 63 \\
\hline KONYA & ILGIN & 6,5 & 0,01 & 1 & 62 \\
\hline AFYON & CAY & 6,5 & 0,01 & 1 & 59 \\
\hline SAKARYA & KARASU & 6,5 & 0,01 & 1 & 57 \\
\hline ANTALYA & KUMLUCA & 6,5 & 0,01 & 1 & 56 \\
\hline MANISA & KIRKAGAC & 6,5 & 0,01 & 1 & 56 \\
\hline ANTALYA & KORKUTELI & 6,5 & 0,01 & 2 & 54 \\
\hline ADANA & IMAMOGLU & 6,5 & 0,01 & 3 & 52 \\
\hline ISPARTA & EGIRDIR & 6,5 & 0,01 & 1 & 50 \\
\hline MUGLA & ORTACA & 6,5 & 0,01 & 1 & 50 \\
\hline SINOP & BOYABAT & 6,5 & 0,01 & 1 & 50 \\
\hline KAYSERI & YAHYALI & 6,5 & 0,01 & 3 & 48 \\
\hline MANISA & DEMIRCI & 6,5 & 0,01 & 1 & 48 \\
\hline AYDIN & INCIRLIOVA & 6,5 & 0,01 & 1 & 47 \\
\hline MUGLA & DALAMAN & 6,5 & 0,01 & 1 & 47 \\
\hline ISPARTA & YALVAC & 6,5 & 0,01 & 1 & 46 \\
\hline KUTAHYA & GEDIZ & 6,5 & 0,01 & 1 & 46 \\
\hline AYDIN & BOZDOGAN & 6,5 & 0,01 & 1 & 45 \\
\hline
\end{tabular}




\begin{tabular}{|c|c|c|c|c|c|}
\hline & SUB-PROVINCE & Intensity & $\begin{array}{c}\text { Relative Loss/ } \\
\text { Loss Rate } \\
\end{array}$ & Hazard Zone & Absolute Loss \\
\hline DENIZLI & SARAYKOY & 6,5 & 0,01 & 1 & 43 \\
\hline ERZURUM & PASINLER & 6,5 & 0,01 & 2 & 43 \\
\hline USAK & BANAZ & 6,5 & 0,01 & 2 & 43 \\
\hline ANTALYA & ELMALI & 6,5 & 0,01 & 2 & 42 \\
\hline KAYSERI & TALAS & 6,5 & 0,01 & 3 & 42 \\
\hline IZMIR & KINIK & 6,5 & 0,01 & 1 & 39 \\
\hline SAKARYA & KOCAALI & 6,5 & 0,01 & 1 & 39 \\
\hline TEKIRDAG & MURATLI & 6,5 & 0,01 & 3 & 39 \\
\hline KASTAMONU & TASKOPRU & 6,5 & 0,01 & 2 & 37 \\
\hline MANISA & GORDES & 6,5 & 0,01 & 1 & 37 \\
\hline MUGLA & DATCA & 6,5 & 0,01 & 1 & 37 \\
\hline ISPARTA & SARKIKARAAGAC & 6,5 & 0,01 & 1 & 35 \\
\hline SIVAS & ZARA & 6,5 & 0,01 & 1 & 35 \\
\hline AFYON & SUHUT & 6,5 & 0,01 & 1 & 34 \\
\hline ORDU & KORGAN & 6,5 & 0,01 & 1 & 34 \\
\hline AYDIN & GERMENCIK & 6,5 & 0,01 & 1 & 33 \\
\hline KARABUK & YENICE & 6,5 & 0,01 & 1 & 33 \\
\hline MUGLA & YATAGAN & 6,5 & 0,01 & 1 & 33 \\
\hline AYDIN & YENIPAZAR & 6,5 & 0,01 & 1 & 32 \\
\hline KUTAHYA & EMET & 6,5 & 0,01 & 1 & 31 \\
\hline SAMSUN & TEKKEKÖY & 6,5 & 0,01 & 2 & 31 \\
\hline KAYSERI & BUNYAN & 6,5 & 0,01 & 3 & 30 \\
\hline AFYON & ISCEHISAR & 6,5 & 0,01 & 2 & 29 \\
\hline BILECIK & SOGUT & 6,5 & 0,01 & 2 & 29 \\
\hline ANKARA & NALLIHAN & 6,5 & 0,01 & 2 & 28 \\
\hline DIYARBAKIR & CERMIK & 6,5 & 0,01 & 1 & 28 \\
\hline ERZURUM & ASKALE & 6,5 & 0,01 & 2 & 28 \\
\hline ORDU & GURGENTEPE & 6,5 & 0,01 & 1 & 28 \\
\hline ANKARA & KIZILCAHAMAM & 6,5 & 0,01 & 2 & 27 \\
\hline AYDIN & KARACASU & 6,5 & 0,01 & 1 & 27 \\
\hline DENIZLI & ACIPAYAM & 6,5 & 0,01 & 1 & 27 \\
\hline GUMUSHANE & KELKIT & 6,5 & 0,01 & 1 & 27 \\
\hline ISPARTA & KECIBORLU & 6,5 & 0,01 & 1 & 27 \\
\hline KONYA & DOGANHISAR & 6,5 & 0,01 & 1 & 27 \\
\hline ORDU & KUMRU & 6,5 & 0,01 & 1 & 27 \\
\hline ADANA & POZANTI & 6,5 & 0,01 & 3 & 26 \\
\hline ANTALYA & KALE (DEMRE) & 6,5 & 0,01 & 1 & 26 \\
\hline ISPARTA & SENIRKENT & 6,5 & 0,01 & 1 & 26 \\
\hline K.MARAS & CAGLAYANCERIT & 6,5 & 0,01 & 1 & 25 \\
\hline ADANA & KARATAS & 6,5 & 0,01 & 2 & 24 \\
\hline ADANA & KARAISALI & 6,5 & 0,01 & 3 & 24 \\
\hline ANTALYA & KEMER & 6,5 & 0,01 & 1 & 24 \\
\hline BALIKESIR & KEPSUT & 6,5 & 0,01 & 1 & 24 \\
\hline EDIRNE & IPSALA & 6,5 & 0,01 & 3 & 24 \\
\hline IZMIR & KIRAZ & 6,5 & 0,01 & 1 & 24 \\
\hline MUS & HASKOY & 6,5 & 0,01 & 1 & 24 \\
\hline ANTALYA & FINIKE & 6,5 & 0,01 & 1 & 23 \\
\hline AYDIN & KUYUCAK & 6,5 & 0,01 & 1 & 23 \\
\hline BITLIS & GUROYMAK & 6,5 & 0,01 & 2 & 23 \\
\hline IZMIR & BEYDAG & 6,5 & 0,01 & 1 & 23 \\
\hline MUGLA & KOYCEGIZ & 6,5 & 0,01 & 1 & 23 \\
\hline AFYON & BASMAKCI & 6,5 & 0,01 & 1 & 22 \\
\hline AYDIN & KOSK & 6,5 & 0,01 & 1 & 22 \\
\hline ELAZIG & KARAKOCAN & 6,5 & 0,01 & 2 & 22 \\
\hline MUGLA & ULA & 6,5 & 0,01 & 1 & 22 \\
\hline SINOP & DURAGAN & 6,5 & 0,01 & 1 & 22 \\
\hline GAZIANTEP & ARABAN & 6,5 & 0,01 & 3 & 21 \\
\hline
\end{tabular}




\begin{tabular}{|c|c|c|c|c|c|}
\hline & SUB-PROVINCE & Intensity & $\begin{array}{c}\text { Relative Loss/ } \\
\text { Loss Rate } \\
\end{array}$ & Hazard Zone & Absolute Loss \\
\hline ISPARTA & ULUBORLU & 6,5 & 0,01 & 1 & 21 \\
\hline VAN & GEVAS & 6,5 & 0,01 & 2 & 21 \\
\hline AFYON & SULTANDAGI & 6,5 & 0,01 & 1 & 20 \\
\hline AYDIN & BUHARKENT & 6,5 & 0,01 & 1 & 20 \\
\hline BURSA & ORHANELI & 6,5 & 0,01 & 2 & 20 \\
\hline MALATYA & DOGANSEHIR & 6,5 & 0,01 & 1 & 20 \\
\hline AFYON & COBANLAR & 6,5 & 0,01 & 1 & 19 \\
\hline AYDIN & SULTANHISAR & 6,5 & 0,01 & 1 & 19 \\
\hline BILECIK & PAZARYERI & 6,5 & 0,01 & 2 & 19 \\
\hline DENIZLI & BEKILLI & 6,5 & 0,01 & 1 & 19 \\
\hline USAK & ULUBEY & 6,5 & 0,01 & 2 & 19 \\
\hline ADANA & YUMURTALIK & 6,5 & 0,01 & 1 & 18 \\
\hline AYDIN & KOCARLI & 6,5 & 0,01 & 1 & 18 \\
\hline DENIZLI & HONAZ & 6,5 & 0,01 & 1 & 18 \\
\hline ISPARTA & GELENDOST & 6,5 & 0,01 & 1 & 18 \\
\hline KUTAHYA & HISARCIK & 6,5 & 0,01 & 1 & 18 \\
\hline AFYON & BAYAT & 6,5 & 0,01 & 2 & 17 \\
\hline CORUM & BAYAT & 6,5 & 0,01 & 2 & 17 \\
\hline DENIZLI & BABADAG & 6,5 & 0,01 & 1 & 17 \\
\hline KONYA & DERBENT & 6,5 & 0,01 & 3 & 17 \\
\hline MANISA & KOPRUBASI & 6,5 & 0,01 & 1 & 17 \\
\hline ANTALYA & KAS & 6,5 & 0,01 & 1 & 16 \\
\hline CANAKKALE & YENICE & 6,5 & 0,01 & 1 & 16 \\
\hline CORUM & MECITOZU & 6,5 & 0,01 & 1 & 16 \\
\hline KONYA & HUYUK & 6,5 & 0,01 & 2 & 16 \\
\hline KUTAHYA & SAPHANE & 6,5 & 0,01 & 1 & 16 \\
\hline BURDUR & AGLASUN & 6,5 & 0,01 & 1 & 15 \\
\hline DIYARBAKIR & DICLE & 6,5 & 0,01 & 1 & 15 \\
\hline ISPARTA & ATABEY & 6,5 & 0,01 & 1 & 15 \\
\hline \begin{tabular}{|l|} 
CANKIRI \\
\end{tabular} & ELDIVAN & 6,5 & 0,01 & 2 & 14 \\
\hline NIGDE & CAMARDI & 6,5 & 0,01 & 4 & 14 \\
\hline SAMSUN & SALIPAZARI & 6,5 & 0,01 & 2 & 14 \\
\hline TOKAT & PAZAR & 6,5 & 0,01 & 1 & 14 \\
\hline AFYON & DAZKIRI & 6,5 & 0,01 & 1 & 13 \\
\hline KUTAHYA & ALTINTAS & 6,5 & 0,01 & 2 & 13 \\
\hline \begin{tabular}{|l|} 
ISPARTA \\
\end{tabular} & GONEN & 6,5 & 0,01 & 1 & 12 \\
\hline KONYA & TUZLUKCU & 6,5 & 0,01 & 1 & 12 \\
\hline KUTAHYA & PAZARLAR & 6,5 & 0,01 & 1 & 12 \\
\hline AFYON & EVCILER & 6,5 & 0,01 & 1 & 11 \\
\hline ERZURUM & TEKMAN & 6,5 & 0,01 & 1 & 11 \\
\hline ORDU & CATALPINAR & 6,5 & 0,01 & 2 & 11 \\
\hline SAKARYA & KAYNARCA & 6,5 & 0,01 & 1 & 11 \\
\hline ADIYAMAN & GERGER & 6,5 & 0,01 & 1 & 9 \\
\hline AYDIN & KARPUZLU & 6,5 & 0,01 & 1 & 9 \\
\hline BURDUR & CELTIKCI & 6,5 & 0,01 & 1 & 9 \\
\hline BURSA & KELES & 6,5 & 0,01 & 2 & 9 \\
\hline \begin{tabular}{|l|} 
CANKIRI \\
\end{tabular} & SABANOZU & 6,5 & 0,01 & 2 & 9 \\
\hline CORUM & ORTAKOY & 6,5 & 0,01 & 2 & 9 \\
\hline DENIZLI & CAMELI & 6,5 & 0,01 & 1 & 9 \\
\hline GAZIANTEP & YAVUZELI & 6,5 & 0,01 & 3 & 9 \\
\hline DENIZLI & BEYAGAC & 6,5 & 0,01 & 1 & 8 \\
\hline ESKISEHIR & MIHALGAZI & 6,5 & 0,01 & 2 & 8 \\
\hline KUTAHYA & CAVDARHISAR & 6,5 & 0,01 & 1 & 8 \\
\hline \begin{tabular}{|l|} 
AFYON \\
\end{tabular} & IHSANIYE & 6,5 & 0,01 & 2 & 7 \\
\hline AMASYA & GOYNUCEK & 6,5 & 0,01 & 1 & 7 \\
\hline MALATYA & KALE & 6,5 & 0,01 & 1 & 7 \\
\hline OSMANIYE & SUMBAS & 6,5 & 0,01 & 1 & 7 \\
\hline
\end{tabular}




\begin{tabular}{|l|l|c|c|c|r|}
\hline & SUB-PROVINCE & Intensity & $\begin{array}{c}\text { Relative Loss/ } \\
\text { Loss Rate }\end{array}$ & Hazard Zone & Absolute Loss \\
\hline TUNCELI & OVACIK & 6,5 & 0,01 & 1 & 7 \\
\hline KUTAHYA & DUMLUPINAR & 6,5 & 0,01 & 2 & 6 \\
\hline VAN & SARAY & 6,5 & 0,01 & 1 & 6 \\
\hline BILECIK & INHISAR & 6,5 & 0,01 & 2 & 5 \\
\hline BILECIK & YENIPAZAR & 6,5 & 0,01 & 1 & 5 \\
\hline ESKISEHIR & SARICAKAYA & 6,5 & 0,01 & 2 & 5 \\
\hline KUTAHYA & ASLANAPA & 6,5 & 0,01 & 1 & 5 \\
\hline TUNCELI & NAZIMIYE & 6,5 & 0,01 & 1 & 4 \\
\hline KILIS & MUSABEYLI & 6,5 & 0,01 & 3 & 2 \\
\hline KONYA & AKOREN & 6,5 & 0 & 4 & 6 \\
\hline
\end{tabular}

C: Central

Comparison of the Metropolitan Cities Prioritized According to the Absolute Loss with the Hazard Zones Determined by the Official Earthquake Hazard Map

\begin{tabular}{|l|l|c|c|c|r|}
\hline $\begin{array}{c}\text { Metropolitan } \\
\text { Cities }\end{array}$ & SUB-PROVINCE & Intensity & $\begin{array}{c}\text { Relative Loss } \\
\text { (Loss / } \\
\text { Building) }\end{array}$ & $\begin{array}{c}\text { Hazard } \\
\text { Zone }\end{array}$ & $\begin{array}{c}\text { Absolute } \\
\text { Loss }\end{array}$ \\
\hline KOCAELI & KOCAELI (M) & 8 & 0,17 & 1 & 24077 \\
\hline SAKARYA & SAKARYA (M) & 8 & 0,16 & 1 & 8070 \\
\hline ISTANBUL & ISTANBUL (M) & 7,5 & 0,10 & 2 & 83824 \\
\hline BURSA & BURSA (M) & 7,5 & 0,08 & 1 & 16506 \\
\hline IZMIR & IZMIR (M) & 7 & 0,03 & 1 & 14531 \\
\hline ADANA & ADANA (M) & 6,5 & 0,01 & 2 & 1913 \\
\hline ANTALYA & ANTALYA (M) & 6,5 & 0,01 & 2 & 1402 \\
\hline KONYA & KONYA (M) & 6,5 & 0,01 & 4 & 1355 \\
\hline ERZURUM & ERZURUM (M) & 6,5 & 0,01 & 2 & 439 \\
\hline
\end{tabular}

M: Metropolitan 


\section{APPENDIX I}

COMPARISON OF THE PROVINCES PRIORITIZED ACCORDING TO THE ABSOLUTE LOSS WITH THE LOCATION OF SETTLEMENTS ACCORDING TO THE INVESTMENT PRIORITY REGIONS

\begin{tabular}{|c|c|c|c|}
\hline PROVINCE & $\begin{array}{c}\text { Absolute } \\
\text { Loss }\end{array}$ & $\begin{array}{c}\text { Priority of } \\
\text { Incentives Region }\end{array}$ & $\begin{array}{c}\text { Relative Loss/ } \\
\text { Loss Rate }\end{array}$ \\
\hline ISTANBUL (M.) & 83824 & 1 & 0,10 \\
\hline KOCAELI (M.) & 24077 & 1 & 0,17 \\
\hline BURSA (M.) & 19168 & 1 & 0,08 \\
\hline IZMIR (M.) & 15727 & 1 & 0,03 \\
\hline SAKARYA (M.) & 10936 & 2 & 0,14 \\
\hline TOKAT & 3985 & 5 & 0,07 \\
\hline MANISA & 3875 & 3 & 0,03 \\
\hline HATAY & 3189 & 4 & 0,03 \\
\hline BALIKESIR & 3111 & 3 & 0,03 \\
\hline BOLU & 2990 & 2 & 0,14 \\
\hline ERZINCAN & 2925 & 4 & 0,14 \\
\hline TEKIRDAG & 2558 & 2 & 0,05 \\
\hline YALOVA & 2484 & 2 & 0,17 \\
\hline VAN & 2474 & 6 & 0,06 \\
\hline ADANA (M.) & 2343 & 2 & 0,01 \\
\hline AMASYA & 2210 & 4 & 0,06 \\
\hline CORUM & 1687 & 4 & 0,04 \\
\hline ANTALYA (M.) & 1644 & 1 & 0,01 \\
\hline KONYA (M.) & 1617 & 2 & 0,01 \\
\hline KASTAMONU & 1614 & 4 & 0,07 \\
\hline SAMSUN & 1614 & 3 & 0,09 \\
\hline AYDIN & 1425 & 2 & 0,01 \\
\hline OSMANIYE & 1318 & 5 & 0,02 \\
\hline DUZCE & 1179 & 4 & 0,07 \\
\hline ADIYAMAN & 1132 & 5 & 0,03 \\
\hline DENIZLI & 1097 & 2 & 0,02 \\
\hline SIVAS & 1094 & 4 & 0,10 \\
\hline CANAKKALE & 1086 & 2 & 0,03 \\
\hline CANKIRI & 957 & 5 & 0,05 \\
\hline MUS & 875 & 6 & 0,04 \\
\hline MUGLA & 740 & 1 & 0,01 \\
\hline ERZURUM & 738 & 5 & 0,02 \\
\hline K.MARAS & 669 & 5 & 0,01 \\
\hline AFYON & 638 & 4 & 0,01 \\
\hline BINGOL & 630 & 6 & 0,05 \\
\hline BURDUR & 624 & 3 & 0,02 \\
\hline KUTAHYA & 612 & 4 & 0,01 \\
\hline ISPARTA & 605 & 2 & 0,01 \\
\hline
\end{tabular}




\begin{tabular}{|c|c|c|c|}
\hline PROVINCE & $\begin{array}{c}\text { Absolute } \\
\text { Loss }\end{array}$ & $\begin{array}{c}\text { Priority of } \\
\text { Incentives Region }\end{array}$ & $\begin{array}{c}\text { Relative Loss/ } \\
\text { Loss Rate }\end{array}$ \\
\hline BILECIK & 516 & 3 & 0,02 \\
\hline BITLIS & 494 & 6 & 0,03 \\
\hline ORDU & 439 & 5 & 0,02 \\
\hline KARABUK & 400 & 3 & 0,02 \\
\hline EDIRNE & 399 & 2 & 0,03 \\
\hline GIRESUN & 384 & 5 & 0,07 \\
\hline ICEL(MERSIN) & 361 & 3 & 0,01 \\
\hline ELAZIG & 274 & 4 & 0,03 \\
\hline GAZIANTEP & 247 & 3 & 0,02 \\
\hline USAK & 182 & 3 & 0,02 \\
\hline DIYARBAKIR & 177 & 6 & 0,01 \\
\hline ANKARA & 125 & 1 & 0,02 \\
\hline KAYSERI & 121 & 2 & 0,01 \\
\hline TUNCELI & 104 & 5 & 0,07 \\
\hline SINOP & 84 & 5 & 0,01 \\
\hline MALATYA & 79 & 4 & 0,02 \\
\hline GUMUSHANE & 64 & 5 & 0,02 \\
\hline ZONGULDAK & 30 & 3 & 0,02 \\
\hline NIGDE & 14 & 5 & 0,01 \\
\hline ESKISEHIR & 13 & 1 & 0,01 \\
\hline KILIS & 2 & 5 & 0,01 \\
\hline AĞRI* & - & 6 & - \\
\hline AKSARAY* & - & 5 & - \\
\hline ARDAHAN* & - & 6 & - \\
\hline ARTVIN* & - & 4 & - \\
\hline BARTIN* & - & 4 & - \\
\hline BATMAN* & - & 6 & - \\
\hline BAYBURT* ${ }^{*}$ & - & 5 & - \\
\hline HAKKARI** & - & 6 & - \\
\hline IĞDIR* & - & 6 & - \\
\hline KARAMAN* & - & 3 & - \\
\hline KARS* & - & 6 & - \\
\hline KIRIKKALE* & - & 4 & - \\
\hline KIRKLARELI* & - & 2 & - \\
\hline KIRŞEHIR* $*$ & - & 4 & - \\
\hline MARDİ* & - & 6 & - \\
\hline NEVŞEHİR* & - & 4 & - \\
\hline RİZE* & - & 4 & - \\
\hline SIIIRT* & - & 6 & - \\
\hline ŞANLIURFA* & - & 6 & - \\
\hline ŞIRNAK* & - & 6 & - \\
\hline TRABZON* & - & 3 & - \\
\hline YOZGAT* & - & 5 & - \\
\hline $\begin{array}{l}\text { GÖKCEADA-BOZCADA } \\
\text { DISTRICTS* }\end{array}$ & - & 6 & - \\
\hline
\end{tabular}

* All settlements with an expected hazard intensity level of 6.0 and less are excluded from the analyses assuming that insignificant damage is likely to take place in these settlements. 


\section{APPENDIX J}

COMPARISON OF THE SETTLEMENTS PRIORITIZED ACCORDING TO THE RELATIVE LOSS WITH THE LOCATION OF SETTLEMENTS ACCORDING TO THE INVESTMENT PRIORITY REGIONS

\begin{tabular}{|c|c|c|c|}
\hline PROVINCE & $\begin{array}{c}\text { Relative Loss/ } \\
\text { Loss Rate } \\
\end{array}$ & $\begin{array}{c}\text { Priority of } \\
\text { Incentives Region }\end{array}$ & $\begin{array}{c}\text { Absolute } \\
\text { Loss } \\
\end{array}$ \\
\hline KOCAELI (M.) & 0,17 & 1 & 24077 \\
\hline YALOVA & 0,17 & 2 & 2484 \\
\hline SAKARYA (M.) & 0,14 & 2 & 10936 \\
\hline BOLU & 0,14 & 2 & 2990 \\
\hline ERZINCAN & 0,14 & 4 & 2925 \\
\hline ISTANBUL (M.) & 0,10 & 1 & 83824 \\
\hline SIVAS & 0,10 & 4 & 1094 \\
\hline SAMSUN & 0,09 & 3 & 1614 \\
\hline BURSA (M.) & 0,08 & 1 & 19168 \\
\hline TOKAT & 0,07 & 5 & 3985 \\
\hline KASTAMONU & 0,07 & 4 & 1614 \\
\hline DUZCE & 0,07 & 4 & 1179 \\
\hline GIRESUN & 0,07 & 5 & 384 \\
\hline TUNCELI & 0,07 & 5 & 104 \\
\hline VAN & 0,06 & 6 & 2474 \\
\hline AMASYA & 0,06 & 4 & 2210 \\
\hline TEKIRDAG & 0,05 & 2 & 2558 \\
\hline CANKIRI & 0,05 & 5 & 957 \\
\hline BINGOL & 0,05 & 6 & 630 \\
\hline CORUM & 0,04 & 4 & 1687 \\
\hline MUS & 0,04 & 6 & 875 \\
\hline IZMIR (M.) & 0,03 & 1 & 15727 \\
\hline MANISA & 0,03 & 3 & 3875 \\
\hline HATAY & 0,03 & 4 & 3189 \\
\hline BALIKESIR & 0,03 & 3 & 3111 \\
\hline ADIYAMAN & 0,03 & 5 & 1132 \\
\hline CANAKKALE & 0,03 & 2 & 1086 \\
\hline BITLIS & 0,03 & 6 & 494 \\
\hline EDIRNE & 0,03 & 2 & 399 \\
\hline ELAZIG & 0,03 & 4 & 274 \\
\hline OSMANIYE & 0,02 & 5 & 1318 \\
\hline DENIZLI & 0,02 & 2 & 1097 \\
\hline ERZURUM & 0,02 & 5 & 738 \\
\hline BURDUR & 0,02 & 3 & 624 \\
\hline BILECIK & 0,02 & 3 & 516 \\
\hline ORDU & 0,02 & 5 & 439 \\
\hline KARABUK & 0,02 & 3 & 400 \\
\hline GAZIANTEP & 0,02 & 3 & 247 \\
\hline
\end{tabular}




\begin{tabular}{|c|c|c|c|}
\hline PROVINCE & $\begin{array}{c}\text { Relative Loss/ } \\
\text { Loss Rate }\end{array}$ & $\begin{array}{c}\text { Priority of } \\
\text { Incentives Region } \\
\end{array}$ & $\begin{array}{c}\text { Absolute } \\
\text { Loss }\end{array}$ \\
\hline USAK & 0,02 & 3 & 182 \\
\hline ANKARA & 0,02 & 1 & 125 \\
\hline MALATYA & 0,02 & 4 & 79 \\
\hline GUMUSHANE & 0,02 & 5 & 64 \\
\hline ZONGULDAK & 0,02 & 3 & 30 \\
\hline ADANA (M.) & 0,01 & 2 & 2343 \\
\hline ANTALYA (M.) & 0,01 & 1 & 1644 \\
\hline KONYA (M.) & 0,01 & 2 & 1617 \\
\hline AYDIN & 0,01 & 2 & 1425 \\
\hline MUGLA & 0,01 & 1 & 740 \\
\hline K.MARAS & 0,01 & 5 & 669 \\
\hline AFYON & 0,01 & 4 & 638 \\
\hline KUTAHYA & 0,01 & 4 & 612 \\
\hline ISPARTA & 0,01 & 2 & 605 \\
\hline ICEL(MERSIN) & 0,01 & 3 & 361 \\
\hline DIYARBAKIR & 0,01 & 6 & 177 \\
\hline KAYSERI & 0,01 & 2 & 121 \\
\hline SINOP & 0,01 & 5 & 84 \\
\hline NIGDE & 0,01 & 5 & 14 \\
\hline ESKISEHIR & 0,01 & 1 & 13 \\
\hline KILIS & 0,01 & 5 & 2 \\
\hline AĞRI* & - & 6 & - \\
\hline AKSARAY* & - & 5 & - \\
\hline ARDAHAN* & - & 6 & - \\
\hline ARTVIN* & - & 4 & - \\
\hline BARTIN* & - & 4 & - \\
\hline BATMAN* & - & 6 & - \\
\hline BAYBURT* & - & 5 & - \\
\hline HAKKÂRI* & - & 6 & - \\
\hline IĞDIR* & - & 6 & - \\
\hline KARAMAN* & - & 3 & - \\
\hline KARS* & - & 6 & - \\
\hline KIRIKKALE* & - & 4 & - \\
\hline KIRKLARELI* & - & 2 & - \\
\hline KIRŞEHIR* & - & 4 & - \\
\hline MARDIN* & - & 6 & - \\
\hline NEVŞEHİR* & - & 4 & - \\
\hline RIZZE* & - & 4 & - \\
\hline SİIRT* & - & 6 & - \\
\hline ŞANLIURFA* & - & 6 & - \\
\hline ŞIRNAK* & - & 6 & - \\
\hline TRABZON* & - & 3 & - \\
\hline YOZGAT* & - & 5 & - \\
\hline $\begin{array}{l}\text { GÖKCEADA-BOZCADA } \\
\text { DISTRICTS* }\end{array}$ & - & 6 & - \\
\hline
\end{tabular}

* All settlements with an expected hazard intensity level of 6.0 and less are excluded from the analyses assuming that insignificant damage is likely to take place in these settlements. 


\section{PERSONAL INFORMATION}

Surname, Name: Sönmez Saner, Tuğçe

Nationality: Turkish (TC)

Date and Place of Birth: 1 November 1983, Lefkoşa

Email: tugcesonmez@gmail.com

\section{EDUCATION}

\section{$\begin{array}{lll}\text { Degree Institution } & \text { Year of Graduation }\end{array}$}

MS METU City Planning 2008

BS GAZI University City and Regional Planning 2005

High School 19 Mayıs TMK, Girne 2000

\section{WORK EXPERINCE}

$\begin{array}{lll}\text { Year } & \text { Place } & \text { Enrollment } \\ 2006-2008 & \text { InfoPlan GIS Planning } & \text { City Planner } \\ 2003 & \text { Pamir Planning } & \text { Intern Planner } \\ 2002 & \text { Nicosia Municipality } & \text { Intern Planner }\end{array}$

\section{FOREIGN LANGUAGES}

Advanced English, Intermediate German

\section{PUBLICATIONS}

1. Sönmez T., "Determination of Seismic Vulnerabilities and Risks for Urban Mitigation Planning in Turkey", The Association of European Schools of Planning (AESOP) 26th Annual Congress, Ankara, July 2012.

2. Sönmez T., Türkiye'de Sakınım Planlaması için Kentsel Yerleşmelerin Sismik Zarar Görebilirliklerinin ve Risklerinin Belirlenmesi, Kentsel ve Bölgesel Araştırmalar Ağı (KBAM) -2.Sempozyumu, Ankara, 2011.

3. Sönmez T., Türkiye Büyükşehirlerinde Risk Oluşturan Etkenlerin Karşılaştırılması, Dünya Şehircilik Günü 34. Kolokyumu, Kayseri, 2010.

4. Sönmez T., Aspects of Urban Seismic Risks: A Comparison of Risk Factors in the Metropolitan Cities of Turkey, Disaster Symposium, Chamber of Civil Engineers -TMMOB, 2007, Ankara. 